\title{
CIÊNCIAS DA SAÚDE
}

\section{APRENDIZADOS, ENSINO E PESQUISA NO CENÁRIO CONTEMPORÂNEO}

\section{VOLUME}

ORGANIZADORES NEUDSON JOHNSON MARTINHO CAROLINA CARBONELL DEMORI JOÃO VITOR ANDRADE

\section{Doroopa \\ ZAMPLLA}




\section{CIÊNCIAS DA SAÚDE}

\section{APRENDIZADOS, ENSINO E PESQUISA NO CENÁRIO CONTEMPORÂNEO}

\section{VOLUME II}

morosent

ZAMPLLA
ORGANIZADORES NEUDSON JOHNSON MARTINHO CAROLINA CARBONELL DEMORI JOÃO VITOR ANDRADE 


\section{groou \\ ZAMPLLA}

2021 - Editora Amplla

Copyright @ Editora Amplla

Editor Chefe: Leonardo Pereira Tavares

Design da Capa: Editora Amplla

Projeto Gráfico: Editora Amplla

Diagramação: Higor Costa de Brito

Ciências da saúde: aprendizados, ensino e pesquisa no cenário contemporâneo está licenciado sob CC BY 4.0.

(c) (1) Esta licença exige que as reutilizações deem crédito ao criador. Ele permite que os ou formato, mesmo para fins comerciais.

O conteúdo da obra e seus dados em sua forma, correção e confiabilidade são de responsabilidade exclusiva dos autores, não representando a posição oficial da Editora Amplla. É permitido o download da obra e o compartilhamento desde que sejam atribuídos créditos aos autores. Todos os direitos para esta edição foram cedidos à Editora Amplla.

ISBN: 978-65-88332-52-8

DOI: 10.51859/amplla.csa528.2121-0

Editora Amplla

Campina Grande - PB - Brasil contato@ampllaeditora.com.br www.ampllaeditora.com.br 


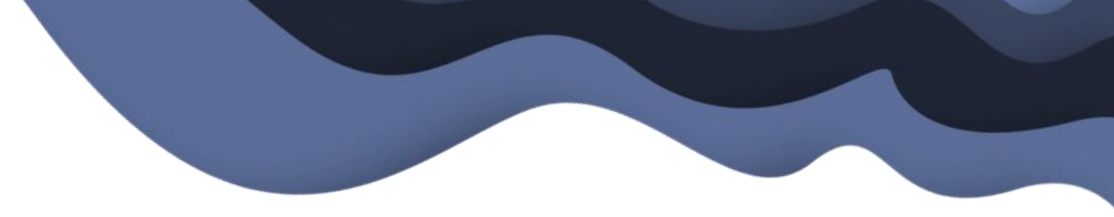

\section{CONSELHO EDITORIAL}

Andréa Cátia Leal Badaró - Universidade Tecnológica Federal do Paraná Andréia Monique Lermen - Universidade Federal do Rio Grande do Sul Antoniele Silvana de Melo Souza - Universidade Estadual do Ceará Bergson Rodrigo Siqueira de Melo - Universidade Estadual do Ceará Bruna Beatriz da Rocha - Instituto Federal do Sudeste de Minas Gerais Caio César Costa Santos - Universidade Federal de Sergipe Carina Alexandra Rondini - Universidade Estadual Paulista Carla Caroline Alves Carvalho - Universidade Federal de Campina Grande Carlos Augusto Trojaner - Prefeitura de Venâncio Aires Carolina Carbonell Demori - Universidade Federal de Pelotas Cícero Batista do Nascimento Filho - Universidade Federal do Ceará Clécio Danilo Dias da Silva - Universidade Federal do Rio Grande do Norte Daniela de Freitas Lima - Universidade Federal de Campina Grande Denise Barguil Nepomuceno - Universidade Federal de Minas Gerais Dylan Ávila Alves - Instituto Federal Goiano Edson Lourenço da Silva - Instituto Federal de Educação, Ciência e Tecnologia do Piauí Elane da Silva Barbosa - Universidade Estadual do Ceará Érica Rios de Carvalho - Universidade Católica do Salvador Gilberto de Melo Junior - Instituto Federal do Pará Higor Costa de Brito - Universidade Federal de Campina Grande Italan Carneiro Bezerra - Instituto Federal da Paraíba Ivo Batista Conde - Universidade Estadual do Ceará Jaqueline Rocha Borges dos Santos - Universidade Federal Rural do Rio de Janeiro Jessica Wanderley Souza do Nascimento - Instituto de Especialização do Amazonas João Henriques de Sousa Júnior - Universidade Federal de Santa Catarina João Manoel Da Silva - Universidade Federal de Alagoas

João Vitor Andrade - Universidade de São Paulo Joilson Silva de Sousa - Instituto Federal do Rio Grande do Norte José Cândido Rodrigues Neto - Universidade Estadual da Paraíba Jose Henrique de Lacerda Furtado - Instituto Federal do Rio de Janeiro Josenita Luiz da Silva - Faculdade Frassinetti do Recife Josiney Farias de Araújo - Universidade Federal do Pará Karina de Araújo Dias - SME/Prefeitura Municipal de Florianópolis Laíze Lantyer Luz - Universidade Católica do Salvador Lindon Johnson Pontes Portela - Universidade Federal do Oeste do Pará Lucas Capita Quarto - Universidade Federal do Oeste do Pará Lúcia Magnólia Albuquerque Soares de Camargo - Unifacisa Centro Universitário Luciana de Jesus Botelho Sodré dos Santos - Universidade Estadual do Maranhão Luís Paulo Souza e Souza - Universidade Federal do Amazonas Luiza Catarina Sobreira de Souza - Faculdade de Ciências Humanas do Sertão Central Manoel Mariano Neto da Silva - Universidade Federal de Campina Grande Marcelo Alves Pereira Eufrasio - Centro Universitário Unifacisa Marcelo Williams Oliveira de Souza - Universidade Federal do Pará Marcos Pereira dos Santos - Faculdade Rachel de Queiroz Marcus Vinicius Peralva Santos - Universidade Federal da Bahia Marina Magalhães de Morais - Universidade Federal de Campina Grande Nadja Maria Mourão - Universidade do Estado de Minas Gerais Natan Galves Santana - Universidade Paranaense Nathalia Bezerra da Silva Ferreira - Universidade do Estado do Rio Grande do Norte Neide Kazue Sakugawa Shinohara - Universidade Federal Rural de Pernambuco Neudson Johnson Martinho - Faculdade de Medicina da Universidade Federal de Mato Grosso Patrícia Appelt - Universidade Tecnológica Federal do Paraná 
Paulo Henrique Matos de Jesus - Universidade Federal do Maranhão Rafael Rodrigues Gomides - Faculdade de Quatro Marcos

Reângela Cíntia Rodrigues de Oliveira Lima - Universidade Federal do Ceará

Rebeca Freitas Ivanicska - Universidade Federal de Lavras

Renan Monteiro do Nascimento - Universidade de Brasília

Ricardo Leoni Gonçalves Bastos - Universidade Federal do Ceará

Rodrigo da Rosa Pereira - Universidade Federal do Rio Grande

Sabrynna Brito Oliveira - Universidade Federal de Minas Gerais

Samuel Miranda Mattos - Universidade Estadual do Ceará

Shirley Santos Nascimento - Universidade Estadual Do Sudoeste Da Bahia

Silvana Carloto Andres - Universidade Federal de Santa Maria

Silvio de Almeida Junior - Universidade de Franca

Tatiana Paschoalette Rodrigues Bachur - Universidade Estadual do Ceará

Telma Regina Stroparo - Universidade Estadual do Centro-Oeste

Thayla Amorim Santino - Universidade Federal do Rio Grande do Norte

Virgínia Maia de Araújo Oliveira - Instituto Federal da Paraíba

Virginia Tomaz Machado - Faculdade Santa Maria de Cajazeiras

Walmir Fernandes Pereira - Miami University of Science and Technology

Wanessa Dunga de Assis - Universidade Federal de Campina Grande

Wellington Alves Silva - Universidade Estadual de Roraima

Yáscara Maia Araújo de Brito - Universidade Federal de Campina Grande

Yasmin da Silva Santos - Fundação Oswaldo Cruz

Yuciara Barbosa Costa Ferreira - Universidade Federal de Campina Grande 


\section{ZIAMPLLA}

2021 - Editora Amplla

Copyright @ Editora Amplla

Editor Chefe: Leonardo Pereira Tavares

Design da Capa: Editora Amplla

Projeto Gráfico: Editora Amplla

Diagramação: Higor Costa de Brito

Dados Internacionais de Catalogação na Publicação (CIP)

Sueli Costa CRB-8/5213

Ciências da saúde [livro eletrônico]: aprendizados, ensino e pesquisa no cenário contemporâneo / organização Neudson Johnson Martinho, Carolina Carbonell Demori, João Vitor Andrade. Campina Grande : Editora Amplla, 2021 .

$2 \mathrm{~V}$.

Formato: $\mathrm{PDF}$

ISBN: 978-65-88332-51-1 (Volume 1)

ISBN: $978-65-88332-52-8$ (Volume 2)

1. Medicina 2. Enfermagem 3. Odontologia 4. Farmacologia 5. Psicologia 6. Epidemiologia I. Martinho, Neudson Johnson II. Demori, Carolina Carbonell III. Andrade, João Vitor IV. Título

$\mathrm{CDD}-610.6$

\section{Índices para catálogo sistemático:}

1. Profissionais de saúde 610.6

Editora Amplla

Campina Grande - PB - Brasil contato@ampllaeditora.com.br www.ampllaeditora.com.br 


\section{PREFÁCIO}

Novos desafios surgem a cada dia na área de saúde, os quais vem demonstrando que somente a partir da confluência de saberes e fazeres das diversas áreas do conhecimento os sistemas de saúde estarão fortalecidos para o enfrentamento deles, tendo em vista a complexidade das ações que se fazem necessárias em todos os níveis de atenção: primário, secundário e terciário.

As rápidas mudanças epidemiológicas e demográficas, concomitante ao surgimento de pandemias e recrudescimento de doenças transmissíveis e não transmissíveis no mundo, evocam novos olhares e fazeres que requerem transformações desde a formação dos profissionais, produção de conhecimentos com vistas à processos de trabalhos colaborativos nos serviços de saúde, nos quais ocorram uma compreensão quanto a complementariedade dos diversos saberes e fazeres que compõem a equipe de saúde, desconstruindo a cultura das ações sobrepostas ou, a falácia que algumas profissões são mais importantes e portanto, hegemônicas frente as outras.

O mundo é complexo e dinâmico, logo, os seres humanos que nele existem também o são em suas dimensões existenciais considerando que estão imbricados no mundo e, por esta característica fenomenológica, o saber / fazer de uma única profissão jamais será capaz de compreender e atender as complexas necessidades factuais destes seres em todo o seu ciclo vital, tendo em vista a imprevisibilidades e incertezas oriundas delas.

Com base nas afirmações supracitadas e partindo do princípio de que o trabalho em saúde não tem um produto concreto final, sendo seu resultado consequência das relações profissionais e interpessoais que subjazem suas ações de cuidado e não apenas resultante do saber/fazer de um único profissional, é importante enfatizar que toda a centralidade do processo de trabalho em saúde deve ser o usuário e suas complexas necessidades, as quais só poderão ser realmente atendidas com um cuidado interprofissional / colaborativo.

Portanto, mudanças no modus operandi e modus faciendi na formação dos profissionais de saúde e no processo de trabalho suscitam o desenvolvimento de novas competências e habilidades que devem permear a arte de ensinar, pesquisar e 
extensionar, reverberando no verdadeiro trabalho em equipe nos serviços de saúde, algo somente alcançável através da implementação de uma educação interprofissional nas universidades e cursos técnicos, assim como, a criação de políticas indutoras para o trabalho colaborativo, no qual os diversos saberes e fazeres profissionais sejam valorizados e reconhecidos quanto sua importante complementariedade, visando decisões terapêuticas compartilhadas no atendimento às necessidades de saúde no contexto mundial vigente frente a pandemia de COVID-19 e outras demandas biopsicossociais de cuidado humano.

Nesta perspectiva, pensar em ciências da saúde é refletir sobre novos aprendizados, novas metodologias de ensino e novas formas de pesquisar em um cenário contemporâneo que desvela um mix de processos antigos que recrudescem e novos que surgem, apontando a urgência de novas tomadas de decisões, as quais sejam rápidas e eficazes em responder às complexas necessidades dos usuários do sistema de saúde, contribuindo para o resgate e manutenção da qualidade de vida.

Desejamos a todos uma profícua leitura desta obra, a qual pela diversidade de temáticas abordadas, permitirá ao leitor não somente uma leitura do mundo sob o prisma dos autores ao socializarem os resultados alcançados em seus estudos, mas, sobretudo, poderá instigá-lo de certa forma à "reescrevê-lo", no sentido de transformálo a partir da apreensão e ressignificação de conhecimentos contidos nas diferentes pesquisas que corporificam este e-book, permitindo um movimento de cruzamento e interdependência entre variadas competências.

Neudson Johnson Martinho Enfermeiro; Doutor em Educação; Mestre em Enfermagem em Saúde Comunitária; Especialista em Docência na Saúde; Professor Associado da Faculdade de Medicina da Universidade Federal de Mato Grosso (UFMT) 


\section{SUMÁRIO}

CAPÍTULO I - OPINIÃO NÃO É ESTUDO! PRECISAMOS DE MAIS MEDICINA BASEADA EM EVIDÊNCIAS........................11

CAPÍTULO II - CIANOBACTÉRIA ARTHROSPIRA PLATENSISCOMO FONTE DE PEPTÍDEOS ANTI-HIPERTENSIVO .........20

CAPíTULO III - EFEITOS ADVERSOS DO USO INDISCRIMINADO DE ANTITROMBÓtICOS NO TRATAMENTO PROFILÁTICO EM PUÉRPERAS: UMA REVISÃO INTEGRATIVA ..................................................................................

CAPITULO IV - INFLUÊNCIA DAS FORMULAÇ̃̃ES DE ANFOTERICINA B NA OCORRÊNCIA DE HIPOCALEMIA EM PACIENTES COM LEISHMANIOSE VISCERAL: UMA REVISÃO SISTEMÁTICA. 45

CAṔTULO V - OS EFEITOS DO CUIDADO MÃE CANGURU EM RECÉM-NASCIDOS PREMATUROS: UMA REVISÃO INTEGRATIVA. .. .59

CAPÍTULO VI - SCOPING REVIEW. ANÁLISE DE VÍDEOS PUBLICADOS ONLINE SOBRE CATETERISMO VESICAL EM PACIENTES PEDIÁTRICOS.

CAPÍTULO VII - DETERMINAÇ̃̃O DO PERIOODO DE JEJUM PRÉ-OPERATÓRIO: CONTRIBUIÇ̄̃ES NA ASSISTÊNCIA DE ENFERMAGEM PRÉ-OPERATÓRIA. 85

CAPITULO VIII - PRÁTICAS DE AVALIAÇ̃̃o DA QUALIDADE DO CUIDADO EM SAÚDE NOS CENTROS CIRÚRGICOS: UMA REVISÃO BIBLIOGRÁFICA. 98

CAPíTULO IX - ATUAÇ̃̃o DO ENFERMEIRO NA PREVENÇ̃̃o dA SíFILIS ADQUIRIDA NA ATENÇÃO PRIMÁRIA. 108

CAPíTULO X - REFLEXÃO SOBRE A TEORIA DAS RELAÇ̃̃ES INTERPESSOAIS DE HILDEGARD PEPLAU E A TEORIA DA ABORDAGEM CENTRADA NA PESSOA DE CARL ROGERS: IMPLICAÇ̃̃ES PARA A ENFERMAGEM .118

CAPÍTULO XI - DIAGNÓSTICO DE ENFERMAGEM SOFRIMENTO ESPIRITUAL PADRONIZAÇÃO E IMPLEMENTAÇÃO NA PRÁTICA CLÍNICA: REVISÃO INTEGRATIVA.

CAPÍTULO XII - LINGUAGEM BRASILEIRA DE SINAIS NA FORMAÇ̃̃O EM ENFERMAGEM: REFLETINDO CONCEITOS PARA RESSIGNIFICAR PRÁTICAS NA ASSISTÊNCIA À PARTURIIÇÃo 146

CAPÍTULO XIII- 0 ENSINO REMOTO NA FORMAÇ̃̃O EM ENFERMAGEM: DISCUTINDO ASPECTOS HISTÓRICOS PARA RESSIGNIFICAR PROCESSOS EM TEMPOS DE PANDEMIA. 163

CAPÍTULO XIV- ATIVIDADE FÍSICA NA QUALIDADE DE VIDA DE IDOSOS ATIVOS E SEDENTÁRIOS. 183

CAPÍTULO XV - EQUILÍBRIO ESTÁTICO E DINÂMICO EM IDOSOS INSTITUCIONALIZADOS: REVISÃO INTEGRATIVA ... 194

CAPITULO XVI - NIVEEL DE INDEPENDÊNCIA FUNCIONAL DE IDOSOS INSTITUCIONALIZADOS .208

CAPÍTULO XVII - RELAÇÕES ENTRE HABILIDADES MOTORAS FUNDAMENTAIS, FUNÇ̃̃ES EXECUTIVAS E DESEMPENHO ACADÊMICO EM CRIANÇAS .221

CAPÍTULO XVIII - ESTUDO DA FARMACOTERAPIA EM IDOSOS: REAC̄̃̃ES ADVERSAS E INTERAÇÕES MEDICAMENTOSAS 


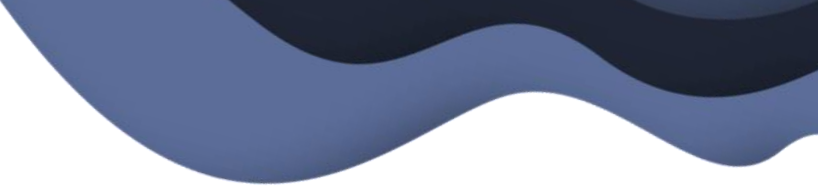

CAPÍTULO XIX - ANÁLISE DAS INTOXICAÇÕES EXÓGENAS REGISTRADAS PELO SISTEMA DE INFORMAÇÃO DE AGRAVOS DE NOTIFICAÇÃO NO DISTRITO FEDERAL NO PERÍODO DE 2015 A 2019 239

CAPÍTULO XX - A IMPORTÂNCIA EPIDEMIOLÓGICA DA MENINGITE BACTERIANA NO BRASIL 255

CAPÍTULO XXI - ESTUDO EPIDEMIOLÓGICO SOBRE INTERNAÇÕES POR ESCLEROSE MÚLTIPLA NO BRASIL COMPARANDO SEXO, FAIXA ETÁRIA E REGIÃO ENTRE JANEIRO DE 2008 A JUNHO DE 2019 269

CAPÍTULO XXII - ASPECTOS EPIDEMIOLÓGICOS DOS ACIDENTES OFÍDICOS NO MUNICÍPIO DE PORTO VELHO .281

CAPÍTULO XXIII - ANÁLISE FITOQUÍMICA E DO PERFIL DE ÁCIDOS GRAXOS DO ENDOSPERMA DE COCOS NUCIFERA L. USADO NA OBTENÇÃO DE ÓLEO: UMA REVISÃO NARRATIVA DA LITERATURA. 292

CAPÍTULO XXIV - EFEITO MICROBIOLÓGICO DE ÓLEOS ESSENCIAIS EM PRODUTO CÁRNEO PROCESSADO 299

CAPÍTULO XXV - A ADERÊNCIA DA VITAMINA A EM FORMULAÇÕES FARMACÊUTICAS E SUA IMPORTÂNCIA NO COMBATE AO ENVELHECIMENTO PRECOCE: UMA REVISÃO INTEGRATIVA 309

CAPÍTULO XXVI - DESENVOLVIMENTO DE LISTAS DE VERIFICAÇÃO COM OS PONTOS CRÍTICOS DE CONTAMINAÇÃO CRUZADA POR GLÚTEN - DO PLANTIO AO CONSUMO 322

CAPÍTULO XXVII - ESTUDO FOTOPROTETOR UTILIZANDO A FASE CLOROFÓRMICA DA ESPÉCIE RHAPHIODON ECHINUS (NESS \& MART.) SCHAUER. 340

CAPÍTULO XXVIII - ANÁLISE DAS TÉCNICAS ANATÔMICAS E DA APLICABILIDADE DA GLICERINAÇÃO COMO PROPOSTA DE SUBSTITUIÇÃO DO FORMOL

CAPÍTULO XXIX - ATAXIA DE FRIEDREICH: RELATO DE CASO DE IRMÃOS COM FENÓTIPOS CLÍNICOS DISCORDANTES

CAPÍTULO XXX - ACIDENTE VASCULAR CEREBRAL HEMORRÁGICO NAS ENTRELINHAS DA LITERATURA 373

CAPÍTULO XXXI - ESTADO DO CONHECIMENTO: LEPTOSPIROSE E SUA IMPORTÂNCIA ZOONÓTICA 385

CAPITULLO XXXII - POTENCIAL TRIPANOCIDA DE COMPOSTOS OBTIDOS DE ALGAS E CIANOBACTÉRIAS 402

CAPÍTULO XXXIIII - POLÍTICA NACIONAL DE SAÚDE INTEGRAL DA POPULAÇÃO NEGRA: (IN)VISIBILIDADE DE UMA AÇÃO ESTATAL

CAPÍTULO XXXIV - ERGONOMIA EM SALAS DE ECOGRAFIA: BOAS PRÁTICAS NO TRABALHO DO ULTRASSONOGRAFISTA 427

CAPÍTULO XXXV - SISTEMA CEREC NA ODONTOLOGIA: DA EVOLUÇÃO AOS DIAS ATUAIS. 441

CAPÍTULO XXXVI - REABILITAÇÃO ESTÉtICA E FUNCIONAL: UM RELATO DE CASO SOBRE CUIDADOS INTERDISCIPLINARES.

CAPÍTULO XXXVII - AFASTAMENTOS POR LER/DORT NO BRASIL: NECESSIDADE DE ATENÇ̃̃O INTEGRAL PARA A SAÚDE DO TRABALHADOR 461

CAPÍTULO XXXVIII - IMPACTO DO USO DE SMARTPHONE NA QUALIDADE DE VIDA E NO RISCO PARA NOMOFOBIA..471 


\section{CAPÍTULO I}

\section{OPINIÃO NÃO É ESTUDO! PRECISAMOS DE MAIS MEDICINA BASEADA EM EYDEANCIAS}

Wasim Aluísio Prates Syed. ${ }^{1}$

Artur Acelino Francisco Luz Nunes Queiroz ${ }^{2}$

Mariana Kiomy Osako. ${ }^{3}$

\footnotetext{
' Farmacêutico Bioquímico- Faculdade de Ciências Farmacêuticas da Universidade de São Paulo- USP. Ribeirão Preto.

${ }^{2}$ Mestre em Ciências, Escola de Enfermagem de Ribeirão Preto da USP.

${ }^{3}$ Professora doutora do departamento de Biologia Celular, Molecular e Bioagentes Patogênicos da Faculdade de Medicina de Ribeirão Preto da Universidade de São Paulo (FMRP-USP).
}

\section{RESUMO}

A medicina baseada em evidências (MBE) aplica o uso consciente, explícito e judicioso da melhor evidência atual para a tomada de decisão sobre o cuidar individual do paciente. Em outras palavras, a MBE é aquela que se baseia nas melhores evidências científicas disponíveis para conduzir a prática clínica, de forma que o paciente tenha o melhor diagnóstico e o melhor cuidado médico de forma racional. Quando avaliada por um profissional da saúde ou um pesquisador, sua experiência com o medicamento pode ser compartilhada na comunidade científica como um relato de caso, e se mais pacientes forem avaliados, como uma série de casos. O capítulo busca demonstrar a hierarquia das evidências para sistematizar essa hierarquia, criaram-se os chamados níveis de evidências, representados aqui em um funil, no qual os níveis mais simples e mais enviesados estão na entrada, e os níveis contendo evidências mais robustas e completas, no final.

Palavras-chave: BEM. Medicina baseada em Evidências. Hierarquia de evidências.

\section{INTRODUÇÃO}

Negligenciar, hoje, a força das evidências científicas é condenar o paciente ao acaso, e toda a estrutura de um sistema de saúde, ao fracasso. O que é medicina baseada em evidências? A medicina baseada em evidências (MBE) aplica o uso consciente, explícito e judicioso da melhor evidência atual para a tomada de decisão sobre o cuidado individual do paciente. (ATALLAH ; CASTRO, 1998).

Em outras palavras, a MBE é aquela que se baseia nas melhores evidências científicas disponíveis para conduzir a prática clínica, de forma que o paciente tenha o 
melhor diagnóstico e o melhor cuidado médico de forma racional. A MBE busca avaliar todas as opções de tratamento, por exemplo, nas condições que o paciente e a equipe médica se encontram. Dessa forma, a MBE almeja promover maior segurança e eficácia na prática clínica para o paciente.

\subsection{Como é o profissional que aplica a MBE?}

Imagine que você foi diagnosticado com COVID-19 e tem a opção de consultar dois médicos, um que prescreve cloroquina e azitromicina, e outro que receite, com muito cuidado, lopinavir e ritonavir. Em qual desses você confiaria?

É natural que confiemos em comportamentos autoritários e confiantes, e isso pode até fazer sentido, se essa autoridade apresentar seus argumentos de forma lógica e embasada, mas nenhum argumento baseado em autoridade ou retórica poderá salvar sua vida. Você pode não ter acesso aos estudos de cloroquina, azitromicina e à combinação lopinavir-ritonavir, mas o profissional que se baseia na MBE terá a conduta mais alinhada e atualizada com os bons estudos científicos para tratar o seu caso de COVID-19.

A MBE contempla que a medicina está sujeita a mudanças em vez de se basear em certezas irrefutáveis. É, também, sobre permitir que outros profissionais da saúde de pouca autoridade em relação ao médico mais "experiente" apresentem evidências que confrontam este ou quaisquer outras autoridades.

\section{REVISÃO BIBLIOGRÁFICA}

\subsection{HIERARQUIA DE EVIDÊNCIAS}

As evidências não estão todas em pé de igualdade: há evidências derivadas de estudos mais robustos e outras de estudos mais simples. Para sistematizar essa hierarquia, criaram-se os chamados níveis de evidências, representados aqui em um funil (Figura 1), no qual os níveis mais simples e mais enviesados estão na entrada, e os níveis contendo evidências mais robustas e completas, no final. 
Figura 1. Hierarquia das evidências

\title{
Hierarquia de evidências
}

\begin{abstract}
As evidências não estão todas em pé de igualdade: há evidências derivadas de estudos mais robustos e outras de estudos mais simples, como série de casos e até opiniões. Para sistematizar essa hierarquia, criaram-se os chamados níveis de evidências, representados aqui em um funil, no qual os níveis mais simples e mais enviesados estão no topo, e os níveis contendo evidências mais robustas e completas, na base. Essa hierarquia é definida, aqui, com base no sistema tradicional, proposto por Guyatt $\delta$ Sackett (1995). No entanto, não é o único. Um mais recente e completo pode ser encontrado no Center for Evidence-Based Medicine. Guyatt, G. H. (1995). Users' Guides to the Medical Literature. JAMA, 274(22), 1800. doi:10.1001/jama.1995.03530220066035
\end{abstract}

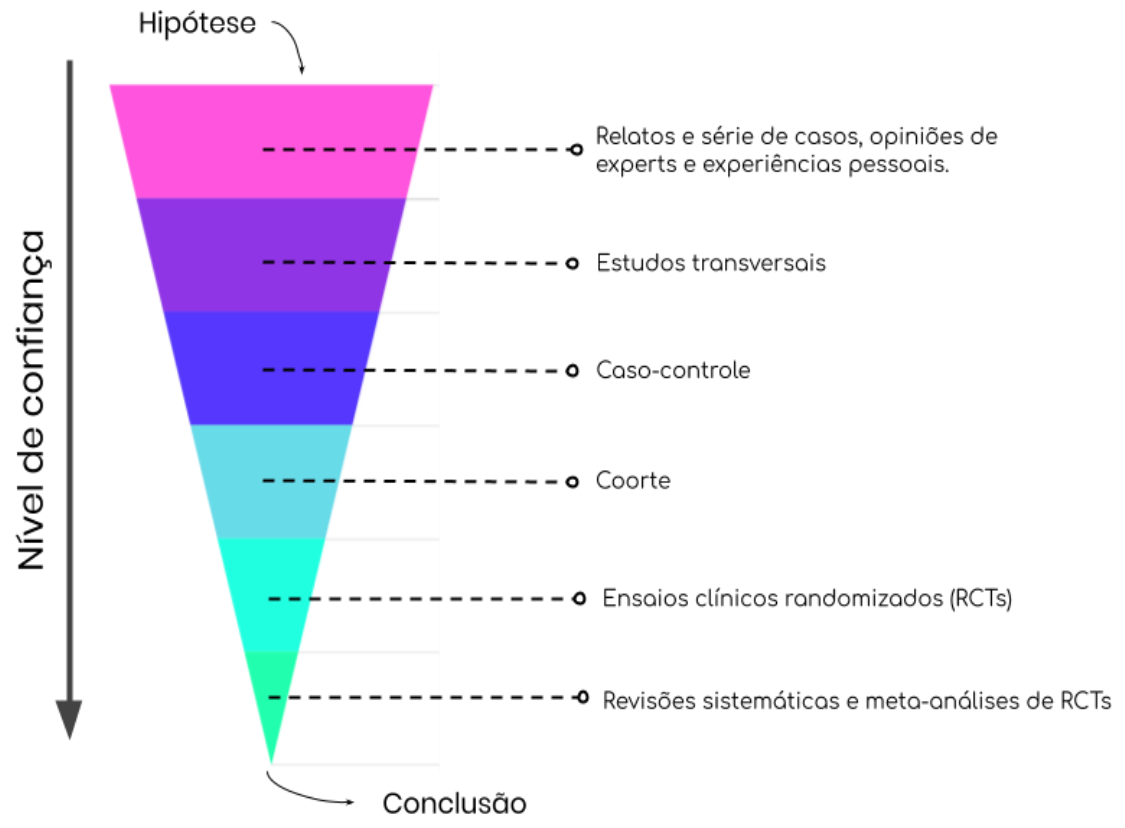

Com enviesados, me refiro a ser suscetível a uma opinião ou crença prévia, que não necessariamente corresponde à verdade, além de outros fatores de confusão que podem enfraquecer a evidência.

Essa hierarquia é definida, aqui, com base no sistema tradicional, proposto por (GUYATT ; SACKETT, 1995). No entanto, não é o único sistema. Perguntas diferentes exigem métodos diferentes de estudos - assim como não é possível realizar um estudo clínico para entender os sentimentos de um indivíduo, não podemos realizar uma série de entrevistas com médicos para determinar a melhor terapia contra, digamos, câncer de mama. Um dos sistemas mais recentes e completos pode ser encontrado no Center for Evidence-Based Medicine.

Em geral, as evidências obtidas nos níveis inferiores da pirâmide podem ser usadas para gerar hipóteses, que serão testadas e validadas nos níveis superiores.

As revisões sistemáticas de ensaios clínicos randomizados (ECRs; randomized clinical trials (ensaios clínicos randomizados) , RCTs, em inglês) placebo-controlados são 
consideradas padrão-ouro, mas nem sempre são bem conduzidas ou são possíveis de ser realizadas, por questões financeiras e até éticas.

Apesar de serem as mais desejadas na conclusão de uma hipótese, não significa que os níveis inferiores devam ser descartados, mas avaliados com cuidado antes dessas evidências serem usadas na prática por profissionais da saúde.

\subsection{RELATOS E SÉRIES DE CASOS, EXPERIÊNCIAS PESSOAIS E OPINIÕES DE EXPERTS}

Uma experiência pessoal sobre a utilização de um medicamento ou qualquer terapia são interessantes para compartilhar em fóruns de discussão. Quando avaliada por um profissional da saúde ou um pesquisador, sua experiência com o medicamento pode ser compartilhada na comunidade científica como um relato de caso, e se mais pacientes forem avaliados, como uma série de casos. Apesar de não serem úteis para estabelecer uma correlação causal definitiva para provar se uma terapia funciona ou não, séries de casos são interessantes muitas vezes para ensinar de graduação, relatar eventos adversos não descritos na literatura e gerar hipóteses e evidências que suportem estudos futuros mais complexos.

Portanto, as recomendações de uma prática médica têm pouca credibilidade quando são embasadas em relatos e experiências pessoais justamente por serem enviesadas, pouco objetivas e muitas vezes utilizam evidências já inválidas. Entretanto, a sangria, a Talidomida e os benzodiazepínicos também foram práticas aplicadas com base em opiniões de experts e provadas prejudiciais por evidências posteriores (KANG; PEDERSEN, 2008).

A seguir os autores supracitados apresentam os conceitos das práticas aplicadas com base em opiniões.

\subsubsection{SANGRIA}

A sangria era utilizada para qualquer doença aguda (inclusive hemorragia) e em 1820, foi provada como ineficaz e prejudicial, causando até a morte de Mozart e Lord Byron. 


\subsubsection{TALIDOMIDA}

A talidomida foi utilizada como anti emético (anti vômito) e sedativo em grávidas, de 1957 a 1960, quando provou-se que causava má-formação em bebês, acometendo mais de 8000 bebês em todo o mundo.

\subsubsection{BENZODIAZEPINICOS}

Por fim, os benzodiazepínicos (diazepam) foram usados para o tratamento de ansiedade e insônia desde os anos 90. Em 1975, provou-se que causavam dependência química, e em 1990, seu uso teve queda, sendo restrito a alguns grupos de pacientes.

\subsubsection{ESTUDOS TRANSVERSAIS}

Em estudos transversais, indivíduos de uma população são analisados, uma única vez, quanto à exposição a um agente biológico e ao desenvolvimento de uma doença, por exemplo.

Estes estudos são considerados observacionais e não permitem estabelecer uma relação de causa, somente uma relação de eventos. Apesar disso, são úteis para indicar investigações pelos níveis acima.

\subsubsection{CASO-CONTROLE}

Neste tipo de estudo, são selecionados dois grupos de pessoas, aquelas que têm uma doença e aquelas que não a têm. Ambas são comparadas de acordo com sua exposição a agentes tóxicos, por exemplo, ao longo de sua história. É considerado um estudo retrospectivo, porque busca estabelecer uma correlação entre a exposição durante um período da vida desses pacientes e o desenvolvimento de uma doença, no entanto não prova causalidade (A causou B).

É um tipo de estudo útil para responder a perguntas como:

"A vacina da coqueluche causa danos cerebrais?"

"Será que comer em uma pizzaria particular em um período específico causa hepatite $A$ ?"

"A vacina da coqueluche se relaciona com maior incidência de danos cerebrais?"

“Comer em pizzaria $\mathrm{X}$ em um período específico está relacionado com a incidência de hepatite A?" 


\subsubsection{ESTUDOS DE COORTE}

Em um estudo de coorte, 2 ou mais grupos de pessoas correspondentes a diferentes graus de exposição a medicamentos, doenças, cirurgias, comportamentos (tabagismo) ou agentes (radioativos) são selecionados. Os grupos são acompanhados ao longo do tempo para comparar os resultados de cada grupo. Diferente das RCTs, não se preocupam com o tratamento, mas com a etiologia da doença.

Um exemplo famoso é o estudo sobre a incidência de câncer em tabagistas, realizado por 10 anos e publicado em 1964. Neste tipo de estudo, a ideia não é necessariamente estabelecer uma relação causa-efeito ("fumar causa câncer", por exemplo), mas responder qual o risco adicional que aquele evento pode ter sobre um resultado esperado ("fumar aumenta as chances de câncer").

\subsubsection{ENSANOS CLINICOS RANDOMIZADOS}

Em um ensaio clínico randomizado (ECR) ou, em inglês, randomized clinical trial (RCT) prova-se o efeito de uma intervenção - medicamentosa ou não - aplicando-a e acompanhando dois ou mais grupos de pacientes com a mesma condição ou doença que se quer tratar.

Em um grupo, os pacientes recebem a terapia A, e no outro - o grupo controle —, outros pacientes receberam um placebo - uma pílula de amido, por exemplo - ou a terapia B com a qual se quer comparar. No entanto, devem ser duplo-cegos para minimizar o viés: nem o paciente, nem o pesquisador sabem quais pacientes receberão A ou B (ou placebo).

Nem sempre é possível e necessário realizar um estudo RCT, pois são caros ou não são aplicáveis para aquele fim.

\subsection{REVISÕES SISTEMÁTICAS DE RCTS E META-ANÁLISES}

As revisões sistemáticas dão um panorama dos estudos clínicos realizados para provar a eficácia ou não de uma terapia, geralmente utilizando estatística (metaanálise). Os estudos são selecionados de acordo com sua qualidade metodológica definida por critérios, filtrando os melhores estudos para análise final. Esse tipo de estudo tem alta relevância, visto que é completo e muito pouco enviesado. 


\subsubsection{ESTUDOS TAMBÉM PODEM SER MAL-FEITOS.}

Como visto, há uma hierarquia de evidências da qual podemos inferir sua confiabilidade. No entanto, todos os estudos estão sujeitos a erros metodológicos. Embora classificar uma pesquisa como boa ou ruim seja difícil, uma vez que é necessário uma análise criteriosa da sua metodologia, podemos selecionar com um pouco mais de confiança alguns tipos de estudos para pautar uma discussão mais séria. Para isso, recomendo o livro "How to read a paper: The Basics of Evidence-Based Medicine and Healthcare", de Trisha Greenhalgh.

\subsubsection{POLITICAS DE SAÚDE BASEADAS EM EVIDÊNCIAS}

A boa notícia é que políticas de saúde baseadas em evidências (PSBE) vêm se estruturando no mundo desde a década de 90 devido aos avanços na medicina baseada em evidências. Nelas, parte-se da premissa de que se a medicina deve se basear em evidências, então devem, também, as políticas em saúde.

Assim, investir em políticas de baixa eficácia no tratamento e prevenção da COVID19, por exemplo, como a compra de cloroquina e distribuição de medicamentos homeopáticos, não só traz perdas orçamentárias, mas resulta em mais mortes e infectados.

Evidências científicas também reduzem a influência de opiniões políticas nas decisões quanto à implantação de fármacos e tratamentos e evitam o favorecimento de determinados grupos econômicos.

Essa transparência nos custos e decisões que acompanha sua formulação garante também a igualdade e justiça social. Não por acaso, discute-se sua importância no sistema de saúde público de países como o Brasil (SUS) e o Reino Unido (NHS). Em sistemas públicos de saúde, nos quais o orçamento é estatal e nem sempre suficiente ainda que sejam um direito do cidadão -, as PSBE são um bem necessário para sua continuidade.

No entanto, nem sempre é possível encontrar revisões sistemáticas úteis para a implantação dessas políticas, e, não raro, algumas evidências compreendem somente países desenvolvidos ou aqueles que investiram nessas pesquisas, o que resulta em uma sub-representação dos dados. 
Um volume de evidências robusto requer não só a perspectiva médica, clínica, mas também econômica, social, política e cultural. Logo, o investimento em pesquisas nessas outras ciências garantem a amplitude de conhecimento necessária para a decisão na aplicação dessas PSBEs.

A implantação de PSBEs é dificultada por barreiras políticas complexas, que envolvem o corpo político do governo e a sociedade, e pela distância entre os agentes políticos e a comunidade acadêmica. Neste caso, amplia-se a atuação dos pesquisadores na sociedade: políticos não sabem pesquisar e pesquisadores não sabem fazer política, mas sem pesquisa e política, não há uma boa política pública em saúde baseada em evidências.

\subsubsection{ONDE ENCONTRAR INFORMAÇÕES SOBRE MBE?}

Se sua pergunta já está bem formulada e sabe quais tipos de estudos você precisa ler (RCT, coorte, séries de casos, etc.), então é hora de pesquisar. No entanto, a pesquisa também deve ser bem-feita e fora de uma simples pesquisa no Google, embora seja difícil com o volume imenso de publicações e a falta de prática.

Abaixo, listo alguns sites úteis para pesquisar.

- Oxford Centre for Evidence-Based Medicine;

- National Institute for Health and Care Excellence;

- National Health Service (NHS) Centre for Reviews and Dissemination;

- BMJ Best Practice;

- Cochrane

- Uptodate

\section{CONSIDERAÇÕES FINAIS}

Evidências científicas devem pautar a prática clínica. Confiar em evidências baseadas em relatos pessoais e opiniões de autoridades não pode nortear o tratamento de uma doença, especialmente quando esta é nova, como é o caso do novo coronavírus.

Erros do passado, como a sangria e o desastre da Talidomida, não podem ser repetidos e sabemos, a partir da gama de estudos existentes, quais outros erros podem ser evitados. Para isso, é necessário que os profissionais de saúde busquem sempre estar a par das melhores evidências científicas disponíveis. 
Ao promover e aplicar estudos de boa confiabilidade, seguindo a hierarquia de evidências proposta, e de boa qualidade, o profissional da saúde, no ambiente clínico, e os tomadores de decisão, na formulação de políticas públicas em saúde, poderão apresentar maiores garantias aos pacientes, cidadãos e governos. Negligenciar, hoje, a força das evidências científicas é condenar o paciente ao acaso, e toda a estrutura de um sistema de saúde, ao fracasso.

\section{REFERÊNCIAS}

ATALLAH AN, CASTRO AA. Evidências para melhores decisões clínicas. São Paulo, Centro Cochrane do Brasil; 1998.

GUYATT GH, SACKETT DL, COOK DJ. Users' guides to the medical literature. II. How to use an article about therapy or prevention. A. Are the results of the study valid? Evidence-Based Medicine Working Group. JAMA; 270:2598-2601.1993.

KANG, L; PEDERSEN, N. Quackery: a brief history of the worst ways to cure everything. Evidence-Based Public Health Policy V Lin, La Trobe University, Bundoora, Victoria, Australia, Elsevier, 2017. 


\title{
CAPÍTULO ॥
}

\section{CIANOBACTÉRIA ARTHROSPIRA PLATENSIS COMO FONIE DE PEPTÍDEOS ANTI-HIPERTENSIVO}

\author{
Andreza Pereira de Amorim ${ }^{1}$ \\ Yanara Alessandra Santana Moura ${ }^{2}$ \\ Gabrielly Hilário da Silva ${ }^{3}$ \\ Karoline Mirella Soares de Souza ${ }^{4}$ \\ Ana Lúcia Figueiredo Porto ${ }^{5}$ \\ Raquel Pedrosa Bezerra ${ }^{6}$
}

\begin{abstract}
${ }^{1}$ Graduanda do curso de Licenciatura em Ciências Biológicas. Universidade Federal Rural de Pernambuco- UFRPE
${ }^{2}$ Graduanda do curso de Bacharelado em Ciências Biológicas. Universidade Federal Rural de Pernambuco- UFRPE

${ }^{3}$ Mestranda em Biociência Animal. Programa de Pós-Graduação em Biociência Animal - UFRPE

${ }^{4}$ Doutoranda em Ciências Biológicas. Programa de Pós-Graduação em Ciências Biológicas - UFPE

5 Professora Titular do Departamento de Morfologia e Fisiologia Animal. Universidade Federal Rural de Pernambuco - UFRPE

${ }^{6}$ Professora Adjunto do Departamento de Morfologia e Fisiologia Animal. Universidade Federal Rural de Pernambuco - UFRPE
\end{abstract}

\section{RESUMO}

Peptídeos bioativos têm gerado numerosos benefícios à saúde humana. Em particular, os peptídeos inibidores da enzima conversora de angiotensina (iECA) têm mostrado atividade promissora para o controle da hipertensão, visto que essa enzima é uma das principais envolvidas no controle da pressão arterial. Fontes de origem animal, vegetal, e mais recentemente, os micro-organismos fotossintetizantes têm sido explorados para obtenção desses peptídeos. Um dos micro-organismos fotossintetizantes em destaque para obtenção de peptídeos inibidores da ECA (iECA) é a cianobactéria Arthrospira platensis, uma vez que em sua composição nutricional há alta quantidade de proteínas, podendo atingir até $70 \%$ do seu peso seco. Diante disso, este capítulo apresenta uma visão geral do potencial da $A$. platensis como uma fonte de peptídeos iECA.

Palavras-chave: Bioativos. Enzima conversora de angiotensina. Hipertensão. Inibidores.

\section{INTRODUÇÃO}

Peptídeos bioativos são fragmentos de proteínas, nos quais desempenham benefícios à saúde humana (RIZZELLO et al., 2017) e podem ser liberados por fermentação, hidrólise química ou enzimática (MANZANARES et al., 2015; MURRAY; FITZGERALD, R., 2007; NONGONIERMA; FITZGERALD, R. J., 2018). Diversas atividades já 
foram relatadas de peptídeos obtidos por hidrólise enzimática, tais como antioxidante (XIA et al., 2020), antimicrobiana (TANIGUCHI et al., 2020), anticoagulante e antihipertensiva (BEZERRA et al., 2019). Além disso, sabe-se que quando comparado com os medicamentos sintéticos, os peptídeos bioativos não se acumulam em órgãos específicos, podendo assim reduzir os efeitos colaterais causados pelos fármacos sintéticos (LORDAN; ROSS; STANTON, 2011).

Peptídeos bioativos têm sido uma alternativa para o tratamento de algumas doenças, como a hipertensão (PAN, S. et al., 2016; SHI et al., 2020). Nos últimos anos, a hipertensão tem atingido cerca de $24,1 \%$ da população brasileira, sendo ainda mais predominante no sexo feminino (MALTA et al., 2017). Além disso, contribui direta ou indiretamente para 50\% das mortes por doenças cardiovasculares (SCALA; MAGALHÃES; MACHADO, 2015). Vários estudos têm associado a inibição da enzima conversora de angiotensina (ECA, EC 3.4.15.1) como alvo para o tratamento da hipertensão, pois é uma das principais enzimas envolvidas no controle da pressão arterial (ZHENG, Y.; ZHANG, Yufeng; SAN, 2020).

Dessa forma, já foram isolados vários peptídeos inibidores da ECA (iECA) de proteínas derivadas de animais, plantas, fungos e micro-organismos fotossintetizantes, os quais incluem as algas e cianobactérias (SUGANYA et al., 2016). O uso de microorganismos fotossintetizantes para exploração desses peptídeos tem crescido nos últimos anos (PAN, S. et al., 2016; XIE et al., 2018), e tem se demostrado como uma alternativa de alto valor, visto que diversos estudos demostraram seus benefícios a saúde humana e animal (GALASSO et al., 2019).

Em particular, destaca-se a cianobactéria Arthrospira platensis como uma fonte potencial biotecnológico para produção de peptídeos anti-hipertensivo (ANEKTHANAKUL et al., 2019) por ser uma biomassa rica em proteínas, podendo chegar a $70 \%$ do seu peso seco, além de conter carboidratos, pigmentos, vitaminas e propriedades protetoras ao sistema cardiovascular, como a atividade oxidante, e reduzir a absorção de colesterol pelas células do intestino (NAGAOKA et al., 2005; VIRDIS et al., 2013). Nesse sentido, esse capítulo fornece uma revisão geral a respeito do potencial da A. platensis como uma fonte importante para produção de peptídeo iECA com atividade anti-hipertensivos. 


\section{REVISÃO BIBLIOGRÁFICA}

\subsection{HIPERTENSÃO}

A hipertensão é uma doença não transmissível, caracterizada pelos níveis da pressão arterial ser maior ou igual a140/90 mmHg (NOBRE; MION JUNIOR, 2016), que pode estar associada a outras doenças como diabetes e obesidade (VERDECCHIA; ANGELI; REBOLDI, 2018), sendo por sua vez considerada um fator de risco para diversas doenças cardiovasculares, no quais incluem o acidente vascular cerebral, coronariana, doença arterial, fibrilação atrial e doença vascular (CAPPUCCIO; MILLER, M. A., 2016).

A principal causa da hipertensão ainda está esclarecida, mas sabe-se que é uma doença silenciosa, detectada tardiamente e que geralmente não é controlada de forma adequada (VERDECCHIA; ANGELI; REBOLDI, 2018). No Brasil, é estimado que aproximadamente 32,5\% da população seja acometida pela hipertensão (MALACHIAS et al., 2016) e cerca de um bilhão em todo o mundo sendo, portanto, considerada uma das principais causas de morte e um problema de saúde pública (CHOW, 2013).

Alves \& Faerstein, (2016) e Marques et al. (2020) têm relatado que a desigualdade socioeconômica e baixa escolaridade têm sido fatores de risco para o desenvolvimento da hipertensão, visto que isso fortalece uma má alimentação, sedentarismo e baixo acesso ao serviço de saúde. Diante disso, mudanças no estilo de vida como controle de peso, redução e prevenção da ingestão excessiva de álcool, dieta com baixa ingestão de sal e carboidratos podem auxiliar na prevenção e no tratamento da hipertensão (SHEA et al., 2011; WHELTON et al., 2018). Além disso, sabe-se que a hipertensão possui relação direta com o aumento da idade, sendo mais frequente em pessoas acima dos 65 anos de idade (BURNIER, 2019). Isto porque, no decorrer dos anos, ocorrem alterações fisiológicas no organismo, que podem estar relacionadas com o sistema renina angiotensina aldosterona (SRAA), um dos principais sistemas envolvido no controle central e periférico da pressão arterial (MUÑOZ-DURANGO et al., 2016; RIET, TE et al., 2015).

Assim, a supressão do SRAA tem sido uma alternativa para controle da hipertensão, na qual pode ser realizada de forma medicamentosa a partir inibidores da ECA, enzima que está envolvida no SRAA (MUÑOZ-DURANGO et al., 2016; RIET, TE et al., 2015). No entanto, a adesão ao tratamento farmacológico ainda é considerada baixa 
entre os hipertensos, devido aos efeitos colaterais ocasionados pelos medicamentos sintéticos, levando assim um maior tempo de tratamento e consequentemente maior custo financeiro.

\subsection{SISTEMA RENINA ANGIOTENSINA ALDOSTERONA (SRAA)}

O sistema renina angiotensina aldosterona (SRAA) desempenha um papel importante no controle da pressão arterial, visto que mantém a estabilidade hemodinâmica (CHOUDHARY et al., 2017; KAPARIANOS; ARGYROPOULOU, 2011). Quando há diminuição da pressão arterial, a renina, uma enzima sintetizada e armazenada nas células justaglomerulares dos rins, atua na clivagem do angiotensinogênio, uma proteína presente no fígado que apresenta cerca de 118 aminoácidos. A clivagem dessa proteína resulta na formação da angiotensina I, que por sua vez é catalisada pela ação da ECA em angiotensina II, o principal peptídeo efetor deste sistema (HORIUCHI; IWANAMI; MOGI, 2012; MOLTZER et al., 2010; ZENNARO; RICKARD; BOULKROUN, 2013). A angiotensina II atua nos receptores AT1 promovendo a vasoconstrição dos vasos sanguíneos e na estimulação a liberação de aldosterona, um hormônio esteróide sintetizado na zona glomerulosa da glândula adrenal, que tem como ação a reabsorção de sódio e água, que como consequência eleva a pressão arterial (ALUKO, 2015; MURRAY; FITZGERALD, R., 2007).

A ECA é uma (dipeptidilcarboxipeptidase) zinco-protease, na qual pode variar de tamanho entre 130 e $170 \mathrm{kDa}$, isso porque está enzima apresenta em sua estrutura diferentes porções de carboidratos. Além disso, sabe-se que a mesma apresenta dois domínios, o domínio $\mathrm{N}$ e o domínio $\mathrm{C}$, no qual cada um tem um sítio ativo de ligação ao cofator (BERNSTEIN et al., 2013; METZGER et al., 2011). A ECA é expressa em diversos tecidos, sendo mais predominante nos pulmões, rins, testículos, duodeno e placenta (FITZGERALD et al., 2011; MURRAY; FITZGERALD, R., 2007). Além da conversão de angiotensina I em angiotensina II no SRAA, a ECA é responsável pela inativação catalítica da bradicinina, um hormônio que tem ação de vasodilatação, em que leva a diminuição da pressão arterial (JANG et al., 2011; PATEL et al., 2017).

Diante disso, sabe-se que uma alta atividade do SRAA pode promover doenças crônicas e agudas, na qual incluem a hipertensão (MCMANUS; CAULFIELD; WILLIAMS, B., 2012). Portanto, medicamentos que atuam suprimindo o SRAA têm sido utilizados 
para o controle da hipertensão, nos quais incluem diferentes classes como: bloqueadores dos receptores da angiotensina II, inibidores da renina e da ECA (GUANG et al., 2012).

Os iECA são os mais frequentemente utilizados para o controle da hipertensão, pois reduzem os níveis de angiotensina II circulante, reduzindo a pressão arterial e os riscos de desenvolvimento de outras doenças (BALTI et al., 2015; COOPER et al., 2006; KIM, S; IWAO, 2000; KOSTIS, W. J. et al., 2018). Porém, trabalhos têm mostrado os diversos efeitos colaterais promovidos por esse medicamento sintético, como angioedema, erupções cutâneas, malformação congênita, reações alérgicas e distúrbios no paladar (DENG et al., 2018; LIU, C. et al., 2018). Tratamentos alternativos têm sido estudadas para promover uma melhor abordagem terapêutica para os pacientes hipertensos (MINE, 2007), como por exemplo o uso de peptídeos bioativos, pois eles já demonstraram diversas atividades biológicas, tais como anti-hipertensiva, antimicrobianas, anticâncer e antioxidante. Além do mais, eles podem ser isolados a partir de diversas fontes naturais como plantas (DASKAYA-DIKMEN et al., 2017), e microorganismos fotossintetizantes (XIE et al., 2018).

\subsection{MICRO-ORGANISMOS FOTOSSINTETIZANTES COMO FONTE DE PEPTIDEOS IECA}

Os micro-organismos fotossintetizantes são seres unicelulares, cianobactérias e microalgas, que utilizam a luz como fonte de energia e podem ser encontrados em uma variedade de lugares, como águas residuais, doces e marinhas. Esses micro-organismos são capazes de produzir diferentes biomoléculas, tais como proteínas, carboidratos, lipídeos, carotenoides e vitaminas (ABO et al., 2019; KIURU et al., 2014; LOUREIRO et al., 2018).

Diversas aplicações desses micro-organismos em diferentes áreas da biotecnologia já foram relatadas (MAMO; MEKONNEN, 2020). Por exemplo, microalgas como Nannochloropsis oculata e Scenedesmus spp podem ser utilizadas para produção de biocombustíveis (LI, K. et al., 2019), e outras espécies podem ser usadas no tratamento de águas residuais. Enquanto gêneros da Chlorella e Arthropira são frequentemente utilizadas como suplemento alimentar (BITO et al., 2020; LAFARGA et al., 2020) e fontes de peptídeos bioativos (RIZZELLO et al., 2017). Peptídeos bioativos de 
micro-organismos fotossintetizante apresentam diversas atividades bioativas tais como: anticâncer, antioxidante, anti-inflamatório (SUH et al., 2018) e anti-hipertensivo, sendo assim consideradas fontes promissoras (SAMARAKOON et al., 2013; XIE et al., 2018).

Nos últimos anos, a produção de peptídeos anti-hipertensivos com mecanismo de inibição da ECA foi explorada a partir de algumas espécies de microalgas e cianobactérias. Peptídeos iECA purificados a partir de espécies como Chlorella vulgaris e C. ellipsiodea promoveram inibição significativa da ECA (KO, S.-C. et al., 2012; XIE et al., 2018). Samarakoon et al. (2013) purificou dois peptídeos inibidores da ECA (GlyMet-Asn-Asn-Leu-Thr-Pro e Leu-Glu-GIn) a partir do hidrolisados de proteínas da microalga N. oculata, e Lin et al. (2018) obteve duas sequências peptídicas (Trp-Val, ValTrp, Ile-Trp, and Leu-Trp) derivadas da C. sorokiniana. Além disso, estudos in silico demostraram que peptídeos derivados da $C$. vulgaris não apresentam efeitos tóxicos (XIE et al., 2018) ao contrário dos medicamentos sintéticos que apresentam efeitos colaterais

\subsection{ARTHROSPIRA PLATENSIS}

Arthrospira platensis também conhecida como "Spirulina" é uma cianobactéria filamentosa que se reproduz por fissão binária, apresenta um rápido crescimento e tem uma excelente capacidade de tolerar altos valores de $\mathrm{pH}$. Além de ser facilmente cultivada, podendo ser através de diferentes sistemas, como tanque aberto, fotobiorreatores fechados (tubulares ou em placas). Outro fator interessante é ela apresenta uma parede celular formada por celulose, na qual facilita a extração dos seus componentes intracelular (FARAG et al., 2015; LUPATINI et al., 2017).

Devido ao seu alto valor nutricional, a biomassa é comercializada como como aditivo em cosméticos e como suplemento alimentar em humanos e animais, sendo considerada um alimento seguro pela "The European Food Safety Authority" (EFSA) e "Food and Drug Administration" (FDS) (VIRDIS et al., 2013) e tem sido promissora na produção de fármacos. Diversos autores relataram a variedade de efeitos benéficos dessa cianobactéria para a saúde humana. (BRITO et al., 2018) relataram propriedades antioxidantes da $A$. platensis nas quais ajudam a diminuir os riscos de doenças cardiovasculares (PAN, H. et al., 2015; ZHENG, J. et al., 2017). 
Recentemente, peptídeos com atividade iECA foram identificados a partir das proteínas da $A$. platensis por análises in silico e demostraram ter potencial para inibir $50 \%$ da ECA nas concentrações de 1,748 mM, além de não apresentarem efeitos tóxicos para fibroblastos do rim de macaco e pele humana (ANEKTHANAKUL et al., 2019). Da mesma forma, Wang et al. (2021) verificaram in silico que peptídeos iECA produzidos a partir da hidrólise da A. platensis por pepsina não eram tóxicos e nem alergênicos, diferente dos resultados obtidos do estudo de Garcia-Vaquero et al. (2019) em que algumas sequências peptídicas iECA da macroalga Ulva $s p$ podem ter a capacidade alergênica, bem como os hidrolisados do feijão, que apesar de ter atividade iECA in vitro, apresentaram efeitos tóxicos in silico, sendo inviável a sua aplicação em animais (CHAY et al., 2018). Dessa forma, a A. platensis tem se destacado para sua inserção como alimento nutracêutico, devido ser uma fonte segura, visto que a não alergenecidade dos peptídeos é um fator importante, pois caso ao contrario podem provocar reações adversas comprometendo sistemas como circulatório e nervoso (VALENTA et al., 2015).

Os peptídeos iECA podem ser gerados in vitro por de diversas condições enzimáticas (DASKAYA-DIKMEN et al., 2017), no entanto, ainda há poucos estudos que tenham produzidos esses peptídeos a partir da A. platensis. Wang et al. (2020) mostraram que entre diferentes enzimas (tripsina, pepsina, papaína, alcalase, neutrase e flavourzyme), a pepsina promovia o peptídeo com a sequência Pro-Thr-Gly-Asn-ProLeu-Ser-Pro com o menor valor de $\mathrm{IC}_{50}(1,54 \mathrm{mg} / \mathrm{mL})$. Isso pode estar relacionado com a especificidade da pepsina na clivagem de aminoácidos aromáticos, nos quais proporcionam maior grau de inibição da ECA (SORNWATANA et al., 2015). A digestão gástrica simulada foi utilizada para avaliação da resistência e estabilidade desse peptídeo frente a enzimas gastrointestinal, e atividade iECA do peptídeo Pro-Thr-GlyAsn-Pro-Leu-Ser-Pro não sofreu diferenças significativas, assim como quando foram avaliados em diferentes valores de temperatura e pH (WANG, K. et al., 2021).

Suetsuna \& Chen, (2001) também hidrolisou as proteínas da A. platensis por pepsina, no entanto, eles identificaram cinco peptídeos iECA diferentes com sequência de Ile-Ala-Glu, Phe-Ala-Leu, Ala-Glu-Leu, Ile-Ala-Pro-Gly e Val-Ala-Phe, sendo entre esses o menor valor de IC50 encontrando no tretapeptideo Ile-Ala-Pro-Gly (IC50 de 11,4 $\mu \mathrm{M})$, na qual isto pode estar relacionando com a composição de aminoácidos. Além disso, eles administraram in vivo uma fração peptídica, e obteve resultados promissores e 
superiores quando comparado com outras microalgas. Por exemplo, em seu estudo, uma fração péptica $A$. platensis foi capaz de reduzir $39,5 \mathrm{mmHg}$ em 2 horas, e o efeito anti-hipertensivo continuou por 4 horas. Em contraste, o peptídeo iECA derivado da microalga C. ellipsoidea reduziu $22.8 \mathrm{~mm} \mathrm{Hg}$ da pressão arterial após 4 horas (KO et al., 2012). Portanto, a A. platensis pode ser considerada uma potencial fonte para o desenvolvimento de produtos farmacêuticos para o controle da pressão arterial.

Por outro lado, um tripeptídeo (Ile-Gln-Pro) obtido dos hidrolisados da $S$. platensis por alcalase, apresentou um valor de IC 50 de $5.77 \mu \mathrm{M}$ (LU, J. et al., 2010), sendo essa atividade superior quando comparado com estudos anteriores que utilizaram fontes diferentes e até mesmo outros micro-organismos fotossintetizantes (KO, S.-C. et al., 2012; LIU, P. et al., 2019). He et al. (2018) demostraram que o peptídeo lle-Gln-Pro não era tóxico para células do intestino (Caco-2) nas concentrações de 1 a $5 \mu \mathrm{M}$, bem como eram absorvidos com sucesso por essas células. Além disso, há evidências que esse peptídeo é capaz de reduzir a expressão dos componentes do SRAA e exibir efeitos in vivo em ratos espontaneamente hipertensos durante uma semana (LU, J. et al., 2011). Esses resultados são bastantes promissores, pois é importante que os peptídeos sejam absorvidos intactos para que possam apresentar atividade iECA (JAO; HUANG, S.-L.; HSU, 2012). Com base nesses estudos anteriores, a A. platensis tem sido uma fonte promissora para obtenção dos peptídeos iECA a partir de diferentes enzimas. No entanto, é necessárias maiores explorações dessa cianobactéria como fonte alternativa.

\section{CONSIDERAÇÕES FINAIS}

A cianobactéria $A$. platensis apresenta uma variedade de benefícios à saúde humana e tem sido uma potencial fonte para exploração de peptídeos iECA, devido à sua rica composição de proteínas. Alguns estudos já demostraram que é possível obter esses peptídeos a partir de hidrolise enzimática com resultados promissores, tanto in vitro quanto in vivo. Além disso, há evidencias, in silico, que seus peptídeos não apresentam efeitos tóxicos nem alergênicos, indicando, portanto, que a A. platensis pode ser útil na produção de anti-hipertensivos. No entanto, os estudos a respeito das características desses peptídeos a partir de microalgas e cianobactérias ainda são escassos, quando comparados com outras fontes. Portanto, são necessárias maiores 
explorações para que possam ser compreendidas suas características e, assim, serem utilizados como possíveis anti-hipertensivos, visto que há uma demanda crescente na busca de alternativas para o controle da hipertensão, devido aos efeitos adversos provocados pelos iECA sintéticos.

\section{AGRADECIMENTOS}

Os autores agradecem à Fundação de Amparo à Ciência e Tecnologia do Estado de Pernambuco (FACEPE) (BIC-0033-2.08/20; APQ-0252-5.07/14), a Coordenação de Aperfeiçoamento de Pessoal de Nível Superior (CAPES) (Código de processo 88887.785013 / 2020-00, Código Financeiro 001) e ao Conselho Nacional de Desenvolvimento e Cientifico e Tecnológico (CNPq) pelo auxílio financeiro e pelas bolsas concedidas.

\section{REFERÊNCIAS}

ABO, B. O. et al. Microalgae to biofuels production: a review on cultivation, application and renewable energy. Reviews on Environmental Health, 26 Mar. 2019. v. 34, n. 1, p. 91-99.

ALUKO, R. E. Structure and function of plant protein-derived antihypertensive peptides. Current Opinion in Food Science, Aug. 2015. v. 4.

ALVES, R. F. S.; FAERSTEIN, E. Educational inequalities in hypertension: complex patterns in intersections with gender and race in Brazil. International Journal for Equity in Health, 17 Dec. 2016. v. 15, n. 1, p. 146.

ANEKTHANAKUL, K. et al. Natural ACE inhibitory peptides discovery from Spirulina (Arthrospira platensis) strain C1. Peptides, Aug. 2019. v. 118, p. 170107.

BALTI, R. et al. Nine novel angiotensin I-converting enzyme (ACE) inhibitory peptides from cuttlefish (Sepia officinalis) muscle protein hydrolysates and antihypertensive effect of the potent active peptide in spontaneously hypertensive rats. Food Chemistry, Mar. 2015. v. 170, p. 519-525.

BECKER, E. W. Micro-algae as a source of protein. Biotechnology Advances, Mar. 2007. v. 25 , n. 2, p. 207-210.

BERNSTEIN, K. E. et al. A Modern Understanding of the Traditional and Nontraditional Biological Functions of Angiotensin-Converting Enzyme. Pharmacological Reviews, Jan. 2013. v. 65, n. 1. 
BEZERRA, T. K. A. et al. Identification of Angiotensin I-Converting Enzyme-Inhibitory and Anticoagulant Peptides from Enzymatic Hydrolysates of Chicken Combs and Wattles. Journal of Medicinal Food, 1 Dec. 2019. v. 22, n. 12, p. 1294-1300.

BITO, T. et al. Potential of Chlorella as a Dietary Supplement to Promote Human Health. Nutrients, 20 Aug. 2020. v. 12, n. 9.

BRITO, A. De F. et al. Aortic Response to Strength Training and Spirulina platensis Dependent on Nitric Oxide and Antioxidants. Frontiers in Physiology, 31 Oct. 2018. v. 9.

BURNIER, M. Treatment of hypertension in the elderly in 2017/2018 - what's new? Expert Opinion on Pharmacotherapy, 13 Oct. 2019. v. 20, n. 15.

CAPPUCCIO, F. P.; MILLER, M. A. Cardiovascular disease and hypertension in subSaharan Africa: burden, risk and interventions. Internal and Emergency Medicine, 21 Apr. 2016. v. 11, n. 3, p. 299-305.

CHAY, S. Y. et al. Blood-pressure lowering efficacy of winged bean seed hydrolysate in spontaneously hypertensive rats, peptide characterization and a toxicity study in Sprague-Dawley rats. Food \& Function, 2018. v. 9, n. 3.

CHOUDHARY, R. et al. Therapeutic targets of renin-angiotensin system in ocular disorders. Journal of Current Ophthalmology, Mar. 2017. v. 29, n. 1.

CHOW, C. K. Prevalence, Awareness, Treatment, and Control of Hypertension in Rural and Urban Communities in High-, Middle-, and Low-Income Countries. JAMA, 4 Sep. 2013. v. 310, n. 9, p. 959.

COOPER, W. O. et al. Major Congenital Malformations after First-Trimester Exposure to ACE Inhibitors. New England Journal of Medicine, 8 Jun. 2006. v. 354, n. 23, p. 2443-2451.

DASKAYA-DIKMEN, C. et al. Angiotensin-I-Converting Enzyme (ACE)-Inhibitory Peptides from Plants. Nutrients, 23 Mar. 2017. v. 9, n. 4, p. 316.

DENG, Z. et al. Antihypertensive Effects of Two Novel Angiotensin I-Converting Enzyme (ACE) Inhibitory Peptides from Gracilariopsis lemaneiformis (Rhodophyta) in Spontaneously Hypertensive Rats (SHRs). Marine Drugs, 27 Aug. 2018. v. 16, n. 9, p. 299.

FARAG, M. R. et al. Nutritional and Healthical Aspects of Spirulina (Arthrospira) for Poultry, Animals and Human. International Journal of Pharmacology, 15 Dec. 2015. v. 12, n. 1, p. 36-51.

FITZGERALD, C. et al. Heart Health Peptides from Macroalgae and Their Potential Use in Functional Foods. Journal of Agricultural and Food Chemistry, 13 Jul. 2011. v. 59, n. 13, p. 6829-6836. 
GALASSO, C. et al. Microalgal Derivatives as Potential Nutraceutical and Food Supplements for Human Health: A Focus on Cancer Prevention and Interception. Nutrients, 29 May. 2019. v. 11, n. 6.

GARCIA-VAQUERO, M.; MORA, L.; HAYES, M. In Vitro and In Silico Approaches to Generating and Identifying Angiotensin-Converting Enzyme I Inhibitory Peptides from Green Macroalga Ulva lactuca. Marine Drugs, 30 Mar. 2019. v. 17, n. 4.

GUANG, C. et al. Three key proteases - angiotensin-l-converting enzyme (ACE), ACE2 and renin - within and beyond the renin-angiotensin system. Archives of Cardiovascular Diseases, Jun. 2012. v. 105, n. 6-7, p. 373-385.

HE, Y.-Y. et al. Transport of ACE Inhibitory Peptides Ile-GIn-Pro and Val-Glu-Pro Derived from Spirulina platensis Across Caco-2 Monolayers. Journal of Food Science, Oct. 2018. v. 83, n. 10.

HORIUCHI, M.; IWANAMI, J.; MOGI, M. Regulation of angiotensin II receptors beyond the classical pathway. Clinical Science, 1 Aug. 2012. v. 123, n. 4, p. 193-203.

JANG, J.-H. et al. Characterisation of a new antihypertensive angiotensin I-converting enzyme inhibitory peptide from Pleurotus cornucopiae. Food Chemistry, Jul. 2011. v. 127, n. 2.

JAO, C.-L.; HUANG, S.-L.; HSU, K.-C. Angiotensin I-converting enzyme inhibitory peptides: Inhibition mode, bioavailability, and antihypertensive effects. BioMedicine, Dec. 2012. v. 2, n. 4.

KAPARIANOS, A.; ARGYROPOULOU, E. Local Renin-Angiotensin II Systems, AngiotensinConverting Enzyme and its Homologue ACE2: Their Potential Role in the Pathogenesis of Chronic Obstructive Pulmonary Diseases, Pulmonary Hypertension and Acute Respiratory Distress Syndrome. Current Medicinal Chemistry, 1 Aug. 2011. v. 18, n. 23.

$\mathrm{KIM}, \mathrm{S}$; IWAO, H. Molecular and cellular mechanisms of angiotensin II-mediated cardiovascular and renal diseases. Pharmacol Rev., 2000.

KIURU, P. et al. Exploring Marine Resources for Bioactive Compounds. Planta Medica, 9 Sep. 2014. v. 80, n. 14, p. 1234-1246.

KO, S.-C. et al. A novel angiotensin I-converting enzyme (ACE) inhibitory peptide from a marine Chlorella ellipsoidea and its antihypertensive effect in spontaneously hypertensive rats. Process Biochemistry, Dec. 2012. v. 47, n. 12, p. 2005-2011.

KOSTIS, W. J. et al. ACE Inhibitor-Induced Angioedema: a Review. Current Hypertension Reports, 8 Jul. 2018. v. 20, n. 7, p. 55.

LAFARGA, T. et al. Spirulina for the food and functional food industries. Food Research International, Nov. 2020. v. 137, p. 109356. 
LI, K. et al. Microalgae-based wastewater treatment for nutrients recovery: A review. Bioresource Technology, Nov. 2019. v. 291, p. 121934.

LIN, Y.-H. et al. Purification and Identification of Angiotensin I-Converting Enzyme Inhibitory Peptides and the Antihypertensive Effect of Chlorella sorokiniana Protein Hydrolysates. Nutrients, 1 Oct. 2018. v. 10, n. 10, p. 1397.

LIU, C. et al. Exploration of the molecular interactions between angiotensin-I-converting enzyme (ACE) and the inhibitory peptides derived from hazelnut (Corylus heterophylla Fisch.). Food Chemistry, Apr. 2018. v. 245, p. 471-480.

LIU, P. et al. Purification, Characterization and Evaluation of Inhibitory Mechanism of ACE Inhibitory Peptides from Pearl Oyster (Pinctada fucata martensii) Meat Protein Hydrolysate. Marine Drugs, 8 Aug. 2019. v. 17, n. 8.

LORDAN, S.; ROSS, R. P.; STANTON, C. Marine Bioactives as Functional Food Ingredients: Potential to Reduce the Incidence of Chronic Diseases. Marine Drugs, 14 Jun. 2011. v. 9, n. 6, p. 1056-1100.

LOUREIRO, C. et al. Exploration and exploitation of the environment for novel specialized metabolites. Current Opinion in Biotechnology, Apr. 2018. v. 50, p. 206-213.

LU, J. et al. Isolation of an Antihypertensive Peptide from Alcalase Digest of Spirulina platensis. Journal of Agricultural and Food Chemistry, 23 Jun. 2010. v. 58, n. 12.

et al. One-Week Antihypertensive Effect of Ile-Gln-Pro in Spontaneously Hypertensive Rats. Journal of Agricultural and Food Chemistry, 26 Jan. 2011. v. 59, n. 2.

LUPATINI, A. L. et al. Potential application of microalga Spirulina platensis as a protein source. Journal of the Science of Food and Agriculture, Feb. 2017. v. 97, n. 3, p. 724-732.

MALACHIAS, M. et al. Capítulo 1 - Conceituação, Epidemiologia e Prevenção Primária. Arquivos Brasileiros de Cardiologia, 2016. v. 107, n. 3.

MALTA, D. C. et al. Prevalence of and factors associated with self-reported high blood pressure in Brazilian adults. Revista de Saúde Pública, 2017. v. 51, n. suppl 1.

MAMO, T. T.; MEKONNEN, Y. S. Microwave-Assisted Biodiesel Production from Microalgae, Scenedesmus Species, Using Goat Bone-Made Nano-catalyst. Applied Biochemistry and Biotechnology, 11 Apr. 2020. v. 190, n. 4, p. 11471162.

MANZANARES, P. et al. Unraveling the mechanisms of action of lactoferrin-derived antihypertensive peptides: ACE inhibition and beyond. Food \& Function, 2015. v. 6, n. 8 , p. $2440-2452$. 
MARQUES, A. P. et al. Fatores associados à hipertensão arterial: uma revisão sistemática. Ciência \& Saúde Coletiva, Jun. 2020. v. 25, n. 6, p. 2271-2282.

MAS-CAPDEVILA, A. et al. Dose-Related Antihypertensive Properties and the Corresponding Mechanisms of a Chicken Foot Hydrolysate in Hypertensive Rats. Nutrients, 12 Sep. 2018. v. 10, n. 9, p. 1295.

MCMANUS, R. J.; CAULFIELD, M.; WILLIAMS, B. NICE hypertension guideline 2011: evidence based evolution. BMJ, 13 Jan. 2012. v. 344, n. jan13 1, p. e181-e181.

METZGER, R. et al. Heterogeneous distribution of angiotensin I-converting enzyme (CD143) in the human and rat vascular systems: Vessel, organ and species specificity. Microvascular Research, Mar. 2011. v. 81, n. 2.

MINE, Y. Egg Proteins and Peptides in Human Health-Chemistry, Bioactivity and Production. Current Pharmaceutical Design, 1 Mar. 2007. v. 13, n. 9.

MOLTZER, E. et al. Effects of Angiotensin Metabolites in the Coronary Vascular Bed of the Spontaneously Hypertensive Rat. Hypertension, Feb. 2010. v. 55, n. 2, p. 516-522.

MUÑOZ-DURANGO, N. et al. Role of the Renin-Angiotensin-Aldosterone System beyond Blood Pressure Regulation: Molecular and Cellular Mechanisms Involved in EndOrgan Damage during Arterial Hypertension. International Journal of Molecular Sciences, 23 Jun. 2016. v. 17, n. 7.

MURRAY, B.; FITZGERALD, R. Angiotensin Converting Enzyme Inhibitory Peptides Derived from Food Proteins: Biochemistry, Bioactivity and Production. Current Pharmaceutical Design, 1 Mar. 2007. v. 13, n. 8.

NAGAOKA, S. et al. A Novel Protein C-Phycocyanin Plays a Crucial Role in the Hypocholesterolemic Action of Spirulina platensis Concentrate in Rats. The Journal of Nutrition, 1 Oct. 2005. v. 135, n. 10, p. 2425-2430.

NOBRE, F.; MION JUNIOR, D. Ambulatory Blood Pressure Monitoring: Five Decades of More Light and Less Shadows. Arquivos Brasileiros de Cardiologia, 2016.

NONGONIERMA, A. B.; FITZGERALD, R. J. Enhancing bioactive peptide release and identification using targeted enzymatic hydrolysis of milk proteins. Analytical and Bioanalytical Chemistry, 19 Jun. 2018. v. 410, n. 15, p. 3407-3423.

PAN, H. et al. Long-Term Regulation of the Local Renin-Angiotensin System in the Myocardium of Spontaneously Hypertensive Rats by Feeding Bioactive Peptides Derived from Spirulina platensis. Journal of Agricultural and Food Chemistry, 9 Sep. 2015. v. 63, n. 35, p. 7765-7774.

PAN, S. et al. Purification and characterisation of a novel angiotensin-I converting enzyme (ACE)-inhibitory peptide derived from the enzymatic hydrolysate of Enteromorpha clathrata protein. Food Chemistry, Nov. 2016. v. 211, p. 423-430. 
PATEL, S. et al. Renin-angiotensin-aldosterone (RAAS): The ubiquitous system for homeostasis and pathologies. Biomedicine \& Pharmacotherapy, Oct. 2017. v. 94, p. 317-325.

RIET, L. TE et al. Hypertension. Circulation Research, 13 Mar. 2015. v. 116, n. 6.

RIZZELLO, C. G. et al. Improving the antioxidant properties of quinoa flour through fermentation with selected autochthonous lactic acid bacteria. International Journal of Food Microbiology, Jan. 2017. v. 241, p. 252-261.

SAMARAKOON, K. W. et al. Purification and identification of novel angiotensin-I converting enzyme (ACE) inhibitory peptides from cultured marine microalgae (Nannochloropsis oculata) protein hydrolysate. Journal of Applied Phycology, 1 Oct. 2013. v. 25, n. 5, p. 1595-1606.

SCALA, L. C.; MAGALHÃES, L. B.; MACHADO, A. Epidemiologia da hipertensão arterial sistêmica. 2. ed. São Paulo: Livro Texto da Sociedade Brasileira de Cardiologia., 2015.

SHEA, M. K. et al. The effect of intentional weight loss on all-cause mortality in older adults: results of a randomized controlled weight-loss trial. American Journal of Clinical Nutrition, 1 Sep. 2011. v. 94, n. 3, p. 839-846.

SHI, J. et al. Purification and the secondary structure of a novel angiotensin I-converting enzyme (ACE) inhibitory peptide from the alcalase hydrolysate of seahorse protein. Journal of Food Science and Technology, 15 Nov. 2020. v. 57, n. 11, p. 3927-3934.

SORNWATANA, T. et al. Chebulin: Terminalia chebula Retz. fruit-derived peptide with angiotensin-I-converting enzyme inhibitory activity. Biotechnology and Applied Biochemistry, Nov. 2015. v. 62, n. 6.

SUETSUNA, K.; CHEN, J.-R. Identification of Antihypertensive Peptides from Peptic Digest of Two Microalgae, Chlorella vulgaris and Spirulina platensis. Marine Biotechnology, 1 Jul. 2001. v. 3, n. 4.

SUGANYA, T. et al. Macroalgae and microalgae as a potential source for commercial applications along with biofuels production: A biorefinery approach. Renewable and Sustainable Energy Reviews, Mar. 2016. v. 55, p. 909-941.

SUH, S.-S. et al. Anti-inflammation and Anti-Cancer Activity of Ethanol Extract of Antarctic Freshwater Microalga, Micractinium sp. International Journal of Medical Sciences, 2018. v. 15, n. 9, p. 929-936.

TANIGUCHI, M. et al. Identification and characterization of multifunctional cationic peptides from enzymatic hydrolysates of soybean proteins. Journal of Bioscience and Bioengineering, Jan. 2020. v. 129, n. 1, p. 59-66.

VALENTA, R. et al. Food Allergies: The Basics. Gastroenterology, May. 2015. v. 148, n. 6. 
VERDECCHIA, P.; ANGELI, F.; REBOLDI, G. Hypertension and Atrial Fibrillation. Circulation Research, 19 Jan. 2018. v. 122, n. 2, p. 352-368.

VIRDIS, A. et al. Microvascular Endothelial Dysfunction in Obesity and Hypertension. Current Pharmaceutical Design, 1 Mar. 2013. v. 19, n. 13, p. 2382-2389.

WANG, K. et al. Novel antioxidant and ACE inhibitory peptide identified from Arthrospira platensis protein and stability against thermal/pH treatments and simulated gastrointestinal digestion. Food Research International, 1 Jan. 2021. v. 139.

$\begin{array}{lllll}\text { WHELTON, } & \text { P. } & \text { K. } & \text { et } & \text { al. }\end{array}$ ACC/AHA/AAPA/ABC/ACPM/AGS/APhA/ASH/ASPC/NMA/PCNA Guideline for the Prevention, Detection, Evaluation, and Management of High Blood Pressure in Adults: Executive Summary: A Report of the American College of Cardiology/American Heart Association Task Force on Clinical Practice Guidelines. Hypertension, Jun. 2018. v. 71, n. 6, p. 1269-1324.

$\mathrm{XIA}$, J. et al. Purification and characterization of antioxidant peptides from enzymatic hydrolysate of mungbean protein. Journal of Food Science, 29 Jun. 2020. v. 85, n. 6, p. $1735-1741$.

XIE, J. et al. Antihypertensive Effects, Molecular Docking Study, and Isothermal Titration Calorimetry Assay of Angiotensin I-Converting Enzyme Inhibitory Peptides from Chlorella vulgaris. Journal of Agricultural and Food Chemistry, 14 Feb. 2018. v. 66, n. 6, p. 1359-1368.

ZENNARO, M.-C.; RICKARD, A. J.; BOULKROUN, S. Genetics in endocrinology: Genetics of mineralocorticoid excess: an update for clinicians. European Journal of Endocrinology, Jul. 2013. v. 169, n. 1, p. R15-R25.

ZHENG, J. et al. Effects of IQP, VEP and Spirulina platensis hydrolysates on the local kidney renin angiotensin system in spontaneously hypertensive rats. Molecular Medicine Reports, Dec. 2017. v. 16, n. 6, p. 8485-8492.

ZHENG, Y.; ZHANG, Yufeng; SAN, S. Efficacy of a Novel ACE-Inhibitory Peptide from Sargassum maclurei in Hypertension and Reduction of Intracellular Endothelin1. Nutrients, 28 Feb. 2020. v. 12, n. 3, p. 653. 


\title{
CAPITULO III
}

\section{EFETIOS ADVERSOS DO USO INDISCRIMINADO DE ANIIIROMBÓTCOS NO TRATAMENTO PROFIĹTICO EM PUÉRPERAS: UMA REVISÃO INTEGRATIVA}

\author{
Alexia Floriano Rodrigues da Silva ${ }^{1}$ \\ Ana Carolina Tubaldini Vilela ${ }^{1}$ \\ André Ribeiro Alexandre ${ }^{1}$ \\ Gabriela Rodrigues Rezende ${ }^{1}$ \\ Maria Paula Moraes Vasconcelos ${ }^{2}$
}

\begin{abstract}
${ }^{1}$ Discente do curso de medicina. Universidade Estadual de Minas Gerais (UEMG) - Unidade Passos
${ }^{2}$ Médica Ginecologista e Obstetra da maternidade da Santa Casa de Misericórdia de Passos (SCMP)
\end{abstract}

\section{RESUMO}

O risco de eventos tromboembólicos em mulheres grávidas ou em pós-parto é sabidamente maior quando comparado com mulheres da mesma idade não grávidas; sendo os antitrombóticos medicações importantes no tratamento e profilaxia dessas doenças. No entanto, existem controvérsias a respeito do risco-benefício do uso profilático dessas drogas em puérperas, já que pode tanto prevenir o tromboembolismo venoso, uma das principais causas de morte associada à gravidez, quanto propiciar efeitos adversos desnecessários em mulheres de baixo risco. O objetivo deste artigo é orientar sobre os efeitos adversos causados pelo uso indiscriminado de antitrombóticos em puérperas. Para tanto, foram pesquisados 47 estudos em periódicos indexados nos portais SciELO, Embase, PubMed e LILACS, em março de 2021; além de 5 diretrizes encontradas por análise de referências. Após avaliação, 4 artigos foram incluídos na revisão. Diante disso, hemorragias e reações urticariformes foram observadas em estudos como efeitos adversos do uso da tromboprofilaxia. Ademais, ficou estabelecida a necessidade de protocolos institucionais próprios que guiem os profissionais de saúde no manejo da questão por meio da análise de fatores de risco. Nesse sentido, a profilaxia medicamentosa demonstrou ser uma alternativa válida nas puérperas de alto risco. Por fim, concluiu-se que existem muitas divergências nas indicações da profilaxia farmacológica entre os serviços de saúde, além de poucos estudos sobre o riscobenefício da intervenção, o que dificulta a padronização do tratamento. Desse modo, espera-se que o resultado dessa revisão estimule o planejamento de intervenções eficazes nesse sentido.

Palavras-chave: Tromboembolismo Venoso. Período pós-parto. Profilaxia. 


\section{INTRODUÇÃO}

A Trombose Venosa Profunda (TVP) é um processo patológico vascular complexo que pode ocorrer em vasos arteriais e venosos, sendo o último, o Tromboembolismo Venoso (TEV), mais frequente. Tais entidades caracterizam-se por uma resposta hemostática anormal, resultando na formação de um trombo que obstrui, parcial ou completamente, a luz vascular. Trata-se de uma condição influenciada tanto por fatores genéticos quanto por ambientais (SIMÕES, 2014).

Nesse contexto, há mais de 150 anos foi postulada a Tríade de Virchow, a qual define os três principais fatores de risco para o desenvolvimento de tromboses, sendo eles: alteração no fluxo sanguíneo, hipercoagulabilidade e lesão da parede vascular. Ressalta-se que, ainda hoje, tal tríade continua válida (GARCIA et al, 2019).

A gestação, por si só, caracteriza-se como um período de intensas transformações fisiológicas em todo o período gestacional, englobando pré-natal, parto e puerpério. Essas modificações afetam os três componentes da tríade de Virchow: devido aos hormônios vasodilatadores e à compressão física das veias pélvicas pelo útero gravídico ocorre estase venosa, isto é, alteração do fluxo sanguíneo; preparando o organismo para o desafio hemostático do parto ocorre aumento dos níveis de fatores de coagulação, levando a hipercoagulabilidade; já o parto, seja normal ou cesárea, causa lesões nos vasos pélvicos (SIMCOX et al, 2015).

Sendo assim, observa-se a correlação entre os eixos temáticos gestação e trombose, confirmada por dados que apontam o risco de TEV em gestantes como quatro a cinco vezes maior quando comparado a outras mulheres (DARGAUD et al, 2017). Ademais, o TEV é uma das principais causas de morbimortalidade materna durante a gestação e o puerpério, sendo cerca de 75 a $80 \%$ desses casos devido a TVP e cerca de 20 a $25 \%$ causado por embolia pulmonar, a principal complicação das tromboses (OLIVEIRA, 2016).

Em relação à epidemiologia da doença em questão, tem-se que a incidência de TEV na população geral de gestantes é de, aproximadamente, 1,2 a 1,4 por 1000 partos (SKEITH, 2017), já quanto ao pico de incidência, há evidências que comprovam o maior risco de TEV durante o puerpério. Segundo autores, tal incidência aumenta à medida 
que a gravidez progride, chegando a ser 10 vezes maior durante o pós-parto (DARGAUD et al, 2017).

Devido a isso, existem protocolos que sustentam e orientam o início de antitrombóticos, fármacos que agem na prevenção da formação de coágulos sanguíneos, no pós-parto de forma profilática. Contudo, não há um padrão-ouro, havendo uma diversidade de protocolos que se diferem em muitos aspectos. Sendo assim, a decisão a favor ou contra a tromboprofilaxia farmacológica deve ser realizada de forma individualizada, considerando o risco de TEV e, também, os efeitos colaterais e adversos no uso da medicação de forma indiscriminada a toda gestante (HART et al, 2020).

Posto isso, o objetivo principal deste estudo é avaliar os efeitos adversos do uso indiscriminado de antitrombóticos profiláticos no puerpério.

\section{METODOLOGIA}

O presente artigo científico consiste em uma revisão integrativa da literatura, de abordagem qualitativa e caráter descritivo, sobre os efeitos adversos do uso indiscriminado de antitrombóticos no tratamento profilático em puérperas e as diferentes estratégias utilizadas por serviços de saúde para indicar e contraindicar tal intervenção.

Os estudos metodológicos de caráter qualitativo em saúde configuram-se em tal categoria devido a formulação de opinião por parte dos pesquisadores, após a interpretação e análise dos dados coletados no estudo. A própria revisão, por sua vez, caracteriza-se como uma busca pelo conhecimento, muitas vezes como uma tentativa de encontrar soluções para problemas do cotidiano profissional (PEREIRA et al, 2018).

A pesquisa bibliográfica foi realizada em março de 2021. Os artigos foram selecionados por busca nos portais SciELO, EMBASE, PubMed e LILACS. Foram utilizados os descritores: "Postpartum Period" and "Thrombophilia" sendo que esses deveriam aparecer associados ("and"). Nesse momento, considerando as 4 fontes de artigos, foram encontrados 2919 resultados.

Utilizou-se como critério de inclusão a data de publicação entre 2016 e 2021, o que reduziu os resultados para 47 artigos indexados nas fontes consultadas, sendo 31 
encontrados no PubMed; 12, no EMBASE; 2, na SciELO; e 2, no LILACS. O critério de exclusão utilizado nessa revisão foi artigos que não abordassem a temática em questão.

Os títulos dos 47 artigos foram lidos, sendo selecionados para a revisão aqueles que se adequassem aos propósitos da pesquisa. Sendo assim, 29 artigos foram excluídos e 18 foram selecionados. Na sequência, os resumos desses 18 artigos foram lidos, sendo 13 selecionados para leitura completa e 5 excluídos. Então, 13 dos 47 artigos foram selecionados para serem lidos na íntegra. Nesse momento 10 artigos foram excluídos após leitura completa por não satisfazerem os critérios estabelecidos, o que não havia sido percebido nas etapas anteriores. Por meio da análise de referência dos três artigos selecionados, cinco diretrizes foram selecionadas para serem lidas na íntegra, sendo que após leitura somente um estudo foi selecionado, totalizando 4 estudos analisados, de fato, nesta revisão, como consta, de forma esquemática, na figura 01.

Figura 01: esquema metodológico da revisão

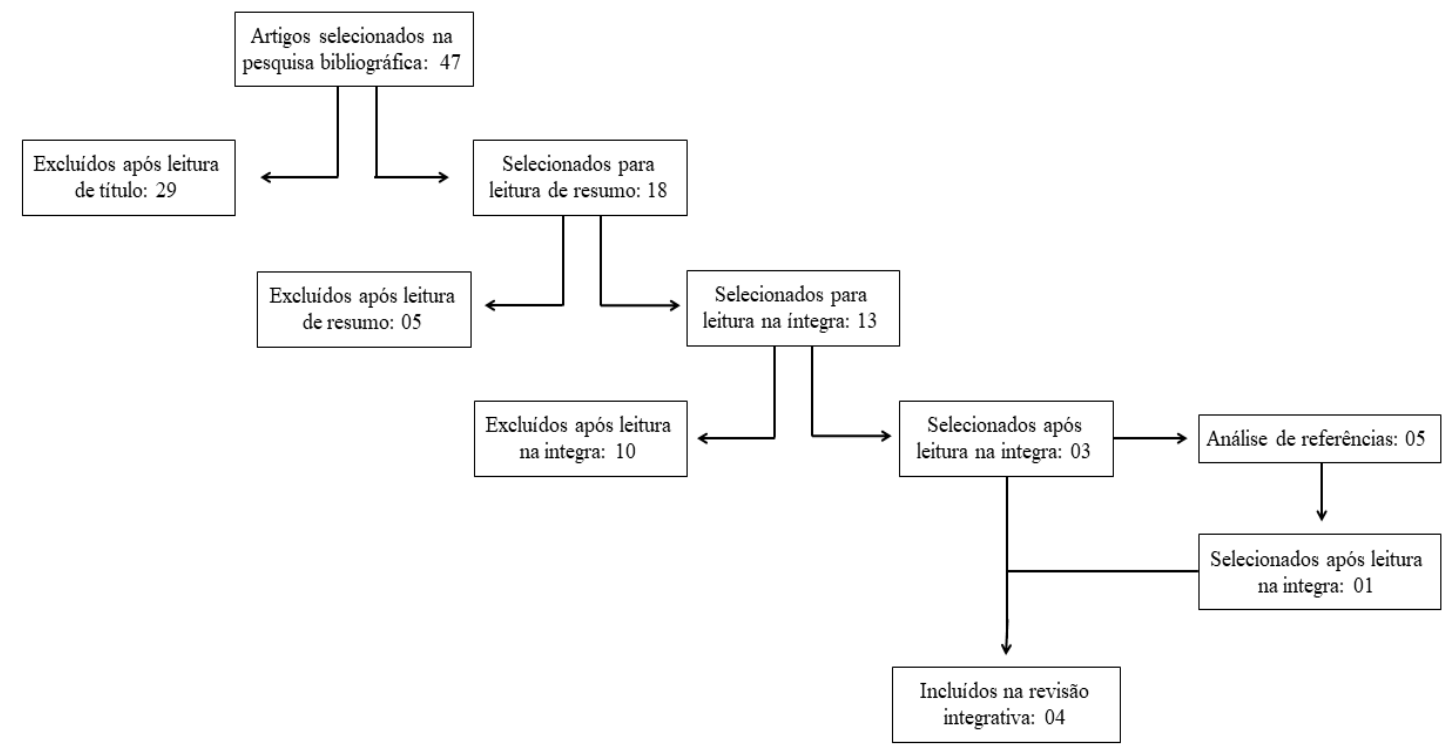

Fonte: Autoria própria

\section{RESULTADOS}

Com a análise dos textos completos incluídos nesta revisão, foi possível confirmar a afirmativa: não há uma padronização com relação à recomendação da profilaxia para TEV no pré-parto e pós-parto. Diante disso, a mensuração dos efeitos 
adversos do uso indiscriminado de antitrombóticos no tratamento profilático em puérperas se torna uma tarefa complexa, pois não existem muitos ensaios clínicos com gestantes em que essa problemática seja avaliada.

Visando a tromboprofilaxia ideal, recomenda-se uma avaliação individual do risco de TEV, entretanto, para tal análise, não há uma ferramenta validada que ajude na estratificação do risco e que indique o melhor momento para iniciar a anticoagulação, além de atentar-se aos efeitos do uso universal do fármaco. Apesar da dificuldade, foi possível reunir algumas recomendações dos estudos incluídos nesta revisão.

Em uma pesquisa foi observado um possível quadro de hemorragia relacionado ao uso de Heparina de Baixo Peso Molecular (HBPM) e quatro quadros de reações urticariformes nos locais das injeções do fármaco. Ainda assim, pontua-se que, nesse estudo, apesar do apontado pela literatura, nenhum caso de osteoporose sintomática e trombocitopenia induzida por heparina foi diagnosticado. Ademais, o mesmo artigo aponta outras consequências nefastas do uso indiscriminado de antitrombótico no tratamento profilático de puérperas: $3 \%$ das 810 gestantes que foram avaliadas e tratadas de acordo com um escore alemão tiveram sangramentos graves relacionados ao uso de antitrombóticos (DARGAUD et al, 2017).

Em outro estudo abordando para quais pacientes indicar a tromboprofilaxia, reuniu-se recomendações com relação à prevenção de eventos tromboembólicos durante a gravidez e no pós-parto. Em síntese, defende-se que não há benefício clínico com a profilaxia quando o risco de TEV no pré-parto ou pós-parto é menor que $1 \%$, mas sim quando é maior que 3\%. Por outro lado, foi concluído que esses números servem apenas como ponto de partida e que a tomada de decisão envolve outros fatores além do histórico familiar e das preferências da paciente (SKEITH, 2017).

Já de acordo com a American College of Obstetricians and Gynecologists (ACOG), tendo em mente que o risco de TEV é ainda mais elevado após o parto cesáreo, todas as mulheres submetidas a esse devem receber profilaxia mecânica com dispositivos de compressão desde o pré-operatório até que a mulher deambule. Essa é uma intervenção de baixo custo e segura para todas as gestantes submetidas ao parto cesariana, diferente da profilaxia farmacológica, a qual pode ser associada de acordo com os riscos de forma individualizada. Também orienta-se que cada instituição desenvolva uma 
política de segurança para essas pacientes, a fim de diminuir a morbidade materna (PACHECO et al, 2020).

Por fim, sabe-se que o risco relativo de TEV na gravidez aumenta ainda mais no pós parto, sendo de 9 a 11 vezes maior. Apesar da literatura abordar os fatores de risco e a recomendação de utilização da tromboprofilaxia, deixa claro que não há evidências suficientes para basear essas recomendações, visto que são limitadas no campo científico (GREEN-TOP GUIDELINES; 2015).

\section{DISCUSSÃO}

A profilaxia para TEV em puérperas é realizada segundo um protocolo institucional próprio, sendo que não há um padrão universal estabelecido. No entanto, norteia-se por meio da realização de uma estratificação de risco, sendo vários fatores envolvidos, por exemplo história pregressa, história familiar e genética, alterações ambientais e vias de parto.

Nesse sentido, pode-se valer da profilaxia mecânica, com uso de dispositivos compressivos, recomendada em determinados casos, por exemplo os partos cesáreos; bem como da profilaxia farmacológica, a qual deve ser utilizada quando os riscos são superiores aos malefícios, segundo cada protocolo institucional.

Os agentes farmacológicos utilizados para profilaxia de TEV são heparina de baixo peso molecular (HBPM) e heparina não fracionada (HNF), sendo o primeiro, representado pela enoxaparina, o fármaco de primeira escolha, e o segundo usado de forma mais restrita. A enoxaparina possui eliminação renal, logo não é recomendada em puérperas com disfunção renal significativa; já a HNF possui eliminação, preferencialmente, pelo sistema reticuloendotelial, sendo uma opção para essas pacientes. Ressalta-se que o uso de novos anticoagulantes orais durante o puerpério não é recomendado por falta de estudos suficientes (PACHECO et al, 2020).

Como já mencionado anteriormente, o uso de medidas para profilaxia de TEV é orientado por meio de sistematização que classifica as gestantes de acordo com os fatores de risco.

O escore de Lyon TEV, por exemplo, é um dos diversos protocolos que enquadram-se na temática em questão. Ele foi avaliado por um estudo quanto à eficácia 
e a tolerabilidade, considerando uma análise de 10 anos e 455 gestantes com histórico de TEV. Tal instrumento foi construído para colaborar na temática, dado a ausência de diretrizes padrão-ouro. O mesmo classifica o risco de TEV em gestantes em 3 grupos, sendo que cada um deles deve receber um esquema de tratamento pré-determinado: risco moderado (<3 pontos: não deve receber antitrombótico no período anteparto), alto risco (entre 3 e 5 pontos: dose profilática de HPBM deve ser introduzida a partir do terceiro trimestre diariamente) e muito alto risco (>6 pontos: dose profilática de HBPM desde o início da gestação) (DARGAUD et al, 2017).

Recomendações de conduta, como essa apresentada, são importantes, porém, para correta estratificação e manejo, é necessário que as variáveis utilizadas para classificar em moderado, alto e muito alto risco sejam padronizadas. Na pontuação do escore de Lyon as variáveis analisadas são: histórico pessoal de TEV, gestante portadora de trombofilia, idade superior a 35 anos, índice de massa corporal (IMC) $>30 \mathrm{~kg} / \mathrm{m}^{2}$, repouso ou imobilização e gestação gemelar.

Além dessas variáveis, outras condições médicas gerais, como veias varicosas, algumas doenças hematológicas e distúrbios inflamatórios, também são considerados fatores de risco por outros protocolos. Dado a ausência de ensaios clínicos randomizados comparando diferentes estratégias de tromboprofilaxia, as condutas são baseadas no equilíbrio do risco percebido de TEV com os efeitos adversos da tromboprofilaxia. Mesmo assim, todas as gestantes devem receber instruções sobre os sinais e sintomas de TEV e em caso de incerteza sobre a relação risco-benefício, as preferências das pacientes também podem ser consideradas (LUSSANA et al, 2012).

Diante disso, estudos demonstraram que pacientes de alto risco, isto é, com história prévia de trombose, estimulação hormonal, mutação gênica, gestação tardia, obesidade grave ou outras doenças concomitantes pregressas, podem se beneficiar com a profilaxia medicamentosa. Isto porque, a geração de um potencial benefício pode superar o efeito adverso latente (KALIL, et al. 2008). No entanto, esta realidade não é válida para as pacientes de baixo risco, já que o risco de consequências prejudiciais da tromboprofilaxia, por exemplo hemorragia, osteoporose, urticária e plaquetopenia; são maiores quando comparadas ao risco de desenvolvimento de TEV (SARNO, et al. 2016 ).

De acordo com outras literaturas, outras condições configuram fatores de risco para eventos trombóticos em puérperas e necessitam de atenção, sendo eles idade

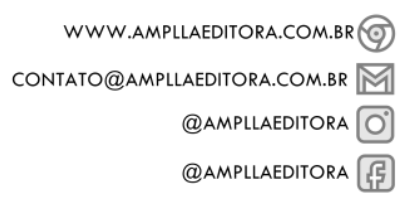


avançada, coloração de pele negra, patologias cardíacas, doença falciforme, diabetes, lúpus sistêmico, tabagismo, gravidez múltipla e cesarianas. Essa última, por exemplo, de acordo com um estudo analítico que avaliou o risco de TEV, concluiu que esse é 6 vezes maior quando comparados aos partos vaginais (KOLETTIS E CRAIGO, 2018).

Por fim, é importante considerar que a incidência relativamente baixa de TEV torna os estudos prospectivos difíceis. Por isso, as recomendações para a prática são amplamente baseadas em pequenos estudos retrospectivos, estudos epidemiológicos e opinião de especialistas (KOLETTIS E CRAIGO, 2018). Sendo assim, reforça-se que o potencial benefício da profilaxia trombótica deve ser pesado contra possíveis resultados adversos em puérperas e que seu uso indiscriminado deve ser evitado.

\section{CONSIDERAÇÕES FINAIS}

A presente revisão verificou os efeitos adversos da utilização indiscriminada de antitrombóticos em puérperas e demonstrou que pacientes de alto risco trombótico apresentam risco-benefícios compensatórios no tratamento profilático. Por outro lado, não existe uma estratégia padrão e com alto grau de evidência quando relacionada a pacientes sem riscos iminentes, devido a limitação de estudos disponíveis para essa revisão.

Essa conclusão confere evidências de utilidade para a prática clínica, no sentido de que expõe a divergência de conduta e limitação de estudos alusivo às indicações do manejo fármaco-profilático em pacientes com baixo e moderado risco para TEV, uma vez que a utilização indiscriminada desses, pode gerar complicações significativas para a puérpera.

Sugere-se, portanto, novas pesquisas, com intuito de agregar melhores evidências para o manejo desses pacientes. Além disso, é imprescindível a estimulação de um planejamento de intervenções eficazes e padronizadas, a fim de oferecer a melhor conduta para as puérperas.

\section{REFERÊNCIAS}

DARGAUD, Y. et al. Personalized thromboprophylaxis using a risk score for the management of pregnancies with high risk of thrombosis: a prospective clinical study. Journal of Thrombosis and Haemostasis, v. 15, n. 5, p. 897-906. 2017. 
Disponível em: https://onlinelibrary.wiley.com/doi/full/10.1111/jth.3660. Acesso em 8 de maio de 2021.

GARCIA, Antônio César Franco et al. Realidade do uso da profilaxia para trombose venosa profunda: da teoria à prática. Jornal Vascular Brasileiro, v. 4, n. 1, p. 3541, $2019 . \quad$ Disponível em: http://www.jvb.periodikos.com.br/article/5df251650e88254c2bb5f733/pdf/jvb -4-1-35.pdf. Acesso em 10 de maio de 2021.

GREEN-TOP GUIDELINE. Reducing the Risk of Venous Thromboembolism during Pregnancy and the Puerperium. Royal College of Obstetricians and Gynaecologists. 2015. N. 37, p. 1-40. Disponível em: https://www.rcog.org.uk/globalassets/documents/guidelines/gtg-37a.pdf. Acesso em 09 de maio de 2021.

HART, Christina et al. Prevention of Venous Thromboembolism during Pregnancy and the Puerperium with a Special Focus on Women with Hereditary Thrombophilia or Prior VTE-Position Paper of the Working Group in Women's Health of the Society of Thrombosis and Haemostasis (GTH). Hämostaseologie, 2020. Disponível em: https://gth-online.org/wp-content/uploads/2020/11/2020-GTHAG-Womens-Health-VTE-Prophylaxe-in-der-Schwangerschaft.pdf. Acesso em 08 de maio de 2021.

KALIL, Jorge Agle et al. Investigação da trombose venosa na gravidez. J. vasc. bras., [S. I.], v. 7, n. 1, março 2008. Disponível em: https://www.scielo.br/j/jvb/a/NQMvHsk7YHHYSnJ4F9TYR3j/?lang=pt. Acesso em: 24 maio 2021.

LUSSANA, Federico et al. Pregnancy-related venous thromboembolism: Risk and the effect of thromboprophylaxis. Thrombosis Research, v. 129, n. 6, p. 673-680. 2012. https://linkinghub.elsevier.com/retrieve/pii/S004938481200045X. Acesso em 24 de maio de 2021.

OLIVEIRA, André Luiz Malavasi Longo de; MARQUES, Marcos Arêas. Profilaxia de tromboembolismo venoso na gestação. Jornal vascular brasileiro, v. 15, n. 4, p. 293-301. 2016. Disponível em: https://www.scielo.br/scielo.php?pid=S167754492016000400293\&script=sci_arttext. Acesso em 09 de maio de 2021.

PACHECO, Luis; SAADE George; METZ Torri. Society for Maternal-Fetal Medicine Consult Series \#51: Thromboembolism prophylaxis for cesarean delivery. Society for Maternal-Fetal Medicine (SMFM). v. 223, issue 2, pb11-b17, agosto 2020. Disponível em: https://pubmed.ncbi.nlm.nih.gov/32360109/. Acesso em 25 de maio de 2021.

PEREIRA, Adriana Soares; et al. Metodologia da pesquisa científica. [e-book]. Santa Maria.

Ed. UAB/NTE/UFSM. 2018 Disponível

em: 
https://repositorio.ufsm.br/bitstream/handle/1/15824/Lic_Computacao_Meto dologia-Pesquisa-Cientifica.pdf?sequence=1. Acesso em 04 de maio de 2021.

SARNO, M.A.C et al. Trombose Venosa Profunda na Gestação e Puerpério. EBSERH. [S. I.: $\quad$ s. $\quad$ n.], $2016 . \quad$ cap. $27 . \quad$ Disponível em: http://www2.ebserh.gov.br/documents/215335/4407336/Protocolo+Trombos e+Venosa+na+Gestacao+e+Puerperio.pdf/0306a1bf-8f9e-4c97-ae2667f350368473. Acesso em: 24 maio 2021.

SIMCOX, Louise E. et al. Pulmonary thrombo-embolism in pregnancy: diagnosis and management. Breathe, v. 11, n. 4, p. 282-289. 2015. Disponível em: https://breathe.ersjournals.com/content/11/4/282.short. Acesso em 9 de maio de 2021.

SIMÕES, Myriam Solange Martins Bohana E OLIVEIRA, Rúbia Pinto. Principais fatores de risco para trombose venosa profunda. Revista Atualiza Saúde. 2014. Disponível em: $\quad$ http://atualizarevista.com.br/wp-content/uploads/2014/10/SIMOESMyriam-Solange-Martins-Bohana-OLIVEIRA-Rubia-Pinto-de.pdf. Acesso em 10 de maio de 2021.

SKEITH, Leslie. Preventing venous thromboembolism during pregnancy and postpartum: crossing the threshold. Hematology. The American Society of Hematology Education Program Book, v. 2017, n. 1, p. 160-167. 2017. Disponível em: https://ashpublications.org/hematology/article/2017/1/160/21100/Preventingvenous-thromboembolism-during-pregnancy. Acesso em 10 de maio de 2021.

KOLETTIS, Diana; CRAIGO, Sabrina. Thromboprophylaxis in pregnancy. Obstetrics and Gynecology Clinics. v. 45, n. 2, p. 389-402. 2018). Disponível em: https://www.obgyn.theclinics.com/article/S0889-8545(18)30007-X/abstract. Acesso em 24 de maio de 2021. 


\title{
INFLUÊNCLA DAS FORMULACÕES DE ANFOTERICINA B NA OCORRÊNCLA DE HIPOCALEMIA EM PACIENTES COM LEISHMANIOSE VISCERAL: UMA REVISÃO SISTEMÁTCA
}

\author{
DOI: 10.51859/amplla.csa528.2121-4
}

\author{
Mário Henrique da Silva Lima ${ }^{1}$ \\ Ana Tárcila Alves de Almeida ${ }^{1}$ \\ Débora Cavalcante Braz ${ }^{2}$
}

${ }^{1}$ Graduando(a) do curso de Farmácia. Universidade Federal do Piauí - UFPI

2 Professora Adjunto do Curso de Farmácia. Universidade Federal do Piauí - UFPI

\section{RESUMO}

A anfotericina $b$, apresentada em formulação desoxicolato e variações lipídicas, é um fármaco utilizado como alternativa no tratamento da leishmaniose visceral (LV). Um dos eventos adversos deste medicamento é a hipocalemia, que corresponde a depleção de potássio. Em condições graves, pode levar à morte do indivíduo. $\mathrm{O}$ objetivo do estudo foi avaliar a influência da apresentação farmacêutica do medicamento na ocorrência do quadro hipocalêmico em pacientes portadores de LV, através do levantamento na literatura vigente. Refere-se, portanto, a uma revisão sistemática conduzida através do aplicativo Rayyan ${ }^{\circledR}$, utilizando as bases de dados Scielo, PubMed e LILACS, fazendo-se uso dos descritores: "hypokalemia", "hypopotassemia", "hypopotassemias", "amphotericin b", "amphotericin", "human", "kala-azar', "visceral leishmaniasis" e "black fever". A hipocalemia foi registrada durante o tratamento com anfotericina b desoxicolato e lipossomal, sendo mais frequente para a desoxicolato. Em contrapartida, as formulações lipídicas foram notadas como responsáveis por minimizar os eventos adversos. A revisão permitiu observar ainda que pacientes com LV e outras doenças foram excluídos dos estudos. Assim, a ocorrência de eventos adversos, incluindo a hipocalemia, deveria ser avaliada nessa população durante tratamento com a anfotericina B, principalmente, as formulações desoxicolato e lipossomal.

Palavras-chave: Leishmaniose Visceral. Anfotericina B. Evento Adverso. Potássio. Hipocalemia.

\section{INTRODUÇÃO}

A leishmaniose visceral ou calazar, segundo Gontijo e Melo (2004), corresponde uma antropozoonose amplamente distribuída em regiões tropicais, como as 
Américas. Em terras nacionais, de acordo com Brasil (2006), a prevalência da doença ocorre em zonas rurais, apesar de se expandir cada vez mais para territórios urbanos.

Os agentes etiológicos da doença referem-se à protozoários do gênero Leishmania, enquanto os responsáveis pela transmissão através da picada são flebotomíneos, sobretudo os das espécies Lutzomyia longipalpis e Lutzomyia cruzi, a primeira representando o principal vetor nacionalmente, e a segunda, sendo a responsável por afligir o estado do Mato Grosso do Sul (AMORIM et al., 2015).

O tratamento se dá através do uso de antimoniais pentavalentes, como é o caso da n-metil-glucamina, fornecida pelo Ministério da Saúde, através do Sistema Único de Saúde (SUS). Entretanto, existem tratamentos alternativos que são implementados em caso de resposta insatisfatória ao medicamento de primeira escolha, como a Anfotericina B, por exemplo, apresentada convencionalmente como desoxicolato ou em formulações lipídicas que, segundo Filippin e Souza (2006), diferem em tamanho, formato e conteúdo do fármaco.

O formato lipossomal, segundo Souto e Lopes (2011) e Filippin e Sousa (2006), possui um conjunto vesicular em formato esférico formado por uma ou mais camadas lipídicas de colesterol ou fosfatidilcolina hidrogenada de soja. Quanto às dispersões coloidais, Robinson e Nahata (1999) esclarecem que o fármaco é disperso em sulfato de colesterila sódica, formado em microdiscos em diâmetro nanométrico. No que se refere aos complexos lipídicos, são compostos por diesteroilfosfatidilcolina e diesteroilfosfatidilglicerol, gerando uma estrutura lamelar; enquanto as emulsões apresentam fases dispersa e dispersante, normalmente óleo em água (O/A) ou água em óleo (A/O) (SOUTO \& LOPES, 2011).

Apesar de ser considerada uma das drogas leishmanicidas mais potentes disponíveis no mercado e vir sendo utilizada clinicamente nos últimos anos em países como Brasil e Índia, os eventos adversos da anfotericina B, todos em caráter dosedependente, são diversos e surgem numa rápida frequência. Os problemas renais são os mais alarmantes, uma vez que ocorre a redução da filtração glomerular em cerca de $40 \%$ dos pacientes (BRASIL, 2006).

A hipocalemia ou hipopotassemia também é reconhecida como um dos eventos adversos e, por estar associada à redução de potássio sérico, que é fundamental para o funcionamento de nervos, células e músculos, pode provocar anormalidades no 
organismo. A gravidade varia de acordo com a depleção do eletrólito: em quadros leves e/ou moderados, tem-se uma concentração do mineral entre 2,5 e 3,5 mEq/L, geralmente não causando sintomas, enquanto em condições graves, alcança-se valor < 2,5 mEq/L, onde as células tubulares renais e os músculos são os alvos mais afetados, promovendo fraqueza, paralisia, insuficiência respiratória e, em último caso, a morte. Entretanto, valores abaixo de 4,0 mEq/L já são um indicativo de depleção de potássio corporal e, portanto, deve ser um fator avaliado com cautela. (DUTRA et al., 2012; KARDALAS et al., 2018; VERDE et al., 2008).

Diante do exposto, o estudo propôs a realização de levantamento bibliográfico sobre a influência das formulações de anfotericina B no surgimento de hipopotassemia em portadores de leishmaniose visceral.

\section{METODOLOGIA}

O estudo realizado corresponde à uma revisão sistemática norteada pela seguinte pergunta de pesquisa: "Em pacientes portadores de leishmaniose visceral que fazem tratamento com Anfotericina B, a apresentação medicamentosa influencia na ocorrência da hipocalemia?", fundamentada pela estratégia PICO:

População - portadores de leishmaniose visceral;

Intervenção - Anfotericina B;

Comparação - formas de apresentação do medicamento (desoxicolato, lipossomal e complexo lipídico);

Outcome/Desfecho - ocorrência de hipocalemia.

\subsection{CRITÉRIOS DE INCLUSÃO}

Incluiu-se pacientes diagnosticados com Leishmaniose Visceral, de qualquer idade e que, obrigatoriamente, estivessem fazendo uso de algum tipo de anfotericina $b$ como tratamento. Além disso, levou-se em consideração apenas estudos realizados entre os anos de 2000 a 2020.

\subsection{CRITÉRIOS DE EXCLUSÃO}

Foram excluídas pesquisas em animais, estudos in vitro, revisões sistemáticas, trabalhos com enfoque em aspectos imunológicos, além daqueles onde pacientes 
estivessem fazendo tratamento da Leishmaniose Visceral com outros medicamentos além da anfotericina $B$.

\subsection{BUSCA E IDENTIFICAÇÃO DE ARTIGOS}

As bases de dados utilizadas como fonte de literatura foram PubMed, Lilacs e Scielo. A busca foi realizada em novembro de 2020, não havendo delimitação quanto aos idiomas dos artigos. Com relação a determinação dos descritores, foram utilizados os operadores booleanos "or" e "and". Os termos empregados, segundo o Descritores em Ciências da Saúde (DeCS) e Medical Subject Headings (MeSH), foram: "hypokalemia" OR "hypopotassemia" OR "hypopotassemias"; "amphotericin b" OR "amphotericin"; "human"; "kala-azar' OR "visceral leishmaniasis". Somente o termo "black fever" foi atribuído à plataforma MeSH.

\subsection{SELEÇÃO DOS ESTUDOS}

A triagem foi realizada em duas etapas: a primeira, através do aplicativo Rayyan ${ }^{\circledR}$ (Qatar), de maneira autônoma, por dois revisores, levando em consideração o título, palavras-chave, resumo e os critérios de elegibilidade. Na existência de discordâncias, um terceiro avaliador determinava a inclusão final. A segunda etapa correspondeu à triagem após a leitura do estudo na íntegra.

\section{RESULTADOS}

Dos 295 estudos identificados nas bases de dados, 5 eram duplicados e 290 foram avaliados através do título, resumo e palavras-chave disponibilizados, resultando na exclusão de 257 trabalhos, por não atenderem aos critérios de inclusão estabelecidos. Posteriormente, realizou-se a leitura integral dos 33 artigos sujeitos a elegibilidade, culminando no descarte de 25 , dessa vez por não evidenciarem informações sobre a depleção de potássio. Posto isso, 8 pesquisas foram incluídas na revisão. 
Figura 1. Fluxograma da revisão de literatura.

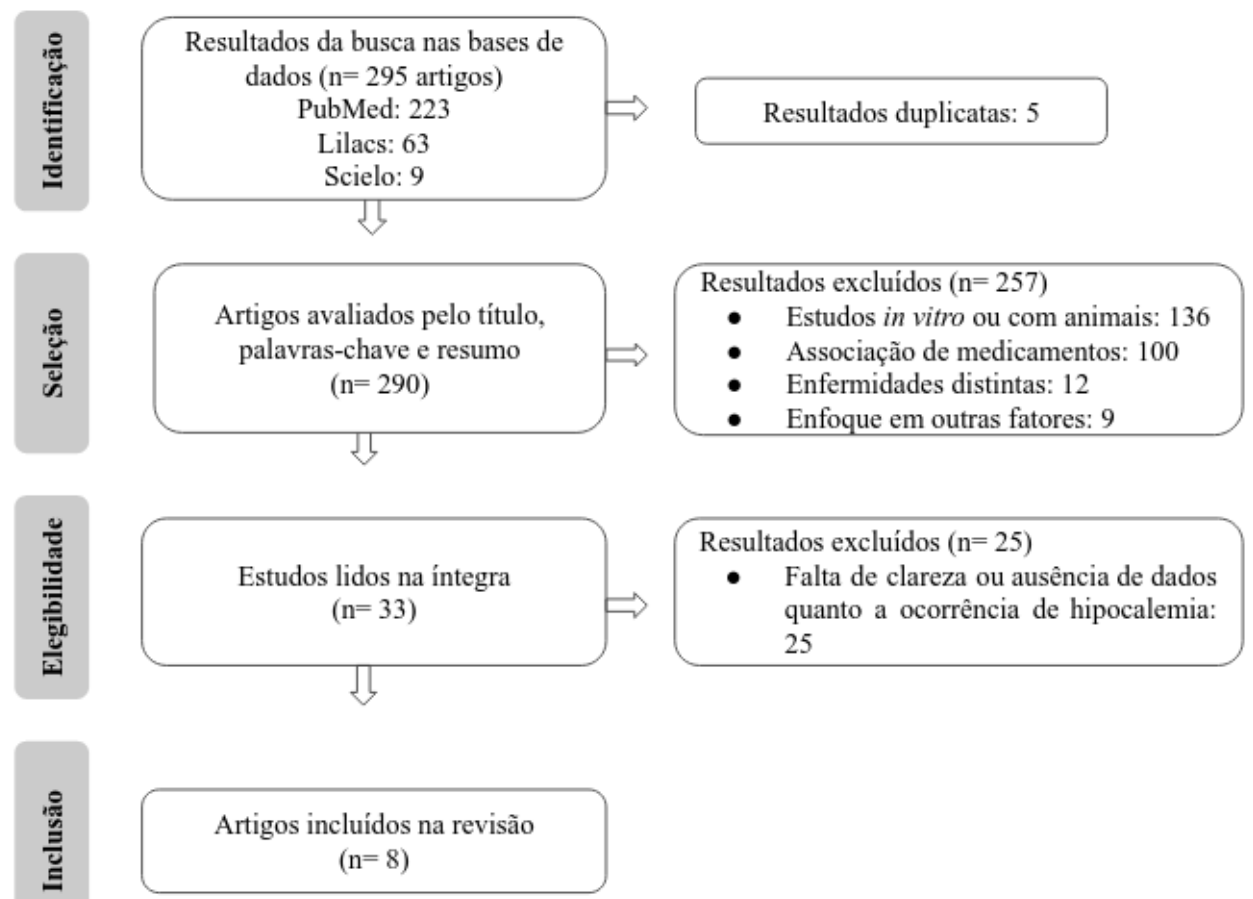

Fonte: Autoria própria.

A maioria das pesquisas foram publicadas entre os anos de 2010 a 2014 (37,5\%), no continente asiático, especificamente na Índia, representando o equivalente a 62,5\%. As revistas com maior número de publicações foram PLOS Neglected Tropical Disease e Clinical Infectious Diseases, ambas com dois trabalhos, cada (Tabela 1).

Tabela 1. Características bibliográficas dos estudos incluídos na revisão sistemática

\begin{tabular}{llc}
\hline Características & $\mathbf{n}$ & $\mathbf{\%}$ \\
\hline Ano de publicação & & \\
\hline $2000-2004$ & 1 & 12,5 \\
\hline $2005-2009$ & 2 & 25 \\
\hline $2010-2014$ & 3 & 37,5 \\
\hline $2015-2019$ & 2 & 25 \\
\hline 2020 & - & - \\
\hline Autores por publicação & & - \\
\hline$\leq 3$ & - & 62,5 \\
\hline $4-6$ & 5 & 37,5 \\
\hline$\geq 6$ & 3 & 25 \\
\hline Revista da publicação & & 12,5 \\
\hline PLOS Neglected Tropical Disease & 2 & 12,5 \\
\hline Revista da Sociedade Brasileira de Medicina Tropical & 1 & 12,5 \\
\hline Tropical Medicine \& International Health & 1 & 25
\end{tabular}




\begin{tabular}{lcc}
\hline The American Journal of Tropical Medicine and Hygiene & 1 & 12,5 \\
\hline Continente de origem do estudo & 2 & \\
\hline América & 5 & 25 \\
\hline Ásia & 1 & 62,5 \\
\hline África & 8 & 12,5 \\
TOTAL & 100 \\
\hline
\end{tabular}

Fonte: Autoria própria. Legenda: $\mathrm{n}$ (número de estudos); \% (porcentagem)

No tocante ao tipo de estudo, todos correspondiam a ensaios clínicos randomizados. A faixa etária mais avaliada eram crianças, adolescentes e adultos, totalizando $37,5 \%$ das pesquisas, seguido de crianças, adolescentes, adultos e idosos com $25 \%$. Em $100 \%$ dos estudos, ambos os sexos eram avaliados. Outrossim, as comorbidades não eram critério de inclusão. Com relação a amostra para análise de potássio, o sangue demonstrou maior prevalência (Tabela 2).

Tabela 2. Características metodológicas dos estudos incluídos na revisão sistemática

\begin{tabular}{|c|c|c|}
\hline Características & $\mathbf{n}$ & $\%$ \\
\hline \multicolumn{3}{|l|}{ Tipo de estudo } \\
\hline Clínico randomizado & 8 & 100 \\
\hline \multicolumn{3}{|l|}{ Tamanho da Amostra } \\
\hline$\leq 100$ & 1 & 12,5 \\
\hline $101-200$ & 3 & 37,5 \\
\hline$\geq 201$ & 4 & 50 \\
\hline \multicolumn{3}{|l|}{ Faixa etária } \\
\hline Crianças (6 meses a 12 anos) & 1 & 12,5 \\
\hline Crianças, adolescentes e adultos ( 2 a 65 anos) & 3 & 37,5 \\
\hline Crianças, adolescentes, adultos e idosos ( $\geq 4$ anos) & 2 & 25 \\
\hline Adolescentes e adultos (12-65 anos) & 1 & 12,5 \\
\hline Não especificado & 1 & 12,5 \\
\hline \multicolumn{3}{|l|}{ Sexo dos participantes } \\
\hline Feminino & - & - \\
\hline Masculino & - & - \\
\hline Ambos & 8 & 100 \\
\hline \multicolumn{3}{|l|}{ Comorbidade } \\
\hline Presença & - & - \\
\hline Ausência & 8 & 100 \\
\hline \multicolumn{3}{|l|}{ Amostra coletada para avaliação de potássio } \\
\hline Sangue & 6 & 75 \\
\hline Não especificado/identificado & 2 & 25 \\
\hline TOTAL & 8 & 100 \\
\hline
\end{tabular}

Fonte: Autoria própria. Legenda: n (número de estudos); \% (porcentagem).

Foram encontradas pesquisas envolvendo a formulação convencional do medicamento (desoxicolato), bem como as formulações lipídicas (Tabela 3). 
Tabela 3: Avaliação de níveis de potássio e ocorrência de hipocalemia

\begin{tabular}{|c|c|c|c|c|c|}
\hline $\begin{array}{l}\text { Autor, } \\
\text { ano }\end{array}$ & $\begin{array}{c}\text { Apresentação } \\
\text { da } \\
\text { Anfotericina } \\
\text { B }\end{array}$ & Dose diária & Idade & $\mathbf{n}$ & Resultado \\
\hline $\begin{array}{l}\text { ROMERO } \\
\text { et al, } \\
2017\end{array}$ & Lipossomal & $3 \mathrm{mg} / \mathrm{kg} /$ dia por 7 dias & $\begin{array}{c}6 \text { meses a } \\
50 \text { anos }\end{array}$ & 109 & $\begin{array}{l}\text { Nível médio de } \\
\text { potássio sérico de } 4,3 \\
\mathrm{mEq} / \mathrm{L} \text { em } 104 \text {. }\end{array}$ \\
\hline $\begin{array}{l}\text { BORGES } \\
\text { et al, } \\
2017\end{array}$ & Desoxicolato & $\begin{array}{c}1 \mathrm{mg} / \mathrm{kg} / \text { dia por } 14 \\
\text { dias }\end{array}$ & $\begin{array}{c}6 \text { meses a } \\
12 \text { anos }\end{array}$ & 50 & $\begin{array}{l}11 \text { pacientes } \\
\text { apresentaram } \\
\text { hipocalemia } \\
\text { moderada. }\end{array}$ \\
\hline $\begin{array}{l}\text { SUNDAR } \\
\text { et al, } \\
2004\end{array}$ & $\begin{array}{l}\text { A. } \\
\text { Desoxicolato } \\
\text { B. Lipossomal } \\
\text { C. Complexo } \\
\text { lipídico }\end{array}$ & $\begin{array}{c}\text { A. } 1 \mathrm{mg} / \mathrm{kg} \text { em dias } \\
\text { alternados por } 30 \text { dias } \\
\text { B. } 2 \mathrm{mg} / \mathrm{kg} / \text { dia por } 5 \\
\text { dias } \\
\text { C. } 2 \mathrm{mg} / \mathrm{kg} / \text { dia por } 5 \\
\text { dias }\end{array}$ & $\begin{array}{c}\text { Média } \\
\text { (alcance) } \\
\text { A. } 16(3-50) \\
\text { B. } 12(4-60) \\
\text { C. } 13(1-60)\end{array}$ & $\begin{array}{l}\text { A. } 51 \\
\text { B. } 51 \\
\text { C. } 51\end{array}$ & $\begin{array}{l}9 \text { pacientes tratados } \\
\text { com Anfo B } \\
\text { desoxicolato } \\
\text { apresentaram } \\
\text { hipocalemia < } 3 \\
\text { mEq/L. }\end{array}$ \\
\hline $\begin{array}{l}\text { SUNDAR } \\
\text { et al, } \\
2010\end{array}$ & $\begin{array}{l}\text { A. Lipossomal } \\
\text { B. } \\
\text { Desoxicolato }\end{array}$ & $\begin{array}{l}\text { A. } 10 \mathrm{mg} / \mathrm{kg} \text {, via } \\
\text { infusão intravenosa } \\
\text { por } 1 \text { hora } \\
\text { B. } 15 \text { infusões de } 1 \\
\text { mg/kg em dias } \\
\text { alternados durante } 29\end{array}$ & 2 a 65 anos & $\begin{array}{l}\text { A. } 204 \\
\text { B. } 108\end{array}$ & $\begin{array}{l}\text { Hipocalemia em } 2 \\
(2 \%) \text { pacientes } \\
\text { tratados com Anfo B } \\
\text { desoxicolato. }\end{array}$ \\
\hline
\end{tabular}
dias.

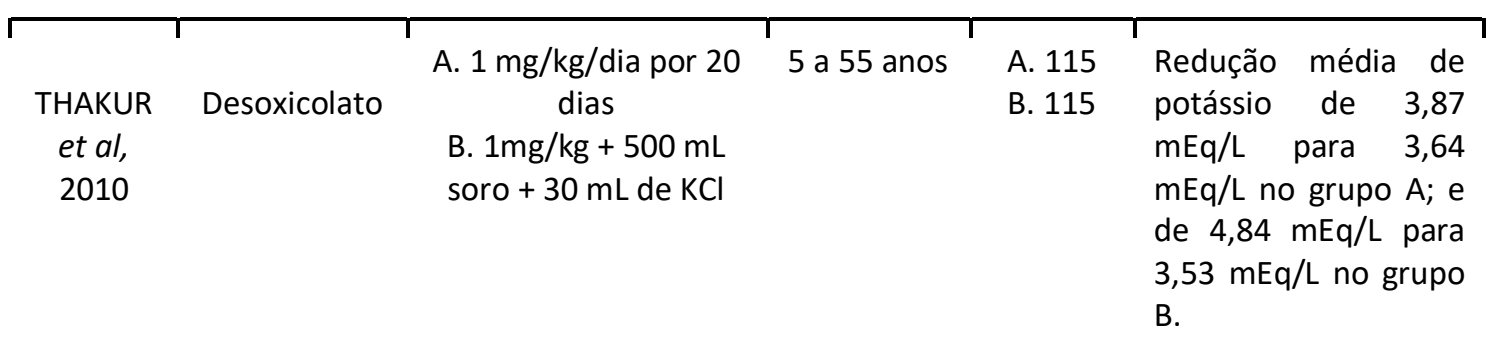

\begin{tabular}{|c|c|c|c|c|c|}
\hline $\begin{array}{c}\text { SUNDAR } \\
\text { et al, } \\
2006\end{array}$ & $\begin{array}{l}\text { Dispersão } \\
\text { coloidal }\end{array}$ & $\begin{array}{c}\text { A. } 0,5 \mathrm{mg} / \mathrm{kg} \text { no dia } 1 \text {, } \\
\text { seguido de } 1 \mathrm{mg} / \mathrm{kg} \text { no } \\
\text { dia } 2 ; \text { e } 1,5 \mathrm{mg} / \mathrm{kg} \text { nos } \\
\text { dias } 3-6 \\
\text { B. } 0,5 \mathrm{mg} / \mathrm{kg} \text { no dia } 1 \text {, } \\
\text { seguido por } 1,5 \mathrm{mg} / \mathrm{kg} \\
\text { no dia } 2 ; \text { e } 2 \mathrm{mg} / \mathrm{kg} \\
\text { nos dias } 3-6 . \\
\text { C. } 1 \mathrm{mg} / \mathrm{kg} \text { no dia } 1,2 \\
\mathrm{mg} / \mathrm{kg} \text { do dia } 2 ; \text { e } 3 \\
\mathrm{mg} / \mathrm{kg} \text { nos dias } 3-6\end{array}$ & $\begin{array}{c}\text { Média } \\
\text { (alcance) } \\
\text { A. } 22(2-60) \\
\text { B. } 20(3-60) \\
\text { C. } 10(2-55)\end{array}$ & $\begin{array}{l}\text { A. } 135 \\
\text { B. } 135 \\
\text { C. } 135\end{array}$ & 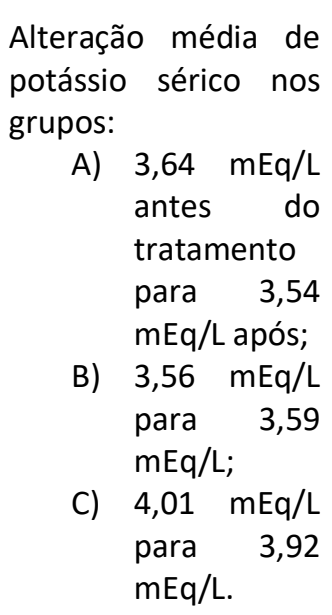 \\
\hline $\begin{array}{l}\text { SUNDAR } \\
\text { et al, }\end{array}$ & & $\begin{array}{c}\text { A. } 5 \mathrm{mg} / \mathrm{kg} / \text { dia por } 3 \\
\text { dias }\end{array}$ & $\begin{array}{c}12 \text { a } 65 \\
\text { anos }\end{array}$ & $\begin{array}{l}\text { A. } 15 \\
\text { B. } 15\end{array}$ & $\begin{array}{l}\text { Alteração média de } \\
\text { potássio sérico nos }\end{array}$ \\
\hline
\end{tabular}




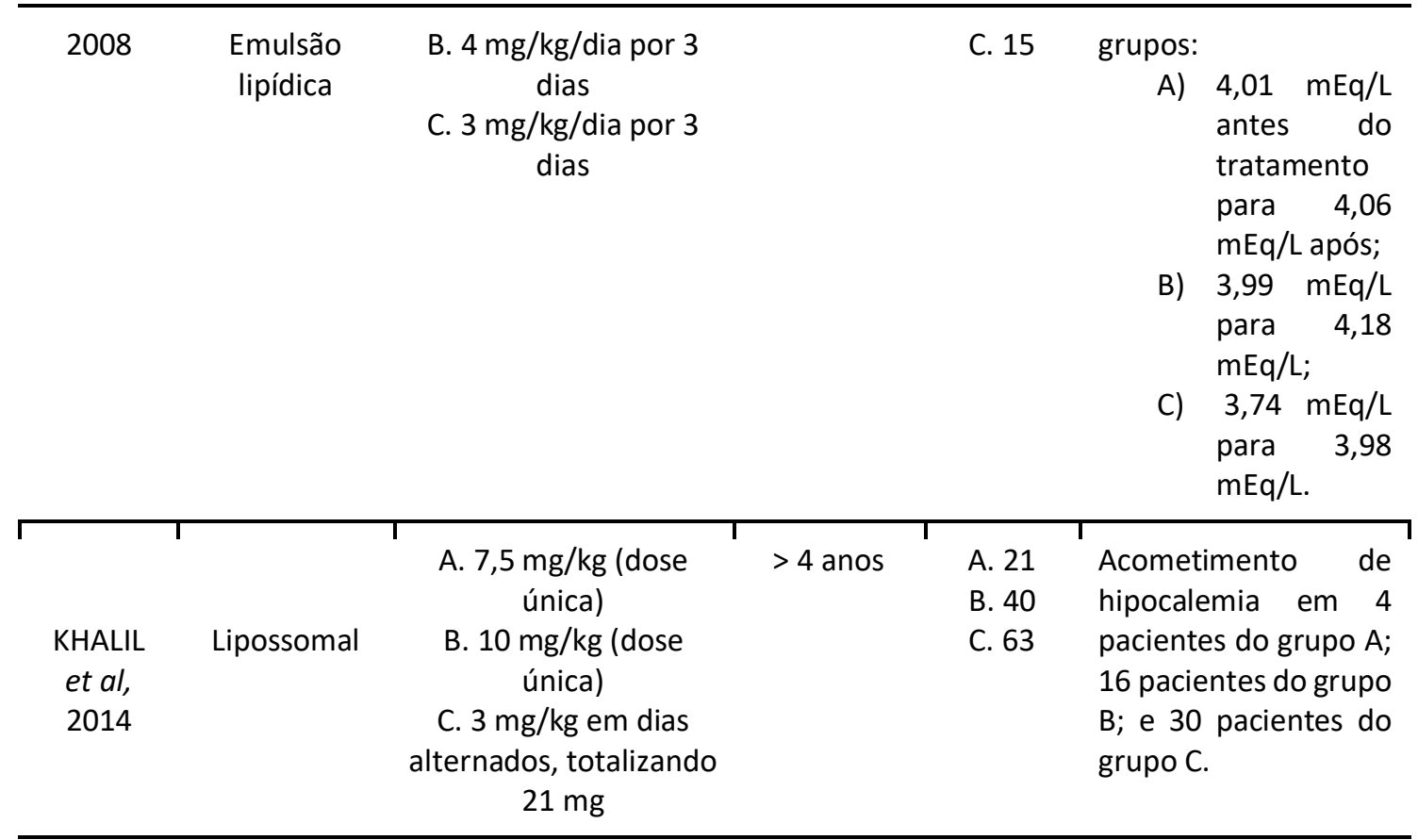

Fonte: Autoria própria. n: número total da população estudada.

\section{DISCUSSÃO}

A maioria dos estudos desta pesquisa foram publicados a partir dos anos 2010 e realizados na Índia, uma região endêmica, uma vez que $90 \%$ dos casos concentram-se no país, junto com Brasil, Nepal e Bangladesh (WHO, 2013). Segundo BRASIL (2020), no ano de 2019, a região Nordeste brasileira apresentou o maior número de casos da doença no país, seguido do Norte, que representa o local de realização da pesquisa feita por Borges et al. (2017), na cidade de Araguaína, no Tocantins. Nenhum dos estudos descreveu características dos pacientes hipocalêmicos, tais como idade, sexo ou classe social, de forma a contribuir para um levantamento epidemiológico. Além disso, através da Plataforma Sucupira, constatou-se que as revistas onde foram publicadas as pesquisas, apresentam qualis considerado bom à excelente.

A hipocalemia, durante uso de anfotericina $B$, ocorre em decorrência do mecanismo de ação do fármaco que, por atuar interferindo no ergosterol, isto é, em um componente da membrana celular do protozoário. No entanto, afeta também células ricas em colesterol dos mamíferos como as dos humanos. Nesse processo, poros permeáveis de eletrólitos se formam e, por princípio osmótico, concentrações 
volumosas de potássio acabam sendo eliminadas (TAKANO et al., 1985; ZAGER et al., 1992; ZEIDER et al., 1986).

A forma desoxicolato esteve presente na maioria dos casos em que houve incidência de hipocalemia, compreendendo 4 dos estudos inclusos na revisão e, apesar de alguns destes não apresentarem valores numéricos dos níveis do potássio, havia o índice qualitativo, isto é, o registro da presença do quadro hipocalêmico, além do número de pacientes acometidos dentro da população estudada e a gravidade do evento, sendo esta última de extrema importância, por ser um fator utilizado para a determinação do tratamento (KARTALAS et al., 2018).

A anfotericina B desoxicolato, apesar de ser considerada eficaz no tratamento da leishmaniose, apresenta uma baixa tolerabilidade, principalmente pelo caráter nefrotóxico, promovendo alterações na filtração dos glomérulos e disfunção tubular. Além disso, a própria hipocalemia pode comprometer e suscitar danos renais (BARRATT \& LEGRAND, 2005). Romero et al. (2017) optaram por interromper a farmacoterapia com essa apresentação, justamente pelo surgimento de muitos eventos adversos e o tratamento descontinuado pelos pacientes.

Thakur et al. (2010) realizaram uma pesquisa interessante, avaliaram a administração de anfotericina B desoxicolato com soro fisiológico e $\mathrm{KCl}$ e observaram que os níveis de creatinina sérica desses pacientes foram significativamente menores, quando comparado ao grupo que recebeu apenas a anfotericina $B$, parece ter prevenido lesões renais. A administração de $\mathrm{KCl}$ não promoveu diferença significativa nos níveis séricos de potássio entre esses grupos, mas o nível desse eletrólito se manteve dentro da normalidade durante o tratamento. O que corrobora com Berdichevski (2003), que chegou à conclusão, através da análise de inúmeros estudos, de que a reposição desses eletrólitos é eficaz contra a nefrotoxicidade, mas não contra distúrbios eletrolíticos.

Além dos efeitos passíveis de ocorrência a nível renal, a medula óssea também é um dos alvos da anfotericina desoxicolato, principalmente em relação à redução de leucócitos e hemoglobina do sangue (Schöffski et al., 1998). Dois pacientes com anemia grave do estudo de Sundar et al. (2004) foram a óbito, faziam tratamento com essa formulação, um deles apresentava hipocalemia grave, com potássio sérico de 2,5 mEq/L. No Brasil, em quadros anêmicos, realiza-se um suporte hemoterápico, através da transfusão de hemoderivados. Além disso, em casos graves, a desoxicolato não é 
utilizada em tratamento de primeira linha, somente em caso de reincidência da doença ou não efetividade dos antimoniais pentavalentes ou da anfotericina na forma lipossomal (BRASIL, 2006; BRASIL, 2016).

A propósito, das quatro pesquisas envolvendo anfotericina lipossomal, apenas a publicada por Khalil et al. (2014) registrou hipopotassemia, sendo equivalente ao maior número de pacientes com hipocalemia dentre as pesquisas incluídas no estudo, totalizando 50 pacientes. É interessante ressaltar ainda que o maior número de casos de hipocalemia foi observado nos pacientes que receberam a maior concentração desse fármaco. Esse estudo considerou indivíduos de todas as idades, em contrapartida, Borges et al. (2017), avaliou a anfotericina desoxicolato em crianças de até 12 anos e observou 11 casos de hipocalemia, o maior número observado para esse fármaco dentre os estudos incluídos no presente estudo de revisão. Dessa forma, a ocorrência desse evento adverso a ocorrência de hipocalemia em crianças poderia ser avaliada em estudos posteriores.

A apresentação lipossômica da anfotericina, segundo Sampaio \& Marsden (1997), possui vantagem em comparação com a convencional, porque promove uma maior interação com o ergosterol do parasito e menor com o colesterol do hospedeiro, uma vez que os lipossomas acabam sendo fagocitados por macrófagos, célula que comporta a infecção. Entretanto, apenas minimiza as chances, não necessariamente impossibilita a ocorrência dos eventos adversos. Além disso, seu uso é limitado por ser um medicamento de alto custo.

Quanto ao estudo envolvendo a forma dispersão coloidal, Sundar et al. (2006) alegaram que, apesar da relativa redução de potássio corporal, nenhum dos pacientes apresentou um quadro hipocalêmico e 99\% deles atingiram a cura parasitológica, independente da dose administrada, em cerca de duas semanas após o tratamento. Febre e calafrios foram os sintomas mais frequentes nos pacientes tratados e nenhuma alteração significativa a nível renal ou hepático foi relatada.

Acerca da emulsão lipídica, Sundar et al. (2008) não identificaram hipocalemia, lesão renal ou de outros órgãos. Entretanto, em 11\% dos pacientes, que equivale aos indivíduos que receberam a maior dose do medicamento, foram observadas reações alérgicas que, segundo Barquist et al. (199) e Hernandez et al. (2000), representam uma das desvantagens dessa preparação, além do uso de variadas 
concentrações de lipídios e necessidade de agitação do frasco de infusão, pela tendência de sedimentação da anfotericina. Ainda assim, no estudo, a formulação apresentou-se segura e eficaz.

Em adição ao exposto, notou-se que comorbidades foram adotadas como critérios de exclusão, principalmente HIV/SIDA e tuberculose. Tal procedimento é adotado em algumas pesquisas porque a presença de comorbidade, segundo Jacomini e Silva (2011), submete o paciente ao uso de mais de um medicamento e interfere nos resultados da pesquisa. Pode-se observar ainda a ocorrência de interações medicamentosas, como relatado por Fontele et al. (2021). Esse estudo mostrou o caso clínico de um paciente coinfectado HIV/Leishmania que apresentava níveis elevados de ureia e creatinina, um achado sugestivo de nefrotoxicidade como um evento adverso ao tratamento tenofovir e anfotericina B lipossomal. Neste sentido, medidas de prevenção poderiam ser padronizadas em um maior número de pacientes como a administração de $\mathrm{KCl}$ e soro fisiológico proposta por Thakur et al. (2010).

\section{CONSIDERAÇÕES FINAIS}

A análise dos artigos mostrou que os pacientes tratados com anfotericina B nas formulações desoxicolato e lipossomal apresentaram hipocalemia, sendo a maior ocorrência registrada para a desoxicolato. Desta forma, ações de farmacovigilância precisam ser padronizadas para permitir o monitoramento da função renal e do potássio sérico. Além disso, a reposição de eletrólitos durante o tratamento precisa ser avaliada quanto à prevenção de lesão renal. Evidenciou-se ainda que pessoas com calazar associada a outras doenças não foram incluídas nos estudos e, portanto, a ocorrência de eventos adversos como a hipocalemia não foram descritos para essa população. Assim, a presente revisão sugere estudos em pacientes com LV e outras doenças como os coinfectados HIV/Leishmania, bem como a descrição epidemiológica dessas populações.

\section{REFERÊNCIAS}

AMORIM, C. F. et al. Levantamento de flebotomíneos às margens do Rio Mossoró no nordeste do Brasil. Revista Baiana de Saúde Pública. vol. 39. no 3. p. 584-597. 2015. 
ASSIS, T. J. C. F. et al. Paralisia Periódica Hipocalêmica Tipo 1: Envolvimento dos Canais de Cálcio Dependentes de Voltagem. Rev. Neurocien. 2012; 20 (4): 588-596.

BARQUIST, E.; FEIN, E.; SHADICK, D.; et al. (1999) A randomized prospective trial of amphotericin B lipid emulsion versus dextrose colloidal solution in critically ill patients. Journal of Trauma. 47, 336-340.

BARRATT, G \& LEGRAND, P. Comparison of the efficacy and pharmacology of formulations of amphotericin B used in treatment of leishmaniasis. CurrOpInfectDis. 2005; 18 (6):527 - 530 .

BERDICHEVSKI, R. H. Nefrotoxicidade associada à anfotericina $B$ em pacientes de baixo risco. 2003. 71 f. Dissertação (Mestrado em Nefrologia) - Faculdade de Medicina - Universidade Federal do Rio Grande do Sul, Porto Alegre, 2003.

BORGES, Myrlena Mescouto; PRANCHEVICIUS, Maria Cristina da Silva; NORONHA, Elza Ferreira; et al. Efficacy and safety of amphotericin B deoxycholate versus $\mathrm{N}$ methylglucamine antimoniate in pediatric visceral leishmaniasis: an open-label, randomized, and controlled pilot trial in Brazil. Revista da Sociedade Brasileira de Medicina Tropical, v. 50, n. 1, p. 67-74, 2017.

BRAJTBURG, J. et al. (1990). Amphotericin B: Delivery Systems. Antimicrobial Agents and Chemotherapy, 34(3), pp. 381-384.

BRASIL. Ministério da Saúde. Secretaria de Vigilância em Saúde. Coordenação-Geral de Desenvolvimento da Epidemiologia em Serviços. Guia de Vigilância em Saúde: [recurso eletrônico] / Ministério da Saúde, Secretaria de Vigilância em Saúde, Coordenação- Geral de Desenvolvimento da Epidemiologia e Serviços. - 1. ed. atual. - Brasília : Ministério da Saúde, 2016. 773 p.

BRASIL. Ministério da Saúde. Secretaria de Vigilância em Saúde. Departamento de Vigilância Epidemiológica. Manual de vigilância e controle da leishmaniose visceral / Ministério da Saúde, Secretaria de Vigilância em Saúde, Departamento de Vigilância Epidemiológica. - Brasília: Editora do Ministério da Saúde, 2006.

BRASIL. Ministério da Saúde. Secretaria de Vigilância em Saúde. Leishmaniose visceral grave: normas e condutas / Ministério da Saúde, Secretaria de Vigilância em Saúde, Departamento de Vigilância Epidemiológica. - Brasília: Editora do Ministério da Saúde, 2006. 60 p. - (Série A. Normas e Manuais Técnicos).

BRASIL. Secretaria de Vigilância e Saúde (2020a). Casos confirmados de Leishmaniose Visceral, Brasil, Grandes Regiões e Unidades Federadas. 1990 a 2019. Disponível em: <https://www.gov.br/saude/pt-br>.

COORDENAÇÃO DE APERFEIÇOAMENTO DE PESSOAL DE NÍVEL SUPERIOR. CAPES. Plataforma Sucupira. Versão Beta. Disponível em: <https://sucupira.capes.gov.br/sucupira/> . Acesso em: 14 mai. 2021. 
DUTRA, V. F.; TALLO, F. S.; RODRIGUES, F. T.; et al. Desequilíbrios hidroeletrolíticos na sala de emergência. Rev Bras Clin Med. São Paulo, 2012 set-out;10(5): 410-9.

FILIPPIN, F. B. e SOUZA, L. C. Eficiência terapêutica das formulações lipídicas de anfotericina B. Revista Brasileira de Ciências Farmacêuticas. 2006; 42 (2).167194.

FONTELE, S. B. C.; AGUIAR, L. C. T.; IBIAPINA, A. B.; BRAZ, D. C. A LEISHMANIOSE VISCERAL ASSOCIADA A OUTRAS PATOLOGIAS: O TRATAMENTO E SEUS EVENTOS ADVERSOS - RELATO DE CASOS CLÍNICOS. Science \& Saúde. Ciência e atualizações na área da saúde. volume 2 / Organizadores Lennara Pereira Mota, Paulo Sérgio da Paz Silva Filho, Rafael Everton Assunção Ribeiro da Costa. - Rio de Janeiro, RJ: e-Publicar, 2021.

GONTIJO, C. M. F.; MELO, M. N. Leishmaniose Visceral no Brasil: quadro atual, desafios e perspectivas. Rev. Bras. Epidemiol. Minas Gerais. vol. 7. no 3. 2004.

Hernandez G, Altermatt F, Bernucci $F$ et al. Use of amphotericin B in lipid emulsions: does it prevent its toxicity in critically ill patients? Revista Medica de Chile. 128, 1101-1107. 2000.

KARDALAS, E.; PASCHOU, S. A.; ANAGNOSTIS, P. et al. Hypokalemia: a clinical update. Endocrine Connections. 2018. vol. 7, p. 135-146.

KHALIL, Eltahir A. G.; WELDEGEBREAL, Teklu; YOUNIS, Brima M.; et al. Safety and Efficacy of Single Dose versus Multiple Doses of AmBisome ${ }^{\circledR}$ for Treatment of Visceral Leishmaniasis in Eastern Africa: A Randomised Trial. PLoS Neglected Tropical Diseases, v. 8, n. 1, p. e2613, 2014.

JACOMINI, L. C. L.; SILVA, N. A. Interações medicamentosas: uma contribuição para o uso racional de imunossupressores sintéticos e biológicos. Rev. Bras. Reumatol. 2011. 51(2):161-174 CElsevier Editora Ltda.

Mourad Ouzzani, Hossam Hammady, Zbys Fedorowicz, and Ahmed Elmagarmid. Rayyan - a web and mobile app for systematic reviews. Systematic Reviews (2016) 5:210, DOI: 10.1186/s13643-016-0384-4.

ROBINSON, R. F.; NAHATA, M. C. A comparative review of conventional and lipid formulations of amphotericin B. J Clin Pharm Ther. 1999; 24(4):249-257. DOI: 10.1046/j.1365-2710.1999.00220.x

ROMERO, Gustavo Adolfo Sierra; COSTA, Dorcas Lamounier; COSTA, Carlos Henrique Nery; et al. Efficacy and safety of available treatments for visceral leishmaniasis in Brazil: A multicenter, randomized, open label trial. PLOS Neglected Tropical Diseases, v. 11, n. 6, p. e0005706, 2017.

SAMPAIO, R. N. R. \& MARSEN, P. D. Tratamento da forma mucosa de Leishmaniose sem resposta a glucantime, com anfotericina B lipossomal. Revista da Sociedade Brasileira de Medicina Tropical. 1997; 30 (2). 
SANDLER, E. S.; MUSTAFA M. M.; TKACZEWSKI, I.; et al. Use of amphotericin B colloidal dispersion in children. J Pediatr Hematol Oncol. 2000;22(3):242-6. http://dx.doi. org/10.1097/00043426-200005000-00009. PMid:10864055.

SCHÖFFSKI, P.; FREUND, M.; WUNDER, R.; PETERSEN, D.; KÖHNE, C.H.; HECKER, H.; SCHUBERT, U.; GANSER, A. Safety and toxicity of amphotericin B in glucose $5 \%$ or intralipid $20 \%$ in neutropenic patients with pneumonia or fever of unknown origin: randomized study. BMJ, v. 317, p. 379-384. 1998.

SOUTO, E. e LOPES, C. (2011). Novas Formas Farmacêuticas para Administração de Fármacos. Porto, edições Universidade Fernando Pessoa.

SUNDAR, S.; CHAKRAVARTY, J.; AGARWAL, D.; et al. Safety of a pre-formulated amphotericin B lipid emulsion for the treatment of Indian Kala-azar. Tropical Medicine \& International Health, v. 13, n. 9, p. 1208-1212, 2008.

SUNDAR, Shyam; CHAKRAVARTY, Jaya; AGARWAL, Dipti; et al. Single-Dose Liposomal Amphotericin B for Visceral Leishmaniasis in India. New England Journal of Medicine, v. 362, n. 6, p. 504-512, 2010.

SUNDAR, S.; MEHTA, H.; CHHABRA, A.; et al. Amphotericin B Colloidal Dispersion for the Treatment of Indian Visceral Leishmaniasis. Clinical Infectious Diseases, v. 42, n. 5, p. 608-613, 2006.

SUNDAR, Shyam; MEHTA, Himanshu; SURESH, A. V.; et al. Amphotericin B Treatment for Indian Visceral Leishmaniasis: Conventional versus Lipid Formulations. Clinical Infectious Diseases, v. 38, n. 3, p. 377-383, 2004.

TAKANO, T.; SOLTOFF, S. P.; MURDAUGH, S. et al. Intracellular respiratory dysfunction and cell injury in short-term anoxia of rabbit proximal tubules. J Clin Invest. 1985; 76: 2377-84.

VERDE, F. A. L. et al. Distúrbios Ácido-Base na Leishmaniose Visceral. Jornal Brasileiro de Nefrologia. 2008; 30 (3): 172-179.

WHO, 2013. The Special Programme for Research and Training in Tropical Diseases. Leishmaniasis: Disease information.

ZAGER, R. A.; BREDL, C. R.; SCHIMPF, B. A. Direct amphotericin B-mediates tubular toxicity: Assessments of selected cytoprotective agents. Kidney Int. 1992. vol. 41. p. 1588-94.

ZEIDEL, M. L.; SEIFTER, J. L.; LEAR, S. et al. Atrial Peptides inhibit oxygen consumption in kidney medullary collecting duct cells. Am J Physiol. 1986; 251: F379-83. 


\title{
CAPITULO V
}

\section{OS EFEITOS DO CUIDADO MÃE CANGURU EM RECÉM-NASCIDOS PREMATUROS: UMA REVISÃO INIEGRATIVA}

Géssica Santos Marques ${ }^{1}$

Adinaiara Dantas Carvalho ${ }^{2}$

Isis Nunes Veiga ${ }^{3}$

\begin{abstract}
${ }^{1}$ Fisioterapeuta pelo Centro Universitário Dom Pedro II / Salvador / Bahia / Brasil
${ }^{2}$ Fisioterapeuta pelo Centro Universitário Dom Pedro II / Salvador / Bahia / Brasil

${ }^{3}$ Fisioterapeuta/ Docente do Centro Universitário Dom Pedro II / Salvador / Bahia / Brasil e Docente da Unifacs Unime / Lauro de Freitas / Bahia / Brasil
\end{abstract}

\section{RESUMO}

O Cuidado Mãe Canguru (KMC) é uma alternativa terapêutica de baixo custo, disponível, praticável e bastante humanizada, que consiste no posicionamento vertical do recémnascido no peito da mãe, do pai ou responsável, com a finalidade de aumentar o vínculo afetivo familiar e reduzir os danos da prematuridade. O objetivo deste estudo é confirmar os efeitos do cuidado mãe canguru em recém-nascidos prematuros, mediante a metodologia da revisão integrativa, empregando 10 estudos escolhidos nas bases de dados indexadas entre 2010 e 2020. Demonstrou assertivamente os efeitos favoráveis, expressando a relevância deste método tanto para o desenvolvimento dos bebês prematuros quanto para o fortalecimento da relação mãe e bebê. É perceptível que o método canguru é um recurso acessível e benéfico, podendo ser utilizado em âmbito hospitalar, ambulatorial e domiciliar como recurso coadjuvante no tratamento de prematuros.

Palavras-chave: Prematuro. Método Mãe Canguru. Pré-Termo. Pele a Pele.

\section{INTRODUÇÃO}

O nascimento de recém-nascidos prematuros é um determinante de saúde que possui extrema relevância em todo o mundo, no qual dispõe níveis de gravidade distintos de acordo com a classificação da idade gestacional. Dentre os motivos que podem contribuir para que um parto ocorra antes do tempo devido estão os fatores biológicos como idade materna, doenças pré-existentes, complicações durante 
a gestação, estilo de vida, além das condições socioeconômicas e ambientais. (GUIMARÃES et al.,2017; OLIVEIRA et al.,2016).

Conforme definição da Organização Mundial de Saúde (OMS), a prematuridade refere-se ao nascimento que antecede a 370 semana de gestação, e atinge cerca de 15 milhões de neonatos por ano em todo o mundo, além de constituir uma das principais causas de morte em crianças com idade inferior a 5 anos. Em contrapartida, estima-se que caso as unidades de cuidado de saúde neonatal adotem práticas de intervenção mais humanizadas, cerca de 360 mil neonatos podem ter uma hipótese maior de sobrevida até o ano de 2030. (BROTHERTON, 2020; CIRIK; EFE, 2020; OPAS Brasil, 2020; SBP, 2020).

O manejo adequado na atenção de prematuros demonstra fundamental importância uma vez que a imaturidade dos seus órgãos e sistemas não favorece a uma satisfatória adaptação ao ambiente extrauterino. Além disso, a influência dos fatores externos como forte luminosidade, ruídos, intervenções invasivas e dolorosas, e o afastamento do vínculo materno deixa o neonato mais propenso a apresentar déficit no ganho de peso, estresse e alterações a nível neurológico e comportamentais, resultando em agravo no prognóstico dos neonatos. (KAHRAMAN et al., 2018; OZDEL; SARI, 2019; TANEJA et al., 2020.).

Dentre inúmeros procedimentos terapêuticos existentes com o intuito de amenizar os prejuízos resultantes da prematuridade, o Cuidado Mãe Canguru (KMC) destaca-se devido aos múltiplos benefícios a curto e longo prazo que podem ser obtidos através da técnica. Além disso, é um método não farmacológico, de fácil aplicação, baixo custo e altamente humanizada, uma vez que favorece a interação familiar. Tal conduta requer como critério de elegibilidade que o neonato esteja hemodinamicamente estável. Posteriormente o recém-nascido é aninhado na posição vertical, em contato com a região do peito materno ou paterno. Desta forma, se torna possível a interação pele a pele, adjunto ao aleitamento materno. (CHAVULA et al., 2020; PRASHANTHA et al., 2019; WHO, IMMEDIATE KMC STUDY GROUP, 2020).

Sendo assim, o objetivo deste estudo é ratificar os efeitos do método mãe canguru em recém-nascidos prematuros. 


\section{METODOLOGIA}

O presente estudo trata-se de uma revisão integrativa cuja metodologia permite que o conhecimento científico possa ser colocado em prática, através de uma análise minuciosa da literatura sobre o assunto proposto em questão. A pesquisa foi realizada através de uma revisão nas bases de dados eletrônicas: PubMed, Lilacs e SciELO. Foram avaliados artigos durante o período de março a maio de 2020, buscando materiais que fossem publicados nos últimos 10 anos utilizando como critério de inclusão estudos nos quais a conduta terapêutica aplicada consistia no cuidado mãe canguru, bem como os efeitos obtidos em recém-nascidos prematuros, além de serem artigos escritos em língua estrangeira. Foram excluídos os estudos nos quais o desenho metodológico não consistia em ensaio clínico randomizado, aqueles que abordassem o cuidado mãe canguru apenas no ambiente hospitalar, e materiais cuja conduta aplicada restringia-se apenas a bebês a termo ou pós termo. Foram utilizados os seguintes descritores: "premature", "kangaroo mother care", "pré-termo" e "pele a pele".

Para a elaboração da pesquisa, foi necessário estabelecer os seguintes passos:

\subsection{ELABORAÇÃO DA PESQUISA NORTEADORA}

Quais os efeitos adquiridos com o uso do cuidado mãe canguru em recémnascidos prematuros?

\subsection{BUSCA OU AMOSTRA NA LITERATURA}

Após análise nas bases de dados eletrônicas SciELO, Lilacs e PubMed, foram selecionados 10 artigos, cujo tema principal abordasse unicamente o cuidado mãe canguru em prematuros, além de estarem escritos em língua estrangeira. Foram excluídas as literaturas que associaram o cuidado mãe canguru a outro tipo de intervenção.

\subsection{COLETA DE DADOS}

A busca na literatura compreendeu o período de março a maio de 2020, nas bases de dados mencionados acima, utilizado seus respectivos descritores. 


\section{RESULTADOS}

Os resultados encontrados foram adquiridos a partir da leitura detalhada de 156 resumos e artigos (Figura 1), selecionando aqueles que correspondiam ao propósito deste estudo. As informações obtidas foram ordenadas e tabuladas conforme a coleta de dados que seguiu desta maneira: base de dados, palavras-chave, quantidade de referentes encontrados, resumos verificados, referências destacadas para verificação e artigos escolhidos para a revisão. Consoante os requisitos de inclusão, 19 artigos foram antepostos para triagem, sendo 9 artigos eliminados segundo os requisitos de exclusão.

Foi confeccionado um quadro com os aspectos dos estudos elegidos (Quadro 1).

Figura 1: Fluxograma dos artigos adquiridos

PubMed $(\mathrm{n}=26)$
Lilacs $(\mathrm{n}=94)$

\section{(1)} $\operatorname{SciELO}(\mathrm{n}=36)$

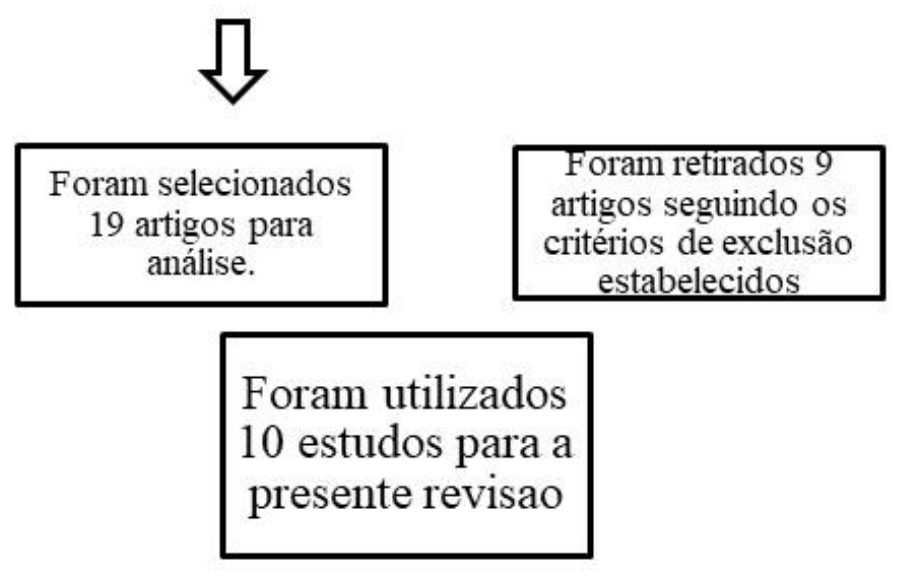

Fonte: Autoria própria. 


\subsection{DISCUSSÃO DOS RESULTADOS E APRESENTAÇÃO DA REVISÃO INTEGRATIVA}

Nas últimas duas fases, os resultantes provenientes da compreensão e análise minuciosa dos artigos, foram compilados por homogeneidade de temática, empregando a esfera inicial o uso do método canguru em recém-nascidos prematuros.

O quadro 1 apresenta dados sobre os efeitos do cuidado mãe canguru em recémnascidos prematuros. Deste modo é possível observar os achados do estudo de cada autor, o ano de publicação, além dos objetivos, a metodologia aplicada e os resultados obtidos.

Quadro 1-Quadro de resultados

\begin{tabular}{|c|c|c|c|}
\hline Autor/ano & Objetivo & Metodologia & Resultados \\
\hline $\begin{array}{c}\text { Nimbalkar et al. } \\
\text { (2013). }\end{array}$ & $\begin{array}{l}\text { Determinar os efeitos do } \\
\text { cuidado mãe canguru } \\
\text { (KMC), na redução de dor } \\
\text { após exame de triagem } \\
\text { neonatal, em recém- } \\
\text { nascidos prematuros. }\end{array}$ & $\begin{array}{l}\text { Atuaram neste ensaio clinico randomizado } \\
\text { duplo cego, } 47 \text { prematuros, alocados da } \\
\text { seguinte forma: } 19 \text { no grupo controle e } 28 \\
\text { no (KMC). Os neonatos do grupo KMC } \\
\text { receberam a intervenção de } 15 \text { min antes } \\
\text { do procedimento e permaneceu até } 15 \text { min } \\
\text { após, em posição vertical nos seios } \\
\text { maternos. Enquanto o grupo controle } \\
\text { permaneceu posicionado em decúbito } \\
\text { ventral na incubadora. Após procedimento } \\
\text { foi realizado teste PIPP para dor, e aferido } \\
\text { sinais vitais. }\end{array}$ & $\begin{array}{l}\text { Os recém-nascidos que } \\
\text { receberam o (KMC), } \\
\text { apresentaram redução da } \\
\text { frequência cardíaca e } \\
\text { melhor performance } \\
\text { comportamental, } \\
\text { indicando assim redução } \\
\text { de estresse e dor após o } \\
\text { procedimento. }\end{array}$ \\
\hline $\begin{array}{l}\text { Holditch-Davis et } \\
\text { al. (2014). }\end{array}$ & $\begin{array}{l}\text { Comparar os efeitos do } \\
\text { método canguru e um } \\
\text { programa multissensorial, } \\
\text { na relação mãe e bebê e } \\
\text { estresse psicológico } \\
\text { materno. }\end{array}$ & $\begin{array}{l}\text { Integraram esse ensaio clínico randomizado } \\
240 \text { pessoas que foram divididas da } \\
\text { seguinte forma: } 78 \text { no grupo } \\
\text { multissensorial, } 81 \text { no grupo método } \\
\text { canguru e } 81 \text { no controle. No grupo } \\
\text { programa multissensorial, foram auditivos, } \\
\text { visual e tátil por } 15 \text { minutos; no grupo } \\
\text { método canguru, os prematuros foram } \\
\text { posicionados entre os seios da mãe, } \\
\text { verticalmente, apenas com fralda e chapéu, } \\
\text { por no mínimo } 15 \text { minutos. Momentos da } \\
\text { interação foram filmados, bebês dos } 2 \text { aos } 6 \\
\text { meses de idade, totalizando } 45 \text { minutos } \\
\text { realizando estímulos. }\end{array}$ & $\begin{array}{l}\text { O método canguru } \\
\text { promoveu mais condutas } \\
\text { sociais dos bebês e menor } \\
\text { nível de angústia materna. }\end{array}$ \\
\hline \multirow[t]{2}{*}{ Gao et al. (2015). } & $\begin{array}{l}\text { Analisar a eficácia do } \\
\text { cuidado mãe canguru } \\
\text { (KMC), nos aspectos } \\
\text { comportamentais e } \\
\text { fisiológicos após } \\
\text { procedimento doloroso. }\end{array}$ & $\begin{array}{l}\text { Participaram deste estudo controlado,80 } \\
\text { neonatos pré-termos subdivido em } \\
\text { quantidades iguais para (40) grupo } \\
\text { incubadora e (40) grupo KMC. O } \\
\text { procedimento durou } 30 \text { min, repetido a } \\
\text { cada procedimento doloroso realizado. } \\
\text { Após a intervenção foi aferido FC, choro e } \\
\text { feição de dor. }\end{array}$ & $\begin{array}{l}\text { Os neonatos submetidos } \\
\text { ao (KMC), demonstraram } \\
\text { um período mais breve } \\
\text { nas feições de dor e choro, } \\
\text { além de melhor } \\
\text { estabilidade na frequência } \\
\text { cardíaca. }\end{array}$ \\
\hline & $\begin{array}{l}\text { Comparar os efeitos do } \\
\text { cuidado mãe canguru }\end{array}$ & $\begin{array}{l}\text { Foram randomizados } 80 \text { recém nascidos } \\
\text { estáveis e com peso inferior a } 2.500 \mathrm{~g} \text { para }\end{array}$ & $\begin{array}{l}\text { Os bebês do grupo KMC e } \\
\text { do controle, tiveram } \\
\text { diminuição no índice de }\end{array}$ \\
\hline
\end{tabular}




\begin{tabular}{|c|c|c|c|}
\hline $\begin{array}{l}\text { Dezhdar et al., } \\
\text { (2016). }\end{array}$ & $\begin{array}{l}\text { (KMC) versus a contenção } \\
\text { em panos durante o } \\
\text { procedimento de amostra } \\
\text { de sangue. }\end{array}$ & $\begin{array}{l}\text { participarem do estudo. Os mesmos foram } \\
\text { divididos em } 3 \text { grupos: } 1 \text { ○ KMC, } 2 \text { o grupo de } \\
\text { cuidados de rotina e } 3 \text { o grupo controle. A } \\
\text { duração de cada conduta durou } 10 \text { min, no } \\
\text { qual foi mantido durante a punção venosas. } \\
\text { O grupo KMC ficou aninhado no peito da } \\
\text { mãe enquanto o grupo controle foi coberto } \\
\text { por um pano fino. }\end{array}$ & $\begin{array}{l}\text { dor, relaxamento muscula } \\
\text { e redução da frequência } \\
\text { cardíaca e respiratória. }\end{array}$ \\
\hline $\begin{array}{l}\text { Sharma, Murki e } \\
\text { Pratap (2016). }\end{array}$ & $\begin{array}{l}\text { Comparar os efeitos do } \\
\text { método canguru na } \\
\text { enfermaria e cuidados } \\
\text { intensivos intermediário, } \\
\text { em prematuros com peso } \\
<1.100 \mathrm{~g} .\end{array}$ & $\begin{array}{l}\text { Participaram desse ensaio clínico } \\
\text { randomizado, } 141 \text { prematuros (71 no grupo } \\
\text { método canguru e } 70 \text { no grupo cuidados } \\
\text { intensivos intermediários). Os bebês } \\
\text { randomizados no grupo método canguru, } \\
\text { foram posicionados nos seios da mãe por } \\
\text { meio de tecido; os bebês do grupo de } \\
\text { cuidados intensivos intermediários ficaram } \\
\text { em incubadoras aquecidas, e quando } \\
\text { possível em método canguru por pelo } \\
\text { menos } 6 \mathrm{~h} \text { ao dia. }\end{array}$ & $\begin{array}{l}\text { Os bebês participantes do } \\
\text { grupo método canguru, } \\
\text { apresentaram menor } \\
\text { queda de saturação, maior } \\
\text { ganho de peso, } \\
\text { comprimento e perímetro } \\
\text { cefálico. }\end{array}$ \\
\hline $\begin{array}{l}\text { Bastani et al., } \\
\text { (2017). }\end{array}$ & $\begin{array}{l}\text { Verificar os efeitos do } \\
\text { cuidado mãe canguru na } \\
\text { regulação entre estado } \\
\text { comportamental de sono e } \\
\text { vigília em prematuros. }\end{array}$ & $\begin{array}{l}\text { Integraram esse ensaio controlado } \\
\text { randomizado } 70 \text { recém-nascidos. No qual } \\
\text { (35) estavam no grupo KMC, no qual os } \\
\text { neonatos foram colocados em decúbito } \\
\text { ventral sobre o peito da mãe, apenas } \\
\text { vestido de fralda, e (35) no grupo controle, } \\
\text { onde os bebês estavam dentro de uma } \\
\text { incubadora aquecida na posição supina. A } \\
\text { duração total da conduta foi de } 70 \text { min. } \\
\text { Posteriormente o grupo KMC foi recolocado } \\
\text { em DV na incubadora e observado durante } \\
20 \text { min. }\end{array}$ & $\begin{array}{l}\text { Os prematuros do grupo } \\
\text { KMC apresentaram o } \\
\text { estado de sono mais } \\
\text { profundo, e quando } \\
\text { acordados estavam mais } \\
\text { alertas, em comparação ao } \\
\text { grupo controle. Não houve } \\
\text { diferença entre o choro. }\end{array}$ \\
\hline $\begin{array}{l}\text { Vahdati, } \\
\text { Mohammadizadeh } \\
\text { e Talakoub (2017). }\end{array}$ & $\begin{array}{l}\text { Averiguar o efeito do } \\
\text { método canguru associado } \\
\text { a musicoterapia na } \\
\text { interação mãe e bebê. }\end{array}$ & $\begin{array}{l}\text { Integraram esse estudo } 64 \text { pessoas, que } \\
\text { foram divididas igualmente em grupo } \\
\text { método canguru e método canguru } \\
\text { combinado com música. A intervenção foi } \\
\text { executada em } 3 \text { datas seguidas, por } 60 \\
\text { minutos, com o bebê em posição vertical } \\
\text { entre os seios maternos; no grupo } \\
\text { intervenção, as mães escutaram em fone de } \\
\text { ouvido música neutra por } 20 \text { minutos, antes } \\
\text { de iniciar o cuidado pele a ele. Antes e após } \\
\text { a intervenção, a conduta materna foi } \\
\text { avaliada por } 15 \text { minutos, durante os } \\
\text { primeiros } 30 \text { segundos de cada minuto, nos } \\
\text { dois grupos. Foi usada a escala Avant. }\end{array}$ & $\begin{array}{l}\text { Os recém-nascidos que } \\
\text { integraram o grupo } \\
\text { intervenção, obtiveram } \\
\text { uma melhor interação } \\
\text { mãe e bebê, quando } \\
\text { comparado com o grupo } \\
\text { controle. }\end{array}$ \\
\hline $\begin{array}{l}\text { Fontana et al. } \\
\qquad \text { (2018). }\end{array}$ & $\begin{array}{l}\text { Verificar a eficácia da } \\
\text { promoção prematura na } \\
\text { alimentação com leite } \\
\text { materno e alimentação } \\
\text { bucal integral. }\end{array}$ & $\begin{array}{l}\text { Participaram desse ensaio clínico } \\
\text { randomizado, } 57 \text { prematuros que foram } \\
\text { divididos em grupo El (29) e SC (28). Os pais } \\
\text { do grupo El foram treinados conforme o } \\
\text { protocolo PremieStart, para reconhecer } \\
\text { sinais de conduta infantil e orientados a } \\
\text { realizarem massagem terapêutica em } \\
\text { sessões de } 10 \text { minutos, } 2 \text { vezes ao dia, com } \\
\text { o bebê estado alerta ou ativo de acordo } \\
\text { com a escala Brazelton; no grupo SC, foram }\end{array}$ & $\begin{array}{c}\text { Os prematuros } \\
\text { participantes do grupo El, } \\
\text { tiveram maior ingestão de } \\
\text { leite e alimentação bucal } \\
\text { integral antes dos bebês } \\
\text { do grupo SC, além de uma } \\
\text { maior probabilidade de } \\
\text { serem alimentados } \\
\text { unicamente com leite } \\
\text { materno. }\end{array}$ \\
\hline
\end{tabular}




\begin{tabular}{|c|c|c|c|}
\hline & & $\begin{array}{l}\text { realizados ninhamento e manipulação } \\
\text { mínima, sendo realizados método canguru e } \\
9 \text { sessões em ambos os grupos. }\end{array}$ & \\
\hline $\begin{array}{c}\text { Coskun e Gunay } \\
\text { (2019). }\end{array}$ & $\begin{array}{l}\text { Averiguar o impacto do } \\
\text { método canguru na } \\
\text { produção de leite e } \\
\text { estresse em mães de } \\
\text { prematuros. }\end{array}$ & $\begin{array}{l}\text { Colaboraram para este ensaio clinico, } 80 \\
\text { neonatos prematuros, divididos em grupo } \\
\text { método canguru (42) e grupo cuidado } \\
\text { padrão (38). Ambas intervenções foram } \\
\text { realizadas } 1 \text { vez ao dia, durante } 15 \text { a } 20 \mathrm{~min} \text {, } \\
5 \text { vezes na semana, por } 3 \text { semanas. }\end{array}$ & $\begin{array}{l}\text { Foi notado o aumento na } \\
\text { produção de leite e } \\
\text { diminuição de estresse nas } \\
\text { mães participantes do } \\
\text { grupo método canguru. }\end{array}$ \\
\hline $\begin{array}{l}\text { Nimbalkar et al., } \\
\text { (2020). }\end{array}$ & $\begin{array}{l}\text { Analisar os efeitos do } \\
\text { cuidado mãe canguru em } \\
\text { comparação a ingestão de } \\
\text { sacarose, na redução de } \\
\text { dor neonatal. }\end{array}$ & $\begin{array}{l}\text { Participaram deste ensaio randomizado } \\
\text { cruzado, } 100 \text { neonatos prematuros } \\
\text { alocados em partes iguais no grupo (A) } \\
\text { cuidado mãe canguru (KMC), e grupo (B) } \\
\text { oferta de sacarose. O procedimento KMC } \\
\text { foi realizado } 15 \text { min antes do teste de } \\
\text { glicose no calcanhar. Foi aplicado o teste } \\
\text { PIPP, aferição de sinais vitais e observação } \\
\text { de expressão facial de dor. }\end{array}$ & $\begin{array}{l}\text { Os recém nascidos do } \\
\text { grupo(A) além de } \\
\text { demonstrar melhora da } \\
\text { dor, apresentou outros } \\
\text { estabilidade } \\
\text { comportamental mais } \\
\text { eficaz. }\end{array}$ \\
\hline
\end{tabular}

D.V: Decúbito Ventral; Escala Avant: instrumento que avalia o apego entre a mãe e o bebê; Escala de Brazelton: Escala Neonatal de Avaliação Comportamental definido por seis estados comportamentais:

(1) sono profundo; (2) sono ativo; (3) sonolência; (4) alerta tranquilo; (5) despertar ativo; (6) choro intenso. Perfil de Dor Infantil Prematura (PIPP): Escala de avaliação de dor aguda neonatal diferenciando, observando o que pode expressar menos dor.

\section{DISCUSSÃO}

Devido a imaturidade sensorial, os recém-nascidos pré-termos possuem um maior senso doloroso, deixando-os vulneráveis a lesão neuronal estimulada por dor e estresse. Amadurecimento neurológico débil, mudanças no amadurecimento no eixo hipotalâmico hipófise adrenal, anomalias na sensação de dor, alterações comportamentais, oscilação no desempenho neuroendócrino e cognitivo a longo prazo estão relacionados a dor prematura. (NIMBALKAR et al., 2020; PROVENZI et al.,2016).

De acordo com os resultados encontrados no estudo de Nimbalkar et al. (2020) que comparava os efeitos da glicose oral e do método canguru em relação a dor, a glicose oral demonstrou ser melhor analgésico no teste do pezinho. Contudo, apesar do alívio doloroso, a ingestão recorrente de sacarose em prematuros está associada a uma diminuição do desenvolvimento neurológico, motor, da disposição e concentração. Em contrapartida, os resultados encontrados por Gao et al. (2015) em um estudo que comparava as reações comportamentais e fisiológicas de recém-nascidos prematuros 
em incubadoras e método canguru, mostrou que o cuidado pele a pele foi mais eficaz em promover redução do choro, estabilidade na frequência cardíaca e pontuação facial, após o teste do pezinho. Desta forma, este método não apenas induziu uma reação diminuta, como também uma restauração mais célere dos parâmetros fisiológicos, o que significa habilidade em conservar a homeostase, e consequentemente, um melhor desenvolvimento. O estudo realizado por Nimbalkar et al. (2013) também corroborou a eficácia do método canguru quando contrastado com a posição prona durante o teste do pezinho. A analgesia promovida pelo método ocorre devido a inibição do eixo hipotálamo hipófise adrenal, consecutiva diminuta de cortisol no sangue e acréscimo no fluxo de opioide e endorfina.

As reações ao cortisol são singulares e diversificam de acordo com a exposição acumulativa ao estresse e a imaturidade do eixo hipotálamo hipófise adrenal. (SRINATH et al., 2015).

Os achados encontrados por Dezhdar et al. (2016) corroboraram a eficácia do método cuidado pele a pele, em um estudo que comparava os efeitos do método canguru, swaddle e incubadora, antes, durante e após a punção venosa. Uma hipótese para explicar os efeitos ocasionados pelo método seria que a restrição cinésica gerou repouso muscular, e por conseguinte, melhorou a frequência respiratória, cardíaca e a saturação de oxigênio. Os resultados achados por Bastani et al. (2017) apresentaram outro efeito positivo do cuidado pele a pele em um estudo que comparava o sono do recém-nascido pré-termo posicionado no método canguru e em colo. Os bebês randomizados no grupo método canguru tiveram um sono mais profundo e estado silêncio acordado, em virtude da imediação da frequência cardíaca, do calor e cheiro do corpo materno.

É notório que o leite materno melhora a funcionalidade gastrointestinal, imunológica, reduz a incidência de infecção auricular e urinária, auxilia na involução uterina, diminui o estresse puerperal e promove analgesia. Devido a sua composição, o leite materno possui efeito antinociceptivo, mediante a ativação de opioides e inibição de fibras dolorosas, sendo uma alternativa mais barata e segura que a sacarose. (CIRIK; EFE, 2020; HUANG et al., 2019).

Coskun e Gunay (2019) demonstraram em seu estudo a eficácia do método canguru em relação ao aumento da produção de leite materno após intervenção. É 
conjecturado que esse efeito ocasionado pelo método canguru ocorre pela diminuição de estresse e fortalecimento do vínculo mãe e bebê. Fontana et al. (2018) encontraram resultados similares no estudo que comparava os efeitos de um programa que incluía massagem terapêutica e outro que continha nidificação e manipulação mínima, sendo realizado método canguru em ambos os grupos. O grupo que foi aplicado a massagem terapêutica obteve respostas melhores devido a capacitação de genitores para reconhecimento de sinais e zelo rotineiros para melhoria de aptidão oral em prematuros. Sharma, Murki e Pratap (2016) comprovaram os efeitos positivos do método canguru em enfermaria quando confrontado com os do grupo métodos canguru em cuidados intensivos intermediário em relação a ganho de peso, comprimento, perímetro cefálico e a ocorrência de apneias. O método canguru está associado a uma maior possibilidade de amamentação e a um maior consumo de leite materno e, portanto, ao ganho de peso.

Em estudos anteriores foi demonstrado que o método canguru aprimorou a saúde física e mental de mães e bebês, assim como potencializou este vínculo através de conduta mais afetiva e dedicada das mães, e consequentemente, maior senso de realização materna. (COOIJIMANS et al., 2017; SRINATH et al., 2015).

Vahdati, Mohammadizadeh e Talakoub (2017) comprovaram o efeito benéfico do método canguru sobre a interação mãe e bebê em um estudo que averiguava o benefício do método cuidado pele a pele associado a musicoterapia. Dessa maneira, assim como o método canguru reduz os níveis de estresse e ansiedade, a musicoterapia distrai pacientes de estímulos nocivos. Holditch-Davis et al. (2014) ratificaram a repercussão positiva do método canguru no quesito relação mãe e bebê e estresse psicológico materno em um estudo que verificava os efeitos cuidado pele a pele e um programa de estimulação multissensorial. O método canguru proporcionou menos angústia às mães e os bebês tiveram mais interação com a mãe e comportamento amadurecido. Possivelmente esses resultados ocorreram devido a maior possibilidade de movimentação, exercícios intermediários e brincadeiras autônomas. 


\section{CONSIDERAÇÕES FINAIS}

Diante do exposto, o método canguru demonstrou efeitos benéficos em bebês prematuros, seja em ambiente de terapia intensiva, de enfermaria ou ambulatorial. Por meio de intervenções em que o método canguru era aplicado de forma isolada ou associada a outro recurso, foi constatado o controle da dor, a diminuição do estresse, a promoção de um sono mais tranquilo e um estado mais quieto desperto, a estabilidade dos parâmetros fisiológicos, um aumento da produção e consumo de leite materno, assim como ganho de peso e crescimento, além de melhorar o tônus, reduzir a angústia materna e, consequentemente, melhorar a relação mãe e bebê. Contudo, apesar das benesses desencadeadas pelo método, é essencial ressaltar também a necessidade de mais estudos originais para reforçar os efeitos a longo prazo por meio de ensaios clínicos randomizados cegos.

\section{REFERÊNCIAS}

BASTANI, F et al. The Effects of Kangaroo Care on the Sleep and Wake States of Preterms Infants. The Journal of Nursing Research. Basingstoke, v. 25, n. 3, p. 231-239, jun. 2017.

BROTHERTON, $\mathrm{H}$. et al. Protocol for a randomised trial of early kangaroo mother care compared to standard care on survival of pre-stabilised preterm neonates in The Gambia (eKMC). BMC Part of Springer Nature. Basingstoke, v. 21, n. 247, p. 114, mar. 2020.

CIRIK, V. A; EFE. E. The effect of expressed breast milk, swaddling and facilitated tucking methods in reducing the pain caused by orogastric tube insertion in preterm infants: A randomized controlled trial. International Journal of Nursing Studies. Basingstoke, v. 104, abr. 2020.

CHAVULA, K. et al. Improving Skin-to-Skin Practice for babies in Kangaroo Mother Care in Malawi through the use of a customized baby wrap: A randomized control trial. Journal Plos One. São Francisco, v.15, n. 3, p.1-16, mar. 2020.

COOIJMANS, K.H.M, et al. Effectiveness of skin-to-skin contact versus care-as-usual in mothers and their full-term infants: study protocol for a parallel-group randomized controlled trial. BMC Pediatrics. Basingstoke, v. 17, n.154, p.1-16, jul. 2017.

COSKUN, D; Gunay, U. The effects of kangaroo care applied by Turkish mothers who have premature babies and cannot breastfeed on their stress levels and amount 
of milk production. Journal of Pediatric Nursing. Amsterdã, v. 50, p. 26-32, out. 2019.

DEZDAH, S et al. The Effects of Kangaroo Mother Care and Swaddling on Venipuncture Pain in Premature Neonates: A Randomized Clinical Trial. Iran Red Crescent Med J. Genebra, v. 18, n. 4, p. 1-9, abr. 2016.

FONTANA, $C$ et al. Effects of early intervention on feeding behavior in preterm infants: A randomized controlled trial. Early Human Development. Amsterdã, v. 121, p. 15-20, abr. 2018.

GAO, $\mathrm{H}$ et al. Effect of repeated Kangaroo Mother Care on repeated procedural pain in preterm infants: A randomized controlled trial. International Journal of Nursing Studies. Amsterdã, v. 52, n. 7, p. 1157-1165, abr. 2015.

GUIMARAES, E.E.A. et al. Prematurity and associated factors in Divinópolis, Minas Gerais state, Brazil, 2008-2011: analysis of the Information System on Live Births. Epidemiol. Serv. Saúde. Brasília, v. 2016, n. 1, p. 91-98, jan-mar. 2017.

HOLDITCH-DAVIS, D et al. Maternally administered interventions for preterm infants in the NICU: Effects on maternal psychological distress and mother-infant relationship. Infant Behavior and Development. Amsterdã, v. 37, n. 4, p. 695710, ago. 2014.

HUANG, P. et al Individualized intervention to improve rates of exclusive breastfeeding A randomised controlled trial. Medicine. Baltimore, v.98, n.47, p.1-7, nov. 2019.

KAHRAMAN, A. et al. The effect of nesting positions on pain, stress and comfort during heel lance in premature infants. Pediatrics and Neonatology. Amsterdã, v.59, n. 4, p. 352-359, ago. 2018.

NIMBALKAR, S.M et al. Kangaroo Mother Care in Reducing Pain in Preterm Neonates on Heel Prick. Indian J Pediatric. Karamsad, v. 80, n. 1, p. 6-10, jan. 2013.

NIMBALKAR, S et al. Blinded randomizes crossover trial: Skin-to-skin care vs. sucrose for preterm neonatal pain. Journal of Perinatology. Basingstoke, v. 40, p. 896-901, mar. 2020.

OLIVEIRA, L.L. et al. Maternal and neonatal factors related to prematurity. Journal of School Nursing USP. São Paulo, v.50, n.3, p.382-389, jun. 2016.

OPAS Brasil. Quase 30 milhões de recém-nascidos prematuros e doentes necessitam de tratamento para sobreviver todos os anos. OPAS Brasil. Disponível em: <https://www.paho.org/bra/index.php?option=com_content\&view=article \&id=5821:quase-30-milhoes-de-recem-nascidos-prematuros-e-doentesnecessitam-de-tratamento-para-sobreviver-todos-os-anos\&ltemid=820>. 
Acesso em: 20 de maio de 2020.

ÖZDEL, D.; SARI, H, Y. Effects of the prone position and kangaroo care on gastric residual volume, vital signs and comfort in preterm infants. Japan Journal of Nursing Science. Tóquio, v. 17, n.1, p.1-8, out. 2019.

PRASHANTHA, YN. et al. Onsite mentoring of special newborn care unit to improve the quality of newborn care. Indian Journal of Public Health. Bombaim, v. 63, n.4, p. 357-361 octo/dec 2019.

PROVENZI, L et al. Pain-related stress in the Neonatal Intensive Care Unit and salivary cortisol reactivity to socio-emotional stress in 3-month-old very preterm infants. Psychoneuroendocrinology. Amsterdã, v.72, p. 161-165, out. 2016.

SBP. Departamento Científico de Neonatologia da SBP divulga publicação com ênfase na prevenção da prematuridade. SBP. Disponível em:< https://www.sbp.com.br/imprensa/detalhe/nid/departamento-cientifico-deneonatologia-da-sbp-divulga-publicacao-com-enfase-na-prevencao-daprematuridade>. Acesso em: 20 de maio de 2020.

SHARMA, D; MURKI, S; PRATAP, O.T. The effect of kangaroo ward care in comparison with "intermediate intensive care" on the growth velocity in preterm infant with birth weight $<1100$ g: randomized control trial. Eur J Pediatr. Londres, v. 175, n. 10, p. 1317-1324, out. 2016.

SIRINATH, BK .et al. Kangaroo care by fathers and mothers: comparison of physiological and stress responses in preterm infants. Journal of Perinatology. Basingstoke, v.36, p.401-404, dez. 2015.

TANEJA, S. et al. Community initiated kangaroo mother care and early child development in low birth weight infants in India-a randomized controlled trial. BMC Pediatrics. Basingstoke, v.20, n.150, p.1-12, abr. 2020.

VAHDATI, M; MOHAMMADIZADEH, M; TALAKOUB, S. Effect of Kangaroo Care Combined with Music on the Mother-premature Neonate Attachment: A Randomized Controlled Trial. Iranian Journal of Nursing and Midwifery Research. Isfahan, v. 22, n. 5, p. 403-407, set-out. 2017.

WHO Immediate KMC Study Group. Impact of continuous Kangaroo Mother Care initiated immediately after birth (eKMC) on survival of newborns with birth weight between 1.0 to < $1.8 \mathrm{~kg}$ : study protocol for a randomized controlled trial. BCM Part of Springer Nature. Basingstoke, v. 21, n. 280, p.2-13, mar. 2020. 


\section{SCOPING REVIEW: ANÁLISE DE VÍDEOS PUBUCADOS ONUNE SOBRE CATEIERISMO VESICAL EM PACIENIES PEDIÁTRICOS}

\section{DOI: 10.51859/amplla.csa528.2121-6}

Michele Antunes ${ }^{1}$ ${ }^{1}$ Doutora em Informática na Educação pela Universidade Federal do Rio Grande do Sul (UFRGS). Professora Adjunta
do curso de Enfermagem da Universidade Feevale.

\section{RESUMO}

Os vídeos produzidos podem colaborar para o ensino de procedimentos de enfermagem como uma ferramenta multissensorial capaz de esclarecer as dúvidas e, dessa forma, facilitar o aprendizado. O objetivo foi analisar os vídeos publicados online sobre cateterismo vesical em pacientes pediátricos. Trata-se de um scoping review, realizado na plataforma YouTube, em língua portuguesa e espanhola no período de 01 de janeiro de 2013 a 15 de fevereiro de 2021. A amostra foi composta por três vídeos, e a análise permitiu identificar quatro categorias temáticas, foram: "Ausência de higienização das mãos", "Não realiza fixação e/ou a realiza de maneira incorreta", "Não realiza o descarte do material" e "Não explica o procedimento a ser realizado". Os vídeos sobre cateterismo vesical precisam ser aprimorados, tendo em vista que em todos os vídeos analisados foi identificada alguma fragilidade ou lacuna, seja de orientação aos familiares/paciente ou execução da técnica

Palavras-chave: Cateterismo vesical; Pediatria; Enfermagem.

\section{INTRODUÇÃO}

A formação em enfermagem vem se deparando com desafios que apontam para a necessidade do desenvolvimento integral do profissional, envolvendo aspectos objetivos de sua atuação (competências técnicas), bem como aspectos subjetivos relacionados a sua história, emoções e relações (JÚNIOR; FILHO; TAVARES, 2020). Os autores Tavares et al. (2014), por exemplo, indicam como os filmes podem ser utilizados na formação em enfermagem como facilitadores se aprendizados teóricos, bem como recursos para a experimentação, por universitários, de práticas sociais e culturais.

Compreendeu-se que os vídeos produzidos podem colaborar para o ensino de procedimentos de enfermagem como uma ferramenta multissensorial capaz de esclarecer as dúvidas e, dessa forma, facilitar o aprendizado, além de ser uma tecnologia 
de fácil acesso e uma forma de ensino que favorece o aprendizado de aspectos práticos, por subsidiar um processo de ensino/ aprendizagem em ambiente seguro (SALVADOR et al, 2017).

Estes podem ser usados para o ensino de alunos de graduação, bem como para aprimorar o conhecimento de pacientes e familiares que devem realizar um determinado procedimento (BESKIND; STOLZ; THIEDE et al, 2016; CONCEIÇÃO; PEDRO; MARTINS, 2017). O vídeo pode ser usado em várias situações de ensino como salas de aula, laboratórios de simulação e educação à distância, promovendo a aquisição de novas habilidades e melhorando o processo de aprendizado dos alunos (LOPES et al, 2020).

Todavia, existem poucos estudos, e os que são identificado na literatura, tem nos seus resultado, aspectos positivos e que ainda são conclusões empíricas, ou mesmo de estudos com baixo nível de evidência científica, o que torna problematicamente insuficiente a existência de evidências quanto ao benefício do uso de tecnologias para o ensino na educação em enfermagem (BHOOPATHI; SHEORAN; ADAMS, 2007). Além disso, destaca-se que, na atualidade, a principal fonte de busca dos vídeos educativos se constitui na Internet, em especial, as plataformas virtuais como o YouTube, que não garantem eficácia e qualidade das informações, o que demanda uma triagem adequada, pautada em protocolos de ensino (SALVADOR et al, 2017).

Acredita-se que os vídeos que estão disponíveis online na plataforma YouTube configuram-se como uma fonte de consulta dos estudantes, e que estes podem estar apresentando erros e/ou falhas nos procedimentos, assim como, trazer aspectos com comprometimentos éticos. Sendo assim, emerge a necessidade avaliar estes recursos que estão sendo utilizado como fontes de consulta e pesquisa junto aos estudantes, pois se estes estão sendo apresentados de maneira incorreta, podem comprometer o processo de aprendizagem e a qualidade do cuidado.

Diante do exposto, e buscando responder ao problema de pesquisa: "Qual a análise de vídeos publicados online sobre cateterismo vesical em pacientes pediátricos?", elaborou-se o objetivo de analisar os vídeos publicados online sobre cateterismo vesical em pacientes pediátricos. O procedimento cateterismo vesical em pediatria foi escolhido tendo em vista que este é um procedimento privativo do enfermeiro, exigindo conhecimento e competências técnicas específicas. 


\section{MÉTODO}

A metodologia deste estudo trata-se de scoping review na plataforma YouTube. Esta técnica de seleção é descrita pelos autores Arksey e O’Malley (2005), e atualizada por Levac, Colquhoun e O'Brien (2010). Trata-se de uma ferramenta ideal para determinar a cobertura de um corpo de literatura sobre um determinado tópico, indicando de maneira clara, o volume de literatura e estudos disponíveis, bem como, uma visão geral (ampla ou detalhada) (MUNN et al., 2018).

O método de análise dos vídeos foi a de imagens em movimento, com abordagem quantitativa. A linguagem do vídeo tem uma natureza sintética, articula imagens, sons, falas, poucos textos, e cria uma superposição de códigos e significações, predominantemente audiovisuais. Tem, destarte, um significativo poder de ilustração, prende atenção quando bem estruturado e elaborado, além de muitas vezes ser autoexplicativo (SCHNEIDER; CAETANO; RIBEIRO, 2012).

A coleta de dados foi realizada no período de dezembro de 2020 a março de 2021 por visitas no sítio de compartilhamento de vídeos do YouTube. Para realizar a busca neste repositório, utilizou-se se a palavra-chave cateterismo vesical entre aspas, associado ao termo pediatria, em língua portuguesa e espanhola no período de 01 de janeiro de 2013 a 15 de fevereiro de 2021. Foram identificados sete vídeos e excluídos três devido serem com foco no paciente pediátrico.

Os vídeos foram analisados individualmente com apoio de instrumento de modo a caracterizá-los quanto à autoria, categoria, enfoque e operacionalização do procedimento de cateterismo vesical em pacientes pediátricos. Para tratamento descritivo e cálculo de frequências simples, os dados foram tabulados no programa Excel. Tendo em vista que o material tratava-se de domínio público, não houve necessidade de submissão do mesmo para avaliação em Comitê de Ética em Pesquisa.

\section{CATETERISMO VESICAL DE DEMORA EM PEDIATRIA}

A cateterização urinária é um procedimento invasivo em que é inserido um cateter uretral até a bexiga com a finalidade, dentre outras, de drenagem da urina em pacientes com problema de eliminação urinária. A drenagem urinária pode ser realizada 
por meio de sistema aberto (intermitente ou alívio) ou fechado (demora) (GOULD; UMSCHEID; AGARWAL et al, 2009).

Sabe-se que o cateterismo urinário intermitente e de demora, realizados em ambiente hospitalar, é uma técnica asséptica (QUEIRÓS; CIPRIANO; SANTOS et al, 2011). Segundo a Resolução 450/2013, do Conselho Federal de Enfermagem (COFEN), a sondagem vesical é um procedimento invasivo e que envolve riscos ao paciente, que está sujeito a infecções do trato urinário e/ou a trauma uretral ou vesical, destacando ainda que:

\footnotetext{
"Requer cuidados de Enfermagem de maior complexidade técnica, conhecimentos de base científica e capacidade de tomar decisões imediatas $e$, por essas razões, no âmbito da equipe de Enfermagem, a inserção de cateter vesical é privativa do Enfermeiro, que deve imprimir rigor técnicocientífico ao procedimento. $O$ procedimento de Sondagem Vesical deve ser executado no contexto do Processo de Enfermagem, atendendo-se às determinações da Resolução Cofen no 358/2009 e aos princípios da Política Nacional de Segurança do Paciente, do Sistema Único de Saúde".
}

As infecções do trato urinário (ITU) estão entre as infecções bacterianas mais comuns em crianças. Até $8 \%$ das crianças experimentam pelo menos uma ITU entre um mês e 11 anos (HOBERMAN; CHAO et al, 1993; MARILD; JODAL, 1998) e até 30\% dos bebês e crianças experimentam infecções recorrentes durante os primeiros 6 a 12 meses após a ITU inicial (MANGIAROTTI; PIZZINI et al, 2000; NUUTINEN; UHARI, 2001).

Conforme a resolução no0450 de 11/12/2013, foram estabelecidas diretrizes para a atuação da equipe de enfermagem durante a atividade, visando a segurança do paciente submetido ao procedimento, sendo a SV um procedimento invasivo que requer conhecimento científico e capacidade de tomar decisões imediatas, sendo competência privativa do enfermeiro, pois a prática envolve risco ao paciente, como o trauma uretral, além da ITU (COFEN, 2013).

Segundo Silva, Oliveira e Mak (2020) algumas diretrizes recomendam a cateterização da urina; por outro lado, alguns autores argumentam a favor da coleta pela bolsa de urina, apesar da prevalência de achados falso-positivos. Essas e outras questões ainda não foram resolvidas. No entanto, alguns conselhos gerais devem ser levados em consideração pelo pediatra. 


\section{ANÁLISE E DISCUSSÃO dOS RESULTADOS}

Após a análise a amostra foi composta por três vídeos, que após a visualização, foram preenchidos instrumentos de avaliação (APÊNDICE A), de modo a caracterizá-los quanto a autoria, categoria, enfoque e operacionalização do procedimento de cateterismo vesical em pacientes pediátricos. Os resultados foram organizados a fim de responder a questão de pesquisa, conforme Quadro 1.

Quadro 1. Caracterização dos estudos que compuseram a amostra. Novo Hamburgo, Rio Grande do Sul, 2021.

\begin{tabular}{l|l|l|r|} 
Número \\
do vídeo
\end{tabular}

Fonte: Dados da pesquisa, 2021.

No que se refere ao idioma dos vídeos, a totalidade (3-100\%) dos vídeos foram publicados em idioma espanhol, postados em páginas pessoais dos profissionais no YouTube, sendo realizados em manequins.

Quanto ao procedimento que foi realizado, dois $(66,6 \%)$ tiveram como foco a sondagem vesical de demora. Ressalta-se que não foi possível identificar qual a formação daqueles que estão realizando a simulação do procedimento.

No que se refere ao cenário, dois $(66,6 \%)$ foram agravados em laboratório, sendo estes os vídeos de números 1 e 3 . 0 de número 2, não foi possível identificar se tratavase de um laboratório ou sala de aula. Entretanto, o de número 2, foi o único que utilizou 
uma abordagem mista, na qual simulou as orientações e a descrição do procedimento ao acompanhante/paciente, e posteriormente executou a técnica de sondagem.

No vídeo de número 01, Figura 1, trata-se do cateterismo vesical de demora, usando um manequim. Entretanto, não é orientado que o profissional deva apresentarse ao paciente e acompanhante e explicar o procedimento a ser realizado.

Também não é realizada a higienização das mãos, realiza o procedimento de maneira parcial, não apresentando a sequência de calçar as luvas e nem a antissepsia da pele do paciente. Assim como, este não apresenta de que forma deva ser realizada a fixação da sonda e nem o descarte do material utilizado.

Figura 1 - Vídeo de número 1 disponível do YouTube sobre cateterismo vesical. Novo Hamburgo, Rio Grande do Sul, 2021.

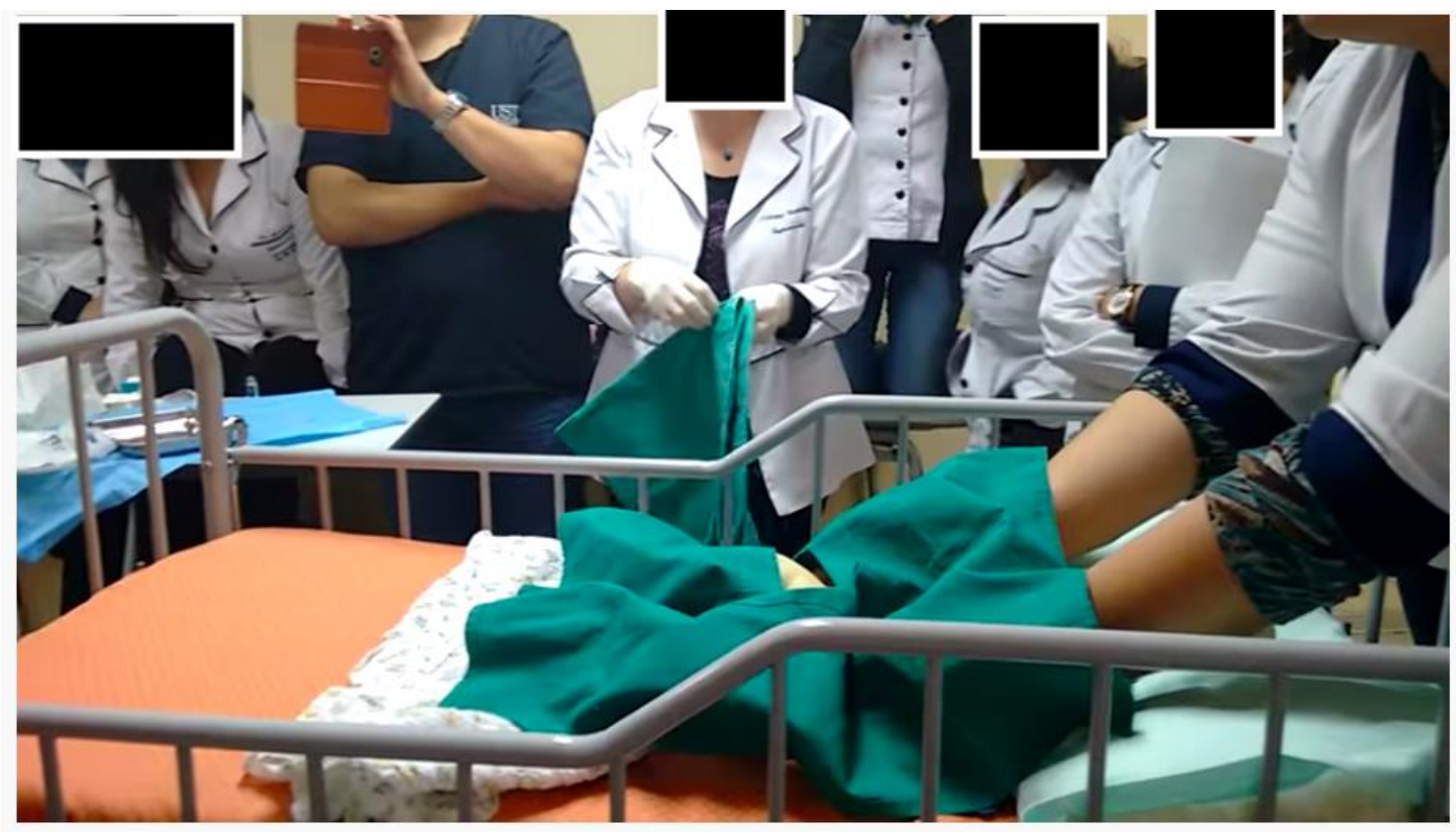

Fonte: Dados da Pesquisa, 2021.

No vídeo de número 02, Figura 2, trata-se do cateterismo vesical de alívio em paciente pediátrico, usando um modelo de simulação de baixa fidelidade. $O$ vídeo orienta que o profissional deve apresentar-se ao paciente/acompanhante e explicar o procedimento a ser realizado. Neste, é realizado o procedimento de parcial completa, apresentando a sequência deste o calçar das luvas e antissepsia da pele do paciente, mas não a fixação e nem o descarte de materiais. 
Outro aspecto a ser considerado consiste no fato de não ser realizada a higienização das mãos, e não utilizar pinças estéreis para o procedimento, e nem campo fenestrado. Realizando a coleta de urina sem cuba rim, posicionando a sonda para drenar diretamente no saco coletor. Neste, ao finalizar o procedimento de inserção da sonda uretral, realiza a fixação desta diretamente no períneo do manequim.

Figura 2 - Vídeo de número 2 disponível do YouTube sobre cateterismo vesical. Novo Hamburgo, Rio Grande do Sul, 2021.

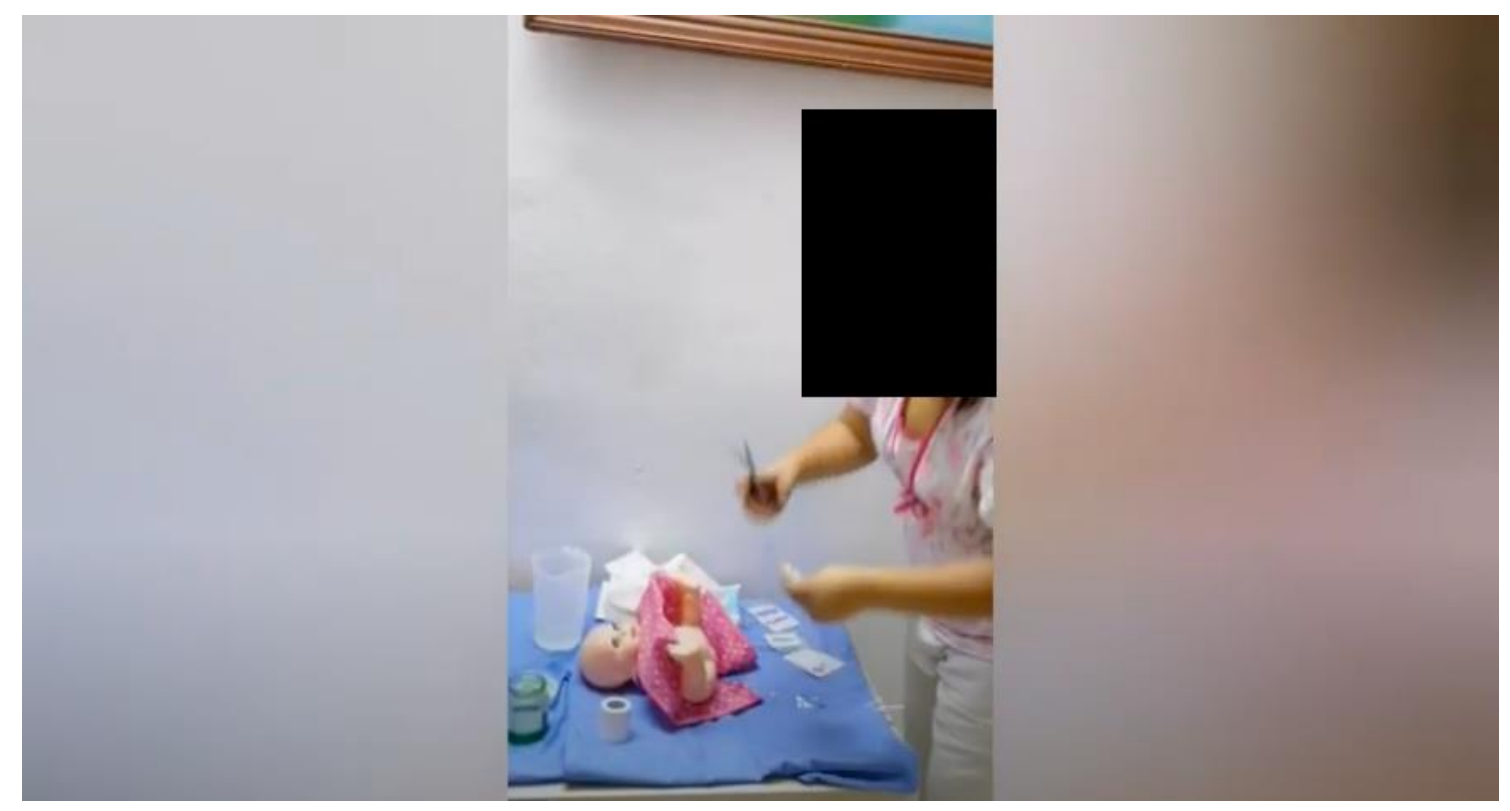

Fonte: Dados da Pesquisa, 2021.

No vídeo de número 03, Figura 3, o profissional realizou o cateterismo vesical de demora, em manequim de baixa fidelidade. Orientou que deva ser realizada a higiene do períneo antes do procedimento, e o profissional utiliza luvas para realizá-lo. Neste, é feito o procedimento de maneira incompleta, apresentando a sequência deste o calçar das luvas e antissepsia da pele do paciente, mas não orienta a fixação da sonda e nem o descarte de materiais.

No referido vídeo, não é realizada a higienização das mãos, e o executor não utiliza pinças estéreis para o procedimento, mas usa campo fenestrado. 
Figura 3 - Vídeo de número 3 disponível do YouTube sobre cateterismo vesical. Novo Hamburgo, Rio Grande do Sul, 2021.

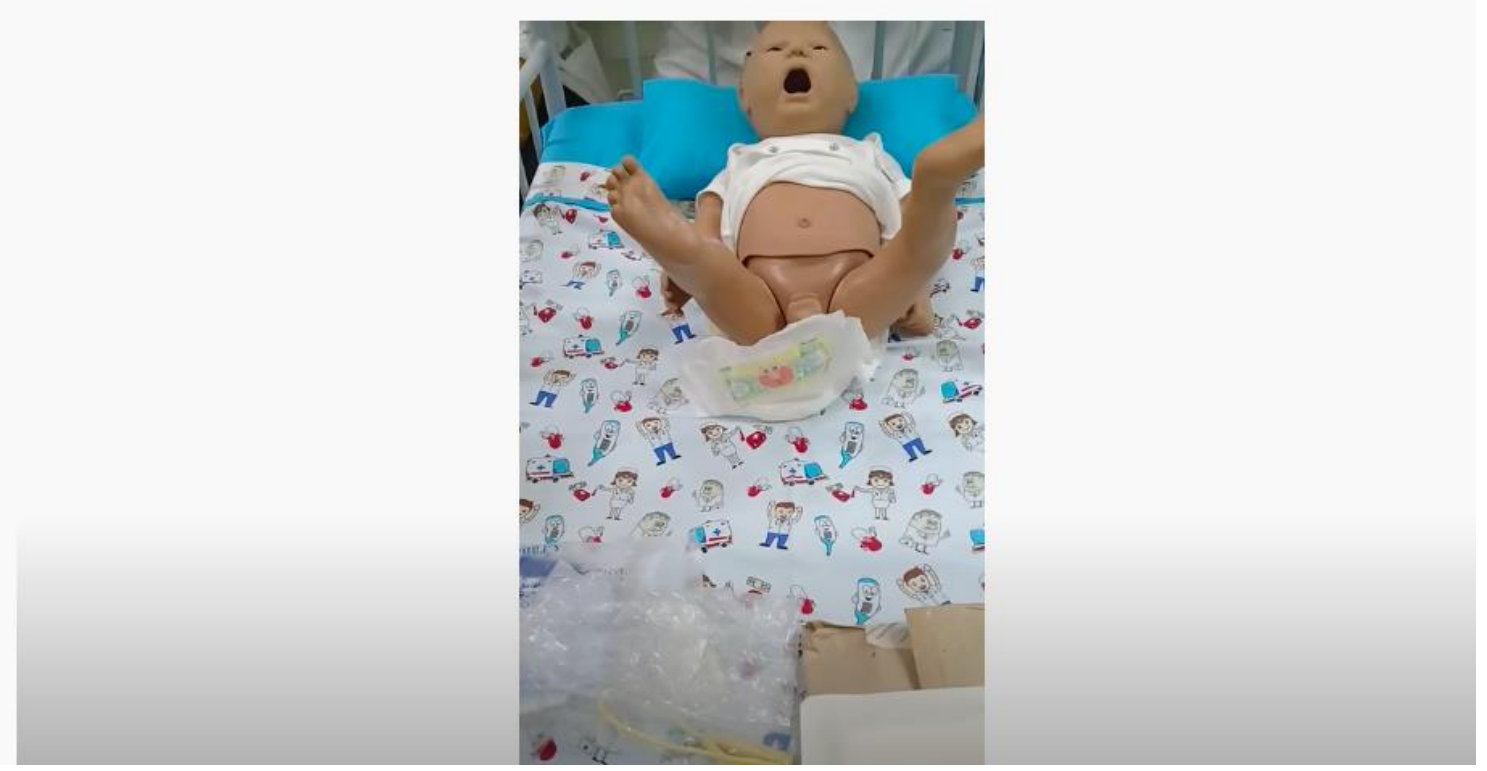

Fonte: Dados da Pesquisa, 2021.

Quanto às características de aspectos identificados nos vídeos, foram identificadas quatro categorias temáticas, quais sejam: "Ausência de higienização das mãos", "Não realiza fixação e/ou a realiza de maneira incorreta”, "Não realiza o descarte do material" e "Não explica o procedimento a ser realizado", conforme Tabela 1.

Tabela 1. Categorias temáticas identificadas. Novo Hamburgo, Rio Grande do Sul, 2021.

\begin{tabular}{cc}
\hline Categoria temática & Números dos vídeos \\
\hline Ausência de higienização das mãos & $1,2,3$ \\
Não realiza fixação e/ou a realiza de maneira incorreta & $1,2,3$ \\
Não realiza o descarte do material & $1,2,3$ \\
Não explica o procedimento a ser realizado & 1,3 \\
\hline
\end{tabular}

Fonte: Dados da pesquisa, 2021.

As categorias temáticas "Ausência de higienização das mãos", "Não realiza fixação e/ou a realiza de maneira incorreta", "Não realiza o descarte do material" foram as mais prevalentes, com três (100\%) vídeos. Já a categoria “Não explica o procedimento a ser realizado" foi identificada em dois $(66,6 \%)$.

O protocolo de coleta de urina deve considerar limitações e riscos de cada método e também a prática local e viabilidade. Todas as decisões em relação a uma 
criança com ITU devem basear-se em histórico clínico detalhado, exame físico e julgamento clínico cuidadoso para evitar, por um lado, exames invasivos desnecessários e, por outro lado, resultados adversos futuros para a função renal (SILVA; OLIVEIRA; MAK, 2020).

A prática de higienização das mãos (HM) é algo ensinado em todos níveis de formação durante o ensino da saúde, e deve ser reforçada junto a estes profissionais. Esta consiste na primeira medida de prevenção de infecções, sendo de baixo custo e de fácil execução.

A HM tem por objetivo remover material orgânico ou inorgânico e microrganismos,

podendo comprometer a segurança e a qualidade da assistência se não realizada., e a adesão a este procedimento, de modo habitual, transformou-se em uma maneira eficaz de promover a segurança à saúde (PORTELA et al, 2020). A HM é um procedimento simples e barato e é eficaz na promoção do controle de infecções e no aumento da qualidade no cuidado prestado ao paciente, auxiliando na redução de custos e de morbimortalidade, fenômenos esses que são requisitos fundamentais na busca por eficiência na área da saúde (VASCONCELOS, et al., 2018).

Uma vez que há um risco aumentado de infecção em pacientes neonatais , a prevenção e o controle das IRAS nessas unidades dependem de conscientização e de motivação do profissional de saúde em realizar correta e frequentemente a higienização das mãos (MENDONÇA et al, 2003). A ANVISA reforça a importância da higienização das mãos como uma medida de impacto na prevenção das IRAS, isto é, ela entende como uma medida preventiva realizada na obtenção de bons resultados e ferramenta para a melhoria contínua da qualidade da assistência (BRASIL, 2017).

O enfermeiro supervisiona os cuidados da equipe de enfermagem em relação às técnicas corretas de lavagens das mãos, levando em consideração as condições físicas e anatômicas do paciente, avaliar criteriosamente a manipulação e fixação da sonda, e conscientizando o paciente que estiver lúcido e seus familiares (CAMELO, 2012).

A correta fixação do cateter, a identificação do dispositivo (Nome do profissional, data da inserção, número do cateter), a manutenção da bolsa coletora abaixo do nível da bexiga. O volume de urina abaixo de $2 / 3$ para evitar refluxo, o fluxo urinário desobstruído, a desinfecção adequada do plug para coleta de exames (urocultura e EAS), 
a justificativa diária de manter o cateter, por meio de prescrição de enfermagem (sistematização da assistência se enfermagem) e prescrição médica registradas em prontuário eletrônico (MIRANDA, 2016).

O Enfermeiro precisa além do conhecimento técnico-científico orienta e treinar a equipe para realizar as técnicas corretas para e rotinas que previna as infecções do trato urinário, através das lavagens das mãos, manuseio adequado da sonda, higiene correta, fixação correta da sonda, orientar o paciente se ele estiver consciente, seguir as normas da Comissão de Controle de Infecção Hospitalar (CCIH) (NOGUEIRA et al, 2017).

A fixação da sonda foi um dos indicadores com o menor índice de adequação, mesmo sendo uma simples medida foi relevante para a conclusão impróprias das práticas diária da unidade de terapia intensiva, a fixação imprópria do cateter vesical de demora pode lesionar a uretra pela tração durante a movimentação do paciente. Ainda que existem os protocolos publicados e atualizados sobre a instalação e manutenção dos cateteres vesicais, observa-se que na prática tem passado por muitas dificuldades da implementação, pois existem falhas na execução e no acompanhamento dos procedimentos, que colaboram para o crescimento de Infecções relacionadas à assistência à saúde (IRAS) (MATTEDE, 2015).

No que se refere ao descarte de resíduos, destaca-se que é de responsabilidade do profissional que executa o procedimento, pois o mesmo deve realizar todos os passos, desde o inicio até o fim. Ressalta-se que o descarte pode deixar o trabalhador exposto a acidente de trabalho, pois este fica exposto a materiais que estão dispostos durante o procedimento que foi realizado por outra pessoa.

Os Resíduos de Serviços de Saúde são classificados em Grupo A (presença de agentes biológicos), Grupo B (produtos químicos), Grupo C (rejeitos radioativos), Grupo D (resíduos comuns) e Grupo E (perfurocortantes) (BRASIL, 2018).

A enfermagem vem sendo exigida sobre a busca por novos conhecimentos para inovar a capacidade da prevenção de uma maneira mais eficaz, promovendo a saúde e qualidade do serviço humanizado (SPERANCETA et al., 2016). Cabe ao enfermeiro assistente a liderança da sua equipe, no sentido de orientar e supervisionar, o que sensibiliza cada vez mais sua equipe e se traduz num maior 
envolvimento/comprometimento com a qualidade do cuidado e prevenção de eventos adversos (ARAIS et al., 2017).

Os registros da equipe de Enfermagem são consideradas os principais meios de comunicação entre toda a equipe de saúde e estão diretamente relacionadas com a segurança do paciente e a qualidade da assistência em saúde prestada, pois, além de indicar as ações, procedimentos e orientações prestadas aos pacientes, possibilitam informações para a sua continuidade e planejamento, de acordo com as suas necessidades (ARAIS et al., 2017).

Neste contexto destaca-se se a comunicação entre o paciente e profissionais, no qual o mesmo deve ser orientado sobre o que será realizado e quais os cuidados antes, durante e após o procedimento. A dimensão não verbal é responsável pela maior parte da troca de informações entre as pessoas e deve ser decodificada adequadamente para que haja uma compreensão efetiva (BORBA; SANTOS; PUGGINA, 2017).

O investimento em educação continuada e a atualização do conhecimento da equipe de enfermagem, são medidas importantes para prevenção de infecções relacionadas a sondagem vesical (LOPES et al., 2018). A comunicação para ser efetiva necessita ser compreendida em sua amplitude por todos os envolvidos, porém podem ocorrer barreiras comunicacionais que dificultem ou impeçam a total compreensão da informação (BORBA; SANTOS; PUGGINA, 2017).

A análise permitiu identificar que ainda existem lacunas a serem abordadas, tendo em vista de que na totalidade dos vídeos houveram itens que estavam em não conformidade com o que foi avaliado. Estes resultados nos permitiram verificar que devemos atentar para os conteúdos que estão sendo disponibilizados nas plataformas, a fim de investigar a qualidade destes.

\section{CONCLUSÕES}

O presente estudo teve como objetivo analisar os vídeos publicados online sobre cateterismo vesical em pacientes pediátricos, utilizando a plataforma YouTube. Verificou-se que a totalidade de vídeos que compuseram a amostra não estavam em conformidade, permitindo a elaboração de quatro categorias temáticas . 
As categorias identificadas foram "Ausência de higienização das mãos", "Não realiza fixação e/ou a realiza de maneira incorreta", "Não realiza o descarte do material" foram as mais prevalentes, com três (100\%) vídeos. Já a categoria "Não explica o procedimento a ser realizado" foi identificada em dois $(66,6 \%)$.

Diante do exposto, pode-se afirmar que ainda existem lacunas a serem abordadas no que refere-se a elaboração de vídeos sobre cateterismo vesical em pediatria, tendo em vista de que na totalidade dos vídeos, houveram itens que estavam em não conformidade com o que foi avaliado. Dessa forma, questiona-se a fidedignidade dos conteúdos que estão sendo disponibilizados nas plataformas, a fim de investigar a qualidade destes.

Como limitações desta pesquisa, destacam-se a quantidade de vídeos sobre a temática no repositório analisado, assim como, a autoria daqueles que o estão postando. Como estudos futuros, sugere-se a realização de mais pesquisas que objetivem avaliar a qualidade de vídeos como ferramenta de ensino na Enfermagem.

\section{REFERÊNCIAS}

ARKSEY, H.; O'MALLEY, L. Scoping studies: towards a methodological framework. International journal of social research methodology, v. 8, n. 1, p. 19-32, 2005.

ARRAIS ELM, et al. Prevenção de infecção urinária: indicadores de qualidade da assistência de enfermagem em idosos. Rev Enferm UFPE on line, 2017; 11(8): 3151-7.

BHOOPATHI PS, SHEORAN R, ADAMS CE. Educational games for mental health professionals: a Cochrane review. Int. J. Psychiatr. nurs. res. 2007; 12(3):1497502.

BORBA AP, SANTOS BM, PUGGINA AC. Barreiras de comunicação nas relações enfermeiro-paciente: revisão integrativa. Rev Saúde [Internet]. 2017; [citado 2019 jan 25];11(1-2):48-61. Disponível em: http://revistas.ung.br/index.php/saude/article/view/2848/2205

BRASIL. Agência Nacional de Vigilância Sanitária (ANVISA). Medidas de Prevenção de Infecção Relacionada à Assistência à Saúde. Brasília: ANVISA, 2017. 122p Disponível em: http://portal.anvisa.gov.br/documents/33852/3507912/Caderno+4++Medidas+de+Preven\%C3\%A7\%C3\%A3o+de+Infec\%C3\%A7\%C3\%A3o+Relacion ada+\%C3\%A0+Assist\%C3\%AAncia+\%C3\%A0+Sa\%C3\%BAde/a3f23dfb-2c544e64-881c-fccf9220c373. 
BRASIL. Ministério da Saúde (BR). RDC n. 222 de 28 de março de 2018. Dispõe sobre o regulamento de Boas Práticas de gerenciamento de resíduos de serviços de saúde. [Internet]. 2018 [citado 2019 set 5]. Disponível em: http://portal.anvisa.gov.br/documents/10181/3427425/RDC_222_2018_.pdf/c5d 3081d-b331-4626-8448-c9aa426ec410

CAMELO, S.H.H. Competência profissional do enfermeiro para atuar em Unidade de Terapia Intensiva: uma revisão integrativa. Revista Latino-AM Enfermagem. São Paulo, p 3, jan-fev 2012. Disponível em: WWW: <URL: http://www.scielo.br/pdf/rlae/v20n1/pt_25

CONSELHO FEDERAL DE ENFERMAGEM (COFEN). Resolução COFEN no 0450/2013, de 11 de dezembro de 2013. Normatiza sobre o procedimento de Sondagem Vesical no âmbito do Sistema Cofen/Coren.

GOULD CV, UMSCHEID CA, AGARWAL RK, KUNTZ G, PEGUES DA. Health Care Infection Control Practices Advisory Committeel. Guideline for prevention of catheterassociated urinary tract infections 2009. Atlanta, GA: Healthcare Infection Control Practices Advisory Committee; 2009. 67 p.

HOBERMAN A, CHAO HP, KELLER DM, HICKEY R, DAVIS HW, ELLIS D. Prevalence of urinary tract infection in febrile infants. J Pediatr. 1993;123:17-23.

JÚNIOR AAP, FILHO LACRZ, CMM TAVARES. A produção de sentidos por estudantes a partir de um vídeo educativo na educação em enfermagem. Interfaces da Educ., Paranaíba, v.11, n.31, p. 606 - 624, 2020.

LEVAC, D.; COLQUHOUN, H.; O'BRIEN, K.K. Scoping studies: advancing the methodology. Implementation Science, v. 5, n. 69, 2010.

LOPES, A.M.,et al., Conhecimento Teórico de Estudantes de Enfermagem Sobre o Cateterismo Vesical de Demora. Revista de Enfermagem do Oeste Mineiro. Vol 08. 2018.

MANGIAROTTI P, PIZZINI C, FANOS V. Antibiotic prophylaxis in children with relapsing urinary tract infections: review. J Chemother. 2000;12:115-23.

MATTEDE M.G.S.; PIRAS C.; MATTEDE K.D.S.; FERRARI A.T.; BALDOTTO L.S.; ASSBU M.S.Z. Infecções urinárias causadas por Trichosporon spp. em pacientes graves internados em unidade de terapia intensiva. Rev. bras. ter. intensiva; 27(3): 247251, jul.-set. 2015.

MARILD S, JODAL U. Incidence rate of first-time symptomatic urinary tract infection in children under 6 years of age. Acta Paediatr. 1998;87:549-52. 
MENDONÇA, A. P, et al. Lavagem das mãos: adesão dos profissionais de saúde em uma unidade de terapia intensiva neonatal. Acta Scientiarum. Health Sciences, Maringá, v. 25, n. 2, p. 147-153, 2003.

MIRANDA AL, OLIVEIRA ALL, NACER DT, AGUIAR CAM. Results after implementation of a protocol on the incidence of urinary tract infection in an intensive care unit. Rev. Latino-Am. Enfermagem. 2016;24:e2804.DOI: http://dx.doi.org/10.1590/15188345.0866.2804. URL: http://www.scielo.br/pdf/rlae/v24/pt_0104-1169-rlae-24-02804.pdf

MUNN, Z. et al. Systematic review or scoping review? Guidance for authors when choosing between a systematic or scoping review approach. BMC Medical Research Methodology, v. 18, 2018.

NOGUEIRA, H.K.L.; GÓES, A.C.; et al. Conhecimento de profissionais intensivistas sobre o Bundle para a prevenção de infecção do trato urinário associada ao uso de sondas. Rev Enferm UFPE on line, v. 11. p. 4818-4820, Recife, 2017.

NUUTINEN M, UHARI M. Recurrence and follow-up after urinary tract infection under the age of 1 year. Pediatr Nephrol. 2001;16:69-72.

QUEIRÓS MI, CIPRIANO MAB, SANTOS MCL, CARDOSO MVML. Infecções urinárias e uso de cateter vesical de demora em unidade pediátrica. Rev Rene. 2011;12(2):295301.

SALVADOR, Pétala Tuani Candido de Oliveira; BEZERRILI, Manacés dos Santos; RODRIGUES, Cláudia Cristiane Filgueira Martins; ALVES, Kisna Yasmin Andrade; COSTA, Theo Duarte da; SANTOS, Viviane Euzébia Pereira. Rev. enferm. UERJ ; 25: [e18767], jan.-dez. 2017. tab

SCHNEIDER CK, CAETANO L, RIBEIRO LOM. Análise de vídeos educacionais no youtube: caracteres e legibilidade. Rev. novas tecnologias na educação. 2012; 10(1):1-11.

SILVA, Ana Cristina Simões e; OLIVEIRA, Eduardo A.; MAK, Robert H.. Infecção do trato urinário em pediatria: uma visão geral. J. Pediatr. (Rio J.), Porto Alegre , v. 96, supl. 1, p. 65-79, Mar. 2020 . Available from $<$ http://www.scielo.br/scielo.php?script=sci_arttext\&pid=S002175572020000700065\&lng=en\&nrm=iso>. access on 28 Feb. 2021. Epub Apr 17, 2020. https://doi.org/10.1016/j.jped.2019.10.006.

SPERANCETA MR de $P$. et al. Inconsistências na técnica de cateterismo vesical por acadêmicos de Enfermagem. Rev Enferm UFPI. Pg.22-27. Abr-Jun 2016.

TAVARES et al. Cinema: estratégia de ensino-aprendizagem na disciplina de história da enfermagem. Universitas Humanas, Brasília, v. 11, n. 2, p. 39-48, jul./dez. 2014. 


\title{
CAPÍTULO VII
}

\section{DETERMINACÃO DO PERÍODO DE JEUM PRÉ-OPERATÓRIO: CONIRIBUICOÕES NA ASSISTÊNCLA DE ENFERMAGEM PRÉ- OPERATÓRIA}

\section{DOI: 10.51859/amplla.csa528.2121-7}

\author{
Mylena Veiga da Silva ${ }^{1}$ \\ Mariana Veiga da Silva ${ }^{2}$ \\ Leonardo dos Santos Pereira ${ }^{3}$ \\ Carlos Eduardo Peres Sampaio 4 \\ Marcos Andrade da Silva ${ }^{5}$ \\ Rose Mary Costa Rosa Andrade Silva ${ }^{6}$
}

\begin{abstract}
${ }^{1}$ Graduanda do curso de Enfermagem na Universidade Veiga de Almeida- UVA
${ }^{2}$ Graduanda do curso de Enfermagem na Universidade Veiga de Almeida- UVA

${ }^{3}$ Professor Titular do curso de graduação em enfermagem da universidade Veiga de Almeida (UVA). Mestre em microbiologia e imunologia pela Universidade Federal do Rio de Janeiro - UFRJ

4 Professor Titular da Universidade Veiga de Almeida - UVA; Professor Associado da Faculdade de Enfermagem da Universidade do Estado do Rio de Janeiro (UERJ/DEMC)

${ }^{5}$ Professor, Enfermeiro e Doutor em Ciências do Cuidado em Saúde/UFF

${ }^{6}$ Professor titular da UFF; Doutor em psicologia social (UERJ) e Enfermagem (UFRJ)
\end{abstract}

\section{RESUMO}

Essa pesquisa teve como objetivo identificar de acordo com a revisão da literatura o tempo adequado e as consequências do jejum perioperatório; identificar o tempo de jejum perioperatório e relacionar o desenvolvimento de alterações glicêmicas com o período de jejum realizado. Foi utilizado uma revisão sistemática da literatura com busca de dados nas bases LILACS, MEDLINE e SCIELO com o período decorrente de 2015 a 2019 tendo como resultados as principais alterações fisiológicas, clínicas e metabólicas que podem ocorrer como ansiedade, sede, resistência à insulina no pós operatório e mudanças de paradigma relacionado ao período prolongado de jejum com programas criados para isso como o ERAS (Enhanced Recovery After Surgery) e ACERTO (Aceleração da Recuperação Total pós-operatória). Pode-se concluir com essa pesquisa a importância da atualização acerca da temática para que os pacientes apresentem melhores resultados após a cirurgia, menos tempo de internação e menos índices de complicações pós operatórias.

Palavras-chave: Jejum. Assistência Perioperatória. Cuidados Pós-Operatórios. Cuidados Pré-Operatórios 


\section{INTRODUÇÃO}

Cirurgias representam um grande trauma ao corpo humano, provocando inúmeras reações em resposta ao stress que ela causa. Estima-se que 234 milhões de cirurgias de grande sejam realizadas pelo mundo a cada ano, correspondendo a uma operação para cada 25 pessoas vivas (MINISTÉRIO DA SAÚDE, 2009).

A assistência cirúrgica tem sido um elemento essencial do desenvolvimento da saúde pelo mundo por quase um século, ela faz parte de um dos focos do Primeiro Desafio Global que padroniza e aperfeiçoa a qualidade dos serviços de saúde em qualquer lugar do mundo. Buscando prevenir infecções de sítio cirúrgico e tornar o ato anestésico mais seguro, com menos riscos ao paciente e fazer com que as equipes cirúrgicas estejam seguras dos procedimentos que serão realizados, ou seja, a meta é a realização de procedimentos clínicos e cirúrgicos seguros, que são enfatizados no Segundo Desafio Global onde exploram com maior ênfase a questão de padronizar a segurança onde terá, indubitavelmente, componentes essenciais à assistência à saúde (CARLI, 2015).

Com o procedimento cirúrgico, ocorre alteração do metabolismo basal, que é intensificada pelo jejum perioperatório prolongado (Marcarini, 2017). Em suma, o jejum pré-operatório busca garantir o esvaziamento gástrico, para que seja evitado broncoaspiração, vômitos e regurgitação, que como já dito, são desfechos temidos pela equipe médica (DA SILVA, 2019).

Estudos recentes comprovam que períodos prolongados de jejum não são necessários para diminuir esse risco uma vez que o esvaziamento gástrico para líquidos não calóricos é extremamente rápido, logo a ingestão de líquidos claros é liberada até duas horas antes do procedimento anestésico (SMITH, 2011).

O período prolongado de jejum pré-operatório pode desenvolver sede, ansiedade e cefaleia nos pacientes, fatores que podem contribuir negativamente no período pós operatório. Além disso, esse tempo longo do jejum, pode levar a um estresse metabólico ocasionado pelo trauma cirúrgico gerando outro problema que é a resistência insulínica e ocorrência de reações catabólicas no organismo, desencadeando mais tempo de internação hospitalar e maiores índices de complicações pós operatórias (REIS, 2019). 
Além dos fatores citados acima, pode desencadear outras respostas negativas no corpo, prejuízos metabólicos e clínicos no paciente fazendo com que ele desenvolva complicações em sua qualidade de vida como desnutrição e desidratação (CAMPOS, 2018).

O paciente em desnutrição no pré-operatório pode gerar inúmeras disfunções em órgãos vitais como coração, pulmão, rim e trato gastrointestinal, sem contar com a diminuição da imunidade e da força muscular fazendo com que esses pacientes tenham maiores riscos a infecções e destinados a permanecer internado por mais tempo. Por isso o projeto ACERTO preconiza que seja feita uma triagem nutricional nos pacientes por conta da preocupação para que ele tenha em seu pós-operatório energia suficiente para cicatrizar, coagular, ou seja, se recuperar de maneira mais rápida (HEBERT, 2017).

Geralmente foi preconizado não ingerir líquido antes da cirurgia, porém, alguns estudos dizem que ingesta de líquidos claros algumas horas antes da cirurgia não aumentam o risco de regurgitação nem de broncoaspiração (em alguns casos como em obesos, gestantes e idosos isso deve ser avaliado) no caso, ajuda o paciente no seu pósoperatório a se recuperar e evitar certas complicações relacionados a ingesta hídrica (ERAS, 2013).

Geralmente, a sede é um dos fatores pouco valorizados pela equipe de enfermagem. Mesmo com as informações citadas acima, muitos profissionais desatualizados continuam baseando-se no mito de que não se deve quebrar o jejum. 0 enfermeiro é um profissional de grande importância nesse contexto, então é fundamental que eles saibam realizar os métodos necessários e eficazes para aliviar a sede pois também não adianta realizar o método empiricamente (SIMAS, 2019).

A resistência à insulina tem sido um assunto muito comum nesses pacientes $\mathrm{e}$ pode acontecer tanto em cirurgia de grande como de pequeno porte, isso acontece por conta do jejum prolongado, onde há uma diminuição da captação de insulina pelo corpo, fazendo com que ele perca certa sensibilidade a insulina como em casos de diabetes tipo II, e isso aumenta riscos de infecções e tempo de internação no pós-operatório (NASCIMENTO, 2017).

O programa Enhanced Recovery After Surgery (ERAS) tem como principal objetivo melhorar e acelerar a recuperação desses pacientes perioperatorios, com uma abordagem prática padronizada, com uma equipe cooperativa, desenvolver educação 
tanto do paciente quanto dos profissionais e objetivam também retirar de cena 0 conceito de "paciente doente" para "paciente imponderado", já que também visam uma participação ativa do paciente em seu processo de recuperação. A abreviação do tempo de jejum é uma das orientações do programa ERAS, onde diz que se deve manter dieta oral líquida clara até 2 horas antes da indução anestésica (ERAS, 2013).

Já no Brasil, foi implementado em 2005, o Projeto ACERTO (Aceleração da Recuperação Total Pós-Operatória), que é um pioneiro no território nacional, desenvolvido com ampla revisão bibliográfica sobre cuidados perioperatórios, destacando a importância de questões nutricionais na recuperação do paciente cirúrgico, afirmando que comprometimentos do estado nutricional desse paciente, favorecem maiores riscos de morbimortalidade, gerando consequentemente maiores custos hospitalares (NASCIMENTO, 2017).

\begin{abstract}
As diretrizes desse projeto, estabelecida pelo ESA European Society of Anaesthesiology recomendam que a restrição de alimentos sólidos só tenha início entre seis e oito horas antes da indução anestésica. Essa abreviação do tempo de jejum com ingestão de solução rica em carboidratos até duas horas antes da operação, tal com alimentação precoce no pós operatório, fornece maior conforto ao paciente e ajuda a otimizar o restabelecimento das funções fisiológicas (CARVALHO, 2017).
\end{abstract}

Nessa pesquisa buscou-se identificar de acordo com a revisão da literatura o tempo adequado e as consequências do jejum perioperatório; identificar o tempo de jejum perioperatório e relacionar o desenvolvimento de alterações glicêmicas com o período de jejum realizado.

Neste estudo, utilizou-se uma revisão sistemática da literatura, com busca de dados realizada nas bases: LILACS, MEDLINE e SCIELO. Considerou-se o período decorrente de 2015 a 2019. Na busca com palavras chaves: "Assistência perioperatória"; "Jejum perioperatório".

Operou-se com filtros como: texto estar inteiramente disponível online, nos idiomas português e inglês, tipo de documento: artigos.

Obteve-se assim 30 textos, no qual após a realização de uma leitura profunda, foram-se utilizados 13 textos que por fim responderam às necessidades propostas nesse estudo. Utilizou-se a análise de conteúdo temática.

A Tabela 1 foi dividida em título e ano, base de dados, objetivo e achados importantes dos artigos selecionados. 


\begin{tabular}{|c|c|c|c|}
\hline TÍTULO/ANO & $\begin{array}{c}\text { BASE } \\
\text { DE } \\
\text { DADOS }\end{array}$ & OBJETIVO & ACHADOS IMPORTANTES \\
\hline $\begin{array}{l}\text { Peri-operative } \\
\text { nutrition. (2016) }\end{array}$ & $\begin{array}{l}\text { MEDLI } \\
\text { NE }\end{array}$ & $\begin{array}{l}\text { descrever as evidências } \\
\text { para nutrição no } \\
\text { período perioperatório } \\
\text { e destacar áreas para } \\
\text { pesquisas futuras. }\end{array}$ & $\begin{array}{l}\text { Esta revisão centra-se em } \\
\text { novos desenvolvimentos na } \\
\text { nutrição perioperatório, } \\
\text { visando a melhora dos } \\
\text { resultados dos pacientes } \\
\text { através de apoio nutricional. }\end{array}$ \\
\hline $\begin{array}{l}\text { Abreviação do } \\
\text { jejum: aspectos } \\
\text { clínicos } \\
\text { perioperatórios } \\
\text { de pacientes } \\
\text { submetidos à } \\
\text { cirurgia cardíaca. } \\
\text { (2017) }\end{array}$ & LILACS & $\begin{array}{l}\text { analisar o } \\
\text { comportamento dos } \\
\text { pacientes submetidos à } \\
\text { cirurgia cardíaca com } \\
\text { abreviação do jejum } \\
\text { pré-operatório a partir } \\
\text { da administração de } \\
\text { suplemento nutricional } \\
\text { oral com carboidratos e } \\
\text { proteínas }\end{array}$ & $\begin{array}{l}\text { O estudo busca analisar o } \\
\text { comportamento dos } \\
\text { pacientes submetidos à } \\
\text { cirurgia cardíaca com } \\
\text { abreviação do jejum pré- } \\
\text { operatório a partir da } \\
\text { administração de } \\
\text { suplemento nutricional oral } \\
\text { com carboidratos e } \\
\text { proteínas. }\end{array}$ \\
\hline $\begin{array}{l}\text { Nutritional } \\
\text { prehabilitation: } \\
\text { physiological } \\
\text { basis and clinical } \\
\text { evidence. (2017) }\end{array}$ & $\begin{array}{l}\text { MEDLI } \\
\text { NE }\end{array}$ & $\begin{array}{l}\text { Avaliar o papel das } \\
\text { intervenções de } \\
\text { exercício físico e } \\
\text { nutrição em pacientes } \\
\text { adultos antes da } \\
\text { cirurgia eletiva de } \\
\text { grande porte. }\end{array}$ & $\begin{array}{l}\text { Nesta revisão narrativa, } \\
\text { descreve-se a base } \\
\text { fisiológica para a pré- } \\
\text { habilitação nutricional e } \\
\text { avalia-se as evidências } \\
\text { clínicas para seus atuais } \\
\text { papéis no perioperatório. }\end{array}$ \\
\hline $\begin{array}{l}\text { The } 2015 \text { ESPEN } \\
\text { Arvid Wretlind } \\
\text { lecture. Evolving } \\
\text { concepts on } \\
\text { perioperative } \\
\text { metabolism and } \\
\text { support.(2016) }\end{array}$ & $\begin{array}{l}\text { MEDLI } \\
\text { NE }\end{array}$ & $\begin{array}{l}\text { Revisar as mudanças na } \\
\text { política nutricional } \\
\text { perioperatório ao } \\
\text { longo dos anos }\end{array}$ & $\begin{array}{l}\text { A melhora da condição do } \\
\text { paciente deve ser obtida } \\
\text { pelo reconhecimento e } \\
\text { tratamento da desnutrição, } \\
\text { pela otimização da } \\
\text { composição corporal e pelo } \\
\text { incentivo à atividade física } \\
\text { perioperatória. O uso de } \\
\text { nutrientes específicos com } \\
\text { efeitos metabólicos, bem } \\
\text { como a redução do jejum } \\
\text { pré-operatório e pós- } \\
\text { operatório em uma via de } \\
\text { recuperação melhorada, } \\
\text { pode ajudar a modular o } \\
\text { estresse pós-cirúrgico. }\end{array}$ \\
\hline $\begin{array}{l}\text { Variability of } \\
\text { fasting outcomes } \\
\text { observed in a } \\
\text { single patient. }\end{array}$ & $\begin{array}{l}\text { MEDLI } \\
\text { NE }\end{array}$ & $\begin{array}{l}\text { Observar resultados } \\
\text { encontrados } \\
\text { vastamente diferentes } \\
\text { para o esvaziamento }\end{array}$ & \\
\hline
\end{tabular}




\begin{tabular}{|c|c|c|c|}
\hline & & $\begin{array}{l}\text { gástrico através da } \\
\text { ressonância magnética } \\
\text { abdominal (RM). }\end{array}$ & \\
\hline $\begin{array}{l}\text { Jejum em } \\
\text { pacientes } \\
\text { cirúrgicos } \\
\text { eletivos: } \\
\text { comparação } \\
\text { entre o tempo } \\
\text { prescrito, } \\
\text { praticado e o } \\
\text { indicado em } \\
\text { protocolos de } \\
\text { cuidados } \\
\text { perioperatórios.( } \\
\text { 2015) }\end{array}$ & SCIELO & $\begin{array}{l}\text { Investigar se o tempo } \\
\text { de jejum } \\
\text { perioperatório } \\
\text { prescrito e praticado } \\
\text { pelos pacientes se } \\
\text { encontra em } \\
\text { conformidade com os } \\
\text { protocolos multimodais } \\
\text { atuais e identificar os } \\
\text { principais fatores } \\
\text { associados. }\end{array}$ & $\begin{array}{l}\text { Com esse estudo transversal } \\
\text { mostrou-se que os } \\
\text { pacientes permaneceram } \\
\text { em jejum por tempo } \\
\text { prolongando e a intensidade } \\
\text { dos sinais como fome e sede } \\
\text { aumentaram ao longo do } \\
\text { tempo. Para melhor } \\
\text { recuperação e bem-estar do } \\
\text { paciente deve-se fazer um } \\
\text { protocolo de abreviação do } \\
\text { jejum perioperatório. }\end{array}$ \\
\hline $\begin{array}{l}\text { Fasting in elective } \\
\text { surgical patients: } \\
\text { comparison } \\
\text { among the time } \\
\text { prescribed, } \\
\text { performed and } \\
\text { recommended on } \\
\text { perioperative } \\
\text { care protocols. } \\
(2015)\end{array}$ & SCIELO & $\begin{array}{l}\text { Investigar se o tempo } \\
\text { de jejum } \\
\text { perioperatório } \\
\text { prescrito e praticado } \\
\text { pelos pacientes está } \\
\text { em conformidade com } \\
\text { os protocolos } \\
\text { multimodais atuais e } \\
\text { identifique os } \\
\text { principais fatores } \\
\text { associados. }\end{array}$ & $\begin{array}{l}\text { O jejum pré-operatório } \\
\text { prolongado pode prejudicar } \\
\text { o estado nutricional do } \\
\text { paciente e a sua } \\
\text { recuperação. Em contraste, } \\
\text { alguns estudos mostram } \\
\text { que a abreviatura de jejum } \\
\text { pode melhorar a resposta } \\
\text { ao trauma e diminuir o } \\
\text { tempo de internação } \\
\text { hospitalar }\end{array}$ \\
\hline $\begin{array}{l}\text { Practice } \\
\text { Guideline } \\
\text { Recommendation } \\
\text { s on Perioperative } \\
\text { Fasting: A } \\
\text { Systematic } \\
\text { Review. (2016) }\end{array}$ & $\begin{array}{c}\text { MEDLI } \\
\text { NE }\end{array}$ & $\begin{array}{l}\text { Revisar as atuais } \\
\text { diretrizes de jejum, } \\
\text { avaliar sua qualidade, } \\
\text { resumir as } \\
\text { recomendações } \\
\text { relevantes e identificar } \\
\text { lacunas nas evidências. }\end{array}$ & $\begin{array}{l}\text { Por conta de ainda existir } \\
\text { práticas desatualizadas } \\
\text { relacionadas ao jejum, esse } \\
\text { estudo vem trazendo } \\
\text { protocolos e de recuperação } \\
\text { melhorados, multimodais e } \\
\text { baseados em evidências, } \\
\text { incorporando jejum } \\
\text { perioperatório minimizado, } \\
\text { surgiram para melhorar os } \\
\text { resultados dos pacientes e } \\
\text { agilizar a recuperação }\end{array}$ \\
\hline $\begin{array}{l}\text { Nutritional status } \\
\text { and perioperative } \\
\text { fasting time } \\
\text { versus } \\
\text { complications }\end{array}$ & $\begin{array}{l}\text { MEDLI } \\
\text { NE }\end{array}$ & $\begin{array}{l}\text { Avaliar a influência } \\
\text { do estado nutricional e } \\
\text { do tempo } \\
\text { de jejum perioperatóri } \\
\text { o sobre a ocorrência de }\end{array}$ & $\begin{array}{l}\text { O comprometimento } \\
\text { do estado nutricional e a } \\
\text { extensão do tempo } \\
\text { de jejum perioperatório estãa } \\
\text { o associados à ocorrência de }\end{array}$ \\
\hline
\end{tabular}




\begin{tabular}{|c|c|c|c|}
\hline $\begin{array}{l}\text { and hospital stay } \\
\text { of surgical } \\
\text { patients. (2015) }\end{array}$ & & $\begin{array}{l}\text { complicações cirúrgicas } \\
\text { e de internação } \\
\text { hospitalar, } \\
\text { em pacientes submetid } \\
\text { os à cirurgia do trato } \\
\text { gastrointestinal e / } \\
\text { ou parede abdominal e } \\
\text { submetidos a um } \\
\text { protocolo de } \\
\text { atendimento } \\
\text { nutricional. }\end{array}$ & $\begin{array}{l}\text { complicações cirúrgicas e ao } \\
\text { aumento do tempo de } \\
\text { internação hospitalar. }\end{array}$ \\
\hline $\begin{array}{l}\text { Tempo de jejum } \\
\text { perioperatório e } \\
\text { relação com } \\
\text { nutrição } \\
\text { pacientes } \\
\text { internados em } \\
\text { uma UTI de } \\
\text { trauma. (2016) }\end{array}$ & $\begin{array}{l}\text { Colecio } \\
\text { na SUS }\end{array}$ & $\begin{array}{l}\text { Avaliar o fornecimento } \\
\text { de nutrição durante } \\
\text { o período } \\
\text { perioperatório em paci } \\
\text { entes internados em } \\
\text { uma UTI de trauma. }\end{array}$ & $\begin{array}{l}\text { Esse estudo retrospectivo } \\
\text { mostrou que o período } \\
\text { de jejum perioperatório foi } \\
\text { prolongado, causando } \\
\text { déficit no aporte nutricional } \\
\text { dos pacientes durante a } \\
\text { internação na UTI }\end{array}$ \\
\hline $\begin{array}{l}\text { Physiologic } \\
\text { considerations of } \\
\text { Enhanced } \\
\text { Recovery After } \\
\text { Surgery (ERAS) } \\
\text { programs: } \\
\text { implications of } \\
\text { the stress } \\
\text { response. (2015) }\end{array}$ & $\begin{array}{l}\text { MEDLI } \\
\text { NE }\end{array}$ & $\begin{array}{l}\text { Discutir a fisiopatologia } \\
\text { relevante da resposta } \\
\text { ao estresse cirúrgico } \\
\text { e seus mecanismos } \\
\text { associados que regulam } \\
\text { importantes alterações } \\
\text { metabólica. }\end{array}$ & $\begin{array}{l}\text { Foi demonstrado que } \\
\text { a implementação de } \\
\text { um programa ERAS } \\
\text { direcionada modula a } \\
\text { sensibilidade perioperatória } \\
\text { à insulina, melhorando os } \\
\text { resultados pós-operatórios e } \\
\text { acelerando o retorno da } \\
\text { função basal. }\end{array}$ \\
\hline $\begin{array}{l}\text { Enhanced } \\
\text { recovery after } \\
\text { surgery protocols } \\
\text { for open } \\
\text { hepatectomy-- } \\
\text { physiology, } \\
\text { immunomodulati } \\
\text { on, and } \\
\text { implementation. } \\
\text { (2015) }\end{array}$ & $\begin{array}{l}\text { MEDLI } \\
\text { NE }\end{array}$ & $\begin{array}{l}\text { Concentrar nos dados } \\
\text { disponíveis relativos à } \\
\text { aplicação do ERAS à } \\
\text { hepatectomia aberta. } \\
\text { Focamos em quatro } \\
\text { variáveis fundamentais } \\
\text { que impactam a } \\
\text { fisiologia normal e } \\
\text { exacerbam } \\
\text { inflamação } \\
\begin{array}{l}\text { perioperatória: (1) o } \\
\text { estresse } \\
\text { laparotomia, (2) o uso } \\
\text { de opioides, (3) perda } \\
\text { de sangue e transfusões } \\
\text { de hemoderivados e (4) } \\
\text { jejum perioperatório }\end{array}\end{array}$ & $\begin{array}{l}\text { Coletivamente, os dados } \\
\text { sugerem que a } \\
\text { implementação dos } \\
\text { princípios do ERAS deve ser } \\
\text { fortemente considerada em } \\
\text { todos os pacientes } \\
\text { submetidos à hepatectomia. }\end{array}$ \\
\hline
\end{tabular}




\begin{tabular}{|c|c|c|}
\hline $\begin{array}{l}\text { Perioperative } \\
\text { catabolism. } \\
(2015)\end{array}$ & $\begin{array}{l}\text { Revisar a fisiopatologia, } \\
\text { a relevância clínica e } \\
\text { a terapia da resposta } \\
\text { catabólica ao estresse } \\
\text { cirúrgico. }\end{array}$ & $\begin{array}{l}\text { Embora } \\
\text { a concentração ideal } \\
\text { de glicose para melhorar os } \\
\text { resultados clínicos seja } \\
\text { desconhecida, a maioria } \\
\text { das associações médicas rec } \\
\text { omenda } \\
\text { o tratamento de glicose no } \\
\text { sangue aleatória > } 10 \\
\text { mmol-L } \\
\text { 1). Anestesia neuroaxialemb } \\
\text { ota a resposta ao estresse } \\
\text { neuroendócrino e aumenta } \\
\text { os efeitos an } \\
\text { anabólicos da nutrição. Exist } \\
\text { em evidências que sugerem } \\
\text { que evitar o jejum pré- } \\
\text { operatório evita a } \\
\text { resistência à insulina e } \\
\text { acelera a recuperação após } \\
\text { grandes cirurgias abdominai } \\
\text { s. }\end{array}$ \\
\hline
\end{tabular}

Fonte: Autoria Própria.

\section{RESULTADOS E DISCUSSÕES}

\subsection{JEJUM PROLONGADO}

Para os resultados dessa pesquisa, os artigos foram separados em três categorias após leitura profunda sobre cada um para melhor desenvolver a temática e tornar a leitura mais objetiva e clara. As três categorias selecionadas foram: Jejum: alterações do estado nutricional proveniente de um jejum prolongado; Programa ERAS e resistência à insulina.

O jejum é necessário para evitar os riscos de broncoaspiração, que pode ser uma séria complicação, podendo causar um grande risco de morbidade e mortalidade durante procedimentos cirúrgicos, diagnósticos e terapêuticos eletivos sob anestesia ou sedação. Considerando o tempo de jejum ao quais os pacientes são submetidos, o ato de prolongar este jejum pode acarretar inúmeras consequências negativas e prejuízos metabólicos e clínicos associados a esta pratica, tais como resistência à insulina, desidratação e desnutrição (CAMPOS, 2018). 
Após algumas horas de jejum os níveis de insulina diminuem e os níveis de glucagon aumenta, fazendo com que ocorra a utilização da reserva de glicogênio do ser humano, que pode ser encontrado em sua maioria no fígado. Em menos de 24 horas este glicogênio hepático é totalmente consumido, fazendo com que ative a gliconeogênese e a proteína muscular passe a ser a principal fonte de energia, podendo causar, se este jejum permanecer por um tempo maior, o catabolismo, fazendo com que haja perda da massa magra do paciente (MARCARINI, 2017).

A American Society of Anesthesiologists (ASA) recomenda em seu guia prático desenvolvido em 1999 e revisado em 2011 que o período ideal do jejum pré-operatório seja de 2 horas, para líquidos com ou sem resíduos, como água, chás, sucos de frutas e bebidas ricas em carboidratos, para alimentos sólidos leves recomenda-se que o jejum seja mantido por 6 horas e para refeições por 8 horas, para evitar o hipercatabolismo e complicações associadas ao período prolongado do jejum (CAMPOS, 2018).

Para o período pós-operatório, recomenda-se que o jejum seja mantido até o aparecimento de flatos, ruídos hidroaéreos ou evacuação, que caracteriza o retorno do peristaltismo do paciente. Este período de espera dura em média 5 horas. A abreviação do tempo de jejum pode promover um retorno do peristaltismo mais rápido, fazendo com que o período de jejum após a cirurgia seja reduzido, favorecendo a recuperação metabólica, diminuindo a probabilidade das complicações pós-operatórias e reduzindo o tempo de internação hospitalar (CAMPOS, 2018).

É muito importante ressaltar que o procedimento cirúrgico é uma violação a homeostase do organismo por gerar um estresse metabólico, o qual piora com o longo período de jejum (DA SILVA, 2019).

\subsection{PROGRAMA ERAS}

O conceito de "Enhanced Recovery After Surgery" (ERAS) foi introduzido no final da década de 90 e compreende uma série de cuidados prestados a pacientes cirúrgicos baseados em evidencias. ${ }^{4} \mathrm{~A}$ inserção desses cuidados tem como objetivos reduzir $\mathrm{O}$ tempo de internação, diminuir complicações relacionadas ao extenso período de jejum e proporcionar uma melhor recuperação e qualidade de vida ao paciente (DA SILVA, 2019). 
As ações são divididas em três grupos: medidas pré-operatórias, intraoperatórias e pós-operatórias. Na parte pré-operatória podem ser citados além da orientação acerca do protocolo, a ausência de medicação pré anestésica, o jejum não prolongado e o não preparo do colón em cirurgia colorretal. Na fase do intraoperatório, algumas das recomendações são o uso de anestésicos de ação curta e ausência de drenos na maior parte dos procedimentos e por fim, no pós-operatório, fazem parte do protocolo a remoção precoce de cateteres, a não utilização de cateter nasogástrico, a mobilização e a introdução precoce da dieta oral (MARTINS, 2017).

No Brasil, o protocolo ERAS se tornou o projeto ACERTO (Aceleração da Recuperação Total pós-operatória), buscando eficiência e com objetivo de oferecer o melhor pelo menor custo (MARTINS, 2017).

O ERAS sugere que no período pré-operatório a dieta clara líquida seja mantida até 2 horas antes da sedação anestésica. Após a cirurgia deve-se iniciar a alimentação o quanto antes, acompanhando para ver quando os movimentos peristálticos vão retornar, para que a reinserção da alimentação seja feita de forma segura. Além disso, afirmam que o "sham feeding" (goma de mascar sem açúcar por tempo $\geq 10$ minutos 3 a 4 vezes ao dia) resulta em pequenas melhorias na recuperação do trato gastrointestinal e pode estar relacionado com uma redução no período de internação (MAFRA, 2019).

Este programa se torna relevante pois através da otimização dos recursos financeiros, menores taxas de complicações e menor tempo de internação é possível prover uma assistência de melhor qualidade, beneficiando não somente o cliente, mas também as instituições. Ele divide-se em três principais grupos, com recomendações especificas, sendo eles o período pré-operatório, intraoperatório e o período pósoperatório (ERAS BRASIL, 2020).

\subsection{RESISTÊNCIA À INSULINA}

A insulina é responsável pelo controle da glicose, gordura e metabolismo proteico, logo uma mudança na sua sensibilidade gera um impacto direto a todo o metabolismo. A combinação do estresse perioperatório e inúmeras respostas inflamatórias relacionadas a cirurgia contribuem para as duas principais consequências metabólicas, que são a hiperglicemia e o catabolismo. Há uma redução da captação de 
glicose pela incapacidade do transportador de glicose tipo 4 (GLUT-4) em realizar este evento (CARLI, 2015).

A diminuição da sensibilidade a insulina é uma alteração significativa no metabolismo das proteínas e da glicose, que é caracterizada pelo aumento na produção de glicose hepática endógena, diminuição da captação de glicose periférica e um aumento da degradação da proteína, já que os músculos se tornam os principais tecidos de captação de glicose, ocasionando na degradação da proteína muscular e consequentemente a perda global de massa magra, correspondendo a quase $50-70 \mathrm{~g}$ de proteína por dia (CAMPOS, 2018).

A abreviação do jejum pré-operatório reduz em até $50 \%$ o desenvolvimento da resistência à insulina e a perda de massa magra. Algumas condições pré-operatórias, como o câncer, obesidade mórbida, síndrome metabólica e a diabetes podem contribuir significantemente para o desenvolvimento da resistência à insulina (CARVALHO, 2019).

\section{CONSIDERAÇÕES FINAIS}

Conclui-se então com essa pesquisa que o período prolongado de jejum prolongado gera nos pacientes diversos efeitos adversos que podem prejudicar sua saúde e seu bem-estar após a cirurgia, alguns desses efeitos negativos que podem ser citados são: ansiedade, medo, insegurança, resistência à insulina, estresse entre outros.

Esse estudo trouxe também várias mudanças de paradigmas relacionado como por exemplo a questão de que ingerir líquidos claros duas horas antes da cirurgia não gera risco de broncoaspiração e melhora o bem estar do paciente no pós-operatório. Outro fato bem observado foi a diminuição da sensibilidade a insulina que é um fato frequente.

Por conta desses fatores, esse estudo contribui para o campo da saúde, em especial a área da enfermagem e mostra o quanto é importante que seja revisada sempre as literaturas para a atualização do conhecimento e proporcionar a melhor assistência de enfermagem com inovações relacionado ao paciente em jejum perioperatório. 


\section{REFERÊNCIAS}

Segundo desafio global para a segurança do paciente: Cirurgias seguras salvam vidas (orientações para cirurgia segura da OMS) / Organização Mundial da Saúde; tradução de Marcela Sánchez Nilo e Irma Angélica Durán - Rio de Janeiro: Organização Pan-Americana da Saúde; Ministério da Saúde; Agência Nacional de Vigilância Sanitária, 2009.

CARLI, F. Physiologic considerations of Enhanced Recovery After Surgery (ERAS) programs: implications of the stress response. Can J Anesth/J Can Anesth. 62:110-119. 2015. DOI: 10.1007/s12630-014-0264-0

MARCARINI, M.; DA ROSA, S.; WIECK, F.; BETTI, A. Abreviação do jejum: aspectos clínicos perioperatórios de pacientes submetidos à cirurgia cardíaca. BRASPEN. 32 (4): 375-9. 2017.

DA SILVA, A; MIGUEZ, B.; DE OLIVEIRA, A.; FERREIRA, J. Importância da redução do tempo de jejum pré-operatório: uma revisão literária. Revista Caderno de Medicina Vol 2. No 2. 2019.

Practice Guidelines for Preoperative Fasting and the Use of Pharmacologic Agents to Reduce the Risk of Pulmonary Aspiration: Application to Healthy Patients Undergoing Elective Procedures: An Updated Report by the American Society of Anesthesiologists Task Force on Preoperative Fasting and the Use of Pharmacologic Agents to Reduce the Risk of Pulmonary Aspiration. Asa Publications. 126:376-393. 2017. Doi: https://doi.org/10.1097/ALN.0000000000001452

CAMPOS, SBG; BARROS-NETO JA; GUEDES, GS; MOURA, FA. Jejum pré-operatório: por que abreviar? ABCD Arq Bras Cir Dig. 31(2):e1377. 2018. DOI: /10.1590/0102$672020180001 \mathrm{e} 1377$

Herbert G, et al. Healthcare professionals' views of the enhanced recovery after surgery programme: a qualitative investigation. BMC Health Serv Res.; 17(1):617. 2017. Doi: 10.1186/s12913-017-2547-y.

GUSTAFSSON UO, et al. Guidelines for perioperative care in elective colonic surgery: Enhanced Recovery After Surgery (ERAS $\left({ }^{\circledR}\right)$ ) Society recommendations. World J Surg.; 37(2):259-284. 2013. Doi:10.1007/s00268-012-1772-0

DE-AGUILAR-NASCIMENTO, J. et al. Diretriz ACERTO de intervenções nutricionais no perioperatório em cirurgia geral eletiva. Rev. Col. Bras. Cir. Vol.44, n.6, pp.633648. 2017. DOI: 10.1590/0100-69912017006003

MARTINS, MVDC. Estamos realmente prontos para a implantação do protocolo ERAS? Rev. Col. Bras. Cir.; 44(4): 314-315. 2017. DOI: 10.1590/0100-69912017004015 
MAFRA, C. Veja recomendações para cuidados em cirurgias eletivas colorretais. PubMed. 2018. Disponível em: https://pebmed.com.br/veja-recomendacoespara-cuidado-em-cirurgias-eletivas-colorretais/.

CARVALHO CALB, et al. Benefícios Metabólicos e Inflamatórios da Abreviação do Jejum Pré-operatório em Cirurgia Pediátrica. Rev Col Bras Cir. 47:e20202353. 2019. DOI: 10.1590/0100-6991e-20202353

SIMAS, MCF, et al. Jejum pré-operatório de crianças em situação cirúrgica: uma revisão da literatura. ATENA; 2019. DOI 10.22533/at.ed.39619150814

REIS, PGA. Abbreviated preoperative fasting favours postoperative oral intake at lower hospital admission costs for cancer patients. Rev. Col. Bras. Cir. 46 (3); 2019. DOI: https://doi.org/10.1590/0100-6991e-20192175

CARVALHO, CALB. Changing paradigms in preoperative fasting: results of a joint effort in pediatric surgery. ABCD, arq. bras. cir. dig. 30 (1); Jan-Mar 2017. DOI: https://doi.org/10.1590/0102-6720201700010003 


\title{
CAPITULO VIII
}

\section{PRÁTICAS DE AVALAGÃO DA QUALDADE DO CUIDADO EM SAÚDE NOS CENIROS CIRÚRGICOS: UMA REVISÃO BIBLOGRÁFICA}

\author{
Jefferson Dantas da Costa ${ }^{1}$ \\ Maria Aparecida Fernandes Cardoso ${ }^{2}$ \\ Keila Maria de Azevedo Ponte Marques ${ }^{3}$
}

${ }^{1}$ Graduando do curso de Enfermagem. Universidade Estadual Vale do Acaraú-UVA.
${ }^{2}$ Graduando do curso de Enfermagem. Universidade Estadual Vale do Acaraú-UVA.
${ }^{3}$ Docente do curso de Enfermagem. Universidade Estadual Vale do Acaraú-UVA.

\section{RESUMO}

A avaliação da qualidade do cuidado dos centros cirúrgicos tem como objetivo garantir para a comunidade um serviço de acordo com as suas necessidades em todos os níveis de atenção à saúde. Objetivou-se descrever práticas de avaliação da qualidade do cuidado em saúde em centros cirúrgicos. Trata-se de uma revisão bibliográfica realizada em março e abril de 2021 nas bases de dados LILACS, BDEN e MEDLINE, via Biblioteca Virtual da Saúde com dez artigos científicos. A avaliação do cuidado é feita por meio de indicadores de qualidade, ferramentas de qualidade, avaliação feita por clientes internos e segurança do paciente. Dessa forma, essas práticas são imprescindíveis nos serviços de saúde, visto que os profissionais são treinados e capacitados a oferecer um cuidado de excelência.

Palavras-chave: Enfermagem. Avaliação em Saúde. Centro Cirúrgicos.

\section{INTRODUÇÃO}

A qualidade em saúde é uma temática abordada em diversos contextos das instituições em saúde, na qual há tempos são desenvolvidos métodos para alcançá-la. Cabe apontar, entretanto, que se trata de um processo sem fim, ao passo em que os resultados são alcançados por meio de uma melhoria contínua. Sendo assim, a qualidade deve ser consequência de uma ação gerencial coerente, integrada e sistêmica (BURMESTER, 2013).

Na verdade, não existe um conceito ideal para melhor definir qualidade, tendo em vista a existência de valores inerentes implícitos nessa palavra, daí surge a ideia de que não é uma definição unitária, mas sim diversos tipos de definições e abordagens 
para concretizar o que seja qualidade da assistência (BURMESTER, 2013). Nesse ponto, sabe-se de antemão que a avaliação da qualidade envolve uma ampla gama de variáveis no que diz respeito a sua forma de mensuração e que, com base em evidências científicas, todos os dias surgem novas informações capazes de agregar o conhecimento sobre (BORGES et al., 2017).

Nesse contexto, cabe apontar a categoria práticas de cuidado em saúde como fator determinante para a qualidade dos serviços, ao passo em que permite a compreensão das intersubjetividades, o respeito à singularidade e dignidade humana, bem como a noção do alcance da assistência em sua totalidade. Sob essa ótica, ganha particular relevância que o fenômeno do cuidar se qualifica como a essência da enfermagem, visto que enquanto disciplina, profissão ou conduta social promove ações para melhorar a qualidade da assistência por meio do cuidado científico, ético e humanizado (GOMES et al., 2018).

Nessa perspectiva, insere-se o centro cirúrgico que compreende uma área física dentro de um hospital destinado à realização de procedimentos invasivos. Na verdade, trata-se de um bloco que é composto por centro operatório, sala de recuperação pósanestésica e Centro de Material e de Esterilização (CME). Sendo assim, trata-se de um ambiente complexo e específico que requer atenção especial em seu planejamento (localização e estrutura) e avaliação, para proporcionar qualidade e segurança na assistência prestada ao paciente (POSSARI,2016).

Dessa forma, o objetivo deste estudo é descrever práticas de avaliação da qualidade do cuidado em saúde em centros cirúrgicos.

\section{METODOLOGIA}

Trata-se de uma revisão bibliográfica realizada em março e abril de 2021, em que foram analisados na literatura os conhecimentos acerca do tema abordado dos últimos 10 anos. A pesquisa bibliográfica tem como objetivo apresentar uma síntese sobre o que já foi dito sobre um determinado tema, ao passo em que permite correlacionar e articular os principais achados de estudos já realizados, chegando a conclusões inovadoras (FONSECA, 2012). 
As publicações foram coletadas nas bases de dados Literatura Latino- americana e do Caribe em Ciências da Saúde (LILACS), Sistema Online de Busca e Análise de Literatura Médica (MEDLINE), Base de dados de Enfermagem (BDENF), via biblioteca Virtual da Saúde. Foi realizada uma consulta nos Descritores em Ciências da Saúde (DeCS), na qual foram designados os descritores: enfermagem, avaliação em saúde e centros cirúrgicos.

Foram considerados como critérios de inclusão: artigos disponibilizados gratuitamente nos idiomas inglês, português e espanhol, publicados nos últimos 10 anos. Já como critérios de exclusão foram adotados artigos que não discorriam sobre assuntos específicos ao tema. Dessa forma, foram identificados inicialmente 638 estudos, sendo que, após aplicação dos critérios de inclusão, selecionaram-se 35 para leitura de título e resumo, dos quais, 25 foram selecionados para leitura na íntegra e, após essa etapa, 10 artigos foram admitidos no estudo.

As informações coletadas foram incluídas em uma planilha do Microsoft Office Excel 2016, em que foram agrupados e organizados os seguintes itens: título, autores, ano de publicação, base de dados, idioma, objetivo e principais resultados. A partir daí, foi realizada a análise dos dados e análise crítica dos estudos incluídos, bem como a reflexão dos achados que respondessem ao objetivo da pesquisa. Por fim, e não menos importantes, é realizada a discussão dos resultados buscando similaridades e discordâncias entre os estudos.

\section{RESULTADOS E DISCUSSÃO}

De acordo com os resultados encontrados, observou-se uma maior frequência de publicações no ano de 2016 (4), seguidos de 2020 (2), 2019 (2), 2017 (1) e 2015 (1), sendo que o país de concentração dos estudos foi o Brasil (7), seguido dos Estados Unidos (03). Sendo assim, nota-se que há um perfil não limiar de publicações, no que diz respeito ao ano de publicação.

Já no que diz respeito à base de dados de dados, 7 foram indexados na BDENF e 3 na MEDLINE. Quanto aos locais de publicação de periódicos científicos, foram encontrados 06 revista diferentes, sendo elas: revista SOBECC (5), Revista Gaúcha de Enfermagem (1), Revista Rene (1), Journal of thoracic and cardiovascular surgery (1), 
Journal of clinical anesthesia (1) e Anesthesia \& Analgesia(1). Merece destaque, o fato de que boa parte dos artigos tem como autores profissionais de enfermagem em sua composição, afirmando o empenho e a dedicação em produzir conhecimento sobre a temática.

A partir da avaliação do conteúdo das publicações, foram identificadas, de forma geral, 4 categorias de práticas de avaliação da qualidade do cuidado nos centros cirúrgicos (Quadro 01), a saber: segurança do paciente, indicadores de qualidade, ferramentas de qualidade e avaliação feita por clientes internos.

Quadro 01: Práticas de avaliação da qualidade do cuidado por temática e autor (es) ano.

\begin{tabular}{|l|l|}
\hline TEMÁTICA & AUTOR(ES)/ANO \\
\hline Segurança do paciente & $\begin{array}{l}\text { ABREU et al., 2019; ELIAS et al., 2015; } \\
\text { RAMAN et al., 2016. }\end{array}$ \\
\hline Indicadores de qualidade & ARAUJO et al., 2019; AMARAL et al., 2017; \\
\hline Ferramentas de qualidade & $\begin{array}{l}\text { MOON } \text { et al., 2016; SUN; DEXTER; MILLER, } \\
2016 ; \text { PSALTIKIDIS, 2016 }\end{array}$ \\
\hline Avaliação feita por clientes internos & RIBEIRO et al., 2020; GOUVEIA et al., 2020 \\
\hline
\end{tabular}

Não restam dúvidas de que a qualidade da assistência influencia positivamente no estado de saúde do indivíduo, da família e da comunidade, daí surgem métodos para avaliar a situação de saúde vivenciada nos mais variados campos de atuação em saúde. Nos estudos analisados, um tema bastante recorrente foi a segurança do paciente e sua relação com a qualidade do cuidado em centros cirúrgicos.

Nesse ponto, sabe-se de antemão que a temática segurança do paciente é transversal e que deve estar presente nas mais variadas formas de produzir saúde com qualidade. De acordo com Abreu et al. (2019), o nível de desenvolvimento de um país influencia diretamente na capacidade das instituições de saúde ofertar segurança, tendo em vista que em países em desenvolvimento há uma associação de fatores que favorecem a ocorrência de erros e eventos adversos, como a escassez de equipamentos, superlotação, dentre outros.

No contexto dos centros cirúrgicos, destaca-se a aliança mundial para segurança do paciente, na qual definiu como segundo desafio global para segurança do paciente a 
temática: cirurgias seguras salvam vidas. Dentro dessa perspectiva, foi criado a lista de verificação de segurança cirúrgica (checklist) da Organização Mundial da Saúde (OMS), desde então pesquisas são realizadas para avaliar a aplicabilidade e confiabilidade dessa ferramenta.

Neste estudo de revisão, duas pesquisas associaram diretamente a qualidade do cuidado com segurança do paciente em centros cirúrgicos por meio do checklist da OMS, na qual, de acordo com Elias et al. (2015), o checklist, ao passo em que propõem mudanças para minimizar riscos evitáveis, apresenta dificuldades em sua adesão no que diz respeito ao preenchimento completo de todos os campos que o compõe. Entretanto, a pesquisa apontou que a educação permanente é capaz de sanar essa lacuna e permitir práticas diárias de sua aplicação pelas equipes de saúde.

O segundo estudo RAMAN et al. (2016)., em contrapartida, questiona até que ponto o instrumento é suficiente para gerar segurança ao paciente, tendo em vista a ocorrência de 30 eventos adversos em 380 procedimentos consecutivos de cirurgia cardíaca que aplicaram o método. A pesquisa conclui expondo a necessidade de intervenções adicionais, como a personalização da lista de acordo com a especialidade cirúrgica, bem como a exploração de novos recursos adicionais para melhorar a segurança do paciente. Cabe apontar, assim, que as pesquisas sobre avaliação da qualidade na perspectiva da segurança do paciente, estão voltadas à verificação da eficácia e confiabilidade do checklist da OMS e também por meio da análise da cultura de segurança do paciente.

Tão importante quanto essa temática é a avaliação feita por clientes internos e externos, na qual conforme verificado por estudos, a avaliação da qualidade em saúde não pode ser aplicada somente a um único autor, pois torna o processo avaliativo incompleto e insuficiente. Trata-se, assim, de um conjunto de dimensões percebidas por pacientes, profissionais e gestores que devem ser organizadas e planejadas para proporcionar um serviço de saúde conforme as necessidades da população (FEITOSA et al, 2016).

Nessa perspectiva, cabe apontar uma pesquisa que avaliou o nível de satisfação profissional de 49 enfermeiros que atuam no bloco cirúrgico de um hospital de excelência, da qual, por meio da aplicação do instrumento Índice de Satisfação Profissional (ISP), evidenciou-se resultados de baixa satisfação com os requisitos de 
trabalho. Daí surge a percepção da importância dos gestores investigarem tais informações, tendo em vista a sua capacidade de direcionar práticas de organização e controle direcionadas às necessidades apresentadas pelos clientes (GOUVEIA et al, 2020). Deve-se, no entanto, chamar atenção ao fato de que nesta revisão não houveram trabalhos que tinham como alvo os clientes externos (pacientes e gestores).

Já no que diz respeito às ferramentas de qualidade, elas podem ser criadas para essa finalidade ou incorporadas de outras ciências, em que possuem como principal objetivo o planejamento e análise de problemas (BURMESTER, 2013). Na discussão desse ponto, é importante considerar uma pesquisa realizada em um hospital dos Estados Unidos, na qual, por meio de um fluxograma analisador, foram avaliadas as principais necessidades e o processo que envolve a transferência de um paciente do centro cirúrgico para Unidade de Terapia Intensiva, a pesquisa revelou que os níveis de satisfação de ambos os setores e suas respectivas equipes de enfermagem, aumentaram significativamente após a implementação da ferramenta (MOON et al., 2016).

É preciso, porém, ir além e verificar que as ferramentas de qualidade muitas vezes estão voltadas à avaliação de aspectos tangíveis e intangíveis. Nessa perspectiva, PSALTIKIDIS, 2016, cita que os centros cirúrgicos possuem excessiva carga de tecnologias, na

qual devem ser verificados os seus benefícios e riscos por meio de programas de Avaliação das Tecnologias em Saúde (ATS).

Enfatizando a importância das ferramentas de qualidade, SUN; DEXTER; MILLER, 2016, apontam em um estudo, também realizado nos Estados Unidos, no qual ocorreu a exclusão de regulamentos de supervisão médica a enfermeiros anestesistas, ferramentas estas, que aumentavam o grau de qualidade dos serviços e foram retiradas em uma tentativa de aumentar o acesso da população mal favorecida aos serviços de saúde, foi evidenciado que apesar de aumentar o acesso à cirurgia, principalmente em áreas mais pobres, seja uma meta louvável, os resultados sugerem que a exclusão das ferramentas por si só provavelmente não resolverá esse problema.

Por último e não menos importante, deve-se citar os indicadores de saúde como um dos responsáveis por monitorar os processos que envolvem a garantia e busca por uma assistência de qualidade. Dentro dessa perspectiva, cabe apontar o estudo realizado por ARAÚJO et al. (2019), que utiliza o indicador de cancelamento de cirurgias 
para evidenciar os principais fatores que afetam o quadro cirúrgico e, assim discute estratégias para minimizar ou resolver os problemas evidenciados, bem como inclui a equipe de enfermagem durante a gestão de qualidade.

Nessa perspectiva, é importante resgatar que, de acordo com a lei do exercício profissional da enfermagem 7.498/86, o enfermeiro exerce a avaliação da programação em saúde como integrante da equipe, já avaliação dos serviços da assistência de enfermagem, exerce como atividade privativa. Assim, é pertinente discutir um estudo de revisão que versa sobre a temática de indicadores de saúde, na qual considera que, apesar de existir uma ampla produção científica sobre a temática, existem poucos estudos que retratam indicadores próprios do cuidado de enfermagem, sendo um assunto na qual deve ser ampliado o escopo de pesquisa e busca (AMARAL et al, 2017).

Na discussão dessa temática, cabe uma observação: os métodos avaliativos possuem potencial em gerar qualidade do cuidado, tendo em vista a capacidade de identificar as principais necessidades do serviço e potencializar a gerência de qualidade conforme processos e resultados.

\section{CONSIDERAÇÕES FINAIS}

Diante do exposto é possível verificar que as principais formas de avaliação da qualidade no cuidado de centro cirúrgicos identificadas foram por meio das seguintes categorias: 1) Segurança do Paciente, 2) Indicadores de qualidade , 3) Ferramentas de Qualidade e 4) Avaliação feita por clientes internos, e por meio dos estudos elencados nesta revisão, compreende-se que essas práticas são imprescindíveis nos serviços de saúde, visto que os profissionais de forma multidisciplinar são treinados e capacitados a oferecer um cuidado de excelência e principalmente a assistência de enfermagem oferecida aos pacientes se torna bem mais eficaz.

Além disso, ressalta-se que ainda são necessários novos estudos que tragam a importância das práticas de avaliação de qualidade dos serviços de saúde e principalmente quando essas práticas estão voltadas aos cuidados oferecidos pela equipe de enfermagem. 


\section{AGRADECIMENTOS}

À Fundação Cearense de Apoio ao Desenvolvimento Científico e Tecnológico FUNCAP pela concessão da bolsa de Desenvolvimento Científico Regional.

\section{REFERÊNCIAS}

ABREU, I. M. et al. Cultura de segurança do paciente em centro cirúrgico: visão da enfermagem. Revista Gaúcha de Enfermagem, [S.L.], v. 40, n. , p. 1-8, 2019. FapUNIFESP (SciELO). http://dx.doi.org/10.1590/1983-1447.2019.20180198. Disponível em: 10.1590/1983-1447.2019.20180198. Acesso em: 01 abr. 2021.

AMARAL, J. A. B. et al. Indicadores de qualidade em enfermagem com ênfase no centro cirúrgico: revisão integrativa da literatura. Revista Sobecc, [S.L.], v. 22, n. 1, p. 42-51, 4 abr. 2017. Zeppelini Editorial e Comunicacao. http://dx.doi.org/10.5327/z1414-4425201700010008. Disponível em: https://pesquisa.bvsalud.org/portal/resource/pt/biblio-833448. Acesso em: 04 abr. 2021.

ARAUJO, J. K.M. de et al. Avaliação dos fatores de cancelamento de cirurgias em hospitais do nordeste brasileiro. Revista Sobecc, [S.L.], v. 24, n. 4, p. 175-184, 13 dez. 2019. Zeppelini Editorial e Comunicacao. http://dx.doi.org/10.5327/z14144425201900040002.

Disponível

em: https://pesquisa.bvsalud.org/portal/resource/pt/biblio-1095696. Acesso em: 02 abr. 2021.

BORGES, A. M. M. et al. AVALIAÇÃO DE QUALIDADE EM SERVIÇOS DE SAÚDE: UMA REVISÃO INTEGRATIVA. Revista Rede de Cuidados em Saúde, Duque de Caxias, v. 10, n. 1, p. 1-10, jan. 2017. Disponível em: http://publicacoes.unigranrio.edu.br/index.php/rcs/article/view/3103/2201. Acesso em: 30 mar. 2021.

BURMESTER, H. Gestão de qualidade hospitalar. São Paulo: Saraiva, 2013. 296 p.

ELIAS, A. C. G. Paminonde et al. Avaliação da adesão ao checklist de cirurgia segura em Hospital Universitário Público. Revista Sobecc, [S.L.], v. 20, n. 3, p. 128-133, 1 set. 2015. Zeppelini Editorial e Comunicacao. http://dx.doi.org/10.5327/z14144425201500030002. https://pesquisa.bvsalud.org/portal/resource/pt/lil-772156. Acesso em: 04 abr. 2021.

FEITOSA, A.N.C.; OLIVEIRA, C.L.; DUARTE, E.B.; OLIVEIRA, A.M. Avaliação em saúde: Uma Revisão Integrativa. Id on Line Revista Multidisciplinar e de Psicologia, Julho de 2016, vol.10, n.30, p. 274-281. ISSN 1981-1179. Disponível em: < https://idonline.emnuvens.com.br/id/article/view/457>. Acesso em 10 de jan. de 2020. 
FONSECA, R. C. V. Metodologia do trabalho científico. Curitiba: lesde Brasil, 2012. 90 p.

GOMES, E. T. et al. Contributions by Leonardo Boff for the understanding of care. Revista de Enfermagem Ufpe On Line, [S.L.], v. 12, n. 2, p. 531, 4 fev. 2018. Revista de Enfermagem, UFPE Online.. Disponível em: http://dx.doi.org/10.5205/19818963-v12i2a23563p531-536-2018. Acesso em: 23 abr. 2021.

GOUVEIA, L. H. A. et al. Satisfação profissional de enfermeiros que atuam no bloco cirúrgico de um hospital de excelência. Revista Sobecc, [S.L.], v. 25, n. 1, p. 3341, 3 abr. 2020. Zeppelini Editorial e Comunicacao. http://dx.doi.org/10.5327/z1414-4425202000010006. Disponível em: https://revista.sobecc.org.br/sobecc/article/view/574/pdf. Acesso em: 04 abr. 2021.

MOON, T. S. et al. Improving the quality of the operating room to intensive care unit handover at an urban teaching hospital through a bundled intervention. Journal Of Clinical Anesthesia, [S.L.], v. 31, p. 5-12, jun. 2016. Elsevier BV. http://dx.doi.org/10.1016/j.jclinane.2016.01.001. Disponível em: https://www.sciencedirect.com/science/article/abs/pii/S0952818016000246?vi a\%3Dihub. Acesso em: 04 abr. 2021.

POSSARI, J.F. Centro Cirúrgico: Planejamento, Organização e Gestão. Editora saraiva, São Paulo. $5^{\circ}$ edição, 2016.

PSALTIKIDIS, E.M.. Avaliação de tecnologias no Centro Cirúrgico, Recuperação Pósanestésica e Centro de Material e Esterilização. Revista Sobecc, [S.L.], v. 21, n. 4, p. 223-228, 20 dez. 2016. Zeppelini Editorial e Comunicacao. http://dx.doi.org/10.5327/z1414-4425201600040009. Disponível em: https://revista.sobecc.org.br/sobecc/article/view/134/0. Acesso em: 04 abr. 2021.

RAMAN, J. et al. When a checklist is not enough: how to improve them and what else is needed. The Journal Of Thoracic And Cardiovascular Surgery, [S.L.], v. 152, n. 2, p. 585-592, ago. 2016. Elsevier BV. http://dx.doi.org/10.1016/j.jtcvs.2016.01.022. Disponível em: https://pesquisa.bvsalud.org/portal/resource/pt/mdl-27167018. Acesso em: 04 abr. 2021.

RIBEIRO, O. M. P. L. et al. Qualidade dos cuidados de enfermagem: contribuições de enfermeiros especialistas em enfermagem médico-cirúrgica. Rev Rene, [S.L.], v. 21, p. 1-9, 18 mar. 2020. Rev Rene - Revista da Rede de Enfermagem de Nordeste. http://dx.doi.org/10.15253/2175-6783.20202143167. Disponível em: http://periodicos.ufc.br/rene/article/view/43167/100223. Acesso em: 04 abr. 2021.

SUN, E.; DEXTER, F.; MILLER, T. R.. The Effect of "Opt-Out" Regulation on Access to Surgical Care for Urgent Cases in the United States. Anesthesia \& Analgesia, 
[S.L.], v. 122, n. 6, p. 1983-1991, jun. 2016. Ovid Technologies (Wolters Kluwer Health). http://dx.doi.org/10.1213/ane.0000000000001154. Disponível em: https://journals.lww.com/anesthesia-

analgesia/Fulltext/2016/06000/The_Effect_of_Opt_Out_Regulation_on_Acc ess_to.38.aspx. Acesso em: 04 abr. 2021. 


\section{CAPÍTULO IX}

\section{ATUACÃO DO ENFERMEIRO NA PREVENGÃO DA SÍFILS ADQUIRIDA NA ATENCẼO PRIMÁRIA}

Priscila Araujo Gonçalves da Silva ${ }^{1}$ Jacqueline Arcanjo Rodrigues ${ }^{2}$

Angela Paula de Oliveira ${ }^{3}$ José Rivaldo de Brito Menezes ${ }^{4}$

\footnotetext{
${ }^{1}$ Graduada em Enfermagem pelo Centro Universitário Brasileiro - UNIBRA. Pós-graduanda em ESF - FACESF

2 Graduada em Enfermagem pelo Centro Universitário Brasileiro - UNIBRA. Pós-graduanda em UE - ALPHA

${ }^{3}$ Graduada em Enfermagem pelo Centro Universitário Brasileiro - UNIBRA. Pós-graduanda em UE - ALPHA

4 Psicólogo - FAFIRE. Graduado em Enfermagem pelo Centro Universitário Brasileiro - UNIBRA. Pós-graduando em UE - ALPHA
}

\section{RESUMO}

A sífilis adquirida é uma infecção sexualmente transmissível (IST), que se não diagnosticada e tratada, pode ocasionar no acometimento de vários órgãos e sistemas. O enfermeiro na Atenção Primária à Saúde é o principal profissional responsável pela prevenção da infecção, devendo sempre estar ciente dos sinais e sintomas, a fim de realizar um diagnóstico correto como também o tratamento do paciente e seu parceiro. O presente estudo se caracteriza como uma revisão integrativa (RI), de natureza descritiva. A pesquisa dos dados foi realizada por meio das plataformas: Biblioteca Virtual em Saúde (BVS), onde se encontram disponíveis dados da Literatura Latinoamericana e do Caribe em Ciências da Saúde (LILACS), biblioteca on-line Scientific Eletronic Library Online (SciELO), Bases de dados de enfermagem (BDENF) e a base de dados internacionais PUBMED (Medical Published -service of the U.S. National Library of Medicine) e Google Scholar. Com isso, a presente RI se justifica pela ampla função do enfermeiro na prevenção e tratamento da sífilis adquirida na APS, objetivando-se em mostrar a atuação do profissional enfermeiro na prevenção da sífilis no âmbito primário da saúde.

Palavras-chave: No máximo. Cinco. Separadas por. Ponto.

\section{INTRODUÇÃO}

A sífilis é uma infecção sexualmente transmissível (IST) causada pela bactéria Treponema pallidum. A transmissão do patógeno ocorre durante a relação sexual, podendo ser sexo oral, sexo anal ou vaginal, transmissão congênita ao RN ou transfusão 
de sangue. Caso não tratada, a infecção poderá progredir por 4 estágios: primário, secundário, latente e terciário (OLIVEIRA \& BATTISTON, 2018).

A infecção é facilmente tratada com medicamento, porém, sem o tratamento adequado, consegue causar sérios problemas permanentes, como danos cerebrais, paralisia e cegueira. Por isso ressalta-se a importância de realizar um acompanhamento nas Unidades de Básicas de Saúde (UBS), para a triagem e realização dos testes de ISTs. Seus sintomas são facilmente confundidos com outras doenças, com isso, a realização dos exames laboratoriais são de extrema importância para o diagnóstico, como o VDRL e FTA-abs (ACIOLI, 2017).

No Brasil, o Sistema Único de Saúde oferece o diagnóstico e tratamento gratuito, como também, realizam ações que oferecem avaliações médicas de rotina para as ISTs. Por possuir um alto número de casos da infecção no país, foi criado o Programa Nacional de Doenças Sexualmente Transmissíveis/Síndrome da imunodeficiência adquirida, que desenvolve ações preventivas, diagnóstico e tratamento (BRASIL, 2005).

Por meio da Portaria no 2.472, publicada em 31 de agosto de 2010, a sífilis passou a ser de notificação compulsória em todo território nacional. Portanto, todo caso confirmado deve ser de notificado à vigilância epidemiológica, com a finalidade de evitar a disseminação da infeç̧ão e instituir medidas de controle acerca da infecção (BRASIL, 2010).

A atuação do enfermeiro na Atenção Primária à Saúde (APS) para a sífilis adquirida é voltada principalmente no rastreamento precoce, tratamento e desenvolvendo ações educativas a fim de favorecer a diminuição no número de casos e riscos dos pacientes acometidos com a infecção. O profissional deverá estar preparado para assistir de forma integral o paciente diagnosticado com a sífilis. Por tanto, o enfermeiro possui um papel essencial na educação em saúde voltada para a transmissão e prevenção precoce de sífilis adquirida, como também, a realização do teste rápido para sífilis (SILVA et al, 2021; SOUZA et al, 2018).

Diante disso, a atuação do enfermeiro na prevenção da sífilis é de extrema importância, sendo o principal profissional responsável na prevenção e no rastreamento precoce, diagnosticando os casos positivos e realizando a notificação compulsória e mantendo os órgãos competentes informados. Dessa forma, o presente estudo se justifica pela ampla função do enfermeiro na prevenção e tratamento da sífilis adquirida 
na APS, objetivando-se em mostrar a atuação do profissional enfermeiro na prevenção da sífilis no âmbito primário da saúde.

O presente estudo se caracteriza como uma revisão integrativa (RI), de natureza descritiva. Foram utilizados descritores controlados pelo Descritores em Ciências da Saúde (DECS) que foram combinados entre si com o conector booleano OR, dentro de cada conjunto de termos da estratégia PICO e, em seguida, cruzados com o conector booleano AND.

A pesquisa dos dados foi realizada por meio das plataformas: Biblioteca Virtual em Saúde (BVS), onde se encontram disponíveis dados da Literatura Latino-americana e do Caribe em Ciências da Saúde (LILACS), biblioteca on-line Scientific Eletronic Library Online (SciELO), Bases de dados de enfermagem (BDENF) e a base de dados internacionais PUBMED (Medical Published -service of the U.S. National Library of Medicine) e Google Scholar.

Ao finalizar as pesquisas em cada base, as referências duplicadas foram excluídas. Assim, foi considerado como critérios de inclusão: artigos originais, no idioma de português e inglês publicados a partir do ano de 2005 a 2021, que atendessem aos objetivos do estudo. Os critérios de exclusão foram: artigos repetidos e que não fossem de acesso gratuito

Assim, foram estabelecidos os estudos que fizeram parte da amostra da literatura estudada. Os artigos foram lidos, analisados, interpretados e apresentados sob a forma de texto e tabela presente nessa RI.

\section{REVISÃO BIBLIOGRÁFICA}

\subsection{SIFILIS}

A sífilis é uma infecção causada pela bactéria espirochetiana Treponema pallidum, gênero Treponema, da família dos Treponemataceae, que é patógeno exclusividade humana. Foi descrito pela primeira vez no século XV quando se expandiu rapidamente pela Europa. Naquele século foi descrita "a Grande Varíola", por apresentar feridas e cheiro anormal e grande números de óbitos (LEÃO et al, 2021).

O agente causador da sífilis é uma bactéria gram-negativa, anaeróbia facultativa, de alta patogenicidade e em forma de espiral enrolado sobre o próprio eixo, em forma 
de saca-rolhas, com 0,2 micrômetros de diâmetro e 5 a $15 \mu \mathrm{m}$ de comprimento, podendo ser transmitida por contato sexual, pela via vertical ou parenteral quando a exposição a produtos contaminados com sangue (NAVES, 2018).

Os estágios clínicos são classificados em quatro fases: primária, secundária, latente e sífilis terciária, suas características de acordo com a fase estão disponíveis no Quadro 1, logo abaixo.

Quadro 1: Classificação das fases da sífilis e suas características

\begin{tabular}{|c|c|}
\hline Fase & Característica \\
\hline Primária & $\begin{array}{l}\text { Lesão indolor no local da infecção (boca, ânus, } \\
\text { reto, vagina ou pênis), as feridas se cicatrizam por } \\
\text { conta própria após } 3 \text { a } 6 \text { semanas, podendo ainda } \\
\text { ser transmitida. }\end{array}$ \\
\hline Secundária & $\begin{array}{l}\text { Erupção cutânea que podem ser confundidas } \\
\text { com outras doenças dermatológicas, gânglios } \\
\text { linfáticos inchados e sintomas sistêmicos como } \\
\text { febre, cefaléia, anorexia e dor de garganta. }\end{array}$ \\
\hline Latente & $\begin{array}{l}\text { Não apresenta sinais e sintomas, é dividida em } \\
\text { latente recente e latente tardia, assintomática. }\end{array}$ \\
\hline Terciária & $\begin{array}{c}\text { Apresenta sinais e sintomas como lesões } \\
\text { cutâneas, ósseas, cardiovasculares e neurológicas } \\
\text { que podem levar o acometido a óbito. }\end{array}$ \\
\hline
\end{tabular}

Fonte: Adaptação de Sou \& Castanheira, 2020.

No Brasil, o Sistema Único de Saúde realiza ações que oferecem avaliações médicas de rotina para as ISTs, como também os mutirões de saúde e a realização dos testes rápidos para obter a detecção precoce da infecção. Para obter o diagnóstico da sífilis pelo SUS, o paciente deverá procurar uma Unidade Básica de Saúde (UBS), a fim de obter orientação e realizar o exame. Após a confirmação positiva, o paciente deverá começar o tratamento e informar aos parceiros para realizar a testagem dos mesmo e começar tratamento (BRASIL, 2020).

Com o alto índice da infecção no país, foi criado o Programa Nacional de DST/aids (PN DST/aids), sendo responsável no comando e na aplicação das atividades, diagnóstico, prevenção e tratamento, tendo foco nas ações preventivas como a 
distribuição de materiais informativos e seminários, trazendo a possibilidade de acesso ao diagnóstico da sífilis e outras IST (BRASIL, 2008).

\subsection{DIAGNÓSTICO E TRATAMENTO}

O diagnóstico da sífilis ocorre através de observação clínica, análise sorológica, e microscopia de campo escuro. Os mais realizados são os de sangue, disponíveis em dois tipos, os testes não treponêmicos e os testes treponêmicos. Ambos os testes são necessários para confirmar o diagnóstico de sífilis. Os testes não treponêmicos (VDRL e RPR) são simples, de fácil realização, baratos e costumam ser usados para rastreamento. Contudo, podem produzir um resultado falso-positivo, não sendo suficiente para o diagnóstico da sífilis. Os resultados dos anticorpos de VDRL e RPR devem ser relatados quantitativamente. $O$ indivíduo com o teste não treponêmico positivo, deve realizar o teste treponêmico para a confirmação do diagnóstico da sífilis (GASPAR et al, 2020).

Já os testes treponêmicos, os FTA-abs, MHA-TP/TPHA/TPPA e ELISA conseguem detectar anticorpos específicos da sífilis. Os anticorpos treponêmicos surgem antes dos anticorpos não treponêmicos e geralmente permanecem detectáveis por toda a vida, mesmo após o tratamento concluído. Se um teste treponêmico for usado para triagem e os resultados forem positivos, um teste não treponêmico deve ser realizado para confirmar o diagnóstico e orientação sobre tratamento ao indivíduo acometido (SANTOS et al, 2017).

Para o tratamento, a penicilina benzatina é o fármaco de principal escolha, o esquema de tratamento dependerá da fase que se encontra a infecção. O esquema para cada fase está disponível no Quadro 2, logo abaixo.

Quadro 2: Esquema de tratamento para a sífilis de acordo com a fase

\begin{tabular}{|c|c|c|}
\hline Estadiamento & Tratamento & $\begin{array}{c}\text { Alternativa (exceto para } \\
\text { gestantes) }\end{array}$ \\
\hline $\begin{array}{l}\text { Sífilis recente: sífilis primária, } \\
\text { secundária e latente recente } \\
\text { (com até um ano de evolução) }\end{array}$ & $\begin{array}{l}\text { Benzilpenicilina benzatina 2,4 } \\
\text { milhões UI, IM, dose única (1,2 } \\
\text { milhão UI em cada glúteo) }\end{array}$ & $\begin{array}{c}\text { Doxiciclina } 100 \mathrm{mg} \\
\text { 12/12h, vo, por } 15 \text { dias }\end{array}$ \\
\hline $\begin{array}{l}\text { Sífilis tardia: sífilis latente tardia } \\
\text { (com mais de um ano de }\end{array}$ & $\begin{array}{l}\text { Benzilpenicilina benzatina } 2,4 \\
\text { milhões UI, IM, 1x/semana }(1,2\end{array}$ & $\begin{array}{c}\text { Doxiciclina } 100 \mathrm{mg} \\
\text { 12/12h, vo, por } 30 \text { dias }\end{array}$ \\
\hline
\end{tabular}




\begin{tabular}{|c|c|c|}
\hline $\begin{array}{c}\text { evolução) ou latente com } \\
\text { duração ignorada e sífilis terciária }\end{array}$ & $\begin{array}{c}\text { milhão UI em cada glúteo) por 3 } \\
\text { semanas. Dose total: 7,2 milhões } \\
\text { UI, IM }\end{array}$ & \\
\hline Neurossífilis & $\begin{array}{c}\text { Benzilpenicilina } \\
\text { potássica/cristalina 18-24 milhões } \\
\text { UI, 1x/ dia, EV, administrada em } \\
\text { doses de 3-4 milhões UI, a cada 4 } \\
\text { horas ou por infusão contínua, por } \\
14 \text { dias }\end{array}$ & $\begin{array}{c}\text { Ceftriaxona 2g IV, 1x/dia, } \\
\text { por 10-14 dias }\end{array}$ \\
\hline
\end{tabular}

Fonte: Adaptação de Brasil, 2020.

Após a realização da primeira dose de penicilina, o indivíduo poderá apresentar a reação de Jarisch-Herxheimer, podendo ocorrer nas primeiras 24 horas após a primeira dose. A reação se caracteriza por exacerbação das lesões cutâneas, com eritema, dor ou prurido, febre e cefaléia que regridem após 12 a 24 horas (AVELLEIRA \& BOTTINO, 2006).

\subsection{ATUAÇÃO dO ENFERMEIRO NO TRATAMENTO E PREVENÇÃO DA SiFILIS}

Diante a prevenção da sífilis na APS, o enfermeiro é responsável em desenvolver ações preventivas e a realização de testes rápidos a fim de diagnosticar a infecção. Tendo o foco nas ações informativas em educação, voltadas para as práticas de relações sexuais seguras. Em seu primeiro contato com o paciente, o enfermeiro deve informar sobre a infecção, tratamento e efeitos colaterais referente ao uso da penicilina (SOLINO et al, 2020; COREN-PE, 2020).

Após a confirmação do diagnóstico, o profissional poderá realizar a administração do fármaco de escolha para o tratamento, de acordo com a fase que se encontra a infecção, seguindo o esquema de antibiótico preconizado pelo Ministério da Saúde, caso alergia comprovada, o mesmo, deverá fazer o encaminhamento do paciente para a realização da dessensibilização (SOLINO et al, 2020; COREN-PE, 2020).

O profissional precisa lidar com a situação de forma humanizada, acolhendo o paciente em todo processo de diagnóstico e tratamento, tranquilizando-o sobre todo o processo para a cura, trazendo assim a confiança entre o profissional e paciente. A sífilis é uma doença que possui cura e seu tratamento é disponibilizado de forma gratuita pelo Sistema Único de Saúde (SUS) porém os pacientes ficam chocados ao descobrirem a 
sobre a infecção, podendo causar uma desestabilização emocional e o profissional precisa estar preparado para lidar com a situação (MARISTELA et al, 2020; SOLINO et al, 2020).

O enfermeiro atuante da rede de APS, precisa assistir de forma integral os pacientes e seus parceiros com o diagnóstico positivo para a sífilis. Contribuir para um desfecho positivo e na realização das estratégias que visem o caminho para a assistência de qualidade e acompanhamento desse paciente e seu parceiro (FERNANDES et al, 2017).

Uma das responsabilidades do profissional na APS é a realização da notificação compulsória dos casos positivos de sífilis, com isso ele deverá preencher a ficha e enviála para o órgão competente do município, tendo o objetivo de promover o controle dos agravos. A notificação é de obrigatoriedade ao enfermeiro e profissionais de saúde, é exigida nos serviços público e privado de saúde para o monitoramento das doenças a fim de prevenir surtos dos agravos (LAZARINI \& BARBOSA, 2017; LEITE et al, 2016).

Diante disso, a Portaria 2.488, de 21 de outubro de 2011 que aprova a Política Nacional da Atenção Básica, o enfermeiro se destaca diante a prevenção das ISTs, intervindo através da consulta de enfermagem, na realização da educação em saúde e na solicitação de exames complementares, disposto na Lei 7.498 , de 25 de junho de 1986. Portanto, a orientação da vida sexual e suas práticas, consegue ajudar a minimizar os riscos de infecção da sífilis (BRASIL, 2017; BRASIL, 1989).

Deste modo, é necessário que o enfermeiro compreenda todos processo do tratamento e priorize as ações preventivas, desenvolvendo as ações assistenciais através de campanhas, palestras e nas consultas nas Unidades Básicas de Saúde (UBS). Cabendo ao enfermeiro na APS para a sífilis, a realização da consulta de enfermagem, solicitar exames complementares, prescrever medicamento conforme protocolo, executar ações de assistência integral, realizar orientações na pessoa e as práticas sexuais, oferecer testagem para a sífilis e outras ISTs, ofertar a possibilidade as realização da prevenção combinada para IST/HIV/hepatites virais, tratar, acompanhar em todo processo de cura o paciente e seus parceiros e a realização da notificação compulsória (RODRIGUES et al, 2016; COREN-PE, 2020; FERNANDES et al, 2017). 


\section{CONSIDERAÇÕES FINAIS}

Conclui-se que o enfermeiro possui um papel essencial na prevenção, da sífilis na atenção básica, podendo desenvolver métodos de educação em saúde que contribuem para o diagnóstico precoce da sífilis, como também, fica responsável pela ficha de notificação compulsória da sífilis adquirida no qual promove o controle dos agravos.

\section{REFERÊNCIAS}

ACIOLI, V, O, C. Sífilis Na Gestação: O Conhecer Para Prevenir. Universidade Federal de Santa Catarina. Centro de Ciências da Saúde. Programa de Pós-graduação em Enfermagem. Linhas de Cuidado em Saúde Materna, Neonatal e do Lactante. Florianópolis, SC, 2017.

AVELLEIRA JCR, BOTTINO G. Syphilis: diagnosis, treatment and control. An Bras Dermatol, 2006; 81:111-26.

BRASIL. Governo Federal. Lei no 7498, de 25 de junho de 1986. Dispõe sobre a regulamentação do exercício de enfermagem e dá outras providências. Diário Oficial da União. 1986; Seção 1:9271-5.

BRASIL. Manual de Controle das Doenças Sexualmente Transmissíveis / Ministério da Saúde, Secretaria de Vigilância em Saúde, Programa Nacional de DST e Aids. Brasília: Ministério da Saúde. 2005.

BRASIL. Ministério da Saúde. PN-DST/Aids - PROGRAMA NACIONAL DE DOENÇAS SEXUALMENTE TRANSMISSÍVEIS E AIDS. Boletim Epidemiológico. Brasília, PN DST/Aids, ano I, n. 1, dez. 2008.

BRASIL. Ministério da Saúde. Portaria no 2.472, de 31 de agosto de 2010. Disponível em: bvsms. saude.gov.br/bvs/saudelegis/gm/2010/prt2472_31_08_2010. html.

BRASIL. Ministério da Saúde. Portaria № 2.488, de 21 de outubro de 2011. Aprova a Política Nacional de Atenção Básica, estabelecendo a revisão de diretrizes e normas para a organização da Atenção Básica, para Estratégia de Saúde da Família (ESF) e o Programa de Agentes Comunitários de Saúde (PACS). Diário Oficial [da] República Federativa do Brasil, Brasília, DF, 2011.

COREN. Conselho Regional de Enfermagem-PE (COREN-PE). Protocolo de Enfermagem na Atenção Básica do Coren-PE. PE-Recife: COREN (2a Edição). https://www.coren-pe.gov.br/novo/wpcontent/uploads/2020/09/PROTOCOLO-DE-ATEN\%c3\%87\%c3\%830B\%c3\%81SICA-2020_2\%c2\%baEDI\%c3\%87\%c3\%830-FINAL.pdf. 
FERNANDES, CRS et al. Assistência De Enfermagem A Gestantes Com Sífilis. Revista IESM. v.1 n.1 2017.

GASPAR, PÂMELA CRISTINA et al. Protocolo Brasileiro para Infecções Sexualmente Transmissíveis 2020: testes diagnósticos para sífilis. Epidemiologia e Serviços de Saúde [online]. v. 30, n. spe1. Disponível em: <https://doi.org/10.1590/S16794974202100006.esp1>.

LAZARINI, FM; BARBOSA, DA. Intervenção Educacional na Atenção Básica para Prevenção de Sífilis Congênita. Rev. latinoam. enferm. (Online); 25: e2845, 2017.

LEÃO, M. L. P.; FERREIRA, L. F. G.; OLIVEIRA, I. P.; DIAS, M. G. M.; VIEIRA, L. M.; SILVA, I. J. C.; OLIVEIRA, V. A.; SOUZA, C. L.. Perfil epidemiológico da sífilis gestacional no estado de Minas Gerais entre 2009 e 2019. Scire Salutis, v.11, n.1, p.61-68, 2021. DOI: http://doi.org/10.6008/CBPC2236 9600.2021.001.0007

LEITE, I et al. Assistência de Enfermagem na Sífilis na Gravidez: Uma Revisão Integrativa. 2016. Ciências Biológicas e da Saúde- Maceió- v.3. n.3. p. 165-176. Disponível em < https://periodicos.set.edu.br/index.php/fitsbiosaude/article/view/3417>.

MARISTELA, KILVIA, ANA, RAQUEL, MARIA, MARIA, IZABELLE, et al. Sífilis Na Gestação: Estratégias $E$ Desafios Dos Enfermeiros Da Atenção BÁSICA PARA O TRATAMENTO SIMULTÂNEO DO CASAL. Rev. bras. promoç. saúde. 2016 Dec; 29(Supl): 85-92.

MINISTÉRIO DA SAÚDE. Departamento de Vigilância, Prevenção e Controle das IST, do HIV/AIDS e das Hepatites Virais, Secretaria de Vigilância em Saúde, Ministério da Saúde. Protocolo Clínico e Diretrizes Terapêuticas para Atenção Integral às Pessoas com Infecções Sexualmente Transmissíveis (IST). Brasília 2020.

NAVES, E. F. Soroprevalência da infecção por sífilis em homens privados de liberdade, região sul de Goiás. 2018. 111 f. Dissertação (Mestrado em Enfermagem) Universidade Federal de Goiás, Goiânia, 2018.

OLIVEIRA, D. A.; BATTISTON, F. G. Incidência De Casos De Sifílis Em Município Do Oeste De Santa Catarina. Seminário de Iniciação Científica e Seminário Integrado de Ensino, Pesquisa e Extensão, [S. I.], 2018. Disponível em: https://unoesc.emnuvens.com.br/siepe/article/view/18362.

RODRIGUES, A.R et al. Atuação de enfermeiros no acompanhamento da sífilis na atenção primária. Rev Enferm UFPE.;10(4):1247-55, 2016.

SANTOS A, MARQUES E, PAGNIN D, QUEIROZ V. A new challenge for public health: syphilis. Diversitates Int J. 2017;9(2):65-81.

SILVA, Policardo Gonçalves da et al . Produção e validação de tecnologia educacional sobre cuidados de enfermagem para prevenção da sífilis. Rev. Bras. Enferm., Brasília, v. 74, supl. 5, e20190694, 2021. . 
SOLINO MSS, et al. Desafios do enfermeiro na assistência de enfermagem aos usuários com diagnóstico de sífilis: revisão integrativa. Braz. J. Hea. Rev.,2020;3(5):13917-13930.

SOUZA T, S; CASTANHEIRA G, A. Sífilis: Uma Doença Sistêmica Com Manifestações Orais. Cadernos De Odontologia Do Unifeso. v. 2, n.1, 2020, pp.14-23, Teresópolis - ISSN 2674-8223. 2020.

SOUZA, L. A. et al. Ações De Enfermagem Para Prevenção Da Sífilis Congênita: Uma Revisão Bibliográfica. Revista de Iniciação Científica da LIBERTAS, v. 8, n. 1, p. 108-120, 2018. 


\title{
CAPITULO X
}

\section{REFLEXÃO SOBRE A TEORIA DAS RELACÕES INIERPESSOAIS DE HILEGARD PEPLAU E A TEORIA DA ABORDAGEM CENTRADA NA PESSOA DE CARL ROGERS: IMPUCACGÕES PARA A ENFERMAGEM}

\section{DOI: 10.51859/amplla.csa528.2121-10}

\author{
Daniel Reis Correia ${ }^{1}$ \\ Laís Sousa da Silva ${ }^{2}$ \\ Renata Oliveira Caetano ${ }^{3}$ \\ ${ }^{1}$ Graduando do curso de Enfermagem. Universidade Federal de Viçosa - UFV \\ ${ }^{2}$ Graduanda do curso de Enfermagem. Universidade Federal de Viçosa - UFV \\ ${ }^{3}$ Graduanda do curso de Enfermagem. Universidade Federal de Viçosa - UFV
}

\section{RESUMO}

A base estrutural da ciência da enfermagem corresponde às teorias elaboradas com enfoque nas necessidades dos indivíduos e atreladas ao processo de enfermagem, a partir da sistematização da assistência. Assim, o presente estudo compreende uma reflexão acerca das teorias de Hildegard Peplau e de Carl Rogers, abordando suas convergências, divergências e implicações para o processo de cuidado desenvolvido pela enfermagem. Ambos os teóricos propõem a construção de uma relação interpessoal usuário-profissional que vise à promoção de um cuidado holístico, integral e humanizado, com base em uma interação de respeito e confiança em busca de soluções ao estado de saúde-doença do indivíduo assistido. Além disso, para o estabelecimento desse processo, determina-se a comunicação como elemento indispensável para a efetivação e qualificação do cuidado prestado pelo profissional. Por fim, entende-se que o contato interpessoal favorece tanto o usuário, ao atender suas necessidades, quanto o profissional, o qual agrega experiências a sua prática assistencial.

Palavras-chave: Humanização da Assistência. Processo de Enfermagem. Psicoterapia Centrada na Pessoa. Relações Interpessoais.

\section{INTRODUÇÃO}

As teorias de enfermagem consistem em um conjunto de elos caracterizados como instrumentos do cuidado dentro da prática profissional do enfermeiro, o qual as utilizam para fundamentar suas condutas terapêuticas. As teorias, em consonância com o processo de enfermagem (PE), podem ser identificadas como uma estrutura capaz de articular, investigar, gerenciar e intervir na relação enfermeiro-paciente, contribuindo para o estabelecimento de uma reflexão acerca das ações da enfermagem na situação 
de saúde-doença do indivíduo, a partir da formulação de suas crenças, valores, culturas e hábitos de vida (CARRILHO; ALMEIDA; MARTINS, 2016).

A implementação desses fundamentos corrobora para uma relação interpessoal entre os profissionais e entre o profissional e o indivíduo, configurando um processo comunicativo capaz de beneficiar a integralidade do cuidado ao usuário (SOUZA; COSTA; VILELA, 2020). Esse cenário é muito evidenciado na Atenção Primária à Saúde (APS), a qual busca, por meio do fortalecimento do vínculo entre os envolvidos, a promoção e a proteção à saúde, a prevenção de agravos, o tratamento e a reabilitação do doente (MARTINS et al, 2012; BORGES et al, 2019).

Nesse contexto, a Teoria das Relações Interpessoais de Hildegard Elizabeth Peplau propõe uma interlocução do cuidado, por meio do fortalecimento da relação enfermeiro-paciente, com base nos conceitos do PE. Neste âmbito, destaca-se a estratégia de comunicação voltada para as relações biologicistas, sociais e emocionais do indivíduo, através de uma escuta terapêutica (CARRILHO; ALMEIDA; MARTINS, 2016; SOUZA; COSTA; VILELA, 2020). Assim, compreende-se que o intuito da teoria é de que o cuidado seja desenvolvido em consequência do processo interpessoal centralizado no usuário e na enfermagem (GURGEL; TOURINHO; MONTEIRO, 2014).

Seu embasamento abrange princípios que visam sustentar a interação com o indivíduo, por meio da prestação de um cuidado capaz de promover o aprendizado e o crescimento pessoal dos envolvidos, contribuindo para a melhoria da assistência (GURGEL; TOURINHO; MONTEIRO, 2014; SANTOS et al, 2014). A teoria apresenta quatro etapas, sendo elas, orientação, identificação, exploração e solução, as quais, como supracitado, podem ser relacionadas com as etapas do PE. Dessa forma, entende-se que a mesma apresenta elementos que identificam conceitos e princípios apoiadores de tais relações na prática da enfermagem, de modo que o cuidado possa ser estabelecido por meio da aprendizagem e crescimento pessoal do profissional e do paciente (GURGEL; TOURINHO; MONTEIRO, 2014).

Nessa mesma perspectiva, o psicólogo humanista Carl Ransom Rogers desenvolveu a Teoria da Abordagem Centrada na Pessoa (ACP), a qual se fundamenta na oferta de uma escuta sensível, postulando uma relação de cooperação entre o terapeuta e o usuário. Assim, enaltece-se a natureza humana e social do diálogo para a construção de uma interação recíproca entre o terapeuta e o indivíduo, a fim de 
encontrar, entender e enfrentar as dificuldades subjetivas da pessoa assistida (BORGES et al, 2019).

A ACP propõe, por meio da interpessoalidade, o crescimento psicológico do indivíduo independente do contexto em que se encontra (CALSAVARA; SCORSOLINICOMIN; CORSI, 2018). Nesse método, Rogers identifica a confiança como instrumento indispensável à potencialidade das pessoas em responder melhor às situações em que estão inseridas, entendendo que o próprio indivíduo é quem deve guiar sua reabilitação (ARAÚJO; FREIRE, 2014).

Diante do exposto, nota-se a relação análoga entre as teorias apresentadas, por meio das quais se observa a importância do vínculo na escuta terapêutica e no processo comunicativo na interação profissional-paciente, em busca de tornar o indivíduo protagonista do cuidado proposto. Neste ínterim, constata-se que o profissional deve propiciar um ambiente de aprendizagem onde o usuário seja provedor de uma atenção especial ao seu próprio ser, advinda de experiências únicas carregadas de sentimentos, percepções e valores acerca de sua saúde física e mental (ARAÚJO; FREIRE, 2014; CARRILHO; ALMEIDA; MARTINS, 2016).

Mediante o prelúdio feito sobre as duas teorias abordadas infere-se que, em prol dos interesses do usuário, existem ações nas quais o enfermeiro deve assumir o auxílio ao indivíduo, como educador e participante do processo de cura, em busca de uma relação de cooperação e participação ativa. Assim, o presente estudo objetiva obter uma reflexão acerca da relação entre as teorias de Peplau e Rogers ao apresentar suas implicações para a prática do profissional enfermeiro, visando garantir o holismo e a humanização no meio assistencial.

\section{REVISÃO BIBLIOGRÁFICA}

\subsection{TEORIA DAS RELAÇÕES INTERPESSOAIS DE HILDEGARD PEPLAU}

Hildegard Elizabeth Peplau, tida como a mãe da enfermagem psiquiátrica, nasceu em 1 을 de setembro de 1909, em Reading, na Pensilvânia, e teve o início de sua carreira em 1931, com estudos em um programa de enfermagem em Pottstown, Pensilvânia. Em 1943, Peplau se graduou em Psicologia Interpessoal e já entre os anos de 1947 e 1953 ela obteve seus títulos de Mestre e Doutora, pela Universidade da 
Columbia (D'ANTONIO et al, 2014). No ano de 1952 publicou o seu livro "Interpersonal Relations in Nursing: a conceptual frame of reference for psychodynamic nursing", o qual propõe um novo paradigma para a assistência em enfermagem psiquiátrica, com foco nas relações interpessoais enfermeiro-indivíduo-comunidade (CARRILHO; ALMEIDA; MARTINS, 2016; CARLON et al, 2019).

Com base em seu livro, Peplau desenvolveu a Teoria das Relações Interpessoais (TRI), a qual enfatiza a busca por uma relação terapêutica positiva entre enfermeiros e pacientes durante a experiência do cuidado (FRANZOI et al, 2016). Assim, compreendese a Enfermagem como um processo interpessoal, terapêutico, significativo e educativo capaz de estabelecer, por meio da comunicação, a construção/evolução de uma dinâmica interativa com o seu usuário, valorizando a participação do mesmo na sua situação de saúde e demandando autoconhecimento do profissional (CARLON et al, 2019).

Nessa perspectiva, Peplau identifica quatro fases distintas no relacionamento interpessoal: orientação, identificação, exploração e solução. Todas essas fases são carregadas de percepções particulares do indivíduo e do enfermeiro, sendo que o processo comunicativo é indispensável a cada uma das etapas. Além disso, salienta-se que essas fases podem estar condicionadas às etapas do Processo de Enfermagem, isto é, coleta de dados, diagnóstico de enfermagem, planejamento, implementação e avaliação, as quais auxiliam nas tomadas de decisões durante a assistência de enfermagem (GURGEL; TOURINHO; MONTEIRO, 2014; SANTOS et al, 2014).

A fase de orientação representa o momento em que o indivíduo e/ou família identifica a necessidade da ajuda de um profissional, o qual atua horizontalmente com o cliente para que este tenha confiança para expressar suas dificuldades individuais (GURGEL; TOURINHO; MONTEIRO, 2014). Esta etapa permite o estabelecimento do vínculo entre os envolvidos no processo de cuidado, o que contribui para a minimização da ansiedade dessas pessoas e para o fortalecimento da segurança da assistência (GURGEL; TOURINHO; MONTEIRO, 2014; SANTOS et al, 2014).

Em seguida, na identificação, o profissional de enfermagem e o indivíduo expõem suas percepções e expectativas referentes à situação encontrada, o que favorece uma seleção adequada da assistência (GURGEL; TOURINHO; MONTEIRO, 2014). Nesta fase, por meio do estímulo a participação ativa do indivíduo, o enfermeiro 
e o usuário definem a necessidade da atuação de outros profissionais, para a integralidade da assistência prestada (GURGEL; TOURINHO; MONTEIRO, 2014; SANTOS et al, 2014).

Já na fase de exploração, o indivíduo começa a se sentir integrante do ambiente da assistência e passa a aproveitar os recursos e serviços disponibilizados para a satisfação de suas necessidades (GURGEL; TOURINHO; MONTEIRO, 2014; SANTOS et al, 2014). Além disso, nesta etapa, o usuário torna-se protagonista do processo, favorecendo o desenvolvimento do autocuidado e, consequentemente, adquire a capacidade de entender e reconhecer suas necessidades de saúde-doença (GURGEL; TOURINHO; MONTEIRO, 2014).

Por fim, na etapa de solução, as necessidades do usuário são supridas graças ao sucesso da interação enfermeiro-paciente. Logo, compreende-se o fim do relacionamento terapêutico entre os envolvidos no cuidado (GURGEL; TOURINHO; MONTEIRO, 2014). Entretanto, quando isso ocorre, o sujeito evidencia um equilíbrio emocional mais saudável e apresenta êxito em seu processo saúde-doença (SANTOS et al, 2014).

Diante do exposto, compreende-se que o conceito da teoria dispõe de princípios norteadores das relações interpessoais que se desenvolvem na prática de enfermagem. Dessa forma, as situações podem ser transformadas em experiências de aprendizagem, onde o foco do cuidado deverá estar no enfermeiro, no indivíduo e nos seus respectivos contextos de vida (CARRILHO; ALMEIDA; MARTINS, 2016).

\subsection{TEORIA DA ABORDAGEM CENTRADA NA PESSOA DE CARL ROGERS}

Carl Ramson Rogers, nascido em 1902, na cidade de Oak Park, Illinois, foi um dos psicoterapeutas norte-americanos mais influentes e um dos psicólogos mais avançados de sua área, obtendo destaque no desenvolvimento da psicologia humanista. Além disso, Rogers produziu significantes contribuições para a educação, por meio da valorização das relações humanas para o desenvolvimento contínuo do aluno (ARAÚJO; FREIRE, 2014). Após anos de estudos, Rogers fez cursos de especialização em psicologia no Teachers College of Columbia University e, posteriormente, realizou seu doutorado em Psicologia Clínica. 
Com base em sua formação, em 1974, Rogers desenvolveu a Teoria da Abordagem Centrada na Pessoa (ACP), a qual compreende o estabelecimento de relações interpessoais existentes na interação terapeuta-usuário. O teórico identifica uma visão positiva do ser humano, na qual este possui liberdade e autonomia de decisão, sendo agente ativo e transformador de sua realidade. Nesse sentido, sua teoria abrange o crescimento pessoal e psicológico do indivíduo, independente do ambiente em que este se insere (CALSAVARA; SCORSOLINI-COMIN; CORSI, 2018).

A partir dessa interação, o sujeito aprende a lidar consigo mesmo, físico e emocionalmente, contribuindo para um melhor desenvolvimento individual. Para isso, o entendimento principal da ACP é de que o indivíduo tem dentro de si diversos fatores agregantes a autocompreensão, ao autoconceito e às tomadas de decisões, no que tange as suas atitudes e comportamentos. Além disso, no decorrer das etapas da teoria, a relação terapeuta-usuário contribui para que esses fatores sejam expressos por meio de atitudes facilitadoras (CALSAVARA; SCORSOLINI-COMIN; CORSI, 2018).

Nesse sentido, na visão de Rogers, o psicólogo deve fomentar o desenvolvimento do cliente, oferecendo uma atmosfera de segurança, e é nesse contexto que o teórico propõe três atitudes facilitadoras: autenticidade/congruência, consideração positiva incondicional e postura empática (CALSAVARA; SCORSOLINI-COMIN; CORSI, 2018; ARAÚJO; FREIRE, 2014). Estas atitudes servem para promover um ambiente promissor ao constante incentivo à pessoa, tratando-se de um caminho no qual o terapeuta vai se tornando cada vez mais importante ao longo do processo. Assim, é possível estabelecer etapas no trabalho de Roger, nas quais o profissional se esforça para não intervir com os seus sentimentos no processo saúde-doença-cuidado do usuário, até o ponto em que o papel do psicoterapeuta passa a ser norteado pela noção de centralidade no cliente, a partir da qual o psicólogo começa a refletir acerca dos sentimentos do indivíduo (ARAÚJO; FREIRE, 2014).

Em termos da caracterização das atitudes facilitadoras, compreende-se que a autenticidade, também conhecida como congruência, envolve a necessidade de o indivíduo estar em harmonia consigo mesmo, aberto aos próprios sentimentos, podendo escutá-los, elaborá-los e expressá-los. Ser autêntico abrange o estabelecimento de uma correspondência entre o que o terapeuta observa e o que ele comunica ao usuário, sendo ele mesmo capaz de escutar o outro. Desse modo, para que 
a relação entre os envolvidos seja sadia e eficaz, o profissional precisa estar o mais próximo possível do indivíduo, favorecendo a integralidade do serviço (CALSAVARA; SCORSOLINI-COMIN; CORSI, 2018).

A consideração positiva incondicional pode ser entendida como o respeito à individualidade de cada usuário, acreditando que a pessoa em busca de ajuda tem condições de amadurecer e resolver seus conflitos, a partir da potencialização de suas capacidades, por meio da aceitação do indivíduo sem julgamentos ou questionamentos sobre o modo de vida do mesmo (CALSAVARA; SCORSOLINI-COMIN; CORSI, 2018).

E, por último, a postura empática é caracterizada pela atitude de experimentar o que o outro está sentindo através da condição de se colocar na perspectiva do usuário. Nesta atitude, o profissional busca perceber e compreender a identidade emocional do indivíduo, assimilando sua forma de ser e experienciar o mundo de acordo com as suas práticas de cuidado (CALSAVARA; SCORSOLINI-COMIN; CORSI, 2018).

Segundo Rogers, à medida que o indivíduo experimenta esta atmosfera terapêutica de acolhimento e compreensão, caracterizada também pela ausência de julgamentos e ameaças, os mecanismos de defesas perdem sua função de conservação do quadro de autoimagem ideal (SOUZA-FILHO; PAIVA, 2019; ARAÚJO; FREIRE, 2014). Assim, o terapeuta teria o papel de conversar, acolher, estar mais próximo e, tal como os acompanhantes/familiares, suprir as necessidades emocionais do usuário (BARONIO; PECORA, 2015).

Ademais, Rogers enfatiza que a própria atitude e postura do profissional são fatores essenciais para a prestação de uma assistência eficaz e resolutiva ao sujeito, tendo o terapeuta papel determinante na condução de sua prática. Portanto, a articulação profissional-paciente se mostra indispensável para o favorecimento das condições do indivíduo, uma vez que esta corrobora para uma mudança positiva nos comportamentos e decisões tomadas pelo usuário informado (PUPO; AYRES, 2013).

\subsection{RELAÇÃo ENTRE A TEORIA DE PEPLAU E A TEORIA DE ROGERS}

A teoria das Relações Interpessoais e a teoria da Abordagem Centrada na Pessoa objetivam a interação paciente-profissional, de modo a favorecer um ambiente propício a um constante desenvolvimento na relação entre ambos, e que garanta o respeito ao ser humano. Nessa perspectiva, Rogers propõe um ambiente facilitador, em que o 
terapeuta deve assumir atitudes humanistas frente às situações expostas por seus clientes, por meio da comunicação, sem concepções prévias ou julgamentos de valores, que será fundamental na abordagem do indivíduo, favorecendo o amadurecimento e a segurança na relação interpessoal, sugerida por Peplau (ARAÚJO; VIEIRA, 2013; SANTOS et al, 2014).

Dito isto, ambas as teorias apresentam como foco as relações interpessoais em busca de um cuidado humanizado, ressaltando a escuta como uma importante ferramenta para a obtenção do vínculo e, assim, atendendo não apenas as necessidades físicas, mas também as subjetivas. Nesse sentido, Peplau expressa uma visão holística acerca da abordagem iniciada a partir do reconhecimento da individualidade do usuário, de modo a torná-lo coparticipante do tratamento idealizado pelo seu próprio desejo de melhora (CARRILHO; ALMEIDA; MARTINS, 2016).

Assim, é necessário que os envolvidos no cuidado estejam em contato emocional, isto é, um indivíduo que se vê com uma necessidade e um profissional que irá se comunicar a fim de construir um elo, com o intuito de ajudar o sujeito a solucionar o seu caso, conquistando confiança e lhe provendo assistência e informações do aspecto afetivo das situações identificadas (LUPO; AYRES, 2013).

Dessa forma, no decorrer da aplicação das teorias, constata-se o amadurecimento pessoal tanto do paciente quanto do profissional responsável pela assistência, os quais interagem a fim de identificar as situações problema. Para que isto aconteça efetivamente é necessário que o enfermeiro/terapeuta desenvolva um ambiente acolhedor e seguro, permitindo ao indivíduo se expressar com confiança, sem medo de ser julgado, para juntos buscarem soluções (SOUZA-FILHO; PAIVA, 2019; ARAÚJO; VIEIRA, 2013).

Portanto, evidencia-se a importância de o profissional conseguir construir vínculo com o indivíduo e, consequentemente, focar em suas necessidades, por meio de uma escuta acolhedora e de uma comunicação efetiva. Dessa forma, é possível notar as carências do indivíduo através de aspectos verbais e não verbais, os quais facilitam o reconhecimento do enfermeiro para a prestação do cuidado integral (SANTOS et al, 2014; BORGES et al, 2019).

Nessa acepção, Peplau define o homem como um organismo que vive num desequilíbrio estruturado por conteúdos biológicos, espirituais, sociais e psicológicos 
que necessita de cuidado comprometido com a potencialização da vida (CARRILHO; ALMEIDA; MARTINS, 2016). Já na ACP, o organismo é observado como um elemento constituído por um conjunto de vivências e afetos que atuam sobre um esquema defensivo frente à emergência de sentimentos de ameaça, em busca da autopreservação do mesmo, e procura na figura do profissional a tutela para lidar com seu funcionamento incongruente e adoecido (SOUZA-FILHO; PAIVA, 2019). Tal interação, quando devidamente estabelecida, é fundamental para o desenvolvimento de uma prática assistencial efetiva e qualificada, permitindo a discussão entre paciente e profissional, como elemento inerente ao acompanhamento de saúde do indivíduo (BORGES et al, 2019).

\subsection{APLICABILIDADE DAS TEORIAS NO PROCESSO DE ENFERMAGEM}

Em suas teorias, Hidelgard e Carl convergem seus conceitos quanto à caracterização dos profissionais provedores do cuidado. Na concepção dos teóricos, a enfermagem é compreendida como um processo interpessoal, significativo e terapêutico, em que a essência é a interação profissional-paciente. Nesse sentido, para a efetivação deste contato, é de suma importância que o enfermeiro tenha autonomia para aplicar seus conhecimentos, a fim de solucionar os problemas clínicos identificados na saúde dos indivíduos (ARAÚJO; VIEIRA, 2013; CARRILHO; ALMEIDA; MARTINS, 2016).

Dessa forma, Peplau estabelece quatro etapas para a aplicação de sua teoria: orientação, identificação, exploração e solução. Sendo que cada uma destas pode ser relacionada às etapas do processo de enfermagem: coleta de dados, diagnóstico de enfermagem (identificação dos problemas), planejamento do cuidado, implementação das intervenções e avaliação do processo proposto (CARRILHO; ALMEIDA; MARTINS, 2016). Já Rogers, fundamenta o trabalho do profissional de saúde na qualidade técnica e na interação pessoal, fomentando a humanização da assistência (ARAÚJO; VIEIRA, 2013).

Durante $\mathrm{o}$ atendimento, Rogers destaca a centralidade na pessoa, a construção da relação profissional-paciente e o estabelecimento de metas de caráter adaptativo e objetificante (ARAÚJO; VIEIRA, 2013). Nesse ínterim, ao refletir sobre o conceito de enfermagem que norteia a Teoria de Peplau, entende-se que o enfermeiro deve ser capaz de assumir diversas funções durante o tratamento, sendo flexível para 
abordar o indivíduo, à medida que surgem necessidades, durante o processo, para alcançar as soluções desejadas (CARRILHO; ALMEIDA; MARTINS, 2016).

Por conseguinte, o enfoque da relação recai sobre a definição do problema, a partir das estratégias em que o enfermeiro irá explorar a problemática que levou o usuário a buscar os serviços do profissional. Nesse decurso, o relacionamento interpessoal deve se formar de modo contínuo e sistemático através da comunicação, instrumento essencial para facilitar ou dificultar o cuidado, compreendendo um importante fator para a etapa de introdução do $P E$, a investigação. Nesta, a assistência se permeia no holismo, o qual é indispensável para direcionar informações, valores e emoções no desenvolvimento da confiança e do vínculo entre usuário e equipe de saúde (SANTOS et al, 2014).

De acordo com a ACP, a comunicação dispõe de características que serão fundamentais para o reconhecimento do usuário sobre a sua individualidade e integralidade, tornando-o ativo na identificação e priorização dos seus problemas (MOREIRA, 2010). Dessa forma, para determinar um processo comunicativo eficiente entre duas ou mais pessoas, é necessário ao profissional o uso de habilidades e conhecimentos para aprimorar a sua percepção das reais necessidades de um indivíduo. Por conseguinte, semelhante a Rogers, Peplau descreve a comunicação como ferramenta essencial numa relação interpessoal e que, dentro do PE, corresponde ao compartilhamento de sentimentos, valores e significados advindos de aspectos verbais e não verbais da mesma. Assim, o profissional enfermeiro deverá considerar as diversas formas de expressão e manifestação corporal, estando preparado para utilizar de uma abordagem com linguagem acessível, elemento fundamental para o estabelecimento de uma assistência adequada (SANTOS et al, 2014).

Outra característica aplicável ao $\mathrm{PE}$, é o processo de valorização do organismo como centro da experiência na relação com o profissional. Rogers define o funcionamento do organismo como um locus de pensamentos, emoções, sensações e percepções em interação e transformação com o mundo (ARAÚJO; FREIRE, 2014). Alicerçados neste conceito, os teóricos apresentam uma relação autêntica no contato pessoa-pessoa, regulada por um olhar ampliado sobre o paciente que vá além do seu contexto de doença. Desse modo, incorpora-se o indivíduo de forma atenciosa, integral e ativa à terapia designada, intensificando o interesse do mesmo em oferecer respostas 
às ações do enfermeiro, dentro do planejamento, implementação e avaliação do PE, marcando o aprofundamento dessa interação (BORGES et al, 2019; FRANZOI et al, 2016).

Semelhante elemento do cuidado é observado na postura assumida pelo enfermeiro durante e após o atendimento, no qual atribui o respeito às particularidades de cada um, ao não se fixar em conceitos pré-admitidos, mas permitindo o planejamento de cuidados que tenderão a satisfação de todos os envolvidos (BORGES et al, 2019). Rogers destaca que a ACP deve visar à construção de uma prática eficaz e resolutiva, para então o profissional se concentrar em oferecer condições favoráveis para identificar e priorizar os problemas advindos do indivíduo (LUPO; AYRES, 2013). Logo, através da coleta de informações, a condução da assistência se permeia na análise e compreensão da realidade do sujeito sobre a sua situação de saúde, e, a partir daí, é feita uma mobilização em conjunto para estabelecer metas e objetivos que terão sentido na escolha das técnicas utilizadas (BORGES et al, 2019).

Por fim, esclarecendo as aplicabilidades das teorias no PE, fica claro que ambas se orientam pela disposição de estratégias que colocam o indivíduo no centro da atenção e que o incluam no processo de tomada de decisões sobre a própria saúde, estimulando a sua participação consciente (BORGES et al, 2019). Além do mais, as relações advindas entre o provedor e o portador de necessidades fomentam o escopo dos teóricos, um profissional que precisa reconhecer e oferecer uma assistência integral a partir do referencial do usuário (SANTOS et al, 2014).

\section{CONSIDERAÇÕES FINAIS}

A partir da análise das teorias, tanto de Peplau quanto de Rogers, evidencia-se que os autores se preocupavam com o comprometimento ético dos envolvidos no cuidado, a fim de estabelecer um planejamento efetivo que favoreça uma comunicação constante do provedor com o indivíduo necessitado de assistência. Isto garante a manutenção de um equilíbrio entre os participantes e contribui para o fortalecimento da prática de cuidado estabelecida. Nessa relação, o profissional norteia sua atuação no respeito às particularidades do usuário, o qual interage expondo suas experiências e permitindo uma transação enriquecedora para suprimir suas necessidades. 
Logo, visando garantir o holismo e a humanização na assistência, constata-se no presente estudo que a atuação prática do profissional enfermeiro deve estar embasada na integralidade do cuidado, corroborando para a ampliação da abordagem à saúde do usuário. Observa-se ainda a importância de uma relação interpessoal profissionalpaciente eficiente, para que o sujeito seja acolhido de forma biopsicossocioespiritual, buscando atender não apenas a esfera da saúde física do indivíduo, mas também, e principalmente, a sua saúde mental.

Nesse sentido, percebe-se que as habilidades do enfermeiro, como a escuta, o acolhimento, o diálogo e o estabelecimento de vínculo, são estabelecidas a partir da própria personalidade do profissional, o qual a utiliza inconscientemente para a construção de uma relação terapêutica de confiança com o usuário. Dessa forma, ao promover uma atenção humanizada e acolhedora ao indivíduo, o profissional precisa compreender suas necessidades e, assim, diluir as barreiras que podem dificultar o estabelecimento de uma relação autêntica no cuidado.

Por fim, compreende-se a relevância de uma interação contínua para um cuidado integral ao indivíduo, com ênfase na expressão das carências particulares do sujeito para, então, buscar soluções aos problemas identificados. Portanto, é de suma importância evitar que surjam brechas na relação profissional-paciente que prejudiquem a comunicação entre ambos e provoquem o desequilíbrio na assistência.

\section{REFERÊNCIAS}

ARAÚJO, E.S.C; VIEIRA, V.M.O. Práticas docentes na saúde: contribuições para uma reflexão a partir de Carl Rogers. Revista Semestral da Associação Brasileira de Psicologia Escolar e Educacional, São Paulo, v. 17, n. 1, p. 97-104, jan./jun. 2013.

ARAÚJO, I.C; FREIRE, J.C. Os valores e a sua importância para a teoria da clínica da abordagem centrada na pessoa. Phenomenological Studies - Revista da Abordagem Gestáltica, Goiânia, v. 10, n. 1, p. 93-103, jan./jun. 2014.

BARONIO, M; PECORA, A.R. A relação de cuidado na perspectiva de médicos e pacientes durante a internação em hospital-escola. Revista de Psicologia, São Paulo, v. 24, n. 2, p. 199-228, 2015.

BORGES, J.W.P. et al. Compreensão da relação interpessoal enfermeiro-paciente em uma unidade de atenção primária fundamentada em Imogene King. Revista de Enfermagem do Centro-Oeste Mineiro, São João Del-Rei, v. 9, n. 3011, p. 1-9, 30 
jul. 2019. Disponível em: http://dx.doi.org/10.19175/recom.v9i0.3011. Acesso em: 20 out. 2020.

CALSAVARA, V.J; SCORSOLINI-COMIN, F; CORSI, C.A.C. A comunicação de más notícias em saúde: aproximações com a abordagem centrada na pessoa. Phenomenological Studies - Revista da Abordagem Gestáltica, Goiânia, v. 15, n. 1, p. 92-102, fev./mar. 2018.

CARLON W.P. et al. Teoria das relações interpessoais: reflexões acerca da função terapêutica do enfermeiro em saúde mental. Enfermagem em Foco, [S.L.], v. 10, n. 3, p. 64-69, 2019. Disponível em: http://dx.doi.org/10.21675/2357707X.2019.v10.n3.229. Acesso em: 20 out. 2020.

CARRILHO, C.A.; ALMEIDA, A.N.S.; MARTINS, I.C. Uma reflexão sobre a teoria de Peplau e a teoria psicanalítica: caminho de interseções. Revista Expressão Católica Saúde, [S.L.], v. 1, n. 1, p. 169-176, jun. 2016. Disponível em: http://dx.doi.org/10.25191/recs.v1i1.1392. Acesso em: 20 out. 2020.

D'ANTONIO, P. et al. The future in the past: hildegard peplau and interpersonal relations in nursing. Nursing Inquiry, New Jersey, v. 21, n. 4, p. 311-317, 28 jan. 2014. Disponível em: http://dx.doi.org/10.1111/nin.12056. Acesso em: 20 out. 2020.

FRANZOI, M.A.H. et al. Teoria das relações interpessoais de Peplau: uma avaliação baseada nos critérios de fawcett. Revista de enfermagem UFPE online, Recife, v. 10, n. 4, p. 3653-3661, set. 2016. Disponível em: http://dx.doi.org/10.5205/reuol.9681-89824-1-ED.1004sup201617. Acesso em: 20 out. 2020.

GURGEL, P.K.F.; TOURINHO, F.S.V; MONTEIRO, A.I. Consulta coletiva de crescimento e desenvolvimento da criança à luz da teoria de Peplau. Escola Anna Nery - Revista de Enfermagem, Rio de Janeiro, v. 18, n. 3, p. 539-543, 2014. Disponível em: http://dx.doi.org/10.5935/1414-8145.20140077. Acesso em: 20 out. 2020.

MARTINS, A.R. et. al. Relações interpessoais, equipe de trabalho e seus reflexos na atenção básica. Revista Brasileira de Educação Médica, Brasília, v. 36. n 1 Supl. 2, p. 6-12, 2012.

MOREIRA, V. Revisitando as fases da abordagem centrada na pessoa. Estudos de Psicologia, Campinas, v. 27, n. 4, p. 537-544, out./dez. 2010.

PUPO, L. R.; AYRES, J. R. C. M. Contribuições e limites do uso da abordagem centrada na pessoa para a fundamentação teórica do aconselhamento em DST/Aids. Temas em Psicologia, Ribeirão Preto, v. 21, n. 3, p. 1089-1106, abr. 2013. Disponível em: http://dx.doi.org/10.9788/tp2013.3-ee16pt. Acesso em: 20 out. 2020.

SANTOS L.N.M. et al. Relações interpessoais na estratégia saúde da família: reflexo na qualidade dos cuidados de enfermagem. Revista de enfermagem UFPE online, Recife, v. 8 n. 1, p. 155-159, jan. 2014. Disponível em: 
http://dx.doi.org/10.5205/reuol.4843-39594-1-SM.0801201421. Acesso em: 20 out. 2020.

SOUZA-FILHO, J.A; PAIVA, V.M.B. Actitudes de la transferencia en Psicoterapia centrada en la persona: un estudio de caso. Revista Brasileira de Psicoterapia, Porto Alegre, v. 21, n. 1, p. 99-109, jun. 2019. Disponível em: http://dx.doi.org/10.5935/2318-0404.20190012. Acesso em: 20 out. 2020.

SOUZA, J.S.R.; COSTA, A.C.B.; VILELA, S.C. Relações interpessoais entre enfermeiropaciente na perspectiva da violência atual. Revista Online de Pesquisa: Cuidado é Fundamental, Rio de Janeiro, v. 12, p. 648-653, jan./dez. 2020. Disponível em: http://dx.doi.org/10.9789/2175-5361.rpcfo.v12.9103. Acesso em: 20 out. 2020. 


\title{
CAPÍTULO XI
}

\section{DIAGNÓSTICO DE ENFERMAGEM SOFRIMENTO ESPIRTIUL PADRONIZAGÃO E IMPLEMENTACÃO NA PRÁTICA CÚNICA: REVISÃO INTEGRATIVA}

\author{
DOI: 10.51859/amplla.csa528.2121-11
}

\author{
João Vitor Andrade ${ }^{1}$ \\ Ana Luiza Rodrigues Lins ${ }^{2}$ \\ Juliana Cristina Martins de Souza ${ }^{3}$ \\ Eduardo Frias Corrêa Oliveira ${ }^{4}$ \\ Karen Helen Martins Canazart ${ }^{4}$ \\ Wesley Abijaude ${ }^{4}$
}

\begin{abstract}
${ }^{1}$ Enfermeiro. Especializando em Enfermagem em Saúde Mental e Psiquiátrica na Faculdade de Medicina da Universidade de São Paulo - SP, Brasil.

${ }^{2}$ Enfermeira. Especializanda em Oncologia pelo Instituto Nacional de Câncer José Alencar Gomes da Silva graduada pela Universidade Federal de Goiás, Goiás, Brasil, Rio de Janeiro - RJ, Brasil.

${ }^{3}$ Especialista em Enfermagem em Saúde Mental e Psiquiátrica. Universidade de São Paulo - SP, Brasil.

${ }^{4}$ Discente de Enfermagem. Universidade Federal de Viçosa. Viçosa - MG, Brasil.
\end{abstract}

\section{RESUMO}

Objetivo: avaliar a padronização e a implementação do diagnostico sofrimento espiritual na pratica clínica. Método: trata-se de uma revisão integrativa de literatura, sendo a busca realizada nos meses de janeiro e fevereiro de 2021. Os descritores utilizados foram: "Diagnóstico de Enfermagem"; "Espiritualidade”; “Angústia Espiritual”. Resultados: a amostra final, se compôs de oito artigos. Evidenciou-se duas categorias de análise: padronização do diagnóstico e implementação do diagnóstico na prática clínica. Percebeu-se que existe uma dificuldade na padronização do diagnostico sofrimento espiritual para sua implementação na pratica clínica, sobretudo em decorrência de sua subjetividade e despreparo dos profissionais. Conclusão: abordar a dimensão psicoespiritual, principalmente em relação ao sofrimento espiritual é um processo complexo, sendo essencial a formulação de novos estudos na temática, bem como maior disseminação da temática, visando instrumentalização dos futuros profissionais da saúde para abordagem da dimensão psicoespiritual na prática clínica.

Palavras-chave: Enfermagem. Espiritualidade. Angústia Espiritual. Sistematização da Assistência de Enfermagem. 


\section{INTRODUÇÃO}

A partir da reformulação do conceito de saúde pela OMS (1998), tem-se a instituição de um novo desafio, pois com o acréscimo da dimensão espiritual, referindose às questões de significado e sentido da vida conectado ao "estado dinâmico de completo bem-estar físico, mental, espiritual e social e não apenas a ausência de doença ou enfermidade", os profissionais de saúde devem então estar aptos a fornecer um cuidado holístico, agregando todas as dimensões humanas (POWER, 2006). Sobretudo pelo fato do holismo definir que a pessoa é mais do que a soma das partes e isso inclui todas as dimensões, inclusive a espiritual, que é essencial ao ser humano, não sendo possível que esse subsista sem ela (OLIVER; GUTIÉRREZ; SÁNCHEZ, 2014). Destaca-se que a dimensão espiritual não está separada da física, emocional, social ou cognitiva e, nessa premissa, está baseado o fato de que essas dimensões são interconectadas e influenciam as outras (DELGADO, 2005; ANDRADE et al., 2020).

É bem reconhecido que os pacientes com doenças e agravos não transmissíveis frequentemente expressam necessidades espirituais, e espera-se que os enfermeiros os avaliem e forneçam intervenções adequadas e eficazes para promover o bem-estar espiritual (LEEUWEN; SCHEP-AKKERMAN; LAARHOVEN, 2013). No entanto a espiritualidade dos pacientes é uma dimensão negligenciada e segundo Balboni e colaboradores (2014), muitas vezes associa-se a esse fato a ocorrência de diversas barreiras, tais como: a subjetividade da dimensão espiritual e do conceito de espiritualidade, a falta de preparação educacional, a perspectiva reducionista da espiritualidade em religiosidade ou morte, a falta de tempo para prestar cuidados espirituais, e alguns preconceitos sobre a espiritualidade sendo integrados como um tópico científico.

Para Caldeira, Branco e Vieira (2011), a espiritualidade é reconhecida pela enfermagem quando emerge como necessidade do usuário, sobretudo por ser um fator intrínseco ao ser humano, vinculada ou não a uma religião convencional, podendo ser vivenciada em múltiplas vertentes e não só a religiosa. A pesquisa sobre espiritualidade em saúde e em enfermagem é uma área emergente, que tem se desenvolvido sobretudo nas ultimas décadas, com significativa expressão internacional no tocante as publicações científicas (COCKELL; MCSHERRY, 2012). 
A relevância da espiritualidade nos processos de saúde-doença é reconhecida pelas associações nacionais e internacionais de enfermagem e demonstrada por evidências científicas (SILVA; VITORINO, 2020). O Conselho Internacional de Enfermeiros compreende a espiritualidade como uma prática da enfermagem que promove prestação de apoio e respeito pelo paciente, família e suas crenças espirituais (CALDEIRA et al., 2016). A exemplo disso a North American Nursing Diagnosis Association (NANDA), identificou e instrumentalizou, diagnósticos de enfermagem referentes a espiritualidade e religiosidade, sendo um destes definido como: "estado de sofrimento relacionado à capacidade prejudicada de experimentar significado na vida por meio de uma conexão consigo mesmo, com os outros, com o mundo ou com um ser maior" (HERDMAN; KAMITSURU, 2018). Este, integrado à taxonomia da NANDA desde 1978, foi revisado em 2002 e em 2013, sendo classificado no "domínio 10 - princípios da vida na taxonomia II". Sendo a validação clínica do diagnóstico de enfermagem essencial para avaliar as perspectivas dos pacientes e melhorar as evidências clínicas (CALDEIRA et al., 2012), sabendo que suas características são válidas quando realmente ocorrem e são identificadas em situações clínicas do cotidiano (CALDEIRA; CARVALHO; VIEIRA, 2014b).

Ante ao supra referido, compreende-se a responsabilidade que a enfermagem possui em relação à espiritualidade no cotidiano do cuidar, assim, o objetivo do presente estudo é analisar a produção cientifica relacionada a padronização e implementação do diagnóstico de enfermagem sofrimento espiritual na pratica clínica.

\section{MÉTODO}

Trata-se de um estudo de revisão da literatura, do tipo integrativa, caracterizando-se em uma ampla análise da literatura. Segundo Broome (2000) a revisão integrativa da literatura é essencial para desenvolver uma base de conhecimento substancial sobre o conceito. Além disso Whittemore e Knafl (2005), acrescentam que a revisão integrativa é um dos métodos mais amplo de pesquisa em revisão, permitindo a inclusão de variados tipos de pesquisas (desde que sejam estudos primários) e uma abordagem mais ampla em relação ao entendimento do fenômeno.

A presente pesquisa tem como propósito a compreensão da temática estudada, sendo capaz de encontrar lacunas, remodelar o conhecimento e incentivar a pratica 
baseada em evidências (MENDES, SILVEIRA e GALVÃO, 2019). Para alcançar o objetivo proposto, optou-se por seguir o modelo de seis etapas, delimitado por Mendes, Silveira e Galvão (2019), sendo as etapas: 1) estabelecimento do problema da revisão; 2) seleção da amostra; 3) estabelecimento dos critérios de inclusão e exclusão; 4) análise dos dados; 5) interpretação dos resultados e 6) apresentação da revisão.

A questão norteadora deste estudo foi: "Como é a padronização e a implementação do diagnóstico de enfermagem sofrimento espiritual na prática clínica?" A fim de responder ao objetivo proposto, o levantamento bibliográfico foi realizado online no período de janeiro a fevereiro de 2021 por meio da biblioteca do Portal de Periódicos da Coordenação de Aperfeiçoamento de Pessoal de Nível Superior (CAPES), das bases de dados Medical Literature Analysis and Retrieval System Online (MEDLINE), U.S. National Library of Medicine National Institute of Health (PUBMED), Literatura Latino-Americana e do Caribe em Ciências da Saúde (LILACS), Scientific Electronic Library Online (SciELO), Base de Dados de Enfermagem (BDENF) e Cummulative Index to Nursing and Allied Health Literature (CINAHL).

Utilizou-se a estratégia PICOT para delimitar a revisão integrativa (MENDES; SILVEIRA; GALVÃO, 2019). Sendo a mesma um acrônimo, representando no presente estudo: P) População (pacientes que possuíam critérios para o diagnóstico de enfermagem sofrimento espiritual / enfermeiros que foram avaliados no tocante ao conhecimento e utilização do diagnóstico de enfermagem sofrimento espiritual); I) Intervenção (identificar o diagnóstico de enfermagem sofrimento espiritual); C) Comparação (qual as dificuldades?); O) Desfecho ou resultados (como se dá a implementação e a aplicação prática do diagnóstico de enfermagem sofrimento espiritual?); T) Tempo (estudos publicados nos últimos dez anos 2010/2020).

A busca foi realizada de maneira interdependente por duas duplas de pesquisares, e em casos de impasses uma terceira dupla era acionada. Utilizou-se os descritores controlados disponíveis nos Descritores em Ciência da Saúde (DeCS) e seus correspondentes em espanhol e português da Biblioteca Virtual em Saúde: "Nursing Diagnosis" AND "Spirituality" AND "Spiritual", utilizou-se para o cruzamento dos descritores o operador booleano "AND".

Os estudos foram selecionados pela leitura criteriosa dos títulos, resumos e posteriormente dos artigos na íntegra. Os critérios de inclusão definidos foram artigos 
científicos similares com a temática deste estudo, produções disponíveis na íntegra, nos idiomas português, inglês e espanhol e que detalhassem e versassem o assunto: padronização e a implementação do diagnóstico de enfermagem sofrimento espiritual na prática clínica, independentemente do método de pesquisa utilizado, publicado entre os anos de 2010 a 2020. Artigos que se encontravam repetidos nas bases de dados e não abarcavam a temática principal não foram incluídos na análise.

Para a caracterização dos estudos selecionados utilizou-se um instrumento de fichamento de dados adaptado [incluindo-se os itens autor, ano, título do artigo, base de dados e país de publicação, nível de evidencia, objetivo do estudo e síntese da conclusão], visando a sistematização e organização, pontua-se que todos os artigos selecionados foram avaliados quanto ao nível de evidência (GALVAO, 2006). A análise dos dados deu-se através da leitura dos artigos, sendo as informações utilizadas para elaborar um quadro no Microsoft Word $^{\circledR}$ 2016. A sistematização dos artigos encontrados na busca bibliográfica está apresentada na figura 1.

Figura 1: Sistematização da busca eletrônica dos artigos, 2021.

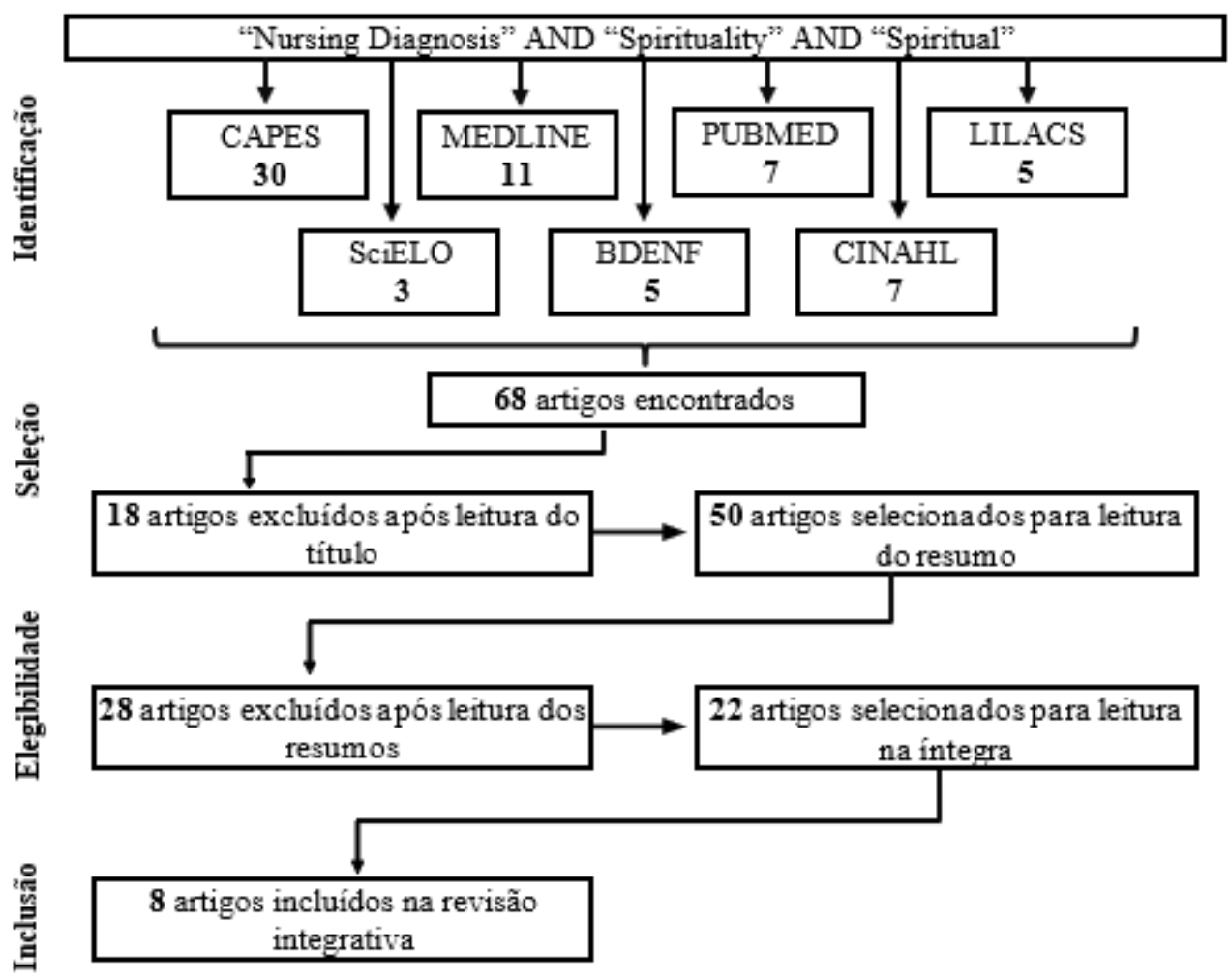

Fonte: Dados do presente estudo, 2021. 


\section{RESULTADOS}

Foram encontrados dois (25\%) artigos na CAPES, na PUBMED e na CINAHL, um artigo (12,5\%) na MEDLINE e na LILACS, totalizando 8 artigos (100\%) para o fim da análise. Em relação aos anos de publicação dos estudos, dois (25\%) estudos foram foi publicados no ano de 2017, e um (12,5\%) estudo respectivamente para os anos de 2010, 2011, 2014, 2015, 2016 e 2018.

Quanto aos tipos de estudos, foram incluídos cinco (62,5\%) transversais, dois estudos (25\%) de validação de conteúdo diagnóstico e um estudo $(12,5 \%)$ descritivo quantitativo. No que tange ao nível de evidência observou-se que cinco estudos (62,5\%) são nível IV, dois estudos (25\%) são nível V e um estudo (12,5\%) é do nível VI. Em relação ao país em que a pesquisa foi realizada, quatro artigos (50\%), são oriundos de Portugal, três estudos (37,5\%) são do Brasil e um estudo (12,5\%) é proveniente de Israel. Com intuito de concentrar, integralizar/sistematizar os achados desta revisão, foi construído um quadro síntese (Quadro 1).

Quadro 1 - Síntese dos artigos selecionados para a análise, 2021.

\begin{tabular}{|c|c|c|c|c|}
\hline $\begin{array}{l}\text { Autor } \\
\text { [Ano] }\end{array}$ & $\begin{array}{l}\text { Título } \\
\text { [País] }\end{array}$ & $\begin{array}{l}\text { Método } \\
\text { [Evidência] }\end{array}$ & $\begin{array}{c}\text { Objetivo } \\
\text { [Amostra] }\end{array}$ & Conclusão \\
\hline $\begin{array}{l}\text { Caldeira } \\
\text { et al. } \\
\text { [2015] }\end{array}$ & $\begin{array}{l}\text { Clinical Validation } \\
\text { of the Nursing } \\
\text { Diagnosis Spiritual } \\
\text { Distress in Cancer } \\
\text { Patients } \\
\text { Undergoing } \\
\text { Chemotherapy } \\
\text { [Portugal] }\end{array}$ & $\begin{array}{l}\text { Transversal } \\
\text { [Nível IV] }\end{array}$ & $\begin{array}{l}\text { Validar o diagnóstico } \\
\text { de enfermagem } \\
\text { sofrimento espiritual } \\
\text { em pacientes com } \\
\text { câncer } \\
\text { [170 pacientes com } \\
\text { câncer] }\end{array}$ & $\begin{array}{l}\text { O diagnóstico de enfermagem } \\
\text { sofrimento espiritual foi } \\
\text { validado. Pacientes com câncer } \\
\text { em sofrimento espiritual } \\
\text { encontram-se em um estado de } \\
\text { sofrimento relacionado à falta } \\
\text { de sentido na vida }\end{array}$ \\
\hline $\begin{array}{c}\text { Caldeira } \\
\text { et al. } \\
\text { [2017] }\end{array}$ & \begin{tabular}{l} 
Spiritual Well- \\
Being and \\
Spiritual Distress \\
in Cancer Patients \\
Undergoing \\
Chemotherapy: \\
Utilizing the \\
SWBQ \\
Component of \\
Holistic Nursing \\
Diagnosis \\
\multicolumn{2}{c}{ [Portugal] }
\end{tabular} & $\begin{array}{l}\text { Transversal } \\
\text { [Nível IV] }\end{array}$ & $\begin{array}{l}\text { Relatar à validação } \\
\text { clínica do diagnóstico } \\
\text { de enfermagem } \\
\text { sofrimento espiritual } \\
\text { em pacientes com } \\
\text { câncer } \\
\text { [169 pacientes] }\end{array}$ & $\begin{array}{l}\text { Concluímos que o SWBQ é um } \\
\text { instrumento útil e confiável } \\
\text { para avaliar o sofrimento } \\
\text { espiritual, o que destaca a } \\
\text { importância de ouvir os } \\
\text { pacientes e questioná-los sobre } \\
\text { as necessidades espirituais, } \\
\text { bem como a importância do } \\
\text { diagnóstico diferencial para } \\
\text { intervenções eficazes }\end{array}$ \\
\hline
\end{tabular}




\begin{tabular}{|c|c|c|c|c|}
\hline $\begin{array}{l}\text { Caldeira } \\
\text { et al. } \\
\text { [2016] }\end{array}$ & 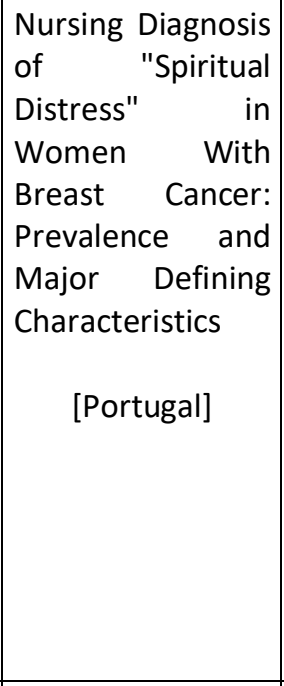 & Transversal & 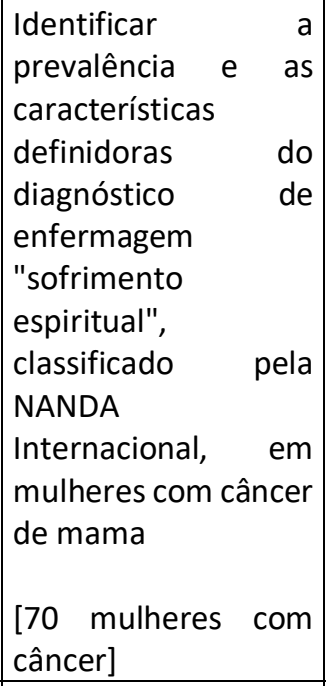 & $\begin{array}{l}\text { A prevalência de sofrimento } \\
\text { espiritual e as principais } \\
\text { características definidoras } \\
\text { fornecem evidências clínicas } \\
\text { sobre o papel do enfermeiro na } \\
\text { prestação de cuidado } \\
\text { espiritual. Os resultados são } \\
\text { úteis para uma melhor } \\
\text { utilização dos diagnósticos da } \\
\text { NANDA International neste } \\
\text { domínio. }\end{array}$ \\
\hline $\begin{array}{l}\text { Caldeira; } \\
\text { Carvalho; } \\
\text { Vieira } \\
\text { [2014a] }\end{array}$ & $\begin{array}{l}\text { Between spiritual } \\
\text { wellbeing and } \\
\text { spiritual distress: } \\
\text { possible related } \\
\text { factors in elderly } \\
\text { patients with } \\
\text { cancer } \\
\quad \text { [Portugal] }\end{array}$ & $\begin{array}{l}\text { Validação de } \\
\text { Conteúdo } \\
\text { Diagnóstico } \\
\text { [Nível V] }\end{array}$ & $\begin{array}{lrr}\text { Descrever } & a \\
\text { avaliação do } & \text { bem- } \\
\text { estar } & \text { espiritual } & \text { de } \\
\text { idosos com } & \text { cancro, } \\
\text { submetidos } & \text { à } \\
\text { quimioterapia, e } & \text { de } \\
\text { possíveis } & \text { fatores } \\
\text { preditivos } & \text { do } \\
\text { diagnóstico } & \text { angústia } \\
\text { espiritual } & \\
\text { [45 idosos } & \text { com } \\
\text { câncer] } & \end{array}$ & $\begin{array}{l}\text { Os resultados enfatizam a } \\
\text { necessidade de clarificar esse } \\
\text { diagnóstico e a } \\
\text { responsabilidade } \\
\text { enfermeiros na assistência } \\
\text { espiritual aos pacientes. As } \\
\text { intervenções deverão ser } \\
\text { adequadas sempre que } \\
\text { identificado um diagnóstico de } \\
\text { enfermagem que constitui uma } \\
\text { resposta complexa e que não se } \\
\text { reduz ao tratamento } \\
\text { farmacológico }\end{array}$ \\
\hline $\begin{array}{l}\text { Chaves } \\
\text { et al. } \\
\text { [2011] }\end{array}$ & $\begin{array}{l}\text { Efficacy of } \\
\text { different } \\
\text { instruments for } \\
\text { the identification } \\
\text { of the nursing } \\
\text { diagnosis spiritual } \\
\text { distress } \\
\text { [Brasil] }\end{array}$ & $\begin{array}{l}\text { Quantifico } \\
\text { descrito } \\
\text { [Nível VI] }\end{array}$ & 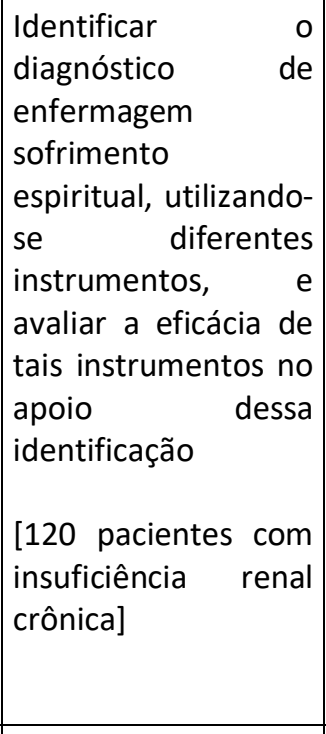 & 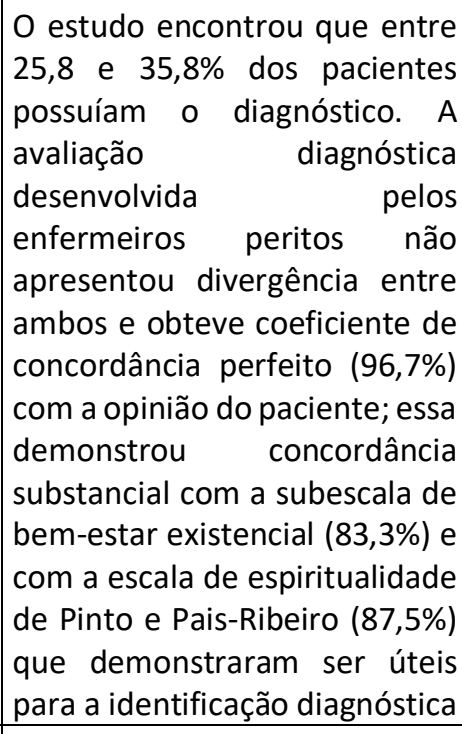 \\
\hline $\begin{array}{l}\text { Chaves; } \\
\text { Carvalho; } \\
\text { Hass } \\
\text { [2010] }\end{array}$ & $\begin{array}{l}\text { Validation of the } \\
\text { nursing diagnosis } \\
\text { Spiritual Anguish: } \\
\text { analysis by } \\
\text { experts } \\
\text { [Brasil] }\end{array}$ & $\begin{array}{l}\text { Validação de } \\
\text { Conteúdo } \\
\text { Diagnóstico } \\
\text { [Nível V] }\end{array}$ & $\begin{array}{l}\text { Realizar a validação } \\
\text { de conteúdo do } \\
\text { diagnóstico } \\
\text { enfermagem } \\
\text { Angústia espiritual } \\
\\
\begin{array}{ll}72 & \text { enfermeiros } \\
\text { especialistas] }\end{array}\end{array}$ & $\begin{array}{l}\text { Uma nova proposta } \\
\text { apresentada ao fenômeno em } \\
\text { estudo foi considerada } \\
\text { pertinente. Este estudo pode } \\
\text { oferecer subsídios para a } \\
\text { validação clínica do diagnóstico } \\
\text { investigado }\end{array}$ \\
\hline
\end{tabular}




\begin{tabular}{|c|c|c|c|c|}
\hline $\begin{array}{l}\text { PINHO et } \\
\text { al. } \\
\text { [2017] }\end{array}$ & $\begin{array}{l}\text { Impaired } \\
\text { religiosity and } \\
\text { spiritual distress } \\
\text { in people living } \\
\text { with HIV/AIDS } \\
\text { [Brasil] }\end{array}$ & $\begin{array}{l}\text { Transversal } \\
\text { [Nível IV] }\end{array}$ & $\begin{array}{l}\text { Verificar a inferência } \\
\text { dos Diagnósticos de } \\
\text { Enfermagem, } \\
\text { Religiosidade } \\
\text { prejudicada e } \\
\text { Sofrimento espiritual } \\
\text { em pessoas vivendo } \\
\text { com HIV/AIDS } \\
\text { [52 pacientes] }\end{array}$ & $\begin{array}{l}\text { Os resultados apontam para a } \\
\text { necessidade de considerar a } \\
\text { dimensão religiosa-espiritual } \\
\text { nos protocolos assistenciais e } \\
\text { de pesquisa em enfermagem }\end{array}$ \\
\hline $\begin{array}{l}\text { Schultz } \\
\text { et al. } \\
\text { [2018] }\end{array}$ & $\begin{array}{l}\text { The cultural } \\
\text { expression of } \\
\text { spiritual distress } \\
\text { in } \\
\text { Israel } \\
\quad \text { [Israel] }\end{array}$ & $\begin{array}{l}\text { Transversal } \\
\text { [Nível IV] }\end{array}$ & 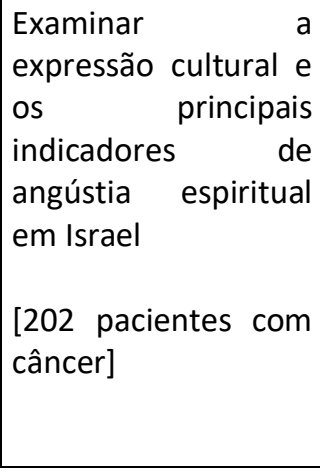 & $\begin{array}{l}\text { Intervenções especialmente } \\
\text { projetadas para reduzir o } \\
\text { sofrimento espiritual devem } \\
\text { abordar as expressões de } \\
\text { sofrimento específicas dessa } \\
\text { cultura. Os estudos sobre a } \\
\text { eficácia do cuidado espiritual } \\
\text { podem examinar a extensão da } \\
\text { angústia espiritual em geral ou } \\
\text { de suas expressões culturais } \\
\text { específicas }\end{array}$ \\
\hline
\end{tabular}

Fonte: Dados do presente estudo, 2021.

\section{DISCUSSÃO}

\subsection{PADRONIZAÇÃO DO DIAGNOSTICO SOFRIMENTO ESPIRITUAL PARA A PRATICA CLINICA EM ENFERMAGEM}

O diagnóstico de enfermagem sofrimento espiritual tem sua padronização na prática clínica dificultada pela subjetividade inter-relacionada envolvida na avaliação da dimensão psicoespiritual. Logo é bastante dificultosa a tarefa de instrumentalizar a avaliação desse diagnóstico de enfermagem, mesmo que seja consenso que a instrumentalização facilitaria sua identificação na prática clínica (CALDEIRA; CARVALHO; VIEIRA, 2014a, 2014b; PINHO et al. 2017). É importante ressaltar que para os profissionais de enfermagem é um desafio, visto que, faz se necessário um conhecimento em relação a dimensão psicoespiritual do paciente, bem como a capacidade de avaliar como uma disfunção dessa dimensão afeta o processo saúdedoença do indivíduo (CHAVES et al, 2011; CHAVES; CARVALHO; HASS, 2010).

Destarte, visando a precisão na identificação do diagnóstico de enfermagem é recomendada a utilização de instrumentos de avaliação da dimensão psicoespiritual, para que desta forma as chances de erro sejam reduzidas. A literatura aponta ausência 
de um instrumento padrão ouro para avaliar o "sofrimento espiritual”, porém Gordon e colaboradores (2018) e CHAVES e demais autores (2011) descrevem a utilização de alguns instrumentos para tal, sendo estes: Escala de Espiritualidade de Pinto e PaisRibeiro e Escala de bem-estar espiritual. Tratando-se da Escala de Espiritualidade de Pinto e Pais-Ribeiro não foi definido uma pontuação de corte, entretanto, a probabilidade de o indivíduo apresentar o diagnostico aumenta conforme a pontuação começa a cair a partir da pontuação 10. No tocante a escala de bem-estar espiritual, um estudo de Chaves e colaboradores (2011), retrata que pessoas ao apresentarem pontuação de corte entre 20 e 30, apresentam 99\% de probabilidade de estarem em sofrimento espiritual.

Ademais, no tocante a definição do diagnóstico proposto pela NANDA, estudos têm sido feitos buscando reduzir as divergências existente entre os pesquisadores, uma vez que, a grande quantidade de características definidoras, bem como a classe, título e domínio utilizado pela Taxonomia II "Princípios da Vida" é um entrave no momento de diagnosticar o paciente (CHAVES et al, 2011; CHAVES; CARVALHO; HASS, 2010). Chaves e colaboradores (2010), evidenciaram que o domínio no qual o diagnóstico se insere é adequado, entretanto foi verificado que se deve buscar uma ampliação da classe no qual se encontra, bem como a priorização das características definidoras, visto que, para a confirmação do diagnóstico é fundamental a presença de uma ou mais das seguintes características definidoras: Apresenta distúrbio ou preocupação em relação ao sistema de crenças e/ou a Deus; Expressa raiva de Deus; Expressa falta de significado/propósito na vida; É incapaz de experimentar transcendência; Expressa alienação ou isolamento; Questiona sofrimento e Expressa falta de serenidade (CHAVES et al, 2011; CALDEIRA; CARVALHO; VIEIRA, 2014b).

Ante a supra referido, é imprescindível que o enfermeiro saiba abordar qual o significado da espiritualidade e religiosidade para o paciente (ANDRADE, J. V. et al. 2020; SILVA; VITORINO, 2020), e para tanto, deve viabilizar meios funcionais de comunicação com o paciente, bem como, possuir a capacitação necessária para realizar a identificação desse diagnóstico clínico (PINHO et al. 2017). Deve-se buscar identificar características subjetivas no paciente, tais como sofrimento e perda de significado na vida, sendo estas, intimamente relacionadas ao sofrimento espiritual (CHAVES; CARVALHO; HASS, 2010; SCHULTZ et al. 2018). 


\subsection{IMPLEMENTAÇÃO DO DIAGNÓSTICO SOFRIMENTO ESPIRITUAL NA PRÁTICA CLINICA}

O cuidado espiritual inclui a avaliação do bem-estar espiritual e uma formalização de diagnósticos que contemplem a dimensão psicoespiritual, visando a implementação da sistematização da assistência em enfermagem (CALDEIRA; CARVALHO; VIEIRA, 2014b). Cada indivíduo confere à espiritualidade um caráter e também uma subjetividade, ligada a fatores como crenças, valores e transcendência (ANDRADE, J. V. et al. 2020; SILVA; VITORINO, 2020). Por conseguinte, espera-se que o enfermeiro tenha competência clínica no momento da identificação dos sinais apresentados por um paciente em sofrimento espiritual (CALDEIRA et al., 2017; PINHO et al. 2017).

Destarte, o profissional de enfermagem deve realizar a avaliação das necessidades espirituais do cliente, com intuito de prover intervenções e cuidados espirituais (CALDEIRA et al., 2017; PINHO et al. 2017; ANDRADE, J. V. et al. 2020; SILVA; VITORINO, 2020). Visto que, a espiritualidade está intimamente ligada ao bem-estar, como também, à capacidade de enfretamento do indivíduo diante situações críticas e finitude da vida (CHAVES; CARVALHO; HASS, 2010). Com intuito de facilitar a identificação do diagnóstico de enfermagem sofrimento espiritual é recomendada a aplicação de instrumentos de avaliação da espiritualidade, entretanto, estudos mostram que os profissionais têm dificuldade de identificar os sinais clínicos deste diagnóstico de enfermagem, devido à sua complexidade (CHAVES; CARVALHO; HASS, 2010; CALDEIRA et al, 2017).

Em um estudo realizado por Caldeira e colaboradores (2016), os autores explicitaram os sinais clínicos que um paciente em sofrimento espiritual apresenta, tais como: medo, sofrimento e isolamento, são similares ao de ínvidos com depressão ou acometido por algum outro transtorno mental, fato este que, contribui para o aumento das chances de erro no momento de determinar o diagnóstico, bem como da medicalização. Portanto, é de suma importância a qualificação dos profissionais de enfermagem para identificar e compreender as diversas formas de espiritualidade e religiosidade, promovendo um espaço de diálogo com os pacientes, visando a eficácia das intervenções na prática clínica (HELIKER, 1992; CALDEIRA et al., 2018). 
Pesquisas na área de enfermagem acerca da espiritualidade vêm emergindo, tem-se então um novo campo de estudo, visto que está área vem ganhando grande expressão científica através das publicações internacionais, nas quais têm-se buscado realizar a reconstrução e remodelação do diagnóstico de enfermagem "sofrimento espiritual". Um recente estudo publicado por Caldeira e colaboradores (2017) revalidou o referido diagnóstico de enfermagem, sendo observada uma prevalência do diagnóstico em 40,8\% da amostra total, evidenciando a necessidade de prover cuidado espiritual, e, portanto, incluí-los no plano de cuidados dos pacientes, bem como do seu núcleo familiar (LINS et al., 2021).

Ademais, estudos mostram que é necessária a realização de mais pesquisas com intuito de buscar práticas eficazes no momento da avaliação das necessidades psicoespirituais dos pacientes, como também a qualificação dos profissionais da saúde na prática clínica, buscando a competência clínica para identificar sinais e sintomas de pacientes em sofrimento espiritual, tornando essa avaliação rotineira na prática clínica (CHAVES; CARVALHO; HASS, 2010; CALDEIRA et al, 2017; CALDEIRA; CARVALHO; VIEIRA, 2014a; PINHO et al. 2017),

\section{CONSIDERAÇÕES FINAIS}

No presente estudo foram identificados os fatores relacionados a abordagem do diagnóstico de enfermagem sofrimento espiritual. Destacam-se como fatores importantes a preparação de profissionais e futuros profissionais da saúde, a subjetividade que envolve esse diagnóstico e também a condição clínica do paciente que possibilite respostas claras.

Os resultados ressaltam questionamentos em relação ao diagnóstico de enfermagem sofrimento espiritual, como os benefícios e consequências da utilização deste na pratica clínica. Sabe-se que a abordagem da dimensão psicoespiritual é necessária para melhores prognósticos e atenção integral aos pacientes, sobretudo em indivíduos acometidos por doenças que ameaçam a vida. Porém, abordar a dimensão psicoespiritual, principalmente em relação ao sofrimento espiritual é um processo complexo que envolve toda a equipe de enfermagem, sendo essencial o auxílio da psicologia, da capelania e também da psiquiatria. 
Ressalta-se que são poucas as publicações sobre a temática, o que mostra a necessidade de pesquisas relacionadas à assistência de enfermagem aos pacientes em sofrimento espiritual. Além disso, o estudo evidenciou que é de suma importância fortalecer a formação do futuro profissional de enfermagem por meio da implementação de disciplinas que busquem dialogar sobre a espiritualidade e religiosidade nas grades curriculares. Com intuito de capacitá-los a implementarem a sistematização da assistência em enfermagem voltada à dimensão psicoespiritual em sua prática clínica.

\section{REFERÊNCIAS}

ANDRADE, J. V. et al. Abordagem à Espiritualidade por meio do questionário FICA: Uma experiência de capacitação com cuidadores de idosos. Revista Longeviver, v. 2, p. 47-54, 2020.

BALBONI, M. et al. Nurse and physician barriers to spiritual care provision at the end of life. Journal of Pain and Symptom Management, v. 48, n. 3, p. 400-410, 2014.

BROOME, M. Integrative literature reviews for the development of concepts. In B. Rodgers \& K. Knafl (Eds.), Concept development in nursing- foundations, techniques, and applications. Saunders: Philadelphia, 2000, 231-250 p.

CALDEIRA, S. et al. Nursing Diagnosis of "spiritual distress" in women with breast cancer prevalence and major defining characteristics. Cancer Nursing, v. 39, n. 4, p. 321327, 2016.

CALDEIRA, S. M. A. et al. Validation of nursing diagnoses-the differential diagnostic validation model as a strategy. Journal of Nursing UFPE, v. 6, n. 6, p. 1441-1445, 2012.

CALDEIRA S. et al. Clinical validation of the nursing diagnosis spiritual distress in cancer patients undergoing chemotherapy. International Journal of Nursing Knowledge, v. 28, n. 1, p. 44-52, 2018.

CALDEIRA, S.; CARVALHO, E. C.; VIEIRA, M. Between spiritual wellbeing and spiritual distress: possible related factors in elderly patients with cancer. Revista LatinoAmericana de Enfermagem, v. 22, n. 1, p. 02-07, 2014a.

CALDEIRA, S.; CARVALHO, E. C.; VIEIRA, M. Spiritual distress - proposing a new definition and defining characteristics. International Journal of Nursing Knowledge, v. 24, n. 2, p. 77-84, 2014b. 
CALDEIRA, S.; BRANCO, Z. C.; VIEIRA, M. A. Espiritualidade nos cuidados de enfermagem: revisão da divulgação científica em Portugal. Revista de Enfermagem Referência, v. 3, n. 5, p. 145-152, 2011.

CALDEIRA, S. et al. Spiritual well-being and spiritual distress in cancer patients undergoing chemotherapy: utilizing the SWBQ as component of holistic nursing diagnosis. Journal of Religion \& Health, v. 56, n. 1, p. 1489-1502, 2017.

CHAVES, E. C. L. et al. Efficacy of different instruments for the identification of the nursing diagnosis spiritual distress. Revista Latino-Americana de Enfermagem, v. 19, n. 4, p. 01-09, 2011.

CHAVES, E. C. L.; CARVALHO, E. C.; HASS, V. J. Validation of the nursing diagnosis Spiritual Anguish: analysis by experts. Acta Paulista de Enfermagem, v. 23, n. 2, p. 264270, 2010.

COCKELL, N.; MCSHERRY, W. Spiritual care in nursing: An overview of published international research. Journal of Pain and Symptom Management, v. 20, n. 8, p. 958-969, 2012.

DELGADO, C. A discussion of the concept of spirituality. Nursing Science Quarterly, v. 18, n. 2, p. 157-162, 2005.

GALVAO, C. M. Níveis de evidência. Acta Paulista de Enfermagem, v. 19, n. 2, p. 5, 2006.

GORDON, B. S. et al. Addressing spirituality during critical illness: A review of current literature. Journal of Critical Care, v. 45, n. 1, p. 76-81, 2018.

HELIKER, D. Reevaluation of a nursing diagnosis: spiritual distress. Nursing Forum, v. 27, n. 4, p. 15-20, 1992.

HERDMAN, T. H.; KAMITSURU, S. Diagnósticos de Enfermagem da NANDA: definições e classificação 2018-2020/ NANDA Internacional. 10 ed. Porto Alegre: Artmed, 2018.

LEEUWEN, R.; SCHEP-AKKERMAN A.; LAARHOVEN H. W. Screening patient spirituality and spiritual needs in oncology nursing. Nursing Older People, v. 27, n. 4, p. 207216, 2013.

LINS, A. L. R. et al. Necesidades de cuidado dentro del hospital del cuidador de personas con cancer. Revista Cuidarte, v. 12, n. 2, p. e1231, 2021.

MENDES, K. D. S.; SILVEIRA, R. C. C. P.; GALVÃO, C. M. Uso de gerenciador de referências bibliográficas na seleção dos estudos primários em revisão integrativa. Texto \& Contexto-Enfermagem, v. 28, 2019. 
OLIVER, E. B.; GUTIÉRREZ, J. B.; SÁNCHEZ, M. D. Spiritualidad en clínica una propuesta de evaluación y acompañamiento espiritual em cuidados paliativos. Madrid: SECPAL, 2014.

OMS - Organização Mundial de Saúde. Resolution EB101.R2. Fifty-Second World Health Assembly A52/24, 1998.

PINHO, C. M. et al. Impaired religiosity and spiritual distress in people living with HIV/AIDS. Revista Gaúcha de Enfermagem, v. 38, n. 2, p. e67712, 2017.

POWER, J. Spiritual assessment: developing an assessment tool. Nursing Older People, v. 18, n. 2, p. 16-18, 2006.

SCHULTZ, M. et al. The cultural expression of spiritual distress in Israel. Supportive Care in Cancer, v. 26, n. 1, p. 3187-3193, 2018.

SILVA, M.; VITORINO, L. M. Religiosidade e espiritualidade na prática clínica da enfermagem: revisão da literatura e desenvolvimento de protocolo: Aplicações práticas. HU Revista, v. 44, n. 4, p. 469-479, 2020.

WHITTEMORE, R.; KNAFL, K. The integrative review: Update methodology. Journal of Advanced Nursing, v. 52, n. 5, p. 546-553, 2005. 


\section{CAPÍTULO XII}

\section{UNGGAGEM BRASILEIRA DE SINAIS NA FORMACÃO EM ENFERMAGEM: REFLTINDO CONCEITOS PARA RESSIGNIFICAR PRÁTCAS NA ASSISTEANCAA À PARTURICG̃̃O}

Joyce Karoliny de Morais Bezerra ${ }^{1}$ Myrelle Alves Sampaio ${ }^{1}$ Nathalia Gonçalves Rabelo ${ }^{1}$ Larissa Pereira de Morais ${ }^{1}$ Mayara de Alencar Amorim ${ }^{1}$ João Paulo Xavier Silva Autor ${ }^{2}$

${ }^{1}$ Graduanda do curso de Enfermagem. Centro Universitário Doutor Leão Sampaio - UNILEÃO.

2 Enfermeiro. Doutorando em Cuidados Clínicos em Enfermagem e Saúde pela Universidade Estadual do Ceará - UECE.

\section{RESUMO}

No contexto da graduação em enfermagem é natural a abordagem sobre assistência humanizada, pois de acordo com os princípios do Sistema Único de Saúde (SUS), essa é uma medida para melhorar a qualidade de vida do cliente assistido. Logo, a formação do profissional enfermeiro deve atender as necessidades sociais da saúde com ênfase no SUS, assegurando a integralidade do cuidado e buscando a qualidade e a humanização do atendimento. Dentre as diversas singularidades que se constituem em necessidades específicas de grupos populacionais, a surdez é uma que merece atenção. Desse modo, destaca-se a importância do conhecimento em Linguagem Brasileira de Sinais (LIBRAS) pelo profissional de enfermagem. Visto que, o enfermeiro é uma peça fundamental no momento do parto, pois ele favorece vínculo e confiança a mulher no momento da parturição.

Palavras-chave: Enfermagem. Língua de Sinais. Parturição.

\section{INTRODUÇÃO}

A LIBRAS é definida como um sistema linguístico de comunicação gesto-visual, com gramática própria. Logo, os surdos apoderaram-se do uso das mãos, simultaneamente com braços, tórax e cabeça, e desta forma conseguem explanar todos os assuntos (GIUSTINA; CARNEIRO; SOUZA, 2015). No Art. 1, da Lei no 10.436, de 24 de abril de 2002, "é reconhecida como meio legal de comunicação e expressão a LIBRAS e outros recursos de expressão a ela associado (BRASIL, 2002a, p.1)." 
Salienta-se, desse modo, a importância do conhecimento em LIBRAS por parte de todos os profissionais que prestam assistência no SUS, dentre os quais se destaca o profissional de enfermagem. Assim, em sua formação é imperativo observar a necessidade de uma capacitação com vistas ao acolhimento e à comunicação efetiva com pessoas surdas. Visto que, segundo as Diretrizes Curriculares Nacionais (DCNS), a formação em enfermagem tem por objetivo

dotar o profissional dos conhecimentos, habilidades e atitudes requeridos para a competência em: Identificar as necessidades individuais e coletivas de saúde da população, seus condicionantes e determinantes; Prestar cuidados de enfermagem compatíveis com as diferentes necessidades apresentadas pelo indivíduo, pela família e pelos diferentes grupos da comunidade [...] (BRASIL, 2001, p. 3-4).

Nessa perspectiva, a literatura científica tem investigado o contexto assistencial em sua interlocução com o conhecimento da LIBRAS no cenário do cuidado de enfermagem. Porém, quando se trata da assistência do enfermeiro às gestantes surdas durante a parturição, encontram-se poucos estudos sobre a temática. Sabe-se que o enfermeiro é uma peça fundamental no momento do parto, pois ele é capacitado para humanizar nascimentos da melhor forma possível, além de favorecer vínculo e confiança, evitando assim traumas emocionais a parturiente (MELO et al., 2018). Este mesmo autor afirma que a enfermagem proporciona a mulher parturiente maior segurança e conforto, além de reduzir sua ansiedade durante o parto, pois sempre oferece escuta atenciosa.

Apesar disso, quando a gestante é surda há um grande desafio em manter uma boa comunicação e uma escuta atenciosa. A gestante é colocada em situação de desatenção quando não é compreendida por não verbalizar seus anseios, suas dúvidas e seus desejos. Diante desta situação, infelizmente, os profissionais de enfermagem nem sempre conseguem realizar seu papel de apoio no momento do parto para ajudar a minimizar o estresse emocional e o desconforto físico da mulher, pelo motivo de não possuírem o privilégio de colar grau com algum conhecimento da LIBRAS. Conforme consta no Decreto № 5.626, de 22 de dezembro de 2005, “§ 2으 A LIBRAS constituir-se-á em disciplina curricular optativa nos demais cursos de educação superior e na educação profissional, a partir de um ano da publicação deste Decreto (BRASIL, 2002b, p.3). " 
Ademais, é visto a importância da comunicação numa assistência de enfermagem, pois é através dela que o profissional consegue compreender, de forma abrangente, a visão de mundo, a maneira de pensar, agir e sentir dos seus clientes. Desta forma, a equipe será capaz de alcançar as necessidades do paciente e, consequentemente, ofertar melhor assistência. Em vista disso, se a comunicação não é efetiva, a assistência é falha (GIUSTINA; CARNEIRO; SOUZA, 2015).

Contudo, estabelecer uma relação de confiança entre a mulher surda e os profissionais de saúde no processo de parturição, procurar manter respeito a cultura e aos sentimentos da gestante, demostrar auxílio para amenizar a ansiedade e insegurança neste processo e ofertar informações e orientações à parturiente sobre o parto são recomendações do Ministério da Saúde (MS) (ALMEIDA; OLIVEIRA, 2005).

A originalidade e individualidade da comunicação dos surdos no ambiente hospitalar requer mais reconhecimento e compreensão da parte dos profissionais de saúde, inclusive do enfermeiro que é quem demanda maior tempo com seus pacientes. A partir dessas considerações, questiona-se: Quais os aspectos históricos da LIBRAS e sua articulação com a saúde no Brasil? De que modo a formação em enfermagem pode se articular com o conhecimento em LIBRAS? Nesse estudo objetivou-se por meio de uma abordagem teórica refletir sobre os conceitos e a historicidade da LIBRAS e sua interlocução com a formação em Enfermagem.

\section{REVISÃO BIBLIOGRÁFICA}

\subsection{SURDEZ E LINGUAGEM BRASILEIRA DE SINAIS: HISTORICIDADE E ARTICULAÇÃo NO CONTEXTO dA SAÚdE}

A deficiência, de certa forma, está diretamente ligada à discriminação e exclusão social. Segundo a Organização das Nações Unidas (ONU) e a Convenção sobre os Direitos das Pessoas com Deficiência (CDPD), uma pessoa deficiente é aquela que possui implicações de longo prazo de condição física, intelectual, mental ou sensorial, e ainda acrescenta que isso pode interferir em sua participação e aceitação na sociedade. Portanto, para que haja mudança é necessário a disponibilidade do acesso ao ambiente físico, social, econômico e cultural, saúde, educação, informação e comunicação em igualdade para essas pessoas (MUNOZ-BAELL et at., 2011; NASCIMENTO, 2019). 
Entre a existência de tantas deficiências, destaca-se a auditiva, que, de acordo com a Classificação Internacional de Doenças (CID-10), é classificada como perda auditiva por transtorno de condução e/ou neuro-sensorial, perda de audição mista, de condução e neuro-sensorial, não especificada (NASCIMENTO, 2019).

A maior implicação da surdez na saúde das pessoas acometidas é a dificuldade na comunicação entre o profissional de saúde e o paciente surdo, pois, na maioria das vezes, o profissional é incapaz de compreender a demanda de necessidade desses usuários com deficiência auditiva (NASCIMENTO, 2019).

Segundo Krause e Klein, (2018) a ausência de acessibilidade, a carência de profissionais qualificados em LIBRAS e a ausência da difusão da LIBRAS afetam diretamente o processo da inclusão social dos surdos. Diante tantas dificuldades impostas à essa população, os próprios surdos preferem nascer com qualquer outro tipo de deficiência, pois consideram a surdez como motivo de maior exclusão social (NASCIMENTO, 2019).

De acordo com Brittos e Silveira (2020), o acolhimento desses indivíduos em todas as suas particularidades e manifestações, o respeito aos seus direitos e o reconhecimento dos seus deveres é extremamente necessário, pois a surdez é uma diferença a ser prezada e não uma deficiência a ser anulada.

A respeito das políticas públicas relacionadas aos direitos da pessoa surda, a Política Nacional de Saúde da Pessoa com Deficiência defende a inclusão dessas pessoas em todos os serviços disponíveis pelo SUS (REIS; SANTOS, 2019). Ademais, o art. 24 do cap. III, da lei no 13.146/15, assegura o direito à serviços de saúde, tanto públicos como privados, para as pessoas com deficiência (KRAUSE; KLEIN, 2018).

No entanto, esses direitos nem sempre são respeitados e várias lacunas são encontradas. A inexistência da qualificação para trabalhar com surdos contradiz o Decreto no 5.626/200539, que determina a inclusão dos surdos nos serviços de saúde, e garante a integralidade na atenção à saúde por profissionais habilitados para o uso da LIBRAS, oferecendo ao surdo qualidade e acessibilidade de atendimento igualitário, obedecendo assim, os princípios de universalidade e equidade do SUS (REIS; SANTOS, 2019, p. 6).

A LIBRAS, por sua vez, apresenta-se como fator essencial para que os surdos possuam acesso à informação e participação na sociedade e na vida, sem ela os surdos

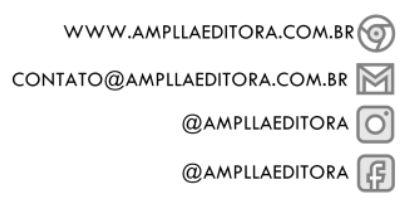


são impedidos de usufruir dos seus direitos e são consequentemente isolados da sociedade. Dessa forma, quando thes é negado o uso dessa linguagem, automaticamente é violado seus direitos humanos fundamentais (MUNOZ-BAELL et at., 2011).

Antes de ser reconhecida legalmente no Brasil, a LIBRAS passou por inúmeros processos. O trajeto para a oficialização da LIBRAS foi longo, e teve início a partir de um projeto de lei em 1993, instituído por uma senadora chamada Benedita da Silva. Este projeto foi aprovado apenas no ano de 2002, sendo regulamentado três anos mais tarde por Luis Inácio Lula da Silva. Antes disso, no século XX, houveram várias mobilizações de movimentos surdos na busca do reconhecimento da LIBRAS como primeira língua das pessoas surdas. Essa mobilização serviu para fortalecer a oficialização da língua no país, chegando ao Congresso Nacional no ano de 2002 afim de realizar a promulgação da Lei de Oficialização da LIBRAS em todo território nacional. Minas Gerais foi o primeiro estado do Brasil a oficializar a LIBRAS. Por mérito de tanta luta persistente dos surdos, finalmente a LIBRAS foi reconhecida pela nação brasileira como a segunda língua oficial do povo surdo através da Lei no 10.436, de 24 de abril de 2002 (DALL'ALBA, 2013).

Porém, nem todas as pessoas possuem acesso ao conhecimento da LIBRAS. Os estudos de Oliveira et al. (2018) confirmam que a LIBRAS ainda não é propalada em todo o pais, consequentemente, os direitos dos surdos são inabilitados. Este processo de difusão da LIBRAS é deficiente desde ao paralelo universitário, quando não há inclusão da língua como disciplina curricular, até a inexistência de uma preparação dos profissionais de saúde para, então, acolherem esses pacientes com dignidade, equidade, integralidade e universalidade conforme testemunha os princípios do SUS a todos os cidadãos.

Nascimento (2019) expõe que os serviços de saúde não estão preparados para atender o povo surdo, assim como seus profissionais não estão qualificados e nem são estimulados para isso. No art. 3, da lei no 10.436, de 24 de abril de 2002, é evidenciado a necessidade de instituições, em especial as de assistência à saúde, prestarem um atendimento de qualidade às pessoas com deficiência auditiva, conforme as normas legais em vigor. Visto que, é direito das pessoas surdas receberem atendimento em instituições públicas através do uso da LIBRAS (KRAUSE; KLEIN, 2018). 
Diante disso, é válido ressaltar a importância da inserção de uma formação em LIBRAS em todos os níveis de educação, inclusive em ensinos da área da saúde. A capacitação em LIBRAS na formação de profissionais da área da saúde, facilita o atendimento e o diagnóstico do paciente surdo, reduz o tempo das consultas, evita conflitos e favorece autonomia ao paciente. Além disso, esta capacitação deve ser aplicada de forma contínua, desde o nível de atenção básica até o nível mais complexo de atendimento, dessa forma é possível exercer integralidade no cuidado e inclusão da pessoa surda no sistema de saúde (NASCIMENTO et al, 2018). Sobre os direitos da pessoa surda na saúde, o Decreto no 5.626, de 2005, estabelece no art. 25:

atendimento às pessoas surdas ou com deficiência auditiva na rede de serviços do SUS e das empresas que detêm concessão ou permissão de serviços públicos de assistência à saúde, por profissionais capacitados para o uso de Libras ou para sua tradução e interpretação; Apoio à capacitação e formação de profissionais da rede de serviços do SUS para o uso de Libras e sua tradução e interpretação (BRASIL, 2019).

Dessa forma, para fornecer um acolhimento/atendimento com integralidade, com inclusão de todas as particularidades, complexidade e integração sociocultural à população surda, os profissionais de saúde devem ser qualificados. Por tanto, trata-se necessário que o ensino da LIBRAS seja incluído na grade curricular dos cursos de graduação na área da saúde, com o intuito de gerar profissionais capacitados para ofertar uma assistência de excelência, com qualidade e inclusão (CAMPOS, 2020).

Apesar disso, de acordo com o Decreto no 5.626, de 22 de dezembro de 2005, o cap. II aborda que "a Libras constituir-se-á em disciplina curricular optativa nos demais cursos de educação superior e na educação profissional, a partir de um ano da publicação deste Decreto" (BRASIL, 2002b).

Sendo assim, é valido a inclusão obrigatória da disciplina LIBRAS no currículo dos cursos de graduação da área da saúde do ensino superior, inclusive na enfermagem, para que, dessa forma, os profissionais sejam formados com entendimento suficiente para atender e entender a demanda dos pacientes surdos, além do que, essa posição trará ao surdo e aos seus familiares um atendimento mais humanizado, justo e holístico (DA LUZ; MOURA, 2018). 


\subsection{ASSISTÊNCIA DE ENFERMAGEM À PARTURIENTE}

Em outrora, a enfermagem era uma atividade de caráter caridoso, mas em 1922, com a atuação da Saúde Pública no início do século XX, e a partir da criação da Escola de Enfermagem Anna Nery, isso começou a mudar, e logo a enfermagem, finalmente, foi considerada uma profissão cientificamente respaldada (FLORES; ALMEIDA; JUNIOR, 2017).

Florence Nightingale definia a enfermagem como uma profissão que desenvolve diversas atividades, e que tem como essência o cuidado com indivíduos, buscando proporcionar o conforto e acolhimento, favorecendo o bem-estar e a autonomia dos pacientes. Diante disso, essa profissão busca gerar relações afetivas com os usuários, sem ter em conta suas condições culturais, econômicas ou sociais, procura aprimorar o cuidado em saúde de forma que contemple todos os saberes, tanto dos profissionais como dos usuários e da comunidade (STOLARSKI; TESTON; KOLHS, 2009; BACKES et al., 2012).

Segundo Rondelli (2019), o campo da obstetrícia é uma das áreas de atuação que o enfermeiro pode operar no campo da assistência, porém, as atividades desta área não são simples de gerenciar, pois variam de acordo com a região e instituição de atuação de cada profissional. Ainda assim, a autora afirma que o Conselho Federal de Enfermagem (COFEN) regulamenta a Enfermagem Obstétrica em todo o território nacional, sendo representada pela Associação Brasileira de Obstetrizes e Enfermeiros Obstetras (ABENFO) através de suas portarias e resoluções.

Neste campo, o enfermeiro obstetra possui aptidão para proceder diversas condutas. Sobre isso, Vilela et al. (2019) expõem algumas condutas de enfermagem no campo da obstetrícia, como, por exemplo, o respeito à individualidade e privacidade da mulher, o estímulo à presença do acompanhante, a orientação à mulher sobre tudo que acontece com ela no momento do parto, e a não realização de procedimentos desnecessários, objetivando a autonomia da mulher em relação aos procedimentos. Os autores ainda declaram que a enfermagem na área da obstetrícia deve ofertar um atendimento sistematizado, mantendo um olhar holístico e ético, estabelecendo assim a segurança do paciente, além de deixar o trabalho da enfermagem mais humanizado e qualificado. 
De acordo com o Decreto $n^{\circ}$ 94.406/87, artigo 8, inciso II, alíneas "h, j e i", compete ao enfermeiro integrante da equipe de saúde:

\begin{abstract}
-prestação de assistência de enfermagem à gestante, parturiente, puérpera e ao recém-nascido; -acompanhamento da evolução e do trabalho de parto; execução e assistência obstétrica em situação de emergência e execução do parto sem distorcia.
\end{abstract}

Art. 9: compete aos profissionais titulares de diploma ou certificados de Obstetriz ou da Enfermagem Obstétrica as seguintes atividades: -prestação de assistência à parturiente e ao parto normal; -identificação das distorcias obstétricas e tomada de providências até a chegada do médico (BRASIL, 1987).

Não obstante, o enfermeiro obstetra ainda possui a responsabilidade por zelar pelos direitos da parturiente, questioná-la sobre seus desejos, apoiá-la em suas decisões e garantir que ela receba um tratamento mais humanizado possível. Para mais, este profissional também deve ofertar acolhimento integral à gestante, uma assistência que considere a autonomia da mulher, visto que qualquer tipo de parto deve ser humanizado, priorizando o respeito e a dignidade da parturiente (OLIVEIRA; ELIAS; OLIVEIRA S., 2020).

Logo, para que isso sobrevenha, é essencial a assistência de um(a) Enfermeiro(a) Obstetra, pois este profissional além de ter conhecimento científico suficiente, é capaz de reconhecer cada mulher como ser único, que carrega sua própria cultura e concede diferentes significados à vivência do parto, à criação de vínculos, apoio, confiança e afeto, deixando-a ser protagonista durante sua parturição (VILELA et al., 2019).

Em vista disso, através de uma comunicação efetiva, entre o profissional e a parturiente, o enfermeiro consegue impulsionar a gestante para ser o sujeito principal durante o parto. Portanto, é necessário que os enfermeiros sejam capacitados e dispostos a terem iniciativas que respeitem a autonomia da mulher e a fisiologia do parto, além de estarem e serem preparados para qualquer variabilidade (VILELA et al., 2019).

De fato, o momento de parturição desencadeia vários sentimentos na mulher. Posto isso, os estudos de Almeida e Oliveira (2005) afirmam que durante o parto a mulher passa por diversos sentimentos, sejam eles positivos, como a alegria e o amor, como os negativos, à exemplo o medo, a insegurança e a dor. 
Por isso, o apoio do enfermeiro no momento do parto ajuda a minimizar o estresse emocional e o desconforto físico da mulher, já que o nascimento de um filho é uma experiência estressante para a mãe. Em razão disso, é necessária uma assistência individualizada e humanizada à parturiente (VILELA et al., 2019; ALMEIDA, OLIVEIRA, 2005).

Conforme o MS e outras instituições não governamentais, o enfermeiro é reconhecido como um profissional de formação abrangente que atua de forma humanizada proporcionando uma assistência que oferta segurança e conforto no cuidado a parturiente. Logo, em momentos no qual a mulher/parturiente se encontra ansiosa, sensível e fragilizada ela é extremamente necessária e faz toda diferença (MELO et al., 2018).

Segundo Tedesco e Junges (2013), existem algumas deficiências no acolhimento das pessoas surdas em ambientes de saúde. Em vista disso, essa deficiência não difere quando o atendimento é dirigido a gestantes surdas. Posto que, no momento de parturição, é indispensável uma escuta de qualidade frente às expectativas e necessidades da gestante, ou seja, nesta fase é extremamente importante ouvi-las (LOPEZ; OSORIO; BLANDÓN, 2020).

Enfatizando as necessidades específicas que as gestantes surdas possuem, Ferreira et al. (2019) expõem a dificuldade de comunicação com os profissionais de saúde, o desrespeito aos direitos da pessoa surda e a apreensão em relação a normalidade da função auditiva do seu bebê. Contudo, é conveniente a discussão sobre a qualidade da assistência prestada a esse público, já que, a profissão de enfermagem é a que mais consegue criar laços de empatia com os pacientes e suas famílias.

Logo, torna-se necessário incluir a LIBRAS na educação permanente, com o objetivo de gerar profissionais capacitados e reorientar os serviços de saúde quanto a importância em ofertar escuta qualificada às necessidades dos indivíduos surdos. Pois, de acordo com a Política Nacional de Humanização (PNH), é direito de qualquer cidadão ter uma equipe qualificada e bem treinada para cuidar dele e informá-lo sobre seu estado de saúde (TEDESCO; JUNGES, 2013; BRASIL, 2013). 


\title{
2.3. FORMAÇÃO EM ENFERMAGEM: DESAFIOS PARA UMA ASSISTÊNCIA INTEGRAL À PESSOA SURDA
}

De acordo com o Código de Ética dos Profissionais de Enfermagem (CEPE), todo enfermeiro possui compromisso com a saúde dos indivíduos e deve manter respeito aos princípios legais e éticos, sem nenhum tipo de preconceito. Os estudos de Silva, Chernichano e Ferreira (2011) relatam sobre alguns deveres do profissional de enfermagem e afirma que,

\begin{abstract}
é dever deste profissional cumprir e fazer cumprir os preceitos éticos e legais da profissão, exercer a enfermagem com justiça, competência, responsabilidade e honestidade, prestar assistência de enfermagem à clientela, sem discriminação de qualquer natureza, respeitar e reconhecer o direito do cliente e decidir sobre sua pessoa, seu tratamento e seu bem-estar (p. 309).
\end{abstract}

Ainda por cima, a enfermagem além de ser uma profissão generalista, critica, reflexiva e humanista, possui um perfil cientifico e intelectual baseado em princípios éticos. Ademais, a formação de enfermagem, segundo as DCN's, visa capacitar os egressos a atuarem como produtores da saúde integral do ser humano, tornando-os capaz de identificar a extensão biopsicossocial dos seus determinantes, de conhecer os problemas de saúde/doença e de intervir para estabelecer as melhores soluções (BRASIL, 2001).

De acordo com Giustina, Carneiro e Souza (2015), numa assistência de enfermagem à usuários surdos, a maioria dos profissionais desconhecem a linguagem utilizada por eles e/ou nem possuem o domínio básico da LIBRAS, pois a comunicação que os surdos utilizam não se enquadra na mesma estrutura lexical deles, deixando-os inseguros ao tentarem manter uma boa comunicação com essa população.

Logo, a dificuldade de comunicação entre o profissional e usuário surdo torna-se um fator preocupante. Trecossi e Ortigara (2013) declaram que a formação do enfermeiro no conhecimento da LIBRAS é essencial, pois dessa forma o profissional de enfermagem consegue estabelecer uma comunicação eficiente com os surdos e não somente assistir sua patologia. Entretanto, não é comum a formação de profissionais de saúde em LIBRAS (GIUSTINA; CARNEIRO; SOUZA, 2015).

Os estudos de Chaveiro e Barbosa (2005) afirmam que o comportamento nãoverbal empata a execução do vínculo entre profissional e cliente. Os autores ainda 
relatam que a dificuldade de comunicação entre profissionais da saúde e surdos é um dos grandes obstáculos da população surda ao procurar serviços de saúde, sendo que os surdos, como qualquer indivíduo, devem ser atendidos com respeito à suas diferenças, crenças e valores.

Trecossi e Ortigara (2013) comprovam que, conforme o CEPE e a Lei no 10.436, o enfermeiro possui o dever e o direito de obter formação em LIBRAS com o objetivo pautado em oferecer uma assistência de qualidade para todos os seus pacientes, inclusive aos surdos, já que a falta de habilidade com a LIBRAS é uma barreira para que isso sobrevenha.

Torna-se então, fundamental que as instituições formadoras adotem métodos de ensino e aprendizagem que ultrapassem o saber técnico/cientifico, afim de responder a imensa dimensão subjetiva de cada ser humano, sendo que, a capacitação dos profissionais da saúde em LIBRAS é uma necessidade de urgência, pois uma formação que considere a comunicação, a cultura surda, as noções básicas da língua e o posicionamento do profissional frente uma assistência ao surdo, garante o acesso aos cuidados de saúde para essa população (PEREIRA; BARROS; AUGUSTO, 2011; CHAVEIRO; BARBOSA; PORTO, 2008).

Nascimento et al (2016) aludem que o enfermeiro deve considerar todas as necessidades dos seus paciente de forma integral e continua. Os autores ainda afirmam que, baseado na literatura, este profissional é encarregado eticamente de abraçar e compreender as crenças e os valores de cada paciente ao estabelecer seu plano de cuidado. O paradigma holístico defende um cuidado que enfatize todas as necessidades do ser humano, buscando proporcionar conforto e satisfação aos pacientes (LEITE, 2019).

No entanto, a inexistência de uma comunicação efetiva pelos profissionais de saúde impossibilita a oferta de um cuidado biopsicosocioespiritual e uma assistência holística para essa população. Diante disso, os profissionais precisam aprender LIBRAS ou pelo menos uma boa parcela dela, para que consigam ofertar um atendimento humanizado através do desenvolvimento de novas habilidades comunicativas (FERREIRA et al., 2019; GIUSTINA; CARNEIRO; SOUZA, 2015).

Entretanto, de acordo com os estudos de Chaveiro e Barbosa (2005), na grade curricular dos cursos superior de enfermagem não há nenhuma disciplina que considere 
enfaticamente os direitos e as necessidades da saúde dos deficientes, o que se houvesse proporcionaria uma assistência humanizada e holística aos surdos.

Contudo, todo profissional de saúde deveria aprender LIBRAS nos seus cursos de graduação. Perante isso, calha às faculdades e aos profissionais da saúde a conduta do preparo para essa realidade, uma vez que se não há mudanças na formação dos profissionais de saúde, qualquer tentativa para reverberar positivamente a atividade profissional é desperdiçada (CHAVEIRO; BARBOSA, 2005; PEREIRA; BARROS; AUGUSTO, 2011).

\section{CONSIDERAÇÕES FINAIS}

Há dezenove anos a LIBRAS foi reconhecida legalmente no Brasil, no entanto, ela não é bem difundida no País devido o desinteresse das pessoas e pouca valorização da língua. Logo, percebe-se a carência educacional nessa área.

A implementação de uma disciplina de LIBRAS na graduação ajudaria a preparar melhor o enfermeiro em como agir diante dessa situação. É imprescindível que o papel do enfermeiro seja efetivamente desempenhado no que tange ao acolhimento, promovendo uma assistência integral e uma "escuta qualificada", que neste caso só será possível com o domínio do profissional na comunicação em LIBRAS, para assim enfrentar essa barreira de linguagem que há no acolhimento da pessoa surda, uma vez que este profissional é crucial na assistência a parturiente.

Dessa forma, o atendimento a pessoa surda deve ser realizado por profissionais capacitados para o uso da LIBRAS ou para tradução e interpretação. Portanto, o enfermeiro deve buscar esta qualificação, visando humanizar o atendimento ao paciente surdo e estabelecer uma maneira mais eficiente de assisti-lo, promovendo interação recíproca e garantindo uma assistência de qualidade baseada em todas as necessidades destes pacientes.

\section{REFERÊNCIAS}

ALMEIDA, N. A. M.; OLIVEIRA, V. C. Estresse no Processo de Parturição. Rev. Eletrônica de Enfermagem. v. 7, n. 1, p. 87-94. 2005. Disponível em: <http://www.revistas.ufg.br/index.php/fen>. Acesso em: 13 de março De 2021. 
BACKES, D. S. et al. O papel profissional do enfermeiro no Sistema Único de Saúde: da saúde comunitária à estratégia de saúde da família. Ciência \& Saúde Coletiva, v.17, n.1, p.223-230. 2012. Disponível em: <https://www.scielosp.org/article/csc/2012.v17n1/223-230>. Acesso em: 10 de abril de 2021.

BRASIL. Concelho Federal de Enfermagem. Decreto $n^{\circ}$ 94.406/87. Regulamenta a Lei $n^{\circ}$ 7.498, de 25 de junho de 1986, que dispõe sobre o exercício da Enfermagem, e dá outras providencias. Brasília, 09 de junho. 1987. Seção 1, p. 8.853-8.855. Disponível em: <http://www.cofen.gov.br/decreto-n-9440687_4173.html>. Acesso em: 10 de abril de 2021.

BRASIL. Lei no 10.436, de 24 de abril de 2002. Dispõe sobre a Língua Brasileira de Sinais - Libras e dá outras providências. Legislação citada anexada pela coordenação de estudos legislativos - cedi. Brasília, 24 de abril de 2002a. Disponível em: <https://www.udesc.br/arquivos/udesc/documentos/Lei_n_10_436_de_24_ de_abril_de_2002_15226896225947_7091.pdf>. Acesso em: 06 de março de 2021.

BRASIL. Decreto no 5.626, de 22 de dezembro de 2005. Regulamenta a Lei no 10.436, de 24 de abril de 2002, que dispõe sobre a Língua Brasileira de Sinais - Libras, e o art. 18 da Lei no 10.098, de 19 de dezembro de 2000. Legislação citada anexada pela coordenação de estudos legislativos - cedi. Brasília, 24 de abril de 2002b. Disponível em: <https://www.udesc.br/arquivos/udesc/documentos/Lei_n_10_436_de_24_ de_abril_de_2002_15226896225947_7091.pdf>. Acesso em: 06 de março de 2021.

BRASIL. Ministério da Mulher, da Família e dos Direitos Humanos. Secretaria Nacional dos Direitos da Pessoa com Deficiência. Estabelece os direitos de pessoas surdas e com deficiência auditiva. Diretos da pessoa Surda, p. 1-6, 2019. Disponível em: $<$ https://www.librasol.com.br/ministerio-lanca-cartilha-sobre-direitos-depessoas-surdas/>. Acesso em: 25 de março de 2021.

BRASIL. Ministério da Educação. Resolução CNE/ CES № 3, de 7 de novembro de 2001. Secretaria de Educação Superior. Institui as diretrizes Curriculares para os Cursos de Graduação em Enfermagem. Disponível em: http://portal.mec.gov.br/cne/arquivos/pdf/Enf.pdf Acesso em: 13 de março de 2021.

BRITTOS, E.; SILVEIRA, Z. M. Os Desafios Na Inclusão Social Dos Surdos Que Dispõem Da Língua Brasileira De Sinais - Libras Em Sua Comunicação. Rev. do Curso de Pedagogia-UNESC-Saberes Pedagógicos, Criciúma, v. 4, n. 3, p. 87-106, setembro/dezembro 2020. Disponível em: <http://periodicos.unesc.net/pedag/article/view/6201>. Acesso em: 25 de março de 2021. 
CAMPOS, C. B. Inclusão Social: Contribuições do Enfermeiro na Assistência de Saúde ao Surdo. 2020. 46f. TCC (Graduação) -Bacharelado em Enfermagem, Faculdade de Educação e Meio Ambiente (FAEMA), Ariquemes/RO, 2020. Disponível em: <http://repositorio.faema.edu.br/handle/123456789/2887>. Acesso em: 23 de março de 2021.

CHAVEIRO, N.; BARBOSA, M. A. Assistência ao surdo na área de saúde como fator de inclusão social. Rev. da Escola de Enfermagem da USP, São Paulo, v. 39, n. 4, p. 417-422. Julho, $2005 . \quad$ Disponível em: <https://www.scielo.br/pdf/reeusp/v39n4/06.pdf>. Acesso em: 18 de abril de 2021.

CHAVEIRO, N. C.; BARBOSA, M. A.; PORTO, C. C. Revisão de literatura sobre o atendimento ao paciente surdo pelos profissionais da saúde. Rev. da Escola de Enfermagem da USP, São Paulo, v. 42, n. 3, p. 578-583. 2008. Disponível em: <https://www.scielo.br/pdf/reeusp/v42n3/v42n3a22.pdf>. Acesso em: 18 de abril de 2021.

DALL' ALBA, C. Movimentos Surdos e Educação: Negociação da cultura surda. 2013. $94 \mathrm{f}$. Tese (doutorado) - Centro de Educação, Programa de Pós-graduação em Educação, Universidade Federal de Santa Maria, RS, 2013. Disponível em: <https://repositorio.ufsm.br/bitstream/handle/1/7063/DALL\%20ALBA\%2c\%20 CARILISSA.pdf?sequence=1\&isAllowed=y>. Acesso em: 23 de março de 2021.

DA LUZ, R. C. F. V.; MOURA, H. A. C. Libras na Graduação: um relato de experiência. In: I Congresso Brasileiro Saúde em Libras, n. 1. 2018, Juazeiro-BA. Anais do I Congresso Brasileiro Saúde em Libras. Juazeiro: UNIVASF 2018, p. 43-44. Disponível em: <http://www.univasf.edu.br/ tcc/000013/00001392.pdf>. Acesso em: 27 de março de 2021.

FERREIRA, D. R. da C. et al. Assistência à gestante surda: barreiras de comunicação encontradas pela equipe de saúde. Saúde em Redes, Pernambuco, v. $5, n$. $3, p$. 31-42. 2019. Disponivel em: <hp://dx.doi.org/10.18310/24464813.2019v5n3p3142>. Acesso em: 13 de abril de 2021.

FLORES, C. A. da S.; ALMEIDA, P. B.; JUNIOR, E. M. Investigação e Documentação Histórica da Enfermagem na Região Norte do Estado de Mato Grosso - Brasil. História da enfermagem Rev. eletrônica [Internet]. v. 8, n. 1, p. 18-26. 2017. Disponível em: <https://pesquisa.bvsalud.org/portal/resource/pt/bde-32306>. Acesso em: 10 de abril de 2021.

GIUSTINA, D. P. F.; CARNEIRO, N. M. D.; SOUZA, M.R. A Enfermagem e a Deficiência Auditiva: assistência ao surdo. Revista de Saúde da Faciplac. Brasília, v. 2, n. 1, jan - Dez 2015.2 Disponível em: <http://revista.faciplac.edu.br/index.php/RSF/article/view/101>. Acesso em: 06 de março de 2021. 
KRAUSE, K.; KLEIN, A. F. Políticas Públicas Para Surdos: os pontos legais e críticos na acessilidade. In: V Seminário Internacional de Direitos Humanos e Democracia, e. 2017, Rio Grande do Sul. Seção Fundamentos e Concretização dos Direitos Humanos, Rio Grande do Sul: Universidade Regional do Noroeste do Estado do Rio Grande do Sul (UNIJUI), 2018, p. 1-13. Disponível em: <https://www.publicacoeseventos.unijui.edu.br/index.php/direitoshumanosed emocracia/article/view/9042>. Acesso em: 23 de março de 2021.

LEITE, M. M. Abordagem holística na formação de enfermeiras. 2019. 97f. Dissertação (Mestrado em Educação nas Profissões da Saúde) - Pontifícia Universidade Católica de São Paulo, Sorocaba-SP, 2019. Disponível em: <https://tede2.pucsp.br/handle/handle/22697>. Acesso em: 19 de abril de 2021.

LOPEZ, C. P.; OSORIO, S. P.; BLANDÓN, D. A. Relación entre el personal de enfermería y las gestantes durante el trabajo de parto. Rev. Ciência \& Cuidado, CútutaColombia, v. 17, n. 1, p. 71-84. Ene-Abr, 2020. Disponível em: <https://doi.org/10.22463/17949831.1636>. Acesso em:11 de abril de 2021.

MELO, A. A. P. et al. Atuação do enfermeiro no parto humanizado. Revista Científica Eletrônica de Enfermagem da FAEF. Ano 1, v. 1, n.1, p. Junho, 2018. Disponível em:

<http://faef.revista.inf.br/imagens_arquivos/arquivos_destaque/ClaOegJjJw8ly xQ_2018-7-26-10-46-43.pdf >. Acesso em: 13 de março de 2021.

MUNOZ-BAELL, I. M. et al. Comunidades sordas: ¿pacientes o ciudadanas? Elsevier España, S.L. Gac Sanit, v. 25, n. 1, p. 72-78, 2011. Disponível em: <https://www.researchgate.net/publication/238000194_Comunidades_sordas _pacientes_o_ciudadanas>. Acesso em: 22 de março de 2021.

NASCIMENTO, I. Acesso à saúde e os direitos das pessoas surdas: uma revisão bibliográfica. 2019. 67f. Monografia (Graduação em Saúde Coletiva) - Instituto de Estudos em Saúde Coletiva, Universidade Federal do Rio de Janeiro, Rio de Janeiro, 2019. Disponível em: <https://pantheon.ufrj.br/handle/11422/6842>. Acesso em: 25 de março de 2021.

NASCIMENTO, L. C. et al. Atenção às necessidades espirituais na pratica clínica de enfermeiros. Aquichan, Colômbia, v. 16, n. 2, p. 179-192, 2016. Disponível em: <https://www.redalyc.org/jatsRepo/741/74146013006/html/index.html>. Acesso em: 19 de abril de 2021.

NASCIMENTO, V. A. S. et al. A Importância Do Ensino De Libras Como Disciplina Nos Cursos De Saúde. In: I Congresso Brasileiro Saúde em Libras, n. 1. 2018, JuazeiroBA. Anais do I Congresso Brasileiro Saúde em Libras. Juazeiro: UNIVASF 2018, p. 36-37. Disponível em: <http://www.univasf.edu.br/ tcc/000013/00001392.pdf>. Acesso em: 27 de março de 2021. 
OLIVEIRA, G. L. et al. A Importância da Língua Brasileira de Sinais - (Libras) na Grade Curricular: um relato de experiência. In: I Congresso Brasileiro Saúde em Libras, n. 1. 2018, Juazeiro-BA. Anais do I Congresso Brasileiro Saúde em Libras. Juazeiro: UNIVASF 2018, p. 61-62. Disponível em: <http://www.univasf.edu.br/ tcc/000013/00001392.pdf>. Acesso em: 27 de março de 2021.

OLIVEIRA, M. R. R.; ELIAS, E. A.; OLIVEIRA, S. R. Women And Delivery: Meanings Of Violence And The Obstetric Nursing Approach. Journal of Nursing UFPE on line. 2020, v.14, e243996. Disponível em: <https://doi.org/10.5205/19818963.2020.243996>. Acesso em: 09 de abril de 2021.

PEREIRA, T. T. S. O.; BARROS, M. N. dos S.; AUGUSTO, M. C. N. de A. O Cuidado em Saúde: o paradigma biopsicossocial e a subjetividade em foco. Mental, Barcelona, v. 9, n. 17, p. 523-536, dezembro, 2011. Disponível em: $<$ http://pepsic.bvsalud.org/scielo.php?script=sci_arttext\&pid=S167944272011000200002\&lng=pt\&nrm=iso>. Acesso em: 19 de abril de 2021.

REIS V. S. L.; SANTOS A. M. Conhecimento e experiência de profissionais das Equipes de Saúde da Família no atendimento a pessoas surdas. Rev. CEFAC, Bahia, v. 21, n. 1, p. 1-8, e. 5418, 2019 Disponível em: <http://dx.doi.org/10.1590/19820216/20192115418>. Acesso em: 23 de março de 2021.

RONDELLI, G. P. H. Competências para o Cuidado de Mulheres no Parto e Nascimento Mobilizadas em Egressos de um Curso Nacional de Especialização em Enfermagem Obstétrica. 2019. 95f. Dissertação (Mestrado)-Escola de Enfermagem, Universidade Federal de Minas Gerais, Belo Horizonte, 2019. Disponível em: <https://pesquisa.bvsalud.org/portal/resource/pt/biblio1007720>. Acesso em: 10 de abril de 2021.

SILVA, F. D.; CHERNICHANO, I. M.; FERREIRA, M. A. Humanização e Desumanização: a dialética expressa no discurso de docentes de enfermagem sobre o cuidado. Esc. Anna Nery (impr.), v. 15, n. 2, p. 306-313, abr-jun. 2011. Disponível em: $<$ https://www.scielo.br/scielo.php?script=sci_arttext\&pid=S141481452011000200013>. Acesso em: 19 de abril de 2021.

STOLARSKI, C. V.; TESTON, V.; KOLHS, M. Conhecimento da Equipe de Enfermagem sobre suas Atribuições Legais. REME - Rev. Min. Enfermagem, v.13, n.3, p. 321-326, jul./set., 2009. Disponível em: <http://www.reme.org.br/artigo/detalhes/196>. Acesso em: 10 de abril de 2021.

TEDESCO, J. R.; JUNGES, J. R. Desafios da prática do acolhimento de surdos na atenção primária. Cad. Saúde Pública, Rio de Janeiro, v. 29, n. 8, p. 1685-1689, agosto de 2013. Disponível em: <http://dx.doi.org/10.1590/0102-311X00166212>. Acesso em: 25 de março de 2021. 
TRECOSSI, M. O.; ORTIGARA, E. P. de F. Importância e Eficácia das Consultas de Enfermagem ao Paciente Surdo. Revista de Enfermagem, FW, v. 9, n. 9, p. 60-69. 2013.

$<$ http://revistas.fw.uri.br/index.php/revistadeenfermagem/article/view/938/16 61>. Acesso em: 18 de abril de 2021.

VILELA, A. T. et al. Percepção dos Enfermeiros Obstetras Diante do Parto Humanizado. Rev. de Enfermagem UFPE [online]. 2019, v.13:e211480 Disponível em: <https://doi.org/10.5205/1981-8963.2019.241480>. Acesso em: 09 de abril de 2021. 


\title{
CAPÍTULO XIII
}

\section{O ENSINO REMOTO NA FORMACÃO EM ENFERMAGEM: DISCUTINO ASPECTOS HISTÓRICOS PARA RESSIGNIFICAR PROCESSOS EM TEMPOS DE PANDEMIA}

\author{
Karolaine Bezerra da Silva ${ }^{1}$ \\ João Paulo Xavier Silva ${ }^{2}$ \\ Fernanda Thayná de Souza Pinheiro ${ }^{3}$ \\ Kerma Márcia de Freitas 4 \\ Rafael Bezerra Duarte ${ }^{5}$
}

\begin{abstract}
1 Acadêmica de enfermagem pelo Centro Universitário Vale do Salgado - UNIVS
2 Enfermeiro. Professor no curso de enfermagem do Centro Universitário Vale do Salgado - UNIVS. Doutorando em Cuidados Clínicos em Enfermagem e Saúde pela Universidade Estadual do Ceará - UECE

${ }^{3}$ Enfermeira. Residente em Saúde da Família e Comunidade pela Escola de Saúde do Ceará - ESP /CE.

${ }^{4}$ Enfermeira. Coordenadora do curso de enfermagem do Centro Universitário Vale do Salgado - UNIVS. Mestre em Saúde Coletiva. Doutoranda em Saúde Coletiva pela Universidade de Fortaleza - UNIFOR.

${ }^{5}$ Enfermeiro. Professor no curso de enfermagem do Centro Universitário Vale do Salgado - UNIVS. Mestrando em Saúde Coletiva pela Universidade Estadual do Ceará - UECE
\end{abstract}

\section{RESUMO}

Na profissão da enfermagem, deve-se ter um domínio teórico-prático voltado para o cuidado em saúde. Mostra-se na formação importância em compreender a história e os aspectos fundamentais da profissão, para isso é ofertada uma ampla grade curricular que visa às necessidades de saúde nos diferentes cenários e ciclos de vida. O presente estudo objetiva discutir aspectos históricos da formação em enfermagem e as inferências causadas pela mudança emergencial para o modelo de ensino remoto. 0 ensino da enfermagem se apresenta com uma variação de modalidades e metodologias, dentre eles: o ensino presencial que é o mais utilizado e indicado na área da saúde, bem como a oferta do ensino à distância (EAD) do tipo semipresencial, que causa muitas controvérsias em relação a área da saúde e temos o ensino remoto que foi adotado em 2020 de maneira emergencial por causa da pandemia por COVID-19. Na atualidade, é notório a imprescindibilidade da adesão da metodologia de ensino remoto como um modo de minimizar os danos que uma paralisação completa do ensino ou continuidade do ensino de forma presencial poderia causar para a enfermagem.

Palavras-chave: Formação em enfermagem. Ensino remoto. Pandemia por COVID-19. 


\section{INTRODUÇÃO}

Na contemporaneidade, o processo de formação em enfermagem passa por constantes desafios que visam uma boa qualificação dos enfermeiros. Dentre os marcos político-legais que tratam dessa formação e tentam superar desafios nesse contexto estão a Lei do Exercício Profissional de Enfermagem de 1986, a Lei de Diretrizes e Bases da Educação Nacional (LDB) de 1996 e as Diretrizes Curriculares Nacionais (DCN) de 2001 (SILVA et al., 2012).

Esses marcos são de suma importância para a consolidação de uma formação em enfermagem cientificamente respaldada e com domínio teórico prático no cuidado em saúde. É nessa perspectiva que se percebe a necessidade de regulamentar a atuação do profissional de enfermagem através do melhor modelo de ensino (SILVA et al., 2012).

Em complementaridade, as DCN colocam que a formação do profissional de enfermagem deve considerar as necessidades de saúde da população, tendo em foco a integralidade da atenção e a qualidade e humanização do atendimento. Contendo uma ampla grade curricular com conteúdo teóricos, prático e articulação teórico-prática, além da obrigatoriedade do estágio supervisionado (BRASIL, 2001).

Nesse contexto, é importante ressaltar a necessidade de uma formação presencial, considerando que o ato de cuidar é a principal ferramenta de trabalho do enfermeiro e deve se dá presencialmente. Dessa forma, o ensino de enfermagem é regulamentado para ocorrer de maneira presencial, porém também existem instituições oferecendo a modalidade de ensino à distância $(E a D)$ do tipo ensino semipresencial (COFEN, 2017).

O EaD é uma modalidade educacional que aborda uma forma didáticopedagógica no processo do ensino que usa de meios e tecnologias de informação e comunicação. As atividades presenciais são reduzidas e substituídas por atividades semipresenciais com tutoriais, avaliações, estágios e práticas em uma proporção inferior (BRASIL, 2017).

Apesar dos autores afirmarem que a modalidade EaD é inovadora, se faz necessário refletir sobre o assunto no campo da formação em enfermagem. Considerando-se que existem prós e contras nesta metodologia, tendo em vista que na 
realidade do cuidado e saúde deve haver competências e habilidades voltadas a uma relação interpessoal, que não se estabelecem à distância (SILVA et al., 2015).

Sob outra perspectiva, o ensino remoto é aquele no qual existem atividades síncronas, permitindo que ocorra interação entre o professor e os acadêmicos, em tempo real, podendo com isso ter um aprendizado dinâmico, com troca de experiências e não é reduzindo o quantitativo de carga horária prática e de estágios (OLIVEIRA et al, 2020).

No cenário de pandemia Covid-19, a metodologia acima apresentada possui forte impacto, pois se fez necessário reajustar o modelo formativo presencial para o modelo remoto, considerando as orientações das autoridades sanitárias de isolamento social. A Covid-19 é uma doença infecciosa causada pelo novo coronavírus que possui alto poder transmissível e põe em risco a vida de acadêmicos no modelo de ensino presencial (OLIVEIRA et al, 2020).

Levando-se em consideração que o ensino remoto possui peculiaridades, como acesso à internet, ambiente tranquilo na residência e capacidade de organização e gestão de tempo, entende-se que as necessidades para uma formação em enfermagem adequada nessa nova forma de ensino merecem atenção no campo de pesquisa. Desse modo, questiona- se: Qual a importância da história da enfermagem em sua formação? Quais os aspectos fundamentais na formação em enfermagem? Quais as implicações do ensino remoto na formação em enfermagem?

Assim, esse estudo torna-se relevante por construir uma análise teórica que aponta peculiaridades inerentes ao ensino remoto na formação em enfermagem. Possibilitando elucidar aspectos pouco discutidos na literatura, porém que guardam importância para a formação em enfermagem. Objetiva-se com esse estudo discutir aspectos históricos da formação em enfermagem e inferências causadas pela mudança emergencial para o modelo de ensino remoto. 


\section{REVISÃO BIBLIOGRÁFICA}

\subsection{ENFERMAGEM: COMPREENDENDO SUA HISTORICIDADE E ASPECTOS FUNDAMENTAIS}

A atuação de profissionais da saúde se situa em várias etapas da história humana de antes, durante e após a idade média, sempre se adaptando e evoluindo com o tempo. $\mathrm{Na}$ antiguidade, deve-se rememorar que a doença era interpretada como castigo divino, fazendo com que os cuidados de saúde na época assumissem uma conotação espiritual em conjunto com os cuidados corporais. Dessa forma, a enfermagem possui sua gênese atrelada à religião, o que constituiu uma imagem de subserviência às ordens dos sacerdotes e médicos. Nesse mesmo contexto, houve uma associação entre o cuidar da enfermagem vinculado à mulher e aos cuidados domésticos, enquanto o curar da medicina se vinculou a figuras masculinas (WIGGERS; DONOSO, 2020).

Os registros históricos apontam que mulheres, independente de classe social ou etnia fizeram parte da origem da profissão. Deve-se relembrar o contexto político e social de cada época, principalmente para se ter uma ideia das condições de trabalho e as dificuldades para se ter uma aprimoração ocupacional. No contexto do passado da história da enfermagem, pode-se dizer que as práticas da profissão eram fundamentadas na intuição e no senso comum (BORGES et al., 2000).

Genericamente, a enfermagem teve a experiência de três momentos que se destacam em sua evolução, que são as fases empírica, evolutiva e de aprimoramento, iniciando-se com os cuidados simples e as práticas baseadas em experiências leigas, atingindo um maior aprimoramento no século XIX com Florence Nightingale. A enfermagem foi sendo influenciada no decorrer dos anos por diferentes contextos, socioeconômico e político, fazendo com que aconteça uma reformulação da imagem profissão de enfermagem (SOUSA et al., 2010).

Desse modo, a história da enfermagem muitas vezes se confunde com a história das mulheres, pois estas contribuíram bastante para a transformação e consolidação desse campo profissional. Nesse processo, a enfermagem enfrentou diversos desafios ao longo da história, dentre eles a construção da sua identidade profissional, o 
reconhecimento no espaço de trabalho e a valorização social (PADILHA; BORENSTEIN, 2006).

Em um breve resgate histórico, visualiza-se que a formação em enfermagem também vem atravessando constantes mudanças, atreladas aos aspectos supra indicados. Nesse resgate, identifica-se no século XIX a criação de um ensino sistematizado, no qual a matriz curricular teve como base o modelo francês voltado aos cuidados básicos. Sequencialmente no século XX, tem-se a criação de um curso voltado para atendimento hospitalar, orientado por enfermeiras (SILVA et al., 2010).

No contexto brasileiro, temos como principais marcos o início de um curso de enfermagem em torno de 1916, pela Cruz Vermelha, onde se tinha como foco preparar os voluntários para as emergências de guerra. Sete anos após, surge no país a primeira escola de Enfermagem no Rio de Janeiro, a Escola Ana Nery. Isso trouxe a perspectiva da formação Nightingaleana, baseada na enfermagem moderna (SILVA et al., 2010).

Florence Nightingale (1820-1910) é considerada a edificadora da enfermagem moderna. Ela proporcionou uma transformação no conceito de enfermagem da época, formando o que hoje se tem como a Enfermagem Moderna. Assim, preconizou uma identidade profissional singular com a associação em termos rituais e simbologia, disciplina e poder. Florence propunha uma visão objetiva que tinha como prioridade o fornecimento de um ambiente que estimula o desenvolvimento da saúde no paciente, e isso seria um diferencial para a recuperação dos doentes, esses são dogmas que asseguram a sua Teoria Ambientalista (HADDAD; SANTOS, 2011).

A Teoria Ambientalista foi fundamentada por Florence na segunda metade do século XIX, durante a guerra da Crimeia. Essa teoria aborda o ambiente na questão do cuidado, pois Florence percebeu que o meio externo interferia diretamente no processo de recuperação dos soldados feridos. Com uma ampla percepção pôde se observar que quando ia se tomando medidas para reduzir a infecção, reduzia-se o número de mortos. Essa é uma teoria que pode se dizer usual é sempre atual, com aplicabilidade na enfermagem, e que contém conceitos fundamentais (BEZERRA et al., 2018).

Ademais, Florence trouxe um lugar para um modelo científico na enfermagem, deste modo trazendo uma sistematização no campo de conhecimento, uma nova arte e nova ciência, enfatizando a importância de uma educação formal, organizada e científica. A enfermagem vem se fortalecendo e evoluindo enquanto ciência, juntando 
os estudos contemporâneos, com a gradativa inquietação em explorar e justificar o cuidado como essência da profissão, do ensino e da prática em enfermagem (SANTO; PORTO, 2006).

Nessa perspectiva, a enfermagem tem se consolidado como ciência e arte, mesmo sendo um desafio perante outras áreas de conhecimento. Tem-se pela origem das palavras derivadas do latim que ciência é o conhecimento e a arte é a habilidade, as duas aliadas permitem que se haja uma competência técnica com dignidade, ética, compaixão e individualização dos cuidados. O cuidar em si acarreta reconhecer que o ser humano tem uma multidimensionalidade e assim colocar em prática a ciência e a arte (SILVA, 2012).

Teoricamente, o que diferencia o profissional de enfermagem dos outros profissionais de saúde é a construção de uma identidade própria que situa a profissão no cenário do cuidar em conjunto com uma realização técnica, tendo assim o cuidado como essência e justificativa para as competências e habilidades dos profissionais de enfermagem. Na prática, mesmo que se aceite o cuidar como essencial, tem-se uma forte resistência para atuar como cuidador. Deve-se acontecer um resgate do valor do cuidado sem desconsiderar ou negligência o valor das técnicas e/ou tecnologias que atravessam esse contexto (OGUISSO; FREITAS, 2016).

Assim, pode-se inferir que o cuidado é o primeiro sinal de existência e o eixo da profissão de enfermagem. Deve-se aderir ao cuidado no panorama ontológico da sua existência, deste modo desenvolvendo o exercício da profissão humano e solidário, para além das técnicas. A enfermagem em sua assistência tem a possibilidade de estabelecer o que caracteriza o cuidado, utilizando uma linguagem na interação humana que expressa seu saber e sua intenção perante a compreensão do outro como um todo (SANTOS et al., 2017).

Todas as áreas têm um padrão para a criação do seu conhecimento específico e para o domínio dele, na Enfermagem não é diferente. As teorias na/de enfermagem são de exímia importância para o conhecimento na área, principalmente para se utilizar na prática. Esse vínculo entre teoria e a prática é um caminho que deve ser percorrido, tendo-se o ideal práxis. E utilizando-se disto para um melhor desempenho para prestar uma assistência na prática profissional (BARROS et al., 2015; GRACIA; NÓBREGA, 2004). 
No contexto brasileiro, a profissão de enfermagem foi legalizada para o exercício por intermédio da Lei $\mathrm{n}^{\circ}$ 2.604/1955, que regulamenta o exercício de Enfermagem, define algumas atribuições da profissão, bem como relatar as categorias que poderiam exercê-la. Em meados de 1958, deu-se o surgimento Código de Ética da Associação Brasileira de Enfermagem assim denominado o primeiro código de ética da profissão, que aconselhava sua realização de acordo com Associação Brasileira de Enfermagem (ABEn), que não possuía autoridade legal para fiscalizar (COSTA; GERMANO; MEDEIROS, 2014).

Os autores ainda relatam que por meio de lutas feitas pela ABEn posteriormente veio a criação por meio da Lei 5.905/1973 dos Conselhos Federal e Regionais (COFEN e CORENs). Estes órgãos vieram para impulsionar a valorização e moralização da profissão, além de defender a sua legalidade e seus princípios. Uma discussão sobre a legislação do exercício profissional veio com o COFEN, dando-se origem à Lei $\mathrm{n}^{\circ}$ 7498/1986 que é utilizada atualmente, para a regulamentação da profissão e dá outras providências, evoluindo referente às diferentes categorias da profissão a definição de suas competências.

Nesse panorama, é possível compreender a historicidade da enfermagem ao longo dos anos e aspectos fundamentais que estiveram relacionados à profissão e que, até hoje, repercutem em sua estruturação. Faz-se necessário, adicionalmente, compreender de maneira mais pormenorizada como se dá o ensino de enfermagem para, desse modo, relacioná-lo à execução das atividades que fazem parte dessa profissão.

\subsubsection{ENSINO DE ENFERMAGEM E A IMPORTÂNCIA DA FORMAÇÃO PRESENCIAL}

No âmbito da formação profissional em enfermagem, a Lei Federal no. 5.540, de 28 de novembro de 1968 denominada Lei de Diretrizes e Bases para Educação Superior regulamentava a educação de nível superior com um modelo metodológico misto, devendo ser constituído por disciplinas obrigatórias e eletivas, dispondo de uma matriz curricular mínima, com assuntos aparentemente desvinculados entre si. Essa lei ficou em vigor até se aprovar a LDB pela Lei Federal no. 9.394, de 20 de dezembro de 1996 (FERREIRA; NASCIMENTO, 2017). 
A LDB inovou em relação à anterior propondo uma expansão do ensino superior, também proporcionando uma maneira mais profícua de organização da matriz curricular. No contexto da formação em enfermagem, essa vinha se expandindo exponencialmente desde o início da década de 90, fazendo-se necessário rever o modelo de ensino vigente, no intuito de atender as demandas sociais e das novas políticas de saúde (MISSIO; LOPES; RENOVATO, 2011).

Nesse cenário, a ABEn por meio dos Seminários Nacionais de Educação de Enfermagem (SENADEn) tem desde 1994 abordado temas relacionados à formação de enfermagem, encontrando com a nova LDB um território fértil para instigar debates relevantes sobre a formação em enfermagem. Por intermédio destes foi percebida uma necessidade de reestruturação da formação, extinguindo a matriz curricular mínima e estabelecendo desta forma novas diretrizes curriculares que potencializam o processo formativo na enfermagem (XAVIER; BAPTISTA, 2010).

Assim, as DCNs vieram como uma mudança para a formação em saúde, sendo repercutidas na elaboração de uma proposta pedagógica que implicou em um compromisso ético-social com a educação e com a saúde. As Diretrizes Curriculares Nacionais do curso de Enfermagem (DCN/ENF) foram aprovadas pelo Conselho Nacional de Educação, através da Resolução CNE/CES №. 3 de 2001, estabelecendo orientações para se elaborar o currículo base da graduação em enfermagem. A implementação da mesma exigiu/exige alteração no processo de formação no que se almeja para um profissional capacitado e qualificado para o atendimento em consonância às necessidades em saúde da população (FERREIRA; NASCIMENTO, 2017; KLOH; LIMA; REIBNITZ, 2014).

As DCN/ENF correspondem assim a um documento que consolida características que auxiliam na formulação das estratégias de ensino com vistas a uma formação de excelência. Esboçam um perfil profissional que direciona para uma formação abrangente, humanista, crítica e reflexiva. Para isso, aborda competências e habilidades gerais que se direcionam para promoção dos conhecimentos exigidos na atenção à saúde. Desse modo, as DCN/ENF apresentam 33 competências e habilidades específicas que são traçadas na compreensão do discente como sujeito do seu processo (FERNANDES; REBOUÇAS, 2013). 
Faz-se presente também a indicação de conteúdos essenciais por meio de eixos temáticos, além da obrigatoriedade do Estágio Curricular Supervisionado em vários campos, buscando uma assimilação teórico-prática. Ademais, tem-se o estímulo para as Atividades Complementares, com o interesse de um desenvolvimento formativo que ultrapasse os muros da universidade. Genericamente, a organização curricular mostra a importância de métodos que associam o saber (teoria), o saber fazer (prática) e o saber conviver (competência/práxis). (FERNANDES; REBOUÇAS, 2013).

Assim, pode-se inferir que o ensino de enfermagem no Brasil é fundamentalmente regido pela LDB e pelas DCNs, o que aponta para a necessidade de uma configuração contemporânea da profissão, que se adeque às questões e necessidades sociais e possa se desenvolver no âmbito do Sistema Único de Saúde (SUS). Atentando-se às características do SUS como prioridade nos atos de promoção e prevenção, tendo a atenção básica de nível primário como nível de atenção majoritário e indispensável (MAGNAGO; PIERANTONI, 2020).

É nesse entendimento que o modelo de ensino de enfermagem no Brasil vem se adaptando à realidade do país em suas múltiplas peculiaridades, no cenário político, econômico e social. Devendo seguir com foco na necessidade e realidade socioepidemiológica da sociedade contemporânea (PAVA; NEVES, 2011).

Consoante a isso, há uma gama de desafios que precisam ser enfrentados. Entre eles, temos a necessidade de formar profissionais aptos para atuar de forma crítica e reflexiva. Além disso, urge a necessidade de se consolidar uma matriz curricular que foque no ser humano, valorizando suas multidimensionalidades e não somente aspectos tecnicistas e fragmentadores do sujeito. Observa-se também a necessidade de uma formação que desenvolva no acadêmico de enfermagem habilidades administrativas, gerenciais e em tecnologias de modo geral, considerando que são campos de atuação significativa para a profissão. Para que isso seja possível, faz-se necessário uma quebra do paradigma metodológico tradicional de ensino (LESSMANN et al., 2012).

Em contrapartida, o mesmo autor menciona, ainda, que também existem potencialidades na formação da enfermagem brasileira e de interesse formativo em um âmbito global, para vivenciar às inevitáveis transformações sociais, bem como a permanente interlocução teórico-prática, nas vivências extramuros e estágios, o que fomentam uma assimilação entre o saber e fazer, trocando experiências empíricas 
durante a aprendizagem, fazendo um elo para a prática profissional no próprio espaço de cuidado.

Assim, elucida-se a necessidade de uma articulação permanente entre teoria e prática no ensino de enfermagem, o que vem a corroborar com a consolidação de uma atuação profissional implicada nas reais carências dos usuários nos serviços de saúde. Para isso, a formação deve se dar em ato, ou seja, no contato direto entre estudantes, professores, profissionais e usuários (OLIVEIRA, V.; GAZZINELLI; OLIVEIRA, P., 2020).

Nesse contexto, o ensino presencial, mostra-se importante por garantir uma aproximação entre os atores envolvidos seja no processo de formação, seja no campo assistencial onde se vivencia a realidade do cuidado em saúde. É desse modo que o ensino presencial oportuniza experiências. Vale ressaltar que no âmbito do ensino, o espaço em si é uma linguagem poderosa que auxilia no processo de aprendizagem e possibilita a consolidação de relações interpessoais de troca e atuação ativa (KENSKI, 2010).

No contexto da enfermagem o ensino presencial é de suma importância por haver uma necessidade de contato humano básico e uma disponibilidade real por parte dos professores, criando uma aproximação entre docentes-discentes. Além de ter uma troca de vivências entre todos os envolvidos, que levam a uma forma de aprendizagem com abordagem associativa de implicações não somente de aprendizado, mas também socioafetivas (GUEDES; OHARA; SILVA, 2012; OLIVEIRA, V.; GAZZINELLI; OLIVEIRA, P., 2020).

Sob outra perspectiva, vivencia-se na contemporaneidade uma verdadeira transformação nos formatos pedagógicos que dão espaço aos ambientes virtuais. O EaD vem tomando espaço como forma de ensino no Brasil e no mundo, em meio ao crescimento da era da informação e da tecnologia. Ainda que apresente diversas variáveis tanto positivas como negativas, existe uma gama de cursos de nível superior que são ofertados em EaD, inclusive cursos na área da saúde (VERMELHO, 2014).

Entende-se por EaD como um método de ensino que é desenvolvido fazendo a utilização de estratégias, ferramentas e tecnologias digitais que mostram muitas vezes um bom custo-benefício. Porém, no campo de formação em enfermagem, essa modalidade merece uma atenção especial por ser a enfermagem uma profissão que demanda o exercício da prática. Questiona-se sobre de qual modo essa forma de ensino 
pode capacitar o profissional de maneira eficiente para atuar na realidade (RABEH et al., 2017; SILVA et al., 2015).

Diversos debates abordam sobre o risco que o EaD pode trazer para a formação em enfermagem e em alguns casos para a saúde pública. O exercício da enfermagem como profissão requer executar procedimentos complexos, o que demanda o estabelecimento de relações presenciais. Indaga-se a sua capacidade de formar profissionais com habilidades, competências e atitudes que deverão ser desenvolvidas presencialmente (COREN-RO, 2017).

Em paralelo, deve-se mencionar o ensino remoto que é uma modalidade distinta da EaD, utilizando-se de web conferências para se transmitir aulas em tempo real, podendo assim acontecer uma mediação ao vivo do professor, contato direto com os docentes, preparo das aulas por mestres e doutores e manutenção da carga horária prática presencial, desta forma tanto discente como docentes podem se organizar de maneira semelhante ao modelo presencial. Além de trazer auxílio mais amplo de professores no processo, o ensino remoto articula atividades síncronas (em tempo real) e assíncronas (gravadas), usado de diversos recursos que garantem a assistência docente e instigam a autonomia do estudante (ARRUDA, 2020; MINHA BIBLIOTECA, 2020).

Nesse panorama, entende-se que dentre os modelos, o ensino presencial é o que mais se adequa a formação em enfermagem. Pois esse modelo conforma as vantagens de se ter contato com atividades e vivências necessárias. No que se refere às aulas práticas, é reconhecida a necessidade de que ocorram presencialmente, possibilitando discussão e esclarecimento sobre a realização dos procedimentos técnicos, fortalecendo a segurança, autonomia e o desenvolvimento acadêmico. Pode-se evidenciar juntamente com isso uma melhora nas relações interpessoais e uma melhor percepção do cuidado que se dá pessoalmente (RODRIGUES et al, 2015).

Apesar disso, vale atentar no ensino remoto como um ajustamento temporário durante a pandemia, no qual ocorre a mediação do aprendizado, ao vivo, possibilitando interação docente-discente, conservando as aulas práticas presenciais, tentando dessa forma preservar a qualidade do ensino (BEZERRA, 2020).

As práticas e estágios sofrem uma flexibilização na modalidade remota podendo ou não serem realizadas. Todavia com a sua obrigatoriedade, tem-se que seguir 
protocolos e medidas gerais para garantir a segurança dos envolvidos. Ademais, adaptou-se à realidade epidemiológica em âmbito internacional, nacional e municipal para dar seguimento à realização de processos que necessitem do contato direto entre as pessoas (BRASIL, 2020a; BRASIL,2020b).

Compreende-se assim a importância do ensino presencial na enfermagem, devido a inúmeros fatores, além dos apresentados. Porém, é reconhecida a necessidade de adoção do ensino remoto a depender de contextos sociais que ponham em risco a saúde dos estudantes, professores e profissionais que atuam no ensino presencial. A pandemia do coronavírus é um desses contextos e merece atenção pelas suas implicações na formação acadêmica.

\subsection{A PANDEMIA do CORONAVIRUS E suAS IMPLICAÇÕES NA FORMAÇÃO ACADÊMICA}

O coronavírus atualmente se apresenta em seis tipos conhecidos que podem acometer humanos. Desses seis tipos, quatro (229E, OC43, NL63 e HKU1) apresentam uma sintomatologia comum de gripe, já os outros dois Severe Acute Respiratory Syndrome (SARS-CoV) e Middle East Respiratory Syndrome (MERS) são relacionados a sintomatologias que levam a quadros graves e uma alta taxa de mortalidade (BELASCO; FONSECA, 2020).

No ano de 2002 houve o primeiro grande surto de coronavírus que causou uma epidemia pelo agente denominado SARS-COV-1, fez-se anos depois no ano de 2012 aconteceu o segundo grande surto que se tornou uma epidemia volta para os países orientais pelo agente MERS-COV-1 e seis anos depois no ano de 2019 começou o terceiro grande surto esse causado pelo denominado SARS-COV-2 ou COVID-19, que se tornou uma pandemia (TORRES FILHO, 2020).

Primeiramente, o COVID-19 foi identificado em dezembro de 2019 na cidade de Wuhan, na China. Tornou-se um surto considerado uma emergência de saúde pública de importância internacional, por apresentar um aumento crescente com relação ao número de casos, de óbitos e na propagação para outros países. A Organização Mundial de Saúde (OMS) declarou em março de 2020 que o COVID-19 apresentava características potenciais para uma pandemia. Foi nesse cenário de pandemia que se fez 
necessário desenvolver medidas de prevenção da doença e proteção da população (SILVA et al., 2020; WHO, 2020).

Nesse contexto, todos os países do mundo tiveram que adotar medidas estratégicas para auxiliar a conter a transmissão do vírus, reduzindo assim a evolução da pandemia. Cada país tem seu próprio modo de implementar as medidas e contam com apoio de órgãos nacionais e internacionais de saúde que dispõe de orientações, assistência técnica, mobilização de equipes para assistência local, e avaliação da eficiência das estratégias (AQUINO et al., 2020).

Dentre as principais estratégias adotadas, conforme os autores supracitados, estão: realizar o isolamento de casos positivos; incentivar a higienização das mãos e a utilização de máscaras faciais caseiras; adotar de medidas progressivas de distanciamento social, com o fechamento de escolas e universidades para o ensino presencial, a proibição de eventos que promovam aglomerações, a restrição de viagens e transportes públicos, e a conscientização da população para a permanência no domicílio, podendo até restringir por completo a circulação nas ruas.

Todavia, as medidas emergenciais adotadas para o combate da pandemia causaram uma intensificação dos impactos sofridos na sociedade. No contexto brasileiro isso se mostra claramente, por exemplo, com o aumento das vulnerabilidades e desigualdades sociais pré-existentes, deixando grupos populacionais mais vulneráveis. Por ser uma emergência pública, nenhum setor da sociedade se mostrou previamente preparado, fazendo com que todos sofressem algum tipo de impacto (BRASIL, 2020c).

Exemplificando, na economia pode se dizer que o maior impacto e desafio se deu pelo aumento da taxa de desemprego, que já era alta anteriormente, mas que se acentuou com a estagnação da capacidade produtiva. Na saúde, há um enfrentamento da falta de profissionais devidamente capacitados principalmente para a atuação necessária no cenário corrente e a escassez de insumos suficientes para se prestar uma assistência adequada. Na educação, se conformou um impacto muito grande, relacionado a dificuldades de acesso de alunos aos novos meios de ensino disponíveis, como também pelo despreparo de docentes com realidade do ensino virtual (BRASIL, 2020c).

Desse modo, educadores e estudantes foram surpreendidos e tiveram que se adaptar à uma nova dinâmica de aprendizagem, na qual se faz necessário utilizar 
maciçamente as ferramentas digitais disponíveis para substituir temporariamente as aulas presenciais. Isso aconteceu em um tempo muito reduzido, não havendo necessariamente preparação, treinamento adequado e até mesmo acessibilidade digital. Expondo dessa forma a carência na educação nacional já existente anteriormente (COSTIN, 2020).

O sistema educacional que se mostrava escasso de várias formas com a situação não mostrou melhora. Já se faziam necessários estímulos governamentais e de políticas educacionais, que no panorama emergencial se amplificaram. Sempre foi referida a importância de se transformar a educação por parte de novos meios de ensino, dentre os quais o ensino remoto, e o estado pandêmico impuseram uma mudança sem uma preparação prévia (PALÚ; SCHÜTZ; MAYER, 2020).

Os mesmos autores também abordam a configuração de um grande desafio para reformular o modelo de ensino presencial que se tinha como "normal" para um novo modelo de ensino remoto, o "novo normal" no processo de ensino-aprendizagem. Essa reformulação, estruturada em tempo recorde, por vezes tem se mostrado irregular e caótica, manifestando que é preciso refletir e repensar sobre o modelo de ensino remoto, principalmente tratando-se do desespero técnico operacional para que houvesse uma continuação do ano letivo.

Na perspectiva do ensino superior, nota-se menos resistência para implementar a utilização das tecnologias digitais. Isso pode se dar pelo seu público-alvo, composto por jovens mais maduros e pela autonomia de cada instituição ao prover meios para essa implementação. De toda forma, há cursos de nível superior que têm a necessidade de aulas presenciais, o que tornou a formulação de uma dinâmica de ensino remoto um tanto que complicado. Esse processo fez com que o profissional da educação refletisse sobre novos métodos de interação e mediação a serem empregadas, obrigando-os a se reinventar e criar alternativas para suprir as necessidades acadêmicas com vistas a reduzir adversidades (ARRUDA, 2020).

Essas adversidades vão desde dificuldades no manuseio de tecnologias digitais, internet e a questões envolvendo a gestão adequada de tempo. Mesmo que no contexto brasileiro o número de pessoas com acesso à internet tenha aumentado com os anos, ainda persistem desigualdades com relação à renda, gênero, raça e regiões, deixando 
uns à frente e outras atrás no quesito acessibilidade. Na questão do novo modelo de ensino isso deve ser levado em conta (VALENTE, 2020).

Nesse contexto, os professores em sua maioria têm como principal dificuldade a falta de experiência em ministrar aulas remotas, além da sobrecarga de trabalho, mesmo estando em casa, devido às gravações de aulas, uploads de arquivos, gestão de ambientes virtuais, dentre outros. Também se tornou perceptível uma diminuição da assiduidade relacionada aos alunos, além da falta de apoio familiar. Com relação aos alunos e professores se tem como principal dificuldade a falta de acesso à internet e/ou dispositivos tecnológicos, como a falta de conhecimento para o seu manejo. Essas e outras dificuldades afetam o estado emocional de todos os envolvidos (OLIVEIRA, 2020).

Os dados da pesquisa realizada por Coutinho et al. (2020), que aborda estudantes universitários para distarem adjetivos em "quarentena" e "atividades remotas", mostram-se de grande importância para o entendimento das implicações psicológicas do COVID-19. Com relação a quarentena, implica-se uma gama de aspectos psicossociais, como isolamento, família, prevenção, restrição entre outros e em aspectos psicoemocionais, como solidão, tristeza, medo, ansiedade, estresse entre outros. Referente as atividades remotas, observa -se um misto de emoções, que avaliam de ruim, estressante, desinteressante a necessário, mesmo com dificuldades.

Tem-se desta forma, discentes e docentes universitários que já se mostravam propensos para alterações psicológicas, agora ainda mais afetadas pelo estado de isolamento social. Mesmo com a presença de poucos estudos sobre a temática, é notável que os níveis de ansiedade, estresse e depressão tendem a aumentar em situações de crise e/ou pandemia, mesmo não podendo se assumir isso como única causa. A mudança do cotidiano nos hábitos acadêmicos, juntamente com a presença dos vários desafios que isso acarreta, acaba por implicar numa relação intrínseca entre a pandemia e as alterações no bem-estar mental e social (MAIA; DIAS, 2020).

\section{CONSIDERAÇÕES FINAIS}

Considerando os elementos dispostos nessa explanação teórica, mostra-se que a enfermagem dispõe de um contexto histórico com diversos aspectos importantes, elencando-se vários pontos fundamentais relacionados à profissão, que são de grande repercussão para a construção de uma metodologia de ensino voltada para o perfil 
profissional. Tornando-se perceptível a importância de uma formação presencial para a enfermagem, considerando diversos fatores como a sua área de atuação profissional.

Considerando os marcos legais que orientam a formação em enfermagem, percebe-se a necessidade de discussão e atualização da Diretrizes Curriculares a fim de aproximar o processo às demandas contemporâneas de saúde da população, inclusive em contexto de crise, como é o caso de uma pandemia.

$\mathrm{Na}$ atualidade, em meio a pandemia do coronavírus é notório a imprescindibilidade da adesão da metodologia de ensino remoto como um modo de minimizar os danos que uma paralisação completa do ensino ou continuidade do ensino de forma presencial poderia causar. Tem-se uma compreensão de que existem diversos fatores relacionados a esta pandemia que estão implicados diretamente na formação acadêmica.

A contemporaneidade da temática exige, assim, investigações de caráter empírico que permitam reflexões e considerações acerca das interferências que o ensino remoto trouxe para a formação, contribuindo desta forma para se encontrar soluções voltadas para as peculiaridades apresentadas nessa forma de ensino.

\section{REFERÊNCIAS}

AQUINO, E.M.L. et al. Medidas de distanciamento social no controle da pandemia de COVID-19: potenciais impactos e desafios no Brasil. Ciênc. saúde coletiva [online]. 2020.

ARRUDA, E.P. Educação remota emergencial: elementos para políticas públicas na educação brasileira em tempos de Covid-19. EmRede. Minas Gerais, 2020.

BELASCO, A.G.S.; FONSECA, C.D. Coronavírus 2020. Rev. Bras. Enferm., 2020.

BARROS A.L.B.L. et al. Processo de enfermagem: guia para a prática / Conselho Regional de Enfermagem de São Paulo. COREN-SP, São Paulo, 2015.

BEZERRA, C.N.B. et al. Análise descritiva da teoria ambientalista de enfermagem. Enferm. Foco, 2018.

BEZZERA, I.M.P. Estado da arte sobre o ensino de enfermagem e os desafios do uso de tecnologias remotas em época de pandemia do corona vírus. J Hum Growth Dev., 2020. 
BORGES, E.L. et al. Reflexões Sobre a Enfermagem Pós-Florence. REME - Rev. Min. Enf., 2000.

BRASIL. Casa Civil. Decreto no. 9.057, de 25 de maio de 2017. Regulamenta o art. 80 da Lei no. 9.394, de 20 de dezembro de 1996, que estabelece as diretrizes e bases da educação nacional. Diário Oficial da República Federativa do Brasil, Brasília, DF, n. 100, 26 maio 2017a, Seção 1, p. 3.

BRASIL. Ministério da Educação e Cultura. Conselho Nacional de Educação Brasil. Câmara de Educação Superior. Resolução CNE/CES no 03 de 07 de novembro de 2001: Diretrizes Curriculares Nacionais do Curso de Graduação em Enfermagem. Diário Oficial da República Federativa do Brasil, Brasília, 9 nov. 2001.

BRASIL. Ministério da Educação. PORTARIA № 544, DE 16 DE JUNHO DE 2020. Dispõe sobre a substituição das aulas presenciais por aulas em meios digitais, enquanto durar a situação de pandemia do novo coronavírus - Covid-19, e revoga as Portarias MEC no 343, de 17 de março de 2020, no 345, de 19 de março de 2020, e no 473, de 12 de maio de 2020a. Disponível em: https://abmes.org.br/arquivos/legislacoes/Portaria-mec-544-2020-06-16.pdf. Acesso em: 09 de outubro de 2020.

BRASIL. DECRETO № 40.939, DE 02 DE JULHO DE 2020. Dispõe sobre as medidas para enfrentamento da emergência de saúde pública de importância internacional decorrente do novo coronavírus e dá outras providências. Diário Oficial da República Federativa do Brasil, Brasília, DF, 2020b.

BRASIL. FRENTE PELA VIDA. Plano Nacional de Enfrentamento à Pandemia da Covid19. VERSÃO 2 - 15/07/2020c.

BRASIL. Sobre a doença COVID-19: como se proteger. Disponível em: https://coronavirus.saude.gov.br/sobre-a-doenca\#como-se-proteger. Acesso em: 20 de setembro de 2020 d.

COFEN, Conselho Federal de Enfermagem. 4 perguntas sobre o Cofen e o EaD na Enfermagem. 24/01/2017. Disponível em: http://www.cofen.gov.br/4perguntas-sobre-o-cofen-e-o-ead-na-enfermagem_48429//html. Acesso em: 25 de setembro de 2020.

COREN-RO. Conselho Regional de Enfermagem, Rondônia. Debate destaca risco da formação EaD em Enfermagem. 09/11/2017. Disponível em: http://www.corenro.org.br/debate-destaca-riscos-da-formacao-ead-em-enfermagem_7466.html. Acesso em: 07 de outubro de 2020.

COSTA, E.O.; GERMANO, R.M.; MEDEIROS, S.M. A Fiscalização do Exercício Profissional no Conselho Federal de Enfermagem. REME - Rev. Min. Enferm., 2014. 
COSTIN, C. OS IMPACTOS DO CORONAVÍRUS NA EDUCAÇÃO BRASILEIRA. 20/05/2020.

Disponível em: https://www.institutomillenium.org.br/os-impactos-docoronavirus-na-educacao-brasileira/. Acesso em: 16 de outubro de 2020.

COUTINHO, M.P.L. et al. Quarentena e aulas remotas representações sociais de universitários da saúde. Revista Diálogos em Saúde, 2020.

FERNANDES, J.D.; REBOUÇAS, L.C. Uma década de Diretrizes Curriculares Nacionais Para a Graduação em Enfermagem: avanços e desafios. Rev. Bras. Enferm., 2013.

FERREIRA, R.G.S.; NASCIMENTO, J.L. Sustentação pedagógica e legislação do ensino aprendizagem: a formação em enfermagem no Brasil. Revista SUSTINERE, Rio de Janeiro, 2017.

GUEDES, G.F.; OHARA, C.V.S.; SILVA, G.T.R. Unidade de terapia intensiva: um espaço significativo para a relação professor-aluno. Acta Paul. Enferm., 2012.

HADDAD, V.C.N.; SANTOS, T.C.F. A teoria ambientalista de Florence Nightingale no ensino. Esc. Anna Nery (impr.), 2011.

KENSKI, V.M. Tecnologias e ensino presencial e a distância. 8a Ed. Papirus, Campinas, 2010.

KLOH, D.; LIMA, M.M.; REIBNITZ, K.S. Compromisso Ético-social na Proposta Pedagógica da Formação em Enfermagem. Texto Contexto Enferm., Florianópolis, 2014.

LESSMANN, J.C. et al. Educação profissional em enfermagem: necessidades, desafios e rumos. REME - Rev. Min. Enferm., 2012.

MAIA, B. R.; DIAS, P. C. Ansiedade, depressão e estresse em estudantes universitários: o impacto da COVID-19. Estudos de Psicologia, 2020.

MAGNAGO, C.; PIERANTONI, C.R. A formação de enfermeiros e sua aproximação com os pressupostos das Diretrizes Curriculares Nacionais e da Atenção Básica. Ciência \& Saúde Coletiva, 2020.

MINHA BIBLIOTECA. Conheça as principais diferenças entre educação a distância e ensino remoto emergencial. 27/08/2020. Disponível em: https://minhabiblioteca.com.br/educacao-a-distancia-ensino-remotoemergencial/. Acesso em: 07 de outubro de 2020.

MISSIO, L.; LOPES, M.M.R.; RENOVATO, R.D. Os reflexos da educação superior pós-LDB de 1996: um foco nos cursos de graduação em enfermagem. Educação e Fronteiras On-Line, Dourados/MS, 2011.

OGUISSO, T; FREITAS, G.F. Care - the essence of the nursing professional identity. Rev. Esc. Enferm., USP. São Paulo, 2016. 
OLIVEIRA, M.S.L. et al. Diálogos com docentes sobre ensino remoto e planejamento didático. EDUFRPE. Recife, 2020.

OLIVEIRA, V.A.C.; GAZZINELLI, M.F.; OLIVEIRA, P.P. Articulação teórico-prática currículo enfermagem. Escola Anna Nery, 2020.

OLIVEIRA, E. Quase $\mathbf{9 0 \%}$ dos professores não tinham experiência com aulas remotas antes da pandemia; $42 \%$ seguem sem treinamento, aponta pesquisa. 08/07/2020. Disponível em: https://g1.globo.com/educacao/noticia/2020/07/08/quase-90percent-dosprofessores-nao-tinham-experiencia-com-aulas-remotas-antes-da-pandemia42percent-seguem-sem-treinamento-aponta-pesquisa.ghtml. Acesso em: $18 \mathrm{de}$ outubro de 2020.

PADILHA, M.I.C.S.; BORENSTEIN, M.S. História da Enfermagem: Ensino, Pesquisa e Interdisciplinaridade. Esc. Anna Nery Rev. Enferm., 2006.

PALÚ, J.; SCHÜTZ, J.A.; MAYER, L. Desafios da educação em tempos de pandemia. Cruz Alta: Ilustração, 2020.

PAVA, A.M.; NEVES, E.B. A arte de ensinar enfermagem: uma história de sucesso. Rev. Bras. Enferm., Brasília, 2011.

RABEH, S.A.N. et al. Terapia tópica para feridas crônicas: contribuições de um módulo de ensino à distância para o conhecimento de estudantes de enfermagem. Enfermería Global № 45 Enero, 2017.

RODRIGUES, J.Z. et al. A IMPORTÂNCIA DA AULA PRÁTICA NA FORMAÇÃO DO PROFISSIONAL DE ENFERMAGEM: um relato de experiência. Revista Panorâmica On-Line, Barra do Garças - MT, 2015.

SANTOS, A.G. et al. O cuidado em enfermagem analisado segundo a essência do cuidado de Martin Heidegger. Rev. Cubana Enferm. [Internet]., 2017.

SANTO, F.H.E; PORTO, I.S. De Florence Nightingale às perspectivas atuais sobre o cuidado de enfermagem: a evolução de um saber/fazer. Esc. Anna Nery Rev. Enferm., 2006.

SILVA, A.N. et al. Limites e possibilidades do ensino à distância (EaD) na educação permanente em saúde: revisão integrativa. Ciência \& Saúde Coletiva, 2015.

SILVA, A.C.O. et al. Máscara de tecido como proteção respiratória em período de pandemia da covid-19: lacunas de evidências. Rev. Bras. Enferm., 2020.

SILVA, K.L. et al. Desafios da formação do enfermeiro no contexto da expansão do ensino superior. Esc Anna Nery (impr.), 2012. 
SILVA, M.G. et al. Processo de formação da(o) enfermeira(o) na contemporaneidade: desafios e perspectivas. Texto Contexto Enferm., Florianópolis, 2010.

SILVA, M.J.P. Ciência da Enfermagem. Acta Paul Enferm., 2012.

SOUSA F.E.M. et al. Percepção de Estudantes de Enfermagem Acerca da Profissão. Rev. Rene. Fortaleza, 2010.

TORRES FILHO, H.M. Coronavírus: tipos, sintomas, transmissão, diagnóstico e prevenção. Disponível em: https://www.richet.com.br/clientes/novidades/coronavirus-tipos-sintomastransmissao-diagnostico-eprevencao/\#: :text=S\%C3\%A3o\%20identificados\%20atualmente\%207\%20tipos, mais\%20brandos\%20de\%20infec\%C3\%A7\%C3\%A30\%20respirat\%C3\%B3ria. Acesso em: 14 de outubro de 2020.

WIGGERS, E.; DONOSO, M.T.V. Discorrendo Sobre os Períodos Pré e Pós Florence Nightingale: a Enfermagem e sua Historicidade. Enferm. Foco, 2020.

WHO, Word Health Organization. Coronavirus disease 2019 (COVID-19) Situation Report - 51. 11 de março 2020. Disponível em: https://www.who.int/docs/default-source/coronaviruse/situationreports/20200311-sitrep-51-covid-19.pdf?sfvrsn=1ba62e57_4. Acesso em: 14 de outubro de 2020.

VALENTE, J. Brasil tem 134 milhões de usuários de internet, aponta pesquisa. 26/05/2020. https://agenciabrasil.ebc.com.br/geral/noticia/2020-05/brasil-tem-134milhoes-de-usuarios-de-internet-aponta-pesquisa. Acesso em 19 de outubro de 2020.

VERMELHO, S. C. Educação a distância: sistemas de aprendizagem on-line. Educar em Revista, Curitiba, Brasil, Edição Especial n. 4/2014, p. 263-268. Editora UFPR.

XAVIER, M.L.; BAPTISTA, S.S. Associação Brasileira de Enfermagem no contexto da reforma educacional de 1996. Rev. Bras. Enferm., Brasília, 2010. 


\title{
CAPÍTULO XIV
}

\section{ATIVIDADE FÍSICA NA QUALIDADE DE VIDA DE IDOSOS ATIVOS E SEDENTÁRIOS}

\author{
Leidiane Miranda de Carvalho ${ }^{1}$ \\ Jessica Maria Lima de Araújo ${ }^{1}$ \\ Bruna Lorena Soares Cavalcante Sousa ${ }^{2}$ \\ Maria Joselha Miranda de Carvalho ${ }^{3}$ \\ Raimunda Vieira Machado ${ }^{4}$ \\ Edna Maria Chaves Silva ${ }^{1}$ \\ Maria dos remédios chaves da Silva ${ }^{1}$
}

\footnotetext{
${ }^{1}$ Graduada em Fisioterapia. Centro universitário Maurício de Nassau - UNINASSAU

${ }^{2}$ Mestre em Ciências e Saúde. Universidade Federal do Piauí - UFPI

${ }^{3}$ Graduada em Enfermagem. Centro universitário Maurício de Nassau - UNINASSAU

${ }^{4}$ Graduada em Enfermagem. Faculdade de Tecnologia e Educação Superior Profissional - FATESP
}

\section{RESUMO}

Objetivo: Descrever a qualidade de vida de idosos ativos e sedentários, a fim de apresentar a relação direta e indireta do exercício físico na saúde do idoso. Materiais e métodos: Trata-se de uma pesquisa revisão de literatura integrativa, foi realizada uma pesquisa nas bases de dados: LILACS e PubMed Bibliotecas eletrônicas SciELO e BVS, a busca foi efetuada com a combinação dos subsequentes descritores: qualidade de vida, exercício físico e idoso. Para a combinação dos termos, utilizou-se o operador booleano AND com as seguintes combinações: idoso AND qualidade de vida AND exercício físico, idoso AND qualidade de vida e idoso AND exercício físico. Quanto aos critérios de inclusão, os artigos disponíveis completos, escritos em português e inglês, publicados entre 2015 e 2020 foram selecionados. Resultados: Na busca foram encontrados 55 artigos, destes 10 foram selecionados após análise crítica. Em síntese, a prática de exercícios propicia mais saúde na terceira idade. Considerações finais: Idosos ativos apresentam melhor funcionalidade e redução de sintomas depressivos, assim, possibilitando melhor qualidade de vida, se comparada aos idosos sedentários. Tornase necessário a expansão de ações sociais direcionadas à saúde do idoso, incentivandoo a uma prática regular de exercícios físicos.

Palavras-chave: Qualidade de vida. Exercício físico. Idoso. 


\section{INTRODUÇÃO}

Verificou-se recentemente um aumento da população idosa até 2050, espera-se que essa população atinja o triplo do número de pessoas em relação a 2010. Nesse contexto, o bem-estar tem sido uma importante área de estudo, pois as pessoas, além de preferir viver mais, também desejam viver com mais qualidade de vida (COUTO et al., 2017; GATO et al., 2018). Fato que além de ser uma realidade para os idosos, também é um pré-requisito das organizações de saúde mundiais. Para a Organização Mundial da Saúde, qualidade de vida é a percepção do indivíduo de sua posição na vida, no contexto da cultura e sistemas de preocupações (FERRETTI et al., 2015).

Nessa circunstância, para garantir que os idosos alcancem esse patamar, alguns aspectos se destacam, como a autoestima e o bem-estar pessoal, assim como o próprio estado de saúde e o estilo de vida. Deste modo, a qualidade de vida do idoso pode ser definida como a manutenção da saúde em todos os aspectos da vida humana, sendo eles: o físico, o social, o psíquico e o espiritual(GONÇALVES et al., 2015; SILVA, NEVIS, 2016).

Uma saúde de qualidade, em idade avançada, entende-se por ações interligadas e sistemáticas, realizadas pelo indivíduo diariamente, tais como: bons hábitos alimentares, uso correto de medicamentos, ausência de tabagismo, baixo consumo de álcool e a prática de atividades físicas regulares (ALMEIDA et al., 2020; FERREIRA, MEIRELES, FERREIRA, 2018).

Considerando que o processo de envelhecimento pode gerar limitações, o exercício físico é uma estratégia que pode ser utilizada para amenizar os processos de declínio observados durante o envelhecimento, mantendo sua capacidade funcional e qualidade de vida em boas condições. Evidências atuais demonstram que o exercício físico traz benefícios à saúde do idoso, mantendo a independência funcional e melhorando sua qualidade de vida (PILLATT etal, 2019; CARVALHO, NASCIMENTO, 2016).

A principal causa para manter apresente revisão integrativa (RI) de literatura com abordagem qualitativa, consiste na influência do tema proposto: qualidade de vida, promovendo o engrandecimento do pensamento crítico referente a população idosa. Sendo assim, objetiva-se verificara qualidade de vida de idosos ativos e sedentários, a fim de apresentar a relação direta e indireta do exercício físico para a saúde do idoso, 
em destaque aos potenciais e benefícios na função cognitiva, na qualidade de vida e na funcionalidade (RAMOS; MATOS, 2019).

\section{MATERIAIS E MÉTODOS}

O trabalho em questão trata-se de uma revisão integrativa da Literatura com abordagem qualitativa. Na formação da pesquisa empregaram-se as seguintes fases: delimitação do tema da pesquisa, resolução da pergunta problema (questão da pesquisa), definição de amostra com critérios inclusão e exclusão, deliberação utilizada para escolha dos artigos.

Realizou-se uma busca nas bases de dados: LILACS (Literatura Latino-Americana e do Caribe em Ciências da Saúde) e PubMed (US National Library of Medicine), assim como em bibliotecas eletrônicas SCIELO (ScientificElectronic Library Online), BVS (Biblioteca eletrônica em saúde). Para a combinação dos termos utilizou-se o operador booleano and da seguinte maneira: idoso and qualidade de vida and exercício físico, idoso and qualidade de vida e idoso and exercício físico.

Os artigos identificados pela estratégia de busca foram avaliados, inicialmente, a partir da leitura dos títulos e resumos. Conforme fluxograma (Figura 1), quanto aos critérios de inclusão, os artigos disponíveis completos, escritos em português e inglês, publicados entre 2015 e 2020 foram selecionados. Sendo excluídos os artigos de revisão, os duplicados e os que não abordaram o tema de interesse da pesquisa. 
Figura 1: Estratégia de busca e seleção utilizadas para revisão

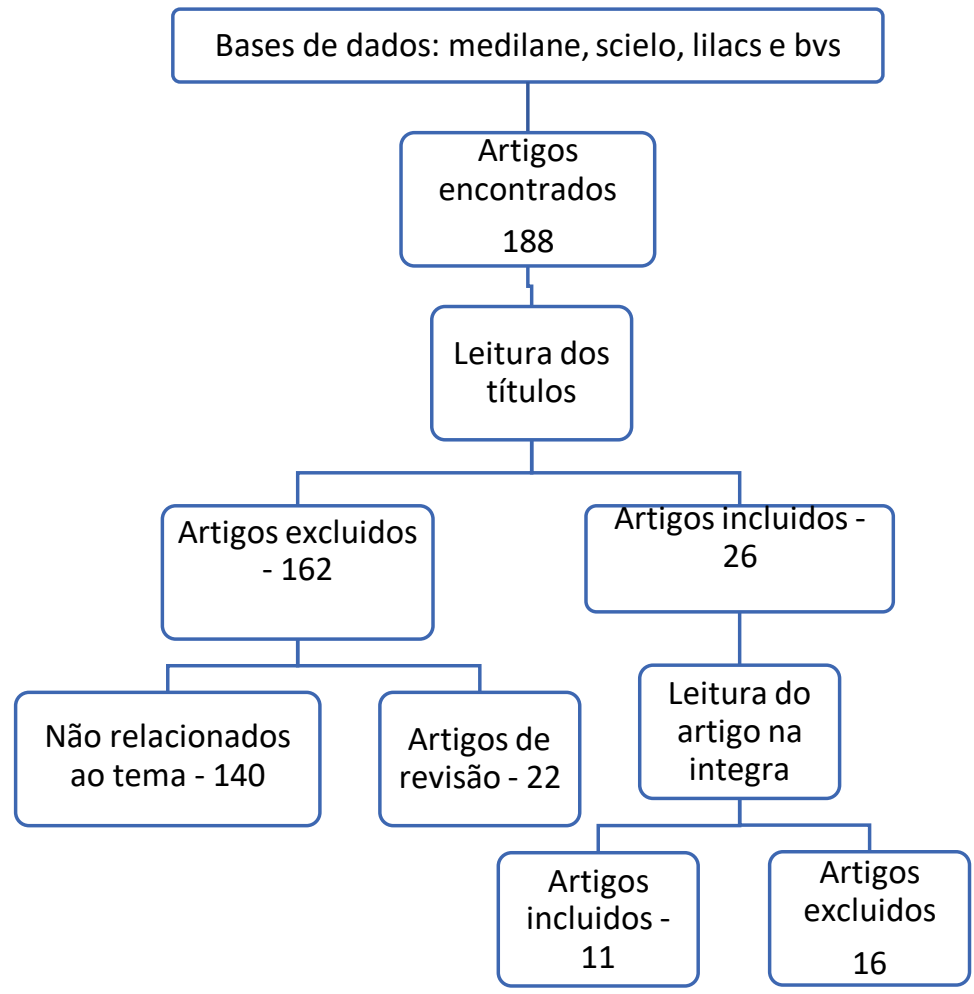

Fonte: Autoria própria.

\section{RESULTADOS}

Foram encontrados 88 artigos nas bases eletrônicas. Após a leitura minuciosa pelos pesquisadores, foram selecionados 11 artigos para a análise final.

Tabela 1. Descrição dos artigos selecionados para revisão

\begin{tabular}{|c|c|c|c|c|c|}
\hline Autor\Ano & Objetivo & Tipo de estudo & Amostra & $\begin{array}{c}\text { Critérios de } \\
\text { avaliação }\end{array}$ & $\begin{array}{c}\text { Considerações } \\
\text { finais }\end{array}$ \\
\hline $\begin{array}{c}\text { (BRUNONI, L. } \\
\text { et al., 2015) }\end{array}$ & $\begin{array}{c}\text { Avaliar os } \\
\text { efeitos do } \\
\text { treinamento } \\
\text { de força, com } \\
\text { prescrição } \\
\text { baseada na } \\
\text { percepção de } \\
\text { esforço, nos } \\
\text { sintomas } \\
\text { depressivos } \\
\text { longitudinal. }\end{array}$ & $\begin{array}{c}\text { Estudo } \\
\text { nualidade }\end{array}$ & 24 mulheres. & $\begin{array}{c}\text { IPAQ (versão } \\
\text { curta) e } \\
\text { Questionário } \\
\text { SF-36 e um }\end{array}$ & $\begin{array}{c}\text { Treinamento de } \\
\text { força baseado na } \\
\text { percepção de } \\
\text { esforço e }\end{array}$ \\
$\begin{array}{c}\text { instrumento de } \\
\text { avaliação da } \\
\text { QVRS. }\end{array}$ & $\begin{array}{c}\text { Participação em } \\
\text { programas de } \\
\text { exercício físico foi } \\
\text { efetivo para uma } \\
\text { redução nos } \\
\text { sintomas }\end{array}$ \\
\hline
\end{tabular}




\begin{tabular}{|c|c|c|c|c|c|}
\hline & $\begin{array}{c}\text { de Vida } \\
\text { Relacionada à } \\
\text { Saúde (QVRS) } \\
\text { de idosas. }\end{array}$ & & & & $\begin{array}{l}\text { retardar declínios } \\
\text { funcionais, e } \\
\text { melhorar a QVRS. }\end{array}$ \\
\hline $\begin{array}{l}\text { (BAZZANELLA; } \\
\text { PICCOLI; } \\
\text { QUEVEDO.201 } \\
\text { 5). }\end{array}$ & $\begin{array}{c}\text { Verificar o } \\
\text { nível de } \\
\text { qualidade de } \\
\text { vida percebida } \\
\text { e de atividade } \\
\text { física de idosas } \\
\text { participantes } \\
\text { do Programa } \\
\text { Municipal de } \\
\text { Saúde da } \\
\text { Terceira Idade } \\
\text { na Região da } \\
\text { Serra Gaúcha, } \\
\text { RS. }\end{array}$ & $\begin{array}{c}\text { Descritivo e de } \\
\text { corte } \\
\text { transversal }\end{array}$ & 58 idosas. & $\begin{array}{c}\text { Questionário } \\
\text { sociodemográfi } \\
\text { co; WHOQOL- } \\
\text { OLD, associado } \\
\text { ao WHOQOL- } \\
\text { BREF; e IPAQ, } \\
\text { adaptado para } \\
\text { idosos. }\end{array}$ & $\begin{array}{c}\text { Foi constatada } \\
\text { uma percepção } \\
\text { satisfatória sobre } \\
\text { a seu } \\
\text { contentamento } \\
\text { com a saúde e a } \\
\text { qualidade de vida } \\
\text { e uma } \\
\text { classificação } \\
\text { insuficientemente } \\
\text { ativa na prática } \\
\text { da atividade } \\
\text { física. }\end{array}$ \\
\hline $\begin{array}{l}\text { (FERRETTI et } \\
\text { al., 2015) }\end{array}$ & $\begin{array}{c}\text { Analisar a } \\
\text { qualidade de } \\
\text { vida em idosos } \\
\text { praticantes (P) } \\
\text { e não } \\
\text { praticantes } \\
\text { (NP) de } \\
\text { exercício físico. }\end{array}$ & $\begin{array}{c}\text { Quantitativo, } \\
\text { descritivo e } \\
\text { transversal. }\end{array}$ & $\begin{array}{l}120 \text { idosos de } \\
\text { ambos os } \\
\text { sexos. }\end{array}$ & $\begin{array}{l}\text { Questionários } \\
\text { WHOQOL-bref } \\
\text { e o WHOQOL- } \\
\text { Old e mini } \\
\text { exame do } \\
\text { estado mental } \\
\text { (MEEM) }\end{array}$ & $\begin{array}{l}\text { Evidenciaram que } \\
\text { os idosos do } \\
\text { grupo praticantes } \\
\text { possuem um } \\
\text { melhor índice de } \\
\text { qualidade de vida } \\
\text { do que os nãos } \\
\text { praticantes. }\end{array}$ \\
\hline $\begin{array}{l}\text { (CASSIANO et } \\
\text { al., 2018) }\end{array}$ & $\begin{array}{l}\text { Avaliar efeitos } \\
\text { de um } \\
\text { protocolo } \\
\text { misto de } \\
\text { exercícios } \\
\text { físicos sobre o } \\
\text { risco } \\
\text { cardiovascular, } \\
\text { qualidade de } \\
\text { vida e } \\
\text { presença de } \\
\text { sintomas } \\
\text { depressivos em } \\
\text { idosos } \\
\text { hipertensos. }\end{array}$ & $\begin{array}{c}\text { Estudo } \\
\text { longitudinal }\end{array}$ & 138 idosas. & $\begin{array}{l}\text { Questionário } \\
\text { Short-Form-36 } \\
\text { (SF-36) e escala } \\
\text { de Depressão } \\
\text { Geriátrica } \\
\text { (GDS-15). }\end{array}$ & $\begin{array}{c}\text { Redução do risco } \\
\text { para o } \\
\text { desenvolvimento } \\
\text { de eventos } \\
\text { cardiovasculares, } \\
\text { além de favorecer } \\
\text { a QVRS e a } \\
\text { redução de } \\
\text { sintomas } \\
\text { depressivos. }\end{array}$ \\
\hline $\begin{array}{c}\text { (SOUZA et al., } \\
\text { 2015). }\end{array}$ & $\begin{array}{l}\text { Avaliar a } \\
\text { qualidade de } \\
\text { vida de idosos } \\
\text { praticantes de } \\
\text { atividade física } \\
\text { regular no } \\
\text { município de } \\
\text { Ponta Porã. }\end{array}$ & $\begin{array}{c}\text { Estudo } \\
\text { exploratório e } \\
\text { descritivo. }\end{array}$ & 60 idosos. & $\begin{array}{l}\text { Questionário } \\
\text { SF-36 e um } \\
\text { questionário } \\
\text { sócio } \\
\text { demográfico. }\end{array}$ & $\begin{array}{l}\text { Permitiu verificar } \\
\text { bons índices de } \\
\text { Qualidade deVida } \\
\text { entre idosos } \\
\text { praticantes de } \\
\text { atividades } \\
\text { esportivas. }\end{array}$ \\
\hline $\begin{array}{l}\text { (CAMBOIM et } \\
\text { al.,2017) }\end{array}$ & $\begin{array}{c}\text { Descrever a } \\
\text { experiência de } \\
\text { idosos perante } \\
\text { os benefícios } \\
\text { da atividade } \\
\text { física para a } \\
\text { qualidade de }\end{array}$ & $\begin{array}{c}\text { Estudo } \\
\text { descritivo, com } \\
\text { abordagem } \\
\text { qualitativa. }\end{array}$ & 5 idosas. & $\begin{array}{c}\text { Entrevista } \\
\text { previamente } \\
\text { elaborada e } \\
\text { questionário } \\
\text { sociodemográfi } \\
\text { co. }\end{array}$ & $\begin{array}{c}\text { A prática de } \\
\text { atividade física } \\
\text { tende a melhorar } \\
\text { o desempenho } \\
\text { nas funções do } \\
\text { dia a dia, } \\
\text { segurança, }\end{array}$ \\
\hline
\end{tabular}




\begin{tabular}{|c|c|c|c|c|c|}
\hline & $\begin{array}{c}\text { vida e citar os } \\
\text { benefícios da } \\
\text { atividade física } \\
\text { para a } \\
\text { qualidade de } \\
\text { vida na } \\
\text { terceira idade. }\end{array}$ & & & & $\begin{array}{l}\text { propiciando } \\
\text { independência } \\
\text { prolongada e } \\
\text { direito de } \\
\text { decisão. }\end{array}$ \\
\hline $\begin{array}{c}\text { (JÚNIOR, et al., } \\
\text { 2015) }\end{array}$ & $\begin{array}{l}\text { Analisar como } \\
\text { um grupo de } \\
\text { idosos } \\
\text { praticantes de } \\
\text { exercícios } \\
\text { físicos } \\
\text { compreendem } \\
\text { os efeitos } \\
\text { proporcionado } \\
\text { s pela prática } \\
\text { física. }\end{array}$ & $\begin{array}{l}\text { Transversal de } \\
\text { análise } \\
\text { qualitativa em } \\
\text { nível } \\
\text { exploratório } \\
\text { descritivo. }\end{array}$ & 13 idosos. & $\begin{array}{c}\text { Entrevista } \\
\text { semiestruturad } \\
\text { a }\end{array}$ & $\begin{array}{l}\text { Constatando-se } \\
\text { que os } \\
\text { participantes } \\
\text { relataram } \\
\text { melhora física e } \\
\text { psicológica após } \\
\text { se exercitarem, } \\
\text { dessa forma, } \\
\text { sugere-se que o } \\
\text { exercício físico é } \\
\text { indispensável } \\
\text { para o controle } \\
\text { da saúde. }\end{array}$ \\
\hline $\begin{array}{c}\text { (LIMA SOUZA., } \\
\text { 2016). }\end{array}$ & $\begin{array}{c}\text { Identificar a } \\
\text { percepção de } \\
\text { idosos sobre os } \\
\text { efeitos da } \\
\text { prática de } \\
\text { exercícios } \\
\text { físicos em } \\
\text { grupo na sua } \\
\text { qualidade de } \\
\text { vida }\end{array}$ & $\begin{array}{l}\text { Observacional, } \\
\text { descritivo } \\
\text { transversal de } \\
\text { análises } \\
\text { quantitativa e } \\
\text { qualitativa. }\end{array}$ & 27 idosos. & $\begin{array}{l}\text { Mini Mental } \\
\text { StateExaminati } \\
\text { on, } \\
\text { questionário } \\
\text { fechado do } \\
\text { perfil } \\
\text { sociodemográfi } \\
\text { co e entrevista } \\
\text { semiestruturad } \\
\text { a baseado em } \\
\text { aspectos do } \\
\text { WHOQOL-OLD. }\end{array}$ & $\begin{array}{l}\text { Infere-se que a } \\
\text { prática de } \\
\text { exercícios físicos } \\
\text { em grupo } \\
\text { interfere } \\
\text { positivamente na } \\
\text { qualidade de vida } \\
\text { dos idosos. }\end{array}$ \\
\hline $\begin{array}{c}\text { (RIBEIR0; } \\
\text { FERRETTI; SÁ. } \\
\text { 2017) }\end{array}$ & $\begin{array}{c}\text { Analisar a } \\
\text { qualidade de } \\
\text { vida em função } \\
\text { do nível da } \\
\text { prática de } \\
\text { atividade física } \\
\text { em idosos } \\
\text { residentes em } \\
\text { meio rural e } \\
\text { urbano. }\end{array}$ & $\begin{array}{l}\text { Descritivo de } \\
\text { corte } \\
\text { transversal. }\end{array}$ & 358 idosos. & $\begin{array}{c}\text { Mini exame do } \\
\text { Estado Mental } \\
\text { (MEEM). } \\
\text { Questionário } \\
\text { de Avaliação } \\
\text { da Qualidade } \\
\text { de Vida } \\
\text { Whoqol-Bref e } \\
\text { o Questionário } \\
\text { de Avaliação } \\
\text { de Qualidade } \\
\text { de Vida } \\
\text { adaptado para } \\
\text { idosos Whoqol- } \\
\text { Old }\end{array}$ & $\begin{array}{l}\text { A qualidade de } \\
\text { vida é } \\
\text { influenciada } \\
\text { positivamente, } \\
\text { quando a } \\
\text { manutenção de } \\
\text { níveis } \\
\text { satisfatórios de } \\
\text { prática de } \\
\text { atividade física. }\end{array}$ \\
\hline $\begin{array}{l}\text { (CAMÕES et } \\
\text { al., 2016). }\end{array}$ & $\begin{array}{l}\text { Descrever a } \\
\text { percepção da } \\
\text { qualidade de } \\
\text { vida em } \\
\text { indivíduos } \\
\text { acima dos } 70 \\
\text { anos, levando } \\
\text { em conta a } \\
\text { participação }\end{array}$ & $\begin{array}{c}\text { Estudo } \\
\text { transversal }\end{array}$ & 250 idosos. & $\begin{array}{l}\text { Questionário } \\
\text { SF36. }\end{array}$ & $\begin{array}{l}\text { Programas de } \\
\text { intervenção com } \\
\text { base na prática } \\
\text { de exercício } \\
\text { físico, mesmo } \\
\text { com pouca } \\
\text { frequência e } \\
\text { duração, } \\
\text { relacionaram-se }\end{array}$ \\
\hline
\end{tabular}




\begin{tabular}{|c|c|c|c|c|c|}
\hline & $\begin{array}{c}\text { em programas } \\
\text { de exercício } \\
\text { físico. }\end{array}$ & & & & $\begin{array}{l}\text { com melhor } \\
\text { qualidade de vida } \\
\text { em idosos. }\end{array}$ \\
\hline $\begin{array}{l}\text { (ALMEIDA et } \\
\text { al., 2020) }\end{array}$ & $\begin{array}{l}\text { Avaliar a } \\
\text { qualidade de } \\
\text { vida dos idosos } \\
\text { que praticam } \\
\text { atividade física. }\end{array}$ & $\begin{array}{l}\text { Estudo } \\
\text { quantitativo, } \\
\text { descritivo, } \\
\text { prospectivo } \\
\text { e transversal. }\end{array}$ & 37 idosos & $\begin{array}{l}\text { Questionário } \\
\text { mini mental } \\
\text { (MEEM). } \\
\text { questionário } \\
\text { WHOQOL-OLD }\end{array}$ & $\begin{array}{c}\text { A prática da } \\
\text { atividade física } \\
\text { melhora a vida do } \\
\text { idoso, } \\
\text { Porque causa um } \\
\text { maior vínculo } \\
\text { familiar tanto na } \\
\text { amizade, como } \\
\text { no lazer, no } \\
\text { social, trazendo } \\
\text { mudança no dia a } \\
\text { dia, além } \\
\text { das condições } \\
\text { físicas, motoras e } \\
\text { saúde geral. }\end{array}$ \\
\hline
\end{tabular}

Fonte: Autoria própria

\section{DISCUSSÃO}

Os estudos demostram que a participação em programas de exercício físico pode aumentar a vitalidade, retardar declínios funcionais, reduzir o risco do desenvolvimento de episódios depressivos e melhorar a qualidade de vida relacionada à saúde (QVRS) (BRUNONI, L., et al. 2015; CAMÕES et al., 2016).

Quanto á prática de atividade física, a amostra referente ao estudo (BAZZANELLA; PICCOLI; QUEVEDO,2015) demonstrou estar insuficientemente ativa, isto é, não alcançou índices mínimos para uma prática que beneficiasse á saúde dos idosos, porém (FERRETTI et al., 2015) utilizando-se do mesmo método e com maior amostra, reforça-se que a prática regular de exercício físico é benéfica para a vida dos indivíduos, principalmente dos idosos, pois além de todos os efeitos que ocasiona a nível orgânico, psicológico e social, também interfere positivamente no que diz respeito à percepção da qualidade de vida (FERRETTI et al., 2015).

Tais achados fortalecem a ideia da prática da atividade como promotora da saúde e qualidade de vida para o idoso, produzindo modificações no metabolismo 
lipídico e lipoproteico, observando-se aumento nos níveis de lipoproteína de baixa densidade (HDL) e uma diminuição na composição do colesterol total e lipoproteína de baixa densidade (LDL) circulante, associado à atividade enzimática. Tais modificações parecem estar associadas ao aumento da cinética no teste direto do colesterol lipoproteína de baixa densidade (LDL-c) na circulação, o que prolonga o período em que o LDL-c permanece na forma reduzida. Portanto, indivíduos fisicamente ativos apresentam níveis séricos mais baixos de colesterol total, triglicerídeos e lipoproteína de baixa densidade e concentrações mais elevadas de HDL em relação aos inativos. As alterações séricas de lipoproteína de alta densidade são atribuídas à diminuição de sua degradação no fígado e aumento de sua síntese. O treinamento de forca pode reduzir a pressão sistólica e diastólica em aproximadamente $3 \mathrm{mmHg}$ e $4 \mathrm{mmHg}$, respectivamente. Demonstra que uma combinação intermitente de alta intensidade ( $>80 \%$ para $60 \%$ de frequência cardíaca máxima) de treinamento aeróbio foi mais eficaz do que o treinamento contínuo com intensidade moderada no estágio da Hipertensão (CASSIANO et al., 2018; CAMBOIM et al.,2017).

Segundo (SOUZA et al., 2015) a prática de atividades físicas assegura maior independência, autonomia e melhor condição de saúde, aumentando o senso de bemestar, a crença de auto eficácia e a capacidade de o indivíduo atuar sobre o meio ambiente e sobre si mesmo. Prática atividade física por recomendação médica, os idosos que não a praticam por esse tipo de recomendação, apresentam melhoras em Qualidade de Vida no domínio Saúde Mental, em relação aos idosos que praticam atividade física por recomendação médica. Essa diferença demonstra que o idoso praticante de atividade física por prazer e voluntariamente consegue obter uma satisfação pessoal positiva antes, durante e depois da prática física, assim como também relata benefícios da prática de exercícios físicos em grupo, obtendo melhora na disposição e aumento do círculo de amizade, maior independência, mobilidade, capacidade, bem-estar físico bem com relações sociais (LIMA SOUZA., 2016).

Nas pesquisas realizadas por (CAMBOIM et al.2017; e JÚNIOR et al.2015) utilizando-se de entrevistas semienterradas discorreram sobre os achados benéficos do exercício físico regular, demostrando que houve diminuição das dores musculares e ósseas, que o hábito de se exercitar proporciona liberdade para suas tarefas rotineiras com capacidade para caminhar sozinhos e com isso independência prolongada, 
enquadrando os benefícios para um envelhecimento com qualidade. Portanto, tem-se o envelhecimento ativo, como um fator primordial para o prolongamento da vida com qualidade para idosos, uma vez que o mesmo proporciona o afastamento da dependência funcional e de desarranjos relacionados ao estado psicossocial do indivíduo, como depressão e isolamento, que conduzem a uma vida sedentária, predispondo ao surgimento de doenças cardiovasculares e de outras disfunções sistêmicas.

Bem como os artigos anteriores relatam como a atividade física é importante (RIBEIRO; FERRETTI; SÁ, 2017) reafirma que o desenvolvimento de atividades físicas diárias, em que a vida produtiva do idoso perdura por mais tempo. Mesmo após a aposentadoria, o idoso continua a desempenhar um trabalho, mantendo-se produtivo e ativo, o que pode ter interferido para que as percepções de qualidade de vida desse grupo fossem mais positivas.

Nesse (ALMEIDA et al., 2020) destaca que os idosos envolvidos regularmente em atividades físicas regulares possuem menor risco de desenvolver alguma patologia ou incapacidade. Melhorando a vida do idoso pois causa um maior vínculo familiar aumenta o círculo de amizade, como no lazer, no social, trazendo mudança no dia a dia, além das condições físicas, motoras e saúde geral.

\section{CONSIDERAÇÕES FINAIS}

Idosos ativos apresentam melhor funcionalidade e redução de sintomas depressivos, assim, possibilitando melhor qualidade de vida, se comparados aos idosos sedentários. Dessa forma, este estudo possibilitou para a população um conhecimento prévio referente à prática de atividade física, validando inúmeros benefícios no envelhecimento e a promoção da saúde para pessoas idosas praticantes. Tão logo, torna-se necessário a expansão de ações sociais direcionadas à saúde do idoso, incentivando-o a uma prática regular de exercícios físicos.

\section{REFERÊNCIAS}

ALMEIDA, B. et al. Quality of life of elderly people who practice physical activity. $\mathbf{R}$ pesq: cuid. fundam. Online, v. 12,p. 466-470, jan/dez,2020. 
BAZZANELLA, L.A.N.; PICCOLI, J.C.J.; QUEVEDO, M.D. Qualidade de vida percebida e atividade física: um estudo em idosas acima de 80 anos participantes de um programa municipal de saúde da terceira idade na serra gaúcha, RS. Estud. interdiscipl. envelhec., Porto Alegre, v. 20, n. 1, p. 249-270, 2015.

BRUNONI, L. et al. Treinamento de força diminui os sintomas depressivos e melhora a qualidade de vida relacionada a saúde em idosas. Rev. bras. educ. fís. esporte [online]. v.29, n.2, pp.189-196, 2015.

CAMBOIM, F. et al. Benefícios da atividade física na terceira idade para a qualidade de vida. Revenferm UFPE online. v.1,n.6, p.2415-22, jun., 2017

CAMOES, M. et al. Exercício físico e qualidade de vida em idosos: diferentes contextos sociocomportamentais. Motri. [online]. v.12, n.1, pp.96-105, 2016.

CASSIANO, A.N. et al. Efeitos do exercício físico sobre o risco cardiovascular e qualidade de vida em idosos hipertensos. Ciênc. saúde coletiva [online]. v.25, n.6, p.22032212, 2020.

CARVALHO, F.C.E; NASCIMENTO, M.M. Repercussões de um programa de atenção psicológica sobre a qualidade de vida de idosas praticantes do método Pilates.Estud. pesqui. psicol, Rio de Janeiro, v. 16, n. 2, p. 488-507, 2016.

COUTO, N. et al. Validação da SubjectiveVitalityScale e estudo da vitalidade nos idosos em função da sua atividade física. Rev. bras. cineantropom. Desempenho hum. [online]. v.19, n.3, p.261-269,2017.

FERRETTI, F. et al. Análise da qualidade de vida em idosos praticantes e não praticantes de exercício físico regular. Rev. Estud. interdiscipl. envelhec., Porto Alegre, v. 20, n. 3, p. 729-743, 2015.

FERREIRA, K.L; MEIRELES, F.F.J; FERREIRA, C.E.M. Avaliação do estilo e qualidade de vida em idosos: uma revisão de literatura. Rev. Bras. Geriatr. Gerontol., Rio de Janeiro; v. 21, n.5, p. 639-651, 2018.

GATO, J. et al. Saúde mental e qualidade de vida de pessoas idosas. AvEnferm.v, 36, n. 3, p. 302$310,2018$.

GONÇALVES, F. et al. Qualidade de vida e indicativos de depressão em idosas praticantes de exercícios físicos em academias da terceira idade em Marigá (PR). Revista Saúde e Pesquisa, v. 8, n. 3, p. 557-567, set./dez. 2015.

JÚNIOR, V. et al. Compreensão de Idosos sobre os Benefícios da Atividade Física. Revista Brasileira De Ciências Da Saúde. v.19, n. 3, p.193-198, 2015.

PILLATT, A.P.; NIELSSON, J.; SCHNEIDER, R.H. Efeitos do exercício físico em idosos fragilizados: uma revisão sistemática. Fisioter. Pesqui. [online], v.26, n.2, p.210217, 2019. 
RAMOS, D. C; Comparação da qualidade de vida em idosos praticantes e não praticantes de exercício físico. Orientador: Philipe Guedes Matos. 2019.69 f. (Mestre em educação física e desporto), Universidade de Trás-os-Montes de Alto Douro, Universidade do Sul de Santa Catarina, Santa Catarina, 2019.

SILVA, A.C.; NEVES, R. Os olhares dos profissionais sobre os programas de atividade física para pessoas idosas. Revista Kairós Gerontologia, v.19, n. 2, p.23-39, 2016.

SOUZA, J.C.; FILGUEIRA JÚNIOR, N.; REZENDE, C.L.; FREIRE, H.B.G. Qualidade de vida dos atletas da terceira idade. PsicólogoinFormação, v. 19, n. 19. 2015.

LIMA, E.S. Percepção da qualidade de vida entre idosos que praticam exercícios físicos em grupo. Monografia; Orientador: Profa. MSc. Wiviane Maria Torres de Matos Freitas. Universidade do Estado do Pará. 2016

RIBEIRO, G.C.; FÁTIMA, F.; SÁ, A.C. Qualidade de vida em função do nível de atividade física em idosos urbanos e rurais. Rev. bras. geriatr. gerontol. [online]. v.20, n.3, p.330-339, 2017. 


\title{
CAPITULO XV
}

\section{EQUUIÚBRIO ESTÁTICO E DINÂMICO EM IDOSOS INSTITUCIONALIZADOS: REVISÃO INTEGRATIVA}

\author{
Roseany Barros Morais Lago ${ }^{1}$ \\ Vitória Silva Almeida ${ }^{1}$ \\ Edna Maria Chaves Silva ${ }^{1}$ \\ Ana Carolina Ramos de Castro ${ }^{1}$ \\ Denise Ribeiro da Silva ${ }^{1}$ \\ Bruna Lorena Soares Cavalcante Sousa ${ }^{2}$
}

${ }^{1}$ Graduanda do curso de Fisioterapia. Centro universitário Maurício de Nassau - UNINASSAU
${ }^{2}$ Mestre em Ciências e Saúde. Universidade Federal do Piauí - UFPI

\section{RESUMO}

Introdução: O processo fisiológico do envelhecimento da pessoa idosa gera um grande declínio nas funções corporais, sendo assim esse processo degenerativo é responsável pela perda progressiva de equilíbrio da pessoa idosa, fazendo com que muitas famílias escolham por repartir a responsabilidade do cuidado com as Instituições de Longa Permanência para Idosos. Objetivo: Descrever o equilíbrio estático e dinâmico de idosos institucionalizados por meio da revisão de literatura. Materiais e Métodos: Trata-se de uma revisão integrativa, onde foram pesquisados textos científicos sobre o tema supracitado e artigos científicos completos no período dos últimos cinco anos (2015 a 2020), nas seguintes bases de dados: Literatura Latino-Americana e do Caribe em Ciências da Saúde (LILACS), e Medical Literature Analysis and Retrieval Sistem online (MEDLINE/PubMed) e na biblioteca eletrônica Scientfic Electronic Library Online (SciELO), os descritores utilizados na busca são todos cadastrados nos Descritores em Ciência da Saúde (DeCS). Foram usados isoladamente e combinados com o operador booleano AND para a realização desta pesquisa, "Saúde do Idoso Institucionalizado and Equilíbrio Postural and Fisioterapia"; "Saúde do Idoso Institucionalizado and Avaliação Geriátrica". Resultado: Foram elegidos trabalhos pelo título, resumo e sua relevância ao trabalho com restrições ao tipo de estudo, sendo encontrados 40 artigos. Depois da leitura destes artigos, 09 foram selecionados, por apresentarem aspectos que respondiam à questão norteadora e objetivo desta revisão. Conclusão: Entende-se que a maioria dos idosos que residem em instituições de longa permanência apresentam um déficit importante no equilíbrio e no sistema cognitivo, revelando a importância desses indivíduos realizarem atividades físicas.

Palavras-chave: Saúde do idoso institucionalizado. Equilíbrio postural. Avaliação geriátrica. Fisioterapia. 


\section{INTRODUÇÃO}

O processo fisiológico do envelhecimento da pessoa idosa gera um grande declínio nas funções corporais, onde a habilidade do sistema nervoso central (SNC) em realizar o processamento dos sinais vestibulares, visuais e proprioceptivos responsáveis pela manutenção da estabilidade do corpo, bem como diminui a habilidade de modificações dos reflexos adaptativos. Sendo assim esse processo degenerativo e responsável pela perda progressiva de equilíbrio da pessoa idosa (ARRUDA et al., 2019; BUSHATSKYI et al., 2018).

Para o equilíbrio corporal satisfatório de acordo com os autores Cordeiro et al (2020) e Samantha e Rosa (2017), é imprescindível a completa integração entre os sistemas sensorial e motor na qual permite a manutenção de uma posição estável que é denominada pelo equilíbrio estático, ou em movimento caracterizada pelo equilíbrio dinâmico, de maneira proporcional e necessária.

Desse modo, cabe ressaltar a alta predominância das doenças crônicas não transmissíveis, perdas cognitivas, declínio sensorial e isolamento social. Assim esses fatores podem causar degeneração na capacidade funcional dos idosos, fazendo-os dependentes de outras pessoas para a responsabilidade dos cuidados diários (MELO et al., 2017). Portanto, o processo de envelhecimento pode acarretar incertezas quanto às possibilidades de cuidado desses idosos, fazendo com que muitas famílias escolham por repartir a responsabilidade do cuidado com as chamadas Instituições de Longa Permanência para Idosos (SOUSA et al., 2014).

Esses Institutos são classificados como um sistema social organizacional que tem por objetivo desempenhar a função de acudir pessoas idosas em situação de vulnerabilidade coletiva, ou seja, sem qualquer tipo de ligação familiar ou com uma família sem condições de garantir sua sobrevivência e carência de moradia, alimentação, saúde e convívio social (LOURENÇO SOUZA et al., 2015; SOUZA; MASSI, 2015).

Essa institucionalização contribui com a instabilidade corporal associando aos fatores predisponentes a quedas. A mudança do ambiente familiar para a ILPI, fato esse que pode levar a alterações psicológicas, cognitivas e funcionais que podem estar relacionadas ao isolamento e falta de exercícios físicos. Somado a isso, o medo de cair nessa população é extremamente frequente, sendo classificado como um fator de risco 
para a independência do indivíduo sendo mais dispostos a um maior número de quedas (ARAÚJO NETO et al., 2017). Por conseguinte, o objetivo desse estudo faz-se por descrever o equilíbrio estático e dinâmico e os efeitos proporcionados pela prática da atividade física em idosos institucionalizados por meio da revisão de literatura.

\section{MATERIAIS E MÉTODOS}

Foram pesquisados artigos científicos completos através do levantamento dos artigos na literatura, foi realizada uma busca nas seguintes bases de dados: Literatura Latino-Americana e do Caribe em Ciências da Saúde (LILACS), e Medical Literature Analysis and Retrieval Sistem online (MEDLINE/PubMed) e na biblioteca eletrônica Scientfic Electronic Library Online (SciELO).

Os descritores utilizados foram: Saúde do idoso institucionalizado, Equilíbrio Postural, Avaliação Geriátrica, Fisioterapia, todos cadastrados nos Descritores em Ciência da Saúde (DeCS), sendo usados isoladamente e combinados com o operador booleano AND para a realização desta pesquisa, "Saúde do idoso institucionalizado and Fisioterapia and Equilíbrio Postural"; "Saúde do idoso institucionalizado and Avaliação Geriátrica".

Os critérios de inclusão aplicados foram: artigos originais publicados no período dos últimos cinco anos (2015 a 2020), com resumos de textos completos disponíveis nos bancos de dados com idiomas português e inglês, sendo selecionados trabalhos pelo título, resumo e sua relevância ao trabalho com restrições ao tipo de estudo.

Os critérios de exclusão descartaram os estudos com duplicidade em base de dados diferentes e que não tiveram relação com o tema proposto.

\section{RESULTADOS}


Figura 1 - Fluxograma da seleção dos artigos usados na revisão

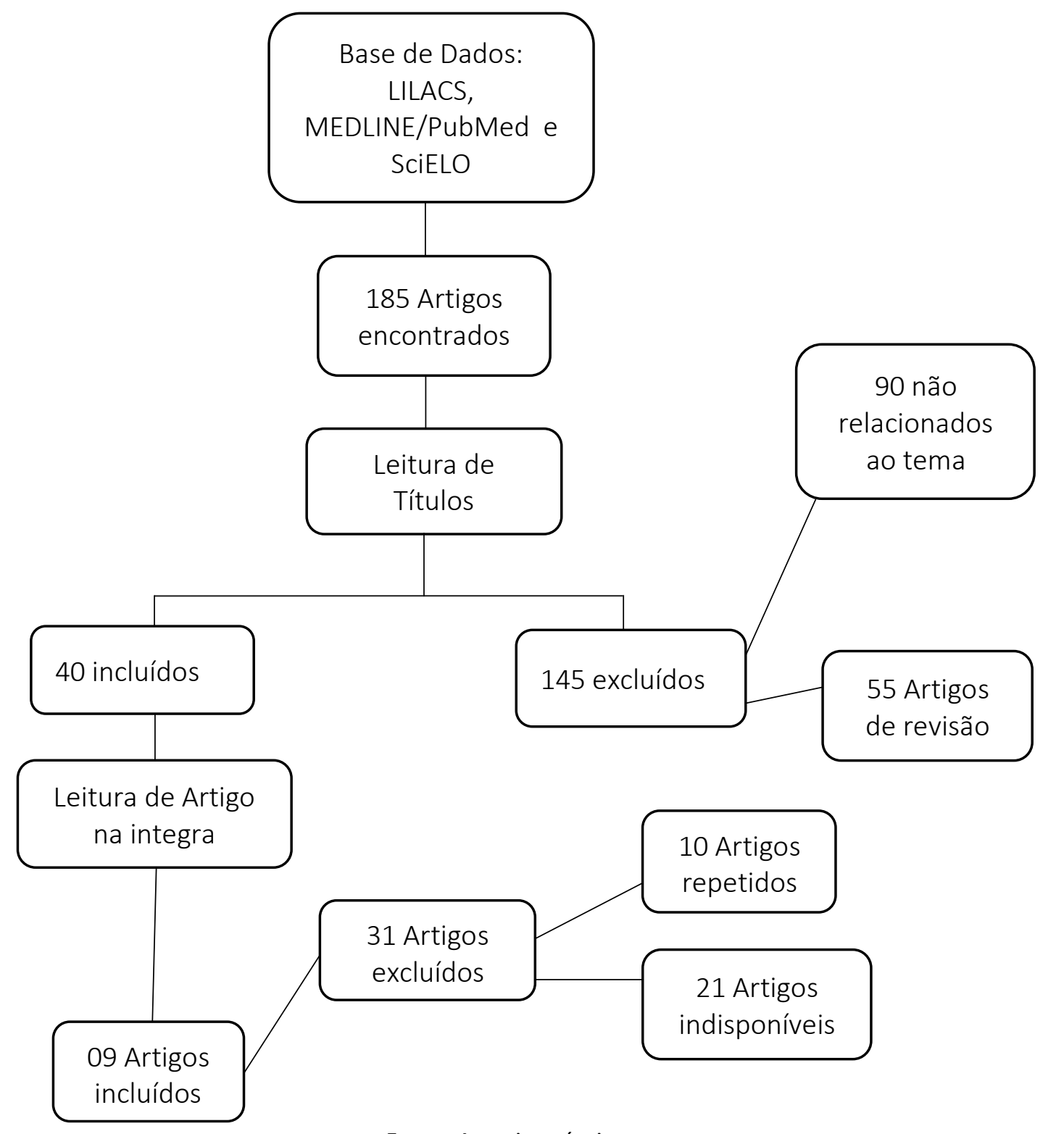

Fonte: Autoria própria. 
Tabela 1 - Descrição dos achados na literatura sobre o equilíbrio postural em idosos institucionalizados.

\begin{tabular}{|c|c|c|c|c|c|c|}
\hline $\begin{array}{c}\text { Autor/ } \\
\text { Ano }\end{array}$ & Objetivo & $\begin{array}{l}\text { Tipo de } \\
\text { estudo }\end{array}$ & Amostra & $\begin{array}{c}\text { Instrume } \\
\text { ntos de } \\
\text { avaliação }\end{array}$ & Resultados & Consideração \\
\hline $\begin{array}{c}\text { Broerin } \\
\text { g et al / } \\
2015\end{array}$ & $\begin{array}{c}\text { Analisar a } \\
\text { influência da } \\
\text { institucionaliza } \\
\text { ção e da } \\
\text { pratica de } \\
\text { atividade física } \\
\text { no equilíbrio e } \\
\text { na mobilidade } \\
\text { funcional de } \\
\text { idosos. }\end{array}$ & $\begin{array}{c}\text { Transver } \\
\text { sal } \\
\text { descritiv } \\
\text { o e } \\
\text { compara } \\
\text { tivo. }\end{array}$ & $\begin{array}{c}\text { (GIN): } 21 \\
\text { idosos } \\
\text { institucionali } \\
\text { zados, (GAT): } \\
20 \text { idosos } \\
\text { não } \\
\text { institucionali } \\
\text { zados ativos } \\
\text { e (GNAT): } 20 \\
\text { idosos não } \\
\text { institucionali } \\
\text { zados não } \\
\text { ativos. Com } \\
\text { idade igual } \\
\text { ou acima de } \\
60 \text { anos, de } \\
\text { ambos os } \\
\text { sexos. }\end{array}$ & $\begin{array}{l}\text { IPAQ, } \\
\text { EEB, } \\
\text { TUG. }\end{array}$ & $\begin{array}{l}\text { Institucionali } \\
\text { zação e } \\
\text { pratica de } \\
\text { atividade } \\
\text { física } \\
\text { influenciam a } \\
\text { mobilidade e } \\
\text { equilíbrio } \\
\text { (p<0,05). }\end{array}$ & $\begin{array}{c}\text { Idosos ativos } \\
\text { apresentaram } \\
\text { melhor } \\
\text { equilíbrio, } \\
\text { mobilidade } \\
\text { funcional e } \\
\text { menor risco de } \\
\text { quedas. Já os } \\
\text { idosos } \\
\text { institucionaliza } \\
\text { dos } \\
\text { apresentaram } \\
\text { menor } \\
\text { equilíbrio, } \\
\text { mobilidade } \\
\text { funcional } \\
\text { reduzida e } \\
\text { maior risco de } \\
\text { quedas. }\end{array}$ \\
\hline $\begin{array}{c}\text { Szydlos } \\
\text { ki et al / } \\
2015\end{array}$ & $\begin{array}{c}\text { Avaliar e } \\
\text { comparar a } \\
\text { marcha e o } \\
\text { equilíbrio em } \\
\text { idosos } \\
\text { institucionaliza } \\
\text { dos pré e pós } \\
\text { programa de } \\
\text { exercícios } \\
\text { físicos. }\end{array}$ & $\begin{array}{l}\text { Estudo } \\
\text { clinico } \\
\text { longitudi } \\
\text { nal. }\end{array}$ & $\begin{array}{l}15 \text { idosos } \\
\text { com idade } \\
\text { igual ou } \\
\text { acima de } 60 \\
\text { anos, de } \\
\text { ambos os } \\
\text { sexos. }\end{array}$ & $\begin{array}{c}\text { Tinetti } \\
\text { (POMA). }\end{array}$ & $\begin{array}{l}\text { Quanto ao } \\
\text { equilíbrio pré } \\
\text { e pós- } \\
\text { intervenção } \\
\text { ( } p>0,05) . \\
\text { Quanto à } \\
\text { marcha pré e } \\
\text { pós- } \\
\text { intervenção } \\
\text { ( } p<0,05) .\end{array}$ & $\begin{array}{l}\text { Foi observado } \\
\text { que ao término } \\
\text { deste estudo, } \\
\text { após o } \\
\text { programa de } \\
\text { exercícios } \\
\text { físicos, os } \\
\text { idosos } \\
\text { apresentaram } \\
\text { melhora na } \\
\text { marcha. }\end{array}$ \\
\hline $\begin{array}{c}\text { Dias; } \\
\text { Maguer } \\
\text { oski e } \\
\text { Piazza / } \\
2016\end{array}$ & $\begin{array}{l}\text { Comparar } \\
\text { equilíbrio, } \\
\text { mobilidade } \\
\text { funcional e } \\
\text { nível de } \\
\text { atividade física } \\
\text { de idosos } \\
\text { institucionaliza } \\
\text { dos que } \\
\text { realizam e não } \\
\text { realizam } \\
\text { fisioterapia. }\end{array}$ & $\begin{array}{c}\text { Transver } \\
\text { sal, } \\
\text { descritiv } \\
\text { o e } \\
\text { compara } \\
\text { tivo. }\end{array}$ & $\begin{array}{c}60 \text { idosos } \\
\text { institucionali } \\
\text { zados, (GF): } \\
30 \text { idosos } \\
\text { que } \\
\text { realizavam } \\
\text { fisioterapia e } \\
\text { (GNF): } 30 \\
\text { idosos que } \\
\text { não } \\
\text { realizavam } \\
\text { fisioterapia. } \\
\text { Com idade } \\
\text { igual ou } \\
\text { acima de } 60 \\
\text { anos de } \\
\text { ambos os } \\
\text { sexos. }\end{array}$ & $\begin{array}{c}\text { EEB, } \\
\text { Tinetti } \\
\text { TUG, e } \\
\text { TAF. }\end{array}$ & $\begin{array}{c}\text { Em } \\
\text { comparação } \\
\text { tanto ao } \\
\text { equilíbrio } \\
\text { quanto } \\
\text { mobilidade e } \\
\text { funcionalida } \\
\text { de entre (GF) } \\
\text { e (GNF) } \\
(p<0,05) .\end{array}$ & $\begin{array}{l}\text { Os idosos que } \\
\text { realizavam } \\
\text { fisioterapia } \\
\text { apresentaram } \\
\text { menor } \\
\text { mobilidade } \\
\text { funcional, } \\
\text { menor alcance } \\
\text { funcional } \\
\text { anterior e } \\
\text { menores níveis } \\
\text { de atividade } \\
\text { física. }\end{array}$ \\
\hline
\end{tabular}




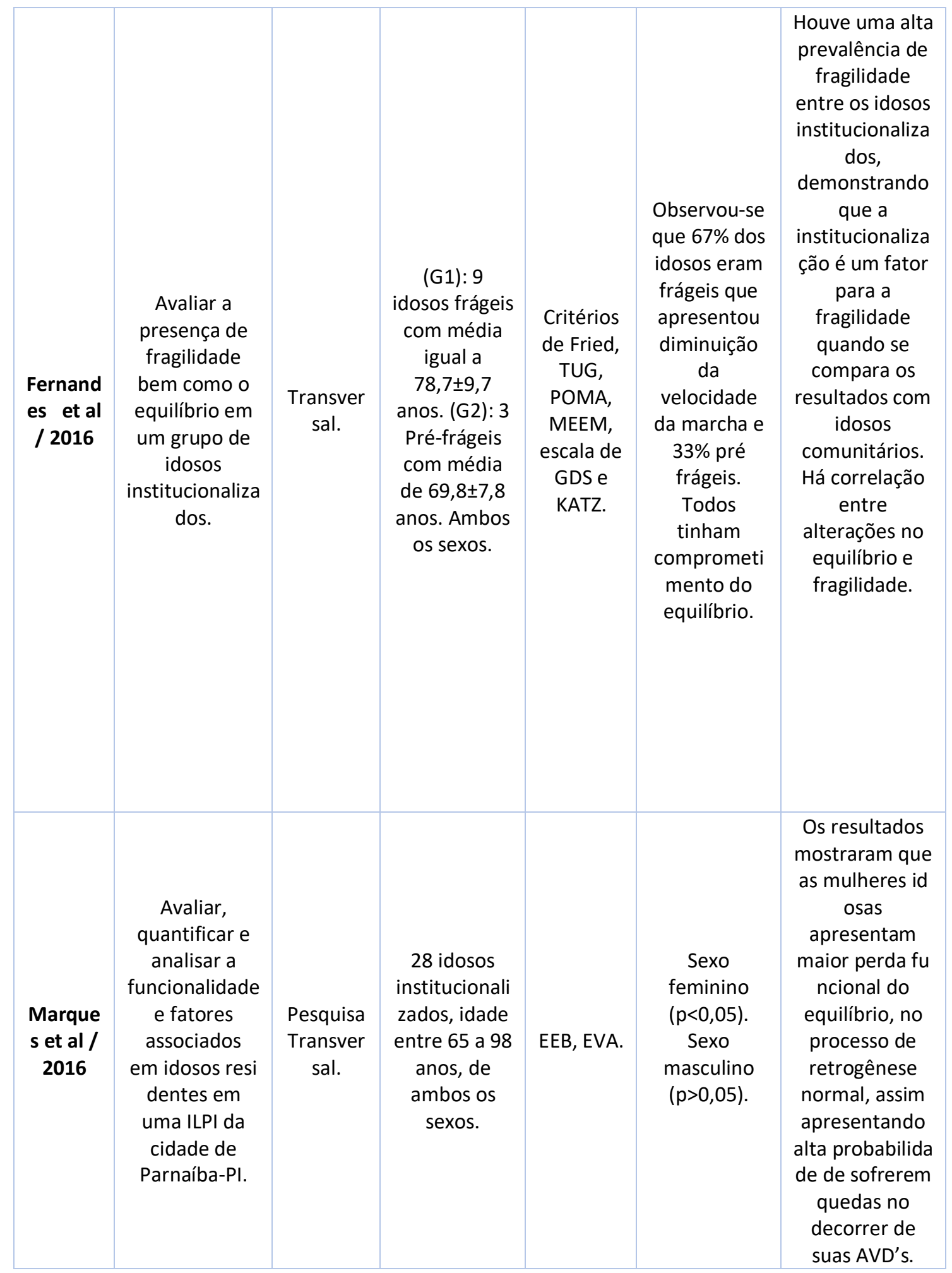




\begin{tabular}{|c|c|c|c|c|c|c|}
\hline $\begin{array}{l}\text { Tomic } \\
\text { ki et } \\
\text { al / } \\
2016\end{array}$ & $\begin{array}{l}\text { Verificar o } \\
\text { efeito de um } \\
\text { programa de } \\
\text { exercícios } \\
\text { físicos no } \\
\text { equilíbrio } \\
\text { postural e no } \\
\text { risco de } \\
\text { quedas em } \\
\text { idosos } \\
\text { institucionaliza } \\
\text { dos. }\end{array}$ & $\begin{array}{c}\text { Ensaio } \\
\text { clínico } \\
\text { randomiza } \\
\text { do. }\end{array}$ & $\begin{array}{c}30 \text { idosos } \\
\text { institucionaliza } \\
\text { dos, (G1): } \\
\text { controle, } 15 \\
\text { idosos e (G2): } \\
\text { intervenção, } \\
15 \text { idosos. Com } \\
\text { idade igual ou } \\
\text { acima de } 60 \\
\text { anos de ambos } \\
\text { os sexos. }\end{array}$ & $\begin{array}{c}\text { TUG e } \\
\text { EEB. }\end{array}$ & $\begin{array}{c}\text { Grupo } \\
\text { controle } \\
(G 1) \\
(p>0,05) \\
\text { Grupo } \\
\text { intervenç } \\
\text { ão }(G 2) \\
(p<0,05) .\end{array}$ & $\begin{array}{l}\text { O programa de } \\
\text { exercícios } \\
\text { físicos } \\
\text { propostos se } \\
\text { mostrou eficaz } \\
\text { na melhora do } \\
\text { equilíbrio } \\
\text { corporal e do } \\
\text { desempenho } \\
\text { em tarefas } \\
\text { funcionais e, } \\
\text { consequentem } \\
\text { ente, } \\
\text { contribuiu na } \\
\text { melhora do } \\
\text { risco de } \\
\text { quedas. }\end{array}$ \\
\hline $\begin{array}{l}\text { Rosa } \\
\text { et al/ } \\
2017\end{array}$ & $\begin{array}{l}\text { Foi analisar as } \\
\text { condições de } \\
\text { equilíbrio } \\
\text { corporal de } \\
\text { idosos } \\
\text { institucionaliza } \\
\text { dos com queixa } \\
\text { de tontura. }\end{array}$ & $\begin{array}{c}\text { Transversa } \\
\text { I, de } \\
\text { caráter } \\
\text { descritivo. }\end{array}$ & $\begin{array}{c}11 \text { idosos } \\
\text { institucionaliza } \\
\text { dos, com faixa } \\
\text { etária de } 60 \text { a } \\
94 \text { anos, de } \\
\text { ambos os } \\
\text { sexos. }\end{array}$ & $\begin{array}{l}\text { Anamnese } \\
\text {, Inspeção } \\
\text { Visual, } \\
\text { Audiometr } \\
\text { ia Tonal } \\
\text { Liminar, } \\
\text { Provas de } \\
\text { Equilíbrio } \\
\text { Estático e } \\
\text { Dinâmico, } \\
\text { Coordena } \\
\text { ção dos } \\
\text { Moviment } \\
\text { os e } \\
\text { Posturogr } \\
\text { afia } \\
\text { Dinâmica. }\end{array}$ & $\begin{array}{c}\text { Na prova } \\
\text { de } \\
\text { Romberg } \\
\text { identifico } \\
\text { u-se a } \\
\text { queda } \\
\text { em dois } \\
\text { (28,6\%). } \\
\text { Na } \\
\text { marcha, } \\
\text { dois com } \\
\text { desvio } \\
\text { para a } \\
\text { direita } \\
\text { (28,6\%); } \\
\text { e na } \\
\text { prova de } \\
\text { Untembe } \\
\text { rg, um } \\
\text { com } \\
\text { desvio } \\
\text { menor } \\
\text { que 45o } \\
\text { para a } \\
\text { direita } \\
\text { (14,3\%). }\end{array}$ & $\begin{array}{c}\text { Os idosos } \\
\text { institucionalizad } \\
\text { os com queixa } \\
\text { de tontura } \\
\text { apresentaram } \\
\text { alterações nas } \\
\text { provas de } \\
\text { equilíbrio, } \\
\text { quando } \\
\text { avaliados com } \\
\text { os olhos } \\
\text { fechados. }\end{array}$ \\
\hline
\end{tabular}




\begin{tabular}{|c|c|c|c|c|c|c|}
\hline $\begin{array}{c}\text { Almei } \\
\text { da et } \\
\text { al / } \\
2018\end{array}$ & $\begin{array}{c}\text { Verificar a } \\
\text { influência de } \\
\text { um programa } \\
\text { de exercícios } \\
\text { na melhora do } \\
\text { equilíbrio em } \\
\text { idosos } \\
\text { institucionaliza } \\
\text { dos, } \\
\text { embasando-se } \\
\text { na Escala de } \\
\text { Equilíbrio } \\
\text { Funcional de } \\
\text { Berg. }\end{array}$ & $\begin{array}{c}\text { Transvers } \\
\text { al. }\end{array}$ & $\begin{array}{c}\text { Grupo controle } \\
\text { (G1): } 8 \text { idosos. } \\
\text { Grupo } \\
\text { intervenção } \\
\text { (G2): } 9 \text { idosos. } \\
\text { Faixa etária de } \\
60 \text { a } 90 \text { anos, } \\
\text { de ambos os } \\
\text { sexos. }\end{array}$ & $\begin{array}{l}\text { Questioná } \\
\text { rio } \\
\text { próprio, } \\
\text { EEB e } \\
\text { TUG. }\end{array}$ & $\begin{array}{c}\text { Grupo } \\
\text { intervençã } \\
\text { o (G2) } \\
\text { após o } \\
\text { programa } \\
\text { de } \\
\text { intervençã } \\
\text { o } \\
\text { (p<0,05). } \\
\text { Houve } \\
\text { aumento } \\
\text { no score } \\
\text { médio da } \\
\text { escala de } \\
\text { equilíbrio } \\
\text { de BERG } \\
\text { no grupo } \\
\text { intervençã } \\
\text { o. }\end{array}$ & $\begin{array}{c}\text { Conclui-se que } \\
\text { o programa de } \\
\text { exercícios foi } \\
\text { eficaz na } \\
\text { melhora do } \\
\text { equilíbrio de } \\
\text { idosos } \\
\text { institucionaliza } \\
\text { dos, desta } \\
\text { forma } \\
\text { promovendo } \\
\text { um resultado } \\
\text { positivo no } \\
\text { escore total do } \\
\text { BERG. Tal } \\
\text { melhora do } \\
\text { equilíbrio é } \\
\text { importante } \\
\text { pois, pode } \\
\text { promover uma } \\
\text { diminuição no } \\
\text { número de } \\
\text { quedas dos } \\
\text { idosos. }\end{array}$ \\
\hline $\begin{array}{c}\text { Santos } \\
\text { et al / } \\
2019\end{array}$ & $\begin{array}{c}\text { Avaliar o } \\
\text { equilíbrio } \\
\text { corporal e o } \\
\text { risco de queda } \\
\text { em idosos } \\
\text { institucionaliza } \\
\text { dos e analisar a } \\
\text { correlação } \\
\text { entre os } \\
\text { instrumentos } \\
\text { de avaliação. }\end{array}$ & $\begin{array}{c}\text { Transvers } \\
\text { al } \\
\text { analítico. }\end{array}$ & $\begin{array}{c}19 \text { idosos } \\
\text { institucionaliza } \\
\text { dos, com faixa } \\
\text { etária de } 60 \text { a } \\
80 \text { anos, de } \\
\text { ambos os } \\
\text { sexos. }\end{array}$ & $\begin{array}{c}\text { Escala de } \\
\text { EEB, TUG, } \\
\text { MFS e } \\
\text { questioná } \\
\text { rio } \\
\text { próprio. }\end{array}$ & $\begin{array}{c}\text { Dos } \\
\text { participan } \\
\text { tes } \\
\text { estudados } \\
\text {, } 12 \text { se } \\
\text { queixaram } \\
\text { de quedas } \\
\text { (63,16\%) } \\
\text { que } \\
\text { tinham } \\
\text { idade } \\
\text { igual ou } \\
\text { superior a } \\
70 \text { anos. } \\
\text { Entre } \\
\text { estes, } 7 \\
\text { (58,33\%) } \\
\text { tiveram } \\
\text { quedas } \\
\text { recorrente } \\
\text { s. }\end{array}$ & $\begin{array}{c}\text { Pode-se } \\
\text { observar que } \\
\text { entre os idosos } \\
\text { institucionaliza } \\
\text { dos o risco de } \\
\text { quedas é maior } \\
\text { e os } \\
\text { instrumentos } \\
\text { de EEB e TUG } \\
\text { estão } \\
\text { relacionados } \\
\text { aos resultados. }\end{array}$ \\
\hline
\end{tabular}

LEGENDA: EEB - Escala de Equilíbrio de Berg; EVA - Escala Visual Analógica; GDS - Escala de Depressão Geriátrica; ILPI - Instituição de Longa Permanência para Idosos; IPAQ - Questionário Internacional de Atividade Física; KATZ- Escala de Independência em Atividades da Vida Diária; MEEM - Mini Exame do Estado Mental; MFS - Escala de Queda Morse; POMA - Avaliação da Mobilidade Orientada da Marcha e Equilíbrio; TAF- Alcance Funcional Anterior; TCLE - Termo de Consentimento Livre e Esclarecido; TUG Timed up and go.

Fonte: Autoria própria. 


\section{DISCUSSÃO}

Em decorrência do progressivo aumento da população idosa, Broering et al. (2015) examinou a influência da institucionalização e da execução de atividade física na homeostase e na mobilidade funcional de pessoas na terceira idade. Na avaliação do equilíbrio pela EEB, foi analisada a diferença entre os três grupos, com maior pontuação no GAT, revelando nos idosos não institucionalizados ativos um melhor equilíbrio e, em consequência, menor exposição a quedas comparado aos voluntários não institucionalizados não ativos e aos institucionalizados. Foi apontada uma limitação desta pesquisa o fato de não haver participantes reconhecidos como ativos nas instituições de longa permanência para assim comparar aos dos outros grupos. Além do mais, o grupo institucionalizado foi formado por sujeitos com idade consideravelmente elevada à dos demais grupos, o que pode intervir nos resultados.

No artigo de Szydlokski et al. (2015), destacam que a maior parte dos idosos apontou alguma deficiência ao executar certas tarefas do POMA, por efeito, houve alterações nos resultados da estabilidade corporal desses indivíduos. Acredita-se que, com o processo de envelhecimento, as pessoas manifestam um declínio em sua funcionalidade, podendo expor alterações no equilíbrio, na marcha, postura, dentre outros problemas associados, relacionado à marcha, os idosos tiveram melhoras significativas após o programa de exercícios, pois o comprimento da passada, a altura, a continuidade, a simetria da passada, o equilíbrio do tronco, o espaçamento dos tornozelos e a direção que avaliou a marcha foram melhores após três meses. Sendo assim, sugerem-se novos estudos com uma amostragem e tempo de intervenção maiores, a fim de se aperfeiçoarem os resultados, como também melhorar o equilíbrio corporal dos idosos em questão.

Após a avaliação da mobilidade funcional pelo TUG foi analisada a diferença entre os dois grupos, do qual o GF levou mais tempo para executar o teste do que o GNF. Acredita-se pela circunstância de que os idosos do GNF terem evidenciado melhor mobilidade funcional que os do GF esteja relacionado ao fato deste grupo, embora não fazer fisioterapia, ser mais ativo que o GF. Assim, estudos têm comprovado os benefícios a efetividade da atividade física para o equilíbrio e a mobilidade funcional dos idosos. Segundo os autores, esse fato se esclarece pela própria particularidade do processo de 
envelhecimento, pois ocorre uma redução na qualidade e quantidade das informações fundamentais para uma mobilidade eficaz, como a propriocepção, força muscular e integridade capsulo-ligamentar (DIAS; MAGUEROSKI; PIAZZA, 2016).

Ainda sobre a análise de Dias, Magueroski e Piazza (2016) na avaliação do alcance anterior através do TAF também foi verificada a diferença entre os grupos, sendo que o GF exerceu menor alcance $(22,4 \pm 5,1 \mathrm{~cm})$ em comparação ao $\operatorname{GNF}(27,6 \pm 6,2 \mathrm{~cm})$. Os idosos do presente estudo mostraram médias maiores que este valor, o que, segundo o teste aponta menor propensão a quedas, fato que prova com os achados do TUG, porém discorda do relato de quedas dos idosos. Na presente pesquisa, observou-se que os idosos que fazem fisioterapia nas ILPI's analisadas são, em sua grande maioria, idosos com maior grau de dependência e maiores implicações funcionais, o que pode esclarecer o fato destes terem demonstrado menores escores nas avaliações efetuadas. Estas constatações salientam o caráter reabilitatório que a fisioterapia tem nas ILPI's.

As comorbidades apresentadas pelos idosos da amostra dessa pesquisa, aumentaram riscos do equilíbrio deficitário e consequentemente comprometendo a velocidade da marcha e evidenciando maior risco a quedas. Nos indicadores avaliados nesse estudo sobre o corpo em movimento retilíneo uniforme e estático, pela escala "Timed up and go" e "POMA" apontam que todos os idosos frágeis que corresponde a $67 \%$ tiveram o equilíbrio acometido e correlacionaram esses idosos frágeis com as alterações no teste de TUG. Constatou-se uma grande prevalência de fragilidade entre os idosos institucionalizados, demonstrando que a institucionalização se faz um fator para essa condição, faz-se importante a identificação precoce da fragilidade com ênfase nos idosos pré-frágeis, realizando medidas preventivas relacionadas a perda de funcionalidade e melhora da qualidade de vida desses idosos (FERNANDES et al., 2016).

Em referência aos dados apresentados na pesquisa de Marques et al. (2016), as idosas apresentam maior índice de equilíbrio deficitário conforme os resultados obtidos pela escala de Berg aplicada, explicam que essa população é mais propensa a limitações funcionais devido à grande quantidade de condições crônicas e devido ao sexo feminino possuir menos massa magra e força muscular comparado ao sexo masculino, consequentemente, apresentando maior fragilidade e predisposição as quedas. Ressaltam ainda, que há maior probabilidade dessas idosas estarem expostas a fatores extrínsecos que ocasionam sarcopenia. 
Para Tomicki et al. (2016), um dos principais achados da pesquisa consiste na comparação entre os achados do G1 baseline e pós-intervenção, o qual não mostrou resultados satisfatórios, ou seja, houve diminuição do equilíbrio corporal e aumento do risco de quedas após os três meses de estudo. Já o G2, apontou melhor desempenho no desdobramento tanto do TUG quanto da EEB após o término da intervenção com exercícios físicos, quando relacionados aos resultados iniciais. Consequentemente, os idosos que vivem nas ILPIs apresentaram um perfil clínico funcional e psicocognitivo mais relacionados aos fatores de risco para quedas.

Foi possível analisar ainda que esses indivíduos tornaram a cair após o período da pesquisa, uma vez que o programa apontado não teve continuidade e as mudanças obtidas, entre o baseline e o pós intervenção nos testes EEB e TUG, não foram suficientes para correlacionar redução de quedas. Portanto os grupos responsáveis pela estabilidade postural estão afetados, diminuindo a capacidade de resposta e de compensação, provocando aumento da instabilidade. Porém, no entanto, cabe ainda aos profissionais atuantes em ILPIs serem mais atentos aos fatores que predeterminam o idoso a quedas e elaborarem estratégias de prevenção, objetivando à melhora da capacidade funcional e, consequentemente, da qualidade de vida (TOMICKI et al., 2016).

As provas realizadas com os idosos institucionalizados, de equilíbrio estático e dinâmico não evidenciam alteração na maior parte dos participantes avaliados, na prova de Romberg foi verificado queda em dois $(28,6 \%)$ dos idosos; na prova de RombergBarré identificaram-se quatro alterados $(57,1 \%)$, dentre eles: dois com lateropulsão $(28,6 \%)$, um com instabilidade (14,3\%), e um apresentou queda (14,3\%). Na prova da marcha, dois dos idosos com desvio para a direita (28,6\%); e na prova de Untemberg, um com desvio menor que 45 으 para a direita (14,3\%). Ressalta-se que os tipos de alterações identificadas nessas provas, foram obtidos com os olhos fechados, sendo que as mesmas provas realizadas com os olhos abertos foram normais, ou seja, sem alterações. Faz-se importante além do equilíbrio estático, a avaliação do equilíbrio dinâmico, pois decresce muito antes do equilíbrio estático, sendo a capacidade fundamental, por exemplo, para a marcha e para levantar-se de uma cadeira (ROSA et al., 2017).

Evidenciam que os idosos residentes nas instituições de longa permanência, possuem um quadro clinico funcional e psicocognitivo mais associado aos fatores de 
riscos predisponentes a quedas, dentre alguns destacam a instabilidade postural como sendo a síndrome geriátrica com sinais e sintomas próprios, na qual influenciam diretamente aos episódios de quedas. Os idosos que fizeram parte do grupo de intervenção - G2 alcançaram melhores pontuações tanto no Timed up and go quanto na Escala de Berg, demonstrando uma melhora significante no equilíbrio corporal e na redução dos riscos relacionados a quedas estimado quando comparado aos idosos do grupo de controle - G1 (ALMEIDA et al., 2018).

Em relação aos recursos utilizados para avaliar o equilíbrio e risco de queda, Escala de Equilíbrio de Berg (EEB) e Escala de Morse Fall Scale (MFS), as duas analisaram o risco de queda razoável nos participantes desse estudo. Referente à escala de EEB, informações similares teriam sido encontradas em outras pesquisas, na qual idosos institucionalizados com a faixa etária entre 60 e 70 anos demonstraram menor exposição a quedas, em contrapartida os superiores há 71 anos certificaram uma exposição mediana. Contudo, é possível observar diante dos resultados obtidos, a maior parte dessa população estudada possui uma instabilidade corporal predisposição a quedas (SANTOS et al., 2019)

Sendo assim, no estudo anterior de Santos et al. (2019), ressalta-se ainda que houve uma maior e importante correlação entre as escalas (Timed Up and Go com o teste de Escala de Equilíbrio de Berg) apontando que o equilíbrio dinâmico e estático é extremamente necessário na capacidade funcional neste padrão de teste. Desse modo, certificou-se a influência da execução de avaliações do equilíbrio e risco de quedas para se reconhecer a necessidade do tratamento fisioterapêutico direcionada para a prevenção de quedas, objetivando ao treino de propriocepção.

\section{CONSIDERAÇÕES FINAIS}

A partir da análise dos artigos selecionados pode-se concluir uma maior representatividade dos idosos na qual residem em instituições de longa permanência apresentam déficit no equilíbrio e no sistema cognitivo, que acabam culminando em quedas.

Neste contexto, os dados da pesquisa evidenciaram a importância desses indivíduos realizarem atividades físicas buscando equilíbrio funcional e garantindo 
maior estimulação da mobilidade, assim proporcionando autonomia e a independência do idoso. Deste modo, ressalta-se a indispensabilidade da elaboração de novas estratégias, que abrangem tanto o equilíbrio quanto a função cognitiva, proporcionando bem estar global desses indivíduos.

\section{REFERÊNCIAS}

ALMEIDA, C.M.; FREIRE, T.A.; PERUCHI, L.H.; GLÓRIA, I.P.S. O efeito de um programa de exercícios no equilíbrio de idosos institucionalizados. Revista Científica UMC, v.1, p. 1-4, 2018.

ARAUJO NETO, A.H.; PATRICIO, A.C.F.A.; FERREIRA, M.A.M.; RODRIGUES, B.F.L.; SANTOS, T.D.; RODRIGUES, T.D.B et al. Falls in institutionalized older adults: risks, consequences and antecedents. Rev Bras Enferm, v.70, n.4, p. 752-758, 2017.

BROERING, J. et al. Influência da institucionalização e da prática de atividade física no equilíbrio e na mobilidade funcional de idosos. ConScientiae Saúde, v.14, n.3, p. 417-424, 2016.

BUSHATSKY, A. et al. Factors associated with balance disorders of elderly living in the city of São Paulo in 2006: Evidence of the health, well-being and aging (SABE) study. Revista Brasileira de Epidemiologia, v.21, Suppl 2, 2018.

DIAS, S.M.S.; SILVA, R.J.M.; PIAZZA, L. Equilíbrio, mobilidade funcional e nível de atividade física de idosos institucionalizados que realizam e não realizam fisioterapia. ConScientiae Saúde, v.15, n.2, p.191-199, 2016.

FERNANDES, L.C.; FERNANDES, V.S.; COSTA, M.N.; SIQUEIRA, A. ; MENEZES, R. Idosos Institucionalizados : Frágeis e sem equilpibrio. Revista Educação em Saúde, v.4, n.2, p.95-102, 2016.

LEGUISAMO, C.P. Marcha e equilíbrio em idosos institucionalizados: avaliação pré- e pós-exercícios físicos. Revista Kairós: Gerontologia, v. 18, n. 2, p. 327-338, 2015.

MARQUES, $H$. et al. Escala de equilíbrio de Berg: instrumentalização para avaliar qualidade de vida de idosos TT - Berg balance range: protocol to evaluate quality of life of elderly. Rev. Salusvita (Online), v. 35, n. 1, p. 53-65, 2016.

MELO, B.R.S et al. Cognitive and functional assessment about elderly people users of health public service. Escola Anna Nery, v. 21, n. 4, p. 1-8, 2017.

SAMANTHA, T.; ROSA, M. Avaliação do equilíbrio corporal em idosos institucionalizados com queixa de tontura. Revista Kairós: Gerontologia, v. 20, n. 4, p. 345-366, 2018. 
SANTOS, J.F. et al. Avaliação Do Equilíbrio E Risco De Queda em idosos institucionalizados. Revista Referências em Saúde da Faculdade Estácio de Sá de Goiás, v. 02, n.3, p. 37-43, 2019.

SOUSA, K. T. et al. Baixo peso e dependência functional em idosos institucionalizados de uberlândia (MG), Brasil. Ciencia e Saude Coletiva, v.19, n.8, p. 3513-3520, 2014.

SOUZA, I.A.L.; MASSI,G.A Saúde Fonoaudiológica a partir do discurso do idoso institucionalizado. Rev. CEFAC, v.17, n.1, p.300-307, 2015.

TOMICKI, C. et al. Efeito de um programa de exercícios físicos no equilíbrio e risco de quedas em idosos institucionalizados: ensaio clínico randomizado. Revista Brasileira de Geriatria e Gerontologia, v.19, n.3, p.473-482, 2016. 


\title{
CAPÍTULO XVI
}

\section{NÍVEL DE INDEPENDÊNCIA FUNCIONAL DE IDOSOS INSTIIUCIONALZADOS}

\author{
Edna Maria Chaves Silva ${ }^{1}$ \\ Maria dos Remédios Chaves da Silva ${ }^{1}$ \\ Vitória Silva Almeida ${ }^{1}$ \\ Leidiane Miranda de Carvalho ${ }^{1}$ \\ Jessica Maria Lima de Araújo ${ }^{1}$ \\ Bruna Lorena Soares Cavalcante Sousa ${ }^{2}$
}

Graduanda do curso de Fisioterapia. Centro Universitário de Teresina - FAP

${ }^{2}$ Mestre em Ciências e Saúde. Universidade Federal do Piauí - UFPI

\section{RESUMO}

Introdução: O envelhecimento populacional é um fenômeno que ocorre de forma acelerada mundialmente. Assim, durante o processo de envelhecimento, podem ocorrer alterações físico-funcionais que são peculiares nessa etapa da vida, mas que estão sujeitas à variação de acordo com as características individuais. Objetivo: Este trabalho possui como objetivo descrever a independência funcional de idosos institucionalizados, buscando direcionar orientações para prevenção do risco de quedas. Métodos: Trata-se de uma revisão integrativa de literatura. Para o levantamento, realizou-se uma busca nas seguintes bases de dados: Literatura LatinoAmericana e do Caribe em Ciências da Saúde (LILACS), Medical Literature Analysis and Retrieval Sistem Online (MEDLINE/PubMed) e na biblioteca eletrônica Scientfic Electronic Library Online (SciELO). Vale ressaltar que todos os descritores utilizados são cadastrados nos Descritores em Ciência da Saúde (DeCS). Sendo usados separados e combinados com o operador booleano and par a realização desta pesquisa: Envelhecimento and Fisioterapia, Idoso and Fisioterapia and Institucionalização. Resultados: Desse modo, do total de 43 artigos levantados durante a busca, selecionouse 8 deles, levando em conta a comparação dos achados na literatura sobre dependência de idosos institucionalizados. Conclusão: Os instrumentos de avaliação apresentados demonstraram ser de grande importância, pois são eficazes na detecção de deficiências e/ou incapacidades que podem estar presentes em idosos institucionalizados.

Palavras-chave: Idoso. Envelhecimento. Institucionalização. Fisioterapia. 


\section{INTRODUÇÃO}

O envelhecimento populacional é um fenômeno que ocorre de forma acelerada mundialmente (MONTEIRO et al., 2020). De acordo com os dados do Instituto Brasileiro de Geografia e Estatística (IBGE) em 2019, a população brasileira manteve a tendência de envelhecimento dos últimos anos, ganhou 4,8 milhões de idosos desde 2012 e superou a marca dos 30,2 milhões em 2017.

Nesse contexto, o processo de envelhecimento caracterizado pela redução biológica da senescência resulta em aumento da fragilidade (PAIVA; LIMA; BARROS, 2020), assim como as alterações decorrentes do envelhecimento refletem não apenas no âmbito físico, mas também nas atividades e na atuação social do indivíduo, podendo gerar graves consequências, como dependência funcional, institucionalização e diminuição da qualidade de vida (MOREIRA et al., 2020).

Em contrapartida, a manutenção da funcionalidade no processo de envelhecimento tem sido apontada como um indicador de saúde e está associada à interação de várias funções, bem como à capacidade física e psicocognitiva, que irão sustentar a execução das atividades cotidianas e a participação social e comunitária. Assim, durante o processo de envelhecimento, podem ocorrer alterações físicofuncionais que são peculiares nessa etapa da vida, mas que estão sujeitas à variação de acordo com as características individuais (LOPES; SANTOS, 2015).

Para Oliveira e Rozendo (2014), todas essas limitações que acompanham o envelhecimento afetam o desempenho funcional do idoso, e às vezes o torna incapacitado para cuidar de si mesmo. No entanto, conforme salienta Cordeiro et al. (2015), devido às alterações ocorridas na estrutura familiar, muitas vezes torna-se impossível que esse cuidado venha da família, levando à institucionalização.

Desse modo, este estudo tem como objetivo descrever a independência funcional de idosos institucionalizados, buscando direcionar orientações para a prevenção do risco de quedas, obtendo assim uma atualização sobre a temática.

\section{MATERIAIS E MÉTODOS}

Este trabalho trata-se de uma revisão integrativa de literatura em que foram pesquisados estudos científicos sobre o tema supracitado, assim como artigos 
científicos completos. Para o levantamento dos artigos na literatura, realizou-se uma busca nas seguintes bases de dados: Literatura Latino-Americana e do Caribe em Ciências da Saúde (LILACS), Medical Literature Analysis an Retrieval Sistem Online (MEDLINE/PubMed) e na biblioteca eletrônica Scientific Electronic Library Online (SCIELO).

Inicialmente, fez-se o levantamento de todos os artigos encontrados com os descritores cadastrados nos Descritores em Ciência da Saúde (DeCS): Idoso, Envelhecimento, Fisioterapia e Institucionalização. Utilizou-se isoladamente e combinados com o operador booleano and para a realização desta pesquisa: Envelhecimento and Fisioterapia, Idoso and Fisioterapia and Institucionalização.

Incluiu-se apenas os artigos originais publicados no período dos últimos 5 anos (de 2015 a 2020), com resumos de textos completos disponíveis nos bancos de dados publicados nos idiomas português e inglês. Selecionou-se trabalhos pelo título, pelo resumo e pela relevância ao trabalho com restrições ao tipo de estudo. Excluiu-se os estudos com textos completos indisponíveis, repetições em base de dados diferentes e que não tiveram relação com o tema proposto.

Nesta busca, foram inicialmente identificados 320 artigos para a leitura exploratória dos resumos e, então, selecionados 43 que foram lidos integralmente. Depois da leitura analítica destes artigos, 08 foram selecionados como objeto de estudo, por apresentarem aspectos que respondiam à questão norteadora e objetivo desta revisão. 
Figura 1- Fluxograma da seleção dos artigos usados na revisão

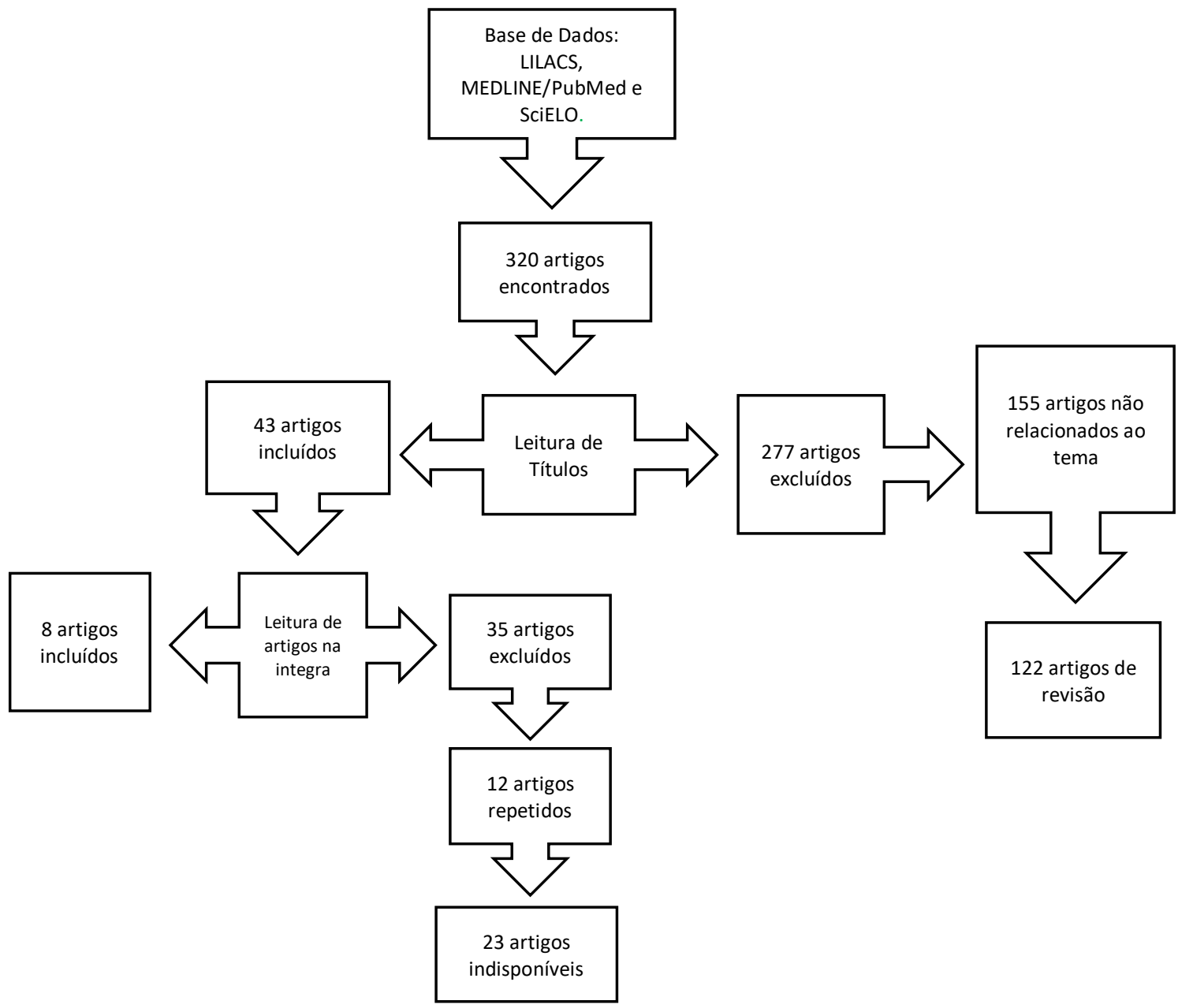

Fonte: Autoria própria.

\section{RESULTADOS}

Tabela 1- Descrição dos artigos incluídos no estudo

\begin{tabular}{|c|c|c|c|c|c|c|}
\hline $\begin{array}{c}\text { Autor(es)/A } \\
\text { no }\end{array}$ & Objetivo(s) & $\begin{array}{l}\text { Tipo(s) de } \\
\text { estudo }\end{array}$ & Amostra & Avaliação & Resultados & $\begin{array}{c}\text { Consideraçõe } \\
\text { s }\end{array}$ \\
\hline $\begin{array}{c}\text { Araujo et al. } \\
\text { (2015) }\end{array}$ & $\begin{array}{c}\text { Avaliar a } \\
\text { funcionalidade } \\
\text { de por meio da } \\
\text { capacidade } \\
\text { funcional e } \\
\text { Qualidade de } \\
\text { Vida, sob a ótica } \\
\text { da CIF, de idosas } \\
\text { institucionalizad } \\
\text { as. }\end{array}$ & $\begin{array}{c}\text { Estudo } \\
\text { observacion } \\
\text { al } \\
\text { transversal. }\end{array}$ & $\begin{array}{l}22 \text { idosas } \\
\text { com idade } \\
\text { igual ou } \\
\text { superior a } \\
60 \\
\text { anos. }\end{array}$ & $\begin{array}{l}\text { Índice de } \\
\text { Barthel, } \\
\text { Questionár } \\
\text { io Perfil de } \\
\text { Saúde de } \\
\text { Nottingha } \\
\text { m e, CIF, } \\
\text { MEEM. }\end{array}$ & $\begin{array}{c}\text { A } \\
\text { institucionalizaç } \\
\text { ão interfere na } \\
\text { capacidade } \\
\text { funcional } \\
(p<0,05) .\end{array}$ & $\begin{array}{c}\text { A CIF } \\
\text { possibilitou } \\
\text { uma visão } \\
\text { mais } \\
\text { ampliada } \\
\text { sobre o } \\
\text { processo de } \\
\text { saúde e de } \\
\text { envelhecimen } \\
\text { to de uma } \\
\text { população } \\
\text { de idosas } \\
\text { institucionaliz } \\
\text { a-das. }\end{array}$ \\
\hline
\end{tabular}




\begin{tabular}{|c|c|c|c|c|c|c|}
\hline $\begin{array}{l}\text { Pagotto et } \\
\text { al. (2016) }\end{array}$ & $\begin{array}{c}\text { Comparar a } \\
\text { prevalência e os } \\
\text { fatores } \\
\text { associados à } \\
\text { incapacidade } \\
\text { funcional para } \\
\text { ABVD em idosos } \\
\text { residentes em } \\
\text { duas } \\
\text { modalidades } \\
\text { institucionais. }\end{array}$ & $\begin{array}{c}\text { Estudo } \\
\text { transversal. }\end{array}$ & $\begin{array}{l}159 \text { idosos } \\
\text { de } \\
\text { instituições } \\
\text { de longa } \\
\text { permanênc } \\
\text { ia e casas } \\
\text { lares, com } \\
60 \text { anos ou } \\
\text { mais, de } \\
\text { ambos os } \\
\text { sexos. }\end{array}$ & $\begin{array}{c}\text { Índice de } \\
\text { Katz, } \\
\text { MEEM. }\end{array}$ & $\begin{array}{l}\text { Incapacida-de } \\
\text { funcional em } \\
\text { relação à idade, } \\
\text { sexo, } \\
\text { depressão, } \\
\text { doenças } \\
\text { osteomus- } \\
\text { culares e tempo } \\
\text { de instituciona- } \\
\text { lização } \\
(p<0,05) .\end{array}$ & $\begin{array}{c}\text { Demonstram } \\
\text { a necessidade } \\
\text { de } \\
\text { intervenções } \\
\text { junto aos } \\
\text { idosos } \\
\text { institucionaliz } \\
\text { a-dos, } \\
\text { principalment } \\
\text { e moradores } \\
\text { em } \\
\text { instituições } \\
\text { de } \\
\text { modalidade } \\
\text { permanência } \\
\text { integral, com } \\
\text { foco no } \\
\text { controle da } \\
\text { depressão. }\end{array}$ \\
\hline $\begin{array}{c}\text { Rodrigues, } \\
\text { Molnare } \\
\text { Abreu } \\
(2016)\end{array}$ & $\begin{array}{l}\text { Comparar o } \\
\text { desempenho } \\
\text { funcional de } \\
\text { idosos } \\
\text { independen-tes } \\
\text { para a marcha } \\
\text { entre } \\
\text { moradores ou } \\
\text { não de ILPI. }\end{array}$ & $\begin{array}{l}\text { Estudo } \\
\text { transversal. }\end{array}$ & $\begin{array}{l}20 \text { idosos } \\
\text { da } \\
\text { comunidad } \\
\text { e e } 29 \\
\text { idosos } \\
\text { instituciona } \\
\text { li-zados, } \\
\text { com } 60 \\
\text { anos ou } \\
\text { mais, de } \\
\text { ambos os } \\
\text { sexos. }\end{array}$ & $\begin{array}{c}\text { EEB, BBS, } \\
\text { DGI, } \\
\text { POMA, } \\
\text { TUG e } \\
\text { GDS. }\end{array}$ & $\begin{array}{l}\text { Equilíbrio, } \\
\text { mobilidade, } \\
\text { depressão e } \\
\text { marcha em } \\
\text { relação à } \\
\text { instituciona- } \\
\text { lização } \\
(p<0,05) .\end{array}$ & $\begin{array}{c}\text { Idosos } \\
\text { institucionaliz } \\
\text { a-dos } \\
\text { apresentaram } \\
\text { maior } \\
\text { comprometi- } \\
\text { mento da } \\
\text { mobilidade, } \\
\text { equilíbrio e } \\
\text { marcha em } \\
\text { comparação } \\
\text { com os idosos } \\
\text { da } \\
\text { comunidade. }\end{array}$ \\
\hline $\begin{array}{l}\text { Güths et al. } \\
\text { (2017) }\end{array}$ & $\begin{array}{l}\text { Descrever } \\
\text { característi-cas } \\
\text { sociodemo- } \\
\text { gráficas, } \\
\text { familiares, } \\
\text { situação de } \\
\text { saúde, } \\
\text { depressão e } \\
\text { grau de } \\
\text { capacidade } \\
\text { funcional em } \\
\text { idosos } \\
\text { institucionali- } \\
\text { zados em } 11 \text { ILPI } \\
\text { na região do } \\
\text { Litoral Norte do } \\
\text { Rio Grande do } \\
\text { Sul, no Brasil. }\end{array}$ & $\begin{array}{c}\text { Estudo } \\
\text { descritivo } \\
\text { transversal. }\end{array}$ & $\begin{array}{c}60 \text { idosos } \\
\text { instituciona } \\
\text { li-zados } \\
\text { com faixa } \\
\text { etária de } \\
70 \text { a } 79 \\
\text { anos de } \\
\text { ambos os } \\
\text { sexo. } \\
.\end{array}$ & $\begin{array}{c}\text { GDS, } \\
\text { MEEM, } \\
\text { Índice de } \\
\text { Barthel. }\end{array}$ & $\begin{array}{l}\text { Morbidade, } \\
\text { funcionali-dade, } \\
\text { depressão, } \\
\text { aspectos } \\
\text { familiares em } \\
\text { relação à } \\
\text { instituciona- } \\
\text { lização } \\
(p<0,05) .\end{array}$ & $\begin{array}{c}\text { Contribuíram } \\
\text { para } \\
\text { conhecer as } \\
\text { condições de } \\
\text { saúde e } \\
\text { capacidade } \\
\text { funcional } \\
\text { desses idosos } \\
\text { institucionaliz } \\
\text { a-dos, } \\
\text { visando } \\
\text { qualificar a } \\
\text { assistência a } \\
\text { esse público. }\end{array}$ \\
\hline
\end{tabular}




\begin{tabular}{|c|c|c|c|c|c|c|}
\hline $\begin{array}{c}\text { Fleig e } \\
\text { Oliveira } \\
\text { (2017) }\end{array}$ & $\begin{array}{l}\text { Demonstrar } \\
\text { por meio da } \\
\text { MIF, as } \\
\text { característi-cas } \\
\text { funcionais de } \\
\text { ILPI, } \\
\text { identificando a } \\
\text { possível } \\
\text { relação desse } \\
\text { instrumento } \\
\text { com a CIF. }\end{array}$ & $\begin{array}{c}\text { Estudo } \\
\text { observacional } \\
\text { descritivo, } \\
\text { com caráter } \\
\text { transversal, } \\
\text { de natureza } \\
\text { quantitativa e } \\
\text { analítica. }\end{array}$ & $\begin{array}{l}55 \text { idosos } \\
\text { com idade } \\
\text { igual ou } \\
\text { superior a } 60 \\
\text { anos, de } \\
\text { ambos os } \\
\text { sexos. }\end{array}$ & $\begin{array}{c}\text { MIF, CIF, } \\
\text { MEEM. }\end{array}$ & $\begin{array}{c}\text { MIF e CIF, } \\
\text { quanto à } \\
\text { instituciona- } \\
\text { lização } \\
(p>0,05) .\end{array}$ & $\begin{array}{l}\text { Os resultados } \\
\text { indicam que } \\
\text { os idosos em } \\
\text { questão } \\
\text { apresentaram } \\
\text { independência } \\
\text { completa para } \\
\text { realizar suas } \\
\text { atividades de } \\
\text { vida } \\
\text { diariamente. } \\
\text { Além disso, } \\
\text { observou-se } \\
\text { uma forte } \\
\text { concordância } \\
\text { entre os } \\
\text { domínios da } \\
\text { MIF e as } \\
\text { categorias da } \\
\text { CIF. }\end{array}$ \\
\hline $\begin{array}{l}\text { Pereira et } \\
\text { al. (2017) }\end{array}$ & $\begin{array}{c}\text { Verificar a } \\
\text { influência da } \\
\text { aplicação de } \\
\text { um protocolo } \\
\text { de } \\
\text { treinamento } \\
\text { funcional sobre } \\
\text { o equilíbrio e } \\
\text { funcionalida- } \\
\text { de de idosos } \\
\text { não } \\
\text { institucionali- } \\
\text { zados. }\end{array}$ & $\begin{array}{l}\text { Estudo } \\
\text { transversal. }\end{array}$ & $\begin{array}{c}21 \text { idosos } \\
\text { não } \\
\text { institucionali- } \\
\text { zados, com } \\
\text { idade entre } \\
65 \text { a } 80 \text { anos, } \\
\text { de ambos os } \\
\text { sexos. }\end{array}$ & $\begin{array}{c}\text { EEB, } \\
\text { Tinetti, } \\
\text { Índice de } \\
\text { Katz, } \\
\text { MEEM. }\end{array}$ & $\begin{array}{l}\text { Equilíbrio e } \\
\text { marcha no } \\
\text { pré-treino em } \\
\text { relação aos } \\
\text { pós- treino } \\
\text { ( }<<0,05) . \\
\text { Atividades de } \\
\text { Vida Diária no } \\
\text { pré-treino em } \\
\text { relação aos } \\
\text { pós-treino } \\
(p>0,05) .\end{array}$ & $\begin{array}{l}\text { Conclui-se que } \\
\text { o protocolo de } \\
\text { treinamento } \\
\text { funcional } \\
\text { utilizado no } \\
\text { estudo foi } \\
\text { eficaz na } \\
\text { melhora do } \\
\text { equilíbrio } \\
\text { estático e } \\
\text { dinâmico dos } \\
\text { idosos, o que } \\
\text { favorece a } \\
\text { redução do } \\
\text { risco de } \\
\text { quedas e } \\
\text { consequente- } \\
\text { mente a } \\
\text { redução da } \\
\text { inabilidade } \\
\text { dessa } \\
\text { população. }\end{array}$ \\
\hline $\begin{array}{c}\text { Oliveira e } \\
\text { Rozendo } \\
(2017)\end{array}$ & $\begin{array}{l}\text { Demonstrar, } \\
\text { por meio do } \\
\text { Índice de } \\
\text { Barthel, as } \\
\text { característi-cas } \\
\text { funcionais de } \\
\text { idosos em ILPI } \\
\text { e relacionar tal } \\
\text { instrumento de } \\
\text { avaliação } \\
\text { funcional à CIF. }\end{array}$ & $\begin{array}{c}\text { Estudo } \\
\text { Observacional } \\
\text { transversal. }\end{array}$ & $\begin{array}{l}55 \text { idosos, } \\
\text { com idade } \\
\text { igual ou } \\
\text { superior a } 60 \\
\text { anos, de } \\
\text { ambos os } \\
\text { sexos. }\end{array}$ & $\begin{array}{c}\text { Índice de } \\
\text { Barthel, } \\
\text { CIF, } \\
\text { MEEM. }\end{array}$ & $\begin{array}{l}\text { A instituciona- } \\
\text { lização } \\
\text { comprome-te } \\
\text { a funcionali- } \\
\text { dade. Relação } \\
\text { entre Índice } \\
\text { de Barthel e } \\
\text { CIF ( } p>0,05) \text {. }\end{array}$ & $\begin{array}{c}\text { Por meio do } \\
\text { índice de } \\
\text { Barthel e ClF } \\
\text { foi possível } \\
\text { identificar que } \\
\text { há } \\
\text { comprometi- } \\
\text { mento } \\
\text { funcional em } \\
\text { idosos } \\
\text { institucionaliza } \\
\text { dos. }\end{array}$ \\
\hline
\end{tabular}




\begin{tabular}{|c|c|c|c|c|c|c|}
\hline $\begin{array}{c}\text { Rosa, } \\
\text { Santos e } \\
\text { Moraes } \\
\text { (2018) }\end{array}$ & $\begin{array}{l}\text { Avaliar a } \\
\text { prevalência e } \\
\text { os fatores } \\
\text { associados ao } \\
\text { prejuízo } \\
\text { cognitivo em } \\
\text { uma amostra } \\
\text { de idosos } \\
\text { residentes em } \\
\text { instituições } \\
\text { filantrópicas. }\end{array}$ & $\begin{array}{c}\text { Estudo } \\
\text { transversal e } \\
\text { descritivo. }\end{array}$ & $\begin{array}{l}98 \text { idosos } \\
\text { institucionali- } \\
\text { zados com } \\
\text { idade igual } \\
\text { ou superior a } \\
60 \text { anos de } \\
\text { ambos os } \\
\text { sexos. }\end{array}$ & $\begin{array}{l}\text { MEEM, } \\
\text { Índice de } \\
\text { Katz, } \\
\text { SPPB. }\end{array}$ & $\begin{array}{l}\text { Prejuízo } \\
\text { cognitivo em } \\
\text { relação à } \\
\text { instituciona- } \\
\text { lização } \\
(p<0,05) .\end{array}$ & $\begin{array}{l}\text { Verificou-se } \\
\text { maior } \\
\text { prevalência de } \\
\text { doenças } \\
\text { endócrinas, de } \\
\text { transtornos } \\
\text { mentais e de } \\
\text { realização de } \\
\text { tratamento } \\
\text { psiquiátrico } \\
\text { nos idosos } \\
\text { com prejuízos } \\
\text { cognitivos. }\end{array}$ \\
\hline
\end{tabular}

LEGENDA: ILPI - Instituição de Longa Permanência para Idosos; CIF - Classificação Internacional de Funcionalidade, Incapacidade e Saúde; KATZ - Escala de Independência em Atividades da Vida Diária; TUG - cronometrado e pronto EEB - Escala de Equilíbrio de Berg; CIF - Classificação Internacional de Funcionalidade, Incapacidade e Saúde; ABVD - Atividade Básica de Vida Diária; IF - Incapacidade Funcional; BBS - Balança Berg Balance; DGI - Índice de Marcha Dinâmica; GDS - Escala de Depressão Geriátrica; POMA - Avaliação da Mobilidade Orientada da Marcha e Equilíbrio; MIF - Medida de Independência Funcional; MEEM - Mini Exame do Estado Mental; e SPPB - Massa curta de performance física.

Fonte: Autoria própria.

\section{DISCUSSÃO}

No estudo de Araújo et al. (2015), apurou-se que a maioria das mulheres idosas que vivem em ILP eram solitárias, analfabetas, todas apresentavam hipertensão e não praticavam atividade física. Esses resultados são confirmados por outros estudos e indicam a necessidade de programas de intervenção que incentivem a redução de um estilo de vida sedentário em idosos institucionalizados. Em relação aos valores encontrados no MEEM, demonstrou-se que as mulheres mais velhas com ensino superior apresentaram melhor média $(21,07 \pm 3,52)$, o que também foi encontrado em estudos semelhantes. Esse resultado mostra que não apenas a falta de independência motora determina a institucionalização dos idosos, como também os aspectos cognitivos são levados em consideração pelos familiares e/ou cuidadores.

Sendo assim, em relação à CIF, os resultados desse estudo indicam uma porcentagem maior de mulheres idosas com pouca dependência, indicando que essas mulheres idosas vivem de forma independente, o que significa boa capacidade de realizar atividades diárias. Apesar do fato de a maioria das mulheres idosas desse estudo 
ter um quadro de dependência leve, a aptidão física foi o domínio mais difícil durante a avaliação da QV. Nesse sentido, vale ressaltar que todas as idosas do estudo não participaram de qualquer atividade física, que pode estar associada ao baixo domínio físico mencionado pelas entrevistadas. Esse método mostrou-se sensível à compreensão do conhecimento sobre as habilidades funcionais e à qualidade de vida das idosas institucionalizadas, como um guia para a relação multidimensional entre a velhice e a institucionalização (ARAUJO et al., 2015).

No estudo de Pagotto et al. (2016), em que se analisou a comparação entre duas instituições, observou-se que os idosos de Casas Lares apresentaram menor frequência de envolvimento em ABVD. No entanto, em ambos os casos, as atividades mais envolvidas foram na seguinte ordem: manter continência, vestir-se e tomar banho. Nos Abrigos de Permanência Integral, os idosos demonstram déficits em relação a outras ABVD. Essa diferença pode ser explicada pelo fato de que, para serem admitidos em instituições de longa permanência com regime domiciliar, devem ser mais independentes, pois não receberão assistência em período integral, como é o caso dos demais procedimentos em questão. Estudos brasileiros com idosos institucionalizados demonstraram envolvimento em várias ABVD: transferir-se, tomar banho, vestir-se, ir ao banheiro e caminhar. Há evidências de que a perda de capacidade funcional começa com o comprometimento das atividades instrumentais, seguido pelo envolvimento das ABVD, sendo assim as atividades instrumentais são mais complexas e estão associadas à participação social do sujeito na sociedade.

Com a idade, a prevalência de incapacidade aumentou, o que está de acordo com estudos anteriores. Sabe-se que o declínio da capacidade de AVD aumenta com a idade e causa a necessidade de cuidados prolongados, seja por familiares, amigos, vizinhos (informalmente) ou por especialistas treinados, o que pode levar à institucionalização do idoso. (PAGOTTO et al., 2015).

Para Rodrigues, Molnar e Abreu (2016) os resultados indicam que idosos institucionalizados, mesmo com marcha independente e boa capacidade funcional, apresentam desempenho ruim em termos de marcha, equilíbrio e atividade em comparação com idosos residentes na comunidade. Os baixos escores obtidos pelos testes POMA, DGI e BBS para idosos institucionalizados indicam que esse grupo 
apresenta o maior risco de queda. O valor médio (38,68 pontos) obtido no grupo institucionalizado do BBS prevê que o desempenho das AVD diminuirá em 18 meses.

Os idosos institucionalizados tiveram os piores resultados nos testes utilizados, o que talvez possa ser explicado pela inclusão de idosos nas ILPI, pois o indivíduo perde contato com amigos, familiares, trabalho remunerado e lazer, ocasionando no isolamento social e na perda de autonomia. Os resultados desse estudo retratam correlações moderadas para idosos institucionalizados e fortes correlações para idosos na comunidade entre os testes BBS e POMA, que indicaram que ambos os testes têm equivalência na detecção de perda de atividade, e esse fato é explicado por muitas tarefas avaliadas em um teste. Apesar dessa relação de equivalência, um teste não substitui outro, o que é uma importante conclusão conjunta para uma melhor avaliação do equilíbrio dos idosos. (RODRIGUES; MOLNAR; ABREU, 2016).

$\mathrm{Na}$ amostra seguinte de Guths et al. (2017), as características da comunidade institucionalizada mostram um predomínio de mulheres, o que confirma o que foi encontrado. A amostra foi dominada pela faixa etária de 70 a 89 anos, sendo a idade um fator inconstante em ILPI brasileiras. A idade sozinha não é um fator decisivo na institucionalização, mas também os determinantes da saúde, dadas as possibilidades funcionais e o déficit cognitivo associado à perda de autonomia e independência. Podese observar que, apesar da maioria dos idosos ser considerada independente funcional e relatar boa saúde, o quadro depressivo foi identificado em $53,3 \%$ dos idosos. Essa aparente contradição entre independência funcional e presença de sintomas depressivos também foi relatada por outros autores. Assim, pode-se explicar que a depressão apresenta fatores de risco relacionados, como estadia superior a 24 meses, histórico conhecido de depressão, dor, carência ou falta de relação social, e dificuldade de se comunicar com os cuidadores.

Para Fleig e Oliveira (2017), em relação à CIF, pode-se concluir que os idosos avaliados apresentam desempenho funcional significativo para as atividades analisadas, em grande parte. Nesse ponto, observou-se com mais frequência as seguintes categorias: comida, bebida, curativo, funções de defecação, mudança de posição corporal, transferência de posição, funções de percepção, recepção de comunicação de mensagens orais e não orais, fala, interações pessoais básicas e funções cognitivas superiores com nenhuma dificuldade, ou seja, qualificador zero. 
A interpretação e discussão dos resultados por meio da relação entre o instrumento de avaliação da capacidade funcional e a CIF proporcionou uma visão mais ampla da saúde e do processo de envelhecimento da população idosa institucionalizada. Esses dados podem ser usados como indicadores para desenvolver estratégias e propostas de intervenção que atendam às necessidades clínicas e pessoais desses idosos. Uma possível limitação desse estudo estaria relacionada ao fato da amostra ser conveniente e referir-se a um único $\mathrm{LTCl}$, o que pode limitar a generalização dos dados a pessoas de outros LTCI e regiões. (FLEIG; OLIVEIRA, 2017).

Frente ao estudo de Pereira et al. (2017), conforme os benefícios do treinamento funcional verificados no estudo, evidenciou-se o aumento da força muscular, porque protocolos devem ser desenvolvidos, incluindo o uso do treinamento de força muscular, para reduzir a perda de massa muscular que ocorre durante o envelhecimento e aumentar o controle neuromuscular.

O programa de treinamento usado no estudo utiliza técnicas semelhantes para ajudar a alcançar os objetivos. Esse achado pode ser observado nos resultados satisfatórios obtidos com a ajuda da Escala de Equilíbrio de Berg, com recuperação de $100 \%$ do equilíbrio pós-treino, assumindo frequência 3 vezes por semana, o que provavelmente contribuiu para reduzir o risco de quedas. Nesses estudos, esse treinamento também afetou os resultados da Escala de Equilíbrio de Tinetti em cerca de $77,77 \%$, com melhorias entre as atividades de escala, como levantar-se de uma cadeira, tentar levantar-se, esterno irregular, rotação de $360^{\circ}$, sentar-se e manter equilíbrio de pé e equilíbrio em pé imediato (PEREIRA ET AL., 2017).

Os resultados encontrados de acordo com os testes aprimorados da força muscular dos membros inferiores e superiores confirmam que o treinamento funcional é eficaz para idosos, pois o treinamento de fortalecimento muscular trabalha para combater a fraqueza e imobilização muscular, melhorar a flexibilidade, reduzir o risco de quedas e aumentar a ativação neuromuscular do sistema nervoso central (PEREIRA et al., 2017).

Segundo Oliveira (2017), a avaliação da memória e da capacidade funcional é de extrema importância no processo de envelhecimento, sendo um importante indicador na institucionalização do idoso. Como resultado da avaliação da capacidade funcional avaliada pelo índice de Barthel, os resultados do estudo mostraram uma porcentagem 
maior de idosos com uma dependência grave, seguida por uma pequena dependência. Portanto, com a comparação do instrumento Barthel com a CIF, fica explícito que havia uma relação entre os dois domínios com as categorias da CIF, a pontuação do instrumento e os qualificadores da CIF.

Assim, a partir do estudo de Oliveira (2017), percebe-se que o Índice de Barthel pode ser uma ferramenta auxiliar no uso da CIF para otimizar a formulação e padronização do diagnóstico fisioterapêutico, e pode ser usado como indicador para desenvolver estratégias e propostas de intervenção que favoreçam as necessidades clínicas e pessoais desses idosos.

Nesse contexto, a interpretação e discussão dos resultados por meio da relação do instrumento de avaliação da capacidade funcional com a CIF permite uma visão mais ampla da saúde e do processo de envelhecimento da população idosa institucionalizada. Ademais, para melhor classificação dessa população o Índice de Barthel pode ser usado para avaliar atividades básicas da vida diária. Esses dados podem ser usados como indicadores para o desenvolvimento de estratégias e propostas de intervenções que favorecem a demanda clínica e pessoal desses idosos (OLIVEIRA, 2017).

Ao analisar a incidência de depressão, a prevalência de idosos é muito alta, em $81,7 \%$. Considerando apenas os idosos com capacidade cognitiva reduzida, essa proporção é ainda maior, ou seja, 92,6\%. No entanto, não houve associação significativa entre o comprometimento cognitivo e a depressão. Esse resultado pode ser devido ao fato de que a ocorrência de depressão é obtida nos prontuários de idosos e, portanto, não pode ser mensurada por instrumentos específicos. Segundo pesquisas, o uso rotineiro de instrumentos específicos para depressão pelos médicos não apenas permitiria o diagnóstico de muitos casos da doença, que passam despercebidos e afetam negativamente a qualidade de vida dos idosos, como também permitiria prever comorbidades existentes. (ROSA; SANTOS; MORAES, 2018).

\section{CONSIDERAÇÕES FINAIS}

Conclui-se que os instrumentos de avaliação apresentados demonstraram ser de grande importância, pois são eficazes na detecção de deficiências e/ou incapacidades que podem estar presentes em idosos institucionalizados, sendo que a deteç̧ão correta 
de tais disfunções torna-se essencial para um diagnóstico preciso e para a prescrição de condutas adequadas, levando assim a um tratamento satisfatório.

Dessa forma, entende-se que a alta prevalência de dependência entre os idosos requer das Instituições de Longa Permanência um maior investimento em recursos humanos, de modo a garantir a atenção interdisciplinar e multiprofissional voltada para a promoção da saúde e prevenção da incapacidade funcional.

\section{REFERÊNCIAS}

Instituto Brasileiro de Geografia e Estatística - IBGE: banco de dados. Disponível em: $<$ https://agenciadenoticias.ibge.gov.br/agencia-noticias/2012-agencia-denoticias/noticias/20980-numero-de-idosos-cresce-18-em-5-anos-e-ultrapassa30-milhoes-em-2017>. Acesso em: 30 maio 2020.

ARAUJO, L. B. et al. Investigação dos saberes quanto à capacidade funcional e qualidade de vida em idosas institucionalizadas, sob a ótica da CIF. Acta Fisiatrica, v. 22, n. 3, p. 111-117, 2015.

CORDEIRO, L.M et al.. Qualidade de vida do idoso fragilizado e institucionalizado. Acta Paul Enfermagem, v. 28, n. 4, p. 361-366, 2015.

FLEIG, T.C.M; OLIVEIRA, M.R. Avaliação da funcionalidade de idosos institucionalizados: relação entre a MIF e a ICF. Revista do Departamento de Educação Física e Saúde e do Mestrado em Promoção da Saúde da Universidade de Santa Cruz do Sul / Unisc, v. 18, n. 3, p. 190-195, 2017.

GÜTHS, J.F.S. et al. Perfil sociodemográfico, aspectos familiares, percepção de saúde, capacidade funcional e depressão em idosos institucionalizados no Litoral Norte do Rio Grande do Sul, Brasil. Revista Brasileira de Geriatria e Gerontologia, v. 20, n. 2, p. 175-185, 2017.

LOPES, G.L; SANTOS, M.I.P.O. Funcionalidade de idosos cadastrados em uma unidade da Estratégia Saúde da Família segundo categorias da Classificação Internacional de Funcionalidade. Revista Brasileira de Geriatria e Gerontologia, v. 18, n. 1, p. 7183, 2015.

MONTEIRO, I.O. et al. A saúde do idoso na graduação em fisioterapia no Brasil: um estudo transversal. Revista Fisioterapia e Pesquisa, v. 27, n. 1, p. 93-99, 2020.

MOREIRA, L.B et al. Fatores associados a capacidade funcional de idosos adscritos à Estratégia de Saúde da Família. Ciência \& Saúde Coletiva, v. 25, n. 6, p. 20412050, 2020. 
OLIVEIRA, J. M.; ROZENDO, C. A. Instituição de longa permanência para idosos: um lugar de cuidado para quem não tem opção? Revista Brasileira de Enfermagem, v. 67, n. 5, p. 773-779, 2014.

OLIVEIRA, M.R. Avaliação da funcionalidade de idosos institucionalizados: relação entre o Índice de Barthel e a Classificação Internacional de Funcionalidade, Incapacidade e Saúde (ICF). Revista Brasileira de Iniciação Científica, v. 4, n. 9, p. 22-33, 2017.

PAGOTTO, V. et al. Comparação da funcionalidade de idosos residentes em duas modalidades institucionais. Revista Eletrônica de Enfermagem, v. 18, n. 1, p. 110, 2016.

PAIVA, M. M.; LIMA, M. G.; BARROS, M. B. A. Desigualdades sociais do impacto das quedas de idosos na qualidade de vida relacionada à saúde. Ciência $\&$ Saúde Coletiva, v. 25, n. 5, p. 1887-1895, 2020.

PEREIRA, L. M. et al. Impacto do treinamento funcional no equilíbrio e funcionalidade de idosos não institucionalizados. Ciência e movimento, v. 25, n. 1, p. 79-89, 2017.

RODRIGUES, N. C.; MOLNAR, P.; ABREU, D. C. C. avaliação funcional de idosos institucionalizados e não institucionalizados independentes para a marcha. Estudos Interdisciplinares Sobre o Envelhecimento, v. 21, n. 2, p. 105118, 2016.

ROSA, T. S. M.; SANTOS, V. A. V. F.; MORAES, A. B. Prevalência e fatores associados ao prejuízo cognitivo em idosos de instituições filantrópicas: um estudo descritivo. Ciência \& Saúde Coletiva, v. 23, n. 11, p. 3757-3765, 2018. 


\title{
CAPITULO XVII
}

\section{RELACÕES ENTRE HABIUDADES MOTORAS FUNDAMENTAIS, FUNÇÕES EXECUITINAS E DESEMPENHO ACADÊMICO EM CRIANCAS}

\section{DOI: 10.51859/amplla.csa528.2121-17}

\author{
Maiara da Silva Martins ${ }^{1}$ \\ Victor Matheus Lopes Martinez ${ }^{2}$ \\ Renan Propodoski Guerine ${ }^{3}$
}

\begin{abstract}
${ }^{1}$ Especialista em Psicomotricidade Escolar PUCRS - Graduada em Educação Física Pontifícia Universidade Católica do Rio Grande do Sul - PUCRS

${ }^{2}$ Mestrando em Psicologia. Programa de Pós-Graduação em Psicologia na Pontifícia Universidade Católica do Rio Grande do Sul - PUCRS

${ }^{3}$ Graduando em Educação Física. Universidade do Vale do Rio dos Sinos - UNISINOS
\end{abstract}

\section{RESUMO}

As funções executivas (FE) são um conjunto de processos cognitivos e metacognitivos que estão envolvidas no controle e direcionamento do comportamento, responsáveis por orientar e gerenciar funções cognitivas e comportamentais. Este artigo tem como objetivo identificar as relações entre as funções executivas, o desenvolvimento das habilidades motoras fundamentais e o reflexo disso no desempenho acadêmico de crianças. Trata-se de uma revisão bibliográfica da literatura de cunho narrativo. Foram utilizadas para a investigação bases de dados, incluindo pesquisas na língua portuguesa e inglesa através de termos referentes ao tema. As funções executivas exercem grande impacto sobre a capacidade do indivíduo de aprender novas informações, afetando diretamente em seu desenvolvimento motor, assim como, em suas funções cognitivas e conotativas. Desta maneira, pode-se concluir com base nos estudos revisados, que há relações entre as funções executivas, habilidades motoras fundamentais e desempenho acadêmico em crianças, assim como tais fatores são indispensáveis para o desenvolvimento do indivíduo.

Palavras-chave: Funções executivas. Desenvolvimento motor. Desempenho acadêmico. Habilidades motoras fundamentais.

\section{INTRODUÇÃO}

A neurociência é uma ciência interdisciplinar que contribui em diversas áreas do conhecimento, sua função é estudar o funcionamento cerebral, seus comportamentos, as funções cognitivas do cérebro entre outros aspectos. Um cérebro saudável está diretamente ligado a um bom desenvolvimento cognitivo e consequentemente ao desenvolvimento das habilidades motoras fundamentais do indivíduo. 
As funções executivas (FE) são um conjunto de processos cognitivos e metacognitivos que estão envolvidas no controle e direcionamento do comportamento, responsáveis por orientar e gerenciar funções cognitivas, comportamentais e emocionais (DIAS, 2014), integram a tríade neurofuncional da aprendizagem, juntamente com as funções cognitivas e as funções conotativas. Quem comanda essas funções é o córtex pré-frontal, região que ocupa no cérebro quase um terço do seu tamanho. O córtex pré-frontal está intimamente conectado com o córtex prépsicomotor, com os gânglios da base e com o cerebelo, todos esses estão envolvidos no controle e execução da motricidade. São exemplos das funções do córtex pré-frontal: a elaboração e a organização de estratégias; a sustentação da atenção; a flexibilidade e a plasticidade comportamental; a mudança de estratégia; a programação, a desprogramação e a reprogramação de condutas; avaliação e verificação de respostas adaptativas ou comportamentais, entre outras.

Em relação ao desenvolvimento e ao aprendizado das habilidades motoras fundamentais, os fatores maturacionais, ambientais e as experiências oportunizadas à criança estão fortemente ligadas (GALLAHUE, 2013). Sendo assim seu desenvolvimento é fundamental para o indivíduo e não depende somente da idade, mas também das oportunidades e experiências motoras que essa criança irá ter ao seu alcance e ao ambiente em que vive, tendo em vista que o desenvolvimento motor é sequencial. $\mathrm{O}$ repertório motor de um indivíduo é consequência de diversas vivências que o mesmo tem ao longo da sua trajetória. Segundo (GALLAHUE, 2013) o desenvolvimento motor é dividido em três estágios: O inicial, o elementar e o maduro, esse desenvolvimento apresenta uma progressão gradual desde que o indivíduo seja estimulado e tenha oportunidade de vivenciar diversas experiências. O inicio do desenvolvimento das habilidades motoras fundamentais se dá por volta do primeiro ano de vida, prolongando-se até aproximadamente os seis ou sete anos e são resultados de diversos fatores e de extrema importância para um bom desenvolvimento infantil, elas apresentam padrões específicos e elementos comuns entre si, assim formam uma boa base motora (HAYWOOD; GETCHELL, 2004).

Sendo assim, este artigo tem como objetivo identificar as relações entre as funções executivas, o desenvolvimento das habilidades motoras fundamentais e o reflexo disso no desempenho acadêmico de crianças. Desta forma, foi realizada uma 
revisão bibliográfica de cunho narrativo, em bases de dados, na língua portuguesa e inglesa, através dos termos "funções executivas", "desenvolvimento motor", "infância", "desempenho acadêmico", "habilidades motoras fundamentais", "motor skills", "Executive Function", "motor development", "academic Success", "cognitive development" e "childhood", "fundamental motor skills" para compor a pesquisa e discussão teórica. O presente estudo tem a pretensão de contribuir para a divulgação e consolidação da importância do estímulo cognitivo e motor, especialmente nos primeiros anos da infância e apresentar dados que comprovem aspectos benéficos no desempenho acadêmico quando o indivíduo é exposto a diversas experiências e estímulos para se desenvolver de forma integral.

\section{FUNÇÕES EXECUTIVAS NA INFÂNCIA}

As funções executivas são processos mentais complexos pelos quais o indivíduo aperfeiçoa o seu desempenho cognitivo, a coordenação, a supervisão e o controle de processos cognitivos e conotativos, otimiza suas respostas adaptativas e o seu desempenho comportamental em situações que requerem operacionalização, as funções executivas são um conjunto de ferramentas que são essenciais para aprender a aprender (FONSECA, 2014). Desempenham um papel importante na vida do indivíduo como a capacidade para inibição de respostas impulsivas, planejamento estratégico, organização do comportamento, memória de trabalho, flexibilidade cognitiva e capacidade de autorregulação, seu bom desenvolvimento envolve a capacidade de conseguir executar diversos processos e diferentes etapas da mesma tarefa.

Estes processos cognitivos caracterizam-se por um conjunto de habilidades que de forma integrada, permitem ao indivíduo direcionar comportamentos a metas, avaliar a eficiência e adequação desses comportamentos, abandonar estratégias ineficientes em prol de outras mais eficientes e assim resolver problemas imediatos, de médio e longo prazo (SARTORI, 2019). Para ter um bom desenvolvimento ao longo de sua trajetória de vida, o indivíduo deve evocar um conjunto muito diversificado de competências executivas, como por exemplo: estabelecer objetivos; gerir, predizer e antecipar tarefas; priorizar e ordenar tarefas no espaço e no tempo determinado; separar ideias e conceitos gerais; pensar, reter, manipular, memorizar e resumir dados; 
flexibilizar, alterar e modificar procedimentos de trabalho, aplicar diferentes estratégias de resolução de problemas; manter e manipular informação na memória de trabalho; entre outras diversas competências.

A maior parte das tarefas exige coordenação e a integração coerentes das múltiplas funções executivas, por tanto, muitas crianças com disfunções ou dificuldades executivas apresentam problemas de sobrecarga de informações, de produtividade, de eficácia e de precisão em seu desempenho escolar.

Compreender o papel das funções executivas na aprendizagem oferece uma nova perspectiva sobre muitos alunos, os brilhantes ou os que não têm rendimento compatível com o seu potencial, além de apresentar novas visões sobre muitos alunos ditos fracos, com diferenças ou dificuldades de aprendizagem que aprendem em diferentes situações de ensino (FONSECA, 2014). Estudos mostram que as funções executivas envolvem diversos tipos de funções do cérebro, pesquisadores reconhecem três principais domínios: Memória de Trabalho, Controle inibitório e Flexibilidade cognitiva (DIAMOND, 2012).

A flexibilidade cognitiva é definida como a habilidade de mudar e se flexibilizar entre alternativas diferentes; mudar as ações de curso e adaptá-las para atender exigências do ambiente; encontrar erros e corrigi-los; rever o jeito de agir diante de novas informações; considerar algo a partir de novas perspectivas. Essa função executiva permite que sejam tomadas diversas decisões em diferentes contextos, está ligada a autocrítica, alterações de condutas, mudanças de estratégias, detecções de erros e obstáculos, busca intencional de soluções, entre outras. Crianças com alterações na flexibilidade cognitiva permanecem rígidas em seus padrões de pensamentos, não possuem autonomia para tentar resolver um problema de forma diferente, podem ficar ansiosas com mudanças de rotinas ou mudanças de planos.

A memória de trabalho é um sistema temporário de armazenamento de informações que permite o monitoramento e o manejo dessas informações e relacionase à retenção da informação em mente e à possibilidade de trabalhar mentalmente com esta informação, relacionando uma coisa a outra, ou usando pistas desta informação para resolver um problema (DIAMOND, 2013). Com relação à memória de trabalho, pelo menos dois tipos podem ser percebidos: um para informações não verbais (também denominado visual-espacial) e outro para informações verbais (BADDELEY, 2003). Estes 
processos de desmontagem e recombinação dos elementos mostram-se fundamentais para a criatividade, além disso, nos permitem levar o conhecimento conceitual para a tomada de decisões (DIAMOND, 2012).

O controle inibitório está relacionado à capacidade de inibir respostas, bem como aquelas que interrompem o curso eficaz de uma ação, especialmente as que já estão em curso (BARKLEY, 2001). Este controle está relacionado, por exemplo, à capacidade de suprimir uma resposta, mesmo quando existem estímulos internos e externos gratificantes e que, dessa forma, envolvem a capacidade de resistir às tentações e não agir de maneira impulsiva ou prematura (SARTORI, 2019).

\section{FUNÇÕEs EXECUTIVAS E habILIDADES MOTORAS COMO PREDITORAS DO DESEMPENHO ESCOLAR}

Atividades cognitivas como funções executivas, atenção, linguagem se desenvolvem a partir da auto-organização e das experiências vividas, assim como o desenvolvimento motor que ocorre de forma sequencial e contínua e é influenciado diretamente pela interação do indivíduo com o mundo, pelas oportunidades e pelo acesso a experiências ao longo da vida, a relação entre desenvolvimento das habilidades motoras e cognitivas reside na existência de conexões neuronais entre o cerebelo, responsável pelo controle e coordenação temporal dos movimentos, e o córtex préfrontal, responsável, principalmente, pelas funções executivas (DIAMOND, 2000), dessa forma, a percepção, a cognição e o desenvolvimento motor são vistos como sistemas funcionalmente interligados (LEONARD, 2016).

O desenvolvimento motor é entendido como sucessivos estados de estabilidade, instabilidade e mudanças de fase que propiciam o amadurecimento do indivíduo, para que novas habilidades motoras sejam adquiridas e refinadas ao longo deste desenvolvimento, é essencial que a criança tenha uma boa base de habilidades motoras fundamentais que incluem correr, saltar, galopar, chutar, rolar, arremessar, receber, entre outras, só assim poderá evoluir e aprender novas habilidades denominadas habilidades motoras específicas utilizadas para esportes, recreação, dança e atividades do dia a dia. Através de processos de experimentação e exploração a criança desenvolve 
diversos aspectos importantes em relação aos seus movimentos e desenvolve consciência de si, relaciona-se com o mundo exterior e se adapta mais facilmente.

As Funções Executivas possuem grande relação com essas habilidades, e atualmente tem sido de grande interesse de investigação, na tentativa de conhecer e compreender como se desenvolvem os processos cognitivos e quais fatores influenciam esse desenvolvimento, são consideradas como um complexo conjunto de processos cognitivos destinados a execução de comportamentos dirigidos a objetivos. Segundo (LIEBERMANN; GIESBRECHT; MÜLLER, 2007), as funções executivas desempenham um importante papel no processo de tomada de decisão, controle de emoções e no comportamento social, pois, são elas as responsáveis pelo comportamento que diz respeito a objetivos, estabelecimento de metas e resolução de problemas. Entre as habilidades que as FE são responsáveis estão incluídas a capacidade para inibição de respostas impulsivas, capacidade de planejamento estratégico, organização do comportamento, memória operacional, flexibilidade cognitiva e a capacidade de autorregulação, essenciais para a cognição humana por sua complexidade e multidimensionalidade.

Tarefas escolares em geral como compreensão da leitura, escrita, solução de problemas matemáticos, resumir textos, fazer anotações, executar projetos de longo prazo, demandam muito das funções executivas e requerem organização e integração dessas múltiplas habilidades. O sucesso escolar passa a depender grandemente da habilidade que o aluno tem de planejar e priorizar tarefas, manejar seu tempo, organizar materiais e informações, mudar de estratégia de forma flexível, monitorar seu progresso e refletir sobre o seu trabalho (MELTZER, 2014).

Diversos estudos têm analisado o desempenho de habilidades motoras fundamentais em crianças e concluindo que a grande maioria se classifica com atraso motor, os fatores para esses resultados são muitos, como por exemplo, falta de estimulação, problemas neurológicos, obesidade, déficits, transtornos, entre outros. Relacionando com as funções executivas, crianças que possuem algum problema no córtex pré-frontal acabam com dificuldades em ter um bom desenvolvimento motor $\mathrm{e}$ assim encontram dificuldades em diversos outros aspectos ao longo da vida.

As funções executivas são de extrema importância para o desenvolvimento de habilidades motoras fundamentais do indivíduo, pois são elas que permitem a tomada

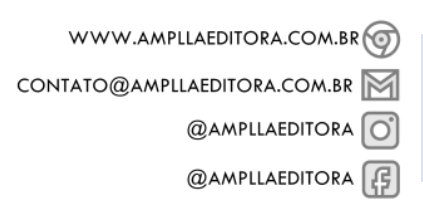


de decisão de forma correta ou flexibilização na hora de tomar uma atitude, mudar a estratégia no meio da atividade, ou até mesmo mudar o rumo da corrida vendo que o outro caminho é mais rápido, por exemplo. Exercem grande impacto sobre a capacidade do indivíduo de aprender novas informações, sendo assim prejuízos nessas habilidades podem gerar um comprometimento significativo no desempenho escolar e tornar tarefas como escrever, somar, ler e interpretar textos, por exemplo, difíceis (MELTZER, 2014), isso ocorre, pois indivíduos que possuem algum déficit no âmbito das habilidades das funções executivas geralmente enfrentam uma sobrecarga de informações tornando-as desorganizadas e mais complicadas com dificuldades de retomá-las ou reiniciá-las, isso traz um prejuízo na vida acadêmica do indivíduo refletindo em suas notas, no seu desempenho e no seu convívio social, ainda revelam que a flexibilidade cognitiva possui um papel fundamental na aquisição de competências matemáticas, estando relacionada à habilidade da criança em processar múltiplas informações de forma flexível.

Assim, quando as funções executivas não se desenvolvem de forma adequada, levam o indivíduo a dificuldades em diversos contextos. Crianças com déficit nas funções executivas são também prejudicadas em seu desenvolvimento motor, pois, o estímulo que deveriam receber dentro do ambiente escolar é insuficiente, por diversos fatores, como a própria criança que não se sente confiante e capaz para interagir com o grupo e acaba se afastando ou pelas oportunidades para as atividades práticas que são em raros momentos, acarretando no atraso motor.

Cabe aos educadores entender o papel essencial do desenvolvimento do indivíduo como um todo, estimulando o corpo e a mente, um indivíduo bem estimulado será um aluno nota dez e consequentemente sua trajetória escolar se tornará mais fácil e bem aproveitada. Cabe também a esses profissionais entender o papel das funções executivas na aprendizagem, pois só assim se terá um olhar diferenciado sobre aqueles alunos prodígios e sob aqueles alunos com diferenças ou dificuldades de aprendizagem que aprendem em diferentes situações de ensino (FONSECA, 2014). 


\section{CONSIDERAÇÕES FINAIS}

Este estudo teve como objetivo principal comparar o desempenho e as relações entre habilidades motoras fundamentais, funções executivas e o desempenho acadêmico em crianças, buscou apresentar definições e trazer informações sobre assuntos relacionados ao tema.

Sabemos o quão importante é para um indivíduo que ele tenha essas habilidades desenvolvidas tanto em seu desenvolvimento motor quanto em suas funções executivas. Após esse estudo então, podemos perceber que existe uma relação entre o desenvolvimento de habilidades motoras fundamentais, funções executivas e desempenho escolar.

Discussões acerca desses temas são pouco publicadas, principalmente materiais que relacionem desenvolvimento motor com funções executivas. Entretanto, podemos perceber que existe uma conexão entre essas funções, de modo que uma criança que é estimulada desde cedo desenvolve o lado cognitivo, emocional e motor de forma igual. Gallahue (2013), descreve justamente que o desenvolvimento e o aprendizado da criança estão diretamente ligados aos seus fatores maturacionais, ambientais e as experiências que são oportunizadas ao indivíduo, não dependendo somente da idade. Concluímos então que o estímulo motor e cognitivo na infância é primordial para um bom desenvolvimento interligado de tais funções, logo um ambiente favorável para que tais aspectos sejam difundidos é preciso e fundamental.

\section{REFERÊNCIAS}

BADDELEY, Alan. Working memory: Looking back and looking forward. Nature Reviews Neuroscience, [s. I.], v. 4, n. 10, p. 829-839, 2003. Disponível em: https://doi.org/10.1038/nrn1201

BARKLEY, Russell A. The Executive Functions and Self-Regulation: An Evolutionary Neuropsychological Perspective. [S. I.]: Springer, 2001. Disponível em: https://doi.org/10.1023/A:1009085417776

DIAMOND, Adele. Close interrelation of motor development and cognitive development and of the cerebellum and prefrontal cortex. Child Development, [s. I.], v. 71, n. 1, p. 44-56, 2000. Disponível em: https://doi.org/10.1111/1467-8624.00117 
DIAMOND, Adele. Executive functions. [S. I.]: Annual Reviews Inc., 2013. Disponível em: https://doi.org/10.1146/annurev-psych-113011-143750

DIAMOND, Adele. Executive Functions. [s. I.], 2012. Disponível em: https://doi.org/10.1146/annurev-psych-113011-143750

DIAS, Natália Martins. Promoção do desenvolvimento de funções executivas em crianças: apresentação do PIAFEx e evidências de estudos nacionais. Anais do Seminário Tecnologias Aplicadas a Educação e Saúde, [s. I.], v. 1, n. 1, p. 48-57, 2014.

FONSECA, Vitor. Papel das funções cognitivas, conativas e executivas na aprendizagem: uma abordagem neuropsicopedagógica. [s. I.], v. 31, n. 96, p. 236-253, 2014.

GALLAHUE, D. L. Compreendendo o desenvolvimento motor: bebês, crianças, adolescentes e adultos. $7^{a}$ ediçãoed. Porto Alegre: [s. n.], 2013.

HAYWOOD, Kathleen; GETCHELL, Nancy. Desenvolvimento motor ao longo da vida. [S. I.: s. n.], 2004.

LEONARD, Hayley C. The impact of poor motor skills on perceptual, social and cognitive development: The case of developmental coordination disorder. [S. I.]: Frontiers Research Foundation, $2016 . \quad$ Disponível em: https://doi.org/10.3389/fpsyg.2016.00311

LIEBERMANN, Dana; GIESBRECHT, Gerald F.; MÜLLER, Ulrich. Cognitive and emotional aspects of self-regulation in preschoolers. Cognitive Development, [s. I.], v. 22, n. 4 , p. 511-529, 2007. Disponível em: https://doi.org/10.1016/j.cogdev.2007.08.005

MELTZER, Lynn. Teaching executive functioning processes: Promoting metacognition, strategy use, and effort. In: HANDBOOK OF EXECUTIVE FUNCTIONING. [S. I.]: Springer New York, 2014. p. 445-473. Disponível em: https://doi.org/10.1007/978-1-4614-8106-5_25

SARTORI, Rodrigo Flores. Funções executivas, habilidades motoras e desempenho escolar em crianças com desordem coordenativa de desenvolvimento. [s. I.], 2019. 


\title{
CAPITULO XVIII
}

\section{ESTUDO DA FARMACOTERAPIA EM IDOSOS: REACG̃̃ES ADVERSAS E INTERAÇÕES MEDICAMENTOSAS}

\section{DOI: 10.51859/amplla.csa528.2121-18}

\author{
Natiely de Araújo Silva Farias ${ }^{1}$
}

\begin{abstract}
${ }^{1}$ Farmacêutica Residente em Saúde da Família. Programa de Residência Multiprofissional em Saúde da Família da Fundação Universidade Federal de Rondônia - UNIR/RO.
\end{abstract}

\section{RESUMO}

Este estudo objetivou analisar as interações e as reações adversas dos principais medicamentos utilizados pelos idosos, caracterizando-se a polifarmácia na geriatria, bem como realizar uma revisão narrativa sobre a polifarmácia, identificando os principais grupos farmacológicos envolvido neste processo, os fatores que contribuem para a prática da polifarmácia em indivíduos geriátricos e sistematizar o uso mais eficiente de medicamentos nestes grupos etários, através do cuidado farmacêutico. Trata-se de uma revisão bibliográfica, realizada em bases de dados científicos nacionais e internacionais. A partir da análise de dados foi possível perceber a importância da interação do usuário/paciente com a equipe de saúde, seguida da capacitação dos profissionais que estão diretamente em contato com o paciente idoso, em especial o profissional farmacêutico. Evidenciou-se com esse estudo uma visão clara e objetiva do que é polifarmácia e seus efeitos no organismo, tornando essencial o acompanhamento e monitoramento pelos profissionais que prestam assistência. Conclui-se que a educação permanente e continuada, aliada a corresponsabilidade, clínica ampliada, assim como a interação com a equipe multiprofissional torna-se a utilização de medicamentos racional e eficiente no acompanhamento da pessoa idosa.

Palavras-chave: Atenção Farmacêutica. Idosos. Medicamento. Polifarmácia.

\section{INTRODUÇÃO}

Com a constante e crescente expectativa de vida da população brasileira e consequente demanda por profissionais específicos, torna-se importante a atuação do profissional Farmacêutico, que vai de encontro com essa realidade.

Neste sentido, o envelhecimento populacional ocasiona mudanças no organismo da pessoa idosa, levando a perda da elasticidade muscular, resistência óssea, diminuição da acuidade visual e auditiva, além de comprometimento das funções corpóreas. 
Consequentemente haverá um aumento no desenvolvimento das condições crônicas de saúde, sendo comum a presença de multimorbidades (ROACH, 2001).

Os idosos são os maiores consumidores de medicamentos e alguns utilizam de cinco ou mais por dia caracterizando-se a Polifarmácia (ONG SM et al., 2018).

A Polifarmácia é caracterizada como o uso de mais de quatro medicamentos por dia por um período de tempo superior a três meses, também pode ser conceituada Polifarmácia quando o indivíduo faz o uso de vários medicamentos sem indicação e prescrição médica (BONGIOVANI et al., 2021).

Agregado a Polifarmácia, cresceu o número de Problemas Relacionados ao uso de Medicamentos (PRM) em todo o território brasileiro, em especial nas regiões onde inexiste ou tem sua oferta insuficiente dos profissionais Farmacêuticos atuando no Sistema Único de Saúde (SUS).

Diante do atual cenário, vê-se a necessidade de cuidados especiais com essa fatia da população, haja vista sua fragilidade em consequência da idade avançada e/ou situação de abandono em que muitos se encontram. A ignorância no processo de administração dos medicamentos é outro fator que potencializa a necessidade de cuidados especiais.

Segundo Carvalho et al., (2012) estima-se que, em 2025, a população brasileira terá aumentado cinco vezes em relação ao ano de 1950, ao passo que o número de pessoas com idade superior a 60 anos terá aumentado cerca de 15 vezes.

Deste modo, o objetivo desse estudo é realizar uma avaliação por meio da revisão de literatura do que já se tem produzido no meio científico, evidenciando as pesquisas que buscam descrever a utilização de medicamentos em pacientes idosos, assim como avaliar as reações adversas e interações medicamentos decorrentes da farmacoterapia.

\section{METODOLOGIA}

O presente estudo trata-se de uma revisão de literatura, de caráter qualitativo e descritivo, tendo como tema o estudo da farmacoterapia em pacientes idosos: reações adversas e interações medicamentosas. A pesquisa bibliográfica anseia pela procura de explicações de um determinado problema utilizando como ponta pé inicial referências 
teóricas já publicadas, a exemplo de livros, revistas, periódicos, artigos científicos, e entre outros. Esse modelo de pesquisa pode ser realizado de maneira totalmente independente, ou como parte de inúmeros outros tipos de pesquisa (BARROS et al., 3o edição 2007).

As publicações passaram por critérios de inclusão e exclusão. Sendo os critérios de inclusão os artigos originais em periódicos nacionais e internacionais, indexados e publicados no período de 2010 a 2021, possibilitando uma melhor atualização bibliográfico e referencial sobre o tema abordado.

Foram utilizados estudos publicados em revistas especializadas, esquematizadas de base de dados disponíveis no meio eletrônico, tais como Literatura Latino-Americana e do Caribe em Ciências da Saúde (LILACS), Medical Literature Analysis and Retrieval System Online (MEDLINE), Scientific Electronic Library Online (SCIELO) e nas bases de dados do National Center for Biotechnology Information (PUBMED). Desta forma os artigos incompletos foram excluídos por não se encaixaram nos critérios de inclusão do estudo.

Os descritores utilizados para a busca dos materiais foram: "Medicamentos and farmacoterapia and interações medicamentosas and reações adversas and geriatria", todos combinados entre si, no idioma português, espanhol e inglês.

Foram encontrados 1584 artigos, na qual 455 em Português, 487 em Espanhol e 642 em Inglês. Foram descartados 1566 pois não atingia o objetivo do estudo, sendo analisado 18 artigos para a construção da pesquisa.

A coleta de dados ocorreu no período de janeiro a abril de 2021, e após a busca e escolha das publicações que atendiam aos critérios de inclusão, os trabalhos selecionados foram analisados e utilizados para a construção do presente estudo.

\section{FARMACOTERAPIA NO IDOSO E O FARMACÊUTICO}

A administração e uso incorreto de medicamentos na pessoa idosa tornou-se um problema que requer muita atenção por parte do governo e sociedade em geral, interferindo diretamente nos resultados clínicos, financeiro e humano do paciente. Tal questão de saúde aliada à prescrição médica indevida e/ou errônea vem a contribuir ainda mais para o agravamento dos problemas. Segundo Regina (2010), a Polifarmácia 
é o uso de cinco ou mais medicamentos, enfatiza-se que a prática tem aumentado nos últimos anos, apesar de ser um hábito milenar.

Oliveira e Pereira (2018), afirma que $56,6 \%$ dos idosos possuem ou já possuíram prescrições com mais de quatro medicamentos, que podem vir a contribuir no agravo de patologias existentes nesses indivíduos. Os autores, através de seus estudos constataram que as interações medicamentosas são responsáveis por $5 \%$ dos erros de medicações e 6,7\% das reações adversas, oriundas da polifarmácia, são de classificação grave e $0,32 \%$ para reações adversas fatais.

Tabela 1 - Interações medicamentosas potenciais e respectivos desfechos clínicos.

\begin{tabular}{|c|c|c|}
\hline Medicamento & Interação com & Desfecho Clínico \\
\hline Amiodarona & $\begin{array}{c}\text { Cisaprida, Tioridazina } \\
\text { Betabloqueadores }\end{array}$ & $\begin{array}{c}\text { Risco de Arritmia cardíaca } \\
\text { Redução do efeito } \\
\text { hipotensor }\end{array}$ \\
\hline BINES & Antidiabéticos orais & $\begin{array}{c}\text { Alterações glicêmicas, } \\
\text { Hipotensão e sedação. }\end{array}$ \\
\hline Digoxina & $\begin{array}{c}\text { Amiodarona, } \\
\text { Benzodiazepínicos, } \\
\text { Hidroclorotiazida, } \\
\text { Furosemida }\end{array}$ & $\begin{array}{c}\text { Intoxicaça digitálica } \\
\text { Captopril }\end{array}$ \\
& $\begin{array}{c}\text { Diurético poupador de } \\
\text { potássio }\end{array}$ & Hipercalemia \\
\hline
\end{tabular}

Fonte: Regina (2010)

A integração do profissional Farmacêutico na equipe multidisciplinar, que compõe o atendimento a pessoa idosa é de suma importância no contexto que envolve a Polifarmácia. Melo et al., (2017 p. 236) relata em sua pesquisa que a assistência à saúde que conta com a atuação do farmacêutico clínico somada a equipe médica e multidisciplinar trazem grandes benefícios para o paciente idoso, visto que a avaliação da prescrição e a escolha criteriosa da melhor farmacoterapia reduz os riscos de reações adversas e interações medicamentosas.

A ignorância quanto à administração do medicamento, o déficit cognitivo e as doenças crônicas são fatores que potencializam a polifarmácia junto a essa população, situações que expõe ainda mais esses indivíduos a um grau maior de vulnerabilidade quanto às reações adversas aos medicamentos. Alguns fatores têm sido associados à polifarmácia entre idosos, como pertencer ao sexo feminino, ter autopercepção de 
saúde ruim, ser de faixa etária mais avançada, ter baixa escolaridade e referência à presença de doenças crônicas (ALMEIDA et al., 2017).

Segundo Oliveira et al., (2018) é preciso ter um extremo cuidado com o uso dos medicamentos, em especial em idosos, tal comportamento é determinantes para o sucesso na recuperação e/ou manutenção da saúde do usuário.

Por utilizarem múltiplos medicamentos, os idosos frequentemente estão expostos aos riscos de combinações inadequadas. Esse risco será mais alto se o paciente tem mais de um médico ou se esteve internado recentemente e recebeu nova prescrição à alta. Os efeitos adversos das medicações são mais frequentes nos pacientes idosos do que em adultos. Cunha et al., (2013) da ênfase aos seguintes medicamentos: Laxativo catártico como Sene, Cascara Sagrada e Bisacodil, pois podem provocar diarreia e desidratação; em longos prazo provocam destruição do pleno mioentérico, comprometendo peristaltismo e agravando a constipação intestinal.

Para melhor compreensão do que é reações adversas medicamentosa (RAM) em idosos, faz-se necessário a conceituação de iatrogenia. Conforme Oliveira et al., (2018):

\footnotetext{
"latrogenia pode ser definido como "o prejuízo provocado a um paciente pela omissão ou ação dos profissionais de saúde, mesmo que a intervenção tenha sido bem indicada e adequadamente realizada". Portanto, iatrogenia significa prejuízo ao paciente, e não necessariamente significa que houve um erro profissional de saúde" (OLIVEIRA et al., $2018 \mathrm{p}-18$ ).
}

De acordo com Silva et al., (2012) quando em sua pesquisa com mais de 3 mil idosos, observou-se que $35,4 \%$ dos idosos entrevistados utilizavam inúmeros tipos de medicamentos, constatando também que a maior incidência dessa prática é, lamentavelmente, ainda maior com idade acima dos 60 anos, mais precisamente no grupo de 60 a 69 anos. Oliveira et al., (2018) constatou que 28,3\% desses idosos confessaram fazer uso de mais de um medicamento, chegando aos $42,7 \%$ em idosos com mais de 70 anos.

Desde os primórdios da existência da prática da medicina, a polifarmácia sempre esteve presente, uma forma daqueles que exerciam a medicina, ainda que de forma caseira e/ou arcaica procurar o "acerto" no tratamento de uma determinada patologia. Com a polifarmácia veio também as "interações medicamentosas", conforme destaca Santos e Seadi (2013, p. 60), interações medicamentosas acontecem quando o efeito de 
um determinado fármaco sofre uma metamorfose em consequência de outro, que geralmente gera um efeito benéfico na terapia, mas que também pode minimizar a eficácia de outros fármacos associado, inclusive causando toxicidade.

Na Tabela 2 estão apresentados a relação de alguns fármacos que quando administrados concomitantemente com outras drogas geram uma determinada interação medicamentosa, quase sempre com resultado maléfico ao paciente.

Tabela 2 - Interações medicamentosas

\begin{tabular}{|c|c|c|}
\hline Medicamentos & Mecanismo & Efeito da Interação \\
\hline Varfarina + Antibióticos & $\begin{array}{l}\text { Os antibióticos inibem o } \\
\text { metabolismo da Varfarina, } \\
\text { e a ação da Varfarina é } \\
\text { prolongada pela redução } \\
\text { da flora intestinal causada } \\
\text { pelo uso dos Macrolídeos. }\end{array}$ & $\begin{array}{l}\text { Potencial risco de } \\
\text { sangramento }\end{array}$ \\
\hline Teofilina + Ciprofloxacino & $\begin{array}{l}\text { Inibição do metabolismo } \\
\text { hepático pelas quinolonas }\end{array}$ & Toxicidade da Teofilina \\
\hline Linesolida + Fluoxetina & $\begin{array}{l}\text { Inibição do metabolismo } \\
\text { da serotonina pela IMAO }\end{array}$ & $\begin{array}{l}\text { Poderá resultar em risco } \\
\text { aumentado de síndrome } \\
\text { serotonérgica. }\end{array}$ \\
\hline
\end{tabular}

Fonte: Santos et al., (2013)

Para Delucia (2017, p. 133), interação medicamentosa é entendida como a resposta de um determinado fármaco associado a demais medicamentos, considerando que os efeitos sejam diferentes de dois agentes uma vez administrados separadamente. Tal situação pode ser apresentada da seguinte forma: Fármaco A + Fármaco B $\rightarrow$ Efeito Final.

Na visão de Santos (2013, p. 60), a interação medicamentosa pode acarretar sérios danos à saúde do paciente e o grau de severidade de cada interação tem como agente determinante fatores diretamente relacionado ao indivíduo, podendo citar como exemplo a rota de absorção e a dose de dependência. Para o autor, a interação medicamentosa só é possível após a ingestão do medicamento pelo próprio indivíduo, e a periculosidade vai aumentando paralelamente a quantidade de fármacos administrados. Existe uma estimativa que isso ocorra em $3 \%$ a $5 \%$ dos pacientes que 
fazem uso de poucos medicamentos, já para aqueles indivíduos que fazem usos de 10 a 20 fármacos, essa porcentagem pode chegar a espantosos $20 \%$, e em pacientes que se encontram em estado crítico, esse número pode ser ainda maior.

Neste sentido, o profissional farmacêutico tem responsabilidade na implementação e implantação de estratégias para promoção do uso racional de medicamentos em virtude das consequências danosas do seu uso inadequado pode ocasionar na saúde do idoso. O trabalho do farmacêutico é componente fundamental da qualidade da assistência Farmacêutica que, por sua vez, tem implicações diretas na eficiência dos sistemas de saúde (BRASIL 2004).

Portanto, os estudos destacam que o farmacêutico é um educador, que pode esclarecer sobre o princípio ativo, a finalidade do medicamento, o tratamento, e favorecer na adesão terapêutica e contribuir para a mudança de comportamento frente ao uso do medicamento (BALESTRE KCB et al., 2007; PEREIRA, LUIZA, CRUZ 2015).

Para concluir Gurro et al., (2012, p. 803), afirma que as consequências da polifarmácia vão além do senso comum em geral. Os autores afirmam que em última instância está diretamente correlacionada de maneira independente à mortalidade em meio à população idosa, não podendo esquecer-se dos seus efeitos sobre a qualidade de vida e a dependência. Para a intervenção na polifarmácia existe de várias formas, ainda que o problema seja complexo, sendo:

1. Formação e qualificação dos profissionais;

2. Uso de sistema computadorizado para tomada de decisão;

3. Intervenção tendo como base a revisão farmacológica e/ou clínica do paciente;

4.Farmacovigilância para o manejo das reações adversas e interações medicamentosas;

5. Educação permanente nos serviços de saúde.

\section{CONSIDERAÇÕES FINAIS}

O desenvolvimento do presente estudo possibilitou uma análise de como a polifarmácia pode ser prejudicial à pessoa idosa através das reações adversas medicamentosas, além disso, também permitiu o entendimento de como a 
problemática pode ter seus efeitos amenizados quando a intervenção é feita de maneira correta. Ao finalizar o estudo, pode-se afirmar que a disseminação do conhecimento e acompanhamento da terapia medicamentosa no idoso torna-se a polifarmácia uma prática segura ao tratamento medicamentoso.

Dada à importância do tema, tornasse necessário o desenvolvimento de projetos de pesquisa que visem à formação continuada de alunos e profissionais da área. Esperase que o referido estudo sirva de inspiração e/ou motivação para outros alunos pesquisadores, aprofundando ainda mais nesse tema. Não se extingue ou mesmo conclui-se esse estudo, haja vista a grandeza monumental que envolve o título desse trabalho.

\section{REFERÊNCIAS}

ALMEIDA, N.A de et al. Prevalência e fatores associados à polifarmácia entre os idosos residentes na comunidade. Revista Brasileira Geriatria Gerontologia, 2017; v. 20, n. 1, p. $138-148$.

BALESTRE K.C.B. et al. Relato de um seguimento farmacoterapêutico de pacientes portadores de diabetes do programa saúde da família de Atalaia, Paraná. Revista Ciências Farmacêuticas Básica Aplicada, 2007; 28(2):203-208.

BARROS, A. J., \& LEHFELD, N. D. (2007). Fundamentos da Metodologia Científica (3a ed.). São Paulo: Pearson Prentice Hall.

BONGIOVANI, L.F.L.A. et al. Multimorbidade e polifarmácia em idosos residentes na comunidade. 2021 jan/dez; 13:349-354. DOI: http://dx.doi.org/0.9789/21755361.rpcfo.v13.8664.

BRASIL. Resolução no 338, de 6 de maio de 2004. Aprova a Política Nacional de Assistência Farmacêutica. Diário Oficial da União 2004.

CARVALHO, M.F.C. et al. Polifarmácia entre idosos do Município de São Paulo. Revista Brasileira de Epidemiologia, 2012, v.15 n. 4, p 817-827.

CUNHA, C. L.F. et al. Políticas e Sistemas de Saúde no Brasil. Caderno Saúde Pública, 2013, v. 29, n. 7, p. 1478-1479.

DELUCIA, R. Farmacologia integrada. São Paulo: Compacta, 2017. p.130-145.

GURRO, G. et al. Medicina de família e comunidade. São Paulo: Artmed Ltda., 2012. p.803. 
MELO, DO; CASTRO, LL. A contribuição do farmacêutico para a promoção do acesso e uso racional de medicamentos essenciais no SUS. Ciência Saúde Coletiva. 2017, v. 22, n. 1, p. 235-244.

OLIVEIRA, NIELMAR. População com 60 anos ou mais cresce quase $19 \%$ em cinco. Revista Saúde Coletiva, 2018, v.6 n.3, p.15-22.

ONG SM, et al. Variation of polypharmacy in older primary care attenders occurs at prescriber level. BMC Geriatrics. 2018.18(1). Disponível em: https://doi.org/10.1186/s12877-018-0750-2.

PEREIRA, C.; OLIVEIRA, $\mathrm{H}$. Uso Inapropriado de Medicamentos pelos Idosos: Polifarmácia e seus Efeitos. 2018 v. 7, n. 1. p-45-60

REGINA, Silvia. Polifarmácia: interações e reações adversas no uso de medicamentos por idosos. Revista Brasileira de Enfermagem. 2010, v.5, n.1

ROACH S. Teorias do Envelhecimento. In: Roach S. Introdução à enfermagem gerontológica. Rio de Janeiro: Guanabara Koogan. 2001. 20-22

SILVA, A. L. et al. Utilização de medicamentos por idosos brasileiros, de acordo com a faixa etária: um inquérito postal. Caderno Saúde Pública, 2012, v. 28, n. 6, p. 1033-1045.

SANTOS, L.; SEADI, M., T. Medicamentos na pratica da farmácia clínica. Porto Alegre: Artmed, 2013.

PEREIRA NC, LUIZA VL, CRUZ MM. Serviços farmacêuticos na atenção primária no município do Rio de Janeiro: um estudo de variabilidade. Saúde em Debate 2015; 39(105):451-468. 


\title{
CAPITULO XIX
}

\section{ANÁLSE DAS INTOXICACÕES EXÓGENAS REGISTRADAS PELO SISTEMA DE INFORMAÇ̃̃O DE AGRAVOS DE NOTIFICACÃO NO DISTRTIO FEDERAL NO PERÍODO DE 2015 A 2019}

\author{
DOI: 10.51859/amplla.csa528.2121-19
}

\author{
Bárbara Lorrane de Souza da Cunha ${ }^{1}$ \\ Giovanna Aparecida Fernandes Silveira ${ }^{1}$ \\ leler Ferreira Ribeiro ${ }^{2}$
}

${ }^{1}$ Graduandas do Curso de Farmácia. Centro Universitário Euro Americano - UNIEURO
${ }^{2}$ Professora do Curso de Farmácia. Centro Universitário Euro Americano - UNIEURO

\section{RESUMO}

Intoxicação exógena é a interação de qualquer agente tóxico com o indivíduo, gerando efeitos nocivos que causam danos ou até mesmo o óbito. O presente estudo teve como objetivo descrever as formas das intoxicações exógenas no Distrito Federal (DF), obtidas pelo Sistema de Informação de Agravos de Notificação (SINAN) no período de 2015 a 2019. Os dados foram obtidos por meio do sistema on-line do SINAN, que dispõe publicamente informações sobre notificações e agravos para toda a população. No DF, foram registrados 14.553 casos de intoxicações nesse período, sendo mais predominante em indivíduos na faixa etária de 20 a 59 anos, do sexo feminino e com o ensino médio completo. Os principais agentes tóxicos foram medicamentos, drogas de abuso, alimentos e bebidas, produtos de uso domiciliar e raticidas, respectivamente. A tentativa de suicídio foi a circunstância mais registrada, seguida da causa acidental. Dentre os indivíduos intoxicados, $44 \%$ obtiveram como desfecho cura sem sequela, sendo que apenas $0,3 \%$ dos casos evoluíram para óbito. Cabe ressaltar a importância da conscientização de profissionais de saúde tanto ao preenchimento correto e completo da ficha de notificação, sendo que uma porcentagem considerável de informações estava incompleta, o que prejudica o aperfeiçoamento das políticas públicas decorrentes do sistema de notificação. Dessa forma, sugere-se que o farmacêutico seja importante na prevenção de seu uso irracional associadas às intoxicações por medicamentos.

Palavras-chave: Intoxicação exógena. Agente tóxico. Automedicação. Medicamento. Drogas de abuso.

\section{INTRODUÇÃO}

Intoxicação exógena é definida pela interação de qualquer agente tóxico com o indivíduo exposto, gerando efeitos nocivos que podem alterar as funções físico-químicas 
do organismo causando danos ou até mesmo óbito. A prevalência dos casos ocorre com medicamentos, saneantes, domissanitários, produtos agrícolas e químicos, drogas de abuso, raticidas e plantas tóxicas que podem ter como vias de exposição a inalação, absorção, aplicação na pele e/ou mucosas e ingestão (FORTES et al., 2016; KINGLER et al., 2016).

O processo de intoxicação no organismo é indicado por quatro estágios, que podem ou não ocorrer concomitantemente, são eles: exposição, toxicocinética, toxicodinâmica e clínica. A fase de exposição refere-se ao contato inicial do indivíduo com o agente tóxico, a toxicocinética é definida pela atividade da substância por meio da absorção, biotransformação, distribuição e excreção. Na etapa da toxicodinâmica, trata-se da ação direta nos sítios específicos e por fim, a fase clínica que compreende o processo de exibição de sinais e sintomas (SILVA; COSTA, 2018).

O desenvolvimento das intoxicações caracteriza-se pela fase aguda ou por meio de exposições curtas a longo prazo apontando a fase crônica, que pode causar diversas doenças neurológicas, imunológicas, hematológicas e dermatológicas causadas pelas substâncias tóxicas. O diagnóstico desta fase é mais difícil de ser identificado, pois os casos clínicos são bem sutis, imprecisos e muitas vezes irreversíveis (BRASIL, 2019).

Segundo a Organização Mundial da Saúde (OMS), estima-se que, anualmente, cerca de 100 mil indivíduos morrem em todo o mundo em decorrência de intoxicações acidentais, sendo que $78 \%$ dos casos poderiam ser evitados. No entanto, apenas $47 \%$ dos países possuem um centro de registro de intoxicação, que pode ser definido como uma unidade especializada em informação, prevenção e tratamento das intoxicações (WORLD HEALTH ORGANIZATION, 2016).

Os envenenamentos podem ocorrer a partir de um ato acidental, ocupacional ou de forma premeditada, tendo em vista que qualquer substância pode gerar efeitos nocivos quando ingeridas em altas doses. De acordo com os dados obtidos no Sistema de Informação de Agravos de Notificação (SINAN), no ano de 2016, no Brasil, foram registrados aproximadamente 102 mil casos de intoxicação exógena por agente tóxico, tendo em primeiro lugar a tentativa de suicídio por medicamentos (BRASIL, 2016).

Com o intuito de prevenir, controlar e obter informações rápidas sobre doenças e agravos, a Portaria MS no 264, que foi implantada inicialmente em 2016 e atualizada em 2020, teve como objetivo integrar os eventos de notificação compulsória, como, por 
exemplo, a intoxicação exógena, devendo ser registrados no SINAN por meio do preenchimento da Ficha de Investigação (BRASIL, 2019). O SINAN é um sistema constituído por notificações de casos de doenças, agravos e eventos de saúde pública que constam na lista nacional de notificação compulsória e é obrigatório que sejam feitas por profissionais de saúde ou responsáveis de empresas públicas ou privadas que prestam assistência ao paciente (BRASIL, 2019).

Dessa forma, as informações apuradas pelo SINAN podem ser acessadas tanto pelos profissionais de saúde como pela comunidade, auxiliando no delineamento e visando a melhoria nos avanços da prevenção da intoxicação e outros agravos, contribuindo para a saúde pública (SINAN, 2016). Portanto, o presente estudo teve como objetivo descrever o perfil das intoxicações exógenas no Distrito Federal (DF), obtidas pelo SINAN no período de 2015 a 2019.

\section{METODOLOGIA}

Trata-se de um estudo de caráter descritivo, retrospectivo e quantitativo. A abordagem quantitativa de caráter descritivo foi escolhida para trabalhar com dados de intoxicação exógena registradas no Distrito Federal do período de 2015 a 2019, obtidos por meio da base de dados públicos do SINAN do Departamento de Informática do Sistema Único de Saúde (DATASUS).

Dados do Centro de Informações Toxicológicas do Distrito Federal (CEATOX-DF) e do Sistema Nacional de Informações Tóxico-Farmacológicas (SINITOX) foram descartados. No Brasil, o SINITOX analisa, coordena e compila todos os dados de intoxicação e é impulsionado por meio dos Centros de Informação e Assistência Toxicológica (CIAT), existentes em todas as regiões brasileiras, entretanto, não é atualizado constantemente (BOCHNER, 2016). Ademais, o CEATOX não disponibiliza dados tabelados de forma on-line, dificultando o acesso às informações.

Foram avaliadas as variáveis: Agente tóxico, Circunstância, Escolaridade, Faixa etária, Sexo e Evolução das intoxicações exógenas. As tabelas e gráficos foram gerados a partir do software Excel, Microsoft $@$, versão 2019, no qual os dados foram criteriosamente analisados. 
De acordo com o Ministério da Saúde (2018), os dados que não se enquadraram nos questionamentos durante o preenchimento da Ficha de Notificação de Intoxicação Exógena (Anexo 1) pela Unidade Notificadora foram categorizados como "Outros", enquanto que as intoxicações que não puderam ser determinadas durante a coleta de dados, foram denominadas como "Ignorado/Branco".

\section{RESULTADOS E DISCUSSÃO}

As intoxicações exógenas indicadas como intencionais ou não intencionais evidenciam vários danos ao organismo por um agente químico, que habitualmente tornam evidentes diversos dados clínicos com riscos notórios à vida. No Brasil, o SINAN registrou 670.830 envenenamentos no período de 2015 a 2019, estando o DF na 13a posição. Observou-se um crescimento dos casos, apresentando grandes riscos para a saúde coletiva, em que é necessária atenção preventiva, fiscalizadora e educativa por parte dos órgãos competentes (GONÇALVES et al., 2018; SILVA; MACIEL JUNIOR; MORAIS, 2018).

Na tabela 1, houve maior frequência de intoxicações na faixa etária de 20 a 59 anos, seguidos de indivíduos com idade relativa de 10 a 19 anos. Quanto ao sexo, observou-se que o feminino foi o mais prevalente nos casos de intoxicações exógenas, correspondendo a cerca de 58 \% do total de registros no período de 2015 a 2019 havendo um maior pico em 2019. Um baixo índice de casos em idosos foi observado, apesar de pertencerem ao grupo com uma maior suscetibilidade às doenças crônicas e, consequentemente, maior propensão ao uso de medicamentos e às reações adversas devido aos processos farmacocinéticos e farmacodinâmicos que mudam com o envelhecimento (PEREIRA et al., 2017; GARCIA et al., 2018).

Em relação ao nível de escolaridade, constatou-se que indivíduos com ensino médio completo tiveram índices mais altos de registros de intoxicações seguidos de ensino fundamental incompleto e ensino médio incompleto, havendo um aumento no número de notificações durante os anos de 2017 e 2019 no DF (Tabela 1). Os analfabetos foram apresentados como o menor número de registros de intoxicações no período analisado e o número de "ignorado/branco" foi indicado como maior valor, o 
que se pode observar a não obtenção dos dados durante o preenchimento da ficha de notificação (Anexo 1).

Tabela 1 - Total de intoxicações exógenas por faixa etária, sexo e escolaridades registradas pelo SINAN no DF no período de 2015 a 2019

\begin{tabular}{|c|c|c|c|c|c|c|}
\hline \multirow[t]{2}{*}{ Faixa etária (anos) } & \multicolumn{3}{|c|}{$\begin{array}{l}\text { Período } \\
\text { (por Ano) }\end{array}$} & \multirow[b]{2}{*}{2018} & \multirow[b]{2}{*}{2019} & \multirow[b]{2}{*}{ Total } \\
\hline & 2015 & 2016 & 2017 & & & \\
\hline$<1$ & 43 & 47 & 62 & 101 & 113 & 366 \\
\hline $1-9$ & 283 & 328 & 430 & 537 & 585 & 2.163 \\
\hline $10-19$ & 304 & 349 & 522 & 768 & 1.119 & 3.062 \\
\hline $20-59$ & 1.138 & 1.045 & 1.366 & 2.138 & 2.906 & 8.593 \\
\hline $60-69$ & 30 & 34 & 44 & 65 & 79 & 252 \\
\hline Acima de 70 & 16 & 12 & 19 & 35 & 34 & 116 \\
\hline Ignorado/ branco & - & - & - & 1 & - & 1 \\
\hline \multicolumn{7}{|c|}{ Sexo } \\
\hline Feminino & 955 & 991 & 1.446 & 2.119 & 3.050 & 8.561 \\
\hline Masculino & 859 & 823 & 997 & 1.524 & 1.785 & 5.988 \\
\hline Ignorado/ branco & - & 1 & - & 2 & 1 & 4 \\
\hline \multicolumn{7}{|c|}{ Escolaridade } \\
\hline Analfabeto & 4 & 4 & 1 & 2 & 7 & 18 \\
\hline $\begin{array}{l}\text { Ensino fundamental } \\
\text { incompleto }\end{array}$ & 58 & 53 & 93 & 125 & 129 & 458 \\
\hline Ensino fundamental completo & 19 & 34 & 33 & 36 & 45 & 167 \\
\hline Ensino médio incompleto & 16 & 21 & 45 & 88 & 121 & 291 \\
\hline Ensino médio completo & 53 & 44 & 48 & 200 & 231 & 576 \\
\hline Ensino superior incompleta & 13 & 23 & 18 & 57 & 69 & 180 \\
\hline Ensino superior completa & 9 & 12 & 28 & 74 & 66 & 189 \\
\hline Não se aplica & 310 & 350 & 466 & 605 & 658 & 2.389 \\
\hline Ignorado/branco & 1.332 & 1.274 & 1.711 & 2.458 & 3.510 & 10.285 \\
\hline Total & 1.814 & 1.815 & 2.443 & 3.645 & 4.836 & 14.553 \\
\hline
\end{tabular}

Fonte: Autoria própria.

De acordo com os dados apresentados na tabela 2, observa-se que medicamentos, drogas de abuso, alimento e bebida, produtos de uso domiciliar e raticidas aparecem, respectivamente, como os principais agentes causadores de intoxicações. Os medicamentos foram os agentes mais notificados em todos os anos analisados, representando cerca de $46 \%$ do total das intoxicações exógenas, o que em comparação com estudos similares, indica que tal classe é a mais frequente em todos os estados brasileiros (NAKAJIMA et al., 2019; GUIMARÃES; LOPES; BURNS, 2019). 
Tabela 2 - Total de notificações por agente tóxico, registrados pelo SINAN no DF no período 2015 a 2019

\begin{tabular}{|c|c|c|c|c|c|c|}
\hline Agente tóxico & & $\begin{array}{l}\text { Período } \\
\text { (por Ano }\end{array}$ & & & & \\
\hline & 2015 & 2016 & 2017 & 2018 & 2019 & Total \\
\hline Medicamento & 590 & 754 & 1.085 & 1.720 & 2.669 & 6.818 \\
\hline Drogas de abuso & 276 & 98 & 163 & 284 & 364 & 1.185 \\
\hline Alimento e bebida & 106 & 91 & 179 & 211 & 160 & 747 \\
\hline $\begin{array}{c}\text { Produto de uso } \\
\text { domiciliar }\end{array}$ & 86 & 95 & 143 & 171 & 227 & 722 \\
\hline Raticida & 98 & 81 & 98 & 144 & 152 & 573 \\
\hline Agrotóxico agrícola & 140 & 111 & 68 & 26 & 25 & 370 \\
\hline Produto químico & 59 & 44 & 48 & 105 & 74 & 330 \\
\hline $\begin{array}{l}\text { Agrotóxico } \\
\text { doméstico }\end{array}$ & 18 & 27 & 14 & 40 & 35 & 134 \\
\hline Cosméticos & 19 & 18 & 26 & 33 & 38 & 134 \\
\hline Planta tóxica & 4 & 12 & 15 & 23 & 31 & 85 \\
\hline $\begin{array}{c}\text { Produto } \\
\text { veterinário }\end{array}$ & 7 & 12 & 9 & 18 & 17 & 63 \\
\hline $\begin{array}{l}\text { Agrotóxico de } \\
\text { saúde pública }\end{array}$ & 32 & 9 & 2 & 2 & - & 45 \\
\hline Metal & 1 & 2 & 7 & 7 & 7 & 24 \\
\hline Ignorado/branco & 341 & 419 & 535 & 673 & 755 & 2.723 \\
\hline Outros & 37 & 42 & 51 & 188 & 282 & 600 \\
\hline Total & 1.814 & 1.815 & 2.443 & 3.645 & 4.836 & 14.553 \\
\hline
\end{tabular}

Fonte: Autoria própria.

Medicamentos são definidos como produtos farmacêuticos tecnicamente elaborados com finalidade profilática, paliativa ou curativa e são de extrema importância para a manutenção da saúde do indivíduo. A facilidade na aquisição de medicamentos sem prescrição médica é capaz de favorecer as intoxicações no Brasil, que pelo uso incorreto e exacerbado, pode causar potencialização ultrapassando o limite da janela terapêutica, assim ocasionando toxicidade e o aumento da quantidade de óbitos e internações hospitalares indicando um preocupante agravo à saúde pública (GONÇALVES et al., 2017; SILVA; ÁLVARES, 2018; ANDRADE et al., 2020; SOUSA et al., 2020).

Em seguida, tem-se intoxicações por drogas de abuso, que estão em 20 lugar nas intoxicações e, apesar do SINAN não informar qual o tipo de droga, elas foram classificadas como substâncias ilícitas e lícitas, que podem causar algum tipo de dependência no organismo (Tabela 2). A bebida alcoólica é a droga lícita mais consumida no Brasil, sendo, provavelmente, a responsável pelas intoxicações, e de acordo com Santana (2020), o sexo masculino é o mais prevalente, pois apresentam uma maior exposição e tendência ao consumo. Segundo a OMS, o álcool é a substância mais 
associada aos danos à saúde, sendo atuante no sistema nervoso como agente psicoativo que gera mudanças de comportamento no indivíduo (BRASIL, 2019; SILVA; LIRA; DINIZ, 2019; SANTANA et al., 2020).

O etanol age em vários neurotransmissores no cérebro como o glutamato sendo excitatório, o ácido gama-aminobutírico (GABA) sendo inibitório e, também, alterando a via dopaminérgica que se caracteriza como o sistema de recompensa do cérebro, ativando indiretamente essas vias. Em uso conjunto com outras substâncias, age como um potencializador ou inibidor do efeito de outras drogas ilícitas, que coincide com a farmacodinâmica do álcool no Sistema Nervoso Central (SNC) na via dopaminérgica, como por exemplo, a cocaína e a maconha que estão entre as drogas mais utilizadas no Brasil (BRASIL, 2020).

Quando se tem intoxicação aguda por bebida alcoólica, o indivíduo apresenta sintomas que variam conforme a dose ingerida. Em doses moderadas, desencadeia sedação, diminuição da coordenação motora e julgamento comprometido. Já em doses mais altas têm-se êmese, delírio, perda da consciência, arritmia, depressão respiratória e pode entrar em estado de coma alcoólico. Acredita-se que os números de intoxicações sejam maiores devido as subnotificações dos casos pelas equipes de saúde, o que reflete na prioridade dada pelo governo em relação ao tratamento correto para o consumo de drogas de abuso (GRANT, GOLDSTEIN, 2015; BRASIL, 2019).

Alimentos e bebidas representaram cerca de $5 \%$ do total de registros durante 0 período avaliado, havendo maior número de casos no ano de 2018 (Tabela 2). Durante as fases do processo de elaboração dos alimentos e bebidas, podem ocorrer contaminações por microrganismos ou suas toxinas que ocasionam intoxicações nos indivíduos gerando sintomas como náuseas, vômitos e diarreias. O aumento de intoxicações alimentares pode estar associado ao crescimento dos produtos disponibilizados para o pronto consumo, ligado ao uso de aditivos e mudança no padrão de alimentação da população (ALMEIDA et al., 2008).

No ano de 2019, foram registrados 141 casos a mais de intoxicações por produto de uso domiciliar (Tabela 2). Esse tipo de produto pode ser utilizado para higienização ou desinfecção de ambientes como alvejantes, desinfetantes, detergentes ou até mesmo os repelentes, havendo mais intoxicações por mulheres adultas e, principalmente, em crianças. Segundo o CIAT, em alguns estados do Brasil, nos anos de 
2018 e 2019, obteve-se um aumento de intoxicações em crianças com idade menor ou igual a 14 anos comparado aos adultos. A Agência Nacional de Vigilância Sanitária (ANVISA), por sua vez, analisou estes dados, emitindo um alerta sobre a exposição tóxica por produtos de limpeza e propondo que se deve ter uma atenção maior em relação a acidente domiciliar com essa faixa etária (FOOK et al., 2013; BRASIL, 2020).

Dentre os agrotóxicos apresentados na tabela 2, os raticidas são os que mais apresentaram notificações no DF no período avaliado, o que sugere a necessidade de maior atenção dos órgãos competentes em relação a essa classe, que podem agir restringindo a aquisição pela população, assim como fiscalizar os distribuidores, uma vez que são utilizados de forma desordenada para diversas finalidades, como, por exemplo, homicídio e suicídio. Tais substâncias podem ser definidas como agentes que atuam no combate de roedores, e segundo a ANVISA, o uso desordenado de raticidas ocasionam um preocupante agravo de saúde coletiva (MAIA et al., 2019).

As notificações por agrotóxicos agrícolas e de saúde pública (controle de vetores) apresentaram um decréscimo das intoxicações no decorrer de 2015 a 2019 observado na tabela 2. Essa diminuição pode ser em decorrência de um declínio de $37 \%$ das vendas de produtos químicos para agricultores locais no DF. O Brasil é considerado um dos maiores produtores de agrotóxicos, entretanto, o DF apresenta um comportamento divergente, pois nos últimos anos houve um aumento do consumo e produção de produtos orgânicos o que pode estar associado à diminuição de casos de intoxicação observada pelos dados do SINAN (BRASILIA, 2017; TAVARES et al., 2019; BRASÍLIA, 2020).

Durante o período de 2015 a 2019 no DF, observou-se um aumento no número de intoxicações por produtos cosméticos e de higiene pessoal, o que representa o dobro de casos registrados inicialmente em 2015 (Tabela 2). Ao decorrer dos anos, é possível identificar um aumento no uso desses produtos, que podem ser definidos, segundo a ANVISA, como substâncias de uso externo que têm o objetivo principal de higienizar, perfumar ou proteger partes de um organismo, gerando um aumento na exposição do indivíduo a compostos químicos que os compõem (PEREIRA; PEREIRA, 2018).

Dados expostos na tabela 3, demonstram que dentre as principais causas de intoxicações exógenas no DF estão a tentativa de suicídio, acidental, abuso, uso habitual e ingestão de alimentos, respectivamente. No período avaliado, o número de suicídio 
aumentou mais de 5 vezes, o que pode estar associado ao crescimento de indivíduos com problemas psiquiátricos e conflitos pessoais, o que eleva a chance de tentativa de suicídio, entretanto, segundo a OMS, doenças como a depressão não estão associadas diretamente com o autoextermínio (WHO, 2019).

Tabela 3 - Total de intoxicações por circunstâncias registradas pelo SINAN no DF no período de 2015 a 2019

\begin{tabular}{|c|c|c|c|c|c|c|}
\hline \multirow[t]{2}{*}{$\begin{array}{l}\text { Circunstâncias das } \\
\text { intoxicações }\end{array}$} & \multicolumn{3}{|c|}{$\begin{array}{l}\text { Período } \\
\text { (por Ano) }\end{array}$} & \multirow[b]{2}{*}{2018} & \multirow[b]{2}{*}{2019} & \multirow[b]{2}{*}{ Total } \\
\hline & 2015 & 2016 & 2017 & & & \\
\hline Tentativa de suicídio & 491 & 583 & 984 & 1.623 & 2.612 & 6.293 \\
\hline Acidental & 280 & 317 & 461 & 646 & 733 & 2.437 \\
\hline Abuso & 202 & 74 & 101 & 326 & 439 & 1.142 \\
\hline Uso habitual & 236 & 159 & 204 & 209 & 175 & 983 \\
\hline Ingestão de alimento & 58 & 70 & 105 & 103 & 71 & 407 \\
\hline Automedicação & 19 & 20 & 30 & 53 & 54 & 176 \\
\hline Erro de administração & 18 & 16 & 15 & 32 & 39 & 120 \\
\hline Ambiental & 7 & 35 & 6 & 8 & 14 & 70 \\
\hline Uso terapêutico & 8 & 8 & 10 & 17 & 17 & 60 \\
\hline Tentativa de aborto & 1 & 6 & 7 & 5 & 4 & 23 \\
\hline Violência/homicídio & 1 & 3 & 4 & 3 & 3 & 14 \\
\hline Prescrição médica & 0 & 1 & 0 & $\underline{2}$ & 2 & 5 \\
\hline Outra & 12 & 12 & 14 & 29 & 36 & 103 \\
\hline Ignorado/branco & 481 & 511 & 502 & 589 & 637 & 2.720 \\
\hline Total & 1.814 & 1.815 & 2.443 & 3.645 & 4.836 & 14.553 \\
\hline
\end{tabular}

Fonte: Autoria própria.

Informações disponibilizadas pela OMS retratam que, o suicídio está entre a segunda causa de morte em alguns países, cerca de 800 mil pessoas morrem a cada ano, estando na faixa etária de 15 a 29 anos. De acordo com registros do SINAN, no período avaliado, o número de tentativas de autoextermínio foi aproximadamente 3 vezes maior no sexo feminino em relação ao masculino (dado não apresentado), o que pôde ser confirmado em estudos que indicaram que mulheres são 4 vezes mais propensas ao comportamento suicida. Dentre os métodos usados para tentativa de suicídio, é incluso o auto envenenamento com alguns medicamentos como analgésicos, antidepressivos e ansiolíticos e também pesticidas como o paraquat, que é classificado como herbicida, que mata cerca de metade das pessoas que o ingere (VERAS; KATZ, 2011; VELOSO et al., 2017; VIEIRA, 2015; OMS, 2019). 
$\mathrm{Na}$ tabela 3, destacou-se também as intoxicações ocasionadas pela automedicação com 176 casos. Santos e Boing (2018) indicaram que no Brasil, o uso inadequado de medicamentos levou ao aumento de morbimortalidade, sendo necessária uma melhor análise na vigilância do paciente visando a segurança do tratamento. A automedicação é crescente na população e está cada vez mais presente no cotidiano dos brasileiros, já que os medicamentos são usados com o propósito de curar determinado sintoma, esses vêm sendo utilizados muitas vezes por meio de indicações de pessoas que não sejam da área da saúde, fator que vem contribuindo para o uso irracional de medicamentos (BRASÍLIA, 2020).

A automedicação influencia negativamente no diagnóstico da doença do paciente, pois, a escolha do medicamento errado, administração incorreta, dosagem inadequada, uso da medicação com o tempo curto ou prolongado além do tempo determinado, pode mascarar os sintomas da doença ou causar intoxicações pelas reações adversas e interações medicamentosas. Como observado na tabela 3 , as intoxicações decorrentes de prescrições médicas representam menos de $1 \%$, demonstrando que a consulta com um profissional de saúde habilitado é de importante relevância, pois, para dar um diagnóstico seguro ou tirar dúvidas sobre os fármacos, se tem o médico e o farmacêutico, sendo os profissionais competentes para informar e minimizar os problemas que causam a automedicação (COSTA et al., 2018; MATOS et al., 2018).

O farmacêutico como profissional de saúde detém grande conhecimento sobre fármacos e sua atuação no organismo, possuindo como dever o fornecimento de informações para o uso racional de medicamentos por meio da atenção farmacêutica. Embora o uso indiscriminado de medicamentos tenha resultados em tentativas de autoextermínio, o farmacêutico pode auxiliar na prevenção sobre os riscos do uso irracional, mantendo nas drogarias a retenção da receita para a aquisição desses medicamentos, dificultando a fácil acessibilidade (BATISTA et al., 2020).

Mesmo os medicamentos sendo utilizados nas doses determinadas na bula, podem causar intoxicações, sendo representados na tabela 3 por uso terapêutico. No período de 2017 a 2019, pôde-se notar que, somente 65 pessoas se intoxicaram por uso terapêutico e prescrição médica no DF, demonstrando que essas circunstâncias não foram tão expressivas quando comparado aos registros por automedicação, que foi 
quase o triplo de notificações. A terapia medicamentosa concede benefícios à saúde do indivíduo, porém, em algumas doenças existem tratamentos com múltiplas medicações, surgindo interações medicamentosas e efeitos adversos secundários que podem influenciar na qualidade de vida do paciente. Nesse contexto, deve-se manter o monitoramento da terapia, estimulado pela farmacovigilância, que monitora a detecção, prevenção e controle das reações adversas contribuindo para o uso racional de medicamentos (BRASIL, 2018; PEPE, 2020).

Em relação ao desfecho dos casos, apenas $0,3 \%$ do valor total de registros, evoluíram para óbito por intoxicação no DF (Tabela 4). Dentre os eventos registrados, $44 \%$ do valor total obtiveram cura sem sequela, o que corrobora com outros estudos similares (NAKAJIMA et al., 2019; GUIMARÃES; LOPES; BURNS, 2019).

Tabela 4 - Total de intoxicações por desfecho registradas pelo SINAN no DF no período de 2015 a 2019

\begin{tabular}{|c|c|c|c|c|c|c|}
\hline \multirow[t]{2}{*}{$\begin{array}{l}\text { Desfecho das } \\
\text { intoxicações }\end{array}$} & \multicolumn{3}{|c|}{$\begin{array}{l}\text { Período } \\
\text { (por Ano) }\end{array}$} & \multirow[b]{2}{*}{2018} & \multirow[b]{2}{*}{2019} & \multirow[b]{2}{*}{ Total } \\
\hline & 2015 & 2016 & 2017 & & & \\
\hline Cura sem sequela & 759 & 716 & 981 & 1.889 & 2.063 & 6.408 \\
\hline $\begin{array}{c}\text { Perda de } \\
\text { seguimento }\end{array}$ & 28 & 18 & 40 & 126 & 134 & 336 \\
\hline Cura com sequela & 20 & 12 & 29 & 27 & 40 & 128 \\
\hline $\begin{array}{l}\text { Óbito por } \\
\text { intoxicação }\end{array}$ & 3 & 5 & 8 & 14 & 16 & 46 \\
\hline $\begin{array}{c}\text { Óbito por outra } \\
\text { causa }\end{array}$ & 4 & 1 & 3 & 5 & 5 & 18 \\
\hline Ignorado/branco & 1.000 & 1.063 & 1.382 & 1.584 & 2.578 & 7.607 \\
\hline Total & 1.814 & 1.815 & 2.443 & 3.645 & 4.836 & 14.553 \\
\hline
\end{tabular}

De maneira geral, observou-se que existem problemas com as notificações compulsórias obtidas pelo SINAN, por esse motivo, não é possível correlacionar os dados necessários dos agentes tóxicos com as outras variáveis como, por exemplo, em medicamentos, não sendo possível obter informações sobre suas classes, impedindo a obtenção específicas das informações. No presente trabalho, nas tabelas 1, 2, 3 e 4 foi analisado que houve um aumento do preenchimento dos campos "ignorado/branco", "outros" e "não se aplica" no decorrer dos anos, o que sugere uma possível dificuldade de obtenção de informações no momento da coleta dos dados. 
Para um possível aperfeiçoamento do sistema e tratamento adequado a todas essas intoxicações, as informações obtidas no presente trabalho reforçam a necessidade da conscientização dos profissionais de saúde, quanto a importância do preenchimento correto da ficha de notificação de intoxicação exógena, visando a coleta dos dados necessários do indivíduo quando possível, e uma melhoria na exposição das instruções de preenchimento da ficha de notificações compulsórias colocadas em fácil acesso no site do DATASUS, para todos os profissionais de saúde.

\section{CONCLUSÃo}

De acordo com o presente estudo, constatou-se que no DF no período analisado, mulheres de 20 a 59 anos com ensino médio completo, foram as mais acometidas por intoxicações exógenas, sendo medicamento o agente tóxico causador mais prevalente. Foi observado que menos de $1 \%$ da população apresentou consequências graves como, por exemplo, óbito por intoxicação, o que evidencia a importância dos profissionais de saúde no manejo da intoxicação.

Como o medicamento foi o principal agente tóxico predominante, os farmacêuticos podem agir como importantes profissionais na promoção do uso racional, sancionando os perigos da utilização indiscriminada e da automedicação, principalmente na classe jovem adulto que foi a principal acometida. Diante do exposto, é essencial ressaltar a importância da capacitação efetiva do profissional de saúde para com o preenchimento da ficha de notificação de forma correta e mais precisa possível, assim como o aperfeiçoamento de políticas públicas para melhorar o conhecimento dos profissionais, de maneira geral, sobre o sistema de notificação. Cabe também ao SINAN expor melhor as informações sobre os agentes tóxicos, especificando por qual substância e circunstância o indivíduo foi intoxicado, e a partir desses dados poderiam contribuir para o governo mostrando em quais situações devem ter mais foco na conscientização da população e profissionais de saúde.

\section{REFERÊNCIAS}

ABREU, Jade. Diminui o comércio de agrotóxicos no DF. Agência Brasília, Subsecretaria de Divulgação do DF, 2016. Disponível em: 
<https://www.agenciabrasilia.df.gov.br/2016/09/12/diminui-o-comercio-deagrotoxicos-no-df/>. Acesso em: 13 de outubro de 2020.

ALMEIDA, Cristiane et al. Perfil epidemiológico das intoxicações alimentares notificadas no Centro de Atendimento Toxicológico de Campina Grande, Paraíba. Rev Bras Epidemiol. v.11, n.1, p. 139-46. 2008.

ANDRADE, Sâmia et al. Caracterização do perfil das intoxicações medicamentosas por automedicação no Brasil, durante o período de 2010 a 2017. Research Society and Development. V. 9, n.7, p.1-16, 2020, e236973952.

BATISTA, Sabrina et al. Polimedicação, Atenção farmacêutica e cuidado farmacêutico. Journal of Biology \& Pharmacy and Agricultural Management. ISSN: 1983-4209. V. 16, n. 4, p-1-15. out/dez 2020. Disponível em: <http://revista.uepb.edu.br/index.php/biofarm/article/view/5657>. Acesso em: 21 de outubro de 2020.

BRASILIA. Área de produção orgânica cresce 150 hectares. Agência Brasília, Subsecretaria de Divulgação do DF, 2020. Disponível em: $<$ https://www.agenciabrasilia.df.gov.br/2020/05/05/area-de-producaoorganica-cresce-150-hectares/>. Acesso em: 22 de outubro de 2020.

BRASIL. Ministério da Saúde. Secretaria de Vigilância em Saúde. Departamento de Vigilância em Saúde Ambiental e Saúde do Trabalhador. Instruções para preenchimento da Ficha de Investigação de Intoxicação Exógena Sinan - Sistema de Informação de Agravos de Notificação, p.42. 2018. ISBN 978-85-334-2674-0. Disponível em: <http://bvsms.saude.gov.br/bvs/publicacoes/intoxicacao_exogena_sinan.pdf>. Acesso em: 12 de outubro de 2020.

BRASIL. Anvisa. Nota técnica no 11/2020. Alerta sobre o aumento da exposição tóxica por produtos de limpeza no Brasil desde o início da pandemia de coronavírus. Brasília, 2020. Disponível em: <https://www.gov.br/anvisa/pt-br/arquivosnoticias-anvisa/471json-file-1>. Acesso em: 14 de outubro de 2020.

BRASIL. Ministério da Saúde. Portaria MS/GM no 264 de 17 de fevereiro de 2020. Lista Nacional de Notificação Compulsória de doenças, agravos e eventos de saúde pública. Disponível em: <https://bvsms.saude.gov.br/bvs/saudelegis/gm/2020/prt0264_19_02_2020.ht $\mathrm{ml}$. Acesso em: 11 de outubro de 2020.

BRASIL. Ministério da Saúde (MS). Secretaria de Vigilância em Saúde. Guia de Vigilância em saúde, 3ㅇ edição, Brasília DF, 2019. Disponível em: $<$ https://portalarquivos2.saude.gov.br/images/pdf/2019/junho/25/guiavigilancia-saude-volume-unico-3ed.pdf>. Acesso em: 08 de setembro de 2020. 
BRASIL. Ministério da saúde. Sistema de Informação de Agravos de Notificação (SINAN).

Disponível

<http://tabnet.datasus.gov.br/cgi/deftohtm.exe?sinannet/cnv/Intoxbr.def>.

Acesso em: 30 de setembro de 2020.

BRASIL. São Paulo. Efeitos danosos do álcool no cérebro. CISA, Centro de Informações Sobre Saúde e Álcool, 2020. Disponível em: $<$ https://cisa.org.br/index.php/pesquisa/dados-oficiais/artigo/item/54-efeitosdanosos-do-alcool-no-cerebro>. Acesso em: 28 de outubro de 2020.

BOCHNER, Rosany. Sistema Nacional de Informações Tóxico-Farmacológicas (SINITOX): 35 anos de resistência. RECIIS - Rev. Eletron. Comum. Inf. Inov. Saúde. 2016 jan.-mar., $10 . \quad$ Disponível em: <https://www.reciis.icict.fiocruz.br/index.php/reciis/article/view/1093/pdf_10 93>. Acesso em 11 de outubro de 2020.

COSTA, Camilla et al. Prevalência de ansiedade e fatores associados em adultos. J. bras. psiquiatr., Rio de Janeiro, V. 68, N. 2, P. 92-100, junho 2019. Disponível em: < https://www.scielo.br/j/jbpsiq/a/PSrDy4ZFSGDCzNgJfJwVRxz/abstract/?lang=pt $>$.

COSTA, Dayane et al. Erros de medicamentos: uma avaliação da prescrição na pediatria de um hospital escola. Rev. Bras. Farm. Hosp. Serv. Saúde, v.9, n.2, p. 01-05, 2018. em: http://v1.sbrafh.org.br/public/artigos/2018090202001320BR.pdf>.

FRIZON, Eliane et al. Perfil das intoxicações exógenas por agrotóxicos de uso agrícola. Ciências Biológicas e da Saúde, Londrina, v. 41, n. 2, p. 177-190, jul./dez. 2020. Disponível em: <https://www.researchgate.net/publication/345088417_Perfil_das_intoxicaco es_exogenas_por_agrotoxicos_de_uso_agricola>.

FOOK, Sayonara et al. Avaliação das intoxicações por domissanitários em uma cidade do Nordeste do Brasil. Cad. Saúde Pública, Rio de Janeiro, v.29, n.5, p.1041-1045, mai, $2013 . \quad$ Disponível em: <https://www.scielo.br/j/csp/a/Py9h8cLpzVFkj73Ktty4D5Q/abstract/?lang=pt>. Acesso em: 14 de outubro de 2020.

FORTES, Adailza et al. Intoxicações exógenas: perfil dos pacientes atendidos em um pronto atendimento. Revista Eletrônica Gestão \& Saúde - ISSN: 1982-4785, V.7, N. 01, P. 211-30, 2016.

GARCIA, Antônio et al. Automedicação e adesão ao tratamento medicamentoso: avaliação dos participantes do programa Universidade do Envelhecer. Rev. Bras. Geriatr. Gerontol., Rio de Janeiro. V.21, n.6, p.715-724, 2018. 
GONÇALVES, Claudiana et al. Intoxicação medicamentosa: relacionada ao uso indiscriminado de medicamentos. Revista Científica da Faculdade de Educação e Meio Ambiente, [S. I.], V. 8, N. 1, P. 135-143, 2017. DOI: 10.31072/rcf.v8i1.449.

GUIMARÃES, T. R. A.; LOPES, R. K. B.; BURNS G. V. Perfil epidemiológico das vítimas de intoxicação exógena em Porto Nacional (TO) no período de 2013 a 2017. Scire. Salutis, ISSN: 2236-9600, v.9, n.2, p.37-48, 2019.

KLINGER, Elisa et al. Intoxicação exógena por medicamentos na população jovem do Rio Grande do Sul. Revista de epidemiologia e controle de infecção, [S.I.], V.6, P. 4452, oct. 2016. ISSN 2238-3360.

MAIA, Sheila et al. Anos potenciais de vida perdidos por intoxicação exógena no Brasil no período de 2007 a 2017. Rev. Enferm. Contemp. V.8, n.2, p. 135-142. 2019.

MATOS, Januária et al. Prevalência, perfil e fatores associados à automedicação em adolescentes e servidores de uma escola pública profissionalizante. Cad. Saúde Colet., Rio de Janeiro, v.26, n.1, p.76-83. 2018.

NAKAJIMA, Noah et al. Análise epidemiológica das intoxicações exógenas no Triângulo Mineiro. BJHBS, Rio de Janeiro. v.18, n.2, p.151-158, 2019.

OLIVEIRA, Eliany et al. Tentativa de suicídio por intoxicação exógena: contexto de notificações compulsórias. Revista Eletrônica Gestão e Saúde, V. 06, N. 03, P. 2497-11, 2015. ISSN-e 1982-4785.

GRANT Bridget, GOLDSTEIN Rise, et al. Epidemiology of DSM-5 alcohol use disorder results from the National Epidemiologic Survey on Alcohol and Related Conditions III. JAMA Psychiatry v.72 n.8, p.757-766, 2015 . doi: 10.1001/jamapsychiatry.2015.0584. Acesso em: 25 de outubro de 2020.

PAULA, Tatiana; BOCHNER, Rosany; MONTILLA, Dalia. Análise clínica e epidemiológica das internações hospitalares de idosos decorrentes de intoxicações e efeitos adversos de medicamentos, Brasil, de 2004 a 2008. Rev. bras. epidemiol., São Paulo, v.15, n. 4, p. 828-844, Dez. 2012.

PEPE, Vera Lúcia Edais; NOVAES, Hillegonda Maria Dutilh. Sistema Nacional de Farmacovigilância no Brasil e em Portugal: semelhanças, diferenças e desafios. Cad. Saúde Pública, Rio de Janeiro, v. 36, n. 7, e00043019, 2020.

PEREIRA, Francisco et al. Automedicação em idosos ativos. Revista de Enfermagem UFPE on line, [S.I.], v. 11, n. 12, p. 4919-4928, dez. 2017. ISSN 1981-8963. Disponível em: <https://periodicos.ufpe.br/revistas/revistaenfermagem/article/view/22289>. Acesso em: 20 de outubro de 2020. 
PEREIRA, Jonathas.; PEREIRA, Thais. Riscos biológicos associados a cosméticos. Global journal of medical research, v. 18, p. 63-70, 2018.

SANTANA, Cleiton et al. Caracterização de pacientes intoxicados por drogas de abuso em terapia intensiva. SMAD, Rev. Eletrônica Saúde Mental Álcool Drog. 2020 jan.-fev.;16(1):-8.

SANTOS, Guidyan; BOING, Alexandra. Mortalidade e internações hospitalares por intoxicações e reações adversas a medicamentos no Brasil: análise de 2000 a 2014. Cad. Saúde Pública, Rio de Janeiro, v. 34, n. 6, P.1-14, e00100917, 2018.

SILVA, Elany; ÁLVARES, Alice. Intoxicação medicamentosa relacionada à tentativa de autoextermínio. Revista de Iniciação Científica e Extensão, V. 2, N. 2, P. 102-108, 2018.

SILVA, Maria; LYRA, Tereza; DINIZ, George. O padrão de consumo de álcool entre as usuárias das Unidades de Saúde da Família no município do Recife (PE). Saúde em Debate [online]. v. 43, n. 122, pp. 836-847.

SILVA, Helena; COSTA, Jaquelin. Intoxicação exógena: casos no estado de santa catarina no período de 2011 a 2015. Arquivos Catarinenses de Medicina, [S.I.], v. 47, n. 3, p. 02-15, out. 2018. ISSN 18064280.

SILVA, Francisca; MACIEL JUNIOR, Francisco; MORAIS, Isabel. Intoxicações exógenas no Brasil: um problema de saúde pública. Mostra Científica da Farmácia, [S.I.], V. 4, N. 2, Ago, 2018. ISSN 2358-9124.

TAVARES, Danielle. Utilização de agrotóxicos no Brasil e sua correlação com intoxicações. Revista S\&G. V.15, N.1, P. 2-10. 2020.

VERAS, Juliana; KATZ, Cintia. Suicide attempts by exogenous intoxication among female adolescents treated at a reference hospital in the city of Recife-PE, Brazil. Rev. bras. enferm., Brasília, V. 64, N. 5, P. 833-838, Out. 2011.

VIEIRA, Leticia; SANTANA, Vivian; SUCHARA, Eliane. Caracterização de tentativas de suicídios por substâncias exógenas. Cad. Saúde Colet., Rio de Janeiro, V.23, N.2: P.118-123, junho 2015.

WORLD HEALTH ORGANIZATION. World health statistics annual: 2016. Geneva, 2016. Disponível em: <https://www.who.int/ipcs/publications/chemicals-publichealth-impact/en/>. Acesso em: 20 de setembro de 2020.

WORLD HEALTH ORGANIZATION. Preventing suicide: a resource for pesticide registrars and regulators, 2019.2 Disponível em:< https://www.who.int/publications/i/item/9789241516389>. Acesso em: $01 \mathrm{de}$ novembro de 2020. 


\title{
CAPÍTULO XX
}

\section{A IMPORTÂNCLA EPIDEMIOLÓGICA DA MENINGIIE BACTERIANA NO BRASIL}

\author{
Poliana de Queiroz Araujo ${ }^{1}$ \\ Vanessa Maria de Lima Valentin ${ }^{2}$ \\ Joel Silva dos Santos ${ }^{3}$ \\ Jordanio dos Reis Pereira ${ }^{4}$ \\ Cristina Sa Severo Araujo ${ }^{5}$
}

\begin{abstract}
Graduada do curso de Biomedicina. Universidade Estacio de São Luis, especialista em saúde pública com ênfase em vigilância sanitária pela faculdade Educa Minas Gerais, Especialista em Microbiologia clinica Pela Faculdade Faveni, Especialista em est udo de ciências pela universidade de ciência e tecnologia do Maranhão, Especialista em neuroimagem pela universidade Faculeste de Belo Horizonte.

${ }^{2}$ Graduada do curso de biomedicina. Centro Universitário Mauricio de Nassau. Especialista em Microbiologia Clinica pelo Insti tuto de Ciências biológica / UFPE.

${ }^{3}$ Graduado do curso de biomedicina. Universidade Estacio de São Luis. Especializando em analises clinicas e toxicológicas pela Centro Nacional de informação /CNI.

${ }^{4}$ Graduado do curso de Biomedicina. Universidade Estacio de São Luis. Especialista em Gerontologia e geriatria pela Faculdade de Minas.

${ }^{5}$ Graduada no curso de Biomedicina. Centro universitário Tiradentes / UNIT. Especializando em Citologia Clinica pelo Centro de Capacitação em Saúde/CCE.
\end{abstract}

\section{RESUMO}

A meningite bacteriana é uma infecção que atinge as meninges que recobrem o sistema nervoso central e que acomete pessoas de todas as faixas etárias, ocasionada por diversos agentes microbianos e que, em alguns casos, o avanço da doença é rápido e letal. O Brasil apresenta uma endemicidade elevada no que se refere aos casos de meningite e a vigilância epidemiológica exerce função importante para informar e entender o avanço da doença na população. Em vista disso, esse estudo teve como objetivo abordar aspectos relacionados com a importância da epidemiologia na meningite bacteriana no Brasil, por meio de uma breve revisão bibliográfica. As meningites estão inseridas no grupo de doenças com notificações compulsórias imediata e devem seguir um guia de recomendações estabelecido pelo Ministério da Saúde. Essa investigação é realizada com o objetivo de informar a caracterização clínica que está ocorrendo em determinada região e a fonte de infecção. Além disso, o Sistema de Informação de Agravos de Notificação é uma ferramenta essencial para informar a situação epidemiológica do local, a possibilidade de surtos, tomadas de decisões sobre prevenção e controle da meningite bacteriana no país. Contudo, sabe-se que no Brasil ainda existe muitos casos subnotificados, o que dificulta o levantamento epidemiológico em determinadas regiões. Dessa forma, é importante que os profissionais de saúde sigam as especificações dos manuais estabelecidos pelo Ministério da saúde, notificando e informando os casos suspeitos, confirmados e descartados, contribuindo com mais conhecimento sobre a doença e sua manifestação na população.

Palavras-chave: Agravo de saúde pública. Meningite bacteriana. Perfil Epidemiológico. Vigilância epidemiológica 


\section{INTRODUÇÃO}

A meningite é uma doença caracterizada como sendo uma inflamação nas membranas que envolvem o encéfalo e a medula espinhal, chamadas de meninges. Essa camada de tecido conjuntivo é composta pela pia-máter, aracnoide e pelo espaço subaracnóideo, sendo os espaços preenchidos pelo líquido cefalorraquidiano (LCR), ou também chamado de líquor (BRASIL, 2010; PORTAL DA SAÚDE, 2010).

A infecção nas meninges pode ser causada por diversos microrganismos, sendo bactérias e vírus os agentes etiológicos mais frequentes. No que se refere à meningite bacteriana, é considerada um sério agravo de saúde pública, causa a forma mais grave da doença, podendo levar à óbito, principalmente, em casos onde o diagnóstico é realizado tardiamente (CDC, 2014).

No brasil, a meningite meningocócica é a mais prevalente, sendo causada pela bactéria Nisseria meningitidis, a infecção ocorre, principalmente, em lactantes, crianças, idosos e pessoas com alguma doença de base, devido ao sistema imunológico suprimido nesses grupos de risco. Segundo Cohn (2010), de uma a cada dez crianças com menos de um ano de idade apresentam o quadro de meningite e vão a óbito. Com uma elevada taxa de mortalidade, também é uma doença que deixa muitas sequelas neurológicas, sendo a taxa de morbidade muito elevada em casos de cura (RODRIGUES; MILAGRES, 2015).

A meningite é uma doença infecciosa considerada um grave problema de saúde pública e, os estudos epidemiológicos são importantes, pois servem como subsídio para compreender a situação atual do país e, também, o curso da doença ao longo do tempo, bem como, de entender quais os agentes que estão causando mais infecções, qual a faixa etária, dentre outros parâmetros importantes na compreensão da indecência da doença em uma dada população.

É uma infecção que está inserida no grupo de doenças de notificação compulsória, segundo o Ministério da Saúde, nos quais os dados epidemiológicos são inseridos no Sistema de Informação de Agravos de Notificação (SINAN), que consiste em uma base de dados nacional com informações sobre os agravos que são notificados em todo o território. É uma ferramenta essencial para a análise da ocorrência de meningite 
no Brasil, levando em considerações fatores sociodemográficos e socioeconômicos (PAIS, 2013).

Em vista disso, a escolha desse tema para a produção deste trabalho teve como motivação a importância da epidemiologia na assistência à saúde em casos de meningite bacteriana, haja vista que é a forma mais trave da doença e que acomete qualquer pessoa de diferentes faixas etárias, podendo ocasionar a morte. Além disso, sabe-se que essa infecção pode ser causada por diversas espécies de bactérias, o que gera ainda mais preocupação no que se refere ao diagnóstico do agente etiológico, bem como, do tratamento de maneira mais rápida e eficaz.

Por ser uma doença de notificação compulsória, é responsabilidade dos serviços de saúde notificarem os casos suspeitos para que possam ser tomadas providencias para a investigação epidemiológica e avaliar se existe a necessidade de medidas de controle. Nesse sentido, é importante destacar a função de todos os profissionais da área da saúde que prestam assistência, uma vez que são responsáveis por essa notificação e, sabe-se que ainda existe muita subnotificação o que dificulta a avaliação do cenário epidemiológico, principalmente, em regiões onde as condições de saúde são precárias.

No Brasil, a meningite meningocócica é responsável por surtos esporádicos, sendo considerada endêmica no país. A incidência nos últimos anos gira em torno de 1,8 casos para cada 100.000 habitantes, com uma letalidade variando de $18 \%$ a $20 \%$, o que poderia ser maior se não fosse os avanços dos métodos de diagnósticos e da assistência terapêutica.

Por isso, esse artigo teve como objetivo realizar um breve levantamento bibliográfico sobre a importância da epidemiologia na meningite bacteriana, bem como, responder a seguinte problemática: "Como os dados epidemiológicos influenciam no conhecimento da meningite bacteriana?".

\section{METODOLOGIA}

Trata-se de um estudo de revisão bibliográfica, de caráter qualitativo descritivo e exploratório, no qual abordou aspectos relacionados com a importância da epidemiologia em casos de meningite bacteriana. 
A natureza do estudo desenvolvido segue os preceitos do estudo exploratório, por meio de uma revisão de bibliografia, na qual, segundo Gilberto (2008), é desenvolvida a partir de estudos e materiais já elaborados, tais como livros e artigos científicos.

No que se refere a revisão bibliográfica, é um tipo de estudo que apresenta um elevado potencial de construção do conhecimento, tendo como objetivo proporcionar uma síntese das informações obtidas nos estudos pesquisados, havendo uma melhor aplicabilidade dos mesmos, melhorando a compreensão do tema (MENDES, 2008).

A análise de forma qualitativa, permite ao pesquisador utilizar-se de abordagens e de diferentes métodos e estratégias na busca pelo significado dos fenômenos no âmbito individual ou coletivo. Atuando como função estruturante para a vida das pessoas, uma vez que as mesmas organizam suas vidas a partir destes significados por elas atribuídos (MINAYO, 2017).

Foram utilizados trabalhos publicados no idioma de inglês, português e espanhol das bases de dados Scientific Electronic Library Online (SCIELO), Literatura Latinoamericana em Ciências da Saúde (LILACS), Biblioteca Virtual em Saúde (BVS) e PubMed. Foram utilizados os seguintes descritores na busca: epidemiologia meningite bacteriana; aspectos epidemiológicos meningite; perfil epidemiológico meningite bacteriana; meningite bacteriana no Brasil.

Como critério de inclusão, foram incluídos estudos nos últimos 10 anos que contiverem em seus títulos e resumos referentes ao tema deste trabalho; apenas foram aceitos os artigos/livros que antecedessem esse período, se o mesmo apresentou material de grande relevância ao assunto. Como critério de exclusão, foram eliminados estudos que antecedessem o período selecionado ou que não possuíssem conteúdo condizente com o tema proposto para este trabalho.

\section{REVISÃO BIBLIOGRÁFICA}

\subsection{A MENINGITE BACTERIANA - ASPECTOS GERAIS}

As meningites bacterianas são consideradas um sério agravo de saúde pública, apresentando taxas de morbidade e mortalidade consideráveis no território brasileiro, além de ser uma infecção capaz de acometer qualquer pessoa de diferentes faixas 
etárias, com destaque para as crianças, idosos, gestantes, lactantes e indivíduos que apresentam alguma doença de base que possam interferir no seu sistema imunológico (SILVA; MEZAROBBA, 2018).

A doença é caracterizada por uma infecção nas meninges, que são membranas de tecido conjuntivo que revestem o encéfalo e a medula espinhal e que são importantes para proteção ao sistema nervoso central. Essa infecção pode ser ocasionada por diversos microrganismos, contudo, as bactérias apresentam uma importância significativa, visto que a meningite bacteriana apresenta um quadro clínico mais grave e elevada taxa de mortalidade entre os acometidos (LONGO et al., 2013).

Dentre os agentes microbianos que mais infectam e causam a meningite no Brasil, pode-se citar: Neisseria meningitidis, Haemophilus influenzae, Streptococcus pneumoniae (esse trio responsável por cerca de 60 a $80 \%$ dos casos), Listeria monocytogenes e Mycobacterium tuberculosis (PELTON, 2010). Segundo o Ministério da Saúde, as causas da meningite bacteriana variam de acordo com a faixa etária, sendo que:

a) Recém-nascidos os mais prevalentes são Streptococcus do grupo B, S. pneumoniae, Listeria monocytogenes e E. coli;

b) Bebês e crianças os mais comuns são S. pneumoniae, Neisseria meningitidis, Haemophilus influenzae e Streptococcus do grupo B;

c) Adolescentes e adultos são mais infectados por S. pneumoniae e Neisseria meningitidis;

d) d.Idosos a infecção ocorre principalmente por S. pneumoniae, Neisseria meningitidis, Haemophilus influenzae, Streptococcus do grupo B e Listeria monocytogenes (BRASIL, 2019a)

Essas bactérias ao romperem a barreira hematoencefálica, disseminam-se pelo líquor ocasionando inflamação meníngea, uma vez que o sistema nervoso central é um órgão imunologicamente privilegiado e o LCR não apresenta produção de anticorpos, logo, a proteção nesse local é comprometida, favorecendo a disseminação do agente infeccioso (POLAND, 2010).

A forma de infecção ocorre por meio do contato com pessoa contaminada, através das vias respiratórias, secreções e gotículas das vias aéreas superiores. Após a pessoa se contaminar, o período de incubação da bactéria vai depender muito da 
espécie a qual infectou o indivíduo, variando de 2 a 10 dias. É importante destacar o período de transmissibilidade que persiste até a bactéria desaparecer das vias aéreas, principalmente, da nasofaringe que ocorre nas primeiras 24 horas após o início do tratamento com antimicrobiano (BRASIL, 2017).

A sintomatologia da meningite bacteriana pode ser muito confunda com outras doenças, apresentando geralmente quadro febril inespecífico, cefaleia, mal-estar, náuseas, vômito, em alguns casos pode haver fotofobia, rigidez no pescoço, confusão mental, dentre outros. Cerca de 15 a 20\% dos pacientes desenvolvem um quadro evolutivo da doença com complicações, com evolução rápida e geralmente fulminante que são caracterizados por manifestações clinicas como o aparecimento da síndrome Waterhouse-Friderichsen (BRASIL, 2017).

O diagnóstico confirmatório é realizado por meio de testes laboratoriais como cultivo da bactéria a partir do LCR ou sangue coletados, Exame quimiocitológico do LCR, Bacterioscopia direta, teste de aglutinação pelo látex e reação em cadeia da polimerase (PCR) (DAZZI; ZATTI; BALDISSERA, 2014). O tratamento deve ser realizado o mais rápido possível, visto que em alguns casos a evolução da doença ocorre de maneira rápida, podendo levar à óbito em um período de tempo curto após o aparecimento dos sintomas, e consiste em antibioticoterapia, podendo ser associado com outros medicamentos para tratamento de suporte (BRASIL, 2017).

A meningite é uma doença grave, que pode levar a óbito em um curto período de tempo, sendo endêmica em diversas regiões do Brasil e, para o controle epidemiológico a vacinação é uma medida de prevenção eficaz, principalmente para as crianças, que são consideradas um grupo de risco à essa infecção.

As vacinas disponíveis pelo Sistema Único de Saúde incluem Vacina meningocócica conjugada sorogrupo C (confere proteção à Doença Meningocócica ocasionada pelo sorogrupo C); pneumocócica 10-valente conjugada (proteção contra as doenças invasivas causadas pelo Streptococcus pneumoniae, incluindo meningite); Pentavalente (age protegendo contra as doenças invasivas causadas pelo Haemophilus influenzae sorotipo $b$, como meningite, e também contra a difteria, tétano, coqueluche e hepatite B); e BCG (protege contra as formas graves da tuberculose) (BRASIL, 2019a). 


\subsection{ASPECTOS EPIDEMIOLÓGICOS NACIONAIS DA MENINGITE BACTERIANA}

No Brasil, a meningite meningocócica é a mais prevalente, sendo considerada endêmica com a ocorrência de surtos esporádicos em todo o território brasileiro. É ocasionada pela bactéria Neisseria meningitidis, podendo infectar indivíduos de todas as faixas etárias, porém, apresenta $30 \%$ dos casos notificados são de crianças com menos de 5 anos, considerados um grupo de risco à essa infecção (BEREZIN, 2013).

A taxa de letalidade no Brasil é de $20 \%$ nos últimos anos, em casos mais graves da meningite meningocócica a letalidade chega a 50\%, configurando um sério agravo de saúde e, por conta disso, existe uma importância significativa da vigilância epidemiológica brasileira, com o objetivo de monitorar os casos notificados no país, detectar surtos precoces, avaliar medidas preventivas e de controle, além de monitorar o perfil de resistência à antibioticoterapia (BRASIL, 2017).

As meningites estão inseridas no grupo de doenças com notificações compulsórias imediata e devem seguir um guia de recomendações estabelecido pelo Ministério da Saúde, no qual indica como deve ser o manejo clínico desse paciente, quais as informações necessárias e importantes para se fazer a notificação, definição do caso suspeito e confirmado e os casos descartados, dentre outras informações. Essa investigação é realizada com o objetivo de informar a caracterização clínica que está ocorrendo em determinada região e a fonte de infecção.

De acordo com a Secretaria de Vigilância e Saúde, a investigação dos casos ocorre por meio do preenchimento da Ficha de Investigação de Meningite, após a confirmação, os casos são classificados em: doença meningocócica (DM), meningite tuberculosa (MCTB), meningite por outras bactérias (MOB), meningite não especificada (MNE), meningite asséptica $(\mathrm{MV})$, meningite por outra etiologia (MOE), meningite por hemofílico (MH) e meningite por pneumococos (MP) (BRASIL, 2019b, p. 01).

O Ministério da Saúde, em 2019, lançou uma edição especial do Boletim Epidemiológico da evolução da situação epidemiológica de algumas doenças frequentes no território brasileiro, dentre essas a meningite meningocócica. Pode-se observar que, no período de 2003 a 2018, houve uma diminuição do número de casos confirmados no Brasil, passando de 2,0 casos/100mil habitantes para 0,5 casos/100 mil habitantes. 
Dentre os confirmados ocorreu um aumento do sorogrupo C, desde de 2010 ocasionando surtos esporádicos, principalmente, em crianças, sendo motivo para ter sido inserida no calendário vacinal (figura 01) (BRASIL, 2019b).

No que se refere à faixa etária, aproximadamente $50 \%$ dos casos notificados entre 2003-2018 ocorreram em crianças com menos de 5 anos (figura 02). É válido ressaltar que é uma doença que apresenta taxa de letalidade em torno de 22 a $25 \%$ nos últimos anos e que a maioria dos casos notificados nesse período do estudo foi no Sudeste (São Paulo e Rio de janeiro, principalmente) e Sul (Rio Grande do Sul e Santa Catarina) do Brasil (BRASIL, 2019b).

Figura 01 - Coeficiente de incidência de doença meningocócica total e por sorogrupos, Brasil, 2003 a 2018.

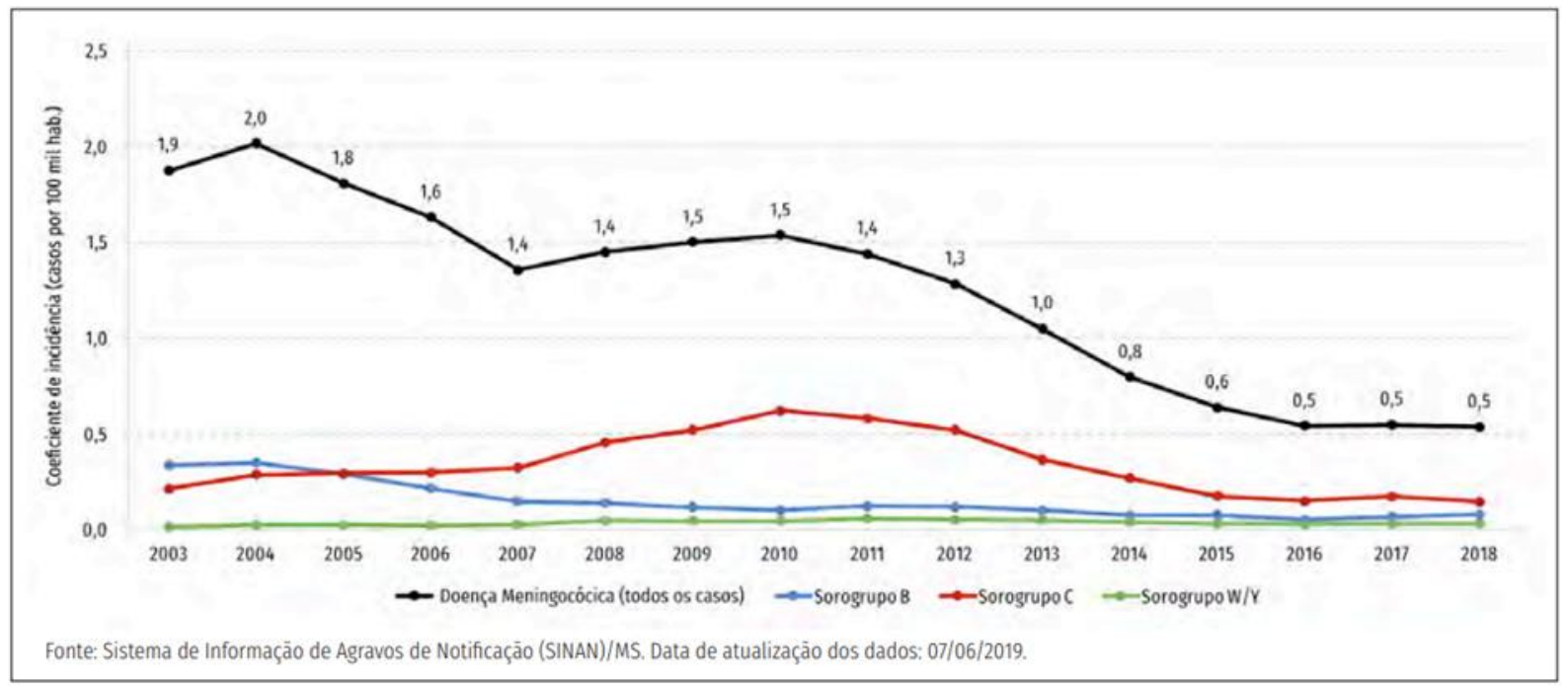

Fonte: BRASIL, 2019b. 
Figura 02 - Coeficiente de incidência de doença meningocócica por faixa etária, Brasil, 2003 a 2018.

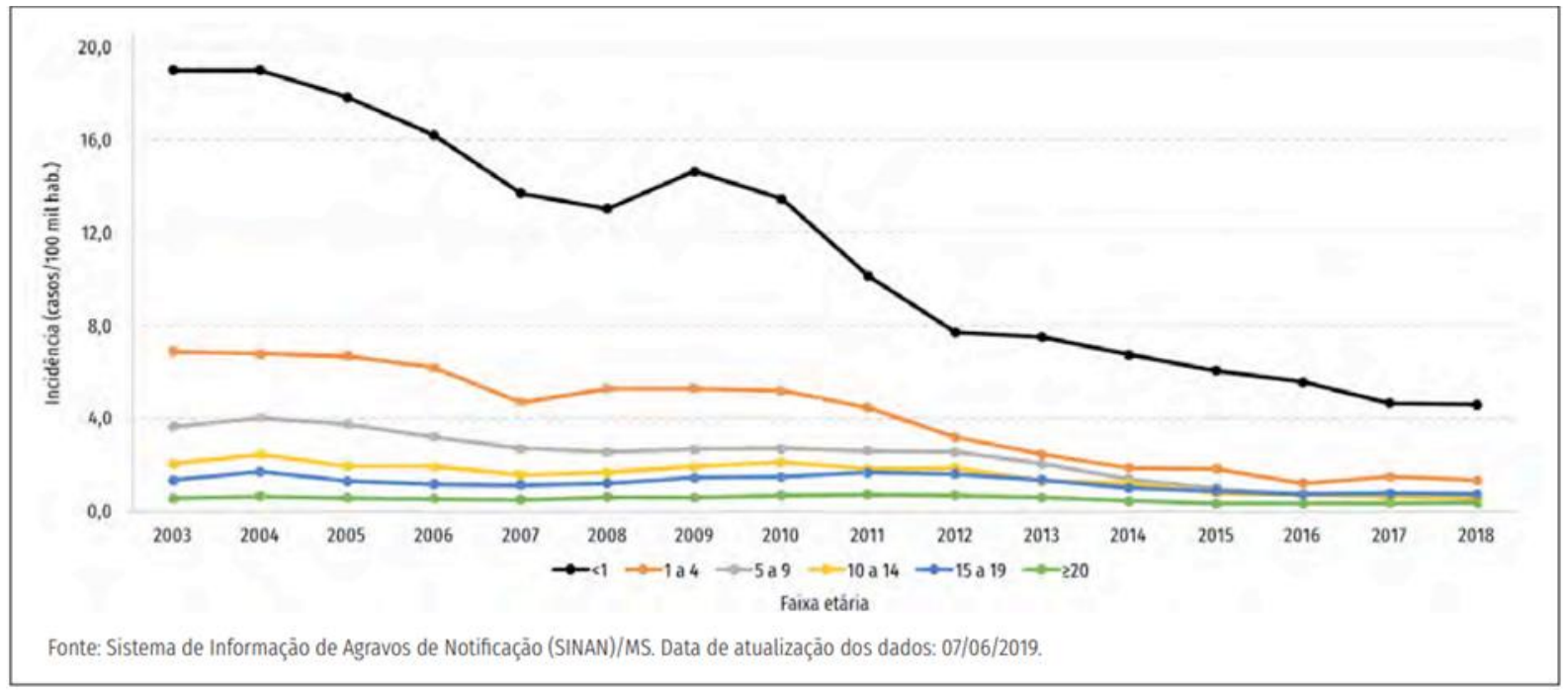

Fonte: BRASIL, 2019b.

A doença meningocócica (como é chamada a meningite meningocócica), continua sendo um agravo de saúde pública no país, ocasionando morbidade e mortalidade em qualquer faixa etária, sendo necessária a vigilância em saúde para a verificação do comportamento epidemiológico da doença. Além disso, as informações geradas pelo sistema de vigilância são importantes para orientar as medidas preventivas e de controle, bem como, de estratégias de vacinação, em especial, para as crianças (BRASIL, 2019b).

\subsection{EPIDEMIOLOGIA DA MENINGITE BACTERIANA NO NORDESTE DO Pais}

A meningite bacteriana ocorre em indivíduos de diferentes faixas etárias e de diversas regiões do Brasil. No que se refere a ocorrência da meningite na região nordeste do país, os dados são obtidos principalmente pelo Departamento de Informática do SUS (DATASUS).

De acordo com informações coletadas de documentos oriundos do Ministério da Saúde, houve diminuição do número de casos de meningite, porém com um aumento de aproximadamente 8,14\% nos anos de 2011, 2012 e 2017. Além disso, no período de 2008 a 2018, o sexo masculino foi o que apresentou maior incidência dos casos confirmados de meningite (CARDOSO et al., 2019). 
No que se refere ao agente etiológico da doença, pode-se observar que no período de 10 anos, houve prevalência da Meningite Meningocócica (MM), com 42,96\%. Entretanto, em 2012 a 2018 houve uma diminuição dos casos por MM e Meningocócica (MCC), 39,25\% e $28,43 \%$ respectivamente (figura 03 ).

Figura 03 - Casos confirmados por Etiologia Meningite meningocócica C na Região Nordeste no período de 2008 a 2018.

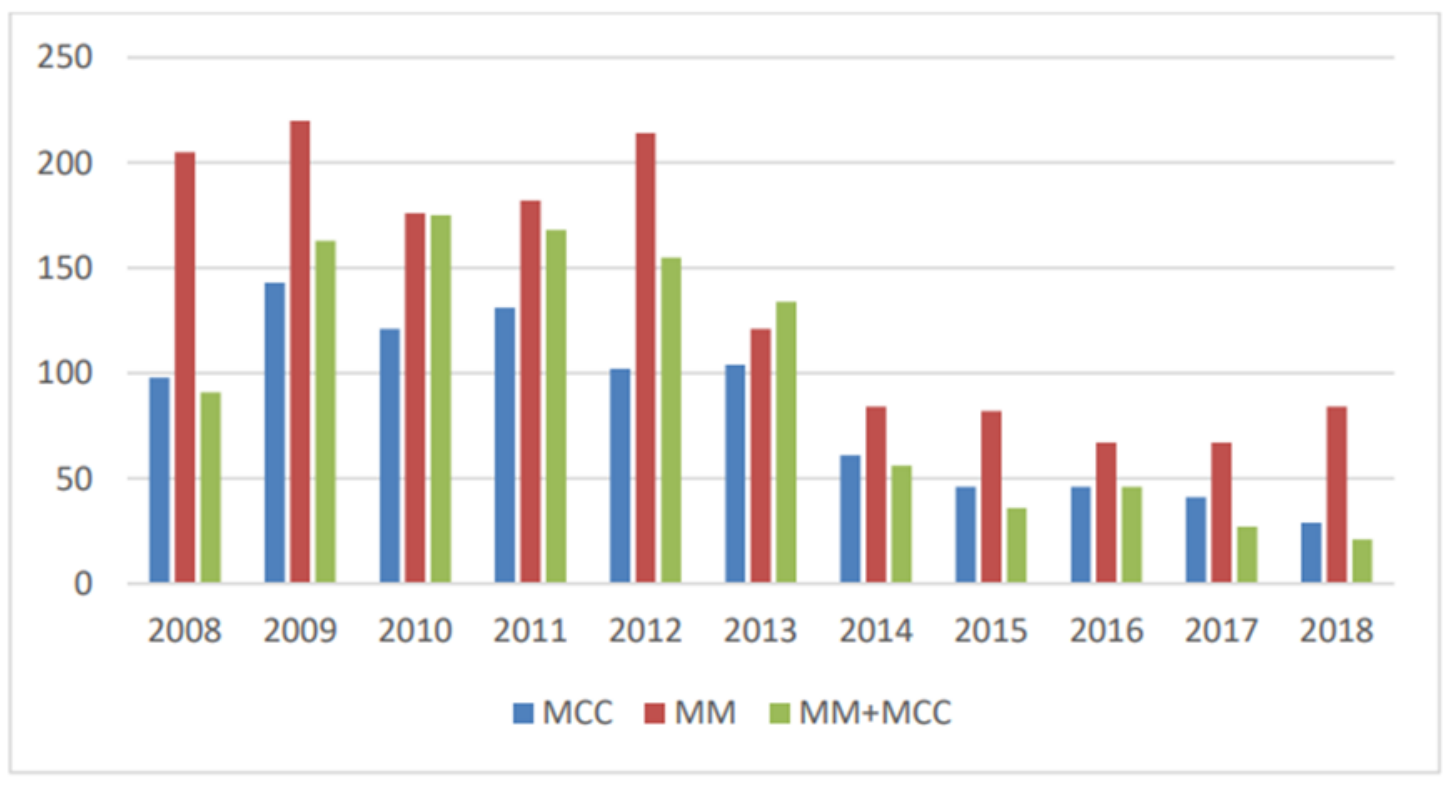

Fonte: Cardoso et al. (2019).

Em relação aos sorogrupos, a região nordeste segue o mesmo perfil observado em outras regiões do Brasil, como Sudeste e Sul, com prevalência do sorogrupo C, compreendendo uma taxa de 79,85\% de 2008 a 2018 (figura 04). 
Figura 04 - Casos confirmados por Sorogrupo Geral na Região Nordeste no período de 2008 a 2018.

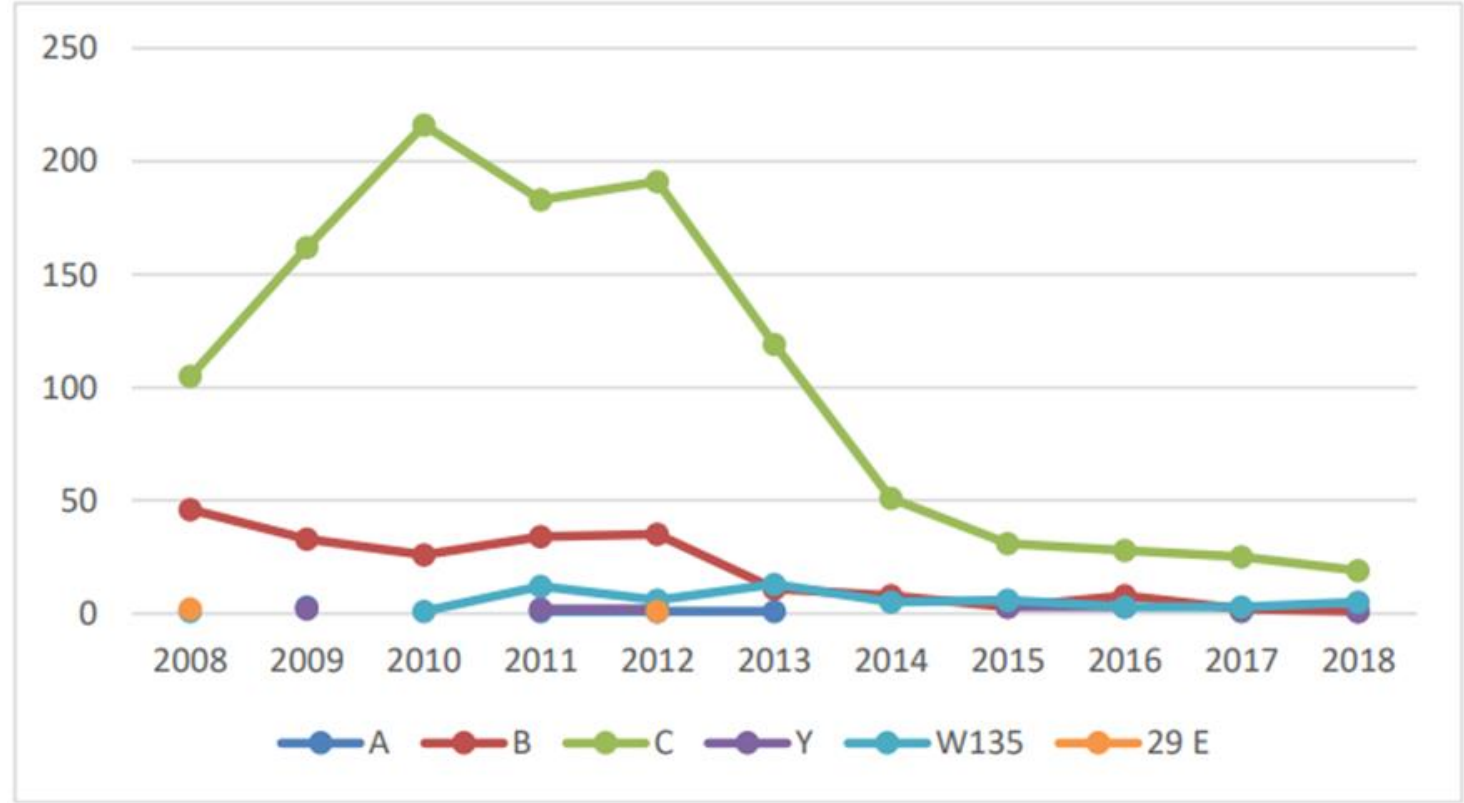

Fonte: Cardoso et al. (2019).

Dessa maneira, apesar da regressão do número de casos em um período de 10 anos na região nordeste do país, ainda existe notificação da doença, principalmente, relacionada com o sorogrupo $\mathrm{C}$ e que exigem medidas de prevenção e controle. $\mathrm{O}$ nordeste do Brasil é considerado a terceira maior região que apresenta casos confirmados de meningite tanto com agente etiológico bacteriano conhecido quanto a chamada "meningite bacteriana não especificada" (BRASIL, 2019c). Por isso a importância da vigilância e das notificações para traçar um perfil epidemiológico das regiões do país.

\section{CONSIDERAÇÕES FINAIS}

O objetivo geral deste artigo foi realizar uma breve revisão bibliográfica sobre a importância da epidemiologia na meningite bacteriana no Brasil. Para tal, foi realizada uma pesquisa teórica em bases de dados e manuais do Ministério da Saúde, no qual foram desenvolvidas as seguintes temáticas: A Meningite Bacteriana - Aspectos Gerais; Aspectos Epidemiológicos Nacionais da Meningite Bacteriana; Epidemiologia da Meningite Bacteriana no Nordeste do País.

Como resposta à questão norteadora desse estudo, pode-se observar que o perfil epidemiológico de doenças infecciosas de importância à saúde pública é essencial 
para compreender como a mesma se manifesta em determinados locais, como no caso da meningite bacteriana, considerada um agravo de saúde pública e doença de notificação compulsória.

Além disso, o Sistema de Informação de Agravos de Notificação é uma ferramenta essencial para que os estados e municípios possam informar a situação epidemiológica do local, a possibilidade de surtos, tomadas de decisões sobre prevenção e controle da meningite bacteriana no país. Contudo, sabe-se que no Brasil ainda existe muitos casos subnotificados, o que dificulta o levantamento epidemiológico em determinadas regiões.

Dessa forma, é importante que os profissionais de saúde sigam as especificações dos manuais estabelecidos pelo Ministério da saúde, preenchendo a Ficha de Investigação de Meningite, notificando e informando os casos suspeitos, confirmados e descartados, contribuindo com mais conhecimento sobre a doença e sua manifestação na população.

\section{AGRADECIMENTOS}

Agradeço primeiro a Deus pela direção e discernimento e depois a minha família e em especial minha mãe q sempre me deu apoio e me ensinou a ser sabia para lidar com as divergências da vida.

\section{REFERÊNCIAS}

BEREZIN, E.N. Epidemiologia da Infecção Meningocócica. Folheto Meningite Fascículo 01. Sociedade Brasileira de Pediatria, 2015. Disponível em:< https://www.sbp.com.br/fileadmin/user_upload/publicacoes/Folheto_Meningi te_Fasciculo1_111115.pdf>. Acesso em 28 de novembro de 2019.

BRASIL. Ministério da Saúde. Secretaria De Vigilância Em Saúde. Departamento de Vigilância Epidemiológica. Nota técnica da doença meningocócica no Brasil. 2010.

<http://portal.saude.gov.br/portal/arquivos/pdf/nt_meningite_brasil15_03.pdf >. Acesso em 28 de novembro de 2019.

BRASIL. Ministério da Saúde. Guia de Vigilância em Saúde. 2ª̣ed. Brasília-DF: Ministério da http://portalarquivos.saude.gov.br/images/pdf/2017/outubro/06/VolumeUnico-2017.pdf. Acesso em 28 de novembro de 2019. 
BRASIL. Ministério da Saúde. Meningite: o que é, causas, sintomas, tratamento, diagnóstico e prevenção. 2019a. http://saude.gov.br/saude-de-az/meningites\#prevencao>. Acesso em 28 de novembro de 2019.

BRASIL. Secretaria de Vigilância em Saúde. Boletim Epidemiológico. Vigilância em Saúde no Brasil 2003|2019 - Da criação da Secretaria de Vigilância em Saúde aos dias atuais.

Ministério 2019bhttp://portalarquivos2.saude.gov.br/images/pdf/2019/setembro/25/bol etim-especial-21ago19-web.pdf>. Acesso em 28 de novembro de 2019.

BRASIL. Secretaria de Vigilância em Saúde. Boletim Epidemiológico. Meningite bacteriana não especificada no Brasil 2007 - 2016: desafio para a vigilância das meningites. Ministério Saúde,http://portalarquivos2.saude.gov.br/images/pdf/2019/fevereiro/01/201 8-038.pdf>. Acesso em 28 de novembro de 2019.

CARDOSO, L.C.C. et al. CARACTERIZAÇÃO DO PERFIL EPIDEMIOLÓGICO DE MENINGITE: estudo ecológico na Região Nordeste de 2008 a 2018. In: 20 Congresso Internacional de Enfermagem - $\mathrm{CIE} / 13^{\circ}$ Jornada de Enfermagem da Unit (JEU), 2019.

COHN, A.C. et al. Changes in Neisseria meningitidis disease epidemiology in the United States, 1998-2007: implications for prevention of meningococcal disease. Clinical Infectious Diseases. Oxford, v. 50, n. 2, p. 184-191, jan. 2010.

CDC (Centers for Disease Control and Prevention). Viral Meningitis. 2014. Disponível em:<http://www.cdc.gov/Meningitis/viral.html>. Acesso em 28 de novembro de 2019.

DAZZI, M.C.; ZATTI, C.A.; BALDISSERA, R. Perfil dos casos De Meningites ocorridas no Brasil de 2009 a 2012. Revista UNINGÁ Review, v. 19, n.3, p. 33-36, 2014.

GILBERTO, C. A. Como elaborar projetos de pesquisa. 4aed. São Paulo: Atlas, 2008.

LONGO, D.L. et al. Meningite, Encefalite, Abcesso Cerebral e Empiema. Medicina Interna de Harrison. 18ª ed. Porto Alegre: Amgh Editora Ltda. 2013. 3410-3420p.

MENDES, K. D. S.; SILVEIRA, R. C. C. P.; GALVÃO, C. M. Revisão integrativa: método de pesquisa para a incorporação de evidências na saúde e na enfermagem. Texto \& Contexto, v.17, n.4, p.58-64, 2008.

MINAYO, M.C.S. Amostragem e saturação em pesquisa qualitativa: consensos e controvérsias. Revista Pesquisa Qualitativa, v. 5, n. 7, p. 01-12, abr. 2017.

PAIS, C.J. Epidemiologia e diagnóstico laboratorial das meningites na região de São Lourenço, Minas Gerais. Revista Biociências, Taubaté, v. 19, n. 1, p. 35-45, 2013. 
PELTON, S.I. Meningococcal disease awareness: clinical and epidemiological factors affecting prevention and management in adolescents. Journal of Adolescent Health. New York, v. 46, p. S9-S15, jun. 2010.

POLAND, G.A. Prevention of meningococcal disease: current use of polysaccharide and conjugate vaccines. Journal of Infectious Diseases. Oxford, v. 50, n. 2, p. S45S53, mar. 2010.

PORTAL DA SAÚDE. BRASIL. MINISTÉRIO DA SAÚDE: Nota meningite. Disponível em:<http://portal.saude.gov.br/portal/arquivos/pdf/nota_meningite_mg_2805 .pdf $>$. Acesso em 28 de novembro de 2019.

RODRIGUES, E.M.B.; MILAGRES, B.S. Meningite: perfil epidemiológico da doença no Brasil nos anos de 2007 a 2013. 2015. 16f. Monografia [Graduação em Biomedicina] - Centro Universitário de Brasília, Faculdade de Ciências da educação e saúde, Brasília. 2015.

SILVA, H.C.G.; MEZAROBBA, N. Meningite no Brasil em 2015: o panorama da atualidade. Arq. Catarin Med., v. 47, n. 1, p. 34-46, 2018. 


\title{
ESTUDO EPIDEMIOLÓGICO SOBRE INIERNACÕES POR ESCLEROSE MÚLTIPLA NO BRASIL COMPARANDO SEXO, FALXA ETÁRIA E REGIÃO ENTRE JANEIRO DE 2008 A JUNHO DE 2019
}

\author{
DOI: 10.51859/amplla.csa528.2121-21
}

\author{
Daniel Pedrosa Cassiano ${ }^{1}$ \\ Antônio Henrique Roberti dos Santos ${ }^{1}$ \\ Daniel de Christo Esteves ${ }^{1}$ \\ Isabela Caruso Cavalcanti ${ }^{1}$ \\ Marina de Rossi ${ }^{1}$ \\ Mylena Sobreira Sena ${ }^{1}$ \\ Guilherme Neumann de Araújo ${ }^{2}$ \\ Raquel Oliveira de Souza ${ }^{3}$
}

\begin{abstract}
* Publicação prévia em: CASSIANO, DANIEL PEDROSA ; SANTOS, ANTÔNIO HENRIQUE ROBERTI DOS ; ESTEVES, DANIEL DE CHRISTO ; ARAÚJO, GUILHERME NEUMANN DE ; CAVALCANTI, ISABELA CARUSO ; ROSSI, MARINA DE ; SENA, MYLENA SOBREIRA ; SOUZA, RAQUEL DE OLIVEIRA . Estudo epidemiológico sobre internações por esclerose múltipla no brasil comparando sexo, faixa etária e região entre janeiro de 2008 a junho de 2019 / Epidemiological study on multiple sclerosis hospitalization in brazil comparing sex, age and region between january 2008 to june 2019. Brazilian Journal of Health Review, v. 3, p. 19850-19861, 2020. DOI:10.34119/bjhrv3n6-359.

${ }^{1}$ Acadêmicos de Medicina na Faculdade de Medicina do Centro Universitário Presidente Antônio Carlos / UNIPAC-JF (Juiz de Fora MG)

${ }^{2}$ Médico pela Faculdade de Medicina do Centro Universitário Presidente Antônio Carlos e especialista em Neurologia pela Universidade Federal de Juiz de Fora (Juiz de Fora - MG)

${ }^{3}$ Médica pela Faculdade de Medicina do Centro Universitário Presidente Antônio Carlos e residente em Radiologia no Hospital Alcides Carneiro (Petrópolis - RJ).
\end{abstract}

\section{RESUMO}

A esclerose múltipla (EM) é uma doença autoimune do sistema nervoso central cursando com desenvolvimento de autoanticorpos contra a bainha de mielina nos axônios, causando sítios inflamatórios desmielinizantes. É uma doença com alta morbimortalidade, incurável, e com uma prevalência próxima a 15 casos por 100.000 habitantes no Brasil. OBJETIVO: realizar uma pesquisa sobre a epidemiologia acerca das internações por EM no Brasil. METODOLOGIA: realizou-se uma revisão de artigos nas bases de dados "New England Journal of Medicine", "Scielo" e "BVSMS", utilizando os descritores "esclerose múltipla" e "epidemiologia da esclerose múltipla". Os dados estatísticos foram coletados na base de dados DATASUS, que apresentou os dados de epidemiologia da EM entre janeiro de 2008 a junho de 2019. RESULTADOS: as internações se elevam a partir dos 15 anos de idade em ambos gêneros e se intensifica nas entre 2029 anos (22\%), 30-39 anos (29\%), 40-49 anos (22\%), 50-59 anos (13\%). Notou-se uma prevalência maior nas mulheres (2,33M:1H). Comparando o ano de 2008 com 2018, houve aumento de 195\% nas internações. A região Sudeste possui o maior índice de hospitalizações pela doença (60\%), seguida pela Sul (21\%), Centro-Oeste (9\%), Nordeste (8\%) e Norte (2\%). CONCLUSÃO: ocorre maior prevalência entre 15-59 anos, e maior importância para os índices a partir dos 20 anos. O predomínio de internações entre as mulheres corrobora a literatura vigente. Sobre o aumento de internações nos últimos 10 anos, podemos pensar em uma possível subnotificação dessa doença no passado ou um real aumento de sua incidência.

Palavras-chave: DataSus, Esclerose Múltipla, Internações. 


\section{INTRODUÇÃO}

A Esclerose Múltipla (EM) é uma doença autoimune crônica do sistema nervoso central que consiste no desenvolvimento de autoanticorpos contra a bainha de mielina nos axônios neuronais, gerando sítios inflamatórios e estresse oxidativo, o que culmina em neurodegeneração e desmielinização dos neurônios afetados (NOSEWORTHY et al., 2000). As lesões provocadas pela EM geram transtornos físicos, cognitivos e neurológicos na vida dos acometidos (GHASEMI et al., 2016), resultando em dificuldade para a realização das atividades da vida diária dos pacientes (NEVES et al., 2017). Tal afecção é uma das causas mais comuns de incapacidade neurológica crônica em adultos (MOREIRA et al., 2000).

No Brasil, a Esclerose Múltipla possui uma taxa de prevalência de 15 casos para cada 100.000 (cem mil) habitantes, com predominância nas mulheres brancas, com os primeiros sintomas aparecendo em torno dos 30 anos e o diagnóstico geralmente aos 45 anos, sendo que a forma clínica remitente-recorrente é a mais comum (MOREIRA et al., 2000; RIBEIRO et al., 2011; NEGREIROS et al., 2015). A EM ainda não possui uma etiologia bem definida, sendo classificada como uma doença multifatorial, contudo, o fator genético está intimamente relacionado (SILVA, NASCIMENTO, 2014).

Do ponto de vista mundial, 2.8 milhões de pessoas possuem a doença, o que se traduz em 1 caso a cada 3.000 habitantes, um aumento de 21\% comparado com 2013, prevalecendo nos países de maior latitude, sendo notável nas nações europeias e da América do Norte (ATLAS OF MS, 2020).

Frente à fisiopatologia da EM, as lesões referentes ao sistema nervoso central são mais evidentes na substância branca cerebral, sendo assim, as áreas focais de desmielinização e inflamação são facilmente evidenciadas, lesões essas que levarão a alterações importantes nas células da glia e, consequentemente, a prejuízos neurológicos importantes (REICH et al., 2018). Atualmente, sabe-se que a substância cinzenta também é envolvida na fisiopatologia desta doença, e, dessa forma, temos que tanto o córtex, quanto o subcórtex pode ser afetado durante o curso dessa enfermidade (MATIAS-GUIU et al., 2018).

A sintomatologia está relacionada com a área acometida, sendo mais comum a apresentação de sintomas como: fraqueza, disgrafia, ataxia, paresia e parestesia de 
membros, diplopia e tremores (LOMA et al., 2011). É geralmente nessa fase que o indivíduo procura atendimento médico pela primeira vez. Além dos citados, é comum o paciente apresentar sintomas autonômicos, como disfunção sexual, dificuldade de controle esfincteriano, além de déficit na fala e mudanças cognitivas (LASSMANN, 2005). A longo prazo, evolui para doença incapacitante.

As manifestações neuropsíquicas acometem mais da metade dos portadores de EM (LANGDON, 2011; AMATO et al., 2013), enquanto os danos cognitivos prevalecem sobre 40 a 70\% dos afetados. No entanto, a evolução para demência parece ser incomum (CHIARAVALLOTI et al., 2013; BENEDICT et al., 2017; GRZEGORSKI, LOSY, 2017; ARTEMIADIS et al., 2012), enquanto a depressão vem sendo fortemente associada aos níveis de evolução da doença (SILVA et al., 2018). Apesar de possuir uma variedade enorme de apresentações clínicas, as manifestações referentes ao sistema nervoso autônomo são grande fonte de preocupação, pois levam a consequências importantes e prejuízo na qualidade de vida (HABEK, 2019).

O diagnóstico atualmente é feito através da clínica apresentada pelo paciente e o exame de imagem, sendo o com maior valor preditivo a Ressonância Nuclear Magnética de crânio (SANTANA et al., 2020). Outro exame que auxilia a propedêutica é a dosagem de bandas oligoclonais no líquor. Por fim, o tratamento multiprofissional atua minimizando a progressão da doença, visando reduzir os surtos e a incapacidade gerada no paciente. Quanto ao tratamento medicamentoso, as terapias modificadoras da doença (TMD) são as mais utilizadas, através de drogas como betainterferonas, Teriflunomida e Acetato de Glatirâmer (TINOCO et al., 2019; LOMA et al., 2011). No entanto, como na maioria das doenças neurológicas crônicas, o custo desse tratamento é elevado, o que dificulta a adesão e piora o prognóstico (NAVARRO et al., 2020).

Tal estudo teve como objetivo relatar o número de casos da doença em diversos setores sociais, a fim de estabelecer vínculo entre a etiologia e promoção de saúde.

\section{METODOLOGIA}

O presente trabalho trata-se de um estudo transversal, realizado no período de outubro de 2019 a novembro de 2020, que se propôs a analisar a prevalência da Esclerose Múltipla de janeiro de 2008 a junho de 2019. 
Inicialmente foi realizada uma busca por artigos de revisão nas bases de dados “New England Journal of Medicine”, "SciELO” e "BVS/BIREME”, utilizando os descritores "Multiple Sclerosis", "Esclerose Múltipla", "Epidemiologia da Esclerose Múltipla" e "Sequelas da Esclerose Múltipla". Como critério de inclusão foram utilizados o ano de publicação mais recente, idioma português e inglês e as publicações que abordassem especificamente o tema. Foram excluídos os estudos não revisionais sobre a moléstia. Deste ponto, foram selecionados os artigos para o estudo.

Após a revisão bibliográfica foram coletados os dados estatísticos na base de dados DATASUS, mediante o tópico "Informações de Saúde (TABNET)" que forneceu os dados de epidemiologia e morbidade referentes à EM entre janeiro de 2008 e junho de 2019, a partir dos quais foram realizadas análises estatísticas acerca do número de óbitos, internações, relação entre gênero, etnia, idade e outros aspectos epidemiológicos. O “Protocolo Clínico e Diretrizes Terapêuticas Esclerose Múltipla" publicado pelo Ministério da Saúde do Brasil em julho de 2019 também foi utilizado como fonte de dados. Para dados referentes à epidemiologia mundial da doença, foi utilizado a 3a edição do "Atlas da Esclerose Múltipla" publicado pela Federação Internacional da Esclerose Múltipla em setembro de 2020.

\section{RESULTADOS E DISCUSSÕES}

De acordo com os dados coletados no DATASUS no período de 2008 a 2019, o número total de internações por EM no Brasil foi de 29.088 nas Regiões Norte, Nordeste, Sul, Sudeste e Centro-Oeste do país. De acordo com dados do IBGE de 2020, o Brasil possui aproximadamente 212 milhões de habitantes. 
Figura 1: Distribuição demográfica do número de pacientes internados por EM no Brasil durante o período de 2008 a 2019 ( $n=29.088)$.

\begin{tabular}{|c|c|c|c|c|c|c|}
\hline Ano/Região & Norte & Nordeste & Sudeste & Sul & Centro-Oeste & $\begin{array}{c}\text { Total } \\
\text { Anual }\end{array}$ \\
\hline $\mathbf{2 0 0 8}$ & 20 & 160 & 838 & 543 & 121 & 1.682 \\
\hline $\mathbf{2 0 0 9}$ & 34 & 174 & 873 & 473 & 143 & 1.697 \\
\hline $\mathbf{2 0 1 0}$ & 48 & 151 & 848 & 504 & 115 & 1.666 \\
\hline $\mathbf{2 0 1 1}$ & 100 & 162 & 902 & 476 & 153 & 1.793 \\
\hline $\mathbf{2 0 1 2}$ & 70 & 157 & 966 & 521 & 92 & 1.806 \\
\hline $\mathbf{2 0 1 3}$ & 49 & 157 & 911 & 581 & 95 & 1.793 \\
\hline $\mathbf{2 0 1 4}$ & 58 & 235 & 1.075 & 577 & 76 & 2.021 \\
\hline $\mathbf{2 0 1 5}$ & 64 & 231 & 1.053 & 604 & 126 & 2.078 \\
\hline $\mathbf{2 0 1 6}$ & 74 & 227 & 2.144 & 469 & 254 & 3.168 \\
\hline $\mathbf{2 0 1 7}$ & 81 & 216 & 2.689 & 478 & 670 & 4.134 \\
\hline $\mathbf{2 0 1 8}$ & 82 & 232 & 3.255 & 552 & 842 & 4.963 \\
\hline $\mathbf{2 0 1 9}$ & 35 & 147 & 1.822 & 235 & 48 & 2.287 \\
\hline TOTAL & $\mathbf{7 1 5}$ & $\mathbf{2 . 2 4 9}$ & $\mathbf{1 7 . 3 7 6}$ & $\mathbf{6 . 0 1 3}$ & $\mathbf{2 . 7 3 5}$ & $\mathbf{2 9 . 0 8 8}$ \\
\hline
\end{tabular}

Em relação ao ano por Região (Figura 1), observou-se o maior número de internações no ano de 2018, com 4.963 episódios. Sendo mais expressivo na Região Sudeste, com 3.255. Seguido pelo ano de 2017 com 4.134, novamente a Região Sudeste com a maior quantidade, 2.689. Além disso, nota-se que o ano de 2010 houve um total de 1.666 , sendo o ano que apresentou menor número de internações.

Figura 2: Relação epidemiológica entre as regiões do Brasil e o número de internações por EM durante o período.

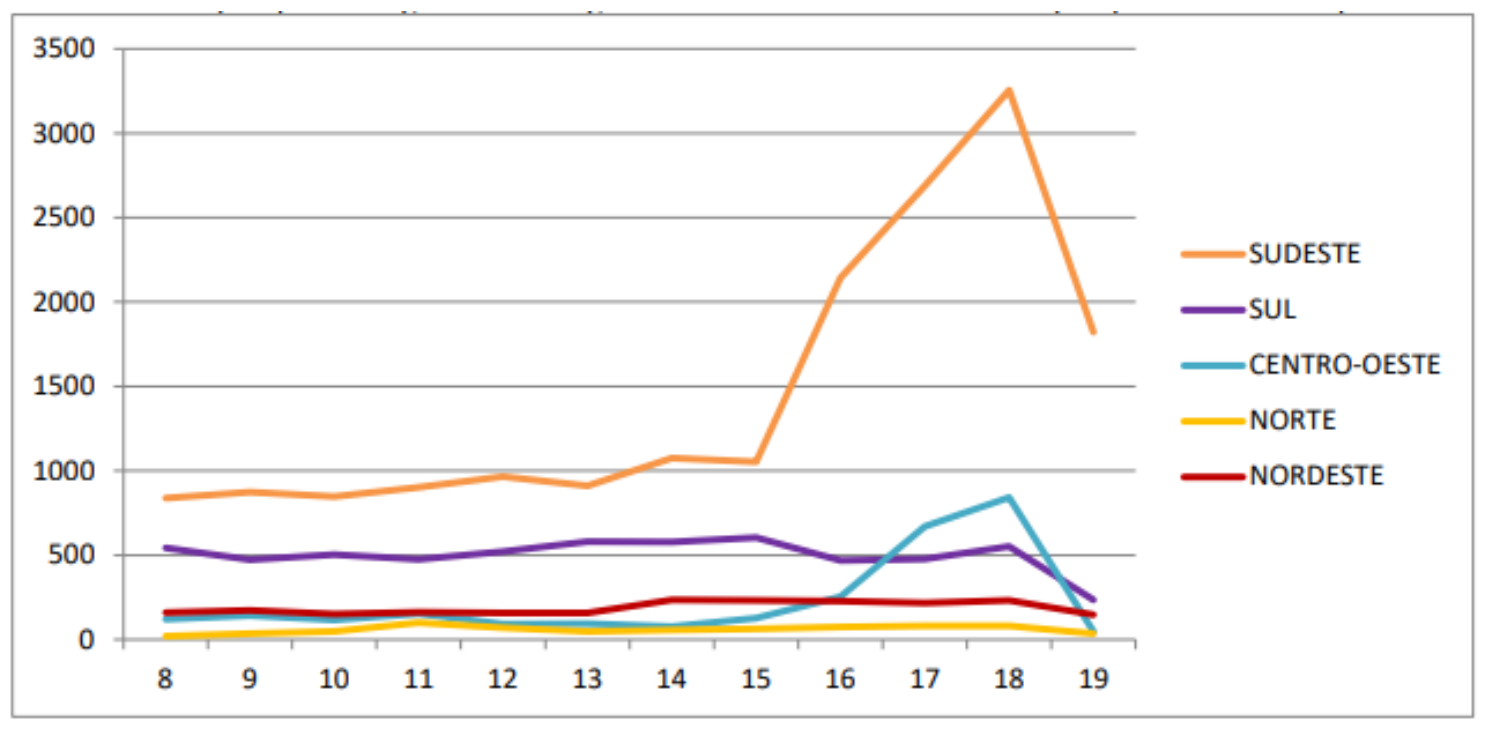

Fonte: Autoria própria. 
A relação ano por Região (Figura 2) revela que no ano de 2011 a Região Norte do país apresentou um aumento de 108,3\% internações em relação a 2010. Os dados estatísticos destacam a Região Sudeste com o maior registro de internações no Brasil por EM (59,7\%), entre 2008 e junho 2019. Em contrapartida, o número de internações anuais na Região Sul foi estável durante todo o período estudado. Ademais, a Região Nordeste também não sofreu grandes alterações nos dados obtidos. A Região Centrooeste do país se destaca pelo aumento expressivo de 595\% entre janeiro de 2008 e dezembro de 2018.

Figura 3: Evolução epidemiológica anual sobre o total de internações por EM durante o período no Brasil.

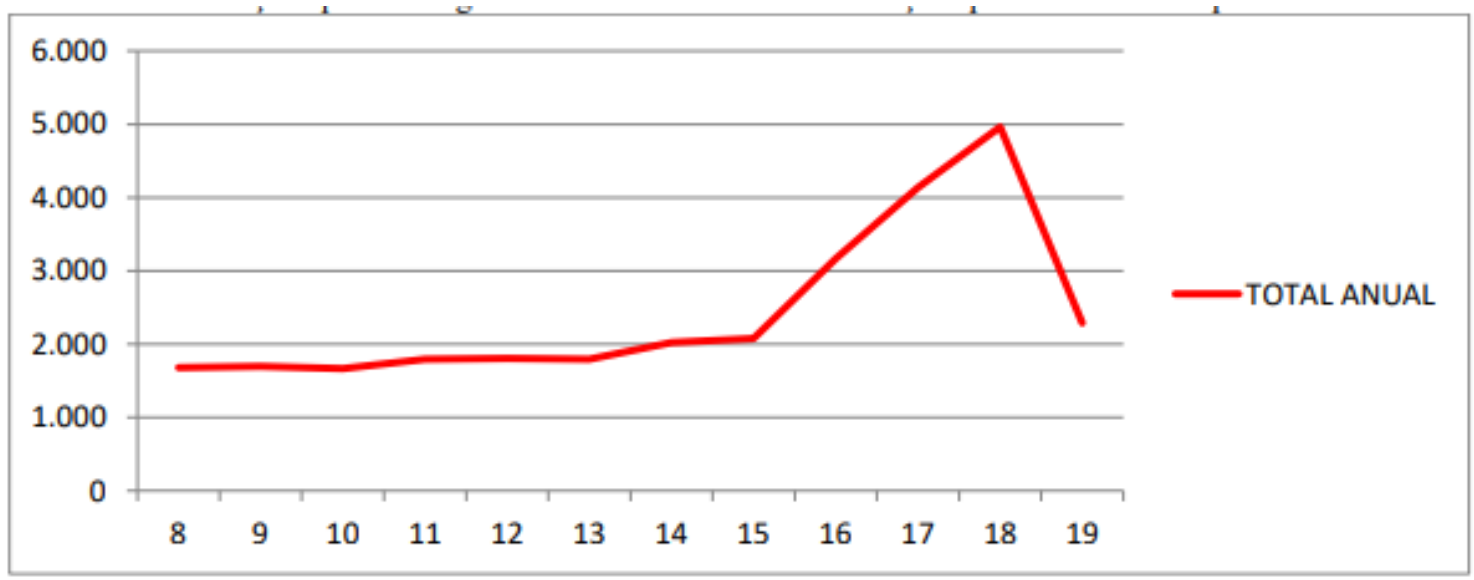

Fonte: Autoria própria.

Em análise comparativa do ano de 2008 em relação ao ano de 2018, no Brasil, houve aumento de $195 \%$ das internações. Um aumento substancial começou a ser observado a partir de 2015.

Figura 4: Distribuição epidemiológica do número total de internações por EM compreendida entre a faixa etária de menores de 1 ano a maiores de 80 anos, relacionando-se sexo feminino e masculino durante o período de 2008 a $2019(n=29.088)$.

\begin{tabular}{|c|c|c|c|c|c|c|c|c|c|c|c|c|c|}
\hline Sexo/Idade & $>$ & $\mathbf{1 -}$ & $\mathbf{5 -}$ & $\mathbf{1 0 -}$ & $\mathbf{1 5}-$ & $\mathbf{2 0 -}$ & $\mathbf{3 0 -}$ & $\mathbf{4 0 -}$ & $\mathbf{5 0 -}$ & $\mathbf{6 0 - 6 9}$ & $\mathbf{7 0 -}$ & $\mathbf{8 0 +}$ & Total \\
& $\mathbf{1}$ & $\mathbf{4}$ & $\mathbf{9}$ & $\mathbf{1 4}$ & $\mathbf{1 9}$ & $\mathbf{2 9}$ & $\mathbf{3 9}$ & $\mathbf{4 9}$ & $\mathbf{5 9}$ & & $\mathbf{7 9}$ & \\
\hline Total & 3 & 6 & 88 & 341 & 139 & 6.458 & 8.335 & 6.339 & 3.854 & 3.346 & 556 & 372 & 29.088 \\
\hline Masculino & 2 & 3 & 28 & 134 & 404 & 1.887 & 2.504 & 1.653 & 1.153 & 523 & 253 & 170 & 8.714 \\
\hline Feminino & 1 & 3 & 60 & 207 & 986 & 4.571 & 5.831 & 4.686 & 2.701 & 823 & 303 & 202 & 20.374 \\
\hline
\end{tabular}


Na relação sexo por faixa etária (Figura 4), entre menores de 5 anos ocorreu apenas 9 internações, sendo 5 em meninos e 4 em meninas. Entre 5 a 9 anos já ocorre uma prevalência maior nas meninas, sendo que foram 28 internações no sexo masculino e 60 no sexo feminino. Entre 15 a 19 anos, elevou os índices de casos, 404 do sexo masculino e 986 do sexo feminino. Entre 20 a 59 anos, ocorreu neste intervalo as maiores incidências de internações, para ambos os sexos. A partir dos 60 anos, houve um declínio dos casos. Contabilizando um total de 8.714 hospitalizações do sexo masculino e 20.374 do sexo feminino. Portanto, a caracterização das faixas etárias demonstrou um predomínio feminino sobre as hospitalizações por EM, em concordância com a prevalência da doença nas mulheres descrita na literatura (GRZESIUK, 2006; CARDOSO et al., 2006; SOUZA et al., 2018; POSER, BRINAR, 2007; LANA-PEIXOTO et al., 2012).

Figura 5: Análise comparativa entre faixa etária (menor que 1 ano a maior de 80 anos) no sexo feminino e masculino e número de internações por EM no período de 2008 e 2019 (n=29.088).

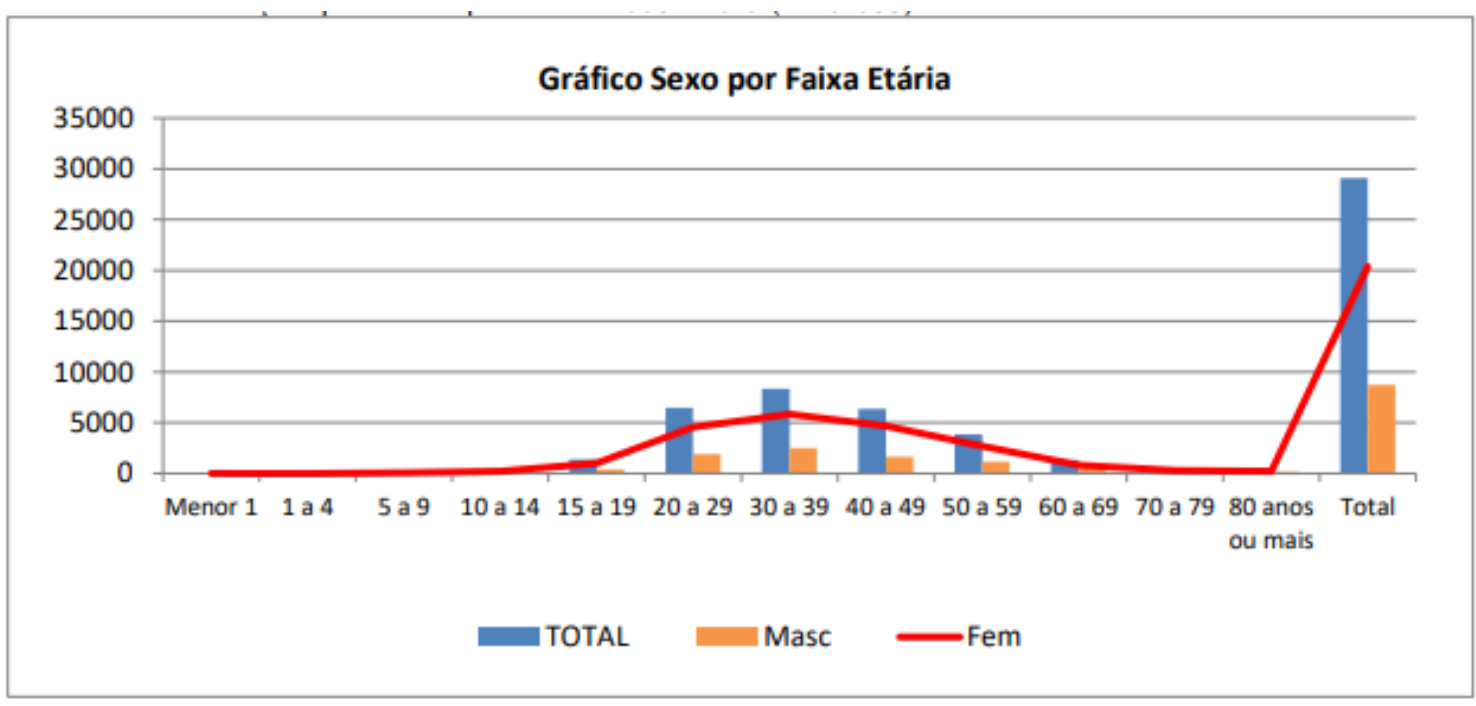

Fonte: Autoria própria.

A figura 5 indica a relação sexo por faixa etária, nota-se que o índice de internações se eleva a partir dos 15 anos de idade em ambos os sexos e se intensifica nas faixas etárias dos 20- 29 anos (22,2\%), 30-39 anos (28,6\%), 40-49 anos (21,8\%), 5059 anos (13,2\%). Neste sentido, nota-se que 85,9\% (24.986) do total de internações (29.088) ocorreram entre 20-59 anos de idade. É possível inferir que entre 20-59 anos pôde ser encontrado o maior número de internações entre as faixas etárias, com grande 
ênfase para a faixa etária dos 30-39 e estas informações somam evidências corroborativas em relação à literatura (GRZESIUK, 2006; CARDOSO et al., 2006; SOUZA et al., 2018; POSER, BRINAR, 2007; LANA-PEIXOTO et al., 2012).

Figura 6: Comparação demográfica entre o número de indivíduos do sexo feminino e masculino internados por EM, distribuídos nas regiões do Brasil, durante o período compreendido entre 2008 e $2019(n=29.088)$.

\begin{tabular}{|c|c|c|c|}
\hline $\begin{array}{c}\text { Região/Unidade da } \\
\text { Federação }\end{array}$ & Masculino & Feminino & Total \\
\hline Total & 8.714 & 20.374 & 29.088 \\
\hline Região Norte & 245 & 470 & 715 \\
\hline Região Nordeste & 717 & 1.532 & 2.249 \\
\hline Região Sudeste & 5.087 & 12.289 & 17.376 \\
\hline Região Sul & 1.925 & 4.088 & 6.013 \\
\hline Região Centro-Oeste & 740 & 1.995 & 2.735 \\
\hline
\end{tabular}

Fonte: Autoria própria.

De acordo com os dados da figura 6, sobre Região por sexo, do total de 29.088 internações por EM no Brasil 70\% aconteceram no sexo feminino, sendo a proporção de 2,33 mulheres para cada 1 homem. Na Região Norte a prevalência de internações foi de 1,91M/1H, Região Nordeste 2,13M/1H e Sudeste a proporção encontrada foi de 2,4M/1H. Na Região Sul 2,12M/1H e na Região Centro-Oeste 2,69M/1H. As estatísticas encontradas demonstram correlação com a literatura médica epidemiológica acerca das prevalências de EM nas regiões brasileiras, que indicam as mulheres como principais portadoras da doença, e consequentemente reflete na prevalência das internações devido a alta morbimortalidade da doença (GRZESIUK, 2006; CARDOSO et al., 2006; SOUZA et al., 2018; POSER, BRINAR, 2007; LANA-PEIXOTO et al., 2012).

A revisão da literatura médica recente levanta dúvidas sobre a confiabilidade das taxas de prevalência relatadas de esclerose múltipla, sobretudo devido à dificuldade do diagnóstico e também sobre a subnotificação ainda devido aos poucos estudos epidemiológicos disponíveis (POSER, BRINAR, 2007). 


\section{CONCLUSÃo}

Os estudos epidemiológicos possuem importantes fundamentos que contribuem na formação de hipóteses a serem analisadas por outras metodologias científicas, principalmente no sentido de fornecer subsídios para o planejamento e a organização das ações de saúde e para a avaliação de programas, atividades, prevenção e outros projetos. Portanto, foi demonstrado a partir deste estudo o perfil epidemiológico das internações de pacientes com EM no Brasil e suas regiões, visando mostrar as diferentes incidências de internamento pela doença, ajudando a produzir conhecimento capaz de promover a saúde através de medidas de alcance coletivo. Ressalta-se a necessidade de maiores estudos sobre o tema, sobretudo para ajudar na organização dos recursos destinados ao tratamento e prevenção das internações pela esclerose múltipla.

\section{REFERÊNCIAS}

1) NOSEWORTHY, John H.; LUCCHINETTI, Claudia; RODRIGUEZ, Moses; WEINSHENKER, Brian G.. Multiple Sclerosis. New England Journal Of Medicine, [S.L.], v. 343, n. 13, p. 938-952, 28 set. 2000. Massachusetts Medical Society. Disponível em: <http://dx.doi.org/10.1056/nejm200009283431307>. Acesso em: 25 de nov. de 2020.

2) GHASEMI, Nazem et al. Multiple Sclerosis: pathogenesis, symptoms, diagnoses and cell-based therapy. Cell J (Yakhteh), [S.L.], v. 19, n. 1, p. 1-10, jan. 2017. Royan Institute, Iranian Academic Center for Education Culture and Research (ACECR). Disponível em: <http://dx.doi.org/10.22074/cellj.2016.4867>. Acesso em: 25 de nov. de 2020.

3) NEVES, Conceição et al. Quality of life of people with multiple sclerosis and their caregivers. Revista de Enfermagem Referência, [S.L.], v. , n. 12, p. 85-96, 24 mar. 2017. Health Sciences Research Unit: Nursing. Disponível em: <http://dx.doi.org/10.12707/riv16081>. Acesso em: 23 de nov. de 2020.

4) MOREIRA, Marcos Aurélio et al. Esclerose múltipla: estudo descritivo de suas formas clínicas em 302 casos. Arquivos de Neuro-Psiquiatria, [S.L.], v. 58, n. 2, p. 460466, jun. 2000. FapUNIFESP (SciELO). Disponível em: <http://dx.doi.org/10.1590/s0004-282x2000000300010>. Acesso em: 27 de nov. de 2020.

5) RIBEIRO, Sônia Beatriz Félix et al. Clinical and epidemiological profile of patients with multiple sclerosis in Uberaba, Minas Gerais, Brazil. Arquivos de NeuroPsiquiatria, [S.L.], v. 69, n. 2, p. 184-187, abr. 2011. FapUNIFESP (SciELO). 
Disponível em: <http://dx.doi.org/10.1590/s0004-282x2011000200008>. Acesso em: 02 de dez. de 2020.

6) NEGREIROS, André Augusto Lemos Vidal de et al. Clinical and epidemiological profile of patients diagnosed with multiple sclerosis in João Pessoa, Paraíba, Brazil. Arquivos de Neuro-Psiquiatria, [S.L.], v. 73, n. 9, p. 741-745, set. 2015. FapUNIFESP (SciELO). Disponível em: <http://dx.doi.org/10.1590/0004282x20150111>. Acesso em: 02 de dez. de 2020.

7) SILVA, Valdete Mota; SILVA, Décio Fragata. Esclerose Múltipla: imunopatologia, diagnóstico e tratamento - artigo de revisão. Interfaces Científicas - Saúde e Ambiente, [S.L.], v. 2, n. 3, p. 81-90, 9 jul. 2014. Universidade Tiradentes. Disponível em: <http://dx.doi.org/10.17564/2316-3798.2014v2n3p81-90>. Acesso em: 22 de nov. de 2020.

8) THE MULTIPLE SCLEROSIS INTERNATIONAL FEDERATION (MSIF) (England and Wales). Atlas of MS: Mapping multiple sclerosis around the world. 3. ed. [S. I.: s. n.], 2020.

9) REICH, Daniel S.; LUCCHINETTI, Claudia F.; CALABRESI, Peter A.. Multiple Sclerosis. New England Journal Of Medicine, [S.L.], v. 378, n. 2, p. 169-180, 11 jan. 2018. Massachusetts Medical Society. Disponível em: <http://dx.doi.org/10.1056/nejmra1401483>. Acesso em: 18 de nov. de 2020.

10) MATÍAS-GUIU, Jordi A. et al. Identification of Cortical and Subcortical Correlates of Cognitive Performance in Multiple Sclerosis Using Voxel-Based Morphometry. Frontiers In Neurology, [S.L.], v. 9, p. 920-953, 29 out. 2018. Frontiers Media SA. Disponível em: <http://dx.doi.org/10.3389/fneur.2018.00920>. Acesso em: 21 de nov. de 2020.

11) LOMA, Ingrid; HEYMAN, Rock. Multiple Sclerosis: pathogenesis and treatment. Current Neuropharmacology, [S.L.], v. 9, n. 3, p. 409-416, 1 set. 2011. Bentham Science Publishers Ltd.. Disponível em: <http://dx.doi.org/10.2174/157015911796557911>. Acesso em: 18 de nov. de 2020.

12) WAXMAN, Stephen. Multiple Sclerosis As A Neuronal Disease. Yale, Estados Unidos da América: Academic Press, 2005. 11. Patologia dos neurônios na esclerose múltipla.

13) LANGDON, Dawn W. Cognition in multiple sclerosis. Current Opinion In Neurology, [S.L.], v. 24, n. 3, p. 244-249, jun. 2011. Ovid Technologies (Wolters Kluwer Health). Disponível em: <http://dx.doi.org/10.1097/wco.0b013e328346a43b>. Acesso em: 22 de nov. de 2020.

14) AMATO, Maria Pia et al. Treatment of cognitive impairment in multiple sclerosis: position paper. Journal Of Neurology, [S.L.], v. 260, n. 6, p. 1452-1468, 23 nov. 2012. Springer Science and Business Media LLC. Disponível em: <http://dx.doi.org/10.1007/s00415-012-6678-0>. Acesso em: 21 de nov. de 2020. 
15) CHIARAVALLOTI, N. D. et al. An RCT to treat learning impairment in multiple sclerosis: the memrehab trial. Neurology, [S.L.], v. 81, n. 24, p. 2066-2072, 8 nov. 2013. Ovid Technologies (Wolters Kluwer Health). Disponível em: <http://dx.doi.org/10.1212/01.wnl.0000437295.97946.a8>. Acesso em: 18 de nov. de 2020.

16) BENEDICT, Ralph $\mathrm{Hb}$ et al. Validity of the Symbol Digit Modalities Test as a cognition performance outcome measure for multiple sclerosis. Multiple Sclerosis Journal, [S.L.], v. 23, n. 5, p. 721-733, 16 fev. 2017. SAGE Publications. Disponível em: <http://dx.doi.org/10.1177/1352458517690821>. Acesso em: 22 de nov. de 2020.

17) GRZEGORSKI, Tomasz; LOSY, Jacek. Cognitive impairment in multiple sclerosis - a review of current knowledge and recent research. Reviews In The Neurosciences, [S.L.], v. 28, n. 8, p. 845-860, 27 nov. 2017. Walter de Gruyter GmbH. Disponível em: <http://dx.doi.org/10.1515/revneuro-2017-0011>. Acesso em 23 de nov. de 2020.

18) ARTEMIADIS, A. K. et al. Stress Management and Multiple Sclerosis: a randomized controlled trial. Archives Of Clinical Neuropsychology, [S.L.], v. 27, n. 4, p. 406416, 3 abr. 2012. Oxford University Press (OUP). Disponível em: <http://dx.doi.org/10.1093/arclin/acs039>. Acesso em 02 de dez. de 2020.

19) SILVA, Maren de Moraes e et al. Testes de rastreio para alterações psiquiátricas em esclerose múltipla - Revisão sistemática com metanálise. Jornal Brasileiro de Psiquiatria, [S.L.], v. 67, n. 4, p. 255-263, dez. 2018. FapUNIFESP (SciELO). Disponível em: <http://dx.doi.org/10.1590/0047-2085000000213>. Acesso em: 01 de dez. de 2020.

20) ABEK, Mario. Immune and autonomic nervous system interactions in multiple sclerosis: clinical implications. Clinical Autonomic Research, [S. I.], v. 29, n. 3, p. 267-275, 8 abr. 2019 < http://dx.doi.org/10.1007/s10286-019-00605-z>. Acesso em: 01 de dez. de 2020.

21) SANTANA, Larissa Marques et al. Differential diagnosis of temporal lobe lesions with hyperintense signal on T2-weighted and FLAIR sequences: pictorial essay. Radiologia brasileira, [S. I.], v. 53, n. 2, p. 129-136, 1 abr. $2020<$ http://dx.doi.org/10.1590/0100-3984.2018.0117> Acesso em: 29 de nov. de 2020.

22) TINOCO, Inês et al. Esclerose Múltipla, o afastar da lupa - relato de caso. Revista Portuguesa de Medicina Geral e Familiar, [S.I.], v. 35, n. 3, p. 232-8, jul. 2019. ISSN 2182-5181. Disponível em: doi:http://dx.doi.org/10.32385/rpmgf.v35i3.12007 >. Acesso em: 01 de dez. de 2020.

23) NAVARRO, Cristian Eduardo; ORDONEZ-CALLAMAND, Eliana; ALZATE, Juan Pablo. Disease modifying therapies in multiple sclerosis: cost-effectiveness systematic 
review. Farm Hosp., Toledo, v. 44, n. 2, p. 68-76, abr. 2020 . Disponível em < https://dx.doi.org/10.7399/fh.11385>. Acesso em 28 de nov. de 2020.

24) GRZESIUK, Anderson Kuntz. Características Clínicas e Epidemiológicas de 20 Pacientes Portadores de Esclerose Múltipla Acompanhados Em Cuiabá - Mato Grosso. Arquivos de Neuro-Psiquiatria., v.64, n.2 p. 635-38, set. 2006. Disponível em <https://dx.doi.org/10.1590/s0004-282×2006000400022> . Acesso em 29 de nov. de 2020.

25) CARDOSO, Eduardo et al. Clinical and epidemiological profile of multiple sclerosis in a reference center in the State of Bahia, Brazil. Arquivos de Neuro-Psiquiatria [S.I]. v. 64, n. 3b, p. 727-730, oct. 2006. Disponível em: <https://doi.org/10.1590/S0004-282X2006000500005>. Acesso em: 01 de dez. de 2020.

26) SOUZA, Luciana Moreira de, et al . Perfil epidemiológico e funcional de pacientes com diagnóstico de esclerose múltipla em Manaus, Amazonas. Revista Acta Fisiátrica, v. 25, n. 4, p. 174-8, Dez. 2018. Disponível em: < https://doi.org/10.11606/issn.2317-0190.v25i4a163863>. Acesso em: 01 de dez. de 2020.

27) POSER, Charles Marcel, BRINAR, Vesna. The Accuracy of Prevalence Rates of Multiple Sclerosis: A Critical Review. Neuroepidemiology, v. 29, n. 3(4), p 150-5, Nov. 2007. Disponível em: < https://doi.org/10.1159/000111576>. Acesso em: 02 de dez. de 2020.

28) LANA-PEIXOTO, Marco, et al . The prevalence of multiple sclerosis in Belo Horizonte, Brazil. Arquivos de Neuro-Psiquiatria., São Paulo, v. 70, n. 2, p. 102-7, Feb. 2012. Disponível em: < https://doi.org/10.1590/S0004-282X2006000500005>. Acesso em 01 de dez. de 2020. 


\title{
CAPITULO XXII
}

\section{ASPECTOS EPIDEMIOLÓGICOS DOS ACIDENIES OFÍDICOS NO MUNICÍPIO DE PORTO VELHO}

\author{
João Gabriel Muniz Kisner ${ }^{1}$ \\ Gabriela Andriolo Dickow ${ }^{2}$ \\ João Pedro Becker de Melo e Silva ${ }^{3}$ \\ Maria Eduarda Rigotti ${ }^{4}$ \\ Rodrigo René Bucar Durlacher ${ }^{5}$ \\ Saymon Albuquerque 6 \\ Arlindo Gonzaga Branco Junior ${ }^{7}$ \\ Rivani Silva Neves ${ }^{8}$
}

\footnotetext{
${ }^{1}$ Discente de Medicina do Centro Universitário São Lucas

${ }^{2}$ Discente de Medicina do Centro Universitário São Lucas

${ }^{3}$ Discente de Medicina do Centro Universitário São Lucas

${ }^{4}$ Discente de Medicina do Centro Universitário São Lucas

${ }^{5}$ Discente de Medicina do Centro Universitário São Lucas

${ }^{6}$ Doutor em Biodiversidade e Biotecnologia. Professor do Centro Universitário São Lucas

${ }^{7}$ Mestre em Saúde da Família. Professor da Universidade Federal de Rondônia. Professor do Centro Universitário São Lucas

${ }^{8}$ Residente de Medicina de Família e Comunidade. Universidade Federal de Rondônia
}

\section{RESUMO}

O presente trabalho apresenta um estudo descritivo dos acidentes ofídicos ocorridos no município de Porto Velho (RO) no período entre 2015 e 2019, tendo como base os dados do banco de dados da plataforma online disponível no SINAN (Sistema de Informações de Agravos de Notificação) do Ministério da Saúde. O perfil epidemiológico mais recorrente das vítimas envolve o sexo masculino $(80,3 \%)$ na faixa etária de 20 a 39 anos $(38,64 \%)$ e que se declararam pardos (73\%). Com relação ao atendimento pelo SUS, a maioria das vítimas (25\%) recebeu atendimento no período de 1 a 3 horas após o acidente. No que se refere à evolução, 94,5\% dos casos evoluíram com cura. As serpentes do gênero Bothrops foram as responsáveis pelo maior número de acidentes (80\%). Em todo o período analisado, o ano de 2018 concentrou a maioria de casos em um ano: 218 (24,5\% do total de casos).

Palavras-chave: Acidentes Ofídicos; Cobras; Epidemiologia; Porto Velho 


\section{INTRODUÇÃO}

Os acidentes ocasionados por ofídicos peçonhentos representam significativo problema de saúde pública, especialmente no Brasil, pela constância com que ocorrem e pelo alto índice de mortalidade (PINHO, 2001).

O Brasil possui diversas famílias de serpentes, entretanto, somente duas são consideradas peçonhentas: a família Viperidae, que a subfamília Crotalinae se destaca por possui os gêneros Crotalus, Bothrops e Lachesis; e a família Elapidae, que possui o gênero Micrurus (MELGAREJO 2003). Em Porto Velho, devido ao tipo de vegetação, não há serpentes do gênero Crotalus, enquanto os acidentes com serpentes do gênero Bothrops são os mais comuns (BRASIL, 2019)

Segundo notificações do Ministério da Saúde, a incidência de acidentes no Brasil tem sido, em média, de 500.901 mil casos nos períodos de 2000 a 2018, com letalidade de 0,4\% (BRASIL, 2018). Contudo, sabe-se que o número de incidência pode ser ainda maior, devido a existência de subnotificações (RIBEIRO, 1997). Entre as regiões brasileiras, a região Norte é a que mais registra casos de acidentes, seguida do Sudeste, Nordeste, Centro-Oeste e, por fim a região Sul (MINISTÉRIO DA SAÚDE, 2019).

Devido ao desmatamento nos últimos anos e em consequência do avanço da agricultura, o número de casos de acidentes por cobras aumentou. Assim, a faixa etária acometida varia entre 15 a 49 anos, representando o grupo etário em que se concentra grande parte da força de trabalho, sendo prevalente em mais de $50 \%$ dos casos ocorridos. Além disso, em torno de $70 \%$ do número de casos ocorrem com pessoas do sexo masculino, $20 \%$ com o sexo feminino e $10 \%$ não foram foi informado o sexo (BRASIL, 2001). O perfil desses acidentes no Brasil se mantém quase que inalterado ao longo dos anos, ocorrendo com maior frequência no início e no final do ano e principalmente em trabalhadores da área rural (BOCHNER \& STRUCHINER, 2003).

No Estado do Rondônia, a soma da vegetação e do clima são extremamente favoráveis à existência de uma fauna diversificada, onde as serpentes se encaixam. 0 clima e vegetação aliadas à uma urbanização desenfreada e não planejada em locais impróprios para à habitação humana aumentam a exposição da população animais ofídicos e, consequentemente, aos acidentes (MORENO et al., 2005). 
Os gêneros Bothrops e Bothrocophias são as serpentes responsáveis pelos acidentes botrópicos. Entre suas espécies, as mais conhecidas popularmente são as jararacas. Serpentes do gênero Bothrops estão em todo território brasileiro, já as do gênero Bothrocophias, apenas na Amazônia. Devido a sua distribuição por todo o território, este tipo de acidente é o maior entre os gêneros de serpentes ofídicas, representando por volta de 90,5\% dos acidentes no Brasil (RIBEIRO \& JORGE, 1997; ARAÚJO et al., 2003; FRANÇA \& MÁLAQUE, 2003).

Acidentes crotálicos são, na maioria das vezes, causados por cascavéis, que é a principal integrante do gênero Crotallus. Este gênero encontra-se, principalmente, no cerrado do Brasil e nas regiões áridas e semiáridas do Nordeste. No Estado de Rondônia, a cascavel está presente apenas nas proximidades de Vilhena, devido às manchas de campos e cerrado (MELGAREJO, 2003).

As serpentes Lachesis muta, popularmente conhecida como surucucu-pico-dejaca, são as causadoras dos acidentes laquéticos. Distribuída pela Amazônia e a Mata Atlântica, pode ser avistada em regiões entre o Rio de Janeiro e a Paraíba (MELGAREJO 2003). Este tipo de acidente é corresponde a cerda de 1,4\% dos acidentes (ARAÚJO et al., 2003; MÁLAQUE \& FRANÇA 2003).

Serpentes do gênero Micrurus causam acidentes elapídicos. Apenas as Leptomicrurus estão presentes na Amazônia. Acidentes causados por esta serpentes correspondem a menos que $1 \%$ dos acidentes ofídicos do país (MELGAREJO, 2003). A atividade neurotóxica de seu veneno acarreta dor local, ptose palpebral, sialorreia, dispneia, parestesia, diplopia e dificuldade na deglutição e mastigação (SILVA JR \& BUCARETCHI, 2003).

Em Rondônia, no município de Porto Velho, foram obtidos os dados numéricos de incidentes por serpentes, separadas por gênero e ano. Entre os anos de 2015 até 2019 foram registrados 709 casos envolvendo o gênero Bothrops, indicando a maior incidência de acidentes por este tipo de serpente. Envolvendo o gênero Lachesis, entre os anos pesquisados, houve apenas 17 casos. Já em relação ao gênero Micrurus, foram obtidos apenas 12 casos. E por fim, com o gênero Crotalus, registraram-se 7 casos. Entretanto, houve 532 casos de cobras não identificadas, prejudicando os dados, e consequentemente a identificação da espécie e, por fim, o tratamento de acordo com o veneno (BRASIL, 2020). 
Os acidentes ofídicos envolvem uma série de riscos e possíveis agravos à saúde dos indivíduos afetados. Isso se deve à ação que o veneno provoca no organismo humano, envolvendo mecanismos de inflamação e coagulação. Grande parte dos venenos botrópicos causa a ativação, de forma isolada ou conjunta, do fator $\mathrm{X}$ e da protrombina; além de possuírem ação similar à trombina, convertendo, assim, o fibrinogênio em fibrina. Essas ações produzem distúrbios da coagulação, consumindo seus fatores e gerando produtos de degradação de fibrina em fibrinogênio, e possibilitam a ocorrência de incoagulabilidade sanguínea, semelhante ao que acontece em um quadro de coagulação intravascular disseminada (CIVD). Pode haver, ainda, alteração da função plaquetária, bem como plaquetopenia. Paradoxalmente, é possível a ocorrência de hemorragias pelo mecanismo das hemorragias, as quais lesionam a membrana basal dos capilares. O sangramento é agravado pela associação com os distúrbios de coagulação e plaquetopenia (RIBEIRO, L. A. \& JORGE, M. T. 1997).

De uma forma geral, as manifestações no local do ataque se caracterizam pela dor e por edema endurado de intensidade variável e, geralmente, de formação precoce e progressiva. São comuns equimoses e hemorragias no local da picada. Durante a evolução do ferimento, pode haver o surgimento de bolhas na região, além do enfartamento ganglionar com risco de necrose. Algumas manifestações sistêmicas qualificam o caso como grave, independentemente do quadro local. São elas: choque, oligoanúria, hipotensão arterial ou hemorragias internas. As manifestações hemorrágicas são passíveis de ocorrer em regiões distantes do local da picada, como por exemplo nas fossas nasais e na gengiva. Dependendo do quadro, há ainda a possibilidade de hematúria e hematêmese. Em gestantes, há risco de hemorragia uterina (RIBEIRO, L.A \& JORGE, M.T. 1990).

\section{METODOLOGIA}

Trata-se de um estudo descritivo, quantitativo, utilizando banco de dados online do Ministério da Saúde.

O intuito do estudo é de analisar o perfil epidemiológico dos acidentes ofídicos nos últimos 5 anos na capital do estado de Rondônia. 
Dessa forma, elaborou-se um banco de dados a partir do uso da plataforma online disponível no SINAN (Sistema de Informações de Agravos de Notificação) do Ministério da Saúde através da interface "Tabnet" do DATASUS, acessado em 2020.

O estudo foi pautado nas notificações de acidentes ocasionados por serpente, no período de 2015 a 2019, no município de Porto Velho. As variáveis epidemiológicas utilizadas foram: número de notificações no período proposto, sexo, etnia, faixa etária, evolução do caso, tempo de picada e de atendimento e a espécie envolvida no acidente.

Para a representação gráfica e análise dos dados foram utilizados os programas Microsoft Excel 2016 e o Microsoft Word 2016.

\section{RESULTADOS}

O estudo foi delimitado segundo os casos notificados de 2015 até 2019. Dentre estes anos de notificação, o ano de maior episódio foi no ano de 2018 (218 notificações), totalizando $24,5 \%$ dos acidentes. O segundo ano com maior número de casos foi o ano de 2019, com 168 casos e porcentagem de, aproximadamente, 19\%. Nos anos de 2015 até 2017 , foram notificados, respectivamente, 148, 184 e 167 casos.

Tabela 1: Notificações segundo ano de acidente

\begin{tabular}{|c|c|}
\hline Ano acidente & Notificações \\
\hline 2015 & 148 \\
\hline 2016 & 184 \\
\hline 2017 & 167 \\
\hline 2018 & 218 \\
\hline 2019 & 168 \\
\hline Total & 885 \\
\hline
\end{tabular}

Fonte: Ministério da Saúde/SVS - Sistema de Informação de Agravos de Notificação - Sinan Net

$\mathrm{Na}$ tabela 2, estão indicados os intervalos de tempo entre os acidentes com serpentes até o momento do atendimento pelo SUS durante os anos de 2015 a 2019. Do total de casos, $25 \%$ foram atendidos entre 1 a 3 horas, $24 \%$ foram atendidos entre 3 a 6 horas e $20 \%$ foram atendidos entre 6 a 12 horas. 
Tabela 2: Notificações segundo o tempo de picada e atendimento

\begin{tabular}{|c|c|c|c|c|c|c|}
\hline Tempo picada/atend & 2015 & 2016 & 2017 & 2018 & 2019 & Total \\
\hline Ign/Branco & 6 & 5 & 6 & 10 & 7 & 34 \\
\hline 0 a 1 horas & 24 & 28 & 21 & 29 & 19 & 121 \\
\hline 1 a 3 horas & 43 & 49 & 34 & 51 & 47 & 224 \\
\hline 3 a 6 horas & 34 & 43 & 43 & 44 & 49 & 213 \\
\hline 6 a 12 horas & 28 & 38 & 37 & 61 & 20 & 184 \\
\hline 12 a 24 horas & 8 & 13 & 17 & 8 & 14 & 60 \\
\hline 24 e + horas & 5 & 8 & 9 & 15 & 12 & 49 \\
\hline Total & 148 & 184 & 167 & 218 & 168 & 885 \\
\hline
\end{tabular}

Fonte: Ministério da Saúde/SVS - Sistema de Informação de Agravos de Notificação - Sinan Net

Ao que refere à evolução do caso, 94,5\% dos casos relatados no período de 20152019 evoluíram com cura e menos de 1\% evoluíram para o óbito. Observa-se 45 de casos não especificados, o que representa $5 \%$ do número total, número consideravelmente alto (Tabela 3).

Tabela 3: Notificações segundo a evolução do caso

\begin{tabular}{|c|c|c|c|c|c|c|}
\hline Evolução caso & $\mathbf{2 0 1 5}$ & $\mathbf{2 0 1 6}$ & $\mathbf{2 0 1 7}$ & $\mathbf{2 0 1 8}$ & $\mathbf{2 0 1 9}$ & Total \\
\hline Ign/Branco & 3 & 17 & 11 & 6 & 8 & 45 \\
\hline Cura & 145 & 166 & 156 & 211 & 160 & 838 \\
\hline Óbito pelo agravo notificado & - & 1 & - & 1 & - & 2 \\
\hline Total & 148 & 184 & 167 & 218 & 168 & 885 \\
\hline
\end{tabular}

Fonte: Ministério da Saúde/SVS - Sistema de Informação de Agravos de Notificação - Sinan Net

Do total de acidentes ocorridos no período de $2015-2019$, a maioria (80\%) foi causada por serpentes do gênero Brothops, totalizando 709 casos. Os acidentes com os gêneros Lachesis, Micrurus e Crotalus totalizaram 17, 12 e 7 casos, respectivamente. Ainda houve 100 acidentes sem a informação da espécie ou causados por espécies desconhecidas, além de 40 acidentes com serpentes não peçonhentas. 
Tabela 4: Notificações de acidentes segundo o tipo de serpente

\begin{tabular}{|l|l|l|l|l|l|l|l|}
\hline Ano acidente & Ign/Branco & Bothrops & Crotalus & Micrurus & Lachesis & Não Peçonhenta & Total \\
\hline 2015 & 25 & 105 & - & 2 & 2 & 14 & 148 \\
\hline 2016 & 20 & 151 & 3 & 3 & 1 & 6 & 184 \\
\hline 2017 & 15 & 137 & 2 & 4 & 3 & 6 & 167 \\
\hline 2018 & 15 & 190 & - & 1 & 5 & 7 & 218 \\
\hline 2019 & 25 & 126 & 2 & 2 & 6 & 7 & 168 \\
\hline Total & 100 & 709 & 7 & 12 & 17 & 40 & 885 \\
\hline
\end{tabular}

Fonte: Ministério da Saúde/SVS - Sistema de Informação de Agravos de Notificação - Sinan Net

Ao que tange a faixa etária mais acometida, 38,64\% representam a faixa de 20 39 anos, $31,07 \%$ a de $40-59$ anos, 7,34\% a de $15-19$ anos, 6,89\% a de $10-14$ anos, 5,87\% a de $60-64$ anos, 3,16\% a de 5-9 anos, 2,59\% a de 70-79 anos, 2,37\% a de $65-69$ anos, 0,9\% a de 1-4 anos e, com a menor porcentagem, a faixa etária menor que 1 ano, representada por $0,56 \%$.

Quanto ao sexo das vítimas, $80,3 \%$ dos acidentes aconteceram com o sexo masculino, enquanto $19,7 \%$ dos casos aconteceram com o sexo feminino. Ao que refere a raça, $73 \%$ das vítimas se declaram pardas, $10,05 \%$ se consideram brancas, $3,84 \%$ se consideram pretas, 1,58\% indígenas e 10,28\% não fizeram declarações a respeito de sua raça.

Ao analisar o grau de instrução das pessoas que tiveram casos notificados durante o período estabelecido, os números que sobressaíram foram referentes a ensino fundamental incompleto $(33,5 \%)$ e os ignorados/brancos que representaram $44,85 \%$.

\section{DISCUSSÃO}

Durante o período de 2015 a 2019 foram analisados, no município de Porto Velho, um número total de 885 casos de acidentes ofídicos notificados. dos quais $80 \%$ foram causados por serpentes do gênero Bothrops. No que se diz respeito ao principal gênero das serpentes envolvidas, os dados obtidos pelo estudo estão de acordo com os dados dos estudos nacionais e do Manual de Diagnóstico e Tratamento de Acidentes por Animais Peçonhentos (2001), e é possível evidenciar que o principal gênero envolvido nos acidentes é o gênero Bothrops, dando um destaque especial à principal serpente 
representante dele, a B. jararaca, espécie do gênero mais abundante na região norte. Essa predominância é explicada pela capacidade das cobras desse gênero de se adaptarem a diferentes climas e vegetações (CAMPBELL, 1989), incluindo a região de floresta tropical da Amazônia, muito presente na maioria do Estado de Rondônia. As espécies do gênero Lachesis e Micrurus vieram em segundo e terceiro lugar, respectivamente, no número de acidentes. No entanto, diferentemente dos dados dos estudos utilizados, o município de Porto Velho apresentou uma incidência de acidentes com o gênero Crotallus inferior a $1 \%$ devido à presença quase nula de espécies desse gênero no município.

O tempo transcorrido entre o acidente e a busca por atendimento médico é um fator primordial para a evolução do caso, ou seja, quanto menor for este tempo, maior a chance de cura. No que se refere ao tempo até a busca de atendimento, a maior parte do grupo analisado (49\%) demorou, em média, menos de 6 horas, com cerca de 94,5\% de todos os casos analisados evoluindo para o melhor desfecho, a cura. É passível de crer que os acidentes ofídicos na Região Amazônica possuem um maior intervalo de tempo antes do atendimento inicial quando comparado a outras regiões. No estudo realizado no Norte de Minas Gerais (LIMA et al., 2009), a quantidade de atendimentos dentro das primeiras 3 horas correspondeu a cerca de $66 \%$ do número total de casos. Isso se deve a maior precariedade de redes de atendimento do serviço público na Região Norte, presentes em menor quantidade como consequência da menor taxa de urbanização nessa porção do território nacional. Desse modo, as distâncias das áreas rurais até o serviço de saúde se tornam maiores em comparação com as cidades do Sul/Sudeste do Brasil.

O principal desfecho dos casos de acidentes ofídicos foi a cura, com um número menor do que $1 \%$ deles evoluindo para a morte. Os dados apresentados por estudos nacionais de outras localidades também evidenciaram que a evolução para a morte foi o desfecho menos comum, apresentando, também, porcentagens inferiores a $1 \%$. Os números de óbitos apresentados pelo Manual de Diagnóstico e Tratamento de Acidentes por Animais Peçonhentos (2001) mostraram que dentre os óbitos, o maior número foi observado em indivíduos que foram atendidos após 6 horas da ocorrência do acidente. No entanto, os números de óbitos para os indivíduos atendidos em até 6 
horas após o acidente também foram elevados, demonstrando a extrema importância da busca rápida pelo atendimento médico.

O grupo mais acometido se estabelece como sexo masculino na faixa etária de 20 a 39 anos. Isso se deve, possivelmente, ao exercício de atividades agropecuárias nas áreas rurais por parte desse grupo. As atividades dessa natureza propiciam os ataques de serpentes por manterem os trabalhadores perto de regiões de floresta de terra firme, onde há maior ocorrência de serpentes do gênero Bothrops (TURCl et al., 2009). Outro estudo realizado em Rio Branco, Acre, também demonstrou uma maior prevalência dos ataques em trabalhadores rurais do sexo masculino (MORENO et al., 2003), corroborando com a hipótese. O mesmo estudo constatou maior prevalência de acidentes com serpentes em uma faixa etária semelhante (10 a 29 anos). A explicação para isso se deve ao fato de que os acidentes ofídicos vitimizam a população mais economicamente ativa, ou seja, a faixa etária na qual concentra a maior parte dos trabalhadores com idade e força de trabalho para contribuir melhor com atividades laborais relacionadas ao campo.

\section{CONCLUSÃO}

Ao analisar os dados expostos acima, constata-se a necessidade de intervenção por parte das ações em Saúde Pública para diminuir a incidência desses acidentes. Apesar dos dados não variarem muito no tempo de atendimento, ainda sim houve grande ocorrência de acidentes em pessoas do sexo masculino e com etnia parda. Devese trazer ao conhecimento por parte de toda a população, principalmente a deste contexto, informando sobre o tipo de cobra mais acometido, o que fazer se por acaso for picado, em uma linguagem simples e clara, indo de encontro com outro achado de que a maioria das pessoas acidentadas não possui ensino fundamental completo. Também propõe-se começar a realizar a instrução do melhor preenchimento das fichas de notificações.

\section{REFERÊNCIAS}

Araujo F. A. A.; Santa Lucia M.; Cabral, R. F.; Epidemiologia dos acidentes por animais peçonhentos. Acesso em 20 Out 2020. 
Bochner, E.; Struchiner, C. J.; Epidemiologia dos acidentes ofídicos nos últimos 100 anos no Brasil: uma revisão. Cadernos de Saúde Pública. 2003.

Brasil. Ministério da Saúde. Manual de diagnóstico e tratamento de acidentes por animais peçonhentos. Brasília: Fundação Nacional de Saúde, 2001.

Brasil, Ministério da Saúde. Banco de dados do Sistema Único de Saúde-DATASUS. Disponível em http://www.datasus.gov.br [Acessado em 20 de outubro de 2020]

Campbell JA, Lamar WW. The venomous reptiles of Latin America. Cornell University, New York, 1989.

Cardoso, J. L. C.; França, F. O. S.; Wen, F. H.; Málaque, C. M. S.; Haddad Jr.; Animais peçonhentos no Brasil: biologia, clínica e terapêutica dos acidentes. São Paulo, Sarvier; FAPESP, 2003. $468 \mathrm{p}$.

Cardoso, J. L. C.; Siqueira França, F. O.; Wen, F. H.; Sant'ana Malaque, C. M.; Haddad, V. J.; Animais peçonhentos no Brasil: biologia, clínica e terapêutica dos acidentes. Editora Sarvier, São Paulo, p. 6-9, 2003.

Lima, J. S.; Júnior, H. M.; Martelli, D. R. B.; Silva, M. S.; Carvalho, S. F.G.; Canela, J. R.; Bonan, R. F.; Perfil dos acidentes ofídicos no norte de estado de Minas Gerais, Brasil. Disponível:< https://www.scielo.br/scielo.php?pid=S003786822009000500015\&script=sci_arttext>. Acesso em: 02 Dez 2020.

Melgarejo, AR. Serpentes Peçonhentas do Brasil. In: Cardoso, LC et al. Animais Peçonhentos no Brasil: biologia, clínica e terapêutica dos acidentes. São Paulo: Savier; 2003, p. 33-61.

Moreno, E.; Albuquerque, M. J.; Pires-de-Campos, V. A. F., Katz, G.; Takaoka, N. Y.; Características clínico epidemiológicas dos acidentes ofídicos em Rio Branco, Acre. Revista da Sociedade Brasileira de Medicina Tropical.

Moreno, E.; Andrade, M. Q.; Silva, R. M. L.; Neto, J. T.; Características clínico epidemiológicas dos acidentes ofídicos em Rio Branco, Acre. Disponível em: < https://www.scielo.br/scielo.php?pid=S0037->. Acesso em: 02 Dez 2020.

Pinho, F. M. O.; Pereira, I. D.; Ofidismo. Revista Associação Médica Brasileira, 2001.

Resende, C. C.; Araújo, F. A. A.; Salle-Nave, R. N. U. R., 1989. Análise Epidemiológica dos Acidentes Ofídicos. Brasília, DF: Ministério da Saúde.

Ribeiro, L. A.; Albuquerque, M. J.; Campos, V. A. P.; Óbitos por serpentes peçonhentas no Estado de São Paulo: Avaliação de 43 casos. 1988/93. Revista Associação Médica Brasileira, 1997. 
RIBEIRO, L.A. \& JORGE, M.T. Fatores prognósticos em acidentes por serpentes do gęnero Bothrops In: CONGRESSO DA SOCIEDADE BRASILEIRA DE MEDICINA TROPICAL, 21, Săo Paulo. 1985. Resumos. p. 28.

Ribeiro, L. A.; Jorge, M.T.; Iverson, L. B.; Epidemiologia dos acidentes por serpentes peçonhentas: estudos de casos atendidos em 1988. Revista de Saúde Pública, 1997.

Turci, L. C. B.; Albuquerque, S.; Bernarde, P. S.; Miranda, D. B.; Uso do hábitat, atividade e comportamento de Bothriopsis bilineatus e de Bothps atrox (Serpentes Viperidae) na floresta do Rio Moa, Acre, Brasil. Disponível em: < https://www.scielo.br/scielo.php?pid=S1676-

06032009000300020\&script=sci_arttext\&tlng=pt>. Acesso em: 02 Dez 2020.

França, F.O.S.; Málaque, C.M.S. 2003. Botropic accident, p. 72-86. In: Cardoso, J.L.C.; França O.S.F.; Wen, F.H.; Málaque, C.M.S.; Haddad Jr, V. (Orgs). Venomous animals in Brazil: biology, clinical and therapeutic of accidents. Sarvier, São Paulo (in Portuguese).

Araújo, FAA, Santalúcia, M, Cabral, RF. In: Cardoso JLC, França, FOdes, Wen, FH, Málaque, CMS, Haddad Jr V. Animais Peçonhentos no Brasil. Biologia, Clínica e Terapêutica dos Acidentes. São Paulo: Sarvier, p. 6-12, 2003

Jorge da Silva Jr N, Bucaretchi F. Mecanismo de Ação do Veneno Elapídico e Aspectos Clínicos dos Acidentes. In: Cardoso JLC, França FOS, Wen FH, Málaque CMS, Haddad Jr V. Animais Peçonhentos no Brasil. Biologia, Clínica e Terapêutica dos Acidentes. 1ạ edição, Sarvier: São Paulo, p. 99-107, 2003. 


\title{
CAPITULO XXIII
}

\section{AMÁLISE FITOQUÍMICA E DO PERFIL DE ÁCIDOS GRAXOS DO ENDOSPERMA DE COCOS NUCIFERA L USADO NA OBTENCẼ̃O DE ÓLEO: UMA REVISÃO NARRATIVA DA LTERATURA}

\section{DOI: 10.51859/amplla.csa528.2121-23}

\author{
Samara Crislâny Araújo de Sousa ${ }^{1}$ \\ Clara Martins Maia ${ }^{1}$ \\ Layla Beatriz Barroso de Alencar ${ }^{1}$ \\ Ismael Lima Silva ${ }^{1}$ \\ Luciano de Brito Júnior ${ }^{1}$ \\ Abrahão Alves de Oliveira Filho ${ }^{2}$
}

${ }^{1}$ Graduando (a) do curso de Odontologia. Universidade Federal De Campina Grande - UFCG

2 Professor da Unidade Acadêmica de Ciências Biológicas (UACB). Universidade Federal de Campina Grande - UFCG

\section{RESUMO}

Introdução: o coqueiro é uma árvore frutífera monocotiledônea, cujo fruto é composto por três camadas: exocarpo, mesocarpo e endocarpo. Este último é preenchido por um caroço constituído por dois endospermas, um sólido e outro líquido. Do endosperma sólido é extraído o óleo de coco que tem ganhado popularidade devido à alta estabilidade e várias vantagens para a saúde. Objetivo: revisar a constituição fitoquímica e o perfil de ácidos graxos do endosperma do Cocus Nucifera L. Materiais e métodos: foi realizada uma busca nos bancos de dados on-line PubMed, SciELO, Lilacs, ScienceDirect e Google Acadêmico, utilizando descritores e sinônimos MeSH e DeCS organizados em lógica booleana e seguindo três campos semânticos: "Coconut oil" em associação com "Constitution" e "Phytochemicals". Foram incluídos artigos publicados nos últimos 20 anos; revisões sistemáticas da literatura e pesquisas laboratoriais que abordassem os constituintes fitoquímicos e os ácidos graxos presentes no Cocos Nucifera L. Artigos publicados fora do intervalo do tempo definido e que não se encaixassem nos critérios estabelecidos foram excluídos. Resultados: Dos estudos encontrados, foi evidenciado a presença de ácidos graxos e fitoconstituintes importantes no endosperma do fruto, destacando -se o seu potencial como agente terapêutico, oferecendo assim, benefícios à população. Conclusão: embora as pesquisas destaquem a presença e importância dos metabólitos secundários e dos ácidos graxos no endosperma do coco, a realização de mais estudos laboratoriais acerca do tema são necessários a fim de melhor elucidar as amplas finalidades do óleo extraído dessa planta.

Palavras-chave: Óleo de coco. Constituição. Compostos fitoquímicos. 


\section{INTRODUÇÃO}

O coqueiro (Cocus Nucifera L.) é uma árvore frutífera monocotiledônea pertencente à família dos Arecaceae (Palmae), cujo cultivo caracteriza-se por seus diversos valores nutricionais e medicinais (DEBMANDAL E MANDAL, 2011). A planta é originária do sudeste da Ásia e das ilhas entre os oceanos Índico e Pacífico. Dessas regiões, acredita-se que foi levada para a Índia, considerada a maior produtora mundial da espécie (LIMA et al., 2015; GHOSH et al., 2014). No Brasil, essa árvore foi qualificada em 1553, no Estado da Bahia, e disseminou-se para o litoral nordestino onde encontrou clima favorável para o seu cultivo. Posteriormente, adaptou-se em outras regiões do país (PINHO E SOUZA, 2018).

Com efeito, o coco, fruto dessa planta perene cultivada em áreas de alta umidade, precipitação regular e solo arenoso, é composto por três camadas: uma externa (exocarpo), uma intermediária (mesocarpo) e outra mais interna (endocarpo), cujo o interior é preenchido por um caroço constituído por um endosperma líquido, popularmente conhecido por água de coco, e um sólido, chamado Kernel ou copra, de onde é extraído o óleo (FERREIRA et al., 2019; GHOSH et al., 2014; PATIL E BENJAKUL, 2018). Hodiernamente, as extrações artesanal, mecânica e por solvente são os principais métodos de obtenção dessa substância (PINHO E SOUZA, 2018).

Nessa perspectiva, no método de extração artesanal, a polpa do fruto é submetida ao cozimento intensivo. Após a fervura, o óleo sobrenadante é separado da parte aquosa, e, por conseguinte, seco e filtrado. A extração mecânica, por sua vez, pode ser realizada pela técnica de prensagem, de modo que o produto obtido mantenha suas propriedades naturais. Para aumentar o rendimento, esse método pode ser combinado à extração por solvente que consiste em colocar a matriz vegetal em contato direto com um solvente orgânico. Após a transferência dos constituintes solúveis da planta, realizase a separação das fases líquida e sólida. Na fase líquida, após a evaporação do solvente, obtém-se o óleo de coco (STEFFANI et al., 2003; PINHO E SOUZA, 2018).

Essa substância tem ganhado popularidade rapidamente devido à alta estabilidade e várias vantagens para a saúde, além de ser amplamente utilizada no prétratamento de fibras na indústria têxtil, na fabricação de sabonetes, detergentes, tintas e vernizes industrias, bem como surfactantes na indústria do petróleo, embora sejam 
necessários mais estudos que comprovem suas finalidades (KUMAR, 2011; PATIL E BENJAKUL, 2018; ZHENG et al., 2019). Dessa forma, tendo em vista a ampla utilização do óleo de coco, o objetivo da presente pesquisa foi revisar a constituição fitoquímica e o perfil de ácidos graxos do endosperma do Cocus Nucifera L. com o intuito de melhor orientar futuros estudos clínicos, usando esta planta de acordo com a finalidade de cada constituinte.

\section{METODOLOGIA}

O presente estudo trata-se de uma revisão narrativa da literatura realizada por meio de busca em artigos científicos acerca da constituição fitoquímica e o perfil de ácidos graxos do endosperma de Cocos Nucifera L., a fim de reunir em um único trabalho informações sobre a temática abordada, tendo em vista que esse tipo de estudo é apropriado para descrever o "estado da arte" de um determinado assunto sob o ponto de vista teórico ou contextual (ROTHER, 2007). A pesquisa foi feita com dados bibliográficos de 2001 a 2021 publicados nos bancos de dados on-line National Libary of Medicine (PubMed), Scientific Electronic Library Online (SciELO), Literatura LatinoAmericana e do Caribe em Ciências da Saúde (Lilacs), ScienceDirect e Google Acadêmico. Para isso, foram utilizados descritores e sinônimos MeSH e DeCS organizados em lógica booleana seguindo três campos semânticos: "Coconut oil" em associação com "Constitution" e "Phytochemicals".

Para seleção dos artigos não foi imposta limitação de idioma, além disso outros critérios de inclusão foram: (1) revisões sistemáticas da literatura; pesquisas laboratoriais (2) estudos que abordem os constituintes fitoquímicos e os ácidos graxos presentes no endosperma do Cocus Nucifera L. Foram excluídos da pesquisa: (1) artigos científicos publicados fora do intervalo de tempo estabelecido; e (2) estudos que não se encaixassem ao objetivo proposto.

Inicialmente, a partir da leitura do título e resumo, foram escolhidos os manuscritos potencialmente elegíveis. Os estudos que se adequavam a temática proposta, foram selecionados para uma leitura completa e posteriormente armazenados no programa de gerenciamento de referência Mendeley Desktop (versão 1.19.5). 
Os artigos completos foram lidos na íntegra por um único pesquisador, e considerando os critérios propostos, foram coletadas algumas informações que posteriormente foram analisadas e categorizadas de forma descritiva/narrativa nesse estudo.

\section{REVISÃO BIBLIOGRÁFICA}

A utilização de óleos vegetais ocorre desde os tempos mais remotos e tem crescido na população hodierna, tornando fundamental o conhecimento acerca das plantas de onde são extraídos. Nesse contexto, uma vez que a utilização de uma espécie vegetal varia de acordo com a porção avaliada, anterior a extração do óleo, é de crucial importância conhecer os compostos contidos nela, e, por conseguinte, a aplicabilidade do óleo obtido (PINHO E SOUZA, 2018).

Nessa perspectiva, cada parte da árvore apresenta diferentes constituintes com finalidades distintas, dentre os quais pode-se encontrar os fitoquímicos, substâncias que fornecem benefícios a saúde, e por isso, são alvos de estudos no que tange, principalmente, à utilização como agentes terapêuticos. Alcaloides, flavonóides, saponinas, glicosídeos e taninos, são alguns dos fitoconstituintes com potenciais significativos para a saúde humana (ODENIGBO E OTISI, 2011).

No que diz respeito aos alcalóides, tal composto é definido por atuar no sistema nervoso central, promovendo efeitos sedativo, calmante, estimulante, analgésico e anestésico (GARLET, 2021). Os flavanóides, por sua vez, apresentam algumas ações sobre os sistemas biológicos, dentre eles, atividades antioxidativa, anti-inflamatória, antimicrobiana e antiviral (LOPES et al., 2010). Já as saponinas, são heterosídeos que desempenham importante papel na defesa contra insetos e microrganismos (FERNANDES et al., 2019). Em relação aos taninos, os mesmos constituem-se como metabólitos secundários complexos, com propriedades de adstringência e função hemostática, servindo como antídoto em casos de intoxicações (MONTEIRO; ALBUQUERQUE; ARAÚJO, 2005). Tais compostos são encontrados em algumas espécies vegetais e seus derivados, utilizados comumente pela sociedade.

Nesse contexto, o óleo de coco, extraído da parte mais interna do fruto do Cocus Nucifera L., tem sido utilizado desde muito tempo pela população como parte 
importante na dieta e principalmente para fins medicinais, devido apresentar ação farmacológica importante e com baixa toxicidade (LIMA et al., 2015). Dessa forma, uma vez que essa substância é extraída do endosperma do fruto, é necessário verificar o seu perfil fitoquímico para melhor entender as suas finalidades.

Nessa perspectiva, Odenigbo e Otisi (2011), visando detectar a presença de metabólitos secundários no endosperma do coco, realizaram uma análise fitoquímica com o extrato dessa planta, obtido por meio de métodos de extração com solvente polar (água) e não polar (n-hexano). Em ambas as análises, verificou-se a presença de alcaloides, terpenoides, glicosídeos e resinas. Em contrapartida, taninos e saponinas foram encontrados apenas no extrato aquoso, tornando evidente que resultados distintos podem ser obtidos a depender da forma como essa substância é extraída. Além disso, esteroides não estiveram presentes nas amostras analisadas, diferindo dos achados de Obidoa, Joshua, Eze (2009) onde observou esse fitoquímico na porção interna do fruto, embora em menor concentração frente aos demais.

No que se refere a composição de ácidos graxos, os corpos oleosos do endosperma de Cocus Nucifera L. contendo triacilglicerois (TAGs) apresentam aproximadamente $92 \%$ de ácidos graxos saturados de cadeia curta e média, os quais pode-se destacar os ácidos capróico, caprílico, cáprico, palmítico, esteárico, araquídico, láurico e mirístico, sendo os dois últimos os mais prevalentes (ZHENG et al., 2019; DAVE; YE; SINGH, 2019). Nesse contexto, aproximadamente $50 \%$ do teor de gordura do coco é composto pelo ácido láurico, substância também presente no leite materno atuando na proteção do bebê contra patógenos prejudiciais (ZHENG et al., 2019; OBIDOA; JOSHUA; EZE, 2009; DEBMANDAL E MANDAL, 2011). Além disso, $8 \%$ do conteúdo de ácidos presentes são insaturados, com destaque para os ácidos oleico, palmitoléico e linolênico (KUMAR, 2011; ZHENG et al., 2019).

Tendo em vista o exposto, verifica-se que a porção mais interna do fruto do coqueiro apresenta constituintes importantes que podem ser utilizados em diferentes setores industriais e, ainda, como agentes terapêuticos, oferecendo a sociedade alternativa viável para a sua extração e consumo. No entanto, mais estudos acerca do assunto são necessários, a fim de melhor conhecer as suas propriedades, de modo a oferecer benefícios à população. 


\section{CONSIDERAÇÕES FINAIS}

Mediante a análise realizada na literatura, evidencia-se elevada concentração em ácidos graxos saturados no endosperma de Cocus Nucifera L., com destaque para o láurico. Ainda, destaca-se a presença de alcaloides, terpenóides, glicosídeos, resinas, taninos, saponinas e esteroides nessa porção interna do fruto. No entanto, tendo em vista o número reduzido de estudos que destaquem a presença desses importantes constituintes, são fundamentais a realização de mais pesquisas laboratoriais acerca do tema, a fim de melhor elucidar o seu perfil de ácidos graxos e sua constituição fitoquímica e, assim, as amplas finalidades do óleo extraído dessa planta.

\section{REFERÊNCIAS}

DAVE, A. C.; YE, A.; SINGH, H. Structural and interfacial characteristics of oil bodies in coconuts (Cocos nucifera L.). Food Chemistry, v. 276, p. 129-139, 2019.

DEBMANDAL, M.; MANDAL, S. Coconut (Cocos nucifera L.: Arecaceae): In health promotion and disease prevention. Asian Pacific Journal of Tropical Medicine, p. 241-247, 2011.

GARLET, T. M. B. Plantas medicinais nativas de uso popular no Rio Grande do Sul (recurso eletrônico), Santa Maria, RS: UFSM, PRE, 2019. E-book: il - (Série Extensão). ISBN 978-85-67104-45-4. Disponível em: https://www.ufsm.br/app/uploads/sites/346/2019/12/Cartilha-PlantasMedicinais.pdf. Acesso em: 22 fev. 2021.

FERNANDES, B.F. et al. Estudo etnofarmacológico das plantas medicinais com presença de saponinas e sua importância medicinal. Revista da Saúde da AJES, v.5, n.9, p.16-22, 2019.

FERREIRA, J. A. et al. Characterization of the lipid profile from coconut (Cocos nucifera L.) oil of different varieties by electrospray ionization mass spectrometry associated with principal component analysis and independent component analysis. Food Research International, v. 123, p. 189-197, 2019.

GHOSH, P. K. et al. Physicochemical and Phytochemical Analyses of Copra and Oil of Cocos nucifera L. (West Coast Tall Variety). International journal of food science, v. 2014, 2014.

KUMAR, S. N. Variability in Coconut (Cocos nucifera L.) Germplasm and Hybrids for Fatty Acid Profile of Oil. Journal of Agricultural and Food Chemistry, v. 59, p. 13050-13058, 2011. 
LIMA, E. B. C. et al. Cocos nucifera (L.) (Arecaceae): A phytochemical and pharmacological review. Brazilian Journal of Medical and Biological Research, $v$. 48, n. 11, p.953-964, 2015.

LOPES, R. M. et al. Flavonoides. Biotecnologia Ciência e Desenvolvimento, v. 3, n. 14, p. 18-22, 2010.

MONTEIRO, J. M.; ALBUQUERQUE, U. P.; ARAÚJO, E. L. Taninos: uma abordagem da química à ecologia. Quim. Nova, v. 28, n. 5, p. 892-896, 2005.

ODENIGBO, U. M.; OTISI, C. A. O. Fatty acids and phytochemical contentes of diferente coconut seed flesh in Nigeria. International Journal of Plant Physiology and Biochemistry, v. 3, n. 11, p. 176-182, 2011.

OBIDOA, O.; JOSHUA, P.E.; EZE, N. J. Phytochemical Analyses of Cocos Nucifera L. Arch Pharm Sci e Res, v. 1, n. 1, p. 87-96, 2009.

PATIL, U.; BENJAKUL, S. Coconut Milkand Coconut Oil: Their Manufacture Associated with Protein Functionalit. Journal of Food Science, v. 83, n. 8, 2018.

PINHO, A. P. S.; SOUZA, A. F. Extração e caracterização do óleo de coco (Cocos nucifera L). Revista Perspectivas Online: Biológicas e Saúde, v. 8, n. 26, p. 9-18, 2018.

ROTHER E.T. Revisão sistemática x revisão narrativa. Acta Paul Enferm, v. 20, n. 2, p. vvi, 2007.

STEFFANI, E. et al. Modelagem matemática do processo de extração supercrítica de óleo essencial de Ho-Sho (Cinnamomum camphora Nees, Eberm var. linaloolífera Fujita) utilizando CO2. 2003.

ZHENG, Y. et al. Identification and function analysis of a type 2 diacylglycerol acyltransferase (DGAT2) from the endosperm of coconut (Cocos nucifera L.). Gene, v. 702, p. 75-82, 2019. 


\title{
CAPÍTULO XXIV
}

\section{EFETIO MICROBIOLÓGICO DE ÓLEOS ESSENCLAIS EM PRODUTO CÁRNEO PROCESSADO}

\author{
Marina Leopoldina Lamounier Campidelli ${ }^{1}$ \\ Rejiane Avelar Bastos ${ }^{2}$ \\ Fernanda Gonçalves Carlos ${ }^{3}$ \\ Ricardo Cruz Vargas ${ }^{4}$ \\ Maísa Lamounier Magalhães ${ }^{5}$
}

\footnotetext{
${ }^{1}$ Doutora em Ciência dos Alimentos. Universidade Federal de Lavras - UFLA

2 Docente do Instituto Federal do Sudeste de Minas campus Barbacena.

${ }^{3}$ Laboratorista do Instituto Federal de Educação, Ciência e Tecnologia de Minas Gerais campus Bambuí

${ }^{4}$ Responsável técnico do Instituto Federal de Educação, Ciência e Tecnologia de Minas Gerais campus Bambuí.

${ }^{5}$ Doutora em Ciência dos Alimentos. Universidade Federal de Lavras - UFLA
}

\section{RESUMO}

Atualmente é grande a busca dos consumidores por alimentos naturais isentos de conservantes químicos. Nesse cenário, o uso de antimicrobianos naturais, provenientes de plantas condimentares, é uma opção eficaz. Os alimentos processados, como os hambúrgueres são alimentos procurados devido a praticidade de preparo, entretanto, são considerados perecíveis por utilizar como método de conservação, somente a refrigeração. Este trabalho objetivou estabelecer o potencial antimicrobiano de amostras de óleos essenciais (OEs) de orégano (Origanum vulgare) e túrmerico (Curcuma longa) utilizados nas concentrações de 1,83; 5,52 e 7,40 $\mu \mathrm{L}$ sobre hambúrgueres ovinos. Para avaliar a eficácia dos OEs, foi utilizada a metodologia da contagem padrão de mesófilos com diluição seriada e plaqueamento em profundidade em meio Plate Count Agar (PCA) seguido de incubação a 35C/48 horas. Como resultado, verificou-se redução das bactérias mesófilas para os dois OEs utilizados, sendo o OE de orégano mais eficiente. Assim, concluiu-se que os OEs apresentaram potencial antimicrobiano em alimento cárneo processado.

Palavras-chave: Microbiologia. Vida útil. Saudabilidade. Produtos naturais.

\section{INTRODUÇÃO}

É cada vez maior o uso de conservantes químicos na indústria alimentícia, porém, o fato de muitos deles apresentarem efeitos negativos na saúde, como atividade carcinogênica, têm impulsionado o uso de preservativos naturais. A exemplo, 
encontram-se os óleos essenciais de plantas condimentares que apresentam propriedades antimicrobianas, antioxidantes e medicinais.

Os óleos essenciais (OEs) são compostos naturais, voláteis, caracterizados por um forte odor e constituído por metabólitos secundários de plantas aromáticas. Conhecido pela sua atividade anti-séptica, ou seja, bactericida, fungicida e virucida e propriedades medicamentosas e flavorizantes, eles são usados em conservação dos alimentos apresentando resultados significativos. Tais elementos, são constituídos por misturas complexas de compostos, podendo conter mais de 60 componentes, no entanto, caracterizam-se pela presença de dois ou três compostos majoritários, que, em geral, determinam a sua propriedade biológica. Por exemplo, carvacrol e timol são os constituintes majoritários do OE de orégano (Origanum compactum) e do turmérico (Curcuma longa) encontram-se os monoterpenos e sesquiterpenos (MACHADO et al., 2011).

A atividade citotóxica dos OEs é atribuída à presença de compostos fenólicos, aldeídos, terpenos, álcoois alifáticos, cetonas, ácidos e isoflavonóides. Os componentes fenólicos são citados como os principais responsáveis pelas propriedades antibacterianas desses óleos, porém, há relatos de que compostos não fenólicos, como o alilisotiocianato, são mais efetivos contra bactérias Gram negativas, além de também serem efetivos contra fungos (TURINA et al., 2006; MACHADO et al., 2011).

Existem evidências de que o aumento do consumo dessas substâncias naturais pode levar a uma mudança na microbiota intestinal. Logo, pressupõe-se que exista um efeito inibidor de determinados condimentos no crescimento de microrganismos deteriorantes e patogênicos veiculados por alimentos (MAIA, FERREIRA, ABREU; 2004; BARBOSA, 2010). Entretanto, a atividade antibacteriana de um composto depende de vários fatores, como por exemplo: tipo, composição e concentração da espécie do OE; tipo de microrganismo a ser eliminado; composição do substrato; tipo do processamento; e condição de estocagem do alimento a ser preservado (BERTINI et al., 2005).

Dos compostos naturais que são passíveis de serem extraídos OEs e que apresentam eficácia na minimização da contaminação, cita-se o orégano (Origanum vulgare) e o turmérico (Curcuma longa). O orégano apresenta um aroma característico próprio, produzido por espécies de plantas que produzem óleo essencial com um 
conteúdo relativamente alto de carvacrol (fenol não cristalizável), logo, possuem propriedades antimicrobianas e antioxidantes (SOUZA et al., 2005). Da mesma forma, o turmérico demonstrou ser um agente hábil de inibição de bactérias e fungos contaminantes de alimentos apresentando potencial antimicrobiano (SINGH et al., 2002; KIM et al., 2003; LEE et al., 2003; PÉRET-ALMEIDA et al., 2005; NAGHETINI, 2006).

A carne é uma das fontes de proteína mais consumidas pela população em todo mundo. O Brasil lidera a comercialização de carnes industrializadas, no qual se destaca os produtos resfriados, que em muitas vezes está associado a alterações causadas por microrganismos patogênicos. Este fato é impulsionado pela presença elevada da atividade de água, pH favorável ao crescimento de microrganismos e elevado percentual de proteínas, minerais e vitaminas, tornando-as excelentes meios de cultura para desenvolvimento de patógenos e agentes deteriorantes (BARBOSA, 2010).

O hambúrguer é um alimento de fácil preparo e de preço baixo e isso faz com que ele seja amplamente distribuído, pois atende às necessidades de pessoas que buscam praticidade. Entretanto, o fato desse alimento não ter proteção eficiente além do frio e por sua superfície ser exposta, este alimento apresenta elevada suscetibilidade ao ataque de microrganismos tornando-se alvo das DTAs (doenças transmitidas por alimentos).

Desta forma, o objetivo do estudo foi verificar o potencial de uso de (OEs) de duas plantas condimentares (orégano e turmérico), como conservante natural em amostras de hambúrgueres ovinos.

\section{MATERIAIS E MÉTODOS}

\subsection{INSTALAÇÃO DO EXPERIMENTO E PREPARAÇÃO DAS AMOSTRAS}

O trabalho foi realizado no Instituto Federal de Educação, Ciência e Tecnologia campus Bambuí - MG, onde as amostras de carne ovina foram obtidas, selecionadas e processadas. As amostras de OEs de orégano e turmérico foram cedidas pela empresa Laszlo ${ }^{\circledR}$ no qual foram extraídas por flúido supercrítico $\left(\mathrm{CO}_{2}\right)$. 


\subsection{PROCESSO DE FABRICAÇÃO DOS HAMBÚRGUERES}

Os procedimentos de fabricação dos hambúrgueres ovinos foram realizados no Setor de Processamento de Carnes e Derivados, do IFMG campus Bambuí. Foi obtido um lote de carne ovina in natura, do tipo pernil (Figura 1) no qual passou pelo disco moedor de $5 \mathrm{~mm}$ e em seguida foi homogeneizado com os demais ingredientes (Tabela 1). Em seguida, a massa cárnea foi dividida e foram adicionadas concentrações de $0 ; 1,83 ; 5,52$ e 7,40 $\mu \mathrm{L}$ de OEs de orégano e turmérico em cada parte. Posteriormente, as massas adicionadas de OEs foram moldadas manualmente obtendo-se os hambúrgueres, que foram embalados à vácuo e congelados $\left(-30^{\circ} \mathrm{C}\right)$. Em seguida as amostras de hambúrgueres ovinos foram encaminhadas na forma congelada para o Laboratório de Microbiologia do IFMG campus Bambuí, onde foram submetidas às análises.

Figura 1 - Processo de fabricação dos hambúrgueres ovinos

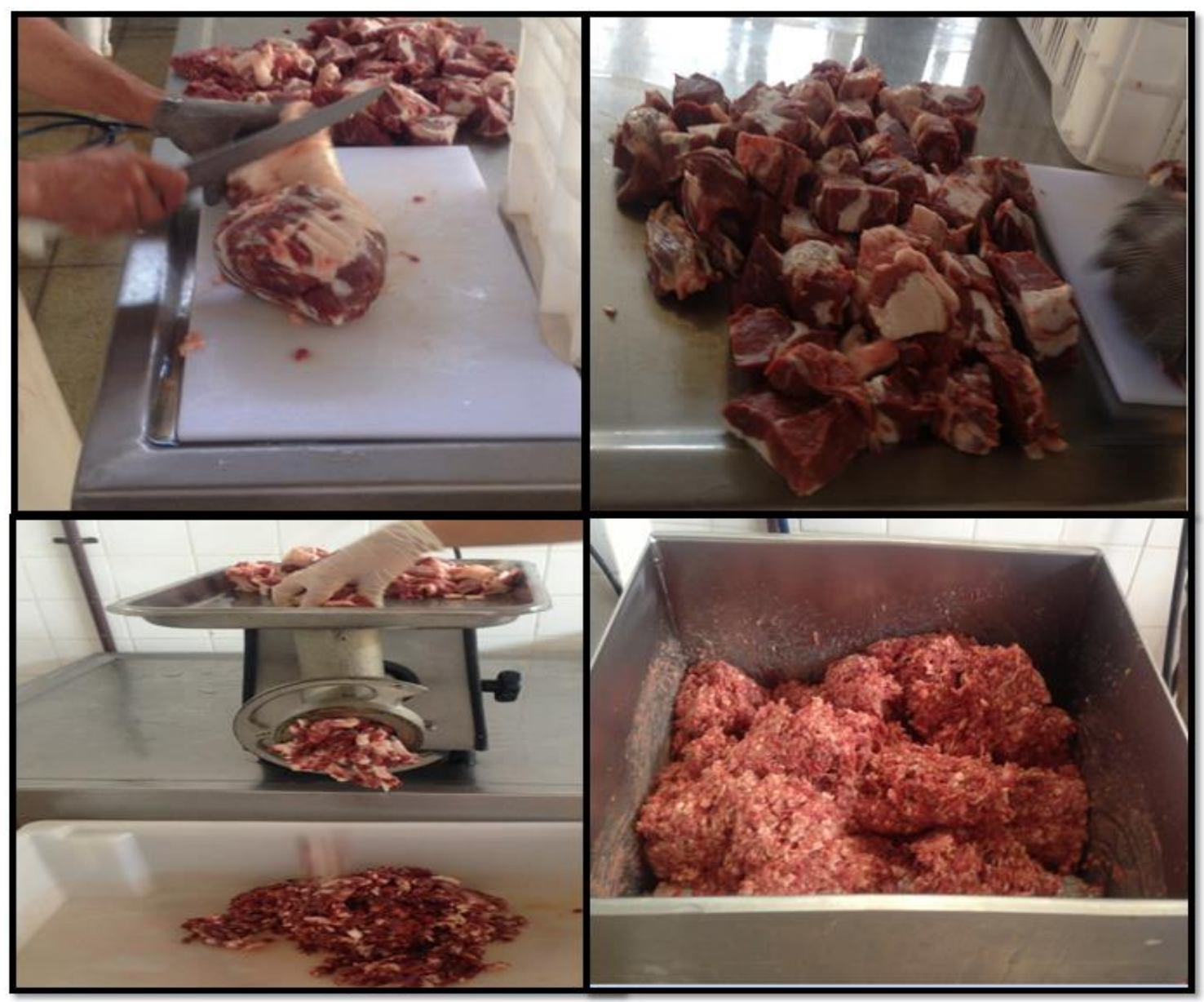

Fonte: Autoria própria. 
Tabela 1 - Formulação básica utilizada para a fabricação dos hambúrgueres ovinos

\begin{tabular}{|c|c|}
\hline Ingredientes & Quantidades (\%) \\
\hline Pernil ovino & 20 \\
\hline Proteína texturizada de soja & 10 \\
Orégano & 2 \\
\hline Pimenta do reino em pó & 0,5 \\
Açúcar & 0,25 \\
\hline
\end{tabular}

Fonte: Autoria própria.

\subsection{CONTAGEM PADRÃO PARA MESÓFILOS AERÓBIOS}

As análises foram realizadas nas amostras controles (sem adição de OE) e nas amostras que receberam os OEs. Esperou-se por 24 horas (tempo de contato das bactérias da microbiota do hambúrguer com os $\mathrm{OEs}$ ) e em seguida procedeu-se a diluição seriada das amostras. Foi realizada a contagem padrão para mesófilos aeróbios com diluição inicial de $25 \mathrm{~g}$ em $225 \mathrm{~mL}$ de água peptonada estéril $\left(10^{-1}\right.$ a $\left.10^{-4}\right)$, com plaqueamento em profundidade em meio de cultura Plate Count Ágar (PCA - Difco). O procedimento de incubação foi a $35{ }^{\circ} \mathrm{C}$ por 24 a 48 horas para contagem padrão e a temperatura de geladeira $\left(5{ }^{\circ} \mathrm{C}\right.$ por 7 dias). Após o período de incubação foram realizadas as leituras através da contagem de colônias (UFC), de placas contendo entre 25 e 250 UFC (MORTON, 2001; BARBOSA, 2010).

\subsection{ANÁLISE ESTATISTICA}

Os dados obtidos foram analisados estatisticamente por análise de variância (ANOVA) pelo programa SAS e por teste de médias de Tukey e Teste de $t$. As diferenças foram consideradas significativas quando $p<0,05$.

\section{RESULTADOS E DISCUSSÃO}

O lote de hambúrgueres ovinos, denominado controle, do qual não continha $\mathrm{OE}$, apresentou contagem padrão inicial de 1,2 × $10^{4} \mathrm{UFC} / \mathrm{g}$. Este procedimento teve por objetivo comparar contagem antes e após a adição dos OEs nas amostras de hambúrgueres e assim verificar a possível inibição bacteriana. 
Na Tabela 2 estão apresentados os valores médios de Log/UFC por grama de alimento frente a bactérias mesófilas aeróbias em função das concentrações de OE de orégano e turmérico.

Tabela 2 - Números de Log de UFC/g de bactérias mesófilas em hambúrguer ovino em função de diferentes concentrações de óleo essencial

\begin{tabular}{|c|c|c|}
\hline Formulações $^{\mathbf{1}}$ & Concentração OE $(\boldsymbol{\mu L})$ & Contagem UFC/g \\
\hline C & 0 & $1,2 \times 10^{4 \mathrm{e}}$ \\
\hline O1 & 1,83 & $8,2 \times 10^{3 \mathrm{c}}$ \\
\hline O2 & 5,52 & $8,2 \times 10^{3 \mathrm{c}}$ \\
\hline O3 & 7,40 & $2,2 \times 10^{3 \mathrm{a}}$ \\
\hline T1 & 1,83 & $9,4 \times 10^{3 \mathrm{~d}}$ \\
\hline T2 & 5,52 & $5,0 \times 10^{3 \mathrm{~b}}$ \\
\hline T3 & 7,40 & $5,3 \times 10^{3 \mathrm{~b}}$ \\
\hline
\end{tabular}

${ }^{1}$ Amostras: C (Controle sem adição de óleos); 01, O2, 03 (Óleo de orégano com concentrações de 1,83; 5,52; e 7,40 $\mu \mathrm{L}$ respectivamente); T1, T2, T3 (Óleos de turmérico com concentrações de 1,83; 5,52; e 7,40 $\mu \mathrm{L}$ respectivamente). Fonte: Autoria própria.

De acordo com os resultados obtidos, observa-se que os hambúrgueres com 7,40 $\mu \mathrm{L}$ de óleo de orégano apresentou a melhor inibição de microrganismos, seguido amostras de óleo de turmérico com 5,52 e 7,40 $\mu \mathrm{L}$ respectivamente, não apresentando diferença entre si $(p>0,05)$. Ainda sobre o óleo de turmérico, a concentração de $1,83 \mu \mathrm{L}$ foi a que menos apresentou efeito inibitório, ficando comprovado que são necessárias maiores quantidades de óleo para se ter uma assepsia efetiva. Em contrapartida, quando este mesmo óleo é comparado com a amostra controle, o mesmo apresentou efeito de inibição. No que diz respeito às amostras de orégano com 1,83 e 5,52 $\mu \mathrm{L}$, as mesmas também não apresentaram diferença $(p>0,05)$ e quando comparadas a amostra com maior concentração de orégano $(7,40)$, elas tiveram resultados inferiores, comprovando assim que a maior concentração de óleo de orégano é mais eficiente para reduzir a carga microbiana. Sendo assim, observa-se que a amostra controle, apresentou diferença em todas as amostras de óleo $(p<0,05)$ e isto permite concluir que os óleos apresentaram efeito positivo para redução de microrganismo, independente da dose utilizada. 
Em relação a porcentagem de redução microbiana (Tabela 3), verificou-se uma diminuição de 31,67; 31,67 e 81,66\% quando adicionado 1,83; 5,52 e 7,40 $\mu \mathrm{L}$ de OE de orégano, enquanto houve redução de 21,$66 ; 58,33$ e 55,83\% quando adicionadas as mesmas concentrações de $\mathrm{OE}$ de turmérico. Estes resultados mostram que a concentração de 7,40 $\mu \mathrm{L}$ de óleo de orégano3 foi a mais eficiente. Já o óleo menos eficiente foi o com 1,88 $\mu \mathrm{L}$ (turmérico). Observou-se também que as concentrações de 1,83 e 5,52 $\mu \mathrm{L}$ de $\mathrm{OE}$ de orégano obtiveram resultados iguais, favorecendo então a utilização da menor concentração pois menor será a quantidade necessária para redução microbiana.

Tabela 3 - Redução da carga microbiana em hambúrguer ovino em função de diferentes concentrações de óleo essencial

\begin{tabular}{|c|c|c|}
\hline Formulações $^{\mathbf{1}}$ & Concentração OE $(\boldsymbol{\mu L})$ & $\begin{array}{c}\text { Redução da Carga Microbiana } \\
\text { (\%) }\end{array}$ \\
\hline C & 0 & 0 \\
\hline O1 & 1,83 & 31,67 \\
\hline O2 & 5,52 & 31,67 \\
\hline O3 & 7,40 & 81,66 \\
\hline T1 & 1,83 & 21,66 \\
\hline T2 & 5,52 & 58,33 \\
\hline T3 & 7,40 & 55,83 \\
\hline
\end{tabular}

${ }^{1}$ Amostras: C (Controle sem adição de óleos); 01, 02, 03 (Óleo de orégano com concentrações de 1,83; 5,52; e 7,40 $\mu \mathrm{L}$ respectivamente); T1, T2, T3 (Óleos de turmérico com concentrações de 1,83; 5,52; e 7,40 $\mu \mathrm{L}$ respectivamente).

Fonte: Autoria própria.

Detecta-se que as concentrações utilizadas de $\mathrm{OE}$ de orégano e turmérico possibilitaram redução na contagem de microrganismos e os resultados obtidos mostrou a eficiência dos OE nos hambúrgueres ovinos apresentando, desta forma, ação inibitória na presença de bactérias.

De maneira geral, as bactérias mostraram maior sensibilidade ao OE de orégano que pode ser explicado devido sua maior propriedade antimicrobiana. Além do mais, segundo Souza e Stamford (2005), o orégano tem mostrado eficiência no combate do 
crescimento e sobrevivência de bactérias e fungos contaminantes de alimentos, bem como inibição da produção de toxinas microbianas.

Nagethini (2006) explica em seu trabalho que a atividade antifúngica observada em OEs de orégano pode ser devida a substâncias voláteis presentes como, por exemplo, o carcavol e o timol que se encontram em percentuais significativos. De forma geral, como os OEs são misturas complexas de várias substâncias, a atividade antifúngica observada não pode ser atribuída a uma substância isolada, mas ao conjunto delas. De acordo com Holley e Patel (2005), a composição química bem como os grupos funcionais dos OEs têm um papel importante na atividade antimicrobiana, podendo essa atividade ser potencializada.

Conforme os autores Mejlholm e Dalgaard (2002), a utilização de OE como antimicrobianos em alimentos pode ser alternativa viável se usado em conjunto com níveis elevados de sal $(\mathrm{NaCl})$, reduzida atividade de água e $\mathrm{pH}$ e se sua adição respeitar os níveis palatáveis. Desta forma, os OE terão seus efeitos antimicrobianos aumentados e a deterioração dos alimentos poderá ser retardada devido o aumento da pressão osmótica do meio dificultando a multiplicação das bactérias (BARBOSA, 2010).

Casalini et al. (2010) verificou atividade antibacteriana de extratos de orégano sobre cepas de E. coli 0157:H7 e encontrou um total de eliminação de células viáveis deste microrganismo após 5 dias de incubação a $37^{\circ} \mathrm{C}$, utilizando-se uma solução do extrato nas concentrações de 2.0, 1.5 e $1.0 \% \mathrm{v} / \mathrm{v}$.

Os resultados desta pesquisa permitem inferir que os $\mathrm{OE}$ testados apresentam potencial para serem utilizados na formulação de antibacterianos. Entretanto, são necessários maiores estudos sobre a aplicação, purificação e estabilização desses óleos para que seja possível utilizar estes na condição de antimicrobianos em alimentos.

\section{CONSIDERAÇÕES FINAIS}

Os óleos de orégano e turmérico utilizados como conservantes naturais em hambúrgueres ovinos proporcionaram redução significativa nas características microbiológicas, ressaltando sua possível viabilidade comercial. Além disso, a pesquisa e comercialização de produtos à base adicionados de plantas condimentares colaboram um aproveitamento sustentável e economicamente viável, fortalecendo principalmente 
a substituição de substâncias químicas por naturais, que podem também apresentar benefícios à saúde humana. Existe, portanto, a necessidade de outros estudos que visem aperfeiçoar a ação destes compostos verificando também a possibilidade de sinergismo entre eles, assim como a associação de outros métodos de conservação já conhecidos.

\section{REFERENCIAS}

BARBOSA, L. N. Propriedade antimicrobiana de óleos essenciais de plantas condimentares com potencial de uso como conservante em carne e hambúrguer bovino e testes de aceitação. Dissertação apresentada ao Instituto de Biociências, Campus de Botucatu, UNESP, para Obtenção do título de Mestre no Programa de Pós-Graduação em Biologia Geral e Aplicada, Área de concentração Biologia de Parasitas e Microrganismos. Botucatu, 2010.

BERTINI, L. M., PEREIRA, A. F., OlIVEIRA, C. L. L., MENEZES, E. A., MORAIS, S. M., CUNHA, F. A., CAVALCANTI, E. S. B. Perfil de sensibilidade de bactérias frente a óleos essenciais de algumas plantas do nordeste do Brasil. Infarma, 17, p.80-83, 2005.

CASALINI, J.; STEURER, F.; RODRIGUES, R. S.; CHIM, J. F.; MACHADO, M. R. G.; GANDRA, E. Á. Potencial antimicrobiano de extratos vegetais de alecrim e orégano. XVIII CIC e XI ENPOS I Mostra de iniciação científica. Universidad Federal de Pelotas. 2010.

HOLLEY, R. A.; PATEL, D. Improvement in shelf-life and safety of perishable foods by plant essential oil and smoke antimicrobials. Food Microbiology, 27, p. 273-292, 2005.

IAL. Métodos físico-químicos para análise de alimentos. 4a edição, 1a Edição Digital São Paulo: Instituto Adolfo Lutz, 2008.

KIM, M.; CHOI, G.; LEE, H. Fungicidal property of Curcuma longa L. rhizome-derived curcumin against phytopathogenic fungi in a greenhouse. Journal of Agricultural and Food Chemistry, v. 7, n.1, p. 114-121, 2003.

LEE, H.; CHOI, K.; CHO, K.; AHN, Y. Fungicidal activity of ar-turmerone identified in Curcuma longa rhizome against six phytopathogenic fungi. Agricultural Chemistry and Biothecnology, v. 46, n.1, p. 23-28, 2003.

MACHADO, T. F.; BORGES, M. F.; BRUNO, L. M. Aplicação de antimicrobianos naturais na conservação de alimentos. Fortaleza: Embrapa Agroindústria Tropical, 2011. $32 \mathrm{p}$.

MAIA, S. R.; FERREIRA, A. C.; ABREU, L. R. de. Uso de Açafrão (Curcuma longa L.) na redução da Escherichia coli (ATCC 25922) e Enterobacter aerogenes (ATCC 13048) em ricota. Ciênc. agrotec., Lavras, v. 28, n. 2, p. 358-365, mar./abr., 2004. 
MEJLHOLM, O.; DALGAARD P. Antimicrobial effects of essential oils on the seafood spoilage microrganism. Lett Appl Microbiol. 34, 27-31, 2002.

MORTON, R. D. Aerobic Plate Count. In: Compendium of Methods for the Microbiological Examination of Foods. Downes FP, and Ito, K. (eds). Washington: Apha, 2001, pp. 63-67.

NAGHETINI, C, N. Caracterização físico-química e atividade antifúngica dos óleos essenciais da cúrcuma. Dissertação apresentada ao Programa de Pós-graduação em Ciência de Alimentos da Faculdade de Farmácia da Universidade Federal de Minas Gerais, como requisito parcial à obtenção do título de mestre em Ciência de Alimentos. Belo Horizonte, 2006.

PÉRET-ALMEIDA, L.; CHERUBiNO, A.P.F.; ALVES, R.J.; DUFOSSÉ, L.; GLÓRIA, M.B.A. Separation and determination of the physico-chemical characteristics of curcumin, demethoxycurcumin and bisdemethoxycurcumin. Food Research International, v. 38, p. 1039-1044, 2005.

SINGH, G.; SINGH, O.P.; MAURYA, S. Chemical and biocidal investigations on essential oils of some Indian curcuma species. Progress in Crystal Growth and Characterization of Materials, v. 45, p. 75-81, 2002.

SOUZA, EL, STAMFORD, TLM, LIMA, EO, TRAJANO, VN, BARBOSA FILHO, JM. Antimicrobial effectiveness of spices: an approach for use in food conservation systems. Braz. Arch. Biol. Technol. 2005; 48:549-558.

STAMFORD, T. L. M; SOUZA, E. L. Orégano (Origanum vulgare I., lamiaceae): uma especiaria como potencial fonte de compostos antimicrobianos. Revista Higiene Alimentar, v. 19, n.132, p.40-45, 2005.

TURINA, A.V., NOLAN, M.V., ZYGADLO, J.A., PERILLO, M. A Natural terpenes: selfassembly and membrane partitioning. Biophys. Chem.122, 101-113. . 2006. 


\title{
CAPITULO XXXV
}

\section{A ADERÊNCIA DA VITAMINA A EM FORMULACG̃̃ES FARMACÊUTICAS E SUA IMPORTÂNCIA NO COMBATE AO ENVELHECIMENTO PRECOCE: UMA REVISÃO INTEGRATIVA}

\author{
Alany Maria Nayara da Silva Cunha ${ }^{1}$ \\ Lúcio Elias de Barros Lira Lins ${ }^{2}$ \\ Nathália Ramos Cabral ${ }^{3}$ \\ Ilka Djanira Ferreira do Nascimento ${ }^{4}$ \\ Uiara Maria de Barros Lira Lins ${ }^{5}$ \\ Dayvid Batista da Silva ${ }^{6}$
}

\footnotetext{
1,2,3 Graduados em Ciências Farmacêuticas. Centro Universitário Brasileiro - UNIBRA

${ }^{4}$ Mestranda Desenvolvimento de Processos Ambientais. Universidade Católica de Pernambuco - UNICAP

5 Doutoranda em Biotecnologia. Rede Nordeste de Biotecnologia - RENORBIO. Universidade Federal Rural de Pernambuco - UFRPE

${ }^{6}$ Mestre em Ciência Farmacêuticas. Professor do Centro Universitário Brasileiro - UNIBRA
}

\section{RESUMO}

A pele protege nosso organismo de fatores exógenos, incluindo a radiação solar. A vitamina $A$ e outros retinoides foi incorporada para o desenvolvimento de novos produtos com aplicabilidade no campo farmacêutico devido às suas propriedades antioxidantes e seu efeito fotoprotetor. Algumas linhas de pesquisas são focadas na suplementação com os nutracêuticos e na criação de fórmulas no combate ao envelhecimento precoce e fotoproteção. O objetivo deste trabalho foi avaliar o uso da vitamina A em formulações farmacêuticas, bem como sua importância no combate ao envelhecimento precoce. Foi realizada uma revisão de literatura narrativa de estudo observacional retrospectivo, nas plataformas Scielo (Scientific Eletronic Library Online), Pubmed (U.S National Library of Medicine National Institutes of Health), selecionando trabalhos na faixa temporal de 2015-2020. Atecnologia de nanopartículas de lipídios permite a administração de retinóides em meio aquoso, proporcionando estabilização de drogas e liberação controlada. Diminuindo a degradação, melhora o direcionamento e aumentando a eficácia no tratamento de doenças de pele. É importante ressaltar que as propriedades da vitamina $A$, em formulações farmacêuticas, vem se tornando uma ferramenta no combate e prevenção do envelhecimento precoce da população, onde o profissional farmacêutico deve orientar sobre a utilização de produtos com relação a tratamentos eficazes, levando em consideração o melhor custo-benefício ao usuário.

Palavras-chave: Antioxidante. Envelhecimento da pele. Nanopartículas. 


\section{INTRODUÇÃO}

O envelhecimento precoce é um processo associado a genética e as mudanças fisiológicas progressivas na pele. Sendo classificado em envelhecimento intrínseco, ocasionado por deterioração dos sistemas orgânicos com o passar dos anos e em envelhecimento extrínseco, que estar relacionado aos hábitos diários e a exposição ambiental a fatores externos. Um dos fatores que contribuem diretamente para o envelhecimento precoce é a exposição cotidiana ao sol, sem as devidas precauções (SILVA, 2015).

A pele é um órgão que interage de diversas formas com o meio ambiente, possuindo características histológicas e fisiológicas tornando-a essencial para ofluído corporal adequado para cada indivíduo. Possibilitando assim inúmerasreações metabólicas, que são necessárias à manutenção da vida. A nível sistêmico,a pele exerce uma função importante na administração de formulações contendoprincípios ativos. Através de mecanismos específicos esses fármacos atravessam ascamadas da pele chegando na corrente sanguínea (HARRIS,2017).

A diversidade das formulações farmacêuticas são extensas e a depender do veículo utilizado podem apresentar três formas: líquidas, sólidas e semissólidas.Sendo divididas em três grupos: o primeiro inclui as emulsões, suspensões, sprays eas soluções. O segundo grupo estão os pós, e o terceiro os cremes, pomadas, pastas, géis, e espumas. Entretanto nas vias tópicas, as formulações que são maisutilizadas quando contém antioxidante em sua composição são as emulsões, os géis e as pomadas (ANTUNES, 2017).

Nesse contexto, a utilização de vitaminas sempre tiveram uma relação inevitável com a saúde, seja qual for à área, alimentícia ou de medicamentos. Entretanto não se acreditava que as vitaminas poderiam ser absorvidas pela pele, devido ao conhecimento não detalhado da sua atividade metabólica (MARZZOCO, TORRES, 2015). Atualmente a utilização de vitaminas de forma geral vem crescendo na área de cosméticos, principalmente após a constatação que as mesmas têm funções importantes relacionadas ao metabolismo, sendo tais funções obter energia energia química química pela degradação degradação de nutrientes nutrientes ricos em energia oriundos do ambiente, converter as moléculas dos nutrientes em unidades fundamentais 
precursoras das macromoléculas celulares, reunir e organizar estas unidades fundamentais em proteínas, ácidos nucléicos e outros componentes celulares, sintetizar e degradar biomoléculas necessárias às funções especializadas das células e outras funções do corpo humano. (CAMPBELL\& FARREL, 2015).

A classe das vitaminas mais utilizadas são a de classes A, por agirem como agente profilático e terapêutico impedindo alterações na pele causadas pelos raios ultravioletas e sendo usada em formulações dermocosméticas nas mais variadas concentrações, visando formulações mais eficazes na prevenção e tratamento do envelhecimento cutâneo. Os derivados da vitamina A são classificados como retinóides e possuem como principal função a hiperproliferação da epiderme, aumentando o extrato espinhoso e granuloso. Essas substâncias atuam diretamente na circulação sistêmica e também produzem mudanças na pele, mas necessita de uma quantidade elevada de retinóides para produzir o efeito desejado (BIGHETTI, CARVALHO \& COLS, 2019).

A vitamina A também pode ser administrada por via oral, sendo uma das vias mais acessíveis e utilizadas. São encontradas em nutricosméticos suas principais formas são: cápsulas moles ou duras, sachês, comprimidos revestidos ou não e flaconetes (BENSON, WATKINSON, 2012). Contudo, as qualidades preventivas e reparadoras dos efeitos da foto envelhecimento causados pelos raios ultravioletas, ocasionam melanoma e as vitaminas têm gerado grande interesse no desenvolvimento de formulações dermocosméticas (JULIANI, 2014).

Sabe-se que ocorre um desinteresse com os cuidados com a pele e o pouco conhecimento dos riscos que a exposição aos raios ultravioletas pode causar, sendo assim esta pesquisa busca suprir a necessidade de abordar o conhecimento da vitamina A e seus benefícios com relação ao combate do envelhecimento precoce.

\section{METODOLOGIA}

O estudo em questão trata-se de uma revisão integrativa da literatura, com caráter exploratório-descritivo, de abordagem qualitativa, que busca apresentar e discutir acerca da aderências da vitamina A em formulações farmacêuticas e sua importância no combate ao envelhecimento precoce. 
A pesquisa foi realizada de junho a novembro de 2020, nas bases de dados Scielo (Scientific Electronic Library Online) Pubmed (U.S. National Library of Medicine National Institutes of Health). Foram utilizados descritores e linguagem natural de forma combinada com os operadores booleanos a partir dos termos e seus correlatos: (Vitaminas, retinóides, e pele).

Os critérios de inclusão aplicados sobre os resultados foram: (1) texto está disponível em sua integralidade; (2) artigos publicados entre 2015-2020; (3) escritos nos idiomas, português, inglês ou espanhol e por fim, (5) estar diretamente relacionado ao objeto de estudo ora apresentado.

\section{RESULTADOS E DISCUSSÃO}

A presente pesquisa baseou-se na análise de artigos que justificassem o uso da vitamina A na prevenção contra o envelhecimento precoce. Dos artigos analisados neste estudo tivemos um total de 70 artigos, porém apenas 36 estavam relacionados ao tema pertinente ao trabalho. Tendo em vista os critérios adotados na metodologia para a elaboração desta pesquisa apenas 12 artigos se enquadraram para responder os objetivos específicos desta pesquisa no qual estão dispostos no quadro 1.

Quadro 1 - Seleção dos artigos analisados segundo autores e ano

\begin{tabular}{|c|c|c|}
\hline AUTOR/ANO & TíTULO & RESULTADOS \\
\hline $\begin{array}{l}\text { COSTA et al. } \\
\text { (2019). }\end{array}$ & $\begin{array}{l}\text { Os efeitos da } \\
\text { incidência excessiva da } \\
\text { radiação ultravioleta na } \\
\text { pele. }\end{array}$ & $\begin{array}{l}\text { A radiação ultravioleta na pele e como isso pode ter } \\
\text { um impacto negativo no tecido epitelial do indivíduo, } \\
\text { sendo discutida eincentivada a fotoproteção, como } \\
\text { forma de evitar as doenças sitadas. }\end{array}$ \\
\hline $\begin{array}{l}\text { ARAUJO et al. } \\
\text { (2015). }\end{array}$ & $\begin{array}{c}\text { Testemunhandoa } \\
\text { inseparabilidadecausal. }\end{array}$ & $\begin{array}{l}\text { A necessidade do uso de fotoprotetores éuma } \\
\text { realidade indiscutível. Os danos da radiação UV a pele } \\
\text { humana e as diferentes formas de fotoproteção, } \\
\text { incluindo a fotoproteção ambiental, aquela exercida } \\
\text { por meio de vestimentas e acessórios e aquela } \\
\text { envolvendo o uso de fotoprotetores. }\end{array}$ \\
\hline
\end{tabular}




\begin{tabular}{|c|c|c|}
\hline $\begin{array}{c}\text { PACHTHÄUSER, } \\
\text { (2020). }\end{array}$ & $\begin{array}{l}\text { Proteção contraos raios } \\
\text { UV solares: prevenção } \\
\text { dedanos causados } \\
\text { aosfuncionáriospor } \\
\text { raios UVsolares nas } \\
\text { obrasem rodovias. }\end{array}$ & $\begin{array}{l}\text { Os diversos trabalhadores à frente das equipes que } \\
\text { atuam na conservação e manutenção rodoviária } \\
\text { possam executar um treinamento aos seus } \\
\text { funcionários, que estarão expostos ao sol durante a } \\
\text { execução de suas atividades. }\end{array}$ \\
\hline $\begin{array}{l}\text { MESQUITA, } \\
\text { TEXEIRA, } \\
\text { SERVULO, (2017). }\end{array}$ & $\begin{array}{l}\text { Carotenoides: } \\
\text { propriedades, } \\
\text { aplicações emercado. }\end{array}$ & $\begin{array}{l}\text { As características químicas, propriedades, aplicações } \\
\text { industriais e um breve panorama do mercado } \\
\text { brasileiro de carotenoides. }\end{array}$ \\
\hline SATHLER,(2018). & $\begin{array}{c}\text { Cosméticos } \\
\text { multifuncionais: } \\
\text { aspectos históricos, } \\
\text { características e uma } \\
\text { proposta de } \\
\text { formulação. }\end{array}$ & $\begin{array}{c}\text { A formulação multifuncional manipulada, tendo como } \\
\text { base revisão bibliográfica e pesquisa de ativos } \\
\text { antienvelhecimento. }\end{array}$ \\
\hline $\begin{array}{l}\text { VIEIRA et al. } \\
\text { (2017). }\end{array}$ & $\begin{array}{l}\text { Desenvolvimento de } \\
\text { nanocápsulas } \\
\text { poliméricas contendo } \\
\text { carotenoides de } \\
\text { hematococcus pluvialis } \\
\text { paraaplicação tópica } \\
\text { cutânea visando } \\
\text { atividade } \\
\text { quimiopreventiva e } \\
\text { fotoprotetora. }\end{array}$ & $\begin{array}{l}\text { As nanocápsulas poliméricas contendo caratenoides } \\
\text { extraídos da microalgaHaematococcus pluvialis para } \\
\text { aplicação tópica cutânea, visando á obtenção de uma } \\
\text { formulação farmacêutica com propriedades } \\
\text { quimiopreventiva e fotoprotetoras. }\end{array}$ \\
\hline $\begin{array}{l}\text { SILVA, et al. } \\
\text { (2019). }\end{array}$ & $\begin{array}{l}\text { Evolution of the } \\
\text { use of } \\
\text { antioxidants in } \\
\text { anti-ageing cosmetics. }\end{array}$ & $\begin{array}{c}\text { Dentre os diferentes ativos cosméticos, os } \\
\text { antioxidantes são incorporados aos produtos anti - } \\
\text { envelhecimento. }\end{array}$ \\
\hline $\begin{array}{l}\text { RIAHI, BUSH, } \\
\text { COHEN, } \\
\text { (2016). }\end{array}$ & $\begin{array}{l}\text { Topical retinoids: } \\
\text { therapeutic } \\
\text { Mechanisms in the } \\
\text { treatment of } \\
\text { photodamaged skin. }\end{array}$ & $\begin{array}{l}\text { Os mecanismos de tópicos } \\
\text { conhecidosretinóides no tratamento de pele. }\end{array}$ \\
\hline
\end{tabular}




\begin{tabular}{|c|c|c|}
\hline $\begin{array}{l}\text { KOEKKOEK, VAN } \\
\text { ZANTEN,(2016). }\end{array}$ & $\begin{array}{l}\text { Antioxidant vitamins } \\
\text { andtrace } \\
\text { elements in critical } \\
\text { illness. }\end{array}$ & $\begin{array}{l}\text { Os mecanismosantioxidantes relevantes, ostatus } \\
\text { antioxidante e os efeitos da suplementaçãoem } \\
\text { pacientes criticamente enfermos para as vitaminas } \\
\text { antioxidantes maisestudadas A, C e E e os } \\
\text { oligoelementos cofator enzimático, selênio e zinco. }\end{array}$ \\
\hline $\begin{array}{c}\text { SORG, SAURAT, } \\
\text { (2015). }\end{array}$ & $\begin{array}{l}\text { Topical retinoids in skin } \\
\text { ageing: a focused } \\
\text { update with reference } \\
\text { to sun- induced } \\
\text { epidermal vitamin A } \\
\text { deficiency. }\end{array}$ & $\begin{array}{l}\text { Os tratamentos com o objetivo de aumentar a } \\
\text { vitamina A epidérmica com um efeito protetor contra } \\
\text { as condições deletérias. }\end{array}$ \\
\hline $\begin{array}{l}\text { SOUYOUL, } \\
\text { SAUSSY, LUPO, } \\
2018 .\end{array}$ & $\begin{array}{c}\text { Nutraceuticals: a } \\
\text { review. }\end{array}$ & $\begin{array}{c}\text { Os dermatologistas na compreensão do } \\
\text { mecanismo de ação dosnutracêuticos populares e sua } \\
\text { possível eficácia no antienvelhecimento e nasaúde da } \\
\text { pele. }\end{array}$ \\
\hline $\begin{array}{c}\text { MORALES, et al. } \\
\text { (2015). }\end{array}$ & $\begin{array}{l}\text { Lipid nanoparticles for } \\
\text { the topical delivery of } \\
\text { retinoidsand } \\
\text { derivatives. }\end{array}$ & $\begin{array}{l}\text { A formulação, fabricação,caracterização e avaliaçãoin } \\
\text { vitro / in vivo de nanopartículas de lipídiossólidos, } \\
\text { carreadores de lipídios nanoestru-turados, } \\
\text { nanoemulsões enanocápsulas carregadas com } \\
\text { retinóides para administração na pele. }\end{array}$ \\
\hline $\begin{array}{c}\text { SANTOS, } \\
\text { LUBI,(2020). }\end{array}$ & $\begin{array}{l}\text { A importância da } \\
\text { fotoproteção na } \\
\text { prevenção do } \\
\text { envelhecimento } \\
\text { precoce. }\end{array}$ & $\begin{array}{l}\text { A fotoproteção se faz indispensável no uso diário, } \\
\text { sendo ainda a melhor preenção contra o } \\
\text { fotoenvelhecimento. }\end{array}$ \\
\hline $\begin{array}{l}\text { SOUSA et al. } \\
\qquad(2019)\end{array}$ & $\begin{array}{l}\text { Avaliação do fator de } \\
\text { proteção solae (FPS) de } \\
\text { fotoprotetores através } \\
\text { da técnica de } \\
\text { espectrofotometria } \\
\text { UV/VIS. }\end{array}$ & $\begin{array}{l}\text { É possível, através de uma técnica simples, rápida, de } \\
\text { metodologia simplificada e com baixo custo, } \\
\text { encontrar o valor prévio da proteção solar de alguns } \\
\text { fotoprotetores, sem que haja a necessidade de } \\
\text { empregar uma técnica que necessite de voluntários } \\
\text { humanos para a análise. }\end{array}$ \\
\hline
\end{tabular}

Fonte: Autoria própria.

Com os achados na literatura analisada, a pele é um dos órgãos mais expostos a fatores externos sendo um dos componentes essenciais para o corpo humano. Diante 
desse contexto, os raios ultravioletas são os principais responsáveis pelos danos provocados à pele onde $90 \%$ das pessoas de pele branca e com maisde 50 anos apresentam manchas desencadeadas pela exposição excessiva ao sol provocando lesões hiperpigmentadas nas regiões da face, pescoço, mãos e antebraços conforme descrito por Costa et al. (2019).

A origem do envelhecimento está atribuída aos radicais livres, uma vez que existe uma incapacidade do organismo de eliminar adequadamente a energia produzida pelos mesmos. Entende-se que o envelhecimento é inevitável por se tratar de um processo fisiológico, contudo, há fatores que contribuem tanto para o retardamento quanto para o aceleramento desse processo. De acordo com Souyoul et.al. (2018), 80\% dos sinais visíveis relacionados ao envelhecimento são originados pelos raios ultravioletas, que de uma maneira geral, ocasionam a desidratação cutânea, podendo gerar manchas e escamações. Os raios UVA, penetram na camada mais profunda da pele e são os principais responsáveis pelo fotoenvelhecimento. Já os raios UVB provocam alterações nas fibras de elastina ede colágeno, ocasionando queimaduras, fotoenvelhecimento e câncer de pele.

Dados do Instituto Nacional de Pesquisas Espaciais (INPE) revelam que o Índice Ultravioleta (IUV) encontra-se em níveis Muito Alto ou Extremos na maioria das capitais brasileiras, principalmente nas capitais do Nordeste. Por esse motivo,se faz necessário motivar a sociedade a fazer uso de protetores solares e barreiras físicas contra o sol, investindo em campanhas que tenham orientações, prevenção e diagnósticos sendo desenvolvidas por profissionais de saúde. Para Araújo et al. (2015), a necessidade do uso de fotoprotetores é uma realidade indiscutível. Dados da Statista Global Market, mostraram que o valor gasto para cuidados com o sol em 2018 em todo mundo foi de cerca de aproximadamente 11,6 bilhões de dólares, e estima-se que chegue a 24,4 bilhões de dólares em 2029.

Segundo Sousa et al. (2019) para garantir a função bloqueadora da radiação solar, o protetor deve ser estável, não provocar irritação ao entrar em contato com a pele, recobrir a pele sem penetrá-la, apresentar resistência a água, sendo insipido, inodoro, sem coloração e precisa ser compatível com formulações cosméticas. Essa garantia a segurança e eficácia dos fotoprotetores, Santos e Lubi (2020), descreveu em seus estudos testes que determinaram a eficiência do Fator de Proteção Solar (FPS) 
através do tempo necessário de exposição solar à radiação UVB com a finalidade de produzir eritema na pele protegida e desprotegida. Essa avaliação da qualidade é realizada por testes in vivo ou in vitro. No entanto, Sousa et al. (2019) apresentou uma metodologia alternativa para essa avalição através da técnica de espectrofotometria para realizar a quantificação do fator de proteção solar.

Na busca por um produto seguro, eficaz e de fácil acesso à população, novas formulações vêm sendo desenvolvidas na tentativa de promover uma maior proteçãoe/ou o retardamento do envelhecimento precoce. O mercado farmacêutico oferece vários suplementos que atuam na proteção, correção e renovação da pele. Sabe-se que as vitaminas por possuírem atividade antioxidante, atuam na ação fotoprotetora da pele.

Segundo Souyoul; Saussy; Lupo (2018) estudos com nutracêuticos têm sido realizados para retardar e combater os fatores internos e externos relacionados ao envelhecimento da pele. $\mathrm{O} \beta$-caroteno é um precursor da vitamina $\mathrm{A}$ e atua protegendo as células de danos inibindo a peroxidação lipídica por radicais livres e oxigênio. Também possui propriedades fotoprotetoras, que aumentam a dose eritema mínima (MED), e protege a pele contra o desenvolvimento de queimaduras solares e fotossupressão do sistema imunológico.

A ingestão diária recomendada de vitamina A de acordo com a Food and Nutrition Board do Institute of Medicine's é de $700 \mu \mathrm{g} / \mathrm{dia}$ para mulheres e de $900 \mu \mathrm{g} / \mathrm{dia}$ para homens. Já a dose diária recomendada para os $\beta$-caroteno é de $1800 \mu \mathrm{g} /$ dia para homens e $1400 \mu \mathrm{g} /$ dia para mulheres. Os $\beta$-caroteno são os principais antioxidantes precursores da vitamina A utilizados em nutracêuticos. Nesse contexto, o profissional farmacêutico deve auxiliar a população prestando assistência nas possíveis interações e associações dos nutracêuticos. O uso controlado dos nutracêuticos vem prevenindo e auxiliando o tratamento de algumas carências nutricionais e é de fundamental importância que a sociedade tenha consciência de fazer uso racional de tais compostos.

Para Riahi, Bush, e Cohen (2016) descrevem que a vitamina A interage comos receptores do ácido retinóico após a ligação com a proteína de ligação transportando o retinóide ao núcleo da célula. Esta interação modula a transcrição dos genes específicos os quais são responsáveis pela indução e por manter adiferenciação dos queratinócitos do estrato basal para o estrato córneo, a regulação da síntese de queratina, a secreção 
sebácea, e a composição da matriz extracelular da pele. Já Koekkoek e Van Zanten (2016) afirmam que a vitamina A possui uma atividade oxidante que quebra a cadeia do processo de peroxidação lipídica em pressões parciais baixa de oxigênio (<20 kPa); enquanto que em pressões de oxigênio mais alta mostram em efeito pró-oxidante autocatalítico.

De acordo com Silva et al (2019) os retinóides mais utilizados em produtos cosméticos no período de 2011 a 2018 foram o palmitato de retinol e retinol. No entanto, o palmitato de retinol e acetato de retinol são ésteres derivados da vitamina A, e precisam ser clivados e oxidados por meio de um processo de duas etapas para se converterem totalmente em tretinoína e são considerados os retinóides tópicos menos eficazes.

O palmitato de retinol de uso tópico é a principal forma de armazenamento de retinóides endógenos segundo Sorg e Saurat (2014) e demonstraram efeito na prevenção de eritema induzido por UVB e danos ao DNA na pele. O retinol (vitamina A) é um precursor de retinaldeído e do ácido retinóico, que de acordo com Silva et al (2019) mostrou induzir menos eritema apresentando um efeito semelhante ao espessamento epidérmico. Além disso, o uso tópico do retinol produziu uma melhoraclínica nas rugas finas, bem como um aumento na expressão de glicosaminoglicanos e produção de colágeno. Silva et al (2019) ainda sugere o uso da retina (retinaldeíno), precursor imediato do ácido retinóico, em formulações cosméticas por apresentar mais eficiência e tolerância, além de ter demonstradouma redução significativa na profundidade, tamanho e rugosidade das rugas e fornecer diferenças significativas em rugas finas, aspereza da pele, redução de TEWL (perda de água pela pele), aumento da hidratação e do índice de melanina.

A utilização de nanopartículas de lipídios permite a administração de retinóides em meio aquoso, proporcionando estabilização de drogas e liberação controlada. 0 estudo realizado por Morales et al. (2015) demonstrou que retinóides em nanopartículas de lipídeos sólidos, transportadores de lipídeos nanoestruturados, nanoemulsões e as nanocápsulas diminuem a degradação, melhora o direcionamento e aumenta a eficácia no tratamento de doenças de pele.

De acordo com Sathler (2018), o tratamento da pele é baseado no efeito sinérgico das substâncias aplicadas localmente onde o problema ocorre, e outras que 
atuam a nível sistêmico corrigindo e restaurando danos celulares ou para apoiar os sistemas endógenos de defesa natural.Diante dos resultados busca-se mudançasno uso de antioxidantes em formulações farmacêuticas. A indústria é voltada para a ciência e altamente inovadora, porém a inovação não parece estar lidando com ingredientes antioxidantes. No entanto, a baixa solubilidade em sistemas aquosos, baixa polaridade e a fotossenbilidade são preocupações que precisam ser superadas durante o processamento e armazenamento. Além disso, a adesão de um novo ingrediente a formulações é um processo de alto custo e demorado.

O desenvolvimento desse projeto busca evidenciar o potencial uso da vitamina A e seus derivados para o desenvolvimento de novos produtos com aplicabilidade nas mais variadas formulações farmacêuticas no combate ao envelhecimento precoce. A tecnologia de microencapsulação pode fornecer a proteção e estabilização necessária a vitamina $A$, prevenindo ou reduzindo suadegradação.

\section{CONSIDERAÇÕES FINAIS}

A tecnologia farmacêutica em cosméticos está atrelada a diversos tipos de tratamentos sendo o antienvelhecimento um deles, por isso, novas formulações farmacêuticas tem sido alvo de um grande interesse a nível industrial. Diversos estudos realizados demonstram que a utilização da vitamina $A$ e suas derivações na adesão em produtos antienvelhecimento tem se tornado promissores. Ainda mais, acredita-se que a vitamina A quando utilizada na pele em concentrações e período adequados, exercem efeitos que previnem e tratam algumas alterações causadas pelo envelhecimento atuando no estímulo da síntese de colágeno e ação antioxidante.

Sendo assim, é importante ressaltar que o entendimento em relação as propriedades da vitamina $A$, na adesão de formulações as farmacêuticas, se torna mais uma ferramenta no combate e prevenção do envelhecimento precoce da população e que o profissional farmacêutico deve estar atento na hora de manipular ou indicar para que a utilização de produtos com este resultem em tratamentos eficazes, levando em consideração o melhor custo-benefício ao usuário. 


\section{REFERÊNCIAS}

ARAÚJO, M. et al. Witnessing causal nonseparability. New Journal of Physics, v. 17, $n$. $10, \mathrm{p}$.

102001, 2015.

ANTUNES, Cláudia Fernandes et al. Antioxidantes em sistemas de veiculação tópicos. 2017. Dissertação de Mestrado.

BENITES, Bruno Deltreggia; ALVAREZ, Marisa Claudia; SAAD, Sara Teresinha Olalla. Small particles, big effects: the interplay between exosomes and dendritic cells in antitumor immunity andimmunotherapy. Cells, v. 8, n. 12, p. 1648, 2019.

BEZERRA, Mildred Paula. Nanotecnologia em cosméticos; Uma tendênciapromissora para formulações antienvelhecimento. Trabalho de conclusão de curso apresentado a Universidade de Brasília, Faculdade de Ceilândia, 2017.

BIGHETTI, Aparecida Erica, CARVALHO E COLS, Wanderley. Cosmetologia aplicada a estética. Editora Farmacêutica. São Paulo, 2019.

CAMPBELL MK, Farrel SO. Viruses, Cancer and Immunology. In: Lockwood L, White A, Summers A, Broyers R (Eds): Biochemistry (6th Edn). Thomson, pp 405-436, 2015.

COSTA, Vitória Rigue et al. Os efeitos da incidência excessiva da radiação ultravioleta na pele. Artigo de Revisão. Revista Interdisciplinar PensamentoCientífico, v. 5, n. 5, 2019.

GOMES F. Carotenóides: uma possível proteção contra o desenvolvimento de câncer. Rev Nutr., v. 20(5), p. 537-48,2007.

HARRIS. Pele do nascimento á maturidade. Editora Senac São Paulo, SãoPaulo, 2017.

INFOMED. (21 de Outubro de 2017). Obtido

De <http://app7.infarmed.pt/infomed/download_ficheiro.php?med_id=4698\&tipo_d oc $=\mathrm{fi}>$ Acessado em 05 de setembro de 2020.

INFOMED. (22 de Outubro de 2017). Obtido de

<http://app7.infarmed.pt/infomed/download_ficheiro.php?med_id=4129\&tipo_d oc=fi> Acessado em 05 de setembro de 2020.

INPE - Instituto Nacional de Pesquisas Espaciais. Índice de Radiação Ultravioleta Disponível em: <http://satelite.cptec.inpe.br/uv/>. Acesso em 31 de outubro de 2020.

INSTITUTE OF MEDICINE: Food and Nutrition Board. Dietary reference intakes for viamin $A$, vitamin $K$, arsenic, boron, chromium, copper, iodine, iron, manganese, molybdenum, nickel, silicon, vanadium, and zinc. Washington, 
DC: National Academy Press. Disponível em: <https://www.nap.edu/read/10026/chapter/9\#242>.. Acesso em 01 de nov. de 2020.

JULIANI, CECILIA SCHIMMING RISCADO. Medicamentos: noções básicas, tipos e formas farmacêuticas. Saraiva Educação SA, 2014.

KOEKKOEK, W.A. AND VAN ZANTEN, A.R. Antioxidant vitamins and trace elements in critical illness. Nutr. Clin. Pract. 31, 457-474, 2016.

MARZZOCO, Anita, TORRES, Bayardo Baptista. Bioquímica Básica. Editora Guanabara Koogan. 4ed, São Paulo, 2015.

MESQUITA, S. S.; TEIXEIRA, C. M. L. L.; SERVULO, E. F. C. Carotenoides: propriedades, aplicações e mercado. Revista virtual de Química, v. 9, n. 2, p. 672-688, 2017.

MORALES, J. O. et al. Lipid nanoparticles for the topical delivery of retinoids and derivatives. Nanomedicine, v. 10, n. 2, p. 253-269, 2015.

PRACHTHÄUSER, Carlos Otavio. Proteção contra os raios UV solares: prevenção de danos causados aos funcionários por raios UV solares nas obras em rodovias. Engenharia Segurança do Trabalho-Florianópolis, 2020.

PRISTA. N. Tecnologia Farmacêutica. pp. 20-50. 2008.

RIAHI, R.R., BUSH, A.E. AND COHEN, P.R. Topical retinoids: therapeutic Mechanisms in the treatment of photodamaged skin. Am. J. Clin. Dermatol.17, 265-276, 2016.

SANTOS CFND, LUBI N. A importância da fotoproteção na prevenção do envelhecimento precoce. 2014.

SANTOS, A. et al. Piezoresistive E-skin sensors produced with laser engraved molds. Advanced Electronic Materials, v. 4, n. 9, p. 1800182, 2018.

SATHLER, Nathalia Souza. Cosméticos multifuncionais: aspectos históricos, características e uma proposta de formulação. Universidade Federal de Ouro Preto, 2018.

SHALITA. A, Miller B, Mente A, Abramovits W, Loven K, Kakita L. Tazarotene cream versus adapalene cream in the treatment of facial acnevulgaris: a multicenter; double-blinder, randomized, parallel-group study. J. Drugs in Dermatol. Mar/Abr; 4(2): 153-158. 2005.

SILVA, S. et al. Evolution of the use of antioxidants in anti-ageing cosmetics. International Journal of Cosmetic Science, v. 41, n. 4, p. 378- 386, 2019. 
SITE LOOKCHEM <https://www.lookchem.com/Retinol-palmitate/> Acessado em 24 de Novembro de 2020.

SITE PORTAL DA VISÃO CURITIBA < https://portaldavisaocuritiba.com.br/raios-uva-uvb/> Acessado em 24 de novembro de 220

SITE TODA MATÉRIA < https://www.todamateria.com.br/camadas-da-pele/> Acessado em 24 de Novembro de 2020.

SOUTO, E., \& Müller, R. Lipid Nanoparticles: Effect on Bioavailability and Pharmacokinetic Changes. pp. 115-141.2010.

SOUSA, A.K. M. et al. Avaliação do fator de proteção solar (FPS) de fotoprotetores através da técnica de espectrofotometria UV/VIS. 2019.

SOUZA, V. M., Júnior, Daniel Antunes. Ativos Dermatológicos: Dermocosméticos e Nutracêuticos - Volume 10. RBE Editora; 1ạ Edição, 2019.

SORG, O. AND SAURAT, J.H. Topical retinoids in skin ageing: a focused update with reference to sun-induced epidermal vitamin A deficiency. Dermatology 228, 314-325, 2015.

SOUYOUL, S. A.; SAUSSY, K. P.; LUPO, M. P. Nutraceuticals: a review. Dermatology and Therapy, v. 8, n. 1, p. 5-16, 2018.

STATISTA GLOBAL - Global Market Value of the Sun Care Market 2018- 2029 Disponível em: < https://www.statista.com/statistics/812522/sun-care- marketvalue-global/ >. Acesso em 31 de outubro de 2020.

STEINER, Denise. Antioxidantes no tratamento do Envelhecimento Cutâneo. .Cometics e Toiletries. v.23, n.5,p.30, set/out 2011.

VIEIRA, Marta Vinha et al. Desenvolvimento de nanocápsulas poliméricas contendo carotenoides de Haematococcus pluvialis para aplicação tópica cutânea visando atividade quimiopreventiva e fotoprotetora. 2017. 


\title{
CAPÍTULO XXVI
}

\section{DESENVOLYMIENTO DE USTAS DE VERIFICACÃO COM OS PONTOS CRÍ⿴囗十COS DE CONTAMINACÃO CRUZADA POR GLÚTEN - DO PLANTO AO CONSUMO}

\author{
DOI: 10.51859/amplla.csa528.2121-26
}

Berenice da Silva Latosinski ${ }^{1}$

Juliane Elisa Welke ${ }^{2}$

Viviani Ruffo de Oliveira ${ }^{3}$

Virgílio José Strasburg ${ }^{4}$

\begin{abstract}
'Graduada em Nutrição. Universidade Federal do Rio Grande do Sul - UFRGS.
2 Professora Associada do Departamento de Ciências dos Alimentos. Instituto de Ciência e Tecnologia de Alimentos. Universidade Federal do Rio Grande do Sul - UFRGS.

${ }^{3}$ Professor Associada do Departamento de Nutrição. Faculdade de Medicina. Universidade Federal do Rio Grande do Sul - UFRGS.

${ }^{4}$ Professor Adjunto do Departamento de Nutrição. Faculdade de Medicina. Universidade Federal do Rio Grande do Sul - UFRGS.
\end{abstract}

\section{RESUMO}

O consumo de grãos, que contém glúten, é um desencadeador de doenças relacionadas a este grupo de proteínas: doença celíaca, sensibilidade não celíaca ao glúten e alergia ao trigo. O único tratamento para essas doenças é a exclusão completa do glúten da dieta do paciente por toda vida. Este estudo teve como objetivo desenvolver listas de verificação (checklists) com os pontos críticos de contaminação cruzada por glúten para as etapas da produção agrícola até a preparação de refeições. Para subsidiar o desenvolvimento da lista de verificação foram realizadas pesquisas em artigos científicos publicados sobre o tema nas seguintes plataformas: Portal de Periódicos CAPES, Scientific Electronic Library Online (SciELO), Science Direct, PubMed e Google Acadêmico. Também, foram contatados órgãos públicos relacionados com a temática investigada. Os itens de verificação foram descritos no mesmo formato do checklist apresentado na Resolução RDC 275/2001 da ANVISA, com resposta do tipo "Sim / Não / Não Aplicável". Com os dados coletados, foi possível desenvolver quatro listas de verificação de forma a abordar os pontos críticos de contaminação por glúten para os seguintes setores da cadeia de produção: agricultura (7 itens), transporte (7 itens), indústria (24 itens) e alimentação coletiva (21 itens). Estudos futuros são necessários para avaliar a aplicabilidade e eficácia dos checklists em contribuir para a prevenção da contaminação cruzada por glúten.

Palavras-chave: checklist. doença celíaca. hipersensibilidade alimentar. produção de alimentos. 


\section{INTRODUÇÃO}

O glúten é uma mistura complexa de centenas de proteínas relacionadas, mas distintas, principalmente a gliadina e a glutenina, encontradas no trigo, na cevada e no centeio. As estruturas e interações destas proteínas contribuem para as propriedades de elasticidade do glúten. As funções resultantes são essenciais para determinar a qualidade da massa de pão e outros produtos de panificação (BIESIEKIERSKI, 2017).

O consumo de alimentos, que contém glúten, é um desencadeador de doenças relacionadas como a doença celíaca (DC), a sensibilidade não celíaca ao glúten e a alergia ao trigo. Elas se manifestam com sintomas inespecíficos: inchaço, desconforto abdominal, diarreia e flatulência, entre outros (ROSZKOWSKA et al., 2019). A doença celíaca (DC) tem origem genética, autoimune, ocorre em resposta à presença de glúten na dieta, onde as próprias células de defesa do organismo, não reconhecem esse conjunto de proteínas como alimento e agem agredindo a mucosa do intestino, atrofiando as vilosidades e favorecendo o desencadeamento de outros processos patológicos, podendo afetar diversos sistemas do corpo (CASTRO-ANTUNES et al., 2011). A DC acomete em torno de $1 \%$ da população mundial e o único tratamento é uma dieta $100 \%$ livre de glúten e de contaminação cruzada por toda a vida (BASCUÑÁN; VESPA; ARAYA, 2017).

O objetivo desse capítulo é o de apresentar listas de verificação (checklists) para a identificação de pontos críticos de contaminação cruzada por glúten para ser aplicada nos setores de: plantio, transporte, indústria e restaurantes.

\section{REFERENCIAL TEÓRICO}

\subsection{DOENÇA CELIACA}

A quantidade de glúten tolerável varia entre as pessoas com doença celíaca. Embora não haja evidências que sugiram um único limiar definitivo, é improvável que uma ingestão diária de glúten <10 miligramas (mg) cause anormalidades histológicas significativas (AKOBENG; THOMAS, 2008). A Comissão do Codex Alimentarius, um Programa Conjunto da Organização Mundial de Saúde (OMS) e da Food and Agriculture Organization (FAO) estabeleceu que alimentos isentos de glúten 
são aqueles que apresentam teores <20ppm (20 partes por milhão) de glúten, não tendo atualizações mais recentes (FAO, 2008). A Comissão Europeia em 2014 e a Food and Drug Administration (FDA) em 2013, seguindo este exemplo, emitiram regulamentos que definem alimentos rotulado como "sem glúten" como contendo menos $(<)$ de 20 partes por milhão (ppm) de glúten (20 mg/kg de alimento) (EU, 2014; FDA, 2013).

\subsection{CONTAMINAÇÃO CRUZADA}

A contaminação cruzada é a transferência de traços de glúten de um alimento para outro alimento, diretamente ou indiretamente. A contaminação cruzada pode ocorrer na área de manipulação de alimentos, mas também pode ocorrer durante o plantio, colheita, armazenamento, beneficiamento, industrialização e no transporte e comercialização dos produtos (SEE et al., 2015).

Estudos comprovam contaminação cruzada em alimentos rotulados como sem glúten. Em uma revisão sistemática feita nos Estados Unidos por exemplo, a qual que teve como objetivo avaliar a prevalência de contaminação por glúten em produtos industriais e não industriais sem glúten, apresentou resultado positivos para contaminação (acima de 20 ppm) em produtos alimentícios industrializados. Os autores mencionaram que os alimentos rotulados como "sem glúten" podem não ser considerados seguros para pacientes com Dieta Restrita ao Glúten (DRG), uma vez que as informações no rótulo sobre a presença / ausência de glúten não eram confiáveis (FALCOMER et al., 2020). Outro estudo mostrou que a maioria dos pacientes celíacos no Canadá ingere uma quantidade mensurável de 1,6 miligramas ( $\mathrm{mg}$ ) de glúten por quilograma ( $\mathrm{kg}$ ) de alimento (SILVESTER et al., 2020). Já uma revisão sistemática feita no Brasil em 2018 mostrou a ocorrência de contaminação cruzada por glúten em serviços de alimentação e na indústria em produtos com rotulagem "sem glúten" (AGUIAR et al., 2018).

\subsection{LEGISLAÇÕES PARA PRODUTOS ISENTOS DE GLÚTEN}

Na legislação da Europa, as empresas do setor alimentício estão autorizadas a utilizar as seguintes alegações relativas à ausência ou presença reduzida de glúten nos alimentos: "sem glúten" e "muito baixo teor de glúten". Sendo os "sem glúten" com no máximo 20 mg de glúten/kg de alimento e os de "muito baixo teor de glúten" no máximo 
com $100 \mathrm{mg}$ de glúten/kg de alimento como vendido para o consumidor final. A condição para fazer uma declaração "sem glúten" na União Europeia está de acordo com o Codex Alimentarius.

No Brasil, a Lei Federal № 10.674, de 16 de maio de 2003, obriga que os produtos alimentícios comercializados informem sobre a presença de glúten, como medida preventiva e de controle da doença celíaca. A RDC N. 26 - ANVISA, de 02 de julho de 2015, dispõe sobre os requisitos para rotulagem obrigatória dos principais alimentos que causam alergias alimentares.

\section{METODOLOGIA}

Essa pesquisa consiste em um estudo de caráter exploratório, com abordagem qualitativa. Os métodos são de pesquisa bibliográfica e procedimentos observacionais (PRODANOV; FREITAS, 2013).

Para subsidiar o desenvolvimento dos checklists foi realizada a coleta de referências científicas sobre o tema mediante o uso das seguintes plataformas: Portal de Periódicos CAPES, Scientific Electronic Library Online (SciELO), Science Direct, PubMed e Google Acadêmico. Foram buscados estudos, sem limitação de espaço temporal, que analisaram contaminação cruzada em diferentes etapas da logística e beneficiamento dos produtos sem glúten.

Foram utilizados como descritores os termos em idioma português e inglês: contaminação cruzada por glúten, lista de verificação, legislação para rotulagem sem glúten, gluten cross contamination, checklist, gluten-free labeling legislation.

Além disso, foram contatados órgãos públicos como a Empresa de Assistência Técnica e Extensão Rural (EMATER), a Agência nacional de Vigilância Sanitária (ANVISA) e a Associação de Celíacos do Brasil (ACELBRA) presentes nos estados de todo o Brasil para a busca de informações e referências técnicas para a temática investigada.

Os itens dos checklists foram elaborados com base no Programa de Controle de Alergênicos (PCAL) (ANVISA, 2018). O programa auxilia as empresas na organização de um maior controle de qualidade no processo e monitoramento dos riscos de contaminação cruzada por alergênicos. Também foram considerados estudos 
encontrados na literatura que comprovaram contaminação cruzada por glúten por meio de testes e as recomendações das diversas unidades das ACELBRA pelo Brasil.

\section{RESULTADOS E DISCUSSÃO}

A contaminação cruzada por glúten nos alimentos pode ocorrer em várias etapas, dentre as quais destaca-se a produção no campo, no transporte de insumos, em plantas industriais e por fim em ambientes de produção de refeições para coletividades.

É importante mencionar que, não foram identificados na literatura estudos de implantação de sistemas e padronizações que comtemplem todas as etapas da cadeia produtiva. Desse modo, são apresentados quatro checklists de forma a abordar os pontos críticos de contaminação por glúten para os seguintes setores de produção: agricultura, transporte, indústria e alimentação coletiva.

Os checklists estão precedidos pelo Quadro 1 que contém dados de identificação com informações gerais e que pode ser utilizado por qualquer uma das empresas dos quatro segmentos. Os checklists elaborados para verificação dos riscos de contaminação cruzada por glúten encontram-se descritos nos Quadros 2 a 5.

Quadro 1. Identificação da empresa

\begin{tabular}{|l}
\hline Data: \\
\hline Razão Social: \\
\hline Nome Fantasia: \\
\hline Setor (es) da cadeia produtiva avaliado (s): \\
\hline Responsável pela aplicação do checklist: \\
\hline Cargo do responsável: \\
\hline Itens em desacordo com o checklist: \\
\hline
\end{tabular}

Fonte: autores. 
Quadro 2. Produção no campo: identificação de pontos críticos de contaminação por glúten

\begin{tabular}{|c|c|c|c|}
\hline 1 ITENS AVALIADOS NO CAMPO & SIM & NÃO & NA \\
\hline $\begin{array}{l}\text { 1.1 As sementes dos cereais sem glúten são selecionadas de forma que não tenha } \\
\text { permitido mistura de sementes que contêm glúten (trigo, centeio e cevada). }\end{array}$ & & & \\
\hline $\begin{array}{l}1.2 \text { Não são utilizados substratos à base de trigo como fertilizantes ou defensivos } \\
\text { agrícolas, como por exemplo, calda bordalesa, uma mistura de cal, cobre e trigo } \\
\text { como defensivo agrícola, nem outro insumo a base de trigo nos cultivos. }\end{array}$ & & & \\
\hline $\begin{array}{l}1.3 \text { O plantio do alimento sem glúten é feito em lavoura localizada com distância } \\
\text { suficientemente segura para que não haja contaminação de sementes na lavoura } \\
\text { do alimento sem glúten (distância de no mínimo } 10 \text { metros, correnteza da chuva } \\
\text { não carrega as sementes para a lavoura sem glúten). }\end{array}$ & & & \\
\hline $\begin{array}{l}\text { 1.4 As máquinas colheitadeiras, tratores e caminhões que colhem e transportam } \\
\text { os grãos sem glúten são exclusivos para a produção de alimentos sem glúten. }\end{array}$ & & & \\
\hline $\begin{array}{l}1.50 \text { armazenamento dos grãos soltos (em silos, caixas e outros recipientes) ou o } \\
\text { armazenamento dos grãos em sacas costuradas é feito em silos e locais exclusivos } \\
\text { para grãos sem glúten. }\end{array}$ & & & \\
\hline $\begin{array}{l}\text { 1.6 Não é feito rodízio sazonal no plantio de cereais e grãos ou alternância do } \\
\text { plantio no mesmo solo entre os com glúten e os sem glúten. Ex: arroz, trigo, } \\
\text { milho, soja, aveia, feijão, arroz, linhaça etc. deixando resíduos no solo, podendo } \\
\text { ser carreados na próxima colheita de um grão distinto. }\end{array}$ & & & \\
\hline $\begin{array}{l}\text { 1.7 Existe um Procedimento Operacional Padrão (POP) baseado no programa de } \\
\text { controle de alergênicos, para cada etapa de beneficiamento, seguido o plantio } \\
\text { até a entrega do alimento para o consumidor final. }\end{array}$ & & & \\
\hline
\end{tabular}

NA: Não Aplicável. Fonte: autores.

O início do processo de contaminação cruzada pode ocorrer na matéria-prima, ainda durante o cultivo no campo. Na maior parte da agricultura brasileira existe rodízio sazonal no plantio de diversas culturas, entre os tóxicos e os não tóxicos para os celíacos. Lavouras de trigo, centeio e cevada deixam resíduos no solo que podem ser carreados na próxima colheita quando a rotação de culturas é empregada, por exemplo, no cultivo de arroz, milho, soja, aveia, feijão, linhaça etc. Substratos à base de trigo como fertilizantes ou defensivos agrícolas também não são regulamentados para proteger os celíacos. Alguns agricultores, especialmente na produção de alimentos orgânicos, usam calda bordalesa, uma mistura de cal e cobre, em que o trigo é usado para melhorar a aderência da calda, e então usado como defensivo agrícola em diversos cultivos (BRASIL, 
2016). A farinha de trigo também é utilizada de forma isolada no combate de pulgões (BARBOSA et al., 2000). As máquinas colheitadeiras e tratores que entram em contato com multiculturas podem ser contaminados por glúten. Não existe uma norma ou modelo de processo de limpeza e descontaminação para glúten nesses tipos de equipamento. Estudos mostram que ocorre contaminação cruzada no cultivo de aveia por meio de práticas agrícolas comuns, que pode se dar pelo uso dos mesmos implementos e por rotação de culturas com fontes de glúten, como centeio, cevada e trigo (KOERNER et al., 2011; HERNANDO et al., 2008).

Depois da colheita de grãos ou de outros alimentos, essas matérias-primas costumam ir para algum segmento de beneficiamento. No Brasil a principal forma de transporte se dá por meio de rodovias (CASTRO, 2013). Os caminhões que transportam trigo, centeio, cevada, e cereais sem glúten também podem ser pontos de contaminação cruzada. Não existe uma norma ou modelo de processo de limpeza e descontaminação para glúten para esses tipos de veículo. Os itens relacionados ao transporte estão apresentados no quadro 3.

Quadro 3. Transporte: identificação de pontos críticos de contaminação por glúten

\section{ITENS AVALIADOS NO VEÍCULO DE TRANSPORTE}

SIM NÃO

2.10 veículo utilizado para o transporte é totalmente isento de contaminação de resíduos de glúten.

2.2 Os colaboradores utilizam uniforme exclusivo para manipulação de alimentos sem glúten ou uniforme que não tenha sido utilizado anteriormente para manipulação de alimentos com glúten, sem ter sido lavado posteriormente. 2.3 Quando do transporte de alimentos com glúten no mesmo veículo, a embalagem é de plástico completamente integro, sem rasgos e furos.

2.4 Os alimentos que contém glúten (embalados) são acondicionados de forma que evite contato com alimentos sem glúten. Ficando os alimentos sem glúten dispostos na parte superior ou são separados por alguma barreira física.

2.50 meio de transporte utilizado não transportou farinhas que contenham glúten por no mínimo $24 \mathrm{~h}$ antes, evitando assim que resíduos suspensos no ar se acomodem no compartimento de carga ou sob alimentos sem glúten.

2.6 Os colaboradores não levam alimentos com glúten (Ex: consumo de pães, bolachas) para dentro da carroceria do veículo de transporte.

2.70 veículo que transporta frutas, legumes e verduras é exclusivo para o transporte desses alimentos, principalmente quando a empresa transporta farinhas que contenham glúten. Quando não é exclusivo há um processo de higiene que garanta a descontaminação.

NA: Não Aplicável. Fonte: autores.

Conforme consta no guia Orientações do PCAL elaborado pela ANVISA, todas as entregas de matérias-primas devem ser averiguadas antes de serem descarregadas a 
fim de verificar se o transporte foi realizado de acordo com os requisitos de garantia de não contaminação cruzada. Deve-se verificar também se as matérias-primas que possuem alergênicos alimentares estão adequadamente identificadas e embaladas para evitar o uso acidental ou a contaminação cruzada. Além disso, o guia ressalta a importância de ter um cuidado especial no transporte e descarga dos insumos alergênicos que estão sob a forma de pó seco, pois estes apresentam um maior risco de provocar a contaminação cruzada de produtos. Não foram encontradas, na literatura, outras referências sobre cuidados com a contaminação cruzada por glúten no transporte.

Quadro 4. Indústria: identificação de pontos críticos de contaminação por glúten

\begin{tabular}{|c|c|c|c|}
\hline 3 ITENS AVALIADOS NA INDÚSTRIA & SIM & NÃO & NA \\
\hline \multicolumn{4}{|l|}{$\begin{array}{l}3.1 \text { O recebimento da matéria-prima sem glúten é feita por colaboradores com } \\
\text { uniformes exclusivos para recebimento de alimentos sem glúten. }\end{array}$} \\
\hline \multicolumn{4}{|l|}{$\begin{array}{l}3.2 \text { É feita uma avaliação dos fornecedores de matéria-prima (auditoria, } \\
\text { questionamento, relatório, documentação, et.) que garanta a aquisição de } \\
\text { matéria-prima não contaminada por glúten. }\end{array}$} \\
\hline \multicolumn{4}{|l|}{$\begin{array}{l}\text { 3.3 A área de armazenamento da matéria-prima é separada com barreira física e } \\
\text { identificação do local sem glúten. }\end{array}$} \\
\hline \multicolumn{4}{|l|}{$\begin{array}{l}\text { 3.4 A embalagem/invólucro da matéria-prima recebida é integra, limpa e com } \\
\text { rotulagem "sem glúten". }\end{array}$} \\
\hline \multicolumn{4}{|l|}{$\begin{array}{l}\text { 3.5 Matérias-primas com glúten armazenadas em depósitos separados de outras } \\
\text { matérias-primas. }\end{array}$} \\
\hline \multicolumn{4}{|l|}{$\begin{array}{l}\text { 3.6 Quando armazenados no mesmo depósito, as prateleiras com matéria-prima } \\
\text { para produção de alimentos sem glúten estão acima das prateleiras de matéria- } \\
\text { prima contendo glúten. }\end{array}$} \\
\hline \multicolumn{4}{|l|}{$\begin{array}{l}\text { 3.7 Ambientes com ar condicionado, sem ventiladores, sem geração de fluxo de ar } \\
\text { e ausência de fluxo de ar natural da área de produção de alimentos contendo } \\
\text { glúten para a área de produção de alimentos sem glúten, evitando um ambiente } \\
\text { com partículas em suspensão. }\end{array}$} \\
\hline \multicolumn{4}{|l|}{$\begin{array}{l}\text { 3.8 Utensílios utilizados para a limpeza das instalações distintos daqueles utilizados } \\
\text { para a limpeza de equipamentos que entram em contato com os alimentos sem } \\
\text { glúten. }\end{array}$} \\
\hline \multicolumn{4}{|l|}{$\begin{array}{l}\text { 3.9 Equipamentos da linha de produção (misturadores, processadores, } \\
\text { liquidificadores, etc.) identificados e exclusivos para a produção de alimentos sem } \\
\text { glúten. }\end{array}$} \\
\hline \multicolumn{4}{|l|}{$\begin{array}{l}\text { 3.10 Equipamentos de processamento térmico (fornos) exclusivos para alimentos } \\
\text { sem glúten ou, quando de uso comum, não utilizados para assar alimentos sem e } \\
\text { contendo glúten simultaneamente. }\end{array}$} \\
\hline $\begin{array}{l}\text { 3.11 Os colaboradores utilizam uniforme exclusivo na linha de produção de } \\
\text { alimentos sem glúten. }\end{array}$ & & & \\
\hline
\end{tabular}


3.12 Os colaboradores recebem treinamento contínuo sobre contaminação cruzada por glúten, adquirindo capacidade de monitorar pontos críticos de contaminação e aplicar medidas corretivas a fim de evitar a contaminação por glúten.

3.13 Os funcionários não manipulam alimentos que contenham e sem glúten simultaneamente, nem se envolvem em qualquer ato que possa levar à contaminação cruzada, como comer durante o preparo dos alimentos.

3.14 A água ou óleo previamente utilizado na preparação de alimentos contendo glúten não são utilizados no preparo de alimentos sem glúten.

3.15 No preparo ou manipulação dos alimentos sem glúten todos os utensílios da cozinha são separados dos utilizados nos alimentos com glúten.

3.16 Quando são utilizados os mesmos utensílios para manipular alimentos com glúten e sem glúten, o processo de higienização segue algum protocolo de higienização que garanta a não contaminação cruzada.

3.17 Os recipientes para o sal, temperos, e demais insumos, que são usados na preparação de alimentos com glúten são distintos dos utilizados na preparação de alimentos sem glúten.

3.18 A área de processamento é exclusiva para produtos sem glúten.

3.19 Os colaboradores não levam alimentos com glúten (ex: pães, bolachas) para dentro da unidade fabril isenta de glúten.

3.20 Quando a empresa embala cereais com glúten e sem glúten na mesma unidade de fabricação, é testado lote a lote com apresentação periódica de laudos. 3.21 Quando a empresa trabalha com cerais que contêm glúten, existe um espaço físico que separa onde há riscos de partículas em suspensão contaminarem os alimentos que serão rotulados "sem glúten".

3.22 Todos os procedimentos de boas práticas de higiene e fabricação são registrados e usados como parte da avaliação de risco no alimento no processo de fabricação, levando em consideração todo e qualquer ponto que esteja potencialmente sujeito a contaminação por glúten (ex: áreas compartilhadas para armazenamento, produção, embalagem, instalações de equipamentos, linhas de transporte etc.).

3.23 Há um plano de limpeza quando a mesma linha de produção e/ou equipamentos são utilizados para produção de alimentos com glúten com avaliação e validação da não contaminação cruzada em cada lote.

3.24 A empresa realiza rastreabilidade do alimento sem glúten vendido ao cliente final, de forma que seja capaz de retirar do mercado um lote específico de alimento contaminado.

NA: Não Aplicável. Fonte: autores.

Nos processos de beneficiamento e fabricação existe uma imensa diversidade de modelos de fabricação, tipos de maquinários e utensílios que podem deixar eminente o risco de contaminação cruzada. Fica difícil o estabelecimento de um POP único que garanta a eficácia no processo de prevenção de contaminação por glúten. 0 recomendado seria de que cada empresa estabelecesse POP, APPCC e PCAL desde a 
escolha dos fornecedores das matérias-primas até a apresentação e armazenamento final ao consumidor.

Na Europa, a Association Of European Coeliac Societies (AOECS) estabelece um padrão e descreve os requisitos técnicos para a produção de um alimento seguro sem glúten para que os fabricantes possam usar a descrição "sem glúten' (AOECS, 2016). Os produtos devem ser preparados com cuidados especiais sob Boas Práticas de Fabricação (BPF) para evitar a contaminação com glúten e a empresa deve possuir um sistema de APPCC que deve ser implementado para excluir a contaminação por glúten.

De acordo com Lobão (2017) da Federação Nacional das Associações de Celíacos do Brasil (FENALCEBRA), ações precisam ser pensadas desde a escolha e compra de produtos até o consumo do alimento. A Associação traz algumas medidas que devem ser adotadas como BPF e cuidados que o celíaco deve adotar diariamente, como por exemplo, ter local e utensílios exclusivos para manipulação de alimentos sem glúten.

A contaminação cruzada por glúten é um desafio para os celíacos, pois os cereais tóxicos, o centeio, a cevada e, principalmente o trigo, devido a alta utilização na indústria, estão presentes em toda a cadeia de produção: da agricultura até a mesa. Sendo assim, somente um controle de qualidade e rastreabilidade em toda a cadeia produtiva, desde a fase da produção no campo até o consumo final pode dar mais tranquilidade para o consumidor celíaco (ROVEDO, 2018).

O Programa de Controle de Alergênicos, elaborado pela ANVISA (2018), embora não seja um programa específico para celíacos, pode ser usado como guia e assim minimizar os riscos de contaminação cruzada por glúten. Os cereais como trigo, cevada e centeio estão na lista de alergênicos da ANVISA, logo se fossem tomados os cuidados recomendados para alergênicos, não haveria necessidade de ter a inscrição de "sem glúten", pois a lei dos alergênicos já garantiria segurança para o consumidor celíaco.

Em unidades de refeições para coletividade a contaminação cruzada por glúten pode ocorrer, por exemplo, no manuseio de alimentos com glúten e sem glúten por meio dos mesmos utensílios, como panelas, talheres, pratos, copos, forno, esponjas, ar condicionado e por contaminação das matérias-primas. Alguns estudos já foram feitos e mostraram contaminação acima de 20 ppm (FARAGE et al., 2019; PARSONS et al., 2020). 
Quadro 5. Refeições para coletividade: identificação de pontos críticos de contaminação por glúten.

\section{ITENS AVALIADOS EM RESTAURANTES, BARES E SIMILARES}

SIM NÃO NA

4.1 O recebimento da matéria-prima sem glúten é feita por colaboradores com vestimenta livre de contaminação por glúten.

4.2 Áreas de recebimento e depósito de matéria-prima são distintos das áreas de produção, armazenamento e expedição do produto final, evitando que matériaprima com glúten contamine os alimentos sem glúten já preparados.

4.3 É feita uma avaliação dos fornecedores de matéria-prima (auditoria, questionamento, relatório, documentação, certificado de análise de glúten do produtor e / ou outra documentação do fornecedor, etc.) que garanta a aquisição de matéria-prima não contaminada por glúten.

4.4 Quando armazenados no mesmo depósito, as prateleiras com alimentos sem glúten estão acima das prateleiras com alimentos contendo glúten.

4.5 Utensílios utilizados para a limpeza de instalações são distintos daqueles utilizados para a limpeza de equipamentos que entram em contato com alimentos, com produtos de higiene e utensílios exclusivos para uso na área de produção de alimentos sem glúten.

4.6 Os resíduos removidos da área de produção de alimentos com glúten não passam pela área de produção de alimentos sem glúten.

4.7 Descongelamento de alimentos sem glúten mantido em local separado dos alimentos que contêm glúten e sem contato com utensílios e equipamentos onde os alimentos contendo glúten são armazenados ou mantidos em locais que são limpos antes do procedimento.

4.8 Na lavagem na máquina, os panos de prato, os guardanapos e as toalhas de mesa que são usados na confecção de alimentos sem glúten são lavados separados dos que podem estar contaminadas por glúten.

4.9 Nas refeições tipo Buffet, as temperaturas são testadas com uso de termômetro, para aferição das preparações, distintos para os alimentos que possuem glúten em sua composição dos que não possuem.

4.10 Os potes para o sal de cozinha, temperos, etc., que são usados na preparação de alimentos com glúten são distintos dos utilizados na preparação de alimentos sem glúten.

4.11 O local possui área exclusiva para manipulação e preparo de alimentos sem glúten.

4.12 O local possui utensílios (panelas, chapas, eletrodomésticos) exclusivos para manipulação e preparo de alimentos sem glúten.

4.13 Os colaboradores recebem treinamento contínuo sobre contaminação cruzada por glúten, adquirindo capacidade de monitorar pontos críticos de contaminação e aplicar medidas corretivas a fim de evitar a contaminação por glúten.

4.14 A água ou óleo previamente utilizado na preparação de alimentos contendo glúten não é utilizado no preparo de alimentos sem glúten.

4.15 Na distribuição de alimentos, os colaboradores seguem procedimentos para eliminar o risco de contaminação do glúten, por meio da higienização das mãos, uso de utensílios de proteção e luvas descartáveis, e outros sempre que houver contato prévio com alimentos que contenham glúten.

4.16 Há placas de identificação nas preparações expostas em Buffet quanto à presença / ausência de glúten. 
4.17 Os colaboradores não levam alimentos com glúten (ex: consumo de pães, bolachas) para dentro do setor isento de produtos sem glúten.

4.18 A unidade de alimentação exige de seus fornecedores de matérias-primas uma análise de perigos e pontos críticos de controle (APPCC) ao longo de toda a cadeia de produção dos insumos, com emissão de laudos e testes de isenção de glúten para assegurar se a matéria prima é isenta de glúten.

4.19 Não são utilizados os mesmos pass-through e balcões térmicos para manutenção e distribuição das refeições.

4.20 Não é utilizada a mesma câmara fria para armazenamento das sobras limpas isenta ou não de glúten.

4.21 Na lavagem de louça, são utilizadas esponjas distintas de cozinha, uma para louças que tiveram contato com o glúten e outra para utensílios que não tiveram.

NA: Não Aplicável. Fonte: autores.

Espaços em cozinhas de restaurantes para coletividade que sejam exclusivos para preparações sem glúten são desafios que requerem um investimento de infraestrutura que seja adequado com barreiras físicas, controles de fluxo e de trabalhadores além de treinamento dos colaborados (GARIPE et al., 2015; FARAGE et al., 2018, 2019; LERNER et al., 2019; VUKMAN et al., 2021). Esses desafios podem ocorrer em restaurantes, ambientes hospitalares, comerciais e institucionais que atendem trabalhadores e estudantes.

Em dietoterapia, uma dieta sem glúten é o tratamento mais seguro em pacientes com doença DC e outros distúrbios relacionados ao glúten. Embora uma DRG seja eficaz no tratamento da DC, ainda existem muitas complicações para manter este tipo de dieta, como a contaminação cruzada de glúten não intencional (FALCOMER et al., 2020a; FARAGE et al., 2019; PARSONS et al., 2020; VERMA et al., 2017). Atualmente, as fontes de contaminação cruzada do glúten em uma DRG não são claras. No entanto, a identificação de possíveis pontos de contaminação cruzada em práticas de manipulação de alimentos pode auxiliar na redução das chances de consumo de glúten em dietas de pacientes com doença celíaca.

$\mathrm{Na}$ Croácia, uma equipe de profissionais de um hospital infantil desenvolveu um protocolo com medidas de prevenção nos pontos críticos de contaminação por glúten e o resultado foi uma menor taxa de contaminação em todas as refeições preparadas no hospital. Porém esse resultado só foi positivo enquanto os colaboradores estavam recebendo treinamento, deixando evidente a importância dos colaboradores para evitar a contaminação cruzada (VUKMAN et al., 2021). 
No Brasil, Farage et al. (2018) desenvolveram um checklist com 30 itens para prevenção da contaminação cruzada por glúten em serviços de alimentação. O checklist foi validado por 60 locais, sendo considerado de boa reprodutibilidade e consistência interna. Porém, é preciso considerar que não foram verificadas as etapas anteriores das matérias-primas e que esse checklist pode ser inviável para muitos serviços de alimentação, devido a questões de adequação de espaço físico, e ao fluxo de pessoas e de matérias-primas.

Esses estudos mencionados acima mostram a importância da regulamentação e controle contínuos dos alimentos certificados "sem glúten", bem como a importância do controle contínuo desses alimentos. A Associação dos Celíacos do Paraná (ACELPAR) juntamente com a ANVISA desenvolveu um selo "sem glúten" para estabelecimentos de serviços de alimentação como restaurantes, bares, lanchonetes, cantinas e similares. 0 processo para obtenção do selo "sem glúten" consiste em auditorias, conduzida por equipe técnica, em toda a cadeia produtiva (armazenagem, matérias-primas, manipulação, preparo, atendimento, entregas) e o cumprimento de uma série de requisitos a fim de garantir a segurança dos produtos para o consumidor celíaco. Essa cadeia produtiva é verificada e são adotadas medidas de controle, treinamento e capacitação da equipe de produção para que não ocorra a contaminação cruzada por glúten. Os itens de inspeção e demais detalhes de verificação para esse selo não são disponibilizados pela ACELPAR. O selo tem validade de um ano após a sua emissão (ACELPAR, 2019).

Há diversos restaurantes, lanchonetes e similares, no Brasil, que oferecem opções sem glúten. No site da ACELPAR está listado os restaurantes que receberam o selo sem glúten e nas ACELBRA dos estados são disponibilizados os estabelecimentos que oferecem opções sem glúten.

\section{CONSIDERAÇÕES FINAIS}

É importante ressaltar que estudos futuros são necessários para avaliar a eficácia dos modelos de checklists que foram propostos nesse trabalho, e dessa forma contribuir para a prevenção da contaminação cruzada por glúten ao longo da cadeia produtiva. 0 ideal seria que os itens descritos nas listas de verificação previamente elaboradas, 
fossem submetidos à apreciação por especialistas para posterior validação. Também como uma recomendação está a realização de testes laboratoriais para detecção da quantidade de glúten nas etapas de cada segmento. A partir dos resultados poderá ser elaborada uma pontuação ponderando cada ponto crítico. Dessa forma a classificação de toda a cadeia de beneficiamento de produtos sem glúten poderá ser feita de acordo com o risco de oferecer alimentos contaminados por glúten. Além disso, as listas de verificação, depois de validadas, pode servir de subsídio para o estabelecimento de POPs para cada fase do beneficiamento e distribuição de alimentos sem glúten. Assim como, para a implementação de um sistema APPCC em linhas de produção de alimentos sem glúten.

\section{REFERÊNCIAS}

AGÊNCIA NACIONAL DE VIGILÂNCIA SANITÁRIA. RDC № 275, DE 21 de outubro de 2002. Dispõe sobre o Regulamento Técnico de Procedimentos Operacionais Padronizados aplicados aos Estabelecimentos Produtores/Industrializadores de Alimentos e a Lista de Verificação das Boas Práticas de Fabricação em Estabelecimentos Produtores/Industrializadores de Alimentos. Brasília: MAPA, 2019. Disponível em: <https://www.gov.br/agricultura/ptbr/assuntos/inspecao/produtos-vegetal/legislacao-1/biblioteca-de-normasvinhos-e-bebidas/resolucao-rdc-no-275-de-21-de-outubro-de-2002.pdf/view>. Acesso em: 06 abr. 2021.

AGÊNCIA NACIONAL DE VIGILÂNCIA SANITÁRIA. RDC № 26, de 02 de julho de 2015. Dispõe sobre os requisitos para rotulagem obrigatória dos principais alimentos que causam alergias alimentares.. Brasília: ANVISA, 2015. Disponível em: $<$ https://www.gov.br/agricultura/pt-br/assuntos/inspecao/produtosvegetal/legislacao-1/biblioteca-de-normas-vinhos-e-bebidas/resolucao-rdc-no275-de-21-de-outubro-de-2002.pdf/view>. Acesso em: 06 abr. 2021.

AGÊNCIA NACIONAL DE VIGILÂNCIA SANITÁRIA. Perguntas e respostas. 5a edição Brasília, 5 de junho de 2017. Disponível em: <https://www.gov.br/anvisa/pt$\mathrm{br} /$ centraisdeconteudo/publicacoes/alimentos/perguntas-erespostas/rotulagem-de-alergenicos.pdf>. Acesso em: 17 abr. 2021

AGÊNCIA NACIONAL DE VIGILÂNCIA SANITÁRIA. Guia sobre Programa de Controle de Alergênicos. Guia n.05, versão 02, de 16 de outubro de 2018. ANVISA, 2018. Disponível em: >https://www.gov.br/anvisa/pt-br/assuntos/noticiasanvisa/2018/disponivel-novo-guia-sobre-controle-de-alergenicos>. Acesso em: 29 mar. 2021. 
AGUIAR, A. L. F.; ARAÚJO, L. S. Contaminação por glúten em serviços de alimentação e indústria: uma revisão sistemática. 2018. 42 f. Trabalho de Conclusão de Curso (Bacharelado em Nutrição)-Universidade de Brasília, Brasília, 2018.

AKOBENG, A. K.; THOMAS, A. G. Systematic review: tolerable amount of gluten for people with coeliac disease. Alimentary pharmacology \& therapeutics, England, v. 27 , n. 11 , p. $1044-1052,2008$

ASSOCIAÇÃO BRASILEIRA DA INDÚSTRIA DO TRIGO. A farinha de trigo. São Paulo: ABITRIGO, 2019. Disponível em: <http://www.abitrigo.com.br/conhecimento/afarinha-de-trigo/> . Acesso em: 16 out. 2020.

ASSOCIAÇÃO DOS CELÍACOS DO PARANÁ (ACELPAR) Associação dos Celíacos do Paraná entrega Selo Sem Glúten para 17 estabelecimentos. Boletim Setorial - FIEPR, Curitiba, 27 de Setembro de 2019. Disponível em: $<$ http://www.fiepr.org.br/boletins-setoriais/1/especial/associacao-dosceliacos-do-parana-entrega-selo-sem-gluten-para-17-estabelecimentos-231762-419434.shtml>. Acesso em: 07 abr. 2021.

ASSOCIATION OF EUROPEAN COELIAC SOCIETIES. AOECS Standard for Gluten-Free Foods: Technical requirements for licensing the Crossed Grain Symbol. Brussels: AOECS, September 2016. Disponível em: <https://www.aoecs.org/sites/default/files/ckeditor/AOECS\%20Standard\%20Se pt\%202016.pdf>. Acesso em: 07 abr. 2021.

BARBOSA, F. R.; SIQUEIRA, K. M. M.; MOREIRA, W. A.; HAJI, F. N.P; ALENCAR, J. A. Estratégias de controle do pulgão da acerola em plantios irrigados no Submédio São Francisco. Embrapa Semi-Árido, Petrolina, PE (Brasil). 5 p. il. (Embrapa SemiÁrido. Instruções Técnicas, 34), 2000.

BASCUÑÁN, K. A.; VESPA, M. C.; ARAYA, M. Celiac disease: understanding the glutenfree diet. European journal of nutrition, Germany, v. 56, n. 2, p. 449-459, 2017.

BIESIEKIERSKI, J. R. What is gluten? Journal of gastroenterology and hepatology, Australia, v. 32 Suppl 1, p. 78-81, 2017.

BRASIL. Ministério da Agricultura, Pecuária e Abastecimento. Caldas de sal e farinha de trigo para controlar insetos prejudiciais. MAPA, 2016. Disponível em: $<$ https://www.gov.br/agricultura/pt-

br/assuntos/sustentabilidade/organicos/fichas-agroecologicas/arquivossanidade-vegetal/23-calda-de-sal-e-farinha-de-trigo-para-controlar-insetosprejudiciais.pdf>. Acesso em: 25 mar. 2021.

CASTRO. A.; MARGARIDA M. et al. Frequency distribution of HLA DQ2 and DQ8 in celiac patients and first-degree relatives in Recife, northeastern Brazil. Clinics (Sao Paulo, Brazil), [s. I.], v. 66, n. 2, p. 227-231, 2011. 
CASTRO, N. Mensuração de externalidades do transporte de carga brasileiro. J. Transp. Lit., Manaus , v. 7, n. 1, p. 163-181, Jan. 2013 . Disponível em <http://www.scielo.br/scielo.php?script=sci_arttext\&pid=S223810312013000100010\&lng=en\&nrm=iso>. Acesso em: 18 abr. 2021.

COMMISSION IMPLEMENTING REGULATION (EU). On the requirements for the provision of information to consumers on the absence or reduced presence of gluten in food. Official Journal of the European Union, n. 828, 30 July 2014. Disponível em: $\quad<$ https://eur-lex.europa.eu/legalcontent/EN/TXT/?uri=CELEX:32014R0828>. Acesso em: 05 abr. 2021.

FALCOMER, A. L. et al. Gluten contamination in food services and industry: A systematic review. Critical reviews in food science and nutrition, United States, v. 60, n. 3, p. 479-493, 2020. a.

FARAGE P, et al. Content Validation and Semantic Evaluation of a Check-List Elaborated for the Prevention of Gluten Cross-Contamination in Food Services. Nutrients. 2017 Jan 6;9(1):36. doi: 10.3390/nu9010036. PMID: 28067805; PMCID: PMC5295080.

FARAGE, P. et al. Gluten-Free Diet: From Development to Assessment of a Check-List Designed for the Prevention of Gluten Cross-Contamination in Food Services. Nutrients, [s. I.], v. 10, n. 9, 2018.

FARAGE, P. et al. Accidental Gluten Contamination in Traditional Lunch Meals from Food Services in Brasilia, Brazil. Nutrients, [s. I.], v. 11, n. 8, 2019.

FEDERAÇÃO NACIONAL DAS ASSOCIAÇÕES DE CELÍACOS DO BRASIL(FENACELBRA). Milhões têm doença celíaca, mas o diagnóstico é difícil. Publicações- Notícias. $2017 . \quad$ Disponível em: <http://www.fenacelbra.com.br/fenacelbra/blog/2015/11/28/milhoes-temdoenca-celiaca-mas-o-diagnostico-e-dificil/>. Acesso em: 14 maio 2021.

FOOD AND AGRICULTURE ORGANIZATION OF THE UNITED NATIONS; WORLD HEALTH ORGANIZATION. CODEX ALIMENTARIUS - Standard for foods for special dietary use for persons intolerant to gluten: CXS 118-1979. Adopted in 1979. Amended in 1983 and 2015. Revised in 2008. [Rome]: FAO, 2008. Disponível em: $<$ http://www.fao.org/fao-who-codexalimentarius/shproxy/en/?Ink=1\&url=https\%253A\%252F\%252Fworkspace.fao.org\%252Fsites\% 252Fcodex\%252FStandards\%252FCXS\%2B118-

1979\%252FCXS_118e_2015.pdf>. Acesso em: 11 abr. 2021.

FOOD AND AGRICULTURE ORGANIZATION OF THE UNITED NATIONS; WORLD HEALTH ORGANIZATION. Codex Alimentarius: International Food Standards. Rome: FAO, WHO, $2021 . \quad$ Disponível em: <http://www.codexalimentarius.org/download/standards/291/CXS_118e_2015 .pdf>. Acesso em: 27 set. 2020. 
FOOD AND DRUG ADMINISTRATION. Gluten-Free Labeling of Foods. FDA, dez. 2013. Disponível em: <https://www.fda.gov/food/food-labeling-nutrition/gluten-freelabeling-

foods\#: :text=On\%20August\%202\%2C\%202013\%2C\%20FDA, defined\%20standa rd\%20for\%20gluten\%20content>. Acesso em: 02 abr. 2021.

FOOD STANDARS AGENCY. Food allergen labelling and information requirements: Technical Guidance. FSA, jun. 2020. Disponível em: <https://www.food.gov.uk/sites/default/files/media/document/fsa-foodallergen-labelling-and-information-requirements-technical-guidance_0.pdf $>$. Acesso em: 26 set. 2020.

GARIPE, L. Y. et al. [Not Available]. Acta gastroenterologica Latinoamericana, Argentina, v. 45, n. 3, p. 190-197, 2015.

HERNANDO, A. et al. Measurement of wheat gluten and barley hordeins in contaminated oats from Europe, the United States and Canada by Sandwich R5 ELISA. European journal of gastroenterology \& hepatology, England, v. 20, n. 6, p. 545-554, 2008.

KOERNER, T. B. et al. Gluten contamination in the Canadian commercial oat supply. Food additives \& contaminants. Part A, Chemistry, analysis, control, exposure \& risk assessment, [s. I.], v. 28, n. 6, p. 705-710, 2011.

LERNER, B. A. et al. Detection of Gluten in Gluten-Free Labeled Restaurant Food: Analysis of Crowd-Sourced Data. The American journal of gastroenterology, [s. I.], v. 114, n. 5, p. 792-797, 2019.

LOBÃO, N. Boas práticas para evitar a contaminação por glúten. Fenacelbra, 2017. Disponível em: <http://www.fenacelbra.com.br/arquivos/livros_download/noadia_lobao_boas _praticas.pdf>. Acesso em 27mar. 2021.

PARSONS, K. et al. Gluten cross-contact from common food practices and preparations. Clinical nutrition (Edinburgh, Scotland), England, 2020.

PRODANOV, C.C.; FREITAS, E.C. Metodologia do trabalho científico: métodos e técnicas da pesquisa e do trabalho acadêmico. Novo Hamburgo: Feevale; 2013 Disponível em: $\quad<$ https://www.feevale.br/institucional/editora-feevale/metodologia-dotrabalho-cientifico---2-edicao>. Acesso em: 28 set. 2020.

ROSZKOWSKA, A. et al. Non-Celiac Gluten Sensitivity: A Review. Medicina (Kaunas, Lithuania), [s. I.], v. 55, n. 6, 2019.

SEE, J. A. et al. Practical insights into gluten-free diets. Nature reviews. Gastroenterology \& hepatology, England, v. 12, n. 10, p. 580-591, 2015. 
SILVESTER, J. A. et al. Most Patients With Celiac Disease on Gluten-Free Diets Consume Measurable Amounts of Gluten. Gastroenterology, [s. I.], v. 158, n. 5, p. 14971499.e1, 2020.

VERMA, A. K. et al. Gluten Contamination in Naturally or Labeled Gluten-Free Products Marketed in Italy. Nutrients, [s. I.], v. 9, n. 2, 2017.

VUKMAN, D. et al. Design and evaluation of an HACCP gluten-free protocol in a children's hospital. Food Control, [s. I.], v. 120, p. 107527, 2021. Disponível em: <https://www.sciencedirect.com/science/article/pii/S0956713520304436>. Aceso em: 09 mar. 2021. 


\title{
CAPITULO XXVII
}

\section{ESTUDO FOTOPROIETOR UIIUZANDO A FASE CLOROFÓRMICA DA ESPÉCIE RHAPHIODON ECHINUS (NESS \& MART.) SCHAUER}

\section{DOI: 10.51859/amplla.csa528.2121-27}

\author{
Maurício André Campos de Medeiros ${ }^{1}$ \\ Aleson Pereira de Sousa ${ }^{2}$ \\ Raline Mendonça dos Anjos ${ }^{3}$ \\ Luciano de Brito Júnior ${ }^{3}$ \\ Gabriela Lemos de Azevedo Maia ${ }^{4}$ \\ Abrahão Alves de Oliveira Filho ${ }^{3}$
}

\begin{abstract}
Graduando do curso de Ciências Biológicas. Universidade Federal De Campina Grande - UFCG
2 Doutorando do Programa de Desenvolvimento e Inovação tecnológica em Medicamentos. Universidade Federal da Paraíba- UFPB.

${ }^{3}$ Professor(a) da Unidade Acadêmica de Ciências Biológicas (UACB). Universidade Federal de Campina Grande - UFCG 4 Professora do Departamento de Ciências Farmacêuticas. Universidade Federal do Vale do São Francisco - UNIVASF.
\end{abstract}

\section{RESUMO}

A radiação ultravioleta que incide na superfície da terra apresenta-se em diferentes comprimentos de onda. A exposição constante a esses raios pode causar sérios problemas dermatológicos. As plantas medicinas são muito utilizadas na prevenção de danos ao organismo, a fitoterapia possui inúmeras substâncias que são sintetizadas no seu metabolismo secundário com propriedades bioativas. Os flavonoides são metabólitos secundários que possuem efeito positivo contra a radiação ultravioleta. A espécie Rhaphiodon echinus, conhecida popularmente como betônica, apresenta esses compostos em sua composição bioquímica. Diante disso, o estudo teve como objetivo, avaliar, in vitro, a atividade fotoprotetora da fase clorofórmica de $R$. echinus. Para efetivação do experimento, utilizou-se a fase clorofórmica da planta, que foi diluído em diferentes concentrações $(50,100,500$ e $1000 \mu \mathrm{g} / \mathrm{mL})$. Produzindo varreduras com auxílio de um espectrofotômetro sobre a faixa UV de 290 a $320 \mathrm{~nm}$ com intervalos de 5 $\mathrm{nm}$, a cada 5 minutos. De acordo com os resultados obtidos, apenas as duas maiores concentrações ( $500 \mu \mathrm{g} / \mathrm{mL}$ e $1000 \mu \mathrm{g} / \mathrm{mL}$ ) apresentaram bons índices de fotoproteção, sendo 11,28 e 25,00 respectivamente. Com isso, a atividade fotoprotetora da fase clorofórmica de $R$. echinus mostrou-se promissora, sugere uma possível utilização de extratos da planta em formulações fitocosméticas.

Palavras-chave: fitoterapia; fotoproteção; metabólitos secundários.

\section{INTRODUÇÃO}

A radiação solar ultravioleta (UV) engloba diferentes tipos, mediante o comprimento de onda considerado, sendo UV-A (320 a $400 \mathrm{~nm}$ ) e UV-B (280 a $320 \mathrm{~nm}$ ) 
os quais ultrapassam a proteção feita pelo camada de gases do ozônio (JUCHEM et al., 1998). A pele, apesar de ser um órgão de proteção do organismo humano, ao prolongarse em constante exposição à radiação, pode sofrer consequências danosas e desenvolver doenças, bem como o surgimento de células neoplásicas (OKUMO; VILELA, 2005).

Muitas pessoas estão expostas aos raios UV, consequentemente por causa da dinâmica de seu trabalho, e a falta de cuidado e orientação sobre esses riscos, desenvolvendo lesões em várias partes do corpo, sendo necessário o incentivo da utilização de protetores ou filtros solares, que podem inibir esses efeitos (HAYASHIDE et al., 2010).

No Brasil, uma das doenças que apresenta grande predominância é o câncer de pele não melanoma, existindo, atualmente, métodos para diagnosticar nos primórdios da doença, beneficiando o paciente com maiores possibilidades de tratamento (INCA, 2016).

Segundo Araújo e Souza (2008), os filtros solares agem diminuindo a absorção da radiação UV no organismo humano, protegendo a pele, e consideram-se também, que o impacto na proteção, que um protetor alcança, está vinculado as informações agregadas de seus componentes como absorção, dispersão e forma de interagir.

As universidades brasileiras possuem maior abrangência em pesquisas com produtos naturais, com isso, uma grande parte de setores empresariais impulsiona a progressão de produtos de fotoproteção de origem natural, estimulando estudiosos em suas pesquisas e desenvolvendo uma melhor interação entre universidades e instituições empresariais para o mercado (GUARATINI et al., 2009).

As plantas medicinais são bastante utilizadas pelo conhecimento popular e apresentam diversos compostos orgânicos em suas estruturas e extratos, podendo trazer resultados promissores em estudos, sendo necessários métodos para avaliar o potencial desses produtos sintetizados por elas (MACIEL et al., 2002).

Os metabólitos secundários das plantas produzem diversas substâncias e, apesar de estarem associadas à adaptação e a predominância no seu habitat, oferecem compostos orgânicos que podem beneficiar à saúde das pessoas em inúmeras atividades (PEREIRA; CARDOSO, 2012). 
Os flavonoides são metabolitos secundários sintetizados por inúmeras plantas e apresenta muitas atividades positivas, como sua utilização com finalidades terapêuticas ou medicinais (ZUANAZZI; MONTANHA; ZUCOLOTTO, 2017). Esses compostos fenólicos têm considerável eficiência na fotoproteção (ROSA et al., 2008).

A espécie Rhaphiodon echinus S. pertence à família Lamiaceae, podendo ser encontrada em alguns biomas do Brasil, a qual o gênero é monotípico (FLORA DO BRASIL, 2020). Em um experimento sobre sua composição bioquímica a espécie apresentou alguns metabólitos secundários, entre eles, flavonoides. No conhecimento popular essa planta é utilizada contra sintomas gripais e cólica intestinal (PIO et al., 2019).

De acordo com as informações expostas sobre à utilização de produtos naturais e a fotoproteção, esse trabalho tem como objetivo avaliar, in vitro, o potencial fotoprotetor da fase clorofórmica da espécie Rhaphiodon echinus.

\section{MATERIAL E MÉTODOS}

\subsection{EXTRATO VEGETAL}

Para o desenvolvimento do estudo in vitro, foi utilizado o extrato fase acetato que foi ofertado pela equipe da Profa. Dra. Gabriela Lemos de Azevedo Maia da Universidade Federal do Vale do São Francisco.

\subsection{AVALIAÇÃo do FATOR DE PROTEÇÃo SOLAR DO EXTRATO FASE ACETATO DE RHAPHIODON ECHINUS}

A análise espectrofotométrica de absorção utilizando a fase acetato da espécie Rhaphiodon echinus, realizou-se no espectro da radiação ultravioleta como proposto por Mansur et al.(1986). Deste modo, efetuaram-se varreduras de 290 a $320 \mathrm{~nm}$, somando a isso, intervalos de $5 \mathrm{~nm}$ com duração de 5 minutos. Ao ser finalizado cada intervalo, foi realizado a mensuração das absorbâncias.

Na obtenção da leitura, foi utilizado o espectrofotômetro digital (Biospectro ${ }^{\circledR}$ ) com cubeta de quartzo de $1 \mathrm{~cm}$. Efetuada a mensuração das absorbâncias, os dados extraídos foram submetidos a equação de Mansur et al. (1986) para verificar o Fator de 
Proteção Solar (FPS) in vitro. Esse método coloca em lista o efeito eritomatogênico e a intensidade da radiação (EE x I) que foram medidos por Sayre et al.(1979) (Quadro 1).

Sendo que a fórmula de Mansur et al.(1986) é também composta pela leitura espectrofotométrica da absorbância da solução e fator de correção (= 10). Essa equação pode ser observada, a seguir:

FPS espectrofotométrico $=$ FC. $\Sigma_{290}^{320} \mathrm{EE}(\lambda) \cdot \mathrm{I}(\lambda) \cdot \operatorname{Abs}(\lambda)$

Na qual: FPS = fator de proteção solar; FC = fator de correção, calculado de acordo com dois filtros solares de FPS conhecidos e testados em seres humanos de tal forma que um creme contendo $8 \%$ de homossalato resultasse no FPS $4 ; \operatorname{EE}(\lambda)=$ efeito eritemogênico da radiação de comprimento de onda; $I(\lambda)=$ a intensidade da luz solar no comprimento de onda e $\operatorname{Abs}(\lambda)=$ a absorbância da formulação no comprimento de onda.

Quadro 1. Relação efeito eritemogênico (EE) versus intensidade da radiação (I) conforme o comprimento de onda $(\lambda)$

\begin{tabular}{|c|c|}
\hline$\lambda / \mathbf{n m}$ & EE x I \\
\hline 290 & 0,0150 \\
\hline 295 & 0,0817 \\
\hline 300 & 0,2874 \\
\hline 305 & 0,3278 \\
\hline 310 & 0,1864 \\
\hline 315 & 0,0839 \\
\hline 320 & 0,0180 \\
\hline
\end{tabular}

Fonte: Sayre et al. (1979)

\section{RESULTADOS E DISCUSSÕES}

A utilização de protetor solar e demais recursos que protejam a pele não pode ser descartada, devendo ser impulsionada para benefício das pessoas, principalmente num contexto em que muitas doenças são causadas pela radiação ultravioleta (BALOGH et al., 2011). 
Com a realização dessa pesquisa, como mostra a Tabela 1, a fase clorofórmica de Rhaphiodon echinus apresentou valores consideráveis de fator de proteção.

Tabela 1. FPS da fase clorofórmica de Rhaphiodon echinus

\begin{tabular}{|c|c|c|c|c|}
\hline Concentrações $(\mu \mathrm{g} . \mathrm{mL}-1)$ & $50 \mu \mathrm{g} / \mathrm{mL}$ & $100 \mu \mathrm{g} / \mathrm{mL}$ & $500 \mu \mathrm{g} / \mathrm{mL}$ & $1000 \mu \mathrm{g} / \mathrm{mL}$ \\
\hline FPS & 2,27 & 3,32 & 11,28 & 25,00 \\
\hline
\end{tabular}

Fonte: Dados da pesquisa, 2020.

Em conformidade com a RDC № 30, de 1ㅇ de junho de 2012, da Agência Nacional de Vigilância Sanitária (ANVISA), ao ser aprovado o regulamento técnico Mercosul sobre protetores solares em cosméticos e dá outras providências, promove-se uma regulamentação técnica aplicada aos produtos e cosméticos destinados a proteção solar da pele, que, apresenta o fator mínimo de proteção solar igual a 6 (FPS) (BRASIL, 2012).

Com base na análise dos dados apresentados, observa-se que apenas as duas maiores concentrações $(500 \mu \mathrm{g} / \mathrm{mL}$ e $1000 \mu \mathrm{g} / \mathrm{mL}$ ) apresentaram valor de fator de fotoproteção acima de 6 (FPS), com os valores de 11,28 e 25,00 respectivamente, sendo, também, às de maiores absorbâncias no experimento, utilizando a fase clorofórmica.

Segundo Medeiros et al. (2020), utilizando o extrato etanólico da espécie Rhaphiodon echinus em um estudo in vitro, o potencial fotoprotetor apresentou-se à cima de 6 (FPS) nas concentrações de $(500 \mu \mathrm{g} / \mathrm{mL}$ e $1000 \mu \mathrm{g} / \mathrm{mL})$, sendo respectivamente 23,65 e 25,00 (FPS). Isso posto, pode-se considerar o potencial biológico que essa planta pode apresentar como produto natural, agregando um possível uso na síntese de fotoprotetores.

Extratos dessa planta podem apresentar outras propriedades biológicas. Em um estudo para verificar o efeito do extrato aquoso e etanólico da espécie utilizando-os em cepas de Candida albicans, os resultados mostraram-se promissores, levando-os a uma possível consideração para o tratamento de doenças, já que se apresentaram com ação fungicida (FERREIRA et al.,2019).

A fitoterapia tem sido uma alternativa terapêutica muito praticada pelas pessoas. O conhecimento popular promove o uso de plantas medicinais, com isso, devem-se impulsionar estudos com estas plantas, visando ampliar sua aplicação em 
diversas situações, onde se possa conhecer sua ação benéfica ou negativa à saúde das pessoas (TOMAZZONI; NEGRELLE; CENTA, 2006).

\section{CONCLUSÃo}

Com base nos dados obtidos nessa pesquisa, pode-se observar que o extrato clorofórmico da espécie Rhaphiodon echinus, apresentou uma atividade promissora como fotoprotetor. No entanto, mesmo apresentando potencial fotoprotetor considerado, in vitro, existe a necessidade de efetuar mais estudos in vivo para confirmar esse potencial biológico e conhecer o mecanismo de ação desta atividade.

\section{REFERÊNCIAS}

ARAÚJO, T. S.; DE SOUZA, S. O. Protetores solares e os efeitos da radiação ultravioleta. Scientia plena, v. 4, n. 11, 2008.

BALOGH, T. S.; VELASCO, M. V. R.; PEDRIALI, C. A.; KANEKO, T. M.; BABY, A. R. Proteção à radiação ultravioleta: recursos disponíveis na atualidade em fotoproteção. An Bras Dermatol, v. 86, n. 4, p. 732-42, 2011.

BRASIL. Agência Nacional de Vigilância Sanitária. Resolução RDC N³0, de 1 으 de junho de 2012. Aprova Regulamento técnico do MERCOSUL sobre protetores solares em cosméticos. Diário Oficial da União. Brasília, DF, 2012.

FERREIRA, J. L. S.; SOUZA SIQUEIRA, D.; DELGADO, L. A.; CAVALCANTE, J. N. M.; OLIVEIRA SILVA, R. C. M.; FILGUEIRA, R. C.; ... OLIVEIRA FILHO, A. A. Comparação da atividade antifúngica dos extratos etanólico e aquoso de Rhaphiodon echinus (Lamiaceae) contra cepas de Candida albicans. REVISTA UNINGÁ, v. 56, n. 3, p. 1-8, 2019.

GUARATINI, T.; CALLEJON, D. R.; PIRES, D. C.; LOPES, J. N. C.; LIMA, L. M.; GIANNELLA NETO, D.; ... LOPES, N. P. Fotoprotetores derivados de produtos naturais: perspectivas de mercado e interações entre o setor produtivo e centros de pesquisa. Química Nova, v. 32, n. 3, p. 717-721, 2009.

HAYASHIDE, J. M.; MINNICELLI, R. S.; OLIVEIRA, O. D.; SUMITA, J. M.; SUZUKI, N. M.; ZAMBIANCO, C. A.; ... MORRONE, L. C. Doenças de pele entre trabalhadores rurais expostos a radiação solar. Estudo integrado entre as áreas de Medicina do trabalho e Dermatologia. Rev Bras Med Trab, v. 8, n. 2, p. 97-104, 2010.

INSTITUTO NACIONAL DO CÂNCER. Monitoramento das ações de controle do câncer de pele. Informativo: detecção precoce, v.3, 2016. Disponível em: 
<https://www.inca.gov.br/sites/ufu.sti.inca.local/files//media/document//infor mativo-deteccao-precoce-3-2016.pdf>. Acesso em: 20 maio 2020.

JUCHEM, P.; HOCHBERG, J.; WINOGRON, A.; ARDENGHY, M.; ENGLISH, R. Riscos à saúde da radiação ultravioleta. Revista Brasileira de Cirurgia Plástica, v. 13, n. 2, p. 3160, 2001.

MACIEL, M. A. M.; PINTO, A. C.; VEIGA JR, V. F.; GRYNBERG, N. F.; ECHEVARRIA, A. Plantas medicinais: a necessidade de estudos multidisciplinares. Química nova, v. 25, n. 3, p. 429-438, 2002.

MANSUR, J. D. S.; BREDER, M. N. R.; MANSUR, M. C. D. A.; AZULAY, R. D. Determinaçäo do fator de proteçäo solar por espectrofotometria. An. Bras. Dermatol, p. 1214, 1986.

MEDEIROS, M. A. C.; SIMÕES, M. M.; SANTOS, B.; MARQUES, F. M. C.; SILVA LEITE, M. F. M.; OLIVEIRA, H. M. B. F.; ... OLIVEIRA FILHO, A. A. Avaliação da atividade fotoprotetora do extrato etanólico de Rhaphiodon echinus Schauer. Research, Society and Development, v. 9, n. 7, p. e585974410-e585974410, 2020.

OKUNO, E.; VILELA, M. A. C. Radiação ultravioleta: características e efeitos. São Paulo. Editora Livraria da Física, 2005.

PASTORE, J. F. B; MOTA, M. C. A. Rhaphiodon in Flora do Brasil $2020 \mathrm{em}$ construção. Jardim Botânico do Rio de Janeiro. Disponível em: <http://floradobrasil.jbrj.gov.br/reflora/floradobrasil/FB8295>. Acesso em: 10 jul. 2020.

PEREIRA, R. J.; CARDOSO, M. G. Metabólitos secundários vegetais e benefícios antioxidantes. Journal of biotechnology and biodiversity, v. 3, n. 4, 2012.

PIO, I. D. S. L.; LAVOR, A. L.; DAMASCENO, C. M. D.; MENEZES, P. M. N.; SILVA, F. S.; MAIA, G. L. A. Traditional knowledge and uses of medicinal plants by the inhabitants of the islands of the São Francisco river, Brazil and preliminary analysis of Rhaphiodon echinus (Lamiaceae). Brazilian Journal of Biology, v. 79, n. 1, p. 87-99, 2019.

ROSA, M. B.; OlIVEIRA, T. G.; CARVALHO, C. A.; SILVA, F. D.; CARVALHO, L. M.; NASCIMENTO, P. C.; PERES, R. L. Estudo espectrofotométrico da atividade fotoprotetora de extratos aquosos de Achillea millefolium, Brassica oleracea Var. Capitata, Cyperus rotundus, Plectranthus barbatus, Porophyllum ruderale (Jacq.). Revista Eletrônica de Farmácia, v. 5, n. 1, 2008.

SAYRE, R. M.; AGIN, P. P.; LEVEE, G. J.; MARLOWE, E. A comparison of in vivo and in vitro testing of sunscreening formulas. Photochemistry and Photobiology, v. 29, n. 3, p. 559-566, 1979. 
TOMAZZONI, M. I.; NEGRELLE, R. R. B.; CENTA, M. L. Fitoterapia popular: a busca instrumental enquanto prática terapeuta. Texto \& Contexto-Enfermagem, v. 15, n. 1, p. 115-121, 2006.

ZUANAZZI, J. A. S.; MONTANHA, J. A.; ZUCOLOTTO, S. M. Flavonoides. In: SIMÕES, C. M. O. et al. Farmacognósia: do produto natural ao medicamento. Porto Alegre: Artmed, 2017. e-PUB 


\title{
CAPITULO XXVIII
}

\section{ANÁLSE DAS TÉCNICAS ANATOOMICAS E DA APUCABILDADE DA GUCERINACÃO COMO PROPOSTA DE SUBSTIIUICÃO DO FORMOL}

\section{DOI: 10.51859/amplla.csa528.2121-28}

\author{
Valberto Barbosa de Oliveira ${ }^{1}$ \\ Clenia Maria Pereira Batista ${ }^{2}$
}

\author{
Mestrando em Desenvolvimento de Processos Ambientais. Universidade Católica de Pernambuco - UNICAP \\ 2 Professora Titular da Faculdade Santa Emília de Rodat - FASER/UNINEVES
}

\section{RESUMO}

As aulas práticas podem ajudar no processo de desenvolvimento de conceitos científicos, além de permitir que os estudantes aprendam como desenvolver soluções para problemas. A utilização de cadáveres é um método de ensino amplamente disseminado nas aulas de anatomia. Em decorrência desse fato existe a necessidade de preservação de corpos para estudos anatômicos e histológicos. O fixador mais utilizado no Brasil é o formol, no qual deve ser evitado porque apresenta propriedades tóxicas, além do potencial de risco para a saúde. A preocupação com a saúde tratando-se de ambientes insalubres é extremamente importante, isso se enquadra perfeitamente dentro dos laboratórios de anatomia. A segunda opção mais usada nos laboratórios de anatomia para fixação é a glicerina, que tem como características ser incolor, inodoro, e exerce atividade antisséptica, atuando contra fungos e bactérias. O objetivo deste projeto foi fazer uma análise da glicerinação a fim de demonstrar a necessidade da substituição do formol. A glicerinação foi realizada em três etapas: desidratação, clareamento e fixação. Após a realização, as peças se mostraram muito mais fáceis de serem manipuladas, quando comparadas às conservadas em formol, apresentando menos peso e cheiro. A glicerinação embora mais cara que a formolização, proporcionou estruturas com aspectos anatômicos mais agradáveis e estéticos, além de uma maior clareza das estruturas. Os benefícios em relação a técnica é principalmente em relação a saúde dos usuários, meio ambiente e o ensino, sendo essa a principal vantagem da glicerinação. Conclui-se que a glicerinação é uma técnica satisfatoriamente capaz de substituir o formol.

Palavras-chave: Técnicas anatômicas. Ensino. Formaldeído. Glicerina.

\section{INTRODUÇÃO}

Para a compreensão do conteúdo de forma eficaz e significativa, os professores devem lançar mão da utilização de planejamento, montagem e aplicação de materiais didáticos que dão à aula a importância de uma prática de ensino diferenciada (VILHENA 
et al., 2006). As aulas práticas podem ajudar no processo de interação e desenvolvimento de conceitos científicos, além de permitir que os estudantes aprendam como abordar objetivamente o seu mundo e como desenvolver soluções para problemas complexos (LUNETTA, 1991).

A utilização de cadáveres nas aulas práticas é um método de ensino amplamente disseminado. Em decorrência desse fato existe a necessidade de preservação de corpos para estudos anatômicos e histológicos o que se torna maior a cada dia, pois é cada vez mais difícil preencher a demanda de cadáveres nas faculdades das áreas de saúde. Portanto, a utilização destes corpos teria que ser otimizada, para que um maior número de alunos e pesquisadores possam usufruir das vantagens do estudo em um corpo natural. A preocupação quanto à conservação anatômica existe a mais de cinco mil anos, sendo importante até os dias de hoje. Devido à contribuição no aprendizado prático melhorando as habilidades aplicativas, assimilativas e compreensivas da disciplina de anatomia, preparando os estudantes para uma situação real, além do caráter científico acadêmico. A conservação de peças cadavéricas tem como objetivo preservar da maneira mais próxima possível, a morfologia e características das peças como in vivo, tal como consistência, coloração e flexibilidade (KIMURA; CARVALHO, 2010).

As observações das dificuldades existentes no uso de laboratórios de anatomia por docentes e discentes, das dificuldades de identificação de algumas estruturas anatômicas, sejam devido ao desgaste ou a não renovação de novos métodos capazes de conservar e preservar melhor as peças anatômicas,... Essas peças cadavéricas são apenas fixadas e conservadas em formol, produto esse que causa náuseas, irritações, dificuldade de respirar, além da exposição ao risco que esse produto traz aos usuários desse local. Notou-se então a necessidade de desenvolver protótipos, capazes de comprovar que existem outros métodos mais eficazes e seguros, além de formas mais didáticas para o ensino. A partir desse ponto, foi proposta a realização de novas técnicas anatômicas. Mostrando de forma didática e estimulando os discentes e docentes a utilizarem estas técnicas permitindo aos mesmos adquirirem conhecimentos, habilidades, experiências e criatividade, as quais poderão ser úteis em sua carreira profissional. 
O objetivo da pesquisa foi de analisar as técnicas anatômicas mais utilizadas na conservação de cadavérica, a fim de demonstrar a necessidade da substituição do formaldeído, e propondo a Técnica de Giocomin (glicerinação) como essa modificação.

\section{TÉCNICAS ANATÔMICAS}

\subsection{CRIODESIDRATAÇÃO}

A técnica de criodesidratação dos tecidos do animal para preservação da peça a seco (Figura 1). As peças são inicialmente fixadas em formol a 10\%. Após a fixação, dáse inicio á técnica, em que as peças serão congeladas em freezer, por um período em torno de 72 horas até o completo congelamento. Posteriormente segue um processo de descongelamento seriado, que consiste em descongelar a peça em temperatura ambiente por 12 horas e retorná-la ao freezer (RODRIGUES, 2010).

Figura 1 - Técnica de criodesidratação aplicada em cachorros

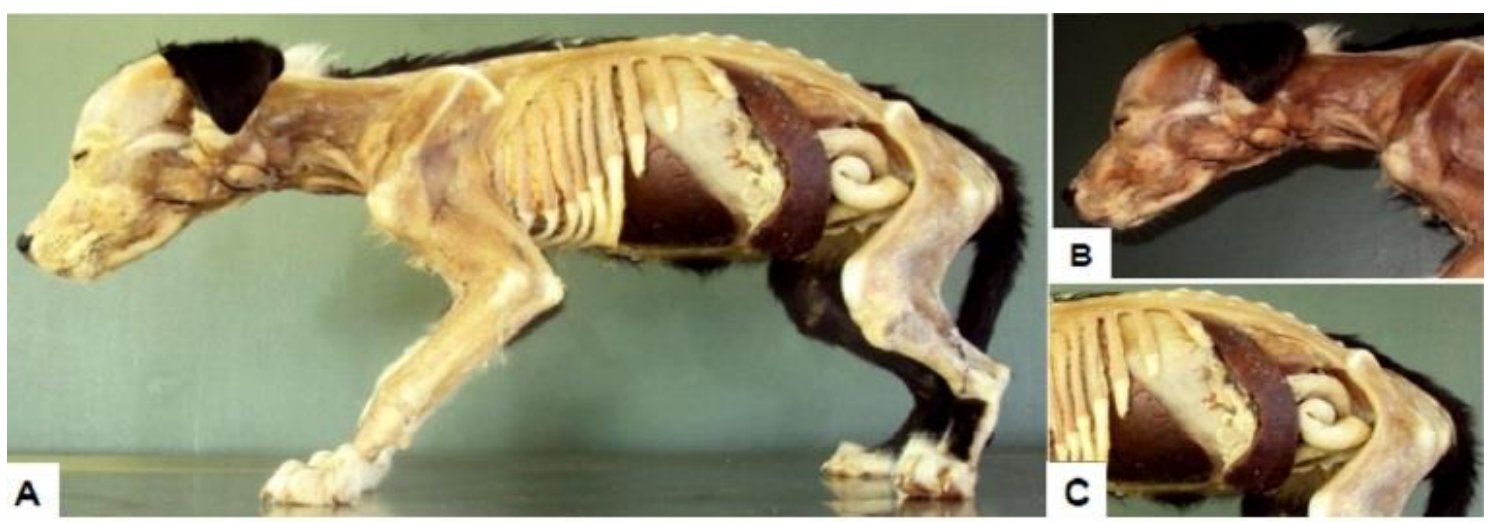

Fonte: Cury, 2013.

\subsection{DIAFANIZAÇÃO}

A diafanização é utilizada desde os anos 70, sendo empregado para estudar o estado da cartilagem e ossos ou pontos de ossificação em diferentes fases do desenvolvimento e também observar anormalidades. Consiste basicamente na digestão do tecido muscular por meio de enzima tripsina e a coloração da cartilagem e esqueleto usando alizarina em espécimes previamente fixados em formalina (RODRIGUES, 2010). 


\subsection{ANGIOTÉCNICA - REPLEÇÃO E CORROSÃO}

A técnica de repleção consiste no preenchimento dos vasos sanguíneos, por meio de injeção de resina acrílica com corante no interior do órgão (Figura 2). 0 procedimento de corrosão consistirá na eliminação do tecido orgânico da amostra, para visibilizar os vasos sanguíneos repletos previamente injetados. Para o processo de corrosão, primeiramente se faz a repleção e, posteriormente, se utiliza um produto químico para executar a corrosão do tecido orgânico. O produto a ser utilizado é o ácido clorídrico, (7\%) (RODRIGUES, 2010).

Figura 2 - Angiotécnica aplicada em rim suíno

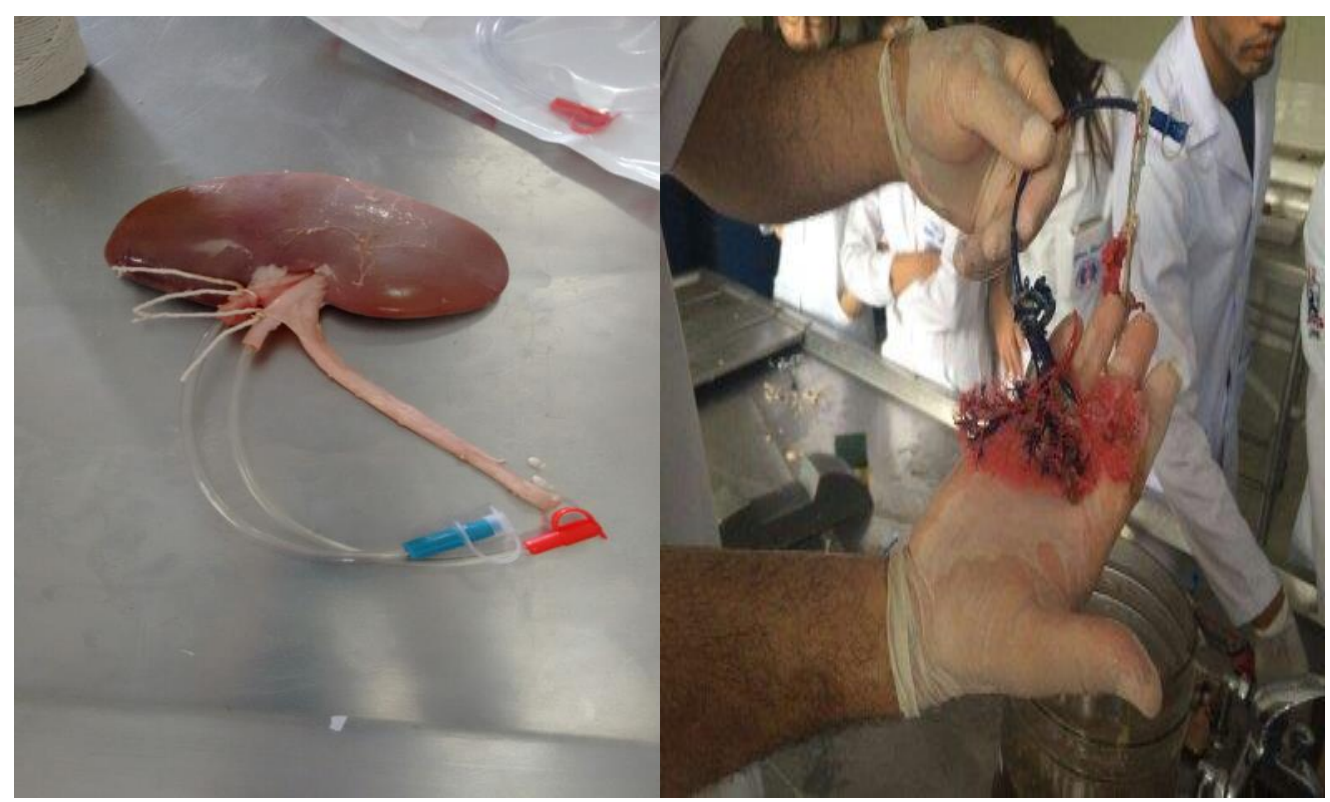

Fonte: Autoria própria (2021).

\subsection{PLASTINAÇÃo}

É um processo desenvolvido por Von Hagens em 1977, que se baseia em impedir a decomposição e preservar espécimes anatômicos para a educação médica e científica, substituindo todos os fluidos teciduais e solúveis em gordura (água e lipídeos) por polímeros (silicone, epóxi, ou copolímero de poliéster), e depois passam por um processo de endurecimento pela luz, calor ou certos gases, que proporcionará a rigidez e conservação dos espécimes (VON HAGENS et al., 1987). Este método apresenta um custo muito alto, e está sendo amplamente utilizado na Europa e nos EUA e já está sendo empregada em algumas universidades brasileiras (SILVA et al., 2008). 
Essas técnicas anatômicas têm sido utilizadas para a preparação de peças para o ensino prático de Anatomia Humana, principalmente a macroscópica. Essas práticas desenvolvidas facilitam o trabalho dos professores, o ensino, a aprendizagem e a interpretação dos modernos exames utilizados nos hospitais tanto do ponto de vista clínico e cirúrgico, como por exemplo, nas bases morfológicas para transplantes de órgãos (RODRIGUES, 2010).

\subsection{FORMOLIZAÇÃO}

Segundo Rodrigues (2010), o fixador mais utilizado no Brasil é o formol, entretanto, deve ser evitado o uso do mesmo como líquido conservador de peças anatômicas, uma vez que esse fixador apresenta propriedades tóxicas e outros efeitos desagradáveis, além do potencial de risco para a saúde. A preocupação com a saúde tratando-se de ambientes insalubres é extremamente importante, isso se enquadra perfeitamente dentro dos laboratórios de anatomia. O formaldeído é um produto químico com pH entre 2,8 e 4, sendo líquido a temperatura ambiente, e apresentando propriedades antifúngicas e bactericidas (VERONEZ et al., 2010).

A IARC - International Agency for Researchon Cancer (Agência Internacional de Pesquisa sobre o Câncer), baseada em literatura específica, adverte sobre uma possível ação mutagênica e genotóxica do formol em cultura de células de mamíferos (HAMAGUCHI; TSUTSUI, 2000), bem como sua forte relação com câncer na parte nasal da faringe e seios paranasais em humanos (HAUPTMANN et al., 2004). Outros tipos de cânceres, como leucemia, entretanto, ainda carecem de estudos mais conclusivos com respeito à sua carcinogenicidade em mamíferos e no homem (IARC, 2004). É necessário que o mesmo seja substituído para preservar a saúde de todos que frequentam os laboratórios, pois além de ser um produto prejudicial ao meio ambiente, possui vários fatores negativos, como: odor desagradável, escurecimento, aumento do peso e rigidez das peças (KRUG et al., 2011).

\subsection{GLICERINAÇÃO}

Como segunda opção mais usada nos laboratórios de anatomia, a glicerina tem características contrárias ao formol, pois é um líquido viscoso à temperatura ambiente $(25$ ㄷ) ), incolor, inodoro, higroscópico (absorve água do ar) e com sabor adocicado. 0 
termo glicerina refere-se ao produto na forma comercial do glicerol com pureza acima de 95\%, mas seu nome oficial pela IUPAC (União Internacional de Química Pura e Aplicada) é propano-1,2,3-triol. Apresenta três grupos hidroxílicos (OH-) hidrofílicos, que são responsáveis por sua solubilidade em água. É um composto orgânico pertencente à função álcool. A glicerina mais utilizada é na concentração de $98 \%$. Uma das principais características da glicerina é a capacidade de desidratação celular (ALVARENGA, 1992; DALECK et al., 1988; PIGOSSI, 1964; 1967). Este fator determina a sua ação antisséptica, atuando contra fungos e bactérias gram-negativas e grampositivas, com exceção para as formas esporuladas (PIGOSSI, 1967). Cabe ressaltar que a desidratação obtida com a glicerina não altera a concentração iônica das células, o que mantém a integridade celular (PIGOSSI, 1964).

O método de glicerinação apesar do alto custo, todas as faculdades que a utilizam, não planejam mudar tal processo de conservação. Sabe-se que essas peças são mais fáceis de manusear e apresentam menor intensidade de peso e cheiro, devido a diminuição de vapores prejudiciais aos manipuladores e excelentes resultados estéticos e morfológicos. Já nas instituições que utilizam o formol, mesmo com as suas desvantagens, 60,7\% não planejam alterar o método. Acredita-se que isso se deve ao fato do formaldeído ainda possuir algumas qualidades, tais como baixo custo, rápida penetração e adequada conservação por longo período (KIMURA et al., 2010; SILVA et al., 2011).

Spaziani et al. (2016) realizou um questionário após expor alunos as duas técnicas: glicerinação e formolização. Após aplicação do questionário constatou-se que cerca de $82,85 \%$ deles preferem peças anatômicas conservadas pela glicerina, pois não geram irritação de mucosas enquanto o estudo é realizado. A mesma porcentagem concordou que as peças de glicerinação possibilitam maior facilidade para o estudo anatômico e clareza (Gráfico 1). 
Gráfico 1- Questionamento de satisfação entre as técnicas de formalização e glicerinação, respondidas por estudantes. É possível observar a maior satisfação pelo uso da glicerinação.

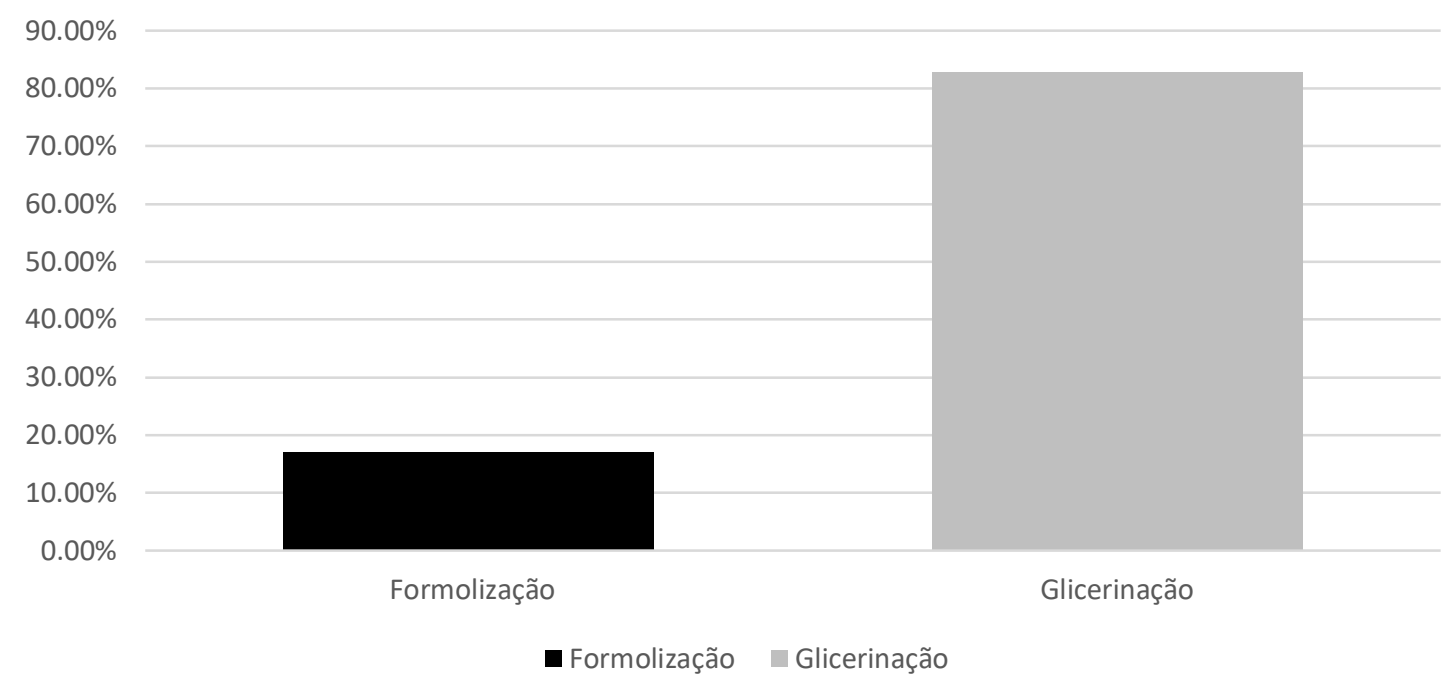

Fonte: Elaborado pelo autor (2021).

Silva et al. (2016) compararam o grau de satisfação dos docentes em relação a utilização de formol e glicerina.Quando questionados sobre a satisfação com o método de conservação, dentre os docentes cujas instituições utilizam a formolização, 41,2\% consideraram-se satisfeitos, enquanto que $58,8 \%$, insatisfeitos. Nas instituições que utilizam glicerinização, 54,5\% consideraram-se satisfeitos e 45,5\%, insatisfeitos com o método utilizado. Nas instituições que fazem uso concomitante de formolização e glicerinização, $61,3 \%$ dos docentes se consideraram satisfeitos e $38,7 \%$, insatisfeitos (Gráfico 2).

Gráfico 2- Comparação do grau de satisfação dos docentes em relação a utilização do uso apenas do formol ou glicerina e o uso das duas técnicas juntas.

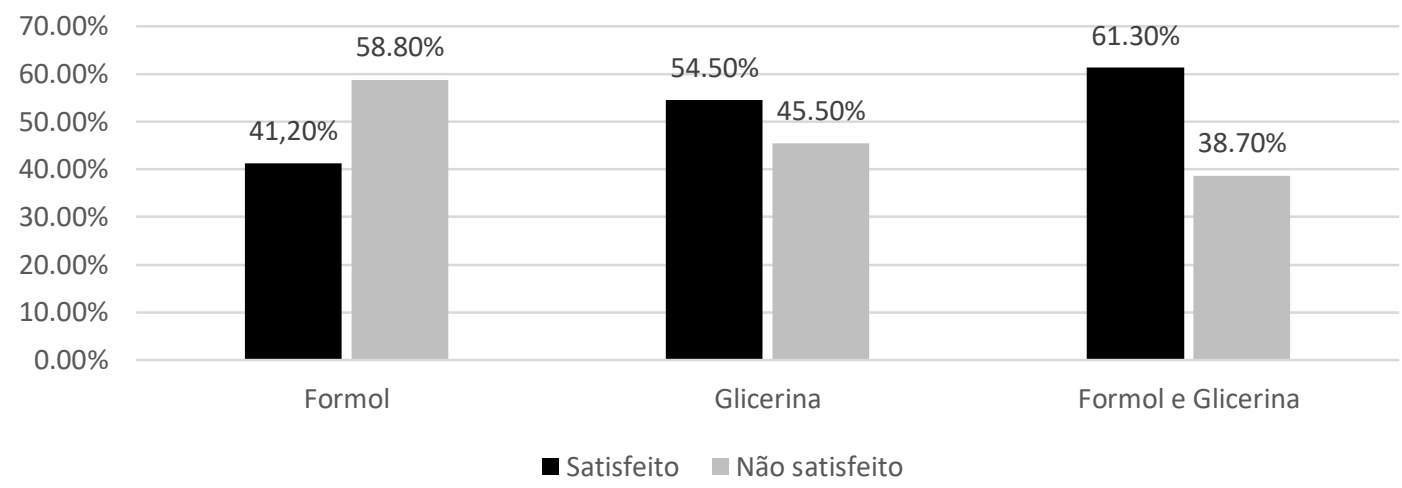

Fonte: Elaborado pelo autor (2021). 


\section{METODOLOGIA}

\subsection{PEÇAS ANATÔMICAS}

Trata-se de um estudo laboratorial com abordagem exploratória. As peças serão protótipos de demonstração da técnica, foram utilizados dois encéfalos bovinos e um suíno, coletadas no Mercado Público Central da cidade de João Pessoa- PB.

\subsection{TÉCNICA DE GIOCOMIN (GLICERINAÇÃO)}

Gigek et al. (2009) utilizou uma técnica de glicerinação baseada principalmente em três etapas: desidratação, clareamento e fixação. Primeiramente, antes das três etapas do protocolo, foi necessária a fixação das peças com formaldeido a $10 \%$ isso durante uma semana, e após essa etapa crucial, foi iniciada a técnica.

Na primeira etapa as peças foram mergulhadas em uma solução com álcool etílico $70 \%$, durante o período de uma semana. O material de estudo foi acomodado em caixas plásticas com tampa e mantido à temperatura ambiente. O álcool atuou no processo de desidratação das peças, retirando a água das mesmas. Na fase de clareamento as peças anatômicas foram mergulhadas em peróxido de hidrogênio 3\%, durante uma semana, sendo novamente acomodadas em caixas plásticas com tampa à temperatura ambiente. Nessa etapa, as peças passaram por um processo de clareamento e "limpeza" de alguns resquícios como coágulos sanguíneos. No terceiro e último período as peças foram colocadas em solução de glicerina e álcool etílico $70 \%$ respeitando sempre a proporção de 1:2 respectivamente. Sendo novamente acomodadas em caixas plásticas com tampa à temperatura ambiente. Esse processo durou aproximadamente uma semana, e aconteceu o contrário das outras duas etapas, a glicerina hidrata as peças que o álcool desidratou, e dá uma cor mais realista ao órgão clareado pelo peróxido de hidrogênio.

Logo as peças passaram por um processo de escoamento da glicerina e secagem das peças que duraram três semanas. As peças anatômicas foram fotografadas, a fim de analisar e garantir a eficácia do método, e depois foram feitos todos os cálculos para entender qual foi à relação custo $\mathrm{x}$ benefício da comparação das técnicas normais de conservação por formol com a técnica de glicerinação. E por fim, foram utilizadas pesquisas bibliográficas para compor entendimento da importância da substituição do 
formol relevante ao ensino e a conservação em nível de satisfação perante o conhecimento da técnica de glicerinação.

\section{RESULTADOS E DISCUSSÃO}

A técnica não excluiu o formol totalmente, pois o mesmo foi utilizado na préfixação das peças anatômicas. Pela necessidade das peças serem submersas em várias soluções por extensos períodos, a Técnica de Giocomini exigiu maior atenção do que em relação ao processo de Formolização.

As peças se mostraram muito mais fáceis de serem manipuladas, quando comparadas às peças conservadas em formol, apresentando menos peso e odor. $\mathrm{O}$ baixo peso se dá pelo fato de não ocorrer encharcamento das peças após o processo, ficando elas guardadas a seco em um recipiente. A menor intensidade de cheiro ocorreu pela utilização de produtos ínfimos de substâncias tóxicas no processo. A glicerinação proporcionou estruturas com aspectos anatômicos próximos à original e ótimo resultado estético, além de uma maior clareza das estruturas dos órgãos cadavéricos e sua fácil identificação (Figuras 4 e 5). 
Figura 3 - Cérebro suíno antes (a) formolizado e depois (b) glicerinizado. Nota- se que as estruturas se mantêm enquanto a cor se altera
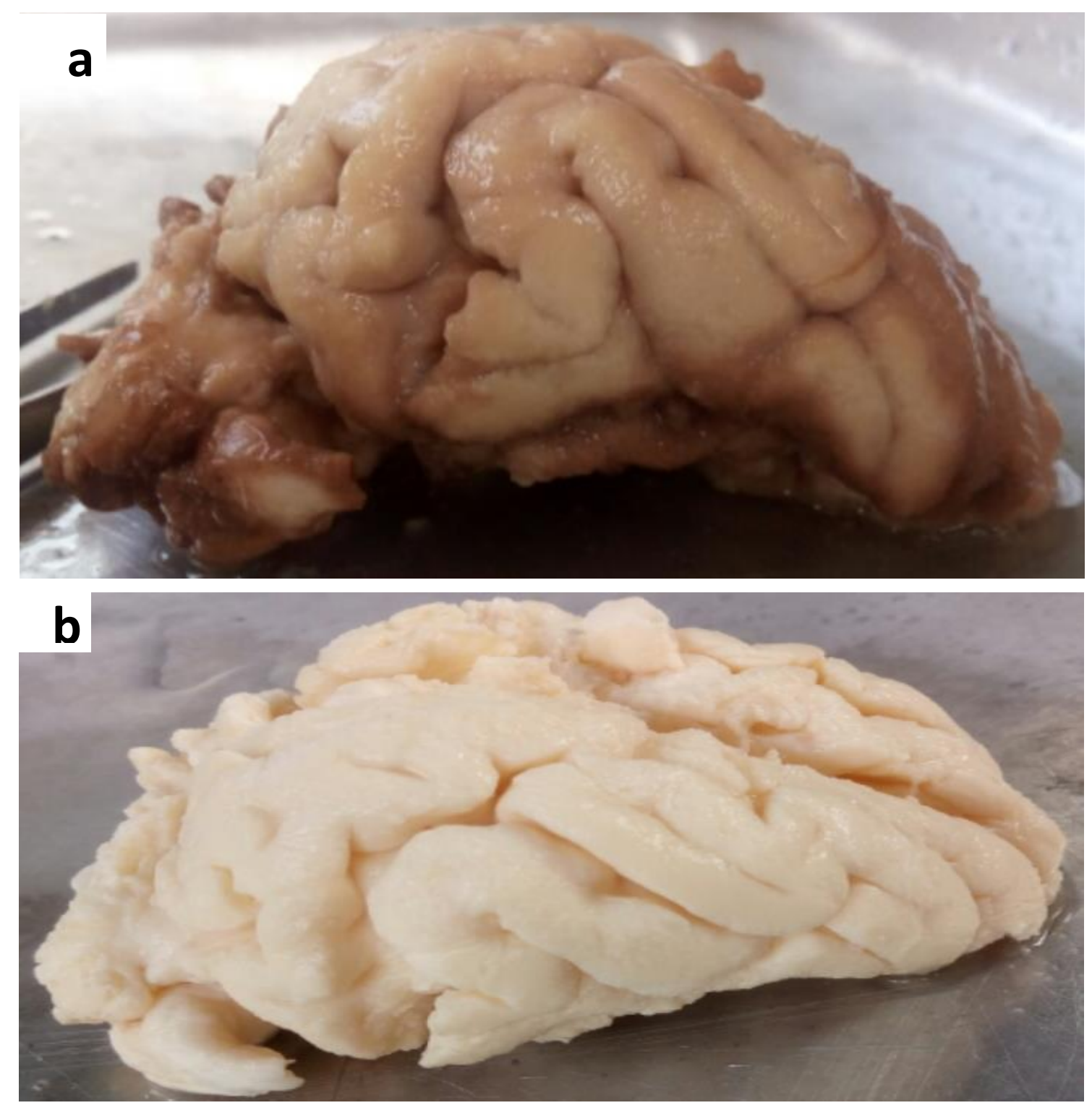

Fonte: Autoria própria (2017).

Silva et al. (2008) já destacava os resultados: A glicerinação permite uma melhor conservação com as vantagens de peças anatômicas mais leves; utilização de produtos menos agressivos as peças, ao meio ambiente como a diminuição e eliminação de vapores prejudiciais à natureza e aos manipuladores; peças anatômicas esteticamente melhores; conservação das peças semelhantes a da formalização; baixo custo e facilidade no manuseio das peças. 
Figura 4 - Tronco encefálico bovino, antes (a) formolizado e depois (b) glicerinizado

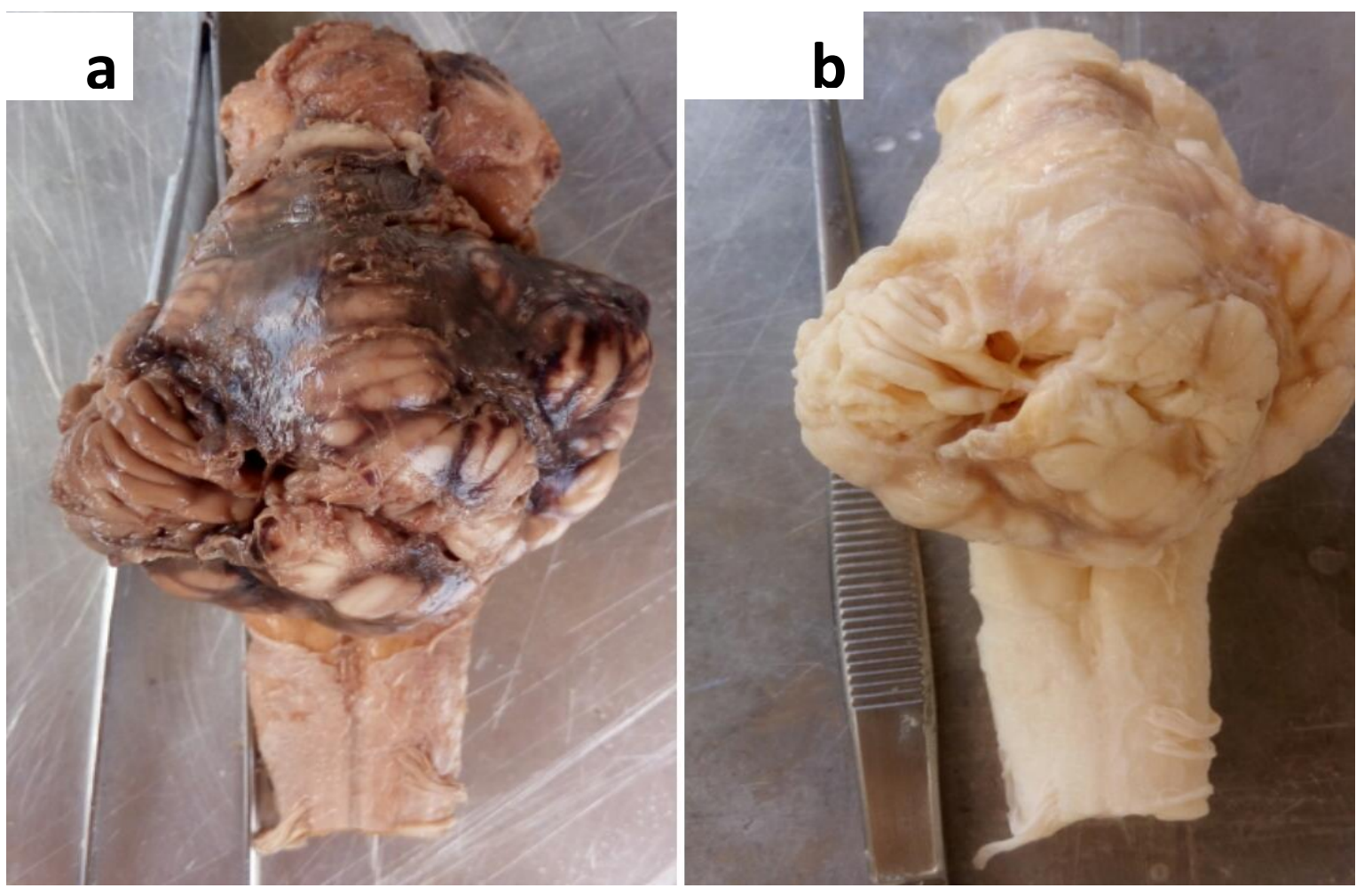

Fonte: Autoria própria (2017).

$\mathrm{Na}$ relação custo-benefício a técnica de glicerinação é mais cara devido a utilização de mais substâncias usadas no processo como o próprio formol (1 litro) e 2 litros de glicerina, álcool e peróxido de hidrogênio, no total de $\mathrm{R} \$ 98,00$. Comparado com a formolização normal, onde foi gasto $\mathrm{R} \$ 18,00$. Porém a glicerinação mantém este valor por muito tempo, pois as substâncias não se perdem com o tempo e as peças deixam de serem guardadas por submersão, não necessitando a renovação do processo em curto prazo como no formol (Tabela 1).

Tabela 1- Relação custo-benefício de cada técnica

\begin{tabular}{|c|c|c|c|c|c|}
\hline & PREÇO & $\begin{array}{c}\text { TEMPO DE } \\
\text { PREPARO }\end{array}$ & $\begin{array}{c}\text { PRECISA } \\
\text { FICAR } \\
\text { SUBMERSA }\end{array}$ & ESCURECIMENTO & PESO \\
\hline FORMOLIZAÇÃO & $\mathrm{R} \$$ & 24 HORAS & SEMPRE & SIM & PESADA \\
\hline GLICERINAÇÃO & $\begin{array}{c}18,00 \\
\text { R\$ }\end{array}$ & 35DIAS & NÃO & NÃO & LEVES \\
\hline
\end{tabular}

Fonte: Elaborado pelo autor (2021). 


\section{CONSIDERAÇÕES FINAIS E PERSPECTIVAS}

Através dos resultados obtidos no presente trabalho, conclui-se que as peças anatômicas utilizadas, ficaram mais claras, leves, inodoros e de aspecto estético semelhante a fresco. A manutenção das peças pode ser mais frequente devido à desidratação em álcool 70\% ao invés de álcool absoluto. No comparativo das técnicas o custo da glicerinação é mais elevado do que a formolização, devido à utilização de mais reagentes e da glicerina ser um pouco mais cara. Porém o grande diferencial é que na glicerinação não há perda destes reagentes podendo muitos desses ser reutilizados e as peças produzidas ficam armazenadas a seco em recipientes fechados com tampa. Neste sentido a uma vantagem a médio e longo prazo com relação ao custo.

De acordo com os benefícios em relação a técnica, a que pode ser considerados como o maior benefício é o que diz respeito aos benefícios a saúde dos usuários, meio ambiente e o ensino, sendo essa a principal vantagem da técnica de Giocomin, privando os mesmos de serem expostos a agentes tóxicos. Portanto a glicerinação é uma técnica satisfatoriamente capaz de substituir o formol.

\section{AGRADECIMENTOS}

Os autores agradecem o suporte financeiro da CAPES, a Faculdade Santa Emília de Rodat - FASER/UNINEVES e a Universidade Católica de Pernambuco - UNICAP.

\section{REFERÊNCIAS}

ALVARENGA, J. Possibilidades e limitações da utilização de membranas biológicas preservadas em cirurgia. In: DALECK, C. R.; BAPTISTA, L. C.; MUKAI, L. S. Tópicos em cirurgia de cães e gatos. Jaboticabal: FUNEP-UNESP, 1992. p. 33-42.

CURY, F. S.; CENSONI, J. B.; AMBRÓSIO, C. E. Técnicas anatômicas no ensino as prática de anatomia animal. Pesq.Vet.Bras. Vol. 33, n. 5, Rio de Janeiro/RJ, 2013. Texto disponível em: <http://dx.doi.org/10.1590/S0100-736X2013000500022>

DALECK, C. R.; ALESSI, A. C.; COSTA NETO, J. M. et al. Substituição de um retalho diafragmático de cão por peritônio de bovino conservado em glicerina: estudo experimental. Ars Veterinária, v. 4, n. 1, p. 53-61, 1988.

GIGEK, T.; OlIVEIRA, J. E. M.; NETO, A. C. A.; CARVALHO, W. L.; PEREIRA, F. V.; ALMEIDA, A. H. Estudo analítico da técnica de glicerinação empregada para conservação de peças anatômicas de bovinos. Anais V Simpósio de ciências da UNESP, Dracena, 
SP, $\quad 2009.1-3, \quad$ Texto disponível em: <http://www2.dracena.unesp.br/eventos/sicud_2009/anais/veterinaria/043_2 009.pdf>

HAMAGUCHI, F.; TSUTSUI, T. Assessment of genotoxicity of dental antiseptics: ability of phenol, guaiacol, p-phenol sulfonic acid, sodium hypochlorite, p-chlorophenol, $\mathrm{m}$-cresol or formaldehyde toinduceunscheduled DNA synthesis in culture dsyrianhamster embrio cells. The Japanese Journal of Pharmacology, Kyoto, v. 83, p. 273-267, 2000.

HAUPTMANN, M. et al. Mortality from solid cancer samongworkers in formaldehyde industries. American Journal of Epidemiology, Cary, NC, v. 159, v. 12, p. 11171130, 2004.

IARC. Classifies formaldehyde as carcinogenicto humans. Press release, n. 153, 2004. Texto disponível em: <http://www.iarc.fr/en/mediacentre/pr/2004/pr153.html>.

KIMURA, A. K. E.; CARVALHO, W.L. Estudo da relação custo $x$ benefício no emprego da técnica de glicerinação em comparação com a utilização da conservação por formol. Trabalho de conclusão de curso de extensão em Higiene Ocupacional, Universidade Estadual Paulista, Araraquara/ SP, 2010.

KRUG, L.; PAPPEN, F.; ZIMMERMANN, F.; DEZEN, D.; RAUBER, L.; SEMMELMANN, C.; ROMAN, L. I.; BARRETA, M. H. Conservação de peças Anatômicas com glicerina loira. Instituto Federal Catarinense, Concórdia/ SC, p. 1-6, 2011. Texto disponível em: $<$ http://mic.ifc-concordia.edu.br/wp-contenet/uploads/2011/09/MIC109_conserva\%C3\%

A7\%C3\%A3o_de_pe\%C3\%A7as_anat\%C3\%B4micas_com_glicerina_loira.pdf>

LUNETTA, V. N. Atividades práticas no ensino da ciência. Revista Portuguesa de Educação, v.2, p. 81-90, 1991.

PIGOSSI, N. A glicerina na conservação de dura-máter - estudo experimental. Tese (Livre docência) - Faculdade de Medicina de São Paulo, Universidade de São Paulo, 1967.

PIGOSSI, N. Implantação de dura-máter homógena conservada em glicerina - estudo experimental em cães. 41f. Tese (Doutorado em Medicina) - Faculdade de Medicina de São Paulo, Universidade de São Paulo, 1964.

RODRIGUES, H. Técnicas Anatômicas. 4 ed. GM Gráfica e Editora, Vitória, ES. 2010.

SILVA, E. M.; SOUZA, G. D. F.; SOUZA, M. C. T.; MARQUES, T.; FURTADO, J. M. Estudo analítico da técnica de glicerinação empregada para conservação de peças anatômica: experiência da disciplina de Anatomia Humana do Departamento de Morfologia da UniFOA. Cadernos UniFOA, Rio de Janeiro, 2008; Edição especial p. 66-69. Texto disponível em: <http://web.unifoa.edu.br/cadernos/especiais/pos-graduacao/01/66.pdf.> 
SILVA, R.; MARIA-DO-Ó, C.; BRITO, V.; OLIVEIRA, B.; COSTA, É.; MOURA, G.Vantagens e desvantagens das técnicas de preparação de materiais didáticos para as aulas práticas de morfologia. Rev. Didática Sistêmica. 2011; n. 13 (2): p. 24-41. Texto disponível em: <https:// www.seer.furg.br/redsis/article/view/2237>.

SILVA, G. R.; CORTEZ, P. O. B. C.; LOPES, I. S. L.; TEIXEIRA, B. A. C. B.; LEAL, N. M. S. Métodos de conservação de cadáveres humanos utilizados nas faculdades de medicina do Brasil. Ver Med (São Paulo), 2016, n. 95(4): p.156-61; Texto disponível em:<http://dx.doi.org/10.11606/issn.1679-9836.v95i4p156-161>.

SPAZIANI, A. O.; FRANCISCO, C. S. V.; ANDREANI, G.; CAETANO, N. M.; CARVALHO, B. K.; FRANCSICO, J. S. V.; TALIARI, J. D. S.; PEREIRA, A. M. Formolização e glicerinação: estudo de preferência de técnica de conservação anatômica por acadêmicos. UNICASTELO, $2016 . \quad$ Texto disponível em:<http://dx.doi.org/10.21270/archi.v5i0.1795>.

VERONEZ, D. A. L.; FARIAS, E. L. P.; FRAGA, R.; FREITAS, R. S.; PETERSEN, M. L.; SILVEIRA, J. R. P. Potencial de risco para a saúde ocupacional de docente, pesquisadores e técnicos de anatomia expostos ao formaldeído. Revista Gestão Integrada em Saúde do Trabalho e Meio Ambiente, São Paulo, v. 5 n. 2 p. 1-13, 2010. Texto disponível em: <http://www.revistas.sp.senac.br/index.php/ITF/article/viewFile/71/97>.

VILHENA, N. Q. et al. Modelos didático-pedagógicos: Estratégias inovadoras para o ensino de biologia. II Simpósio Nacional de Ensino de Ciência e Tecnologia, 2010.

VON HAGENS, G.; TIEDEMANN, K.; KRIZ, W. The current potential of plastination. Anat. Embryol, n. 175 (4), p. 411-421, 1987. 


\title{
CAPITULO XXIX
}

\section{ATAXIA DE FRIEDREICH: RELATO DE CASO DE IRMÃOS COM FENÓTIPOS CUÍNICOS DISCORDANTES}

\author{
Adriana Rosa Deboni Dezuane ${ }^{1}$ \\ Ana Luíza Lemos de Freitas ${ }^{2}$ \\ Helen Fandin dos Santos ${ }^{3}$ \\ Larissa Teotônio Maria ${ }^{4}$ \\ Zumira A. Carneiro ${ }^{5}$ \\ Charles M. Lourenço ${ }^{6}$
}

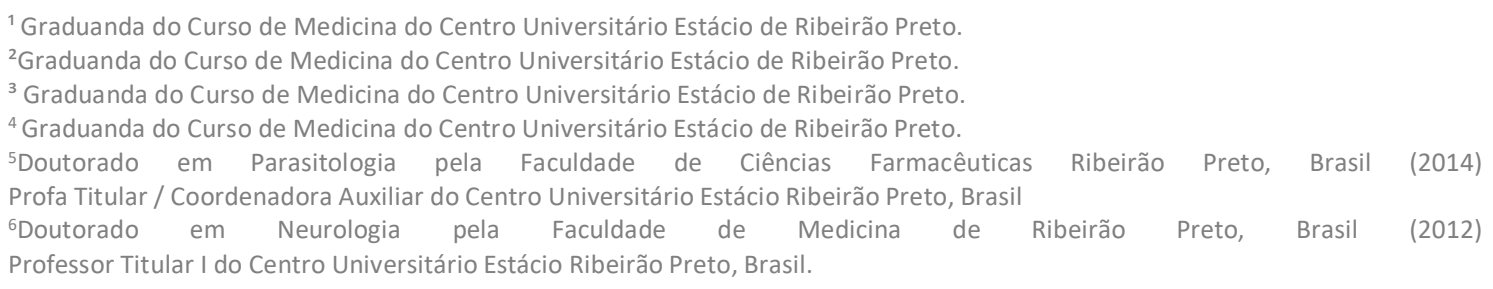

\section{RESUMO}

Introdução: Ataxia de Friedreich (FA) é uma doença neurodegenerativa progressiva, hereditária. Causada por mutações autossômicas recessivas no gene FXN levando à disfunção mitocondrial. Os sinais típicos neurológicos são instabilidade de marcha e fraqueza motora progressiva. Há também risco de desenvolver doença cardíaca, como hipertrofia cardíaca, fibrose miocárdica, arritmias e insuficiência cardíaca no estágio final, sendo esta a principal causa de morte. Objetivo: Relatar o caso de dois irmãos afetados pela FA com diferentes apresentações clínicas, enfatizando a expressividade clínica variável da enfermidade e a necessidade de diagnóstico precoce para intervenções terapêuticas. Relato de casos: Paciente 1, feminino, filha de casal não-consanguíneo, encaminhada para avaliação de neuropatia periférica. Aos 4 anos de idade surgiram os primeiros sinais típicos. Progressivamente, teve piora da ataxia e instabilidade motora, necessitando de cadeira de rodas. Paciente 2 , masculino, irmão da paciente 1 , encaminhado para avaliação de cardiomiopatia hipertrófica. Apresentou normalidades dos marcos motores, sem sinais de neuropatia periférica. Aos 13 anos foi encaminhado para avaliação de cardiomiopatia; foi testado para FA, confirmando ser afetado. Discussão: Os pacientes descritos apresentam fenótipos clínicos discordantes da FA. A paciente feminina apresentou um fenótipo tipicamente neurológico da doença. Seu irmão, no entanto, apresentou como primeira característica, o acometimento cardíaco. As opções de tratamento para FA envolvem proteção antioxidante contra danos mitocondriais. A coenzima Q10 combinada com vitamina $\mathrm{E}$ melhora a bioenergética do tecido cardíaco e do músculo esquelético e atenua os efeitos causados pelo aumento do estresse oxidativo mitocondrial.

Palavras-chave: Ataxia de Friedreich. Cardiomiopatia. Neuropatia periférica. Coenzima Q10. Idebenona. 


\section{INTRODUÇÃO}

A Ataxia de Friedreich (FA) (OMIM 229300) foi identificada, clinicamente, em 1863, por Nikolaus Friedreich e, posteriormente, após descrição em revista médica, em 1877, foi reconhecida como uma doença neurológica específica (SANTOS; et al, 2010). Trata-se de uma doença neurodegenerativa progressiva, hereditária, para a qual atualmente não há cura ou tratamento aprovado (STRAWSER; et al, 2017). Sua prevalência no continente europeu mostra grandes diferenças regionais: no sudoeste, por exemplo, a prevalência é de 1 em 20.000 nascidos vivos, enquanto, no norte e leste, gira em torno de 1 em 250.000 (COOK; GIUNTI, 2017).

A FA é uma mutação genética autossômica recessiva causada por mutações no gene FXN (OMIM 606829) que acarreta uma disfunção mitocondrial (HOFFMANZACHARSKA; et al, 2016).

O gene FXN, localizado no cromossomo 9q21.11, é o responsável por codificar a proteína mitocondrial frataxina (ALSINA; et al, 2018). Essa proteína está envolvida no metabolismo e na homeostase do ferro e, quando não funciona corretamente, aumenta o estresse oxidativo mitocondrial, acarretando processo de toxidade celular em diversos tecidos: miocárdio, nervoso e células beta pancreáticas (COOK; GIUNTI, 2017). (Figura 1).

Figura 1: Mutação do gene da proteína frataxina.

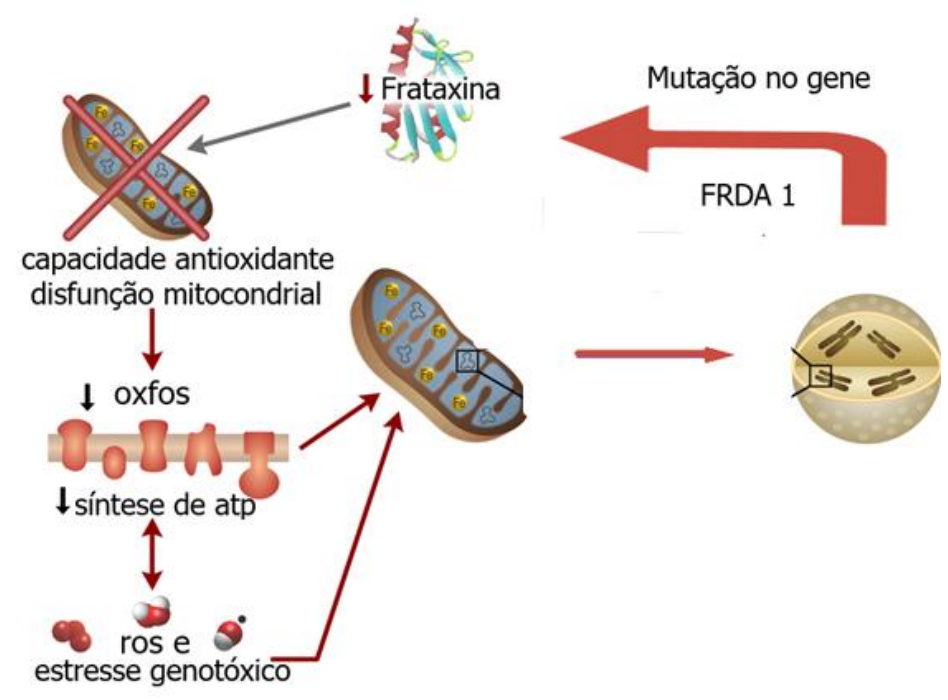

Fonte: Adaptado de C Haugen A, A Di Prospero N, Parker J, D Fannin R, Chou J, Meyer J, et al (HAUGEN; et al, 2010). 
$\mathrm{Na} F A$, as mutações genéticas no gene constituem uma expansão de trinucleotídeos GAA no primeiro íntron (ALSINA; et al, 2018). Usualmente, pacientes afetados possuem essa expansão de trinucleotídeos em ambos os alelos ( $96 \%$ dos pacientes com FA); os demais são heterozigotos compostos, com uma expansão de GAA em um alelo e uma mutação de ponto no outro (esses pacientes podem exibir um fenótipo clínico mais brando que os pacientes homozigotos para a expansão) (TAl; et al, 2018).

Ademais, em pacientes com $\mathrm{FA}$, o número de repetições de GAA tem uma relação inversamente proporcional à idade em que os primeiros sintomas aparecem e, também, determinam a sua gravidade (ALSINA; et al, 2018).

A expressão clínica da doença manifesta-se com acometimento do sistema nervoso central e periférico, além do sistema musculoesquelético (miocárdio) e do endócrino (pâncreas) (SANTOS; et al, 2010).

Comumente, os primeiros sintomas surgem por volta da puberdade, mas a idade de início pode variar desde a infância ( 2 a 3 anos) até a idade adulta (após os 25 anos de idade). Os sinais típicos de apresentação são a instabilidade de marcha e fraqueza motora progressiva (SANTOS; et al, 2010). Sintomas cardíacos, como a hipertrofia de ventrículo esquerdo, não são comumente apresentados na infância, porém quando presentes, podem levar à morte súbita (QUERCIA; et al. 2010).

Do ponto de vista neurológico, a principal característica da doença é a ataxia progressiva e debilitante: os pacientes perdem a capacidade de andar de 10 a 15 anos após o início da doença, necessitando de uma cadeira de rodas para realizarem suas atividades diárias (EVANS-GALEA; et al. 2014).

Nessa doença, os sintomas atáxicos combinam ataxia cerebelar com ataxia sensitiva (alteração da capacidade proprioceptiva), acompanhada por neuropatia sensitiva com perda de reflexos tendinosos profundos, desenvolvimento de respostas extensoras plantares e da escoliose (ANHEIM; et al, 2012).

Progressivamente, os pacientes evoluem com espasticidade, perda dos reflexos dos membros inferiores, alterações sensoriais da coluna posterior, disartria e deformidade do pé, atrofia óptica progressiva, defeitos auditivos, disfunção olfativa, planejamento motor prejudicado e disfunção cognitiva de ordem superior (EVANSGALEA; et al. 2014). 
Os pacientes também têm o risco de desenvolver doença cardíaca, como hipertrofia cardíaca, fibrose miocárdica, arritmias e insuficiência cardíaca no estágio final, sendo a principal causa de morte na FA (YOON; et al, 2012).

A FA, no presente momento, não apresenta cura. As opções de tratamento envolvem proteção antioxidante contra danos mitocondriais (HOFFMAN-ZACHARSKA; et al, 2016), pois o excesso de ferro mitocondrial causa estresse oxidativo e dano celular (ALSINA; et al, 2018).

\section{RELATO DE CASOS}

\subsection{CASO 1}

Paciente feminino, 18 anos, filha de casal jovem não-consanguíneo, foi encaminhada para avaliação de neuropatia periférica. Paciente é produto de uma gestação sem intercorrências, nascida de parto cesáreo, apresentava $49 \mathrm{~cm}$ de comprimento e 3520 gramas de peso. Não apresentou intercorrências durante o período perinatal.

Antecedentes e marcos motores revelam que começou a andar com 1 ano e 3 meses, apresentando crescimento e desenvolvimento de acordo com os parâmetros médicos embasados em marcos adequados. A partir dos 4 anos de idade surgiram os primeiros sinais de fraqueza e falta de equilíbrio em membros inferiores, não conseguindo andar em linha reta. Com o crescimento foi observado piora da miastenia e instabilidade motora.

Paciente tem cardiomiopatia que foi descoberta no hospital durante uma internação, quando ela tinha 6 anos. Aos 11 anos apresentou dificuldade em ouvir, principalmente ruídos a sua volta e também, a escoliose. Teve a necessidade de cadeira de rodas quando tinha 12 anos.

A miocardiopatia, quando realizado o exame de Ecocardiografia, evidenciou contratilidade biventricular preservada e alterações segmentares da contração longitudinal.

Paciente realizou uma cirurgia de correção da escoliose aos 17 anos para melhora da dor e dificuldade de respirar. Apresenta também problema auditivo no 
ouvido esquerdo, não sabendo identificar quando surgiu, ouvindo melhor pelo lado direito.

Após a avaliação de um pediatra, a paciente foi encaminhada para um neurologista que solicitou uma eletroneuromiografia que foi sugestiva de neuropatia sensitivo-axonal. A partir disso, realizou-se a suspeita diagnóstica de Doença de CharcotMarie tipo 1, sendo solicitado painel de genes focalizado para essa doença. Painel genético, contudo, não revelou nenhuma mutação nos genes de neuropatia periférica e a paciente seguiu sem diagnóstico, perpetuando com esse até os 12 anos de idade.

Posteriormente, aos 15 anos de idade, ao ser encaminhada para um serviço de neurogenética, paciente realizou uma nova eletroneuromiografia que foi compatível com neuropatia sensitiva-axonal e, em vista desses achados e da presença de sintomas de ataxia sensitiva, fez-se a suspeita de FA, sendo solicitado o exame para análise molecular de repetições do trinucleotídeo GAA no íntron 1 do gene FRDA1 (cromossomo 9q13-q21) por PCR. Exame da paciente revelou a presença de 2 alelos com repetição de nucleotídeos acima da faixa de normalidade, confirmando o diagnóstico clínico de FA.

Atualmente paciente faz terapia de reabilitação, com fisioterapia, inicialmente 4 sessões por semana, depois 3 sessões e atualmente 1 sessão por semana com duração de 1 hora. Iniciou fonoterapia aos 17 anos e terapia ocupacional aos 18 anos.

Do ponto de vista de tratamento medicamentoso, faz uso das seguintes medicações: Ephynal ${ }^{\circledR}$ de 400 mg, Cewin ${ }^{\circledR}$ de 500 mg, Coenzima Q10 (manipulada) de $400 \mathrm{mg}$ junto com uma colher de sopa de pasta de amendoim e sem a cápsula, Carvedilol $^{\circledR}$ de 6,25 mg (cada comprimido) fazendo uso de 2 comprimidos por dia. Todos são tomados com água, exceto o CoQ10.

\subsection{CASO 2}

Paciente masculino, 14 anos, filho de casal jovem não-consanguíneo, encaminhado para avaliação de cardiomiopatia. Trata-se do irmão da paciente do caso 1. Nascido de uma gestação sem intercorrências de parto cesáreo com 39 semanas, apresentando $51 \mathrm{~cm}$ de comprimento e 3865 gramas de peso, teve dificuldades respiratórias ao nascer, permanecendo na incubadora por 3 dias. 
O crescimento e desenvolvimento do paciente foi de acordo com parâmetros médicos embasados em marcos adequados, engatinhou e depois, com 1 ano, andou.

A cardiomiopatia foi descoberta por meio do Ecocardiograma, feito depois do diagnóstico de FA. A ecocardiografia evidenciou função contrátil normal pelos modos M, bidimensional e Simpson; contudo documentos Strain longitudinal anormal em região lateral.

Diante do diagnóstico confirmado no caso 1 , foi reavaliado o paciente 2 , realizando-se teste para FA, visto que pode haver uma variação fenotípica na doença, e o teste do paciente, feita a análise molecular repetições do trinucleotídeo GAA no íntron 1 do gene FRDA1 (cromossomo 9q13-q21) por PCR, confirmou o diagnóstico de Ataxia de Friedreich.

Quando realizou o teste genético e fez também a eletroneuromiografia, foi evidenciada a neuropatia sensitiva em estágio inicial.

No momento atual, paciente evoluiu com alteração de marcha.

Em relação ao tratamento medicamentoso, faz uso das seguintes medicações: Ephynal $^{\circledR}$ de $400 \mathrm{mg}$, Cewin ${ }^{\circledR}$ de $500 \mathrm{mg}$, Coenzima Q10 (manipulada) de 400 mg junto com uma colher de sopa de pasta de amendoim e sem a cápsula, Carvedilol $^{\oplus}$ de 3,125 mg (cada comprimido) e faz uso de 2 comprimidos por dia.

\section{DISCUSSÃO}

A FA é o tipo hereditário de ataxia mais prevalente, que se apresenta com uma variedade de sinais e/ou sintomas clínicos, os mais comuns incluem ataxia da marcha e dos membros, disartria e perda de reflexos nos membros inferiores (SAGHAZADEH; et al, 2017).

Comumente, os primeiros sintomas surgem por volta da puberdade, mas a idade de início pode variar desde a infância ( 2 a 3 anos) até a idade adulta (após os 25 anos de idade) (ALSINA; et al, 2018).

A principal característica da doença é a ataxia progressiva e debilitante: os pacientes perdem a capacidade de deambular após cerca de 10 a 15 anos do início da doença, necessitando de cadeira de rodas para suas atividades diárias (HAUGEN; et al, 2010). 
Pacientes também têm o risco de desenvolver doença cardíaca, como hipertrofia cardíaca, fibrose miocárdica, arritmias e insuficiência cardíaca no estágio final, sendo essa a principal causa de morte na FA (TAl; et al, 2018).

Os pacientes descritos no relato são irmãos apresentando fenótipos clínicos discordantes da FA. A paciente feminina (caso 1) apresentou como primeira característica clínica o acometimento neuronal com alteração de marcha, fraqueza e falta de equilíbrio nos membros inferiores, evoluindo, com o passar do tempo, para a perda dos movimentos das pernas, possuindo, portanto, um fenótipo tipicamente neurológico da doença e também a forma mais comum de apresentação dessa enfermidade (ANHEIM; et al, 2012) (QUERCIA; et al. 2010).

Seu irmão (caso 2), no entanto, apresentou como primeira característica o acometimento cardíaco, embora, ao exame neurológico, já apresente certa alteração da marcha, apesar de não se queixar clinicamente. O achado ecocardiográfico típico da cardiomiopatia de Friedreich é a hipertrofia do ventrículo esquerdo (SANTOS; et al, 2010) (YOON; et al, 2012). O padrão é o de uma hipertrofia concêntrica de ventrículo esquerdo com espessura da parede diastólica final que, na maioria dos pacientes, é menor que $15 \mathrm{~mm}$ e ausência de obstrução de fluxo de saída. Coortes revelaram geometria analógica do ventrículo esquerdo (com base na espessura da parede diastólica relativa e massa indexada do ventrículo esquerdo) em cerca de $80 \%$ de todos os pacientes e cerca de $40 \%$ de todos os pacientes de Friedreich (WEIDEMANN; et al, 2013).

No presente momento, FA não apresenta cura. As opções de tratamento (figura 2) são profiláticas e envolvem proteção antioxidante contra danos mitocondriais, pois o excesso de ferro mitocondrial causa estresse oxidativo e dano celular (SANTOS; et al, 2010). Ambos os pacientes estão em tratamento com as seguintes medicações: Ephynal $^{\circledR}$ (Vitamina E), Cewin ${ }^{\circledR}$ (Vitamina C), Carvedilol $^{\circledR}$ (Beta bloqueador não seletivo) e Coenzima Q10.

O primeiro medicamento apontado para a FA foi a Desferioxamina. Mas não houve a resposta clínica esperada com esse tratamento, visto que este agente quelante não atravessa totalmente as membranas celulares. Pois, apenas os quelantes capazes de penetrar na mitocôndria são provavelmente úteis na FA (ALSINA; et al, 2018). 
Entre as outras terapias desenvolvidas para essa doença, destacou-se o uso de Deferiprona, uma substância quelante lipossolúvel administrada por via oral, previamente usada para tratar a sobrecarga de ferro em indivíduos politransfundidos com talassemia major (ALSINA; et al, 2018).

Outro fármaco conhecido é a Idebenona (IDE), que foi sintetizada no Japão nos anos 80 e é um análogo da coenzima Q10 (CoQ10), necessário para a transferência de elétrons entre os complexos da cadeia respiratória mitocondrial. Com o seu uso, foi percebido que, na maioria dos casos, houve redução dos marcadores de estresse oxidativo, além da melhora dos sintomas não neurológicos (MONTENEGRO; et al, 2018).

A CoQ10 é uma pequena molécula lipofílica presente dentro da membrana mitocondrial interna em associação com os complexos ETC, que transfere elétrons entre os complexos I e II, e da oxidação de ácidos graxos e aminoácidos de cadeia ramificada, para o complexo III resultando na produção final de ATP. A deficiência da CoQ10 pode causar uma síndrome atáxica de início precoce sendo responsiva à suplementação com CoQ10 (PARKINSON; SCHULZ; GIUNTI, 2013).

A Idebenona é um análogo CoQ10 de cadeia curta e possui função dupla na célula, agindo como um antioxidante, protegendo os lipídios da membrana da peroxidação e um estimulante da fosforilação oxidativa e da produção de ATP transportando elétrons dos complexos I e II para o complexo III na cadeia de transporte de elétrons. Segundo estudos ela apresenta um efeito positivo nas cardiomiopatias (SANTOS; et al, 2010).

Devido a sua facilidade em sofrer reações redox, a CoQ10 atua como um potente antioxidante prevenindo a oxidação de proteínas, lipídios, lipoproteínas e DNA, e mantendo outros antioxidantes, como ácido ascórbico e vitamina $E$, ela também pode ter propriedades anti-inflamatórias e anti-ateroscleróticas (PARKINSON; SCHULZ; GIUNTI, 2013).

A vitamina E é um antioxidante lipossolúvel celular natural que é altamente abundante nas membranas nucleares e mitocondriais. $O$ tratamento de pacientes com vitamina $E$ mostrou efeito terapêutico apenas quando usado em combinação com CoQ10 (SANTOS; et al, 2010). A coenzima Q10 combinada com vitamina E melhora a bioenergética do tecido cardíaco e do músculo esquelético (FERREIRA, 2012). 
As células de pacientes com FA são suscetíveis à produção reativa de espécies de oxigênio. $\mathrm{O}$ ativador do fator nuclear eritroide $2, \mathrm{Nrf2}$, considerado um agente que regula a resposta do antioxidante dentro do corpo humano, induz à expressão de genes, modificando os antioxidantes e proteínas, desempenhando uma função de proteção e sobrevivência celular (HAHN; DE OLIVEIRA; BOCK, 2017). Na FA, a ativação do Nrf2 é suprimida contribuindo para o estresse oxidativo, disfunção mitocondrial e redução da produção de ATP. O aumento da ativação do Nrf2, o uso de uma variedade de compostos aumenta a ativação do Nrf2 e reverte mecanismos endógenos de defesa antioxidante em modelos animais e celulares de FA, tornando a via Nrf2 um potencial alvo terapêutico (LYNCH; et al. 2019).

Omaveloxolona (Omav) é um novo ativador Nrf2 que evita a ubiquitinação de Nrf2 aumentando seus níveis. Nas células de pacientes com FA, ativação Nrf2 aumenta a função mitocondrial. Recentemente, estudo clínico mostrou que o Omav continua a ser um agente terapêutico viável para o desenvolvimento em curso em FA, sendo bem tolerado e associado com relativamente poucos eventos adversos (LYNCH; et al. 2019).

Figura 2. Disfunção celular na FA e possíveis oportunidades terapêuticas.

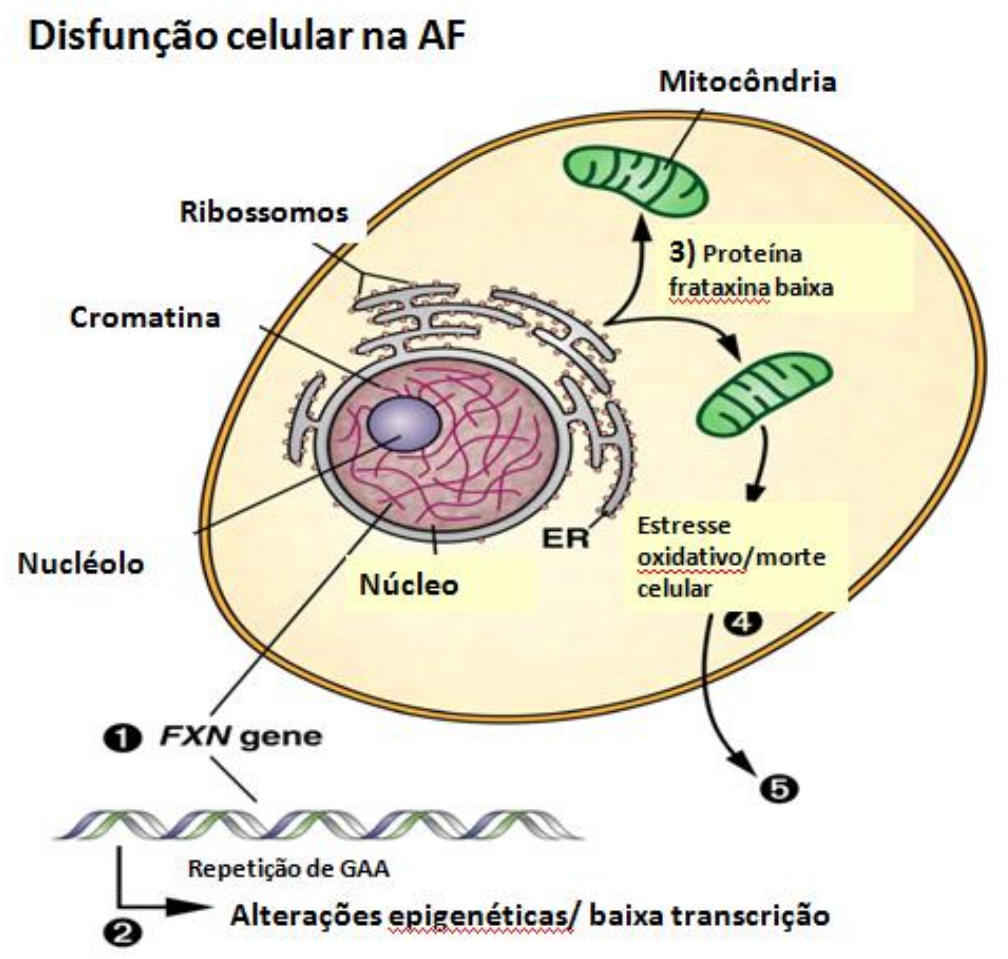

Fonte: Adaptado de Molecular Mechanisms and Therapeutics for the GAA.TTC Expansion Disease Friedreich Ataxia Joel M. Gottesfeld (GOTTESFELD, 2019). 


\section{CONSIDERAÇÕES FINAIS}

Em suma, a ataxia de Friedreich consiste em um doença heredodegenerativa, de caráter progressivo, exibindo marcante variabilidade fenotípica, mesmo entre irmãos. 0 reconhecimento precoce dessa doença permitirá que novos tratamentos sejam realizados antes que danos irreversíveis ao sistema nervoso e cardiovascular estejam instaurados. Embora não haja uma terapia curativa no momento, o uso de antioxidantes pode retardar a progressão da doença, enquanto novas terapias sejam desenvolvidas e se tornem disponíveis clinicamente.

\section{AGRADECIMENTOS}

Agradecemos nossos professores, Zumira e Charles pela oportunidade do trabalho, também à família e os pacientes pela colaboração com a realização da pesquisa.

\section{REFERÊNCIAS}

ALSINA, David et al. Ferro na ataxia de Friedreich: papel central na fisiopatologia ou epifenômeno ?. Pharmaceuticals , v. 11, n. 3, pág. 89, 2018.

ANHEIM, Mathieu et al. Exonic deletions of FXN and early-onset Friedreich ataxia. Archives of neurology, v. 69, n. 7, p. 912-916, 2012.

COOK, A .; GIUNTI, P. Ataxia de Friedreich: aspectos clínicos, patogênese e manejo. Boletim médico britânico , p. 1-12, 2017.

EVANS-GALEA, Marguerite V. et al. Beyond loss of frataxin: the complex molecular pathology of Friedreich ataxia. Discovery medicine, v. 17, n. 91, p. 25-35, 2014.

FERREIRA, Diana Raquel Martins Fernandes Rompante. Ataxia de Fridreich-Revisão bibliográfica e caso clínico. 2012.

GOTTESFELD, Joel M. Mecanismos moleculares e terapêutica para o GAA - Doença de expansão do TTC Friedreich ataxia. Neurotherapeutics, v. 16, n. 4, pág. 10321049, 2019.

HAHN, Gabriela Fernandes; DE OLIVEIRA, Jarbas Rodrigues; BOCK, Patricia Martins. O papel do fator nuclear eritróide 2 relacionado ao fator 2 ( Nrf2) no diabetes mellitus. Clinical \& Biomedical Research, v. 37, n. 3, 2017. 
HAUGEN, Astrid C. et al. Expressão gênica alterada e dano ao DNA em células do sangue periférico de pacientes com ataxia de Friedreich: modelo celular de patologia. PLoS Genet , v. 6, n. 1, pág. e1000812, 2010.

HOFFMAN-ZACHARSKA, Dorota et al. A ataxia de Friedreich não é apenas um distúrbio de expansão de repetição de GAA: implicações para testes moleculares e aconselhamento. Jornal de genética aplicada , v. 57, n. 3, pág. 349-355, 2016.

LYNCH, David R. et al. Segurança, farmacodinâmica e benefício potencial da omaveloxolona na ataxia de Friedreich. Anais de neurologia clínica e translacional , v. 6, n. 1, pág. 15-26, 2019.

MONTENEGRO, Lucia et al. Idebenona: novas estratégias para melhorar sua eficácia sistêmica e local. Nanomateriais , v. 8, n. 2, pág. 87, 2018.

PARKINSON, Michael H .; SCHULZ, Jörg B .; GIUNTI, Paola. Co-enzima Q10 e uso de idebenona na ataxia de Friedreich. Journal of Neuroquímica , v. 126, p. 125-141, 2013.

QUERCIA, Nada et al. Ataxia de Friedreich apresentando-se como morte súbita cardíaca na infância: correlação clínica, genética e patológica, com implicações para testes genéticos e aconselhamento. Neuromuscular Disorders , v. 20, n. 5, pág. 340342, 2010.

SAGHAZADEH, Amene et al. Early-Onset Friedreich's Ataxia With Oculomotor Apraxia. Acta Medica Iranica, p. 128-130, 2017.

SANTOS, Renata et al. Friedreich ataxia: molecular mechanisms, redox considerations, and therapeutic opportunities. Antioxidants \& redox signaling, v. 13, n. 5, p. 651-690, 2010.

STRAWSER, Cassandra et al. Terapêutica farmacológica na ataxia de Friedreich: o estado atual. Revisão especializada de neuroterapêutica, v. 17, n. 9, pág. 895-907, 2017.

TAl, Geneieve et al. Progress in the treatment of Friedreich ataxia. Neurologia $\mathbf{i}$ neurochirurgia polska, v. 52, n. 2, p. 129-139, 2018.

WEIDEMANN, Frank et al. Cardiomiopatia de ataxia de Friedreich. Journal of Neuroquímica , v. 126, p. 88-93, 2013.

YOON, Grace et al. Transplante cardíaco na ataxia de Friedreich. Journal of child neurology , v. 27, n. 9, pág. 1193-1196, 2012. 


\title{
CAPITULO XXX
}

\section{ACIDENIE VASCULAR CEREBRAL HEMORRÁGICO NAS ENIREUNHAS DA LITERATURA}

\author{
Waleska Alves de Oliveira ${ }^{1}$ \\ Elaine Cristina Fernandes Baez Sarti ${ }^{2}$ \\ Everton Souza de Moraes ${ }^{3}$ \\ Fabiola Maria dos Santos 4 \\ Juliana Cristina Martins de Souza ${ }^{5}$ \\ João Vitor Andrade ${ }^{6}$
}

\footnotetext{
${ }^{1}$ Enfermeira. Especialista em Enfermagem em Saúde Mental e Psiquiátrica. Associação Saúde da Família.

${ }^{2}$ Enfermeira. Doutora em Biotecnologia e Biodiversidade. Universidade Federal de Mato Grosso do Sul.

${ }^{3}$ Enfermeiro. Especialista em Cardiologia e Pneumologia. Instituto do Coração da Faculdade de Medicina da Universidade de São Paulo.

${ }^{4}$ Graduanda em Farmácia. Faculdade de Ciências Farmacêuticas da Universidade Federal de Alfenas.

${ }^{5}$ Enfermeira. Especialista em Enfermagem em Saúde Mental e Psiquiátrica. Instituto de Psiquiatria da Universidade de São Paulo.

6 Enfermeiro. Especializando em Enfermagem em Saúde Mental e Psiquiátrica. Instituto de Psiquiatria da Universidade de São Paulo.
}

\section{RESUMO}

O Acidente Vascular Cerebral (AVC), é a segunda principal causa de morte e a primeira causa de incapacidade no Brasil. No intento de agrupar informações sobre essa doença, se construiu o presente trabalho. Trata-se de uma revisão narrativa da literatura. Foi possível estruturar linearmente achados sobre o AVC, relacionados aos fatores de risco e etiológicos, a fisiopatologia, a classificações, expansão do hematoma, qua dro clínico e prognósticos. Por fim, pontua-se que o tratamento pode ser clínico ou cirúrgico e depende da avaliação do volume da lesão, da localização e da condição clínica do paciente. Sendo que, os pacientes tratados cirurgicamente também devem receber suporte clínico e de reabilitação.

Palavras-chave: Transtornos Cerebrovasculares; Acidente Vascular Cerebral; Hemorragia Cerebral.

\section{INTRODUÇÃO}

As doenças cerebrovasculares estão entre as principais causas de morte no Brasil e o Acidente Vascular Cerebral (AVC), caracteriza-se como a segunda principal causa de morte e a primeira causa de incapacidade no país. São registradas cerca de sessenta e oito mil mortes por AVC ao ano no Brasil (BRASIL, 2012). 
Segundo a Organização Mundial de Saúde, o AVC está entre as 10 principais causas de morte no mundo, sendo a segunda maior causa destes óbitos. Das 56,9 milhões de mortes que ocorreram em todo o mundo no ano de 2016, mais da metade (54\%) está relacionada a estas 10 principais causas. A cardiopatia isquêmica e o AVC são os maiores causadores de mortes no mundo, sendo responsáveis por um total de 15,2 milhões de óbitos em 2016. Essas doenças têm permanecido como as principais causas de morte global nos últimos 15 anos (OMS, 2018).

O AVC caracteriza-se em um déficit neurológico de início súbito que ocorre nos vasos do Sistema Nervoso Central, divide-se em dois subtipos: isquêmico (AVCi) (fluxo sanguíneo é interrompido por um trombo/coágulo) e hemorrágico (AVCh) (há o rompimento desse vaso, causando sangramento na área afetada) (LOUIS; MAYER; ROWLAND, 2018).

Embora haja carência de dados epidemiológicos, no Brasil, o AVCh apresenta uma mortalidade aguda em 30 a 40\% de todos os casos, chegando a 50\% após 1 mês. Destes, de $70 \%$ a $90 \%$ dos casos são relacionados a hipertensão arterial; já em idosos com sangramentos lobares, a angiopatia amiloide ainda é a causa mais frequente. No país, as doenças cerebrovasculares não são consideradas agravos de notificação compulsória e a maioria dos dados de morbidade e mortalidade provém de registros hospitalares (PONTES-NETO et al., 2009; LOUIS; MAYER; ROWLAND, 2018).

O AVC é um complexo de sintomas de deficiência neurológica com início agudo que persiste por cerca de vinte e quatro horas, em que há alterações na irrigação sanguínea cerebral, podendo resultar em lesões desta área (SBDCV, 2018).

O AVCi, tipo mais frequente, de origem trombótica ou embólica, ocorre quando há obstrução de um vaso, o que dificulta a irrigação sanguínea de determinada área cerebral, já o hemorrágico manifesta-se como hemorragia subaracnóidea (HSA), em que há extravasamento do sangue para o espaço subaracnóideo, devido à ruptura de aneurisma intracraniano, geralmente, ou hemorragia intracerebral (HIC), frequentemente associada à hipertensão arterial (SBDCV, 2018).

Existem semelhanças entre os sinais e sintomas destes dois tipos gerais, entretanto, há diferenças quanto à etiologia, fisiopatologia, tratamento medicamentoso, cirúrgico e cuidados necessários aos pacientes acometidos (GOULART, 2013). 


\section{MÉTODO}

O presente estudo constitui-se em uma revisão de literatura. Destaca-se que esse tipo de estudo reúne diversos dados e informações a partir de estudos já existentes, e assim, serve de base para incorporar a construção cientifica de determinado tema (LAKATOS; MARCONI, 2003). Revisões narrativas se caracterizam como publicações amplas, sendo apropriadas para descrever e discutir o desenvolvimento, explicitando o 'estado da arte' do assunto em questão, a partir de um ponto de vista teórico-conceitual. Destaca-se que as revisões narrativas contribuem no fomento dos debates de determinadas temáticas, colaborando na aquisição, garimpo e atualização do conhecimento (ROTHER, 2007).

Para a busca bibliográfica utilizou-se os Descritor em Ciências da Saúde (DeCS): "Hemorrhagic Stroke" e "Subarachnoid Hemorrhage", e seus correspondentes em português e espanhol, sendo esses inseridos na Biblioteca Virtual da Saúde (BVS) e nas bases de dados Medical Literatura Analysis and Retrieval System Online (MEDLINE) e Scientific Eletronic Library Online (SCIELO).

A análise dos dados se deu pela leitura dos resumos e dos textos na integra de todos os estudos encontrados, para pré-definir quais seriam incluídos e excluídos da pesquisa. Buscou-se os DeCS no título, resumo ou corpo de estudos, sem recorte de período temporal no tocante a publicação desses estudos. Nesse sentido, definiu-se que seriam incluídas produções disponíveis na íntegra, nos idiomas português, inglês e espanhol, artigos e livros permitam uma melhor coerência com a temática desenvolvida nesta pesquisa.

\section{RESULTADOS E DISCUSSÃO}

\subsection{FATORES DE RISCO E ETIOLÓGICOS}

O AVCh pode ser definido como qualquer coleção de sangue intracraniano, entretanto, neste trabalho foi abordado sangramentos de origem não traumática (espontâneas) relacionados ou não à Hipertensão Arterial Sistêmica (HAS). Trata-se de uma doença grave e comum, porém pouco estudada em relação ao Acidente Vascular 
Cerebral isquêmico (GOULART, 2013). Os principais fatores de risco e etiológicos são abordados no quadro a seguir.

Quadro 1 - Fatores de risco e etiológicos para AVCh.

\begin{tabular}{|c|c|}
\hline Demográficos & $\begin{array}{l}\text { Idade } \\
\text { Raça/ etnia }\end{array}$ \\
\hline Fatores de risco vasculares & $\begin{array}{l}\text { Hipertensão crônica (doença dos pequenos vasos) } \\
\text { Colesterol baixo }\end{array}$ \\
\hline Patologia vascular & $\begin{array}{l}\text { Angiopatia amiloide (incluindo formas hereditárias) } \\
\text { Transformação hemorrágica de uma lesão isquêmica subaguda } \\
\text { Trombose venosa/ de seios venosos cerebrais }\end{array}$ \\
\hline Lesões vasculares preexistentes & $\begin{array}{l}\text { Cavernoma } \\
\text { Malformação arteriovenosa }\end{array}$ \\
\hline Malignos & $\begin{array}{l}\text { Tumores cerebrais } \\
\text { Metástases cerebrais }\end{array}$ \\
\hline Inflamatórios & $\begin{array}{l}\text { Vasculites (cerebrais, sistêmicas) } \\
\text { Endocardite (aneurisma micótico) }\end{array}$ \\
\hline Hematológicos & $\begin{array}{l}\text { Coagulopatias } \\
\text { Trombocitopenia }\end{array}$ \\
\hline latrogênicos & $\begin{array}{l}\text { Anticoagulante } \\
\text { Fibrinólise }\end{array}$ \\
\hline Tóxicos & $\begin{array}{l}\text { Álcool } \\
\text { Fumo } \\
\text { Cocaína } \\
\text { Anfetaminas }\end{array}$ \\
\hline
\end{tabular}

Fonte: LOUIS; MAYER; ROWLAND, 2018, editado.

Os sangramentos decorrentes da HAS e da angiopatia amiloide são denominados primários, diferentemente daqueles que advém de lesões estruturais no encéfalo (p. ex., aneurismas, tumores, metástases, infartos venosos, etc.). A angiopatia amiloide ocorre, geralmente, em pacientes acima de 65 anos, portanto sua frequência aumenta com a idade. A proteína amiloide, de natureza distinta da amiloidose sistêmica, costuma infiltrar as camadas média e adventícia de vasos corticais. Anomalias vasculares como aneurismas, malformações arteriovenosas e cavernomas são causas comuns do AVCh 
em jovens não hipertensos. Tumores primários e metástases podem ocorrer em todas faixas etárias (AZEVEDO; TANIGUCHI; LADEIRA, 2017).

De acordo com Meneghelo e Barroso (2018), os anticoagulantes e trombolíticos têm sido usados de forma crescente nas últimas décadas e são uma das causas emergente de AVCh. Mesmo com a adoção de protocolos de triagem, os sangramentos do Sistema Nervoso Central (SNC) após a trombólise de AVC isquêmico podem ocorrer. Violações dos critérios de seleção para a trombólise na prática clínica podem gerar sangramentos ainda mais frequentes. Casos de trombose de seio ou veia central (infartos venosos de SNC) podem ter como único achado na TC de crânio o sangramento, único ou múltiplo.

O uso de álcool também é tido como fator relacionado ao AVCh, possivelmente por alterações na função plaquetária e coagulação. A hipocolesterolemia (colesterol total abaixo de $160 \mathrm{mg} / \mathrm{dL}$ ) pode estar relacionado a maior risco, mas ainda requer mais análises. Uma associação entre uma mutação específica no fator XIII e o AVCh também foi levantada com possível fator de risco para o desenvolvimento do AVCh, comparadas a AVCi mas a relevância deste achado ainda requer mais explanações (AZEVEDO; TANIGUCHI; LADEIRA, 2017).

\subsection{FISIOPATOLOGIA}

Os sangramentos relacionados à hipertensão arterial são originados em artérias perfurantes de pequeno calibre, encontradas nos locais onde habitualmente ocorrem os AVCh relacionados à hipertensão: núcleos da base (35 a 45\% dos casos), substância branca profunda $(25 \%)$, tálamo $(20 \%)$, cerebelo $(15 \%)$ e tronco (principalmente na ponte) (5\%). Essas artérias de pequeno calibre originam-se diretamente de vasos de maior calibre (p. ex., artéria cerebral média), sem contar com a gradual diminuição de calibre, que mais comumente é vista em outros territórios arteriais (NETO; TAKAYANAGUI, 2013).

Ainda para estes autores, esses ramos ficam bastante expostos aos efeitos deletérios da hipertensão. A exposição crônica à HAS leva a uma série de alterações patológicas que acarretam em constrições focais do calibre desses vasos. Esse processo foi denominado de lipohialinose. 
Figura 1. Estrutura e localização dos núcleos da base.

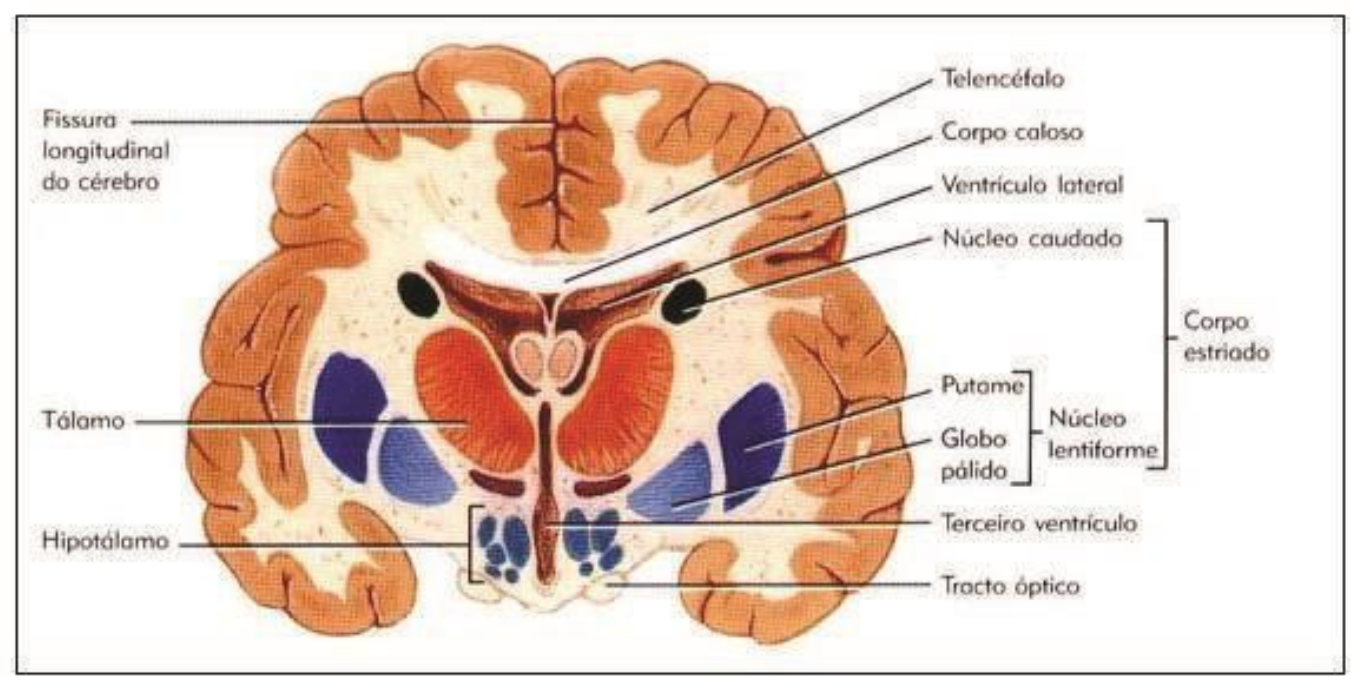

Fonte: NETTER, 2015.

A lipo-hialinose engloba dois processos patológicos que incluem a aterosclerose dos ramos perfurantes de maior calibre (100 a 500 mícrons) e arteriolosclerose dos ramos menores (<100 mícrons). A aterosclerose é mais comum nas bifurcações dos vasos e se caracteriza pela proliferação subintimal de fibroblastos e deposição de macrófagos com gordura no seu interior. Como consequência, os vasos estão com seus calibres diminuídos e com menor complacência, favorecendo a oclusão, que levaria a um AVCi lacunar, ou uma rotura, que levaria à hemorragia (OLIVEIRA; CARDEAL; LIMA, 1997; AZEVEDO; TANIGUCHI; LADEIRA, 2017).

Durante muito tempo, a formação do hematoma foi considerada um evento monofásico, ictal, que rapidamente cessava. As consequências desse hematoma seriam um efeito de massa local e a formação de uma zona de hipoperfusão do tecido sadio em um halo na periferia do coágulo, por efeito mecânico compressivo. Seria formada, nessa visão, uma zona de penumbra isquêmica, à semelhança do que ocorre no AVC isquêmico. A lesão neuronal direta pelo hematoma e a área de penumbra perihematoma levariam a um edema secundário. Em casos de AVCh mais graves, a hipertensão intracraniana (HIC) e herniações aparecem e existe lesão cerebral pelo efeito de massa do hematoma (NETO; TAKAYANAGUI, 2013).

Esse modelo, ainda de acordo com Neto e Takayanagui (2013) entretanto, não explica toda extensão dos danos neurológicos causados pelo AVCh, principalmente em pacientes sem HIC, considerando-se que o hematoma tende a dissecar e respeitar 
planos (acumulando-se e acomodando-se entre os neurônios, divulsionando-os, ou seja, afastando-os em vez de seccioná-los) e posteriormente ser reabsorvido.

Também tem sido proposto um modelo de lesão "inflamatória": com ênfase no papel de citocinas e metaloproteinases, geradas a partir de ativação de leucócitos, que é estimulada pelos produtos da degradação do coágulo que ocorrem na intimidade do tecido neuronal como principais fatores responsáveis pelo edema perilesional e danos irreversíveis após o AVCh. A partir da rotura da artéria perfurante, ocorreria juntamente do sangramento a passagem de glicose e eletrólitos para o meio extravascular, exercendo efeito osmótico e constituindo o primeiro estímulo para a formação do edema perilesional. Depois disso, um coágulo se forma e as plaquetas ativadas liberam mediadores que favorecem o edema local e o recrutamento de leucócitos (OLIVEIRA; CARDEAL; LIMA, 1997; AZEVEDO; TANIGUCHI; LADEIRA, 2017).

Segundo estes autores, os leucócitos na proximidade do coágulo secretam interleucina I, IL-6 e o TNF-a. Essas citocinas no AVCh exercem efeitos inflamatórios locais e sistêmicos. Em uma fase mais tardia (após 72 horas), a lise das hemácias contidas no coágulo leva à liberação de ferro, monóxido de carbono e bileverdina, cristais prismáticos verdes insolúveis em água, formados no organismo a partir da hemoglobina. Essas substâncias interagem com radicais livres e lesam a membrana celular além da liberação de glutamato pelos neurônios (excitotoxicidade) (OLIVEIRA; CARDEAL; LIMA, 1997; AZEVEDO; TANIGUCHI; LADEIRA, 2017).

Além da lesão por excitotoxicidade, a chegada de macrófagos ativados e um aumento na quantidade de metaloproteinases locais levariam a mais destruição celular, apoptose e formação de uma cicatriz local. Somados a esses mecanismos, também já foi descrita disfunção mitocondrial como mecanismo de lesão no AVCh (OLIVEIRA; CARDEAL; LIMA, 1997; AZEVEDO; TANIGUCHI; LADEIRA, 2017).

Estudos recentes corroboram de forma indireta a hipótese da lesão neuronal mediada por uma reação inflamatória. Tais dados sugerem que o conceito da "penumbra" ao redor do hematoma talvez não seja válido. Contudo, usando a ressonância magnética com técnicas de difusão e perfusão e tomografia por emissão de pósitrons, partículas de elétrons com carga positiva usadas em tomografias e na ressonância magnética funcional, mostrou-se que esse hipofluxo ocorre acoplado a um 
menor consumo de oxigênio na periferia do hematoma (AZEVEDO; TANIGUCHI; LADEIRA, 2017).

\subsection{EXPANSÃO DO HEMATOMA}

Com a maior disponibilidade do uso da tomografia seriada, é evidenciado que muitos hematomas continuam crescendo nas primeiras horas após o sangramento, também chamada de expansão do hematoma. O risco de ocorrência da expansão diminui com o passar do tempo, sendo mais prevalente nas primeiras 6 horas de evolução e rara após 24 horas. A expansão ocorre em 17 a 29\% dos pacientes atendidos nas primeiras 6 horas de sangramento podendo ocorrer em até $38 \%$ daqueles atendidos nas 3 primeiras horas de sintomas do AVCh (CONNOLLY et al., 2012; NETO; TAKAYANAGUI, 2013).

Segundo estes autores, ainda, nos pacientes que chegam ao hospital com 6 a 24 horas de evolução, a expansão foi registrada em 2 a 10\% dos casos. Após 24 horas, a expansão é rara, com excessão em casos de coagulopatias, nos quais a expansão pode ocorrer enquanto a discrasia perdurar. Os fatores de risco para a expansão do hematoma não são tão conhecidos e explorados (CONNOLLY et al., 2012; NETO; TAKAYANAGUI, 2013).

Por fim, a expansão do hematoma não deve ser confundida com o ressangramento. O ressangramento nos dias ou semanas subsequentes é incomum nos AVCh causados pela hipertensão arterial, mas pode ser mais frequente nos pacientes com sangramentos secundários a lesões estruturais ou na angiopatia amiloide (CONNOLLY et al., 2012; LOUIS; MAYER; ROWLAND, 2018).

\subsection{CLASSIFICAÇÕES E QUADRO CLINIICO}

O AVCh pode apresentar uma grande variedade de quadros neurológicos, dependendo do local de sangramento. Em geral, há um quadro de instalação aguda, com sintomas neurológicos focais, diminuição e/ou flutuação do nível de consciência e vômitos, presentes em quase metade dos casos. Além disso, é comum a deterioração do nível de consciência nas primeiras horas, no AVCi e na HSA, o déficit costuma apresentar intensidade máxima já na instalação do quadro (AZEVEDO; TANIGUCHI; LADEIRA, 2017). 
Quadro 2: Características clínicas do AVCh de acordo com a localização do sangramento.

\begin{tabular}{|c|l|}
\hline Localização & \multicolumn{1}{c|}{ Características clínicas } \\
\hline Putaminal & $\begin{array}{l}\text { Hemiparesia, hemianestesia, afasia global, paralisia do olhar conjugado horizontal } \\
\text { contralateral (Foville superior); }\end{array}$ \\
\hline Talâmica & $\begin{array}{l}\text { Hemiparesia, hemianestesia, ocasionalmente afasia, paralisia do olhar conjugado } \\
\text { vertical para cima, "skew deviation"(desvio não conjugado vertical do olhar), } \\
\text { síndrome de Horner; }\end{array}$ \\
\hline Lobar & $\begin{array}{l}\text { Hemiparesia e hemianestesia (fronto-parietal), afasia, paralisia do olhar } \\
\text { conjugado horizontal contralateral (frontal), hemianopsia (occipital), convulsões } \\
\text { (20-28\%); }\end{array}$ \\
\hline Cerebelar & $\begin{array}{l}\text { Tríade de Ott: ataxia, paralisia do olhar conjugado horizontal e paralisia facial } \\
\text { periférica. }\end{array}$ \\
\hline Pontina & $\begin{array}{l}\text { Dupla hemiparesia e hemianestesia, paralisia do olhar conjugado horizontal } \\
\text { bilateral, pupilas puntiformes, "bobbing" ocular, postura descerebrada, } \\
\text { instabilidade respiratória. }\end{array}$ \\
\hline
\end{tabular}

Fonte: NETO; TAKAYANAGUI, 2013; LOUIS; MAYER; ROWLAND, 2018.

Os sangramentos putaminais, localizados no putâmen, estrutura redonda localizada na base da parte frontal do cérebro, o telencéfalo, cursam com sinais de hipertensão intracraniana associados a hemiparesia e alterações de sensibilidades, contralaterais à lesão. Os olhos podem estar desviados para o lado contrário ao do déficit. Alterações no campo visual podem ocorrer, mas muitas vezes sua avaliação é dificultada pelos outros déficits, como torpor ou falta de cooperação do paciente. Ainda, lesões no hemisfério dominante podem causar afasia (OLIVEIRA, 2001).

Sangramentos talâmicos costumam apresentar-se com hemiparesia, por envolvimento da cápsula interna adjacente, e alterações contralaterais de sensibilidade. A localização próxima à linha média favorece alterações pupilares e paralisias oculares. Pode ocorrer diminuição do nível de consciência mesmo com hematomas pequenos. É frequente a comunicação do sangramento com o sistema ventricular. Sangramentos de tronco têm apresentação mais grave e o paciente costuma dar entrada já em coma no hospital, em geral dependente de ventilação mecânica e com alto índice de mortalidade (AZEVEDO; TANIGUCHI; LADEIRA, 2017).

O AVCh de cerebelo, por não cursar com déficits motores e frequentemente se apresentar com queixas de instabilidade de marcha, tontura e vômito, pode ser confundido com vestibulopatias ou quadros gastrintestinais autolimitados. Na avaliação 
inicial no setor de emergência é importante a realização do exame neurológico completo em pacientes com suspeita de "labirintite": atentar-se à avaliação da marcha, da coordenação e dos nervos cranianos, é importante, além da observação da resposta a sintomáticos quando o diagnóstico inicial de vestibulopatia for anulado e em caso de dúvidas, realização de tomografia computadorizada (TC) de crânio (LOUIS; MAYER; ROWLAND, 2018).

Não há nenhum sintoma que, isoladamente ou em conjunto, tenha acurácia suficiente para determinar se o AVC é hemorrágico ou isquêmico sem a realização de uma TC de crânio.

\subsection{PROGNÓSTICOS}

Apesar dos avanços nos diagnósticos e na terapêutica, o prognóstico da AVCh continua expressivo, com taxas elevadas de mortalidade e incapacidade; quase metade dos pacientes evoluem para óbito até o final do primeiro mês após o incidente (PONTESNETO et al., 2009; CONNOLLY et al., 2012).

De acordo com estes autores, a mortalidade pode alcançar de mais da metade dos casos de AVCh em até dois anos após o acometimento e poucos casos recuperam a independência funcional em seis meses. Dentre os principais preditores de mortalidade passado os primeiros dias, estão: rebaixamento do nível de consciência na admissão, gravidade do déficit neurológico, idade avançada e volume do sangramento (PONTESNETO et al., 2009; CONNOLLY et al., 2012).

Destaca-se ainda que em casos em que o paciente necessitar internação, os cuidados básicos devem ser devidamente realizados por toda a equipe multidisciplinar envolvida, haja visto que, "mesmo tendo múltiplos avanços em relação às ciências médicas, o essencial ainda é invisível aos olhos" e as necessidades humanas básicas de indivíduos em contextos clínicos e intensivos por vezes não são pautadas no cuidar (ANDRADE et al., 2020).

\section{CONSIDERAÇÕES FINAIS}

Destaca-se que o equilíbrio hídrico e temperatura corporal devem ser mantidos em níveis normais. A pressão intracraniana aumentada pode exigir osmoterapia, hiperventilação controlada ou coma induzido por barbitúricos. Costuma-se se evitar a 
administração de corticosteróides. Exceto em caso de hemorragias cerebelares, qualquer decisão sobre se fazer intervenção, como e quando se deve intervir neurocirurgicamente após uma hemorragia intracerebral está sujeita a discussões atualmente.

O tratamento pode ser clínico ou cirúrgico e depende da avaliação do volume da lesão, da localização e da condição clínica do paciente. Mesmo os pacientes tratados cirurgicamente recebem todo o suporte clínico e de reabilitação. O tratamento visa drenar o sangue presente na área; em alguns casos, coloca-se um cateter para avaliar a pressão intracraniana, que tende a aumentar, devido ao do edema. Em algumas situações, o tratamento cirúrgico é decidido por esta medida e há a necessidade de avaliação para possibilidade de ressangramento. O tratamento clínico tem o objetivo geral o controle da PA e de complicações, como crises convulsivas e infecções.

\section{REFERÊNCIAS}

ANDRADE, J. V. et al. Geração de conhecimento nas ciências médicas: impactos científicos e sociais. Campina Grande: Amplla, 2020.

AZEVEDO, L. C. P.; TANIGUCHI, L. U.; LADEIRA, J. P. Medicina intensiva: abordagem prática, 3. ed. Barueri, SP: Manole, 2017.

BRASIL. Ministério da Saúde. Secretaria de Vigilância em Saúde. Departamento de Análise de Situação de Saúde. Plano de Ações Estratégicas para o Enfrentamento das Doenças Crônicas Não Transmissíveis (DCNT) no Brasil 2011-2022. Brasília: Ministério da Saúde, 2012.

CONNOLLY, E. S. J. et al. Guidelines for the management of aneurysmal subarachnhnoid hemorrhage: a guideline for professionals from the American Heart Association/American Heart Association. AHA Journals, v. 43, p. 1711-1737, 2012.

GOULART, A. C. et al. Predictors of long-term survival among first-ever ischemic and hemorrhagic stroke in a Brazilian stroke cohort. BMC Neurology, v. 13, n. 51, 2013.

LAKATOS E. M.; MARCONI, M. A. Fundamentos de metodologia científica. 5ạed. São Paulo: Atlas, 2003.

LOUIS, E. D.; MAYER, S. A.; ROWLAND, L. P. Merritt tratado neurologia. 13. ed. Rio de Janeiro: Guanabara Koogan, 2018. 
MENEGHELO, Z.M.; BARROSO, C.M. Guia Prático de Anticoagulação. Rio de Janeiro, RJ: Atheneu, 2018.

NETO, J. P. B.; TAKAYANAGUI, O. M. Tratado de Neurologia da Academia Brasileira de Neurologia. Rio de Janeiro, RJ: Elsevier, 2013.

NETTER, F. H. Atlas de anatomia humana. 6. ed. Rio de Janeiro, RJ: Elsevier, 2015.

OLIVEIRA, R. M. C.; ANDRADE, L. A. F. Acidente Vascular Cerebral. Revista Brasileira de Hipertensão, v. 8, n. 3, p. 280-90, 2001.

OLIVEIRA, R. M. C.; CARDEAL, J. O.; LIMA, J. G. C. Ectasia da artéria basilar e acidente vascular cerebral: aspectos clínicos de 21 casos. Arquivos de Neuropsiquiatria, v. 55, n. 3, p.558-562, 1997.

OMS - ORGANIZAÇÃO MUNDIAL DA SAÚDE. 10 Principais causas de morte no mundo. Rio de Janeiro: WHO; 2018. Disponível

em: https://www.paho.org/bra/index.php?option=com_content\&view=article\&id=5 638:10principais-causas-de-morte-no-mundo\&Itemid $=0$

PONTES-NETO, O. M. et al. Diretrizes para o manejo de pacientes com hemorragia intraparenquimatosa cerebral espontânea. Arquivos de Neuropsiquiatria, v. 67, n. 3, p. 940-950, 2009.

ROTHER, E. T. Revisão sistemática X revisão narrativa. Acta Paulista de Enfermagem. v. 20, n. 2, p. 05-06, 2007.

SBDCV - Sociedade Brasileira de Doenças Cerebrovasculares. Comitê Executivo da Sociedade Brasileira de Doenças Cerebrovasculares e Departamento Científico de Doenças Cerebrovasculares da Academia Brasileira de Neurologia. Diretrizes, 2018. Disponível em: http://www.sbdcv.org.br/medica_diretrizes.asp 


\section{CAPITULO XXXI}

\section{ESTADO DO CONHECIMENTO: LEPTOSPIROSE E SUA IMPORTÂNCIA Z00NónCA}

\section{DOI: 10.51859/amplla.csa528.2121-31}

Thaise Marques Alves ${ }^{1}$

${ }^{1}$ Mestra em Ciência Animal. Universidade Estadual de Santa Cruz - UESC

\section{RESUMO}

A leptospirose é uma zoonose causada por bactéria da ordem Spirochetales. Pode acometer cães e seres humanos, os principais transmissores são os roedores que são assintomáticos, mas eliminam a bactéria pela urina contaminando o ambiente. Em cães quando a enfermidade é diagnosticada tardiamente as lesões causadas pela Leptospira spp. podem levar cães ao óbito, além deste animal ser fonte de transmissão tanto para humanos quanto para outros animais contactantes. Diante da importância desta enfermidade infecciosa para a saúde pública o estudo proposto objetivou expor informações acerca da Leptospirose canina trazendo aspectos importantes no que tange a saúde pública, afim de informar e gerar reflexão entre os interessados sobre o assunto.

Palavras-chave: Leptospira spp. Cães. Zoonose.

\section{INTRODUÇÃO}

De acordo Instituto Brasileiro de Geografia e Estatística a população estimada de cães no Brasil até 2013 era de 52,2 milhões, ocupando a 2ª posição em número de cães no mundo (IBGE, 2013). Considerando tais valores, chama-se atenção para o caráter de saúde pública ao compreender a existência de zoonoses, incluindo a leptospirose. Dentre os valores estatísticos de serviços de água e esgoto $45 \%$ dos municípios da região nordeste possuem rede coletora de esgotos, e apenas $12,6 \%$ possui serviço de coleta domiciliar de resíduos sólidos. (IBGE, 2011). A falta de saneamento básico é um dos fatores de risco para transmissibilidade da leptospirose entre humanos e animais, já que na falta deste há condições favoráveis para a manutenção de roedores sinantrópicos, importantes reservatórios da Leptospira spp. Analisando tais fatores de risco, o estudo voltado para a Leptospirose possui relevância para a sanidade animal e humana. Conhecer a enfermidade, é importante para inovação em pesquisas, e atualização dos 
profissionais. Diante da importância desta enfermidade infecciosa para a saúde pública, o estudo proposto objetivou expor informações acerca da Leptospirose canina trazendo aspectos importantes no que tange a saúde pública, afim de informar e gerar reflexão entre os interessados sobre o assunto.

\section{REVISÃO BIBLIOGRÁFICA}

\subsection{AGENTE etiológico E suas caracteristicas de PATOGENICIDADE.}

O agente causador da Leptospirose faz parte da ordem Spirochetales, família Leptospiracea, e possui 20 sorogrupos constituídos por 250 sorovares ou sorovariedade, a Leptospira spp. foi classificada com base em características fenotípicas: $L$. biflexa e $L$. interrogans, caracterizadas como saprófitas e patogênicas respectivamente; porém após 1989 o gênero foi reclassificado com base em técnicas moleculares que permitiram o reconhecimento de novas espécies patogênicas dentre elas: L. borgpetersenii, $L$. inadai, L. meyeri, L. noguchii, L. santarosai, L. weilii, L. wolbachii, L. kirschneri, L. fainei, L. alexanderi, L. wolffii, L. licerasiae, L. kmetyi, L. Santarosai (GOMES, 2013).

Morfologicamente apresentam-se como helicoidais ou espirais, móveis, com tamanho de $0,1 \mu \mathrm{m}$ a $0,2 \mu \mathrm{m}$ de diâmetro e $6 \mu \mathrm{m}$ a $12 \mu \mathrm{m}$ de comprimento, possui extremidade em formato de gancho como demonstrada na figura1(A, B) sua mobilidade ocorre através de endoflagelos localizados no espaço periplásmico (JOHNSON, 2018).

Figura 1-Imagem de Leptospira spp.
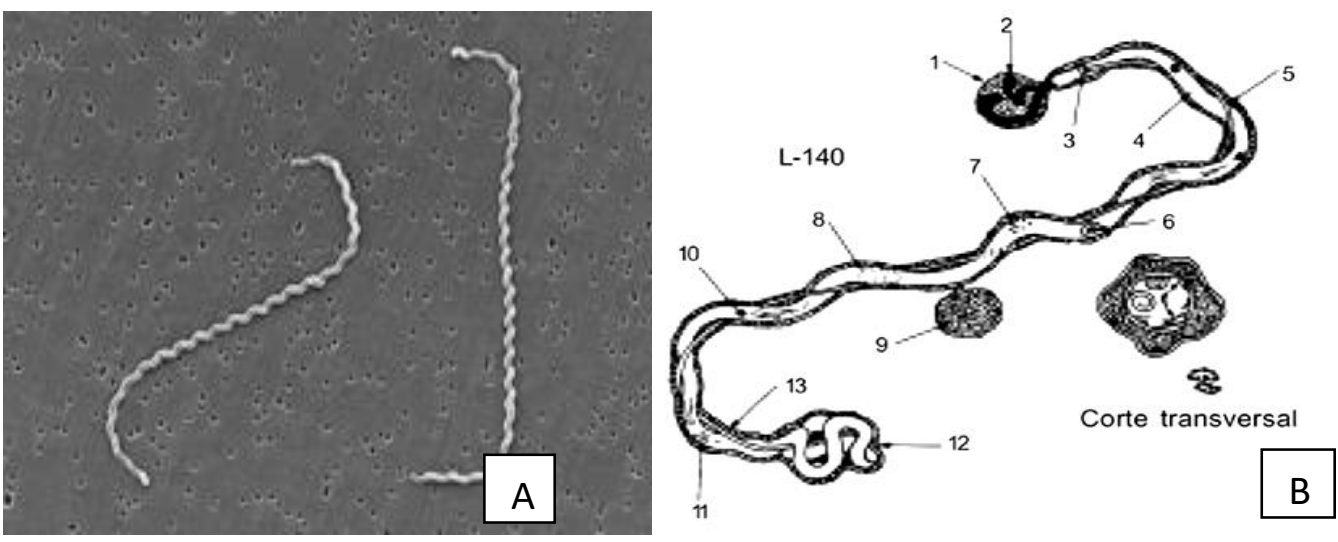

A-Visualização por microscopia eletrônica. B- Esquematização de Leptospira spp. demonstrando 1Apêndice terminal 2-granulo basal 3-cilindro citoplasmático 4-filamentos auxiliares 5- estrutura lamelar 6- Inclusões eletrodensas 7- inclusões permeáveis para elétrons 8- formação globosa 9- inclusões 
eletrodensas 10- Nucleóide de DNA 11- cavidade estrutural 12- membrana externa. Fonte: Macedo, 2005.

São aeróbias estritas, crescem em temperatura ótima de $28 \mathrm{c}^{\circ}$ a $30 \mathrm{c}^{\circ}$, em meios enriquecidos com vitaminas (B12, B2) ácidos graxos de cadeia longa e sais de amônio, já que utilizam estes compostos como fonte de carbono e energia (MURRAY e PATRICK, 2011).

A Leptospira spp. é considerada por alguns autores gram negativas porém apesar de apresentar camada de lipopolissacarídeos (LPS) e possui menor endotoxidade em relação a outras bactérias negativas, não podem ser visualizadas no microscópio óptico comum, assim a coloração de gram não é útil para visualização destas espiroquetas (HAAKE e MATSUNAGA, 2010) sendo realizada através da microscopia de campo escuro sem coloração prévia, no caso de amostras ou meios com baixa ou nenhuma celularidade, e coloração pela técnica de Warthin-Starry, para avaliação histológica de amostras de alta celularidade (ZILBER, 2016).

As espiroquetas possuem uma parede celular e membrana citoplasmática envolvidas pela membrana externa contendo lipoproteínas e porinas as quais permitem a troca de solutos entre o meio externo e o periplasma ou espaço periplasmático; a membrana externa (ME) é formada por uma camada de lipopolissacarídeos (LPS) contendo lipoproteínas (LigA, LigB, LenA, LenB, LcpA, Loa22) porinas ou proteína de transmembrana (OmpL1) e lipoproteínas de superfície (LipL32). Logo abaixo encontrase o espaço periplasmático, seguido da parede celular de peptidioglicano e por fim membrana interna, onde um dos polos entra em contato com o citoplasma como representado didaticamente na figura-2 (FRAGA, 2014).

Figura 2- Esquema da composição de membrana celular de Leptospira sp.

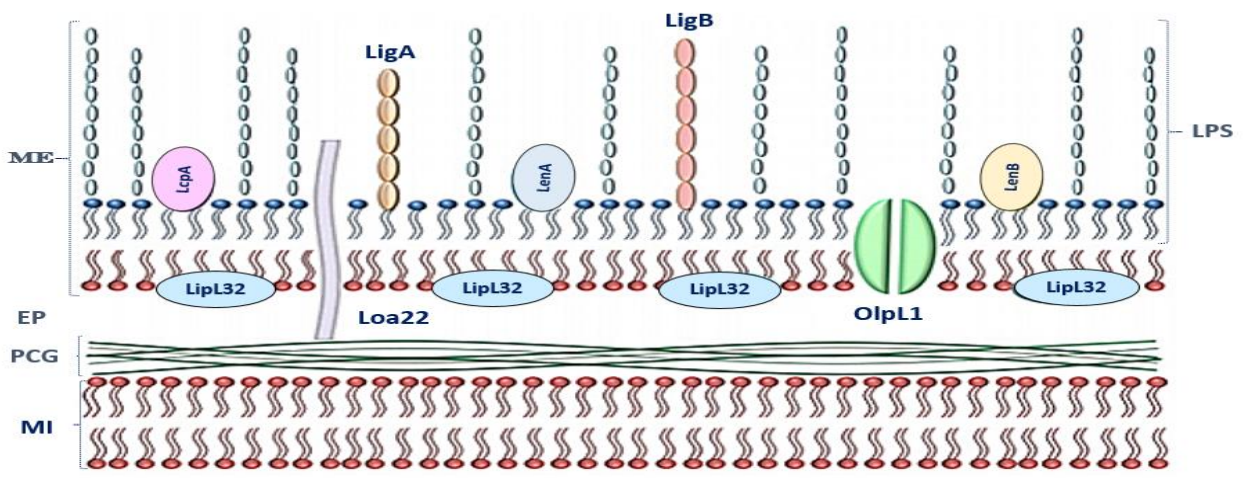

Observa-se a membrana externa contendo uma camada de liopolisacarídeo (LPS) e porinas e lipoproteínas, logo abaixo o espaço periplasmático (EP), parede celular de peptidioglicano (PCG) e membrana interna (MI). Fonte: Adaptado de Fraga ,2014. 
A proteína LipL32 é um antígeno de superfície de membrana externa presente em cepas patogênicas que tem papel importante como imunógeno sendo expressa tanto em cultivo "in vivo" quanto "in vitro", tais características conferem potencial no desenvolvimento de testes de diagnóstico da leptospirose (BOONYOD, 2005). Pavanelli (2008) ao avaliar a expressão dos Toll-like receptor: TLR2, TLR4, e proteína CD14 na superfície de monócitos estimulados “in vitro" com a LipL32 verificou que está proteína é capaz de ser reconhecida pelos monócitos e gerar uma resposta imune com produção de citocinas. Estudos estes contribuem para compreensão da atividade da imunidade inata frente ao patógeno na tentativa de debelar a infecção.

\subsection{RESPOSTA IMUNE}

O organismo animal apresenta condição nutricional, temperatura, e umidade que favorecem o crescimento e manutenção de vários microrganismos, sejam eles patogênicos ou não, portanto é necessário um sistema de defesa que possa atuar evitando a entrada e danos de patógenos no organismo. Dentre os mecanismos de defesa há as barreiras físicas (pele, microbiota indígena) imunidade inata (defensivas, lisozimas) imunidade adaptativa (anticorpos, células de memória); quando a Leptospira spp. adentra o organismo animal estes sistemas de proteção e ação para debelar o agente são acionados (TIZARD, 2014).

A principal resposta imune em cães infectados por Leptospira spp. é a produção de imunoglobulinas, que ocorre por volta de dez dias após a infecção, iniciando com IgM, e mais adiante IgG (CASTRO et al.,2011). A produção de anticorpos contra a bactéria em questão faz parte do mecanismo para debelar a infecção, de acordo (MALE et al.,2014) este são capazes de promover:

- Neutralização, ao se ligar à superfície bacteriana impedindo ação nas células do hospedeiro;

- Opsonização, para facilitar o reconhecimento da bactéria pelos fagócitos mononucleares (monócitos e macrófagos) e neutrófilos;

- Ativação do sistema complemento (via clássica) capaz de ativar uma reação em cascata culminando no complexo de ataque a membrana (MAC) promovendo lise celular; 
- Citotoxidade, mediada por linfócitos, neutrófilos, fagócitos, e células NK, dependentes da ligação de anticorpo para reconhecimento e posterior ação.

No entanto nem sempre o sistema imune é capaz de debelar a infeção, alguns microrganismos conseguem bloquear a ação e evadir. Sabe se que o sistema complemento é formado por um conjunto de proteínas que quando ativadas iniciam um processo em cascata divididas em três vias: via clássica, via das lecitinas, e via alternativa, todas elas culminam na via comum que acionam o MAC definido como complexo de ataque a membrana (TIZARD, 2014).

Ao estudar a interação da Leptospira spp. com o sistema complemento, Valencia (2014) verificou que as proteínas de superfície LigA, e LigB presentes na superfície destas bactérias interagem bloqueando C3b e C4b, moléculas presentes na via clássica, alternativa e lectinas, vias estas que ativam a via comum; ao bloquear o processo, não há destruição dos microrganismos através do MAC.

Como mecanismo de patogenicidade e evasão do sistema imune a Leptospira spp. é capaz de translocar em monocamadas celulares facilitando tanto o transporte para órgãos alvo, quanto evasão ao penetrar temporariamente em células para fugir da fagocitose (ANIZ, 2014).

Os eventos imunológicos desencadeados após a infecção causam não só lesão as células invasoras, mas também lesões ao organismo promovendo desordem em um corpo antes saudável. Uma vez compreendido este processo é possível obter maior eficiência na intervenção terapêutica, diagnóstico (a partir dos vestígios deixados pela passagem da bacteria pelo sistema), bem como prevenção, mediante a produção de imunógenos com base na produção de uma resposta de memória.

\subsection{TRANSMISSIBILIDADE E EPIDEMIOLOGIA}

As condições edafoclimáticas, e o tipo de solo tem relação direta com a manutenção da bactéria no ambiente pois, solos mais porosos com menor capacidade de retenção de água tem menor capacidade de manutenção da bactéria em relação a solos ricos em argila e matéria orgânica, o pH do solo também é outro fator importante, já que solos com $\mathrm{pH}$ mais próximo da neutralidade favorecem o crescimento e manutenção da Leptospira spp. A pluviosidade local gera ainda acúmulo de água que 
carreia e aloja a bactéria propiciando infecção para animais domésticos e humanos (ESCÓCIO et al.,2010).

Os ratos são os principais transmissores da enfermidade e dentre as espécies o Rattus norvegicus é o principal reservatório da Leptospira spp. Apesar de não ser patogênica para os roedores, estes quando estão contaminados eliminam a bactéria pela urina (contaminando água e alimentos) e também através do leite em ratas lactantes promovendo transmissão vertical entre os roedores, favorecendo a disseminação da enfermidade (OLIVEIRA, 2015).

Estudo realizado na capital da Bahia por Falzemburgh (2010) verificaram que o fator risco está relacionado a falta de coleta de lixo e contato com água contaminada e esgotos a céu aberto. Sendo, portanto, uma enfermidade com maior ocorrência em áreas que faltam saneamento básico. Dados estes que corroboram com Cruz (et.al, 2016) que demonstrou a alta ocorrência da enfermidade em bairros carentes da mesma capital com predominância para cepas L. Icterohaemorragiae e L. Cynopteri; esta última cepa chama a atenção para novos estudos já que mamíferos silvestres são os principais reservatórios e até então não era uma cepa comum em ambiente urbano.

Além dos roedores sinantrópicos há outros animais que são potenciais de transmissão; foi detectada e confirmada exposição de guaxinins (Procyon lotor) a dois sorovares de Leptospira (grippotyphosa e icterohemorrhagiae) com prevalência 8,9\% de L. interrogans icterohemorrhagiae, e 6,3\% de L. interrogans grippotyphosa numa população de 159 animais (JUNGE et al.,2007).

A evidência sorológica de infecção por Leptospira interrogans também foi observada em Didelphis virginiana chamados popularmente de Gambás entre 81 amostras de soro 4,9\% foram positivas para anticorpos contra Leptospira spp. sorovares pomona e wolfii tais animais soropositivos foram capturados em São Paulo durante a estação chuvosa (CASA GRANDE et al.,2011) estudos estes corroboram com Horta et al. (2016) que ao colher amostras de 18 municípios do estado de São Paulo, entre 2003 e 2008, verificaram através da soroaglutinação microcópica (SAM) soropossitividade de 3,5\% para os sorovares de Leptospira: autumnalis-Butembo; Mini-Mini; BallumCastellonis; Icterohaemorrhagiae-Icterohaemorrhagiae; IcterohaemorrhagiaeCopenhageni e Grippotyphosa-Grippotyphosa. 
Estudos também chamam atenção para os gatos já que estes são animais de companhia que muitas vezes tem contato com humanos e cães, apesar de não desenvolverem clinicamente a enfermidade quando infectados os gatos podem disseminar a bactéria via urina, é o que afirma alguns estudos (SCHULLER et.al., 2015). Ressalta-se, portanto, a importância epidemiológica destes animais no ciclo de transmissão e manutenção da doença entre humanos e outros animais que possam ser suscetíveis.

Pouco é estudado o potencial de transmissão da leptospirose por cães via reprodutiva, devido ao quadro clínico não está diretamente associado a lesões reprodutivas, apesar de ocorrer com frequência em outras espécies como suínos e bovinos; porém trabalho realizado por Netto (2008) detectou DNA de leptospiras spp. no sémen canino, aumento no número de espermatozoides com a patologia de cabeça isolada, alterações no exame andrológico e prostatite; portanto cães infectados podem ser fonte de infecção para o homem e animais, com capacidade de transmissão via sêmen nos primeiros dias pós-infecção, antes da fase de leptospirúria.

Ao analisar estudos de avaliação soroepidemiológica da leptospirose canina no Brasil, De Mello (2007) observou que não há distinção para as variáveis epidemiológicas: sexo e idade; e que quanto a sorovariadade de maior ocorrência, cada região apresenta diferentes sorovares, dentre estes: Canicola, Icterrohaemorrhagiae, Copenhageni, Autumnalis, Pomona, Gripphotyphosa, Pyrogenes, Bataviae, Andamana, Castellonis, Bratislava, Wolff, Djasiman, Hardjo, Autumnalis, são os mais reportados.

No Brasil ao analisar o período ente 2008-2012 Pereira et al. (2012) observou o crescente número de casos em humanos, chamando atenção para os períodos entre 2005 a 2007 e 2010 a 2012 períodos que correspondem tanto a períodos de seca quanto de chuva respectivamente, ressaltando a importância da atenção no diagnóstico e prevenção da leptospirose independente da ocorrência de chuvas.

Dados do Ministério da Saúde (BRASIL, 2019) figura-5 demonstra a variação no número de casos em Humanos no País, com ocorrência em todos os Estados, e maior número casos na região sul e Sudeste, observa-se significativo aumento em 2006- 4539 casos, 2011- 5011 casos, 2014- 4757 casos e 2015- 4337 casos, considerando apenas os primeiro semestre de 2019 este ano já apresenta um número razoável de casos (2027) quando se considera uma média mensal dos meses anteriores. 
Figura 3- Casos de leptospirose no Brasil no período entre 2000-2019.

Casos confirmados de leptospirose humana no Brasil, entre os anos 2000 a julho de 2019

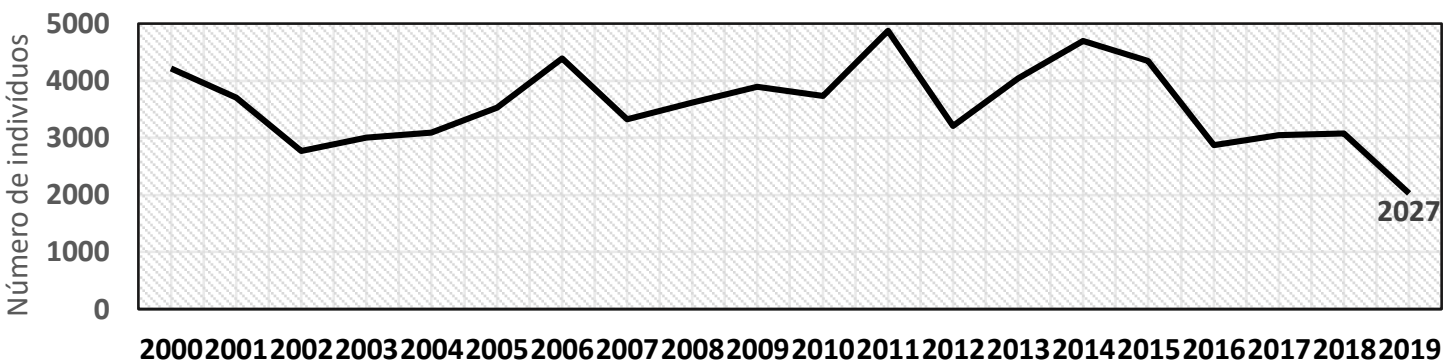

Fonte: adaptado de Brasil 2019.

Ainda discutindo sobre dados do Ministério da Saúde, ao observar o número de óbitos por Leptospirose em humanos, nos anos de 2001 e 2006 ocorreram 436 óbitos e 444 em 2011 (FIGURA 6). E mais uma vez a região Sul e sudeste apresentaram maiores números.

Figura 6: Óbitos em Humanos no Brasil por Leptospirose, de 2000 a julho de 2019

Óbitos em humanos por Leptospirose no Brasil, entre os anos 2000 a julho de 2019

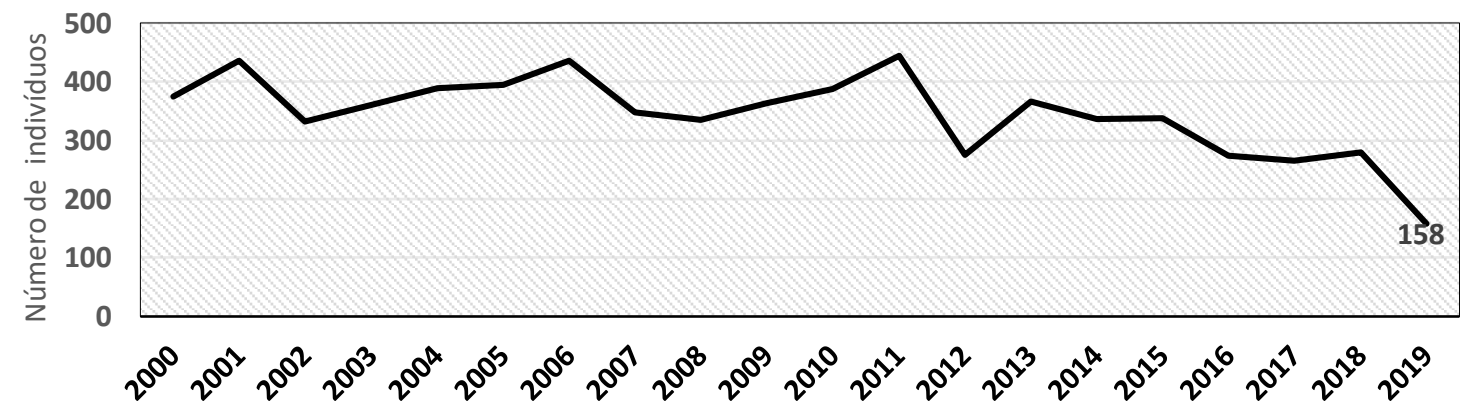

Fonte: adaptado de Brasil 2019.

O número de casos humanos apresentou queda nos últimos anos, mas ainda é possível melhorar, uma vez que há dados epidemiológicos importantes no que diz respeito a como evitar o a bactéria no ambiente, ressaltando a importância do saneamento básico principalmente para controlar os roedores sinantrópicos, que ainda são a maior fonte de transmissão para cães e humanos; levando em consideração a ligação afetiva dos cães como animais de companhia uma vez infectados estes apresentam fonte de risco para seres humanos. 


\subsection{DIAGNÓSTICO LABORATORIAL}

No hemograma, leucograma, bioquímico, e urinais os resultados são muitas vezes inespecíficos para a enfermidade, apesar de não confirmarem a presença do agente estes testes denotam o dano causado por este, e órgãos acometidos. (BARTHÉLEMY et al., 2016; COLANTES et al., 2016). O que é de extrema importância para instituir a terapêutica e suporte eficaz para evitar maiores danos.

Exames mais específicos direcionados ao agente etiológico podem ser diretos e indiretos. Os diretos buscam o agente causador neste caso a Leptospira spp. e os indiretos buscam células, ou frações proteicas geradas em resposta ao contato com a bactéria. Dentre os métodos diretos mais comuns no diagnóstico da leptospirose há: Microscopia de capo escuro, isolamento e cultivo, reação em cadeia de polimerase (PCR). $E$ dos indiretos: Soroaglutinação microscópica (SAM) ou teste de microaglutinação MAT (Microagglutination Test), teste de ELISA (Enzyme Linked Immuno Sorbent Assay), e testes rápidos de imonocromatografia desenvolvidos recentemente (OLIVEIRA, 2015; GOMES, 2016).

O exame direto por microscopia de campo escuro utiliza microscópio com condensador especial que permitem que a luz fique inclinada e não penetre diretamente na objetiva, assim a luz atinge a Leptospira spp. e a porção desviada forma a imagem. Observa-se o fundo claro e a bactéria brilhante em contraste. Não é um teste de confirmação e sim complementar, por ter baixa sensibilidade e especificidade, devido a detecção ocorrer apenas durante os primeiros dias após infecção, e exigir bom treino do laboratorista (OLIVEIRA, 2015; TOKATJIAN, 2016).

O isolamento e identificação do agente etiológico é mais seguro para identificação de animais em fase de leptospirúria, podendo ser isolado da urina. Utilizase mais rotineiramente meio semi-sólido de Fletcher, ou meio líquido Ellinghausem McCullough Johnson Harris (EMJH) enriquecido com $10 \%$ de soro normal estéril de coelho, previamente inativado a temperatura de $56^{\circ} \mathrm{C}$ em banho-maria por $30 \mathrm{~min}$ ou soro bovino. Incubadas de $28^{\circ} \mathrm{Com}$ a $30^{\circ} \mathrm{C}$ por seis semanas avaliando a cada semana se houve crescimento a partir da visualização por microscopia de campo escuro (GOMES, 2016; SHARMA e YADAV, 2008). 
A reação em cadeia de polimerase (PCR) é um bom teste para confirmar o agente etiológico devido sua alta especificidade, no entanto pode haver falso negativo quando há baixa carga bacteriana, diminuindo a possibilidade de encontrar DNA bacteriano na amostra testada (NHAN, 2014). Ao avaliar cães naturalmente infectados e comparar o teste sorológico SAM com o PCR Zardra et al. (2017) observaram que cães reagentes no SAM, nem sempre eram positivos no PCR, evidenciando que os animais demonstraram ter tido contato com a bactéria, porém no momento não estavam eliminando via urinária; ressaltando a importância da colheita de mais de uma amostra para avaliação através do teste molecular, do contrário este pode não detectar a infecção e sendo neste caso o SAM um teste mais fidedigno. Realiza-se a pesquisa da bactéria a partir do cultivo e isolamento ou diretamente do tecido a ser analisado.

A soroaglutinação microscópica (SAM) baseia-se na reação de aglutinação antígeno anticorpo visto por microscopia de campo escuro. O resultado do reagente indica que o animal foi exposto a antígenos de Leptospira spp. ou mais especificamente a epítopos de um ou mais sorotipos, portanto não é possível confirmar exatamente o sorotipo que promoveu a infecção já que pode haver reações cruzadas, ou coexposição simultânea (MASSA, 2017). Durante a execução do teste se faz necessário uma bateria de antígenos que após cultivo são incubados com soro a ser testado, para resultado fidedigno devem ser enviadas para análise amostras pareadas na fase aguda e convalescente (BRASIL, 2014) já que pode haver falso negativo se a amostra for apenas na fase inicial da infeç̧ão, quando a produção de anticorpos lgM ainda não está presente.

Os testes de imunoflorêscencia (IFA) ou imunohistoquímica (IMQ) não são utilizados rotineiramente no diagnóstico da enfermidade, ficando mais restritos ao campo da pesquisa (OLIVEIRA, 2015). Tais técnicas são utilizadas para pesquisa de anticorpo, IFA indireta, e para pesquisa de antígenos, IFA direta e IMQ, em tecidos de animais suspeitos (GIRIO et al., 2004; AOKI, 2010).

A tecnologia de DNA recombinante, permite a manipulação de moléculas específicas de DNA onde é possível inserir material genético de interesse em uma célula capaz de realizar expressão gênica do material inserido (NASCIMENTO et al.,2003). Esta tecnologia também pode ser utilizada para a produção de antígenos recombinantes. Dey (et al 2004) padronizaram um ELISA Sandwich para diagnóstico de leptospirose canina a 
partir de um antígeno recombinante denominado lipL-32 que obteve sensibilidade e especificidade de $97 \%$ demonstrando bom desempenho em relação a soroaglutinação microscópica. A mesma tecnologia foi utilizada para produção de antígeno recombinantes utilizando os genes LigA e LigB, que obtiveram bom desemprenho ao constatar que não possuem afinidade para resposta imune vacinal, mas que respondem em casos de infecção natural, sugerindo a capacidade de diferenciar animais vacinados e naturalmente infectados (PALANIAPPAN et al., 2004).

A partir do estudo e desenvolvimento de moléculas capazes de reagir com anticorpos, houve nos últimos anos o desenvolvimento de testes rápidos de imonocromatografia, com o intuito de facilitar o diagnóstico na rotina da clínica médica de pequenos animais. Estudos com proteína de membrana LipL32 demostrou o uso desta no teste rápido imunoabsorvente SNAP $^{\circledR}$-Lepto, ao comparará-lo com a soroaglutinação microscópica (SAM) foi observado desempenho semelhante na detecção de anticorpos (CURTIS et al., 2015; WINZELBERG et al., 2015).

O teste francês WITNESS ${ }^{\circledR}$ Lepto Zoetis tem o mesmo princípio dos demais, ao detectar IgM, porém utiliza extratos de antígenos de células inteiras de L. kirschneri sorovar Grippotyphosa e L. interrogans sorovar Bratislava, não havendo interferência na resposta vacinal (KODJO et al., 2016). Porém a não interferência citada leva em conta apenas a não detecção de $\lg G$ apesar deste fato ser relevante, deve-se atentar para animais vacinados recentemente e que possam apresentar IgM circulante fruto da imunidade ativa e não necessariamente infecção natural.

O teste ensaio de fluxo lateral ou lateral flow assay $\left(\operatorname{LFA}^{\circledR}\right)$ para detecção de IgM contra Leptospiras spp. em cães é comercialmente utilizado na Europa, apresenta 75,7\% de sensibilidade e $98,3 \%$ de especificidade, em contrapartida animais com resposta vacinal também reagem ao teste, e apesar de ser um teste rápido e confiável, a interpretação do resultado deve ser feita no contexto de sinais clínicos e histórico de vacinação (LIZER et al., 2017).

Tem-se estudado e desenvolvido testes rápidos que são uteis na rotina clínica, estes são importantes na instituição rápida da terapia adequada, e na redução do potencial de transmissibilidade, contudo o raciocínio clinico epidemiológico, histórico vacinal, e conhecimento do princípio do diagnóstico utilizado, se fazem necessários na interpretação dos resultados, para evitar diagnóstico errôneo. 


\subsection{PREVENÇÃO}

As medidas preventivas incluem controle de roedores sinantrópicos, evitar contato do animal com os possíveis transmissores, água ou alimentos possivelmente contaminados, e vacinação. No Brasil a vacina canina contém a cepa de Leptospira interrogans, e sorogrupos: canicola e icterohaemorrhagiae; algumas contém o sorovar L. copenhageni, L. pomona e L. grippothyphosa (LEVETT, 2001)Nos EUA e alguns outros países preconiza os sorogrupos grippothyphosa, pomona e australis; na Austrália é utilizada vacina monovalente contendo o sorogrupo australis e na Nova Zelândia vacinas monovalentes com o sorogrupo icterohaemorrhagiae (DEY et al., 2004) Ao verificar a frequência de aglutininas ante Leptospira spp. em cães assintomáticos os sorovares Canicola, Autumnalis, Icterohaemorrhagiae, foram observados na população de cães do Paraná (DA SILVA ZACARIAS et al.,2014) em centros de controle de zoonose em São Paulo verificou ocorrência do sorovar Canicola e Icterohaemorrhagiae (LANGONI et al., 2015).

Dados que confirmam estudo realizado "in vitro", no qual soro de cães vacinados com vacina comercial contendo antígeno dos sorovares Canicola, Icterohaemorrhagiae, Grippotyphosa e Pomona não responderam positivamente no teste de inibição do crescimento (TICL) de Leptospira spp. "in vitro" para o sorovar Copenhageni evidenciando proteção cruzada incompleta (FRAGA et al., 2013). Contudo, ainda são poucos os estudos que fazem correlação direta entre resposta vacinal e proteção efetiva frente aos diversos sorovares.

\section{CONSIDERAÇÕES FINAIS}

A literatura acerca do tema é vasta e não é possível esgotar o tema. A correlação entre os dados do agente etiológico, da enfermidade em cães e de como a saúde humana pode ser afetada por esta zoonose é fundamental para a reflexão de profissionais da saúde humana e animal; percebeu-se diante do estudo a necessidade de pesquisas para explorar dados estatísticos que demonstrem a correlação entre a ocorrência da doença em humanos, em cães, e as regiões com maior nível de risco no país, afim de contribuir com a prevenção e orientação de medidas sanitárias. 


\section{REFERÊNCIAS}

ANIZ, Patrícia Antônia Estima Abreu. Caracterização funcional de uma provável colagenase de Leptospira interrogans sorovar Copenhageni. 2014. Tese de Doutorado. Universidade de São Paulo. AOKI, V.J. et al. Direct and indirect immunofluorescence. Anais brasileiros de dermatologia, v. 85, n. 4, p. 490-500, 2010.

BARTHÉLEMY, A. H. Hemostatic, and Thromboelastometric disorders in 35 dogs with a clinical diagnosis of leptospirosis: A Prospective Study. Journal of veterinary internal medicine, v. 31, n. 1, p. 69-80, 2016.

BOONYOD, Doojdaol. LipL32, an outer membrane protein of Leptospira, as an antigen in a dipstick assay for diagnosis of leptospirosis. Asian Pacific Journal of Allergy and Immunology, v.23, p.133, 2005.

BRANDÃO. J. Fundação Oswaldo Cruz. Dvd (16min): Ntsc, Son., 2009. Disponível em: <https://www.arca.fiocruz.br/handle/icict/18225>. Acesso em 08 de jul. 2017. II. Color.

BRASIL. Ministério da Saúde. Secretaria de Vigilância em Saúde. Departamento de Vigilância das Doenças Transmissíveis. Leptospirose: diagnóstico e manejo clínico. Brasília: Ministério da Saúde, 2019. P-21.

BROOK, G.F. et al. Microbiologia Médica de Jawetzner, Melnick e Adelberg 26.ed. Porto Alegre AMGH, 2014. p.335.

BROWN, C.A. Leptospira interrogans serovar grippotyphosa infection in dogs. Journal of the American Veterinary Medical Association, v. 209, n. 7, p. 1265-1267, 1996.

CASA GRANDE, R.A. et al. Isolation of Salmonella enterica in opossum (Didelphis aurita and Didelphis albiventris) of the São Paulo State, Brazil. Ciência Rural, v. 41, p. 492-496, 2011.

CASTRO, Jacqueline R. et al. Cinética da resposta imune humoral de cães jovens imunizados contra Leptospira interrogans. Pesquisa Veterinária Brasileira, v. 31, n. 11, p. 1000-1005, 2011.

CLAUS, MV. et al. Leptospirosis in dogs: a retrospective study of seven clinical cases in Belgium. Vlaams diergeneeskundig tijdschrift, v. 77, n. 4, p. 259-264, 2008.

CURTIS, K. M. Performance of a Recombinant LipL32 Based Rapid In-clinic ELISA (SNAP ${ }^{\circledR}$ Lepto) for the Detection of Antibodies Against Leptospira in Dogs. International Journal of Applied Research in Veterinary Medicine, v. 13, n. 3, 2015.

CRUZ, J.S. et al. Incidência de leptospirose em uma comunidade carente de Salvador, Bahia. Sociedade Brasileira de Medicina Tropical, 2016. p.9900. 
DA SILVA ZACARIAS, F. G. et al. Frequência de anticorpos anti-Leptospira spp. em cães atendidos no Hospital Veterinário da Universidade Estadual do Norte do ParanáUENP. Arquivos de Ciências Veterinárias e Zoologia da UNIPAR, v. 17, n. 2, p. 91-95, 2014.

DE MELLO, Luiz Paulo Pimenta; MANHOSO, Fábio Fernando Ribeiro. Aspectos epidemiológicos da leptospirose canina no Brasil. UNIMAR, p. 27, 2007.

DEY, S.M. et al. Recombinant LipL32 antigen-based single serum dilution ELISA for detection of canine leptospirosis. Veterinary microbiology, v. 103, p. 99-106, 2004.

ESCÓCIO, C. I. Influência das condições ambientais na transmissão da leptospirose entre criações de ovinos e bovinos da região de Sorocaba, SP. Arquivos do Instituto Biológico, v. 77, n. 3, p. 371-379, 2010.

FALZEMBURGH, R. D. M. História natural e transmissão da leptospirose urbana: estudo longitudinal prospectivo em uma comunidade de alto risco durante epidemias urbanas em Salvador-Bahia. 2010. 144 f. Tese (Doutorado em Biotecnologia em Saúde e Medicina Investigativa) - Fundação Oswaldo Cruz, Centro de Pesquisas Gonçalo Moniz, Salvador, 2010

FERNANDES, L.G.V. Caracterização e avaliação imunológica de três proteínas de superfície de Leptospira interrogans obtidas em Escherichia coli. 2012. Tese de Doutorado. Instituto Butantan.

FRAGA, Tatiana Rodrigues. Identificação de proteases de Leptospira envolvidas com mecanismos de escape do sistema complemento humano. Tese de Doutorado. Universidade de São Paulo, 2014. il. Collor.

GARCIA-ZAPATA, A. M.T. Júnior, S.S, E. Aspectos fisiopatológicos da febre nas doenças infecto-parasitárias. V.4i1. 26. Universitas: Ciências da Saúde, v. 4, n. 1, p. 111117, 2008.

GIRIO, R.J.S. Investigation of antibodies to Leptospira spp. in wild and feral animals from the region of Nhecolândia, Mato Grosso do Sul, Brazil: use of the immunohistochemistry technique for the agent detection. Ciência Rural, v. 34, p. 165-169, 2004.

GOMES, D.O. Alterações histopatológicas e macroscópicas em um cão sorologicamente positivo para Leptospira spp. Revista de Patologia Tropical, v. 44, n. 2, p. 221228, 2015.

GOMES, D.Olímpia. Estudo da produção de biofilme de isolados de Leptospira spp. 2016. 63 f. Dissertação (Mestrado em Ciências Agrárias) - Universidade Federal de Uberlândia, Uberlândia, 2016. Acesso em 08 de jul. 2016.

GOMES, M.J.P. Gênero Leptospira spp. faculdade de veterinária, Universidade Federal de Rio Grande do Sul, 2013. 
HAAKE, David A.; MATSUNAGA, James. Leptospira: a spirochaete with a hybrid outer membrane. Molecular microbiology, v. 77, n. 4, p. 805-814, 2010.

Hrinivich K. \& Prescott J.F. 1997. Leptospirosis in two unrelated dogs. Can. Vet. J. 38:509510.

HORTA, M. Cl. et al. Ocorrência de anticorpos anti-Toxoplasma gondii, anti-Neospora caninum e antiLeptospira spp. em gambás (Didelphis spp.) no estado de São Paulo, Brasil. Brazilian Journal of Veterinary Research and Animal Science, v. 53, n. 3, p. 01-09, 2016.

IBGE- Instituto Brasileiro de geografia pesquisa e estatística. Atlas de saneamento básico do Brasil, 2011.p.1-32.

IBGE- Instituto Brasileiro de geografia pesquisa e estatística. População de animais de estimação no Brasil, 2013, em milhões, 2013 p.1-5.

JASZCZERSKI, D.C. Souza, F. Cinética da resposta imune humoral em cães imunizados com Leptospira interrogans sorovares icterohaemorrhagiae, canicola, pomona e grippotyphosa. Dissertação, Universidade Federal do Paraná, 2005.

JOHNSON D.I. (2018) Leptospira spp.. In: Bacterial Pathogens and Their Virulence Factors. Springer, Cham. Acesso em 20 de ago. 2019.

JUNGE, R. E.B. King, M. Mtthew E. G. A serologic assessment of exposure to viral pathogens and Leptospira in an urban raccoon (Procyon lotor) population inhabiting a large zoological park. Journal of Zoo and Wildlife Medicine, v. 38, n. 1, p. 18-26, 2007. Acesso em 12 de jun. 2017.

KODJO, A. C.C. Loenser, M. Lin, D.Lizer. A. Rapid in-clinic test detects acute leptospirosis in dogs with high sensitivity and specificity. BioMed research international, v. 2016, 2016.

KOIZUMI, NI. Multiple-locus variable-number tandem repeat analysis and clinical characterization of Leptospira interrogans canine isolates. Journal of medical microbiology, v. 64, p. 288-294, 2015.

LANGONI, $\mathrm{H}$. et al. Pesquisa de anticorpos e DNA de Leptospira spp. em soro canino. Veterinária e Zootecnia, v. 22, n. 3, p. 429-436, 2015.

LEVETT, P. N. Leptospirosis Clinical Microbiology Rev., v. 14, p. 296-326, 2001.

LIN, Xu'ai; CHEN, Yin; YAN, Jie. Recombinant multiepitope protein for diagnosis of leptospirosis. Clinical and Vaccine Immunology, v. 15, n. 11, p. 1711-1714, 2008.

LIZER, J., M. et al. Evaluation of a rapid IgM detection test for diagnosis of acute leptospirosis in dogs. Veterinary Record, v. 180, n. 21, p. 517-517, 2017.

MACEDO, S. Estudio ultraestructural de Leptospira biflexa serovar Andamana cepa JNS al microscopio electrónico de transmisión y barrido. Revista Peruana de 
Medicina Experimental y Salud Publica, v. 22, n. 4, p. 281-289, 2005. MALE, D.B., et al. Imunologia. 8.ed, Rio de Janeiro: Elsevier, 2014.p228.

MARIANI, O. M. et al. A. tratamento da leptospirose canina: uma revisão sistemática. Revista Investigação Medicina Veterinária, v. 14, n. 6, 2015.

MASSA, R. Influência das diferentes interpretações da soroaglutinação microscópica sobre os resultados de pesquisas epidemiológicas com Leptospira spp. 2017.

MONARIS D, S. et al. Protective immunity and reduced renal colonization induced by vaccines containing recombinant Leptospira interrogans outer membrane proteins and flagellin adjuvant. Clin Vaccine Immunol. 2015.

MONTEIRO, G. Goes, R. Efetividade da doxiciclina na profilaxia contra letptospirose. 2003. Dissertação de Mestrado. Universidade Federal do Rio Grande do Norte.

MURRAY, P. R., Ken S.R., Michael A.P. Microbiologia médica. 7.ed- Rio de Janeiro: Elsevier, 2014. p.341.

MURRAY, Patrick. Microbiologia Médica. 7a edição ed. Rio de Janeiro: Elsevier 2011. P421.

NASCIMENTO, A.C.A., Espreafico, E.M., Larson, M.L.P., Monesi, N.,Rossi N.M.M., Rodrigues, V. Tecnologia do DNA recombinante. Universidade de São Paulo. 2003.

NELSON \& COUTO, C.G. Medicina interna de pequenos animais. 2aㅡ, ed., Guanabara Koogan, 2001 p. 13-18.

NETTO, A. Comprometimento fisiológico e seminal de cães machos infectados experimentalmente por leptospira interrogans sorovar Canicola. Universidade Estadual Paulista UNESP, 2008.

NHAN, T. X. Sensitivity of real-time PCR performed on dried sera spotted on filter paper for diagnosis of leptospirosis. Journal of clinical microbiology, v. 52, n. 8, p. 30753077, 2014.

OLIVEIRA, D. S. Leptospira em mama e leite de Rattus norvegicus de áreas urbanas: possível via de transmissão vertical?. 2015. Tese de Doutorado.

PALANIAPPAN, R.U.M et al. Expression of Leptospira immunoglobulin-like protein by Leptospira interrogans and evaluation of its diagnostic potential in a kinetic ELISA. Journal of medical microbiology, v. 53, n. 10, p. 975-984, 2004.

PAVANELLI, Tais Francisco. Avaliação da produção de citocinas inflamatórias apos estimulação por lipoproteína L32(LipL32), lipopolissacarídeo (LSP) e lipopeptídeo ativador de monócitos-2 (MALP-2) e expressão de receptores de superfície em monócitos de pacientes com leptospirose. 2008. 128 p. 
Dissertação (Mestrado em Ciências) - Escola Paulista de Medicina, Universidade Federal de São Paulo, São Paulo, 2008.

PEREIRA, C.A. et al. Barata, R.MM.L. Neto, C.C. Monteiret, G.T.R. Leptospirosis's Trend and Seasonality in Brazil: Statistical Analysis of Notified Cases Between 2008 and 2012. Saúde e Pesquisa, v. 7, n. 3, 2014.

ROCHA, S.C.J. Correlação entre sinais clínicos e soropositividade para leptospirose em cães domiciliados no munícipio de Cruz das Almas, Bahia, Brasil. 2016.

SCHULLER, S.et al. European consensus statement on leptospirosis in dogs and cats. Journal of Small Animal Practice, v. 56, n. 3, p. 159-179, 2015.

SHARMA, M. YADAV, A.. Leptospirosis: epidemiology, diagnosis, and control. J Infect Dis Antimicrob Agents, v. 25, n. 2, p. 93-103, 2008.

TIZARD, I. R. Imunologia Veterinária. 9.ed Rio de Janeiro Elsevier 2014 p.1-5.

TOKATIIAN, M.L. Pesquisa de Leptospira spp. em rins de suínos abatidos em frigoríficos do distrito federal por PCR. 2016. xi, 62 f., il. Dissertação Universidade de Brasília, Brasília, 2016.

VALENCIA, Mónica Marcela Castiblanco. Interação de proteínas de membrana de Leptospira com os reguladores Fator $\mathrm{H}$ e C4BP do sistema complemento humano. 2014. Tese (Doutorado em Imunologia) - Instituto de Ciências Biomédicas, Universidade de São Paulo, São Paulo, 2014. doi:10.11606/T.42.2014.tde-15122014-100724. Acesso em: 2017-09-12.

WINZELBERG, S. et al. Evaluation of SNAP ${ }^{\circledR}$ Lepto in the Diagnosis of Leptospirosis Infections in dogs: Twenty two Clinical Cases. International Journal of Applied Research in Veterinary Medicine, v. 13, n. 3, 2015

YANG, H.L. et al. Thrombocytopenia in the experimental leptospirosis of guinea pig is not related to disseminated intravascular coagulation. BMC Infect. Dis. n.2, v.6,p.19-27, 2001.

YUNES, A. N. et al. Descripción de leptospirosis en rodeos de cría y discusión de un caso sospechoso de leptospirosis. Universidad Nacional del Centro de la Provincia de Buenos Aires. 2016.

ZILBER, A. L., Belli, P., Artois, M., Kodjo, A., \& Djelouadji, Z. First Observation of Leptospira interrogans in the Lungs of Rattus norvegicus. BioMed research international, 2016 Hindawi Publishing Corporation. 


\title{
CAPITULO XXXII
}

\section{POIENCIAL TRIPANOCIDA DE COMPOSTOS OBTDOS DE ALCAS E CLANOBACTÉRIAS}

DOI: 10.51859/amplla.csa528.2121-32

\author{
Yanara Alessandra Santana Moura ${ }^{1}$ \\ José Noé da Silva Júnior ${ }^{2}$ \\ Andreza Pereira de Amorim ${ }^{3}$ \\ Ana Lúcia Figueiredo Porto ${ }^{4}$ \\ Virgínia Maria Barros de Lorena ${ }^{5}$ \\ Daniela de Araújo Viana Marques ${ }^{6}$ \\ Raquel Pedrosa Bezerra ${ }^{7}$
}

\footnotetext{
${ }^{1}$ Graduanda do curso de Bacharelado em Ciências Biológicas. Universidade Federal Rural de Pernambuco - UFRPE

${ }^{2}$ Doutorando em Biologia Aplicada à Saúde. Programa de Pós-Graduação em Biologia Aplicada à Saúde - UFPE

${ }^{3}$ Graduanda do curso de Licenciatura em Ciências Biológicas. Universidade Federal Rural de Pernambuco - UFRPE

4 Professora Titular do Departamento de Morfologia e Fisiologia Animal. Universidade Federal Rural de Pernambuco - UFRPE

${ }^{5}$ Pesquisadora em Saúde Pública do Instituto Aggeu Magalhães - IAM/Fiocruz

${ }^{6}$ Professora Adjunta do Instituto de Ciências Biológicas. Universidade de Pernambuco - UPE

7 Professora Adjunta do Departamento de Morfologia e Fisiologia Animal. Universidade Federal Rural de Pernambuco - UFRPE
}

\section{RESUMO}

A doença de Chagas (DC) é conhecida por ser uma enfermidade negligenciada causada pelo protozoário Trypanosoma cruzi. Aproximadamente 8 milhões de pessoas estão infectadas por T. cruzi no mundo, localizadas principalmente na América Latina, porém sabe-se que a DC está presente também em outros países não-endêmicos da América do Norte e Europa. O tratamento convencional é baseado em duas drogas: Benznidazol e Nifurtimox, contudo ambas apresentam toxicidade elevada além de ter eficiência duvidosa na fase crônica. Portanto, novos compostos obtidos de fontes naturais têm sido explorados como alternativa aos fármacos convencionais. Algas e cianobactérias são fontes promissoras de compostos bioativos devido a seu alto teor de metabólitos com diversas atividades terapêuticas já descritas na literatura, dentre estas a ação antiTrypanosoma. Vários resultados promissores foram descritos, relatando efeitos importantes como redução da parasitemia e das taxas de mortalidade de ratos infectados, além da diminuição do número de amastigotas em macrófagos. Além disso, já foram isolados três princípios ativos de cianobactérias com atividade promissora. Contudo, a maioria dos estudos ainda são muito preliminares e apenas um estudo in vivo foi realizado até agora, o que destaca a necessidade de novos estudos para confirmar e otimizar esses efeitos.

Palavras-chave: Trypanosoma cruzi. Medicamentos. Compostos bioativos. Microalgas. Fontes naturais. 


\section{INTRODUÇÃO}

A doença de Chagas é uma enfermidade negligenciada, cujo agente etiológico é o Trypanosoma cruzi, protozoário hemoflagelado que infecta seres humanos e demais mamíferos por transmissão oral, congênita, transfusão de sangue ou pela via clássica (vetorial) através de insetos hemípteros hematófagos triatomíneos. O inseto torna-se hospedeiro intermediário pela ingestão de sangue de humanos ou animais infectados pela forma infectiva tripomastigotas metacíclicas. Duas fases clínicas podem ocorrer nos pacientes infectados pela doença de Chagas: aguda e crônica. A fase aguda possui elevada parasitemia no sangue e os indivíduos são geralmente assintomáticos. A fase crônica pode se apresentar em diferentes formas: a forma cardíaca, digestiva, cardiodigestiva ou como uma forma indeterminada (também denominada de forma assintomática) depois de anos ou até décadas (LÓPEZ-VÉLEZ; NORMAN; BERN, 2020). Quando não tratados na fase aguda, a maioria dos pacientes entra na fase crônica da Doença de Chagas.

Segundo a Organização Pan Americana de Saúde (OPAS), estima-se que cerca de 6 a 7 milhões de pessoas no mundo todo estão infectadas pelo T. cruzi, porém, a maior quantidade de casos encontra-se na América Latina, onde morrem mais de 12 mil indivíduos infectados por ano (OPAS, 2020). Porém já é conhecido que a doença de Chagas ocorre também em países não endêmicos da América do Norte como Canadá e Estados Unidos, países europeus, principalmente a Espanha, além de Austrália, Nova Zelândia e Japão (ALBAJAR-VIÑAS; JANNIN, 2011; GASCON; BERN; PINAZO, 2010; JACKSON; PINTO; PETT, 2014). Em 2020, a estimativa de pessoas infectadas no Brasil era de pelo menos 1 milhão de pessoas (MINISTÉRIO DA SAÚDE, 2020).

A quimioterapia tradicional utilizada no tratamento de indivíduos portadores da doença de Chagas é realizada através de duas drogas: o benznidazol (BZ) e nifurtimox (NFX), sendo o BZ a droga de escolha no Brasil. Porém, de acordo com estudos, esse fármaco, em menor grau que o Nifurtimox, apresenta toxicidade e pode gerar alguns efeitos colaterais, o principal deles é a toxicidade cutânea que é a mais frequente causa da interrupção do tratamento (MOLINA et al., 2015). Alguns trabalhos ainda descrevem os efeitos deletérios do BZ e NFX no cólon e adrenal em ratos (CASTRO; DE MECCA; BARTEL, 2006). Ademais, apesar de apresentar significativa eficácia na fase aguda, o BZ 
é pouco eficaz ou ineficaz na fase crônica da DC (KAWAGUCHI et al., 2018). Diante do exposto, faz-se necessária a busca de novos compostos com ação eficaz frente ao $T$. cruzi, e vários dados na literatura demonstram que compostos obtidos de fontes naturais são promissores nesse aspecto.

Nesse sentido, as algas e cianobactérias podem ser promissoras na busca desses compostos com ação anti-T. cruzi, visto que são constituídas bioquimicamente por biomoléculas ativas com ações antioxidantes, antitumorais, antimicrobianas e antiinflamatórias já descritas na literatura (ABU-GHANNAM; RAJAURIA, 2013; EL-BAZ; ALY; ABD-ALLA, 2020; IGLESIAS et al., 2019; KHOTIMCHENKO, M. et al., 2020; ZAMANI; RASTEGARI; VARAMINI, 2019). Este capítulo tem por finalidade descrever o potencial tripanocida de compostos bioativos obtidos da biomassa de algas e cianobactérias frente a formas tripomastigota e amastigota de Trypanosoma cruzi.

\section{REVISÃO BIBLIOGRÁFICA}

\subsection{TRYPANOSOMA CRUZI E DOENÇA DE CHAGAS}

O Trypanosoma cruzi é um protozoário causador da doença de Chagas, pertencente à ordem Kinetoplastida e família Trypanosomatidae. Esta espécie é uma população heterogênea constituída por diversas linhagens que circulam na natureza com uma variabilidade genética observada entre eles (MATTEI; GOLDENBERG; MOREL, 1977; NOGUEIRA; COURA, J. R., 1990; REY, 2008). O protozoário possui três formas evolutivas (amastigotas, epimastigotas e tripomastigotas metacíclicos e circulantes) que são identificadas pela posição do cinetoplasto em relação ao núcleo celular e pela emergência do flagelo (HOARE; WALLACE, 1966). A forma amastigota não possui um flagelo exterior e nem membrana ondulatória, por isso realiza seus movimentos apenas por rotação (LEY et al., 1988); a forma epimastogota apresenta um flagelo livre e cinetoplasto anterior ao núcleo celular (LÓPEZ-VELÁZQUEZ et al., 2005); a forma tripomastigota metacíclico possui um núcleo grande e central e cinetoplasto de alta densidade de DNA em uma posição posterior terminal e um flagelo curto emergindo de um corpúsculo basal perto do cinetoplasto; por fim, a forma tripomastigota circulante que está presente no sangue e outros líquidos corporais possui um flagelo longo que 
também emerge de um corpúsculo basal próximo ao cinetoplasto (REY, 2008). A forma evolutiva de $T$. cruzi varia de acordo com as etapas do seu ciclo de vida.

O ciclo biológico completo do T. cruzi ocorre entre insetos hematófagos da subfamília Triatominae e várias espécies de mamíferos, incluindo seres humanos (NOIREAU; DIOSQUE; JANSEN, 2009). No início do ciclo, o triatomíneo se infecta ao se alimentar do sangue de mamífero infectado por T. cruzi. Dessa forma, o triatomíneo infectado pode transmitir o T. cruzi para novos hospedeiros mamíferos infectando-os através da picada. A forma tripomastigota metacíclica é altamente infectante: penetra primeiramente em células fagocíticas do sistema circulatório e, posteriormente, invade e infecta outras células e tecidos. Uma vez dentro das células, se diferenciam em amastigotas, estágio replicativo no qual multiplicam-se por fissão binária, e após alguns ciclos de divisão, os amastigotas evoluem para as formas tripomastigotas que rompem as células e adentram a corrente sanguínea onde podem invadir outras células ou eventualmente são ingeridos pelo inseto triatomíneo. Caso sejam ingeridos pelo triatomínieo, os tripomastigotas convertem-se em epimastigotas no intestino médio do inseto vetor e diferenciam-se em tripomastigotas metacíclicos na região do reto do inseto, completando o ciclo biológico do T. cruzi, que em seu repasto sanguíneo são eliminados nas fezes e/ou urina podendo infectar novo hospedeiro vertebrado (LÓPEZVÉLEZ; NORMAN; BERN, 2020).

A doença de Chagas é caracterizada por possuir uma fase aguda e uma fase crônica da infecção. A fase aguda geralmente é assintomática e marcada por elevada parasitemia. Quando presentes, os principais sintomas são: febre prolongada contínua ou intermitente; mal-estar; aumento do baço, linfonodos e fígado e edemas subcutâneos; e quando a doença é transmitida através da via vetorial, é possível observar edema no local da porta de entrada conhecido como chagoma de inoculação ou sinal de Romaña (quando ocorre na região dos olhos) (RASSI; RASSI; MARIN-NETO, 2010). O diagnóstico na fase aguda é baseado na demonstração do parasita em sangue periférico por meio de exame a fresco ou após coloração (esfregaço espesso) ou por métodos de concentração (RASSI et al., 2017).

A fase crônica inicia em 2 a 4 meses após a infecção inicial, o desaparecimento dos sintomas da fase aguda e a diminuição da parasitemia para níveis indetectáveis. A fase crônica pode se apresentar através de diferentes formas: indeterminada, cardíaca, 
digestiva ou cardiodigestiva (RASSI, et al., 2017). A forma indeterminada se refere ao período de ausência de sinais e/ou sintomas da doença. A forma digestiva está relacionada a disfunções gastrointestinais principalmente megaesôfago, megacólon ou ambos (REZENDE, DE; LUQUETII, 1994). Os pacientes que desenvolvem megaesôfago têm uma prevalência aumentada de câncer de esôfago (MARTINS et al., 2019). A forma cardíaca é a mais severa e mais frequente manifestação clínica dessa fase ocorrendo em cerca de 20 a 30\% dos indivíduos (RASSI, 2000). Quando há uma associação da forma cardíaca com megaesôfaco ou megacólon, ou ambos, diz-se que o paciente desenvolveu a forma cardiodigestiva da DC. Na maioria dos países, o desenvolvimento de megaesôfago precede a doença cardíaca e do cólon, mas a prevalência da forma cardiodigestiva não é conhecida devido à escassez de estudos apropriados (RASSI; RASSI; DE REZENDE, 2012).

\subsection{EPIDEMIOLOGIA}

De acordo com a Organização Mundial da Saúde (OMS), estima-se que cerca de 8 milhões de pessoas são infectadas no mundo, principalmente na América Latina. Além disso, devido ao aumento dos movimentos migratórios, ao longo do último século, a DC tem se espalhado para outros continentes além da América Latina. Cerca de 10.000 pessoas morrem todos os anos devido às manifestações clínicas da doença e mais de 25 milhões de pessoas correm risco de adquirir a doença (ORGANIZAÇÃO MUNDIAL DA SAÚDE, 2019). Em 2020, a estimativa de pessoas infectadas no Brasil era de pelo menos 1 milhão de pessoas (MINISTÉRIO DA SAÚDE, 2020).

O estado de Pernambuco é considerado um estado brasileiro endêmico para a doença. Atualmente, 22 municípios pernambucanos são considerados prioritários para DC no Plano de Enfrentamento (2019-2022) às Doenças Negligenciadas e Relacionadas à Pobreza da Secretaria Estadual de Saúde (SECRETARIA ESTADUAL DE SAÚDE., 2019). No primeiro semestre de 2019 houve um surto que atingiu cerca de 40 pessoas no município de Ibimirim, sertão de Pernambuco, onde 30 pessoas apresentaram resultado laboratorial para a doença e 10 apresentavam sintomas (DIÁRIO DE PERNAMBUCO, 2019). A Vigilância em Saúde da SES coordena, entre várias ações, o acompanhamento dos casos crônicos atendidos nos serviços de referência, o monitoramento das 
localidades de risco e a qualificação do diagnóstico (SECRETARIA ESTADUAL DE SAÚDE., 2019).

\subsection{TRATAMENTO CONVENCIONAL}

Atualmente, dois fármacos estão disponíveis para o tratamento da DC, são eles o Benznidazol (BZ) e Nifutrimox (NFX). Ambos os medicamentos atuam diretamente sobre formas tripomastigotas circulantes e amastigotas intracelulares, onde a chance de cura na fase aguda é igual ou superior a 80\% (COURA; CASTRO, 2002; KHAW; PANOSIAN, 1995). No entanto, a eficácia do BZ e NFX em indivíduos crônicos é questionável, além de serem drogas consideravelmente tóxicas. Não é recomendada a prescrição desses dois medicamentos para mulheres grávidas ou pessoas com insuficiência renal ou hepática e o NFX também não é indicado para pessoas com distúrbios neurológicos ou psiquiátricos (ORGANIZAÇÃO MUNDIAL DA SAÚDE, 2019).

O NFX é um nitrofurano que tem como mecanismo de ação inibir a síntese de ácido pirúvico no T. cruzi. Possui uma série de efeitos colaterais que são frequentemente relatados. Os efeitos colaterais relacionados ao sistema gastrointestinal incluem anorexia, perda de peso, náusea e vômito e acometem até $70 \%$ dos pacientes (JACKSON; PINTO; PETT, 2014; WEGNER; ROHWEDDER, 1972). Também possui efeitos neurotóxicos que incluem irritabilidade, insônia, desorientação e tremores. Além disso, também possui alguns efeitos colaterais mais raros, porém extremamente graves como parestesias, polineuropatia e neurite periférica (DE ANDRADE et al., 1996). Devido a sua alta toxicidade e a resistência de algumas cepas de $T$. cruzi circulante no Brasil, o NFX não é comercializado no Brasil (COURA, 2009), sendo o BZ o medicamento autorizado pela Agência Nacional de Vigilância Sanitária (Anvisa).

O BZ é um derivado do nitroimidazol e é o tratamento mais utilizado para a DC. Os efeitos colaterais mais frequentes são dermatológicos como erupções cutâneas que podem ser tratadas com anti-histamínicos. Casos de dermatite grave ou esfoliativa, dermatite associada à febre, linfadenopatia, neuropatia periférica e supressão da medula óssea podem ocorrer e devem levar à interrupção imediata do tratamento (OLIVERA et al., 2017).

Tendo em vista os diversos efeitos adversos que as drogas convencionais acarretam nos pacientes e as contraindicações para algumas classes de pacientes, 
destaca-se a necessidade de novos tratamentos com atividade antiparasitária frente a T. cruzi.

\subsection{COMPOSTOS OBTIDOS DE ALGAS E CIANOBACTÉRIAS FRENTE A}

\section{T. CRUZI}

Recentemente, a busca por compostos bioativos obtidos de fontes naturais tem crescido consideravelmente devido a sua ampla diversidade estrutural e funcional. Os organismos fotossintetizantes como algas e cianobactérias destacam-se por serem ricos em vários metabólitos primários como diversos tipos de carboidratos, proteínas, lipídeos, vitaminas e alguns minerais, assim como metabólitos secundários como terpenóides, alguns pigmentos, compostos fenólicos e esteróis. Esses compostos são aplicados em diversos campos da biotecnologia, desde setores comerciais, a nível industrial, como alimentação e cosméticos, e, assim como, em várias atividades farmacêuticas, sendo as antimicrobianas, antioxidantes, imunomoduladoras e antitumorais, as principais (MOSTAFA, 2012).

Os estudos envolvendo atividade tripanocida de algas e cianobactérias ainda são preliminares, mas já apresentam resultados importantes e promissores. De forma geral, esses compostos são obtidos através de blender, um homogeneizador industrial, que é em um dos métodos mais eficientes para causar ruptura celular e, consequentemente, promover a obtenção de compostos, além de consumir menos energia comparado a outros métodos de extração (MCMILLAN et al., 2013).

Depois do processo de extração, o extrato é geralmente utilizado para avaliar a atividade tripanocida, a qual é comumente realizada através de ensaios de colorimetria, pois é um método considerado rápido e eficaz comparado ao método de contagem que é trabalhoso, demorado e depende do observador (MUELAS-SERRANO; NOGAL-RUIZ; GÓMEZ-BARRIO, 2000).

Atualmente, ainda são poucos os trabalhos que descrevem a atividade tripanocida de algas frente à forma amastigota de $T$. cruzi, porém três moléculas de princípio ativo já foram identificadas até o momento. Teixeira et al., (2019) isolou a molécula 5-chloro-1-(E)-chloroviny12,4-dibromo-1,5-dimethylcyclohexane e ácido atomárico a partir do extrato orgânico das macroalgas Plocamium brasiliense e Stypopodium zonale, respectivamente. Dentre eles, o ácido atomárico obteve melhor 
atividade baseado no seu maior valor de índice de seletividade de 16,75 comparado ao composto isolado de $P$. brasiliense que obteve índice de seletividade de 2,95 (Tabela 1). Entretanto, também baseado no índice de seletividade, o melhor composto isolado de algas para atividade tripanocida contra amastigotas da cepa $\mathrm{Y}$, a qual é suscetível ao $\mathrm{BZ}$, é o elatol isolado do extrato de hexano-diclorometano obtido da alga Laurencia dendoidea (índice de seletividade $=26,73$ ) (VEIGA-SANTOS et al., 2010).

Em relação a atividade tripanocida de algas frente à forma tripomastigota, ainda não foi identificado nenhum princípio ativo. Contudo, diferentes tipos de extratos obtidos a partir de dezenas de espécies de algas já foram testados in vitro contra tripomastigota. O extrato orgânico da espécie Ulva lactuca obteve a melhor atividade baseado em seus valores de $\mathrm{IC}_{50}(34,9 \mu \mathrm{g} / \mathrm{ml}), \mathrm{CC}_{50}(>90,0 \mu \mathrm{g} / \mathrm{ml})$ e índice de seletividade (> 2,57) (Tabela 1) (SPAVIERI et al., 2010).

Apenas o estudo de Veas et al., (2020) relatou a atividade anti-Trypanosoma de extratos orgânicos de microalgas até a presente data. Os extratos etanólicos e metanólicos da microalga Tetraselmis suecica foram testados contra formas tripomastigotas do parasita e obtiveram significativos valores de índice de seletividade e de atividade, 4,76 e $11,16 \mu \mathrm{g} / \mathrm{mL}$, respectivamente. Nenhum princípio ativo foi identificado para esta atividade, porém provavelmente esses efeitos estão relacionados a ação de metabólitos secundários, em especial o fitol. Mas outros compostos também podem estar associados à esta atividade, portanto, estudos posteriores devem ser realizados a fim de prover esses dados importantes.

Diferente das algas, poucas espécies de cianobactérias foram exploradas quanto ao seu potencial tripanocida, tais como Arthrospira maxima, Arthrospira platensis, Nostoc commune, Rivularia biasolettiana e Oscillatoria nigro-viridis. ReboredaHernandez et al., (2020) relatou a atividade in vivo da administração da biomassa da cianobactéria A. maxima em ratos infectados com $T$. cruzi da cepa NINOA, linhagem predominante no México. Os resultados mostraram que o tratamento com A. maxima diminuíram os níveis de parasitemia, associada a redução da taxa de mortalidade dos ratos e menor quantidade de amastigota. Esse estudo foi o único a relatar a atividade anti-Trypanosoma in vivo de algas ou cianobactérias até agora. Por outro lado, Veas et al., (2020) não observaram atividade tripanocida dos extratos etanólico, metanólico ou aquoso obtidos da cianobactéria A. platensis contra formas tripomastigota de $T$. cruzi. 
O extrato de $N$. commune e $R$. biasolettiana obtido com clorofórmio mostraram $I_{50}$ de 12,3 e 19,4 $\mu \mathrm{g} / \mathrm{ml}$, respectivamente, frente à amastigotas (BRONIATOWSKA et al., 2011), bem como também foi relatada atividade tripanocida obtida a partir do princípio ativo identificado no extrato orgânico de $O$. nigro-viridis, a viridamida $A$, que apresentou $\mathrm{IC}_{50}$ de $1,1 \mu \mathrm{M}$ frente a formas tripomastigota de T. cruzi (SIMMONS et al., 2008). Dentre estudos envolvendo cianobactérias, Simmons et al., (2008) foi o único a identificar algum princípio ativo que age contra a forma tripomastigota.

Nesse sentido, novos estudos são necessários com a finalidade de descobrir informações adicionais importantes relacionadas a esses efeitos, tais como: o mecanismo de ação utilizado pelos princípios ativos descobertos até o momento, novos testes em ensaios in vivo para avaliar possíveis reações adversas nos demais órgãos do organismo, além de outros dados relevantes para o desenvolvimento de fármacos. Contudo, apesar de pouco exploradas, as algas e cianobactérias representam uma fonte promissora de compostos com atividade tripanocida, tendo em vista o grande valor associado à sua biomassa e estudos preliminares que sugerem seu potencial de atividade.

Tabela 1 - Principais características de estudos envolvendo a atividade tripanocida de algas e cianobactérias.

\begin{tabular}{|c|c|c|c|c|c|c|}
\hline Organismo & $\begin{array}{l}\text { Tipo de } \\
\text { ensaio }\end{array}$ & $\begin{array}{l}\text { Forma } \\
\text { evolutiva } \\
\text { do } T . c r u z i\end{array}$ & $\begin{array}{l}\text { Linhagem } \\
\text { celular }\end{array}$ & $\mathrm{IC}_{50}$ & $\mathrm{CC}_{50}$ & Referência \\
\hline Macroalgas & in vitro & $\begin{array}{c}\text { Tripomastig } \\
\text { ota }\end{array}$ & L6 & $>90$ & $>90$ & $\begin{array}{l}\text { Orhan et al. } \\
(2006)\end{array}$ \\
\hline Macroalgas & in vitro & Amastigota & VERO & $\begin{array}{l}2,4 \leq I C 50 \leq \\
58,9 \text { e }>200\end{array}$ & $\begin{array}{c}20,3 \leq \text { CC50 } \\
\leq 154,0 \text { e }> \\
200\end{array}$ & $\begin{array}{l}\text { Teixeira et } \\
\text { al. (2019) }\end{array}$ \\
\hline Macroalgas & in vitro & $\begin{array}{c}\text { Tripomastig } \\
\text { ota }\end{array}$ & ND & 18,8 e 19,1 & ND & $\begin{array}{l}\text { De Felício } \\
\text { et al. (2010) }\end{array}$ \\
\hline Macroalgas & in vitro & $\begin{array}{c}\text { Tripomastig } \\
\text { ota }\end{array}$ & L6 & $\begin{array}{c}34,6 \leq \mathrm{IC} 50 \\
\leq 79,3 \text { e }> \\
90\end{array}$ & $\begin{array}{c}32,7 \leq \mathrm{CC} 50 \\
\leq 62,5 \mathrm{e}> \\
90\end{array}$ & $\begin{array}{l}\text { Spavieri et } \\
\text { al. (2010) }\end{array}$ \\
\hline Macroalgas & in vitro & $\begin{array}{c}\text { Tripomastig } \\
\text { ota }\end{array}$ & L6 & $\begin{array}{c}34,9 ; 80,8 \text { e } \\
\quad>90\end{array}$ & $>90$ & $\begin{array}{l}\text { Spavieri et } \\
\text { al. (2009) }\end{array}$ \\
\hline Macroalgas & in vitro & $\begin{array}{c}\text { Tripomastig } \\
\text { ota }\end{array}$ & L6 & 62,0 e $>90$ & 14,7 e $>90$ & $\begin{array}{l}\text { Süzgeç- } \\
\text { Selçuk et al. } \\
\text { (2010) }\end{array}$ \\
\hline Macroalgas & in vitro & $\begin{array}{c}\text { Tripomastig } \\
\text { ota }\end{array}$ & L6 & ND & $\begin{array}{c}6 \leq \mathrm{CC} 50 \leq \\
88 \text { e }>90\end{array}$ & $\begin{array}{l}\text { Vonthron- } \\
\text { Sénécheau } \\
\text { et al. (2011) }\end{array}$ \\
\hline
\end{tabular}




\begin{tabular}{|c|c|c|c|c|c|c|}
\hline Macroalgas & in vitro & $\begin{array}{c}\text { Tripomastig } \\
\text { ota }\end{array}$ & L6 & $>90$ & 88,6 e $>90$ & $\begin{array}{c}\text { Allmending } \\
\text { er et al. } \\
\text { (2010) }\end{array}$ \\
\hline Macroalgas & in vitro & $\begin{array}{c}\text { Tripomastig } \\
\text { ota }\end{array}$ & $\mathrm{LLCMK}_{2}$ & 1,38 & 27 & \multirow{2}{*}{$\begin{array}{c}\text { Veiga- } \\
\text { Santos et al. } \\
(2010)\end{array}$} \\
\hline Macroalgas & in vitro & Amastigota & $\mathrm{LLCMK}_{2}$ & 1,01 & 27 & \\
\hline Macroalgas & in vitro & Amastigota & HeLa & ND & ND & $\begin{array}{c}\text { Nara et al. } \\
(2005)\end{array}$ \\
\hline $\begin{array}{c}\text { Microalgas } \\
\text { e } \\
\text { cianobacter } \\
\text { ias }\end{array}$ & in vitro & $\begin{array}{c}\text { Tripomastig } \\
\text { ota }\end{array}$ & VERO & $\begin{array}{c}60,9 \leq \mathrm{IC} 50 \\
\leq 68,4\end{array}$ & $\begin{array}{c}2,89 \leq \text { CC50 } \\
\leq 11,16\end{array}$ & $\begin{array}{l}\text { Veas et al. } \\
(2020)\end{array}$ \\
\hline $\begin{array}{c}\text { Cianobactér } \\
\text { ias }\end{array}$ & in vitro & $\begin{array}{c}\text { Tripomastig } \\
\text { ota }\end{array}$ & L6 & $\begin{array}{c}12,3 \leq \mathrm{IC} 50 \\
\leq 85,4 \text { e }>90\end{array}$ & $\begin{array}{c}40,5 \leq \text { CC50 } \\
\leq 84,3 \text { e }> \\
90\end{array}$ & $\begin{array}{c}\text { Broniatows } \\
\text { ka et al. } \\
\text { (2011) }\end{array}$ \\
\hline $\begin{array}{c}\text { Cianobactér } \\
\text { ias }\end{array}$ & in vitro & $\begin{array}{c}\text { Tripomastig } \\
\text { ota }\end{array}$ & ND & 1,1 & ND & $\begin{array}{c}\text { Simmons et } \\
\text { al. (2008) }\end{array}$ \\
\hline $\begin{array}{c}\text { Cianobactér } \\
\text { ias }\end{array}$ & in vivo & $\begin{array}{c}\text { Tripomastig } \\
\text { ota }\end{array}$ & ND & ND & ND & \multirow{2}{*}{$\begin{array}{l}\text { Reboreda- } \\
\text { Hernandez } \\
\text { et al. (2020) }\end{array}$} \\
\hline $\begin{array}{c}\text { Cianobactér } \\
\text { ias }\end{array}$ & in vivo & Amastigota & ND & ND & ND & \\
\hline
\end{tabular}

\section{CONSIDERAÇÕES FINAIS}

Tendo em vista as graves manifestações clínicas causadas pela doença de Chagas, suas consequências geradas nos indivíduos infectados e a clara necessidade de novos compostos de ação tripanocida devido aos sérios efeitos colaterais causados pelas drogas convencionais, as algas e cianobactérias representam uma fonte alternativa promissora de compostos bioativos de ação tripanocida natural, pois são ricas em metabólitos primários e secundários com diversas ações biológicas já descritas, além de serem alvo de estudos recentes quanto à sua ação antiparasitária. Neste trabalho, foram apresentados dados importantes relacionados ao valor da biomassa desses organismos fotossintetizantes e seu alto potencial como possível agente anti-Trypansoma.

\section{AGRADECIMENTOS}

À Fundação de Amparo à Ciência e Tecnologia do Estado de Pernambuco (FACEPE), ao Conselho Nacional de Desenvolvimento e Científico e Tecnológico (CNPq) e à Coordenação de Aperfeiçoamento de Pessoal de Nível Superior (CAPES) pelo auxílio financeiro e pelas bolsas concedidas. 


\section{REFERÊNCIAS}

ABU-GHANNAM, N.; RAJAURIA, G. Antimicrobial activity of compounds isolated from algae. Functional Ingredients from Algae for Foods and Nutraceuticals. [S.I.]: Elsevier, 2013.

ALBAJAR-VIÑAS, P.; JANNIN, J. The hidden Chagas disease burden in Europe separator commenting unavailable. Eurosurveillance, 2011.

ALLMENDINGER, A.; SPAVIERI, J.; KAISER, M.; CASEY, R.; HINGLEY-WILSON, S.; LALVANI, A.; GUIRY, M.; BLUNDEN, G.; TASDEMIR, D. Antiprotozoal, antimycobacterial and cytotoxic potential of twenty-three British and Irish red algae. Phytotherapy Research, v. 24, n. 7, 2010.

ANDRADE, A. L. S. ZICKER, F.; OLIVEIRA, R. M.; SILVA, S. A.; LUQUETTI, A.; TRAVASSOS, L. R.; ALMEIDA, I. C; ANDRADE, S. S.; ANDRADE, J G.; MARTELLI, C. M. Randomised trial of efficacy of benznidazole in treatment of early Trypanosoma cruzi infection. The Lancet, v. 348, n. 9039, 1996.

BERN, C. Chagas' Disease. New England Journal of Medicine, v. 373, n. 5, 2015.

BRONIATOWSKA, B.; ALLMENDINGER, A.; KAISER, M.; MONTAMAT-SICOTTE, D.; HINGLEY-WILSON, S.; LALVANI, A.; GUIRY, M.; BLUNDEN, G.; TASDEMIR, D. Antiprotozoal, antitubercular and cytotoxic potential of cyanobacterial (bluegreen algal) extracts from Ireland. Natural Product Communications, v. 6, n. 5, p. 689-694, 2011.

CASTRO, J. A.; DE MECCA, M. M.; BARTEL, L. C. Toxic side effects of drugs used to treat Chagas Disease (American trypanosimiasis). Human \& Experimental Toxicology, v. 25, n. 8, 2006.

COURA, J. R.; CASTRO, S. L. A Critical Review on Chagas Disease Chemotherapy. Memórias do Instituto Oswaldo Cruz, v. 97, n. 1, 2002.

COURA, José Rodrigues. Present situation and new strategies for Chagas disease chemotherapy: a proposal. Memórias do Instituto Oswaldo Cruz, v. 104, n. 4, 2009.

DIÁRIO DE PERNAMBUCO. Quarenta pessoas em tratamento após surto de doença de chagas em Pernambuco. DIÁRIO DE PERNAMBUCO. 2019.

EL-BAZ, F. K.; ALY, H. F.; ABD-ALLA, H. I. The ameliorating effect of carotenoid rich fraction extracted from Dunaliella salina microalga against inflammationassociated cardiac dysfunction in obese rats. Toxicology Reports, v. 7, 2020.

FELÍCIO, R. D.; ALBUQUeRQUE, S.; YOUNG, M. C. M.; YOKOYA, N. S.; DEBONSI, H. M. Trypanocidal, leishmanicidal and antifungal potential from marine red alga Bostrychia tenella J. Agardh (Rhodomelaceae, Ceramiales). Journal of Pharmaceutical and Biomedical Analysis, v. 52, n. 5, 2010.

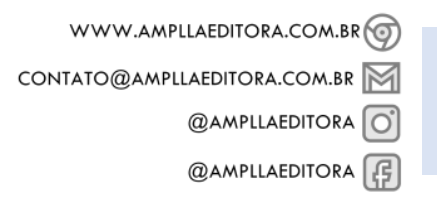


GASCON, J.; BERN, C.; PINAZO, M.-J. Chagas disease in Spain, the United States and other non-endemic countries. Acta Tropica, v. 115, n. 1-2, 2010.

HOARE, C. A.; WALLACE, F. G. Developmental Stages of Trypanosomatid Flagellates: a New Terminology. Nature, v. 212, p. 1385-1386, 1966.

IGLESIAS, M. J.; SOENGAS, R.; PROBERT, I.; GUILLOUD, E.; GOURVIL, P.; MEHIRI, M.; LÓPEZ, Y.; CEPAS, V.; GUTIÉRREZ-DEL-RÍO; I.; REDONDO-BLANCO, S.; VILLAR, C. J.; LOMBÓ, F.; SOTO, S.; ORTIZ, F. L. NMR characterization and evaluation of antibacterial and antiobiofilm activity of organic extracts from stationary phase batch cultures of five marine microalgae (Dunaliella sp., D. salina, Chaetoceros calcitrans, C. gracilis and Tisochrysis lutea). Phytochemistry, v. 164, 2019.

JACKSON, Y.; PINTO, A.; PETT, S. Chagas disease in Australia and New Zealand: risks and needs for public health interventions. Tropical Medicine \& International Health, v. 19, n. 2, 2014.

KAWAGUCHI, W. H.; CERQUEIRA, L. B.; FACHI, M. M.; CAMPOS, M. J.; REASON, I. J. M.; PONTAROLO, R. Efficacy and Safety of Chagas Disease Drug Therapy and Treatment Perspectives. Chagas Disease - Basic Investigations and Challenges, 2018.

KHAW, M.; PANOSIAN, C. Human antiprotozoal therapy: past, present, and future. Clinical Microbiology Reviews, v. 8, n. 3, p. 427-439, 1995.

KHOTIMCHENKO, M.; TIASTO, V.; KALITNIK, A.; BEGUN, M.; KHOTIMCHENKO, R.; LEONTEVA, E.; BRYUKHOVETSCKIY, I.; KHOTIMCHENKO, Y. Antitumor potential of carrageenans from marine red algae. Carbohydrate Polymers, v. 246, 2020.

LEY, V.; ANDREWS, N. W.; ROBBINS, E. S.; NUSSENZWEIG, V. Amastigotes of Trypanosoma cruzi sustain an infective cycle in mammalian cells. Journal of Experimental Medicine, v. 168, n. 2, 1988.

LÓPEZ-VELÁZQUEZ, G.; LÓPEZ-VILLASEÑOR, I.; HERNANDEZ, R.; VIVAS, R. Electron Microscopy Analysis of the Nucleolus of Trypanosoma cruzi. Microscopy and Microanalysis. Microscopy and Microanalysis, v. 11, n. 4, p. 293-299, 2005.

LÓPEZ-VÉLEZ, R.; NORMAN, F. F.; BERN, C. American Trypanosomiasis (Chagas Disease). Hunter's Tropical Medicine and Emerging Infectious Diseases. Elsevier, 2020.

MARTINS, M. C. L.; MIYAZAKI, D.; GABIATTI, C. C. T.; SILVA, L. P.; MACEDO, L. T.; SIQUEIRA, N. S.; ANDREOLLO, N. A.; CARVALHEIRA, B. J. C. Chagasic Megaesophagus-Associated Carcinoma: Clinical Pattern and Outcomes. Journal of Global Oncology, n. 5, 2019.

MATTEI, D. M.; GOLDENBERG, S.; MOREL, C. Biochemical strain characterization of Trypanosoma cruzi by restriction endonuclease cleavage of kinetoplast-DNA. FEBS Letters, v. 74, n. 2, 1977. 
MCMILLAN, J. R.; ALI, M.; WATSON, I. Evaluation and comparison of algal cell disruption methods: microwave, waterbath, blender, ultrasonic and laser treatment. Applied Energy, v. 103, 2013.

MINISTÉRIO DA SAÚDE. Doença de Chagas. 2020.

MOLINA, I.; SALVADOR, F.; SÁNCHEZ-MONTALVÁ, A.; TRENIÑO, B.; SERRE, N.; AVILÉS, A. S.; ALMIRANTE, B. Toxic Profile of Benznidazole in Patients with Chronic Chagas Disease: Risk Factors and Comparison of the Product from Two Different Manufacturers. Antimicrobial Agents and Chemotherapy, v. 59, n. 10, 2015.

MOSTAFA, S. S. M. Microalgal Biotechnology: Prospects and Applications. Plant Science, 2012.

MUELAS-SERRANO, S.; NOGAL-RUIZ, J. J.; GÓMEZ-BARRIO, A. Setting of a colorimetric method to determine the viability of Trypanosoma cruzi epimastigotes. Parasitology Research, v. 86, n. 12, 2000.

NARA, T.; KAMEI, Y.; TSUBOUCHI, A.; ANNOURA, T.; HIROTA, K.; IIZUMI, K.; DOHMOTO, Y.; ONO, T.; AOKI, T. Inhibitory action of marine algae extracts on the Trypanosoma cruzi dihydroorotate dehydrogenase activity and on the protozoan growth in mammalian cells. Parasitology International, v. 54, n. 1, 2005.

NOGUEIRA, N.; COURA, J. R. American Trypanosomiasis (Chagas Disease). Tropical and Geographical Medicine, n. 2, 1990.

NOIREAU, F.; DIOSQUE, P.; JANSEN, A. M. Trypanosoma cruzi : adaptation to its vectors and its hosts. Veterinary Research, v. 40, n. 2, 2009.

OLIVERA, M. J.; CUCUNUBÁ, Z. M.; VALENCIA-HERNANDÉZ, A. A.; HERAZO, R.; AGREDARUDENKO, D.; FLÓREZ, C.; DUQUE, S.; NICHOLLS, R. S. Risk factors for treatment interruption and severe adverse effects to benznidazole in adult patients with Chagas disease. PLOS ONE, v. 12, n. 9, 2017.

ORGANIZAÇÃO MUNDIAL DA SAÚDE. Chagas disease (also known as American trypanosomiasis). OMS, 2020.

ORGANIZAÇÃO MUNDIAL DA SAÚDE. Chagas disease (American trypanosomiasis). 2019.

ORGANIZAÇÃO PAN AMERICANA DE SAÚDE. Chagas Disease. Organização Mundial da Saúde, 2020.

ORHAN, I.; SENER, B.; ATICI, T.; BRUN, R.; PEROZZO, R.; TASDEMIR, D. Turkish freshwater and marine macrophyte extracts show in vitro antiprotozoal activity and inhibit Fabl, a key enzyme of Plasmodium falciparum fatty acid biosynthesis. Phytomedicine, v. 13, n. 6, 2006.

RASSI, A. Fase aguda da doença de Chagas. Trypanosoma cruzi e doença de Chagas. 2a. ed. Rio de Janeiro: Guanabara Koogan, p. 241-245, 2000. 
RASSI, A. J.; RASSI, A; MARIN-NETO, JA. Chagas disease. The Lancet, v. 375, p. 13881402, 2010.

RASSI, A.; NETO, J. A. M.; RASSI, A. Chronic Chagas cardiomyopathy: a review of the main pathogenic mechanisms and the efficacy of a etiological treatment following the Benznidazole evaluation for interrupting Trypanosomiasis (BENEFIT) trial. Memórias do Hospital Oswaldo Cruz, v. 112, n. 3, 2017.

RASSI, A; RASSI, A; MARCONDES DE REZENDE, J. American Trypanosomiasis (Chagas Disease). Infectious Disease Clinics of North America, v. 26, n. 2, 2012.

REBOREDA-HERNANDEZ, O. A.; JUAREZ-SERRANO, A. L.; GARCIA-LUNA, I.; RIVERORAMIREZ, N. L.; ORTRIZ-BUTRON, R.; NOGUEDA-TORRES, B.; GONZALEZRODRIGUEZ, N. Arthrospira maxima Paradoxical Effect on Trypanosoma cruzi Infection. Iranian Journal of Parasitology, v. 15, n. 2, p. 223-232, 2020.

REY, L. Parasitologia. 4a. ed. Rio de Janeiro: Guanabara Koogan, 2008.

REZENDE, J. DE; LUQUETII, A. Chagasic megavisceras. (Pan American Health Organization, Org.). Washington: Scientific publication, p. 149-171, 1994.

SECRETARIA ESTADUAL DE SAÚDE. SES promove curso sobre Doença de Chagas. 2019.

SIMMONS, T. L.; EUGENE, N.; UREÑA, L. D.; ROMERO, L. I.; ORTEGA-BARRIA, E.; GERWICK, L.; GERWICK, W. H. Viridamides A and B, Lipodepsipeptides with Antiprotozoal Activity from the Marine Cyanobacterium Oscillatoria nigro-viridis. Journal of Natural Products, v. 71, n. 9, 2008.

SPAVIERI, J.; ALLMENDINGER, A.; KAISER, M.; CASEY, R.; HINGLEY-WILSON, S.; LALVANI, A.; GUIRY, M. D.; BLUNDEN, G.; TASDEMIR, D. Antimycobacterial, antiprotozoal and cytotoxic potential of twenty-one brown algae (phaeophyceae) from British and Irish waters. Phytotherapy Research, v. 24, n. 11, 2010.

SPAVIERI, J.; KAISER, M.; CASEY, R.; HINGLEY-WILSON, S.; LALVANI, A.; BLUNDEN, G.; TASDEMIR, D. Antiprotozoal, antimycobacterial and cytotoxic potential of some british green algae. Phytotherapy Research, v. 24, n. 7, 2010. Disponível em: <http://doi.wiley.com/10.1002/ptr.3072>.

SÜZGEÇ-SELÇUK, S.; MERIÇLI, A. H.; GÜVEN, K. C.; KAISER, M.; CASEY, R.; HINGLEYWILSON, S.; LALVANI, S.; TASDEMIR, D. Evaluation of Turkish seaweeds for antiprotozoal, antimycobacterial and cytotoxic activities. Phytotherapy Research, v. 25, n. 5, 2011.

TEIXEIRA, V. L.; LIMA, J. C. R.; LECHUGA, G. C.; RAMOS, S. J. B.; PEREIRA, M. C. S.; CALVET, C. M.; BOURGUIGNON, S. C. Natural products from marine red and brown algae against Trypanosoma cruzi. Revista Brasileira de Farmacognosia, v. 29, n. 6, 2019. 
VEAS, R.; ROJAS-PIRELA, M.; CASTILLO, C.; OLEA-AZAR, C.; MONCADA, M.; ULLOA, P.; ROJAS, V.; KEMMERLING, U. Microalgae extracts: Potential anti-Trypanosoma cruzi agents? Biomedicine \& Pharmacotherapy, v. 127, 2020.

VEIGA-SANTOS, P.; ROCHA, K. J. P.; SANTOS, A. O. In vitro anti-trypanosomal activity of elatol isolated from red seaweed Laurencia dendroidea. Parasitology, v. 137, n. 11, 2010.

VONTHRON-SÉNÉCHEAU, C.; KAISER, M.; DEVAMBEZ, I.; VASTEL, A.; MUSSIO, I.; RUSIG, A. M. Antiprotozoal Activities of Organic Extracts from French Marine Seaweeds. Marine Drugs, v. 9, n. 6, 2011.

WEGNER D.H.; ROHWEDDER R.W. Experience with nifurtimox in chronic Chagas' infection: preliminary report. Arzneimittelforschung, v. 22, p. 1631-1641, 1972.

ZAMANI, H.; RASTEGARI, B.; VARAMINI, M. Antioxidant and anti-cancer activity of Dunaliella salina extract and oral drug delivery potential via nano-based formulations of gum Arabic coated magnetite nanoparticles. Journal of Drug Delivery Science and Technology, v. 54, p. 101278, 2019. Disponível em: <https://linkinghub.elsevier.com/retrieve/pii/S1773224719307014>. 


\title{
CAPITULO XXXIII
}

\section{POĹIICA NACIONAL DE SAÚdE INIEGRAL DA POPULAGÃO NEGRA: (IN)VIIBIUDADE DE UMA AÇÃO ESTATAL}

\author{
Clebes Iolanda Leodice Alves ${ }^{1}$ \\ Leonice Aparecida de Fátima Alves Pereira Mourad ${ }^{2}$
}

\footnotetext{
1 Enfermeira especialista em Saúde da Família, Faculdade UniBF, Paraíso do Norte, PR. Prefeitura Municipal de Cariacica/ICEPI, ES.

${ }^{2}$ Doutora em História(UNISINOS) e Geografia(UFSM). Professora e Coordenadora do Mestrado em Ensino de História da Universidade Federal de Santa Maria - UFSM, RS.
}

\section{RESUMO}

Este trabalho tem por escopo discorrer sobre o direito à saúde, como um dever do Estado, em face à Constituição Federal. Faremos o cotejo do direito à saúde como parte fundamental do direito à vida, delimitando a abordagem, em face a necessidade que exsurge da ampla conceituação de saúde, na Política Nacional de Saúde Integral da População Negra (PNSIPN). Essa política teve como semente, a pressão exercida pelo movimento negro, desde 1985, com destaque para a criação do Grupo de Trabalho Interministerial (GTI). Esse grupo tratava da valorização da população negra, sendo a saúde um dos subtemas. Foi ganhando corpo a partir da aprovação unânime do Conselho Nacional de Saúde em criar uma política que reconhecesse as desigualdades raciais como fator determinante da saúde. Todavia, só foi implementada em maio de 2009, através da Portaria № 992. Decorridos 12 anos, percebemos que a reflexão sobre o cuidado em saúde da população negra e a efetiva implantação dessa política, cujo cerne está na equidade, ainda não foi incorporada pelos operadores de saúde, principalmente pelos que atuam na rotina da Atenção Primária à Saúde, principal porta de acesso e de articulação dos usuários ao Sistema Único de Saúde.

Palavras-chave: Saúde pública. População negra. Equidade. Atenção primária à saúde.

\section{INTRODUÇÃO}

No quesito saúde, a Constituição Federal de 1988 representa um marco histórico de proteção normativa à saúde da população brasileira, proteção essa conferida pelo Estado, nas suas três esferas.

Em seu artigo 6으, estabelece, entre outros, a saúde como um direito social fundamental. Já no seu artigo 1960, menciona que "A saúde é direito de todos e dever do Estado, garantido mediante políticas sociais e econômicas que visem à redução do 
risco de doença e de outros agravos e ao acesso universal e igualitário às ações e serviços para sua promoção, proteção e recuperação" (BRASIL, 1988).

Esse reconhecimento da saúde como um bem social inerente a todos, forçou o Estado a implementar essa prestação de serviço, a partir da formulação de políticas públicas sociais e econômicas voltadas à promoção, à proteção e à recuperação da saúde.

Esse preceito é confirmado no artigo 2ำ da Lei Orgânica da Saúde (conhecida como a Lei do SUS), ao referir que "A saúde é um direito fundamental do ser humano, devendo o Estado prover as condições indispensáveis ao seu pleno exercício" (BRASIL, 1990).

A Atenção Primária à Saúde (APS) configura-se como a porta de entrada e o primeiro contato entre usuários e equipe de saúde, garantindo a atenção integral à população. Está integrada aos demais níveis de atendimento, a fim de prevenir, restaurar e reabilitar a saúde dos indivíduos.

Advém desses preceitos, a necessidade em delimitar a ação do Estado na proposição de políticas públicas que permitam o acesso baseados em três pilares, a saber: a universalidade, a integralidade e a equidade no acesso à saúde.

Segundo Werneck (2010), "O conceito saúde da população negra está ancorado em três aspectos importantes: a política, a ciência e a cultura afro-brasileira" (WERNECK, 2010, p. 5).

Desta forma, o vínculo que o serviço estabelece com essa população, entendendo a complexidade desses sujeitos e como são permeados por aspectos como desenvolvimento econômico, social, de gênero e étnico-racial, possibilita contribuir não só nos aspectos de promoção da saúde em si, mas também na correção de iniquidades decorrentes de discriminação, seja ela social ou institucional.

É oportuno ressaltar que a Política Nacional de Saúde Integral da População Negra, instituída em maio de 2009, pela Portaria № 992/2009, tem explicitado como marca, em seu Capítulo I, dos Princípios Gerais, o "Reconhecimento do racismo, das desigualdades étnico-raciais e do racismo institucional como determinantes sociais das condições de saúde, com vistas à promoção da equidade em saúde" (BRASIL, 2009).

Nesse sentido, esse estudo se propõe a apresentar a PNSIPN como um marco histórico para a saúde da população negra e um importante instrumento de ação contra 
as iniquidades em saúde. Promover a visibilidade desse instrumento normativo, entendendo em que contexto se encontra a população negra nos dias atuais, é o primeiro passo para a implementação de suas diretrizes, para que este grupo social, ainda tão submetido a exclusão de direitos, dentre eles, o acesso à saúde, possa usufruir do que Ihes é garantido constitucionalmente.

\section{REVISÃO BIBLIOGRÁFICA}

Nesta seção, faremos uma breve discussão acerca dos principais conceitos que orientam a investigação a fim de compreender a constituição da PNSIPN.

\subsection{AÇÃO DA SOCIEDADE CIVIL E MOVIMENTOS SOCIAIS: BREVE HISTÓRICO dOS ANTECEDENTES DA POLITICA}

No período de questionamento e enfrentamento da ditadura militar, no final dos anos de 1970, e após a queda do regime, houve uma explosão de movimentos contestatórios das desigualdades que assolavam o Brasil. As reivindicações sociais eram tantas, que o movimento negro precisou criar espaços para refletir e propor sobre seus processos de saúde e adoecimento. Ao mesmo tempo que somava forças e clamava pela reconquista plena dos direitos civis básicos da população brasileira, precisou trazer à tona as especificidades estruturais da população negra, que abarca não só questões sociais e econômicas, mas também relativas à saúde.

Vitória incontestável se deu quando a Constituição Federal de 1988, por meio do Inciso XLII do Artigo 5을 definiu a criminalização do racismo (BRASIL, 1988). Em agosto do mesmo ano, por meio da Lei $n^{\circ} 7.668$, foi instituída a Fundação Cultural Palmares, cuja finalidade é "[...] promover a preservação dos valores culturais, sociais e econômicos decorrentes da influência negra na formação da sociedade brasileira" (BRASIL, 1988).

A criação e implementação do SUS, através da Lei Orgânica da Saúde № 8.080/90, apesar de ser um marco significativo para a saúde da população brasileira, não garantiu a atenção à saúde da população negra de maneira efetiva. Dessa forma, foi necessário que o movimento negro continuasse pautando esse debate, para que assim finalmente as diretrizes do SUS os incluísse. 
Ao longo da década de 1990, dois importantes eventos marcaram a forte pressão do movimento negro sob o Estado. O primeiro foi a Marcha Zumbi de Palmares contra o Racismo, pela Cidadania e a Vida, ocorrida em novembro de 1995, na capital federal. Reuniu cerca de 30 mil pessoas que protestavam contra a ausência de políticas públicas para a população negra (JORGE, 2005).

Como resultado dessa Marcha, foi criado o Grupo de Trabalho Interministerial para Valorização da População Negra (GTI), que se estruturou como um espaço de participação ampliada da sociedade civil na discussão e proposição de políticas de reconhecimento da efetiva contribuição histórica e cultural da população negra para o nosso país.

Também em 1995, a saúde da população negra começa a ganhar visibilidade através da instituição e do uso da doença falciforme (anemia falciforme) "como um marcador da qualidade das respostas do SUS à saúde da população negra" (WERNECK, 2010, p. 15).

Destacamos, ainda nos anos 90, mais especificamente em 1992, a inclusão do quesito cor no Sistema Municipal de Informação da Saúde na cidade de São Paulo (WERNECK, 2010, p. 14).

Sobre isso, o Conselho Regional de Psicologia do Paraná - CRP/PR (2020) destaca que

O quesito raça/cor nos sistemas de informação do SUS atende aos objetivos da Política Nacional de Saúde Integral da População Negra, que define os princípios, a marca, os objetivos, as diretrizes, as estratégias e as responsabilidades de gestão voltados para a melhoria das condições de saúde das pessoas negras (CRP/PR, 2020).

Werneck (2016) cita que em 1998, o Ministério da Saúde (MS) publicou o documento intitulado "A Saúde da População Negra, realizações e perspectivas" e que, em 2001, lançou, baseado na origem genética, o "Manual de doenças mais importantes, por razões étnicas, na população brasileira afrodescendente". Neste manual constavam doenças como a anemia falciforme, a deficiência de glicose-6-fosfato-desidrogenase, a hipertensão arterial e gestacional e a diabetes mellitus (WERNECK, 2016, p. 537).

Ainda sobre esse manual, a autora comenta que o mesmo deixou de fora as doenças de origem cuja origem genética não havia sido estabelecida, como miomatoses uterinos e síndrome leucopênica, bem como as doenças cuja determinação social não 
deixa dúvidas, como o alcoolismo, a desnutrição, doenças de veiculação hídrica, tuberculose e outras infecções (WERNECK, 2016, p. 537).

Ainda no ano de 1998, o Brasil participou da III Conferência Mundial contra o Racismo, a Discriminação Racial, Xenofobia e Formas Correlatas de Intolerância, ocorrida em Durban (Africa do Sul), onde foi firmada a resolução intitulada "Unidos contra o racismo, a discriminação racial, a xenofobia e a intolerância" (UNFPA BRASIL, 2018).

Em 2004, foi criado o Comitê Técnico de Saúde da População Negra/CTSPN do MS e realizado o I Seminário Nacional de Saúde da População Negra, promovido pelo MS, que contou com a participação de representantes do SUS e do movimento negro. No ano de 2005, ocorreu a I Conferência Nacional de Promoção da Igualdade Racial, que contou com discussões e deliberações sobre saúde. Outra vitória foi a inclusão da saúde da população negra no Plano Nacional de Saúde , a realização do 2 Seminário Nacional de Saúde da População Negra e o lançamento de publicações relativas a saúde dessa população, representando uma importante contribuição para a promoção da equidade ao trazer a tona, informações sobre a saúde da população negra e as desigualdades raciais ocorridas nesse âmbito (WERNECK, 2010).

Sobre equidade, Brasil (2009) destaca que

\begin{abstract}
Igualmente importante é o princípio da equidade. A iniquidade racial, como fenômeno social amplo, vem sendo combatida pelas políticas de promoção da igualdade racial, regidas pela Lei no $10.678 / 03$, que criou a SEPPIR. Coerente com isso, o princípio da igualdade, associado ao objetivo fundamental de conquistar uma sociedade livre de preconceitos na qual a diversidade seja um valor, deve desdobrar-se no princípio da equidade, como aquele que embasa a promoção da igualdade a partir do reconhecimento das desigualdades e da ação estratégica para superá-las. Em saúde, a atenção deve ser entendida como ações e serviços priorizados em razão de situações de risco e condições de vida e saúde de determinados indivíduos e grupos de população (BRASIL, 2009).
\end{abstract}

Em 2006, o movimento negro teve, pela primeira vez, representação no Conselho Nacional de Saúde/CNS, durante o mandato 2007-2009, fato esse que impulsionou a aprovação, por unanimidade, da criação da Política Nacional de Saúde Integral da População Negra/PNSIPN. Porém, tal política só foi oficializada a partir da publicação, no Diário Oficial, da Portaria №. 992 do MS (Werneck, 2010). 


\subsection{POLITICA NACIONAL de SAÚde INTEGRAL dA POPULAÇÃo NEGRA (PNSIPN)}

Com base em um esforço governamental de incorporar na agenda pública a temática da saúde das populações negras de uma forma efetiva e com base nos princípios do SUS da integralidade, equidade, universalidade e participação social, o Ministério da Saúde instituiu, em 2009, a Política Nacional de Saúde Integral da População Negra (PNSIPN), por meio da Portaria GM/MS no 992, de 13 de maio de 2009

De acordo com Chehuen et al. (2015), a PNSIPN surge como uma forma de compensar e tentar "[...] minimizar os efeitos da discriminação e da exploração sofridas pelos negros ao longo da história brasileira, já que esse histórico se reflete em vários aspectos, não sendo diferente em relação à saúde" (CHEHUEN et al., 2015, p. 1910).

A PNSIPN tem como marca, conforme Batista et al. (2020) “[...] o reconhecimento do racismo, das desigualdades raciais e do racismo institucional como determinantes sociais de saúde" (BATISTA et al., 2020, p. 4).

Todavia, isso não se dá de maneira fácil, conforme nos afirma Batista (2018), quando menciona que

\footnotetext{
Discussões em torno da temática étnico-racial em suma, tem como característica a dificuldade tanto em serem levantadas quanto ao efetivar o debate. Pautar as relações raciais no Brasil é certamente um tema que traz à tona muitas discussões, pois esse debate racial perpassa pela trajetória histórica em diversos segmentos, desde o período da escravização, como também na constituição, na academia, movimentos sociais, e etc (BATISTA, 2018, p. 30).
}

É desafiador tratar de uma política direcionada para a saúde da população negra, uma vez que nos coloca diante da necessidade de reconhecer o racismo, fato esse, negado pela sociedade em geral, o que implica numa visão distorcida acerca das diferenças existentes entre os grupos étnicos-raciais e suas respectivas necessidades.

A PNSIPN tem como objetivo geral "Promover a saúde integral da população negra, priorizando a redução das desigualdades étnico-raciais, o combate ao racismo e à discriminação nas instituições e serviços do SUS" (BRASIL, 2009). Já como diretrizes gerais, 
I - inclusão dos temas Racismo e Saúde da População Negra nos processos de formação e educação permanente dos trabalhadores da saúde e no exercício do controle social na saúde;

II - ampliação e fortalecimento da participação do Movimento Social Negro nas instâncias de controle social das políticas de saúde, em consonância com os princípios da gestão participativa do SUS, adotados no Pacto pela Saúde;

III - incentivo à produção do conhecimento científico e tecnológico em saúde da população negra;

IV - promoção do reconhecimento dos saberes e práticas populares de saúde, incluindo aqueles preservados pelas religiões de matrizes africanas;

V - implementação do processo de monitoramento e avaliação das ações pertinentes ao combate ao racismo e à redução das desigualdades étnicoraciais no campo da saúde nas distintas esferas de governo; e

VI -desenvolvimento de processos de informação, comunicação e educação, que desconstruam estigmas e preconceitos, fortaleçam uma identidade negra positiva e contribuam para a redução das vulnerabilidades (BRASIL, 2009).

Quanto às estratégias de gestão, é pertinente citar o "desenvolvimento de ações específicas para a redução das disparidades [...], sobretudo na morbimortalidade materna e infantil e naquela provocada por: causas violentas; doença falciforme; DST/HIV/aids; tuberculose; hanseníase; câncer de colo uterino e de mama; transtornos mentais" (BRASIL, 2009).

Ainda que seja regulamentada por lei federal, Werneck (2016) alerta-nos que

No entanto, além do rechaço mais ou menos explícito por parte de muitos, verificou-se, também, uma profunda ignorância acerca dos diferentes elementos envolvidos nos processos de realização de ações e estratégias necessárias, que explicam o porquê da PNSIPN não ter sido adequadamente implementada após esses anos. (WERNECK, 2016, p. 539).

A despeito do que representa essa política para a saúde da população negra, Batista (2018) afirma que "[...] ainda nos dias de hoje a PNSIPN não está presente no cotidiano do serviço da USF". E ainda complementa mencionando que há um desconhecimento por parte dos profissionais de saúde a respeito dessa política. Esse desconhecimento é "reflexo de uma sociedade, gestão, município, conselhos, e outras instâncias, que não debate e coloca em pauta as diretrizes e princípios da política" (BATISTA, 2018, p. 30).

\section{O mesmo autor ainda afirma que a}

[...] esfera científica também depara-se com essa realidade, pois ao realizar uma simples revisão da literatura especializada no Brasil encontra-se a baixa 
frequência que a saúde da população negra e a PNSIPN tem nos periódicos nacionais dedicados às Ciências da Saúde (BATISTA, 2018, p. 30).

Para a efetivação dessa política, Werneck (2010) afirma que é necessário que haja "[...] pactuação pelos gestores do SUS", que consiste na definição de ações a serem realizadas nas três esferas de atuação do SUS. Além dessa definição, é preciso que esses gestores definam os recursos a serem empregados, o período de realização e os mecanismos de controle das ações propostas (WERNECK, 2010, p. 20).

Outra normativa importante, a Portaria №. 344/2017 do MS articulado com a Secretaria de Políticas de Promoção da Igualdade Racial - SEPPIR, "[...] tornou obrigatório o preenchimento do quesito raça/cor nos formulários dos sistemas de informação em saúde" (CRP/PR, 2020).

Desta forma, é possível planejar as políticas públicas relacionadas às necessidades reais de cada grupo racial/étnico, melhorando a "[...] qualidade dos sistemas de informação do Sistema Único de Saúde (SUS) frente à coleta, ao processamento e à análise dos dados organizados por cor, etnia e gênero, bem como a promoção da equidade" (CRP/PR, 2020).

\section{CONSIDERAÇÕES FINAIS}

A PNSIPN é um importante instrumento no combate às iniquidades existentes na saúde, pois busca reduzir as disparidades raciais, incluindo a população negra. Tal população, social e economicamente vulnerável, deve ser atendida em seu processo saúde-doença de forma equitativa.

É preciso criarmos espaços para o diálogo, para o conhecimento e efetiva implementação da PNSIPN, mesmo que nos deparemos com discursos contrários, de cunho racista. Afinal, essa discussão não está restrita à população negra, e sim a cada pessoa compromissada com a desconstrução do mito da democracia racial, entoada por muitos, que só faz perpetuar uma falsa igualdade entre desiguais.

Não podemos cerrar os olhos para o fato que o racismo atua como um determinante social, e que reflete de maneira brutal na saúde dessa população. A Atenção Primária à Saúde, articulada com as premissas do SUS, deve atentar para essas especificidade em seus serviços, viabilizando assim, essa política no âmbito da saúde pública. 
Além disso, temos um compromisso com a produção científica e acadêmica que apresente informações e registros sobre a situação da saúde da população negra, através de dados epidemiológicos e séries históricas de indicadores disponibilizadas pelo SUS ou por outras fontes de dados oficiais, através de quesito cor. Essa produção embasará o debate e a ampla divulgação dessa política, contribuindo, assim, para o respeito à diversidade.

Cabe a cada operador de saúde, principalmente àqueles que atuam na rotina da Atenção Primária à Saúde, principal porta de acesso e de articulação dos usuários ao Sistema Único de Saúde, a decisão diária de, ativamente, se envolver no combate ao racismo na saúde e em todas as esferas sociais.

\section{REFERÊNCIAS}

BATISTA, Luís Eduardo et al. Indicadores de monitoramento e avaliação da implementação da Política Nacional de Saúde Integral da População Negra. Saúde e Sociedade (USP). 2020, v. 29, n. 3, e. 190151. São Paulo. Disponível em: <https://www.scielo.br/pdf/sausoc/v29n3/1984-0470-sausoc-29-03e190151.pdf> . Acesso em: 22 Maio 2021.

\section{BATISTA, Mateus do Amaral. A política nacional de saúde integral da população negra numa}

unidade saúde da família: compartilhando saberes. 2018. 37 f. Trabalho de Conclusão de Curso (Bacharel em Terapia Ocupacional), Universidade Federal de São Paulo (UNIFESP), Santos, $2018 . \quad$ Disponível em: $<$ https://repositorio.unifesp.br/bitstream/handle/11600/49824/TCC\%20Mateu s\%20do\%20Amaral. pdf? sequence=1\&isAllowed=y>. Acesso em: 23 Maio 2021.

BRASIL. Constituição (1988). Constituição da República Federativa do Brasil. Brasília, DF: Senado Federal, $1988 . \quad$ Disponível em: <http://www.planalto.gov.br/ccivil_03/constituicao/constituicao.htm>. Acesso em: 22 Maio 2021.

. Lei no 8.080, de 19 de Setembro de 1990. Lei Orgânica da Saúde. Dispõe sobre as condições para a promoção, proteção e recuperação da saúde, a organização e o funcionamento dos serviços correspondentes e dá outras providências. DOU. Brasília, DF, $1990 . \quad$ Disponível em: <http://www.planalto.gov.br/ccivil_03/leis//8080.htm>. Acesso em: 22 Maio 2021.

Portaria № 992, de 13 de Maio de 2009. Institui a Política Nacional de Saúde Integral da População Negra. DOU. Brasília, DF, 2009. Disponível em: <http://bvsms.saude.gov.br/bvs/saudelegis/gm/2009/prt0992_13_05_2009.ht $\mathrm{ml}$. Acesso em: 22 Maio 2021. 
Lei $n^{\circ} 7.668$, de 22 de Agosto de 1988. Autoriza o Poder Executivo a constituir a Fundação Cultural Palmares - FCP, e dá outras providências. DOU. Brasília, DF, 1988. Disponível em: <http://www.palmares.gov.br/wpcontent/uploads/2010/11/legis02.pdf>. Acesso em: 22 Maio 2021.

CHEHUEN, José Antônio et al. Política Nacional de Saúde Integral da População Negra: implementação, conhecimento e aspectos socioeconômicos sob a perspectiva desse segmento populacional. Ciência \& Saúde Coletiva. 2015, v. 20, n. 6, p. 1909-1916. Disponível em: <https://doi.org/10.1590/141381232015206.17212014>. Acesso em: 22 Maio 2021.

CONFERÊNCIA de Durban. Fundo de População das Nações Unidas (UNFPA BRASIL). Brasília, DF, 2018. Disponível em: <https://brazil.unfpa.org/pt-br/conferenciade-durban >. Acesso em: 22 Maio 2021.

CONSELHO REGIONAL DE PSICOLOGIA DO PARANÁ. A importância do quesito raça/cor nos dados de saúde sobre a Covid-19: por uma política de saúde mais justa e igualitária. Curitiba, PR. 2020. Disponível em: <https://crppr.org.br/aimportancia-do-quesito-raca-cor-nos-dados-de-saude-sobre-a-covid-19-poruma-politica-de-saude-mais-justa-e-igualitaria/ >. Acesso em 22 Maio 2021.

JORGE, Cecília. Primeira Marcha Zumbi, há 10 anos, reuniu 30 mil pessoas. Agência Brasil. Empresa Brasil de Comunicação. Brasília, DF, 13/11/2005. Disponível em: <https://memoria.ebc.com.br/agenciabrasil/noticia/2005-11-13/primeiramarcha-zumbi-ha-10-anos-reuniu-30-milpessoas\#: :text=Bras\%C3\%ADlia\%20\%E2\%80\%93\%20A\%20primeira\%20Marcha \%20Zumbi,p\%C3\%BAblicas\%20para\%20a\%20popula\%C3\%A7\%C3\%A3o\%20negr a.>. Acesso em 22 Maio 2021.

WERNECK, Jurema. Racismo institucional e saúde da população negra. Saúde e Sociedade (USP). 2016, v. 25, n. 3, p. 535-549. São Paulo. Disponível em: <https://www.scielo.br/pdf/sausoc/v25n3/1984-0470-sausoc-25-03-00535.pdf >. Acesso em: 22 Maio 2021.

WERNECK, Jurema. Saúde da população negra. Passo a passo: defesa, monitoramento e avaliação de políticas públicas. Criola. Rio de Janeiro, 2010. Disponível em: <http://www.bibliotecadigital.abong.org.br/bitstream/handle/11465/884/79.p df?sequence $=1>$. Acesso em: 21 Maio 2021. 


\title{
CAPITULO XXXIV
}

\section{ERGONOMIA EM SALAS DE ECOGRAFA: BOAS PRÁTICAS NO TRABALHO DO ULIRASSONOGRAFISTA}

\author{
André Marques Martins ${ }^{1}$ \\ Israel Coutinho Sampaio Lima ${ }^{2}$ \\ Iolanda Bezerra dos Santos Brandão ${ }^{3}$
}

\begin{abstract}
1 Graduado em Medicina pela Universidade Federal do Amazonas - UFAM. Especialista em Perícias Médicas pela Faculdade Unimed.

${ }^{2}$ Graduado em Enfermagem pelo Centro Universitário Santo Agostinho - UNIFSA. Especialista em Enfermagem do Trabalho pela Universidade Católica Dom Bosco - UCDB. Doutorando em Saúde Coletiva pela Universidade Estadual do Ceará - UECE.

${ }^{3}$ Graduada em Psicologia pela Universidade Federal de São João Del-Rei. Doutora em Psicologia Social pela Pontifícia Universidade Católica de São Paulo - PUCSP.
\end{abstract}

\section{RESUMO}

Os avanços tecnológicos na área de ultrassonografia como aporte para o diagnóstico médico vêm demandando uma maior procura por este tipo de exame, aumentando assim a carga horária de trabalho do profissional médico, o que eleva os riscos ergonômicos associados a esta atividade. Desta forma o estudo objetivou identificar os principais parâmetros ergonômicos, já evidenciados na literatura, os quais possam ser utilizados por médicos do trabalho diante da orientação sobre a organização e estruturação das salas de ecografia, diante da promoção, prevenção e redução das lesões osteomusculares relacionadas ao trabalho destes profissionais. As evidências científicas demonstram vários fatores relacionados ao ambiente de trabalho como contribuintes para os sintomas relatados pelos ultrassonografistas, como mesas utilizadas, cadeiras inadequadas, tamanho das salas, iluminação e conformação dos aparelhos de ultrassonografia utilizados. Vários problemas de saúde podem acometer o ultrassonografista como fadiga muscular crônica, dores articulares, tensão muscular, estresse mental e fadiga visual. $O$ enfoque ergonômico gera resultados que podem ser aplicados no design dos postos de trabalhos, reduzindo as exigências biomecânicas, assim como ações de proteção e prevenção dos aspectos ocupacionais desta atividade, permitindo que a medicina do trabalho atue com o estudo, o desenvolvimento e a implementação de protocolos os quais busquem melhorar as condições de saúde dos trabalhadores da saúde.

Palavras-Chave: Ergonomia. Ultrassonografia. Radiologia. Medicina do Trabalho. 


\section{INTRODUÇÃO}

A adaptação do homem ao trabalho é definida por Lida (2005), como função ergonômica laboral, a qual busca estudar aspectos correlacionados a interface entre trabalhador e ambiente físico. No Brasil, a Norma Regulamentadora - NR 17, conforme a Portaria MTPS no 3751 de 1990, com última atualização em 2007 (BRASIL, 2007), estabelece parâmetros que permitem a adaptação das condições de trabalho às características psicofisiológicas dos trabalhadores, proporcionando conforto, segurança e desempenho eficiente.

Com a evolução da tecnologia na medicina diagnóstica, especificamente os avanços na área de ultrassonografia, levaram a uma maior procura por parte da população por este tipo de exame. Tamanha demanda vem ocasionando o aumento da carga horária do médico ultrassonografista diante de sua prática laboral, acarretando maior risco ergonômico, tais como: distúrbios psíquicos, físicos e osteomusculares, como as lesões por esforço repetitivo - LER e os Distúrbios Osteomusculares Relacionados ao Trabalho - DORT. Estes riscos são fundamentais para o aumento de riscos à saúde, redução da segurança no trabalho, os quais tendem a reduzir a produtividade laboral (DA SILVA et al., 2010).

Nos trabalhadores da área da saúde os distúrbios musculoesqueléticos é um dos mais importantes problemas de ordem ocupacional (CAILLARD; IWATSUBO, 2000), considerando principalmente os ultrassonografistas (BASTIAN et al., 2009), onde (81\%) apresentam distúrbios musculoesqueléticos (PIKE et al., 1997), tendo como principais áreas de lesões o pescoço (75\%), ombros (74\%) e punhos (65\%).

A sobrecarga de trabalho costuma exigir mais dos membros superiores, em posturas incômodas e inadequadas (SANABIO; CARNEIRO; COUTO, 2003). O uso de equipamentos de alta tecnologia sem um design ergonômico efetivo, podem resultar em mais DORT (JANGA; AKINFENWA, 2012).

Desta forma, a avaliação ergonômica da atividade do ultrassonografista envolve principalmente fatores biomecânicos dos membros superiores e da coluna vertebral, como a repetitividade de movimentos, posturas adotadas e força aplicada durante execução dos exames (SANABIO; CARNEIRO; COUTO, 2003). 
Em adição, ressaltam-se as elevadas demandas sensoriais associadas durante a execução dos exames, como as relacionadas à visão, à precisão de imagens e dos laudos, atenção, foco e controle dos movimentos do corpo (ARVIDSSON et al., 2016).

Fatores como tamanho e iluminação das salas, temperatura, aparelhos utilizados, mesário e cadeiras, além de outros componentes, afetam diretamente a qualidade de trabalho pelos ultrassonografistas, representando desafios ergonômicos conhecidos há muitos anos (SIMONSEN; GARD, 2016).

As condições de trabalho, às quais se incluem aquelas relacionadas ao mobiliário, equipamentos, condições ambientais do posto de trabalho, bem como a própria organização e planejamento do trabalho, caracterizando a análise ergonômica laboral, são de obrigação do empregador, segundo a NR 17 (BRASIL, 2007).

Tomando como base a apresentação desta temática, a relevância deste estudo parte da vivência diária enquanto médico ultrassonografista diante da inadequação da estrutura física das salas de ecografia, as quais tendem a prejudicar a saúde ocupacional e psicossocial dos médicos que as ocupam diariamente. Tais inadequações vêm resultando em problemas de ordem osteomuscular, os quais implicam diretamente na qualidade e quantidade de exames que podem ser realizados.

Não obstante, a produção de uma reflexão sobre está problemática, com base em evidências científicas já publicadas, promoverá a produção de material consubstancial o qual pretende apresentar um guia com padrões normativos, de acordo com a legislação brasileira, para melhor estruturação das salas de ultrassonografia, visando a redução de danos à saúde dos profissionais médicos ultrassonografistas.

O estudo teve como objetivo identificar os principais parâmetros ergonômicos, já evidenciados na literatura, os quais possam ser utilizados por médicos do trabalho diante da orientação sobre a organização e estruturação das salas de ecografia, diante da promoção, prevenção e redução das lesões osteomusculares relacionadas ao trabalho destes profissionais. 


\section{PRINCIPAIS IMPLICAÇÕEs ERgonômicas para a saÚde do PROFISSIONAL ULTRASSONOGRAFISTA}

A atividade do médico ultrassonografista apresenta elevado risco biomecânico que pode vir a causar distúrbios osteomusculares (MACRUZ; SILVA, 2016). Os transtornos musculoesqueléticos em ultrassonografistas têm incidência relatada de (90\%) e são definidos como condições causadas e agravadas por tarefas realizadas no local de trabalho (MAUAD FILHO; FERLIN; MAUAD, 2016).

A Associação de Ultrassonografistas da Austrália - ASA e a Sociedade de Ultrassonografia em Medicina Australiana - ASUM, estimam uma incidência em cerca de (93\%) de lesões musculoesqueléticas relacionadas ao trabalho entre os ultrassonografistas em pesquisa realizada em 2006 (ASA/ASUM, 2010).

A dor é relatada por mais de (80\%) dos médicos ultrassonografistas de todas as especialidades (AKRICH, 2010). Segundo BAKER e COFFIN (2013), (81\%) dos profissionais apresentam dor ou desconforto relacionado ao trabalho. Essas condições têm impacto financeiro e emocional sobre o profissional, afetando sua produtividade e qualidade de atendimento (COFFIN, 2014). Por isso, a análise ergonômica do trabalho busca resolver os problemas da inadequação do trabalho às características humanas (PIZO; MENEGOM, 2010).

Apesar do avanço tecnológico em relação aos equipamentos utilizados na ultrassonografia, as condições ergonômicas de trabalho parecem não ter acompanhado essa evolução, devido a $85 \%$ dos médicos indicarem ter um ou mais sintomas musculoesqueléticos relacionados ao trabalho, decorrentes de posturas inadequadas gerando fadiga e desconforto; a associação positiva entre atividade-dor, o que reforça o papel promocional dos aspectos físicos do trabalho e ocorrência de dor; aspecto temporais, com a duração de cada exame e a distribuição desigual dos exames na agenda, gerando tensão e alta demanda cognitiva nessa atividade; fatores psicossociais e psicológicos negativos, com apreensão e necessidade de se apressar devido à espera dos pacientes, determinando mais tensão muscular; o número de horas trabalhadas e o número de exames realizados por dia como associação positiva para aparecimento dos sintomas;(BARBOSA; COURY, 2004). 
O enfoque ergonômico gera resultados que podem ser aplicados no design dos postos de trabalhos, reduzindo as exigências biomecânicas, através do conhecimento do tempo gasto na operação, a postura e os esforços físicos exigidos dos trabalhadores, possibilitando determinar os pontos de concentração de tensões musculares, que tendem a gerar dores e desconforto (IIDA, 2005).

Parte da abordagem ergonômica do posto de trabalho compreende entender como os locais de trabalho afetam o desempenho e provocam danos físicos aos trabalhadores, através do conhecimento das tarefas que serão executadas, da atividade desenvolvida para realizá-las e das dificuldades enfrentadas para se atingir o desempenho e produtividade exigidos (SLACK; CHAMBERS; JOHSTON, 2002).Estes distúrbios osteomusculares advêm de muitos fatores, destacando-se abdução do braço maior que 30 으, postura do braço muito posterior (figura 1), manobra isométricas repetidas sem descanso compensatório, nível de força aplicada ao transdutor, postura do examinador, tempo maior que 25 minutos e realização de mais de 100 exames por mês(BROWN; BAKER, 2004; MUIR et al., 2004).

Figura 1 - Posicionamento incorreto com ombro/braço direito em ângulo posterior.

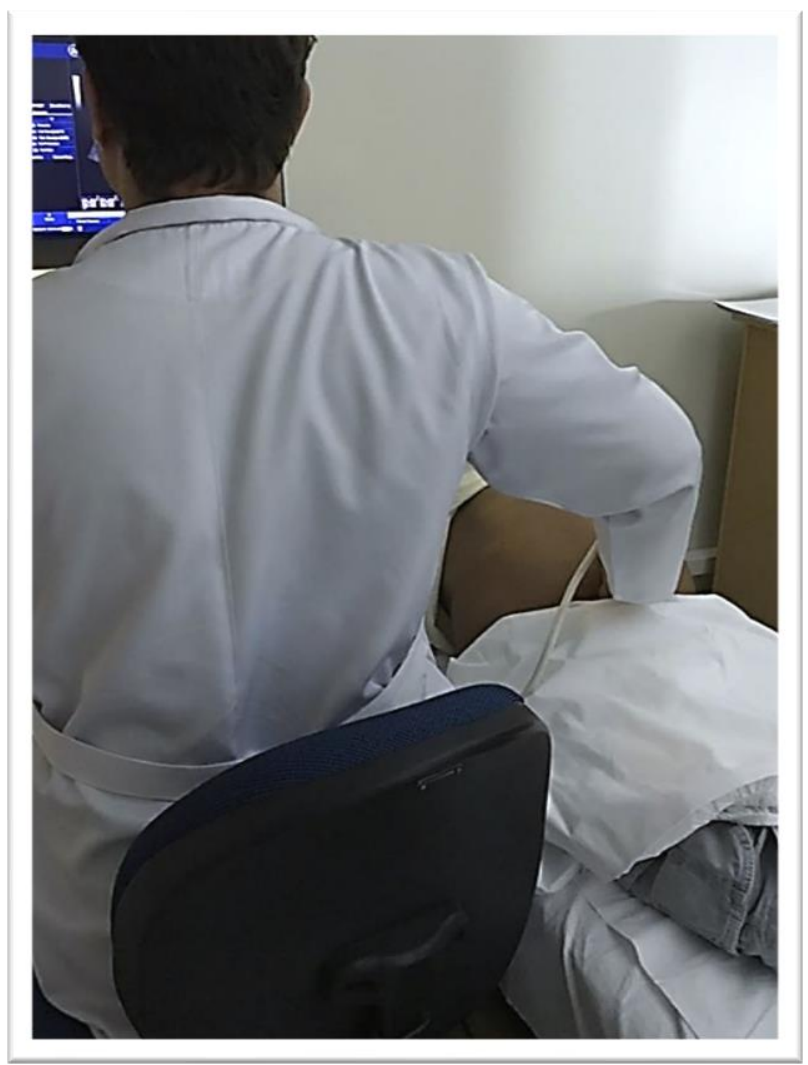

Fonte: Autoria própria. 
Quanto maior o número de exames realizados e horas trabalhadas, maiores são as chances de o médico tornar-se sintomático. Além disso, longos períodos sentado, tempo extenso segurando o transdutor, além de outros fatores de risco como posturas incorretas extremas, trabalho muscular estático de alguns segmentos, movimentos altamente repetitivos, aplicação de pressão, é visto também por Barbosa e Coury (2004), como problemas ergonômicos que tendem a afetar à saúde física, psicológica e cognitiva, exigidas na execução desta atividade.

Segundo Couto (1995), há cinco princípios fundamentais na intervenção ergonômica para minimizar estes riscos: redução da força necessária para execução do trabalho, redução ou eliminação das posturas inadequadas, redução dos movimentos de alta repetição, redução da compressão mecânica e redução do grau de tensão do trabalho.

A ergonomia contribui no projeto e modificação dos ambientes de trabalho, facilitando a interação entre o homem e o trabalho, transformando o ambiente em lugares mais favoráveis à execução das tarefas e benefícios dos trabalhadores, buscando a melhoria da qualidade do trabalho através de planejamento, projetos e avaliação das necessidades e limitações das pessoas, máquinas, ambientes e dos processos durante a realização do trabalho. A interação homem-máquina-ambiente é o foco do estudo ergonômico (IIDA,2005).

A faixa etária mais acometida é a de 24 a 40 anos. Há um aumento progressivo no número de sintomáticos com o aumento de horas trabalhadas. Com uma associação entre a sintomatologia e carga de trabalho do ultrassonografista. A sintomatologia está presente em mais de $75 \%$ dos profissionais. Maioria dos sintomas relatados é de pequena a média intensidade, sendo a dor a principal delas, estando presente durante realização dos exames, interferindo na realização dos mesmos. A utilização de cadeiras mais altas, alternância de postura senta e em pé e utilização de muito gel para o transdutor deslizar mais facilmente, são medidas adicionais de mudança no método de trabalho que podem minimizar as dores (SANABIO; CARNEIRO; COUTO, 2003).

A segunda condição mais associada é a deterioração da acuidade visual (AKRICH, 2010). O repouso ocular é eficaz em reduzir a fadiga visual, para isso se faz necessário reduzir o uso de televisão e computador fora do horário de trabalho. Além utilizar 
iluminação adequada nas salas, permitindo fácil leitura (SANABIO; CARNEIRO; COUTO, 2003).

A NR 17 ressalta que as atividades que exijam sobrecarga muscular estática ou dinâmica de pescoço, ombros, dorso e membros superiores e inferiores, a partir da análise ergonômica do trabalho, deve-se observar: todo e qualquer sistema de avaliação de desempenho para efeito de remuneração e vantagens de qualquer espécie deve levar em consideração as repercussões sobre a saúde do trabalhador; devem ser incluídas pausas para descanso; quando do retorno ao trabalho após qualquer afastamento igualou superior a 15 dias, deverá ser gradativa (BRASIL, 2007).

Além de tais medidas, outras adicionais podem reduzir o impacto do trabalho na saúde do profissional ultrassonografista, como a organização do trabalho em si, evitando-se maior carga de stress, como a administração de encaixes nas agendas reduzindo exames difíceis e consecutivos, a prática de exercícios regulares, beneficiando assim a musculatura para suportar a carga de trabalho e outras mudanças no estilo de vida, como adotar posturas mais ergonômicas, reduzindo o risco potencial de dor e desconforto no trabalho (SANABIO; CARNEIRO; COUTO, 2003). Salienta-se ainda que as condições ergonômicas reduzirem o absenteísmo, aumentando a produtividade e a qualidade de vida do trabalhador (DA SILVA et al., 2010).

A ASA e ASUM (2010) reconhecem que a responsabilidade pela redução da incidência de lesões musculoesqueléticas relacionadas é compartilhada entre empregadores e profissionais, fazendo várias indicações em suas diretrizes, dentre elas:

- Salas devem ter configuração flexível e versátil, além de grande o suficiente permitindo que o aparelho de ultrassom seja facilmente mobilizado;

- Apoio para os pés dos ultrassonografistas;

- Cadeiras móveis, ajustáveis em altura e inclinação, com apoio para as costas e coxas;

- O ultrassonografista deve lembrar o tempo todo de adotar uma boa postura, manter o paciente o mais próximo possível, realizar exercícios de relaxamento de mãos e punhos;

- Fazer pausas regulares, evitar exames difíceis de forma consecutiva; 
- Alongar-se antes, durante e após o trabalho e fazer exercícios fortalecimento muscular;

- O empregador deve fornecer aparelhos ergonomicamente seguros e um espaço de trabalho adequado.

\section{3. contextualização sobre as normas ergonômicas para MONTAGEM DE SALAS DE ULTRASSONOGRAFIA}

Inúmeros fatores no posto de trabalho podem intensificar o desconforto e causar dificuldade constante na realização dos estudos por ultrassonografia. Em relação aos sintomas relacionados ao posto de trabalho, associa-se a cadeira baixa e não regulável e a altura da mesa de exame (MACRUZ; SILVA, 2016). Cadeiras mais altas, ergonômicas e flexíveis tornam possível seu nivelamento com o monitor e o teclado do aparelho de ultrassom. Devem ser fáceis de mover, estofadas e ajustáveis, oferecendo encosto que propicie apoio a coluna vertebral, permitindo sua configuração de acordo com cada exame (SANABIO; CARNEIRO; COUTO, 2003; BAKER; COFFIN, 2013).

Segundo a NR 17, sempre que o trabalho puder ser executado na posição sentada, o posto de trabalho deve ser planejado ou adaptado para esta posição. Os assentos utilizados devem atender os requisitos mínimos de conforto: altura ajustável à estatura do trabalhador e à natureza da função exercida; características de pouca ou nenhuma conformação na base do assento; borda frontal arredondada; encosto com forma levemente adaptada ao corpo para proteção da região lombar. Poderá também ser exigido suporte para os pés, que se adapte ao comprimento da perna do trabalhador, para as atividades realizadas sentadas, a partir da análise ergonômica do trabalho (BRASIL, 2007), conforme demonstrado na figura 2. 
Figura 2 - Cadeira ajustável em altura com bordas arredondadas.

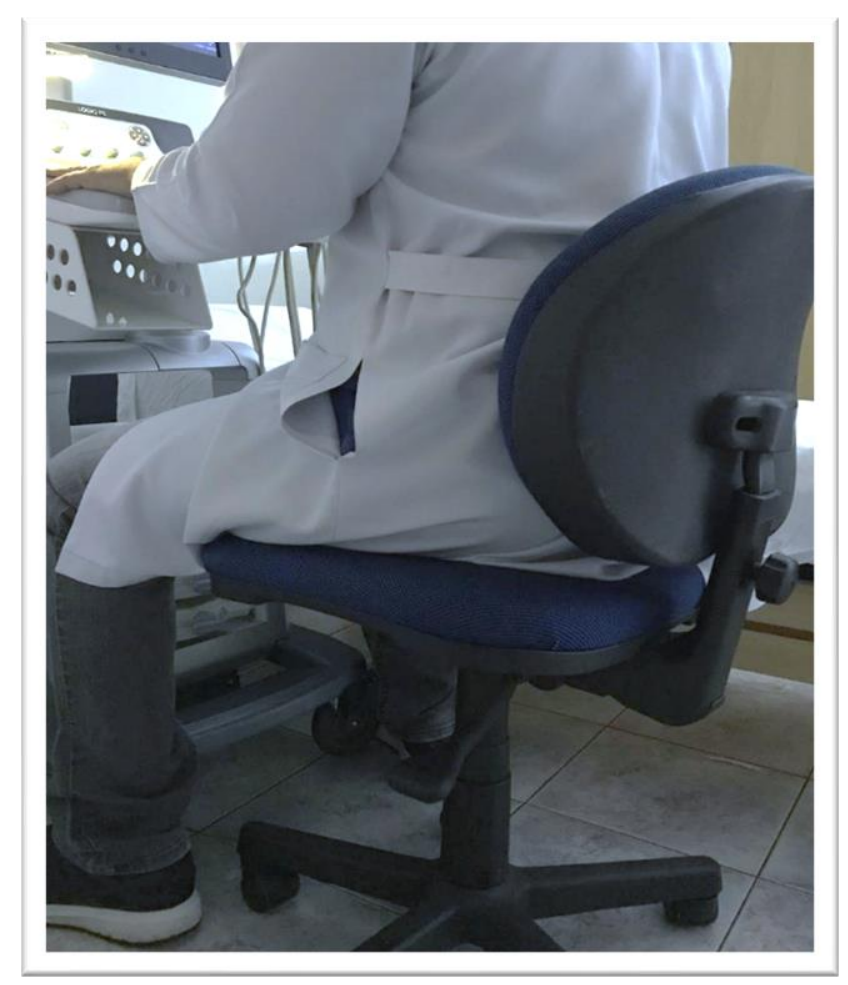

Fonte: Autoria própria.

Mesas mais baixas ou reguláveis para acomodação dos pacientes, busca evitar a elevação do membro superior a uma amplitude maior que 30 ㅇ, o que permite sua elevação em exames que necessitem serem realizado em pé (MACRUZ; SILVA, 2016).

A mesa de exame é um dos fatores que mais contribuem para ergonomia de uma sala de ultrassonografia (MACRUZ; SILVA, 2016). Boas mesas de exame devem ser ajustáveis em altura, inclináveis para trabalhos vasculares, móveis e com rodas fáceis para bloquear e desbloquear. De preferência mesas elétricas, com controles acessíveis e de fácil manipulação, que permitam execução em exames em pé e uma boa distância entre o ultrassonografista e o paciente (SANABIO; CARNEIRO; COUTO, 2003). Ver figura 3. 
Figura 3 - Mesa sem ajuste elétrico, porém com altura de fácil acesso ao paciente e evita elevação do ombro.

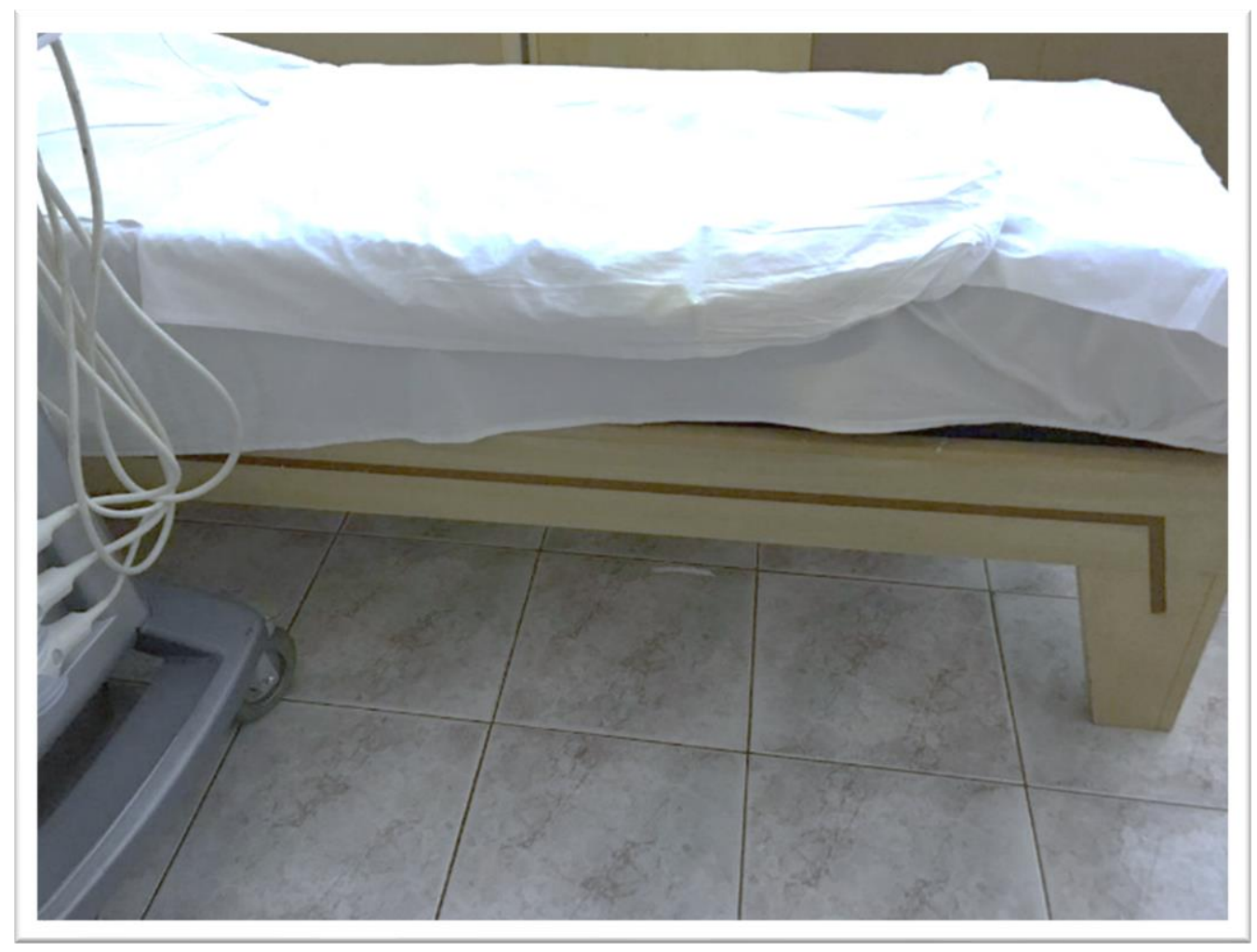

Fonte: Autoria própria.

Segundo Baker e Coffin (2013) as salas de ecografia devem ter no mínimo $14 \mathrm{~m}^{2}$ permitindo uma boa configuração ergonômica que permite acomodação de lavatórios e armários. Uma sala grande o suficiente permite mobilidade do equipamento de ultrassom, proporcionando espaço adequado para cada tipo de exame.

O Sistema de Apoio à Organização e Elaboração de Projetos de Investimentos em Saúde - SOMASUS (BRASIL, 2012), voltado para o apoio ao Diagnóstico e a Terapia (Imagenologia), em conjunto com o grupo de estudos em Arquitetura e Engenharia Hospitalar, da Faculdade de Arquitetura da Universidade Federal da Bahia, desenvolveram um projeto para divulgação da pesquisa em arquitetura e engenharia para a saúde.

Segundo o SOMASUS (BRASIL, 2012) e as Normas para Projetos Físicos de Estabelecimentos Assistenciais de Saúde, do Ministério da Saúde (BRASIL, 1995), as salas de exames de ultrassonografia devem contar com área mínima de $6 \mathrm{~m}^{2}$, ou em média 8 $\mathrm{m}^{2}$, além de dispor de itens mínimos com mesa de exames adequada, mesa auxiliar, armários e cadeira giratória, além de outros itens importantes em relação ao espaço 
físico, condições ambientais e de infraestrutura básica necessária, como pode ser visualizado nas figuras 3 e 4 .

A proposta do SOMASUS (BRASIL, 2012), para a organização das salas de ultrassonografia, quanto aos objetos/equipamentos que deveram existir são: escada com dois degraus, mesa para exames, mesa auxiliar, aparelho de ultrassom diagnóstico, armários, balde cilindro porta-detrito com pedal e uma cadeira giratória com braços.

Já em relação às características do espaço físico, o piso e as paredes devem ser lisos, sem frestas, de fácil higienização e resistente aos processos de limpeza, descontaminação e desinfecção. Os materiais de revestimento não podem possuir índice de absorção de água superior a $4 \%$ individualmente ou depois de instalados, não sendo permitida a existência de divisórias. O teto deve ser contínuo, sendo proibido o uso de forros falsos removíveis, devendo ser de fácil higienização e resistentes aos processos de limpeza, descontaminação e desinfecção. As portas devem ser revestidas de materiais lavável, podendo seu diâmetro variar conforme o equipamento utilizado, com no mínimo de 1,20 × 2,10m (BRASIL, 2012).

No que se referem os condicionantes ambientais, a temperatura deve variar de 21 a $24^{\circ} \mathrm{C}$, com umidade ideal de 40-60\%, com nível de iluminação entre 150 a 300 lux geral, de 300 a 750 lux-mesa de diagnóstico, com necessidade de climatização artificial e exaustão mecânica, devendo ser classificada como área de risco critica para transmissão de infecção (BRASIL, 2012).

Em relação aos aparelhos de ultrassonografia, os cabos pesados e grossos atrapalham seu manuseio, as diferentes disposições do teclado do aparelho e a disposição do aparelho nas salas podem dificultar sua movimentação quando necessário (MACRUZ; SILVA, 2016). Logo, monitores de boa resolução, mobilidade, com ajuste de altura e inclinação, além de teclados com mobilidade, ajuste de altura e inclinação, com transdutores de cabos leves flexíveis e retráteis suspensos por um suporte (SANABIO; CARNEIRO; COUTO, 2003), podem minimizar tais riscos. 


\section{CONSIDERAÇÕES FINAIS}

Os problemas de saúde que frequentemente pode acometer o ultrassonografista são: fadiga muscular crônica, dores articulares, tensão muscular, estresse mental, fadiga visual, dormência e sensação de formigamento, inflamação e edema articular.

A literatura apresenta como principais orientações ou normas para a estruturação das salas de ultrassonografia: mesas elétricas ou ajustáveis às necessidades de cada exame, ambientes bem iluminados, cadeiras confortáveis e ajustáveis às necessidades de cada exame, salas grandes o suficiente que permitam movimentação adequada dos aparelhos de ultrassonografia ou mesas durante o exame.

Assim, todos os aspectos físicos, organizacionais e ergonômicos envolvidos na prática do médico ultrassonografista, brevemente explicitados, exigem ações conhecidas e eficazes de proteção e prevenção dos aspectos ocupacionais desta atividade. Sendo importante conhecer os fatores de riscos envolvidos, participar de processos de educação continuada sobre as características ergonômicas dos equipamentos e do espaço de trabalho.

Como também, torna-se importante o compromisso do empregador em prover tais melhorias, visando minimizar os danos e proteger a saúde deste grupo de trabalhadores, de forma eficiente, organizada e diferenciada, colocando em igual patamar a obtenção de exames de alta qualidade e consonância com uma boa ergonomia.

É importante que a medicina do trabalho seja incluída em todos os serviços de saúde, em especial os de imagem, tendo como potência, o estudo, o desenvolvimento e a implementação de protocolos os quais busquem melhorar as condições de saúde dos trabalhadores da saúde.

\section{REFERÊNCIAS}

AKRICH, Y. Troubles músculosquelettiques de l'échographiste: constats, conseils et postures. Paperpresentedat: 15th Fetal. Medicine Congress: 2010.

ARVIDSSON, I. et al. Cross-sectional associations between occupational factors and musculoskeletal pain in women teachers, nurses and sonographers. BMC MusculoskeletDisord. 17: 35, 2016. 
AUSTRALASIAN SONOGRAPHERS ASSOCIATION (ASA). PROMOTING ULTRASOUND EXCELLENCE (ASUM). Guidelines For Reducing Injuries ToSonographers/Sonologists. ASA/ASUM: 2010.

BAKER, J.P.; COFFIN, C.T. The importance of an ergonomic workstation to practicing sonographers. Journal Of Ultrasound in Medicine. v.32, p. 1363-1375, jan.2013.

BARBOSA, L.H.; COURY, H.C.G. A atividade do médico ultra-sonografista apresenta riscos para o sistema músculo-esquelético?. Radiol Bras, São Paulo, v. 37, n. 3, p. 187191, June 2004 .

BASTIAN, E.J.; et al. Effects of Work Experience, Patient Size, and Hand Preference on the Performance of Sonography Studies. Journal of Diagnostic Medical Sonography. 25;(1):25-37. 2009.

BRASIL. Ministério do Trabalho e Emprego. NR 17 - Ergonomia. Brasília: Ministério do Trabalho e Emprego, 2007.

BRASIL. Ministério da Saúde. Normas para projetos físicos de estabelecimentos assistenciais de saúde. Brasília, Ministério da Saúde: 1995.

BRASIL. Ministério da Saúde. SomaSUS: Sistema de Apoio à Organização e Elaboração de Projetos de Investimento em Saúde. Brasília, Ministério da Saúde: 2012.

BROWN, G.; BAKER, J.; Work-Related Musculoskeletal Disorders in Sonographers. Journal of Diagnostic Medical Sonography. 20(2):85-93, 2004.

CAILLARD, J.F.; IWATSUBO, Y. Prevention of Musculoskeletal Disorders among Health Care Workers. Proceedings of the Human Factors and Ergonomics Society Annual Meeting. 44(31):5-781-784, 2000.

COFFIN, C.T.; Work-related musculoskeletal disorders in sonographers: a review of causes and types of injury and best practices for reducing injury risk. Dove Press J, 7:15-26, 2014.

COUTO, H.A. Ergonomia aplicada ao trabalho: o manual técnico da máquina humana. Belo Horizonte: Ergo, 1995. v. 1. 353 p.

IIDA, I. Ergonomia: projeto e produção. São Paulo: Edgard Blücher, 2005

JANGA, D.; AKINFENWA, O. Work-related repetitive strain injuries amongst practitioners of obstetric and gynaecological ultrasound worldwide. Arch Gynecol Obstet. Aug;286(2):353-6, 2012.

MACRUZ, P.D.; SILVA, A.L. Estudo Ergonômico do Posto de Trabalho de Médicos Ultrassonografistas. Anais da VI Congresso Brasileiro de Engenharia de Produção, APREPRO, 2016. 
DA SILVA, J. S. et al., A Ergonomia como um Fator Determinante no Bom Andamento da Produção: um Estudo de Caso. Anagrama, [S. I.], v. 4, n. 1, p. 1-14, 2010.

MAUAD FILHO F.; FERLIN, R.M.; MAUAD, F.M. Aspecto ergonômicos na rotina da ultrassonografia transvaginal. Revista da Sociedade Brasileira de Ultrassonografia. 21(9): 42-44, 2016.

MUIR, M. et al. The Nature, Cause, and Extent of Occupational Musculoskeletal Injuries among Sonographers: Recommendations for Treatment and Prevention. Journal of Diagnostic Medical Sonography. 20:317-25, 2004.

PIKE, I. et al., The Prevalence of Musculoskeleta Disorders Among Diagnostic Medical Sonograhers. Journal of Diagnostic Medical Sonography. v.13, n.5: 219- 227, 1997.

PIZO, C.A.; MENEGON, N.L.Análise ergonômica do trabalho e o reconhecimento científico do conhecimento gerado. Prod., São Paulo, v. 20, n. 4, 2010.

SANÁBIO, E.; CARNEIRO, T.; COUTO, H. Medical Diagnosis with Ultrasound: Ergonomic Problems of Professionals Involved in this Procedure. Revista Brasileira de Medicina do Trabalho; v.1, n.1, p. 22-30, Jul-Set. 2003.

SIMONSEN, J.G.; GARD, G. Swedish Sonographers' perceptions of ergonomic problems at work and their suggestions for improvement. BMC Musculoskelet Disord. v.17, n.391. 2016.

SLACK, N.; CHAMBERS, S.; JOHSTON, R. Administração da produção. 2.ed. São Paulo: Atlas, 2002. 


\title{
CAPITULO XXXV
}

\section{SISTEMA CEREC NA ODONTOLOGIA: DA EVOLUGÃO AOS DIAS ATUAIS}

\section{DOI: $10.51859 / a m p l l a . c s a 528.2121-35$}

Flávia Kolling Marquezan ${ }^{1}$

Patricia Kolling Marquezan ${ }^{2}$

\begin{abstract}
1 Professora do Curso de Odontologia. Universidade Franciscana - UFN
2 Professora do Departamento de Microbiologia e Parasitologia. Universidade Federal de Santa Maria - UFSM
\end{abstract}

\section{RESUMO}

Com o avanço tecnológico do mundo globalizado nos últimos anos, foi introduzido na odontologia o sistema CAD CAM, visando automatizar o processo manual de produção das peças protéticas vigente até então. Esse sistema consiste no desenho da estrutura protética em um computador e confecção dessa peça na máquina de fresagem. $O$ sistema CEREC aparece como um dos pioneiros dessa tecnologia CAD CAM, evoluindo com o passar dos anos na tentativa de ampliar os materiais utilizados bem como simplificar os passos. Em relação à longevidade e estética, os estudos encontraram resultados similares aos das restaurações ditas convencionais. Além disso, com a evolução do sistema a precisão marginal melhorou significantemente. A tecnologia CEREC incorpora ferramentas que buscam simplificar as reabilitações orais bem como otimizar o tempo clínico, elevando a produtividade e reduzindo custos. Entretanto, essa tecnologia demanda tempo de treinamento e investimento financeiro para sua implantação. Frente a essa imensidão de sistemas CAD CAM disponíveis no mercado odontológico, é preciso destacar que não existe hierarquia de qualidade desses produtos, a escolha depende da melhor adequação ás necessidades do cirurgião dentista bem como a qualificação do profissional para essa tecnologia. Nesse capitulo buscamos apresentar um dos sistemas pioneiros no desenvolvimento do sistema CAD CAM que surgiu no mercado odontológico, o sistema CEREC, destacando suas características a fim de ampliar os conhecimentos sobre essa nova ferramenta tecnológica.

Palavras-chave: Restauração Cerâmica, Sistemas CAD-CAM, Reabilitação Oral

\section{INTRODUÇÃO}

A odontologia atua na prevenção de doenças bucais e promoção de saúde nos indivíduos. A devolução de forma, função e estética aos pacientes passam muitas vezes por etapas restauradoras. Em muitos casos, o amálgama dental e as resinas compostas cumprem a função de material restaurador ideal, pois permitem a aplicação direta intra- 
oral, o que reduz as etapas de confecção, custo e permite realizar preparos cavitários menos invasivos (HILGERT et al., 2009).

No entanto, devido ao alto grau de destruição dental frequentemente há a necessidade de reconstruções maiores, indicando as restaurações indiretas (HILGERT et al., 2009). Os sistemas usados na reconstrução até a década de 90 eram coroas metalocerâmicas. A Revolução Industrial assim como a aparência enegrecida no contorno gengival e aprimoramento das cerâmicas forçava o aparecimento de novos sistemas, culminando, assim com o surgimento da primeira coroa de porcelanato feldspática pura, livre de metal em 1905.

A necessidade de uma qualidade uniforme de material, redução dos custos de produção, a própria Revolução Industrial e a padronização do processo de fabricação incentivaram os pesquisadores a procurar uma forma de automatização do processo manual convencional, surgindo, então, o uso de tecnologia de fabricação assistida por computador (CAD/CAM) evoluindo com o passar dos anos (WITTNEIBER et. al., 2015).

A inovação tecnológica, com o sistema CAD CAM já estava presente na grande área da engenharia. O termo CAD-CAM é o acrônimo das palavras computer aided design e computer aided manufacturing que, em livre tradução, significam "desenho guiado por computador" e "fabricação guiada por computador". Outro termo utilizado para nomear o mesmo sistema é o $\mathrm{CAD} / \mathrm{CIM}$, no qual a segunda sigla é originária de computer integrated machining. Há alguns anos, a fabricação de diversos produtos industrializados já era realizada com auxílio da tecnologia CAD/CAM (BERNARDES, S. R. et al. 2012).

Dentro dessa perspectiva de terreno fértil na área odontológica, empresas tem desenvolvido diversificados sistemas cada um com suas peculiaridades, mas todos com o mesmo princípio de impressão, planejamento e confecção de vários tipos de restaurações (HILGERT, 2009). Em 1980 surgiu o sistema CEREC, sendo necessário um conhecimento da evolução, vantagens e desvantagem desse sistema. Em função disso, realizamos essa revisão de literatura com essa finalidade. 


\section{REVISÃO BIBLIOGRÁFICA}

\subsection{CONTEXTUALIZAÇÃO HISTÓRICA dOS SISTEMAS CAD-CAM}

As primeiras ideias de criação de algo que auxiliasse os dentistas aplicando a tecnologia computadorizada na prática clínica principiaram em 1970, com John Young e Bruce Altschuler, pesquisadores dos Estados Unidos e na França, com François Duret; embora os grandes idealizadores do processo foram Werner Mormann e Marco Brandestini, na Suíça (LIU, 2008).

Motivado pela ideia de obter restaurações da mesma coloração dental, com durabilidade alta o pesquisador resolveu concretizar o projeto para o fabrico de restaurações cerâmicas inlay, de maneira que o dentista pudesse realizar uma ou várias restaurações cerâmicas no consultório, em uma única consulta (MORMANN, 2006).

Para as impressões ópticas das cavidades dentais Mormann contou com o auxílio do engenheiro eletrônico italiano Brandestini, o qual descobriu, por trabalhar com scanner ultrassônico, que a forma óptica se apresenta como a melhor forma de digitalizar a estrutura dental (LIU, 2008).

Entretanto, todo o efeito prático precisava ser canalizado a um software para que fizesse o gerenciamento das informações (PARSELL et al., 2000). O layout do software foi realizado pelo engenheiro de software Alain Ferru, em 1985, que desenvolveu o primeiro sistema operativo do CEREC, alcançando o fundo da cavidade de modo a ser possível construir as superfícies proximais e oclusais (MORMANN, 2006).

Frente á necessidade de um nome para o sistema, Brandestini e Mormann usaram a abreviação CEREC: "computer-assisted CERamic REConstruction". Dr. Brandestini produziu o primeiro desenho para unidade CEREC 1 e para câmera oral. Ele rapidamente concretizou a ideia sobre a aquisição e processamento, criando um computador e vídeo de bordo.

O sistema CEREC 2 e 3 , bem como o CEREC Lab e escâner extraoral e associou as duas versões de software, onde desenvolveu um time de software Siemens and Sirona (Bensheim, Germany). A evolução desse sistema pode ser vista na tabela 1 (MORMANN, 2006): 


\begin{tabular}{|c|c|c|c|c|}
\hline Ano & Hardware & Software & Tipo de Restauração & $\begin{array}{c}\text { Desenvolvido } \\
\text { por }\end{array}$ \\
\hline 1980 & Básico & $2 \mathrm{D}$ & Inlays & $\begin{array}{l}\text { Mormann e } \\
\text { Brandestini }\end{array}$ \\
\hline 1985 & CEREC 1 & $2 \mathrm{D}$ & 1a InlayChairside & $\begin{array}{l}\text { Mormann e } \\
\text { Brandestini }\end{array}$ \\
\hline 1988 & CEREC 1 & $2 \mathrm{D}$ & Inlays, Onlays e Facetas & $\begin{array}{l}\text { Mormann e } \\
\text { Brandestini }\end{array}$ \\
\hline 1994 & CEREC2 & $2 \mathrm{D}$ & Coroas Totais e parciais & Siemens \\
\hline 2000 & $\begin{array}{l}\text { CEREC } \\
\text { 3\&inLab }\end{array}$ & $2 \mathrm{D}$ & Pontes de 3 elementos & Sirona \\
\hline 2003 & $\begin{array}{c}\text { CEREC } \\
3 \& \text { inLab }\end{array}$ & $3 D$ & $\begin{array}{c}\text { Coroas Totais e parciais } \\
\text { além de pontes de } 3 \\
\text { elementos }\end{array}$ & Sirona \\
\hline 2005 & $\begin{array}{l}\text { CEREC } \\
3 \& \text { inLab }\end{array}$ & $3 D$ & $\begin{array}{c}\text { Coroas totais e parciais, } \\
\text { ajuste automático da } \\
\text { oclusão }\end{array}$ & Sirona \\
\hline
\end{tabular}

Enfim, o último passo para completar o sistema de processamento era desenvolver a tecnologia que executasse o corte eficiente da cerâmica a fim de obter uma restauração individualizada e de ótima adaptação, ao mesmo tempo que apresentasse uma boa relação entre a tempo de vida do instrumento utilizado, eficiência de corte e a rugosidade superficial da cerâmica (MORMANN, 2006).

As primeiras pesquisas foram ensaios realizados sobre blocos de cerâmica feldspática que mostraram que este material pode ser fresado em alguns minutos sem a danificar e sem a perda de resistência do resto da estrutura (LIU, 2005).

Todas as pesquisas culminaram, em 1985 , na primeira restauração usando o sistema CEREC chairside ocorrida na Universidade de Medicina Dentária de Zurich, usando-se cerâmica feldspática (Vita Zahnfabrik), (MORMANN, 2006).

Após compreendermos como se articulam as peças desse sistema, precisamos conhecer o modo de processamento do sistema CAD CAM CEREC um dos pioneiros no mercado odontológico e que se apresenta disponível aos profissionais até hoje.

\subsection{TIPOS DE TECNOLOGIA CAD CAM}

No início da utilização do sistema CAD/CAM na Odontologia, só existiam scanners de laboratório e as fresagens eram feitas fora do País, pelos fabricantes dos sistemas. Atualmente, existem vários serviços de fresagem no Brasil, e as clínicas e 
laboratórios interessados podem ter os seus próprios equipamentos, agora menores e mais acessíveis, agregando tempo e agilidade ao processo (DINATO \& FUSO, 2013). A possibilidade de usinagem de peças metálicas, antes fundidas, melhoram a precisão, qualidade e longevidade das reabilitações.

Para que o cirurgião dentista possa usufruir dessa tecnologia em seu consultório, faz-se necessário conhecer alguns termos e características desses sistemas.

Em relação ao sistema fechado do CEREC, também chamado completo, o dentista realiza a impressão digital, desenha a restauração e fabrica até o produto final, fazendo o trabalho em uma só visita, tendo como representantes o sistema CEREC AC e D4D. Já o sistema aberto ou incompleto, como o CEREC Ineos Via, a impressão digital e os dados são enviados para uma central de fresagem onde os dados são concretizados (GUIMARAES, 2012).

\subsection{AQUISIÇÃO DE IMAGENS}

Em relação á captura de imagens, a digitalização pode ser extraoral ou intraoral. Extraoralmente, o preparo dental é escaneado em modelos de gesso, e intraoralmente pode ser através de câmeras intraorais, laser vermelhos com auxílio de um pó para aumentar a visualização da estrutura dental ou com o auxílio de uma sonda de contato para aumentar a distância focal.

Após a aquisição da imagem, esta é armazenada no sistema e a restauração é desenhada para a fabricação dentro do consultório ou digitalmente transmitida para um laboratório dental.

A determinação da relação oclusal também varia. Mas em geral o programa combina escaneamentos das partes superior e inferior tendendo a cêntrica, objetivando mínimos ajustes oclusais no momento de instalação da peça (GUIMARAES, 2012).

\subsection{MATERIAIS RESTAURADORES UTILIZADOS}

Embora vários materiais possam ser utilizados pelo sistema CEREC, as cerâmicas são eleitas os melhores materiais de escolha para restaurações indiretas. Devido á capacidade de reproduzir de forma natural a cor e textura dos dentes, além de apresentarem uma longevidade clínica satisfatória. 
Dentre os tipos de cerâmicas a serem utilizadas em blocos que podem ser colocadas diretamente em boca estão as cerâmicas totalmente sinterizadas. Estes blocos cerâmicos não necessitam ir ao forno para terminar o processo de sinterização, ao contrário dos blocos de cerâmica pré-sintetizados, sendo por isso a cerâmica feldspática geralmente o material de escolha do sistema CEREC chairside (BUSO et al., 2004).

Vários estudos avaliaram as taxas de sobrevivência e indicadores de falha das restaurações cerâmicas pelo sistema de processamento CEREC (FASBINDER, 2006). Martin e Jedynakiewicz (1999), em uma revisão sistemática, constataram que as falhas correspoderam a menos que $3 \%(2,6 \%)$, e ocorreram devido a falha na cerâmica seguido da fratura do dente. A fratura na cerâmica ocorre devido principalmente a pouca espessura ou espessura insuficiente e estresse oclusal. Os resultados desses estudos demonstraram que as falhas estão mais associadas a problemas na técnica do que relacionadas ao sistema CEREC.

Após a escolha do bloco apropriado, as restaurações podem ser maquiadas para a caracterização e glazeadas para o acabamento final utilizando pigmentos de diversas cores.

Na tabela 2, há a descrição dos materiais CAD CAM de sessão única disponíveis (FASBINDER et. al, 2010):

\begin{tabular}{|c|c|}
\hline Cerâmicas & Fabricante \\
\hline Feldspática & $\begin{array}{c}\text { CEREC Blocs (Sirona) } \\
\text { Vitabloc Mark II }\end{array}$ \\
\hline Leucita reforçada & IPS empress (Ivoclar) \\
& Paradigma C (3M ESPE) \\
\hline Ceramica de dissilicato de lítio & IPS e-max CAD (Ivoclar) \\
\hline Resina composta & Paradigma MZ 100 (3M ESPE) \\
\hline Resina composta provisório & Vita CAD - Temp (Vident) \\
\hline Blocos para infra-estrutura de metal & Telio (Ivoclar) \\
\hline Blocos de Zircônia & Vita CAD-Waxx \\
\hline Para implantes & IPS e.maxZirCad (Ivoclar \\
\hline
\end{tabular}




\subsection{SISTEMA CEREC}

Em 1986, foi lançado no mercado odontológico o equipamento CEREC 1 criado por Werner Mormann. Esse sistema de processamento foi o primeiro mecanismo de fabricação imediata. Consistia de um computador de 8 bits um monitor monocromático, com um sistema de fresagem para fabricação de inlays (GUIMARÃES, 2016).

Por ser o primeiro sistema CEREC, apresentava inúmeras limitações como o sistema de corte através de discos, má adaptação das restaurações, tecnologia do software simplória e falta dos contornos das superfícies oclusais; sendo necessário desgastes das peças com broca e turbina de modo a desenvolver os contatos oclusais e a anatomia do dente (RIBEIRO,2015; CONCEIÇÃO, 2005).

Em 1994, a empresa Alemã Siemens \& Sirona desenvolveu a tecnologia visando aprimorar o primeiro equipamento. Houve uma melhora no software, câmera digital com maior resolução e microprocessadores com duas brocas cilíndricas, permitindo a criação de coroas totais, onlays com melhores adaptações marginais e maior anatomia de superfície oclusal (RIBEIRO, 2015, GUIMARÃES, 2016).

A confecção de uma plataforma de trabalho para Microsoft Windows, sistema mais compacto, bem como a separação do sistema de captura de imagens e o de fresamento, marcaram a terceira evolução do sistema CEREC 3, ocorrida em 2000. Embora tenha havido uma melhora na adaptação marginal e anatomia das peças, ainda as imagens se apresentavam em duas dimensões.

Em vista disso, no ano de 2003 desenvolve-se o sistema CEREC 3D, possibilitando a preparação do dente antagonista e registro de mordida (MORMANN, 2006,RIBEIRO, $2015 ;)$.

Em 2009, surge o sistema CEREC AC, com a mesma configuração tridimensional até então, mas acrescido do equipamento mais preciso de captura de imagens: Blue cam (LED azul) unidas por um programa de computador com sistema de cores muito realista (RIBEIRO, 2015; SIRONA, 2012; MEHL, 2009). O uso da luz com menor comprimento de onda facilita o ato de captura e maior precisão alem de ser mais fácil seu uso, pois diferentemente do raio infra-vermelho que requer varias imagens para a captura da superfície dental, a luz azul captura de uma só vez (GUIMARÃES, 2015). 
Atualmente, aboliu-se a necessidade de utilização de um pó para melhor leitura, e a colocação da câmera em uma posição estática devido a presença de câmeras modernas de digitalização. Além disso, o software também evoluiu ao ponto de o próprio já realizar o desenho da restauração na posição ideal, bastando o cirurgião dentista corrigir detalhes ao seu gosto (MUIANGA, 2009; RIBEIRO, 2016).

A figura 2 apresenta a evolução do sistema CEREC de forma esquemática:

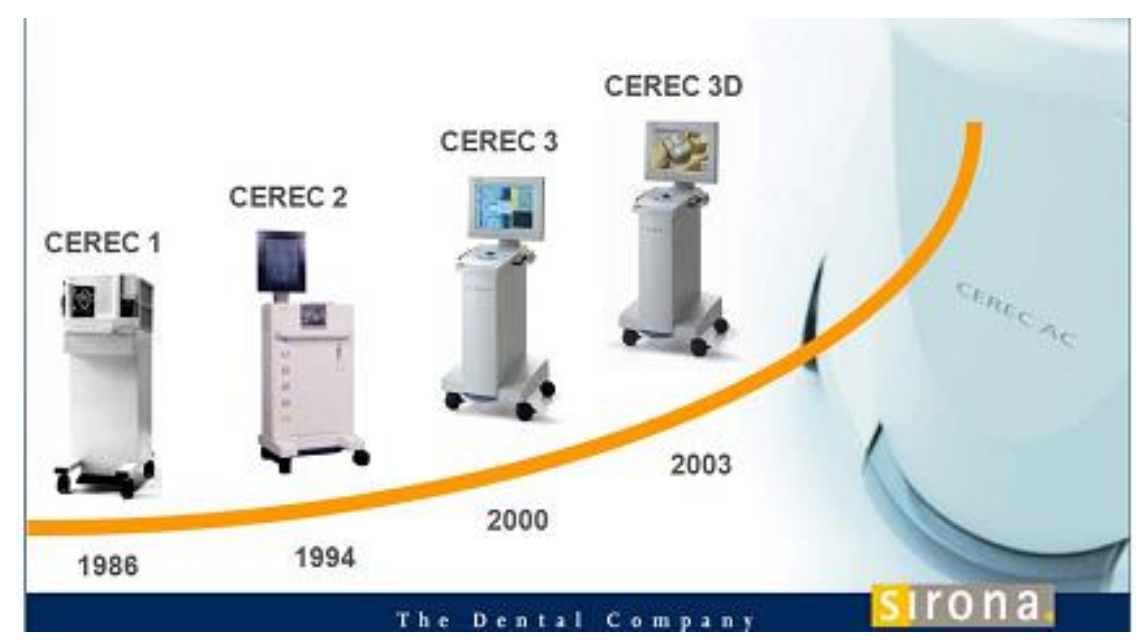

Em relação à metodologia do sistema CEREC é dividida em 5 fases: a administração do paciente (cadastro), aquisição de imagem, modelo virtual, desenho da restauração e fresagem.

Após cadastrarmos o paciente, o escaneamento é realizado com uma câmera e enviado ao programa que obtém o modelo virtual e o modelo antagonista, definindo conjuntamente as margens do preparo.

Realizadas todas essas etapas é feito o desenho da restauração podendo visualizar também as dimensões restauradoras e espessura da peça. Esta se apresenta como uma imagem virtual de três dimensões, permitindo a análise do preparo dentário, dos dentes adjacentes da oclusão e dentes antagonistas. A imagem virtual pode ser vista de qualquer ângulo: mesial, distal, lingual/palatino, vestibular, cervical e oclusal (SIRONA, 2011).

Uma vez pronta a imagem virtual, é necessário avaliá-la juntamente com o modelo antagonista, bem como a relação entre eles, e o ponto de contato, a fim de que se encontre uma correta harmonia dental. O software CEREC possui uma escala de 
quatro cores referentes aos pontos de contacto com os dentes. Esta escala avalia a distância ou o contacto da restauração com os dentes adjacentes e antagonistas (SIRONA, 2011).

Assim que finalizado e escolhido o bloco, tipo e tamanho a ser fresado, essas informações são passadas ao sistema e na ausência de incompatibilidade, o processo se inicia. A unidade de fresagem do sistema CEREC está separada do computador e as informações podem ser trocadas tanto por via cabo como via rádio. O sistema se constitui em duas brocas diamantadas, uma com uma forma cilíndrica para a fresagem da parte interna da restauração e outra com forma tronco-cônica para a fresagem da superfície oclusal da restauração (RIBEIRO, 2015).

Terminada a fresagem, a restauração estará pronta para ser polida (no caso de cerâmica feldspática e resinosa), sinterizada ou glazeada (em cerâmicas de leucita e dissilicato de lítio), antes de realizar a cimentação em boca para obtenção de superfícies mais lisas e resistentes (GUIMARÃES, 2016).

O sistema CEREC é indicado para restaurações do tipo inlay, onlay, coping, coroa total, faceta e ponte.

\section{CONSIDERAÇÕES FINAIS}

É indiscutível que o sistema CAD CAM trouxe e ainda vai trazer muitas vantagens à odontologia restauradora, dentre elas estão (URBANESKI, 2012):

- Automação e redução do tempo clínico;

-Facilidade de produção e disponibilidade de novos materiais de alta resistência;

-Redução de erros da fabricação manual;

-Precisão em termos de adaptação;

-Com o uso do escâner intraoral, há a eliminação da moldagem e todos os passos necessários para tal procedimento;

- Imagem instantânea do preparo, orientando as possíveis correções.

Entretanto há também pontos negativos como:

- Curva de aprendizado do sistema longa;

- Custo alto do equipamento levando a avaliar a quantidade de peças que produz;

- Vinculação do profissional a empresa devido a atualização do software; 
-Imagens subgengivais de difícil obtenção, necessitando de um equipamento auxiliar, o laser diodo, acarretando mais um gasto.

Em relação aos estudos que avaliam sensibilidade, fratura da restauração, pigmentação da margem e longevidade Fasbinder e colaboradores realizaram uma revisão na literatura desde 1985 ate 2006. Em relação á sensibilidade, os estudos encontraram menos de $15 \%$ da amostra com alguma sensibilidade (FASBINDER, 2006.) e a maioria delas desapareceu em algumas semanas. Concluiu-se que, os casos onde houve sensibilidade, são casos atípicos e a causa da sensibilidade é normal em qualquer material restaurador utilizado.

No que se refere á coloração marginal das restaurações realizadas com sistema CEREC, os estudos encontraram que houve um aumento de pigmentação ao longo do tempo, e tem sido atribuído a troca natural da cor do dente e translucidez (FASBINDER, 2006).

Em relação ao espaçamento da interface, em comparação entre CEREC 1 e CEREC 2 e encontraram um menor gap no Sistema CEREC 2 e em comparação com CEREC 3, Além disso, a mínima interface maximiza a longevidade das restaurações, evitando descoloração e cárie secundária.

Assim podemos compreender que a tecnologia CEREC é bem sucedida hoje devido á visão evolutiva dos seus pioneiros. Como Duret previa em seu artigo de 1991: "Os sistemas continuarão a melhorar em versatilidade, precisão e custo-efetividade, e serão parte da pratica odontológica de rotina no início do século XXI" (LIU, 2008).

\section{REFERÊNCIAS}

BASSO, G. R. et al. Reliability and failure behavior of CAD-on fixed partial dentures. Dental Materials, v. 32, n. 5, p. 624-630, 2016.

BERNARDES, S. R. et al. Tecnologia CAD / CAM aplicada a prótese dentária e sobre implantes. Journal, llapeo, v. 6, n. 1, p. 8-13, 2012.

BUSO, L et alli (2004). Odontologia restauradora computadorizada. In: Miyashita, E.,Fonseca, A. Odontologia Estética - o estado da arte. São Paulo, Artes Médicas, pp. 636-661.

CONCEIÇÃO, E. e Sphor, A. (2005). Fundamentos dos sistemas cerâmicos. Porto Alegre, Editora Artmed. 
CONRAD, H. J.; SEONG, W.-J.; PESUN, I. J. Current ceramic materials and systems with clinical recommendations: a systematic review. The Journal of prosthetic dentistry, v. 98, n. 5, p. 389-404, 2007.

DINATO A. FUSO. JC., CAD CAM, uma visão atual. Protese News, v.10 n.1, p.3-25, 2013.

FASBINDER, D. J. Clinical performance of chairside CAD/CAM restorations. The Journal of the American Dental Association, v. 137, n. September, p. 22S-31S, 2006.

FASBINDER, D. J. The CEREC system. The Journal of the American Dental Association, v. 141, n. June, p. 3S-4S, 2010.

FASBINDER, D. J. et al. A Clinical Evaluation of Chairside Lithium Disilicate CAD/CAM Crowns. Journal of the American Dental Association, v. 141, n. June, p. 10S-14S, 2010.

GARCIA, F. R. et al. Análise crítica do histórico e desenvolvimento das cerâmicas odontológicas Critical analysis of the dental ceramics historical and development. RGO - Revista Gaúcha Odontologia., v. 59, p. 67-73, 2011.

GUIMARÃES, M. M. Tecnologia Cerec na Odontologia. p. 1-127, 2012.

HILGERT L.A., SCHWEIGER J., BEUER F, ANDRADA M.A.C., ARAÚJO, D. E. Odontologia Restauradora com Sistemas CAD / CAM : O Estado Atual da Arte Parte 1 Princípios de utilização. n. December 2014, 2009.

JIANG, Y. et al. Measurement of J-integral in CAD/CAM dental ceramics and composite resin by digital image correlation. Journal of the Mechanical Behavior of Biomedical Materials, v. 62, n. June, p. 240-246, 2016.

LI, R. W. K.; CHOW, T. W.; MATINLINNA, J. P. Ceramic dental biomaterials and CAD/CAM technology: State of the art. Journal of Prosthodontic Research, v. 58, n. 4, p. 208-216, 2014.

LIU PR. A panorama of dental CAD/CAM restorative systems. Compendium of Continuing Education in Dentistry. 2005 Jul;26(7):507-8, 510, 512.

MACIEL, B. Comparação Entre Sistemas Cad/Cam: Uma Revisão De Literatura. Trabalho de Conclusão de Curso, Repositório UNISC. 2015.

MANUEL, R.; RIBEIRO, P. Qual a Eficácia Clínica do Sistema CEREC com os seus Diferentes Materiais para Reabilitação em Prótese Fixa e Sobre Implantes? Dissertação de Mestrado. Repositório Institucional da Universidade Fernando Pessoa, 2015.

MEHL, A. et alli (2009). Accuracy testing of a new intraoral 3D camera. International Journal of computerized dentistry, 12 (1), pp. 11-28

MELLO, C. et al. Analysis of Vertical Marginal Adaptation of Zirconia Fixed Dental Prosthesis Frameworks Fabricated by the CAD/CAM System: A Randomized, 
Double-Blind Study. The International Journal of Prosthodontics, v. 29, n. 2, p. 157-160, 2016.

MELLO, C. C. DE. Sistemas CAD / CAM : avaliação da precisão de aquisição de dados. 2014.

MIYAZAKI, T. et al. A review of dental CAD/CAM: current status and future perspectives from 20 years of experience. Dental materials journal, v. 28, n. 1, p. 44-56, 2009.

MORMANN WH. The evolution of the CEREC system. Journal American Dental Association. 2006;137 Suppl:7S-13S

MUIANGA, M. (2009). Data Capture Devide for the CEREC CAD/CAM Chairside Camera. University of the Witwatersrand, Johannesburg

OTTO, T.; SCHNEIDER, D. Long-term clinical results of chairside Cerec CAD/CAM inlays and onlays: a case series. The International journal of prosthodontics, v. 21, n. 1, p. 53-59, 2008.

PARSELL, D. et alli (2000). Effect of camera angulation on adaptation of CAD/CAMrestoration, The Journal of Esthetic Dentistry, 12 (2), pp. 78-84.

RENNE, W. et al. Evaluation of the Marginal Fit of CAD/CAM Crowns Fabricated Using Two Different Chairside CAD/CAM Systems on Preparations of Varying Quality. Journal of Esthetic and Restorative Dentistry, v. 27, n. 4, p. 194-202, 2015.

RUDOLPH, H. et al. Accuracy of intraoral and extraoral digital data acquisition for dental restorations. Journal of Applied Oral Science, v. 24, n. 1, p. 85-94, 2016.

SANNINO, G. et al. CEREC CAD/CAM chairside system. ORAL and Implantology, v. 7, n. 3, p. 57-70, 2014.

SIRONA (2015). Soluções CEREC. Disponível em:http://www.sirona.com.br/ecomaXL/files/pi_video_cerec_646.jpg\&w=646.

STEINMASSL, P.-A. et al. Evaluation of Currently Available CAD/CAM Denture Systems. The International Journal of Prosthodontics, v. 30, n. 2, p. 116-122, 2017 a.

STEINMASSL, P. A. et al. Do CAD/CAM dentures really release less monomer than conventional dentures? Clinical Oral Investigations, v. 21, n. 5, p. 1697-1705, 2017b.

URBANESKY, P. Sistemas-Cad-Cam-Uma-Realidade-. 2012.

WITTNEBEN, J.-G. et al. A systematic review of the clinical performance of CAD/CAM single-tooth restorations. The International journal of prosthodontics, v. 22, n. 5, p. 466-471, 2009. 


\section{CAPITTULO XXXVI}

\section{REABILTACÃO ESTIEICA E FUNCIONAL: UM RELATO DE CASO SOBRE CUIDADOS INIERDISCIPUNARES}

Poliana Andre Borba ${ }^{1}$ Marcos Vinicius Silvério Moraes ${ }^{2}$ Sandra Vicente de Oliveira ${ }^{3}$

\footnotetext{
${ }^{1}$ Mestranda do curso de Reabilitação Oral. Programa de Pós-Graduação em Odontologia - A Faculdade de Medicina e Odontologia e Centro de Pesquisas Odontológicas São Leopoldo Mandic- Campinas.

${ }^{2}$ Mestrando do curso de Reabilitação Oral. Programa de Pós-Graduação em Odontologia - SIMandic - Campinas.

${ }^{3}$ Mestranda do curso de Reabilitação Oral. Programa de Pós-Graduação em Odontologia - SIMandic - Campinas.
}

\section{RESUMO}

O trabalho interdisciplinar para casos em que o acometimento periodontal prejudica o conjunto dos padrões estéticos e funcionais é imprescindível e, exige que o trabalho do cirurgião dentista periodontista seja auxiliado por um protesista. Este relato de caso evidencia a importância do envolvimento de diferentes profissionais da odontologia na resolução individual e personalizada de cada caso, enfatizando a importância de um bom planejamento, o qual deve anteceder os procedimentos a serem realizados, afim de que o tratamento possa ser executado com êxito.

Palavras-chave: Periodontíte. Prótese. Estética. Funcionalidade. Interdisciplinaridade.

\section{INTRODUÇÃO}

Caracterizada por ausência de sintomatologia dolorosa, a periodontite crônica é uma doença que leva o paciente a procurar um cirurgião dentista quando a situação clínica já possui avançados estágios de progressão. Na maioria dos casos, o motivo principal pela procura de um profissional é a queixa estética, e em menor e não menos importante, sangramento gengival e mau hálito.

Como aborda Erpenstein (1986), as tarefas que cabem ao protesista inicialmente, previamente a terapia periodontal, são as remoções e substituições de restaurações, que não favorecem condições de boa higienização, estabelecendo novas, as quais, mesmo que temporárias, dê condições ao paciente de efetiva higiene. Além disso, o protesista deve auxiliar o periodontista na decisão em manter ou não elementos dentários com consideráveis situações de comprometimento, realizar correções 
morfológicas durante fases cirúrgicas com intuito de guiar e manter cicatrização dos tecidos periodontais, bem como aconselhar o periodontista quanto a correções desejáveis.

Uma abordagem interdisciplinar entre o dentista restaurador, periodontista e outras especialistas, pode levar à bons resultados de terapia e motivação aos pacientes (Spear et. al., 2006. Zahra et. al., 2016 e 2019).

Após planejamento, durante a execução dos procedimentos periodontais e protéticos, procedimentos envolvendo outras áreas da odontologia podem ser identificados como necessários, afim de melhorar o prognóstico dos resultados, que, dependentes uns dos outros, somam para a efetividade dos padrões de funcionalidade, saúde dos tecidos e naturalidade do sorriso, que juntas, estas características, podem devolver a desejada estética ao paciente (Abduo \& Lyons, 2017. Lyons \& Darby, 2017).

Este relato de caso evidencia a importância do envolvimento de diferentes profissionais da odontologia na resolução individual e personalizada de cada caso, enfatizando a importância de um bom planejamento, o qual deve anteceder os procedimentos a serem realizados, afim de que o tratamento possa ser executado com êxito (Gasner \& Schure, 2021).

\section{CASO CLINICO}

Paciente R.S.A. 61 anos de idade, gênero masculino, ex fumante, sem alterações sistêmicas, apresentou-se em consultório particular com a queixa estética, sem sintomatologia dolorosa, parafunção ou dor orofacial, relatando qualidade de sono e que gostaria de extinguir os diastemas, solicitando um resultado o mais natural possível (figura 1a E 1B). Ao exame clínico, além de observada a alteração fonética devido a vestibularização dos incisivos superiores, justificada pelo comprometimento dos tecidos periodontais, foram identificadas múltiplas recessões gengivais, cálculo dentário supragengival, ausência do 24, mobilidade grau I generalizada, mobilidade grau II em 41 e 42, profundidade e sangramento a sondagem, restaurações com excessos, fratura de bordo incisal do 31 (figura 7A). Nos movimentos de lateralidade apresentava interferências em 42, 27 e 37. Ao exame radiográfico, lesão de cárie profunda no 16, média profundidade em 22, restauração de amálgama infiltrada por cárie no 26, 
reabsorção óssea horizontal generalizada, do tipo arceforme entre 21 a 25 e cálculo subgengival (figuras $1 \mathrm{~A}, 1 \mathrm{~B}, 2 \mathrm{~A}, 2 \mathrm{~B}$ e 3 ).

Figura 1 - A) Intercuspidação habitual. B) Protrusão

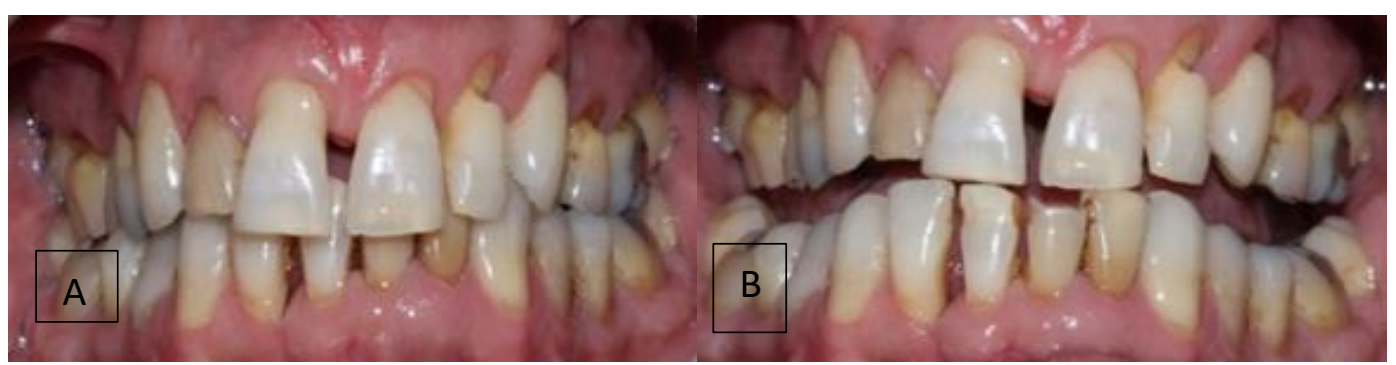

Fonte: Autoria própria.

Figura 2 - A) Lateralidade esquerda. B) Lateralidade Direita
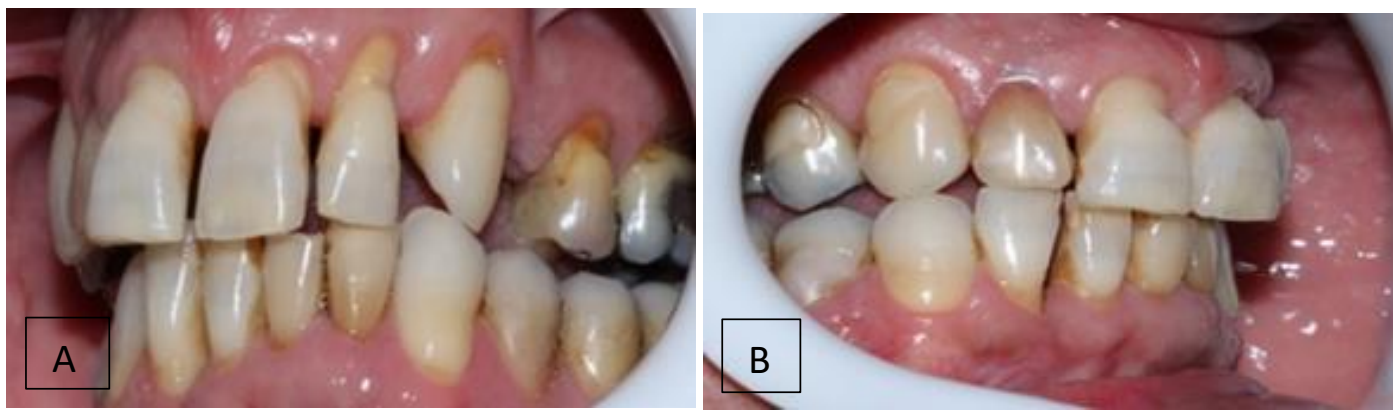

Fonte: Autoria própria.

Figura 3- Situação clínica e radiográfica inicial

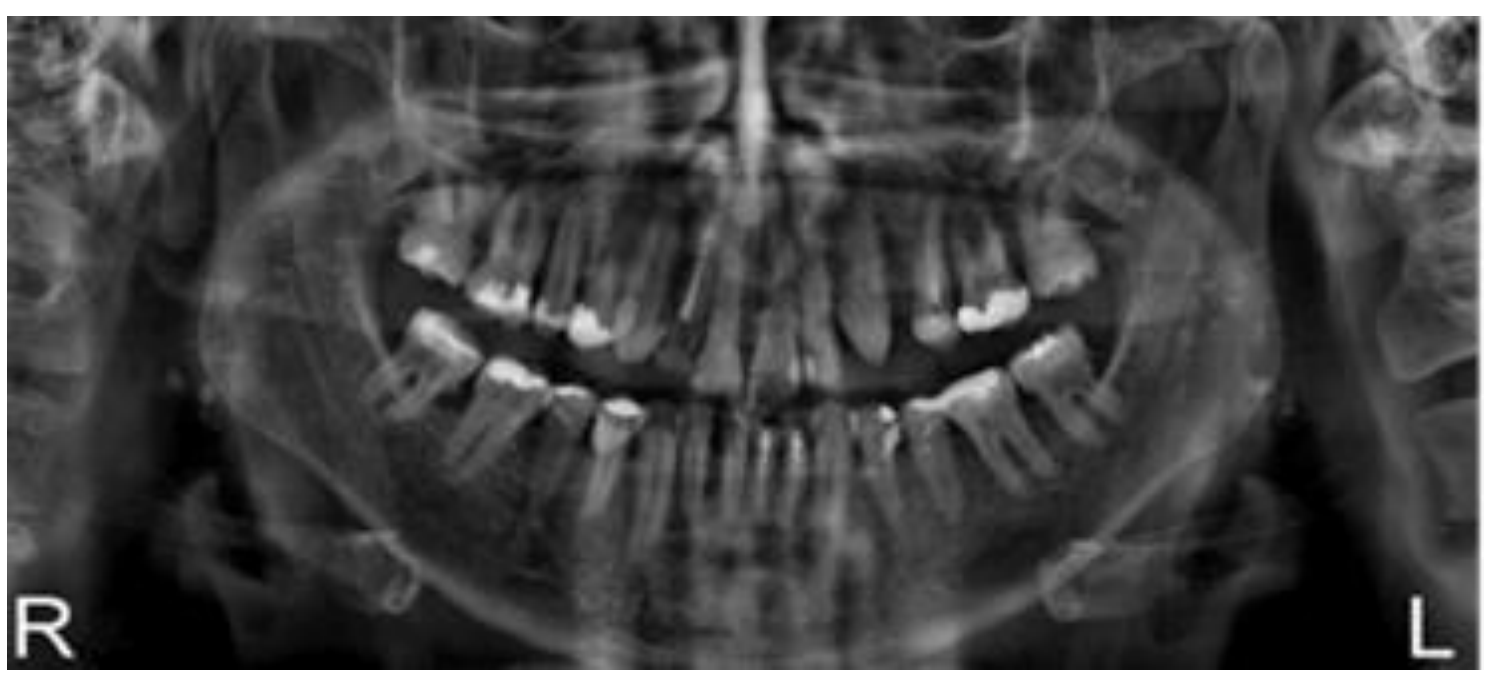

Fonte: Autoria própria.

Inicialmente, o paciente foi submetido a sessões de raspagem supra e subgengival, polimento coronário, endodontia em 16 e 22 e substituição de 
restaurações. Os dentes 12, 11, 21 e 22 foram preparados para receber restaurações do tipo coroas totais em cerâmica livre de metal. Restaurações transitórias em resina foram estabelecidas após enceramento de diagnóstico, reembasadas sobre os preparos em boca e cimentadas com cimento resinoso para provisório em 12, 21 e 22 e, em 11, usado cimento de hidróxido de cálcio devido a extensão em desgaste necessário para devida biomecâmica e alinhamento do sorriso, tentando amenizar injúria pulpar, que mais tarde, em decisão com endodontista, foram realizadas endodontias de 11, 21 e 22. Quando o periodontista sinalizou o fim da terapia periodontal em fase de tratamento, implante osseointegrado foi instalado para recuperar funcionalidade na região do 24 e, restaurações diretas em resina foram confeccionadas em 42, 41, 31 e 32, para estabelecer áreas de contato interproximais, favorecendo resultados quanto a motivação do paciente, que precisava cooperar com boa higienização, a fim de manter estabilidade dos tecidos periodontais (figura 4).

Figura 4- Restaurações em resina indiretas transitórias em 13, 12, 11, 21, 22 e 23; restaurações em resina diretas efetivas em $33,32,31,41,42,43$

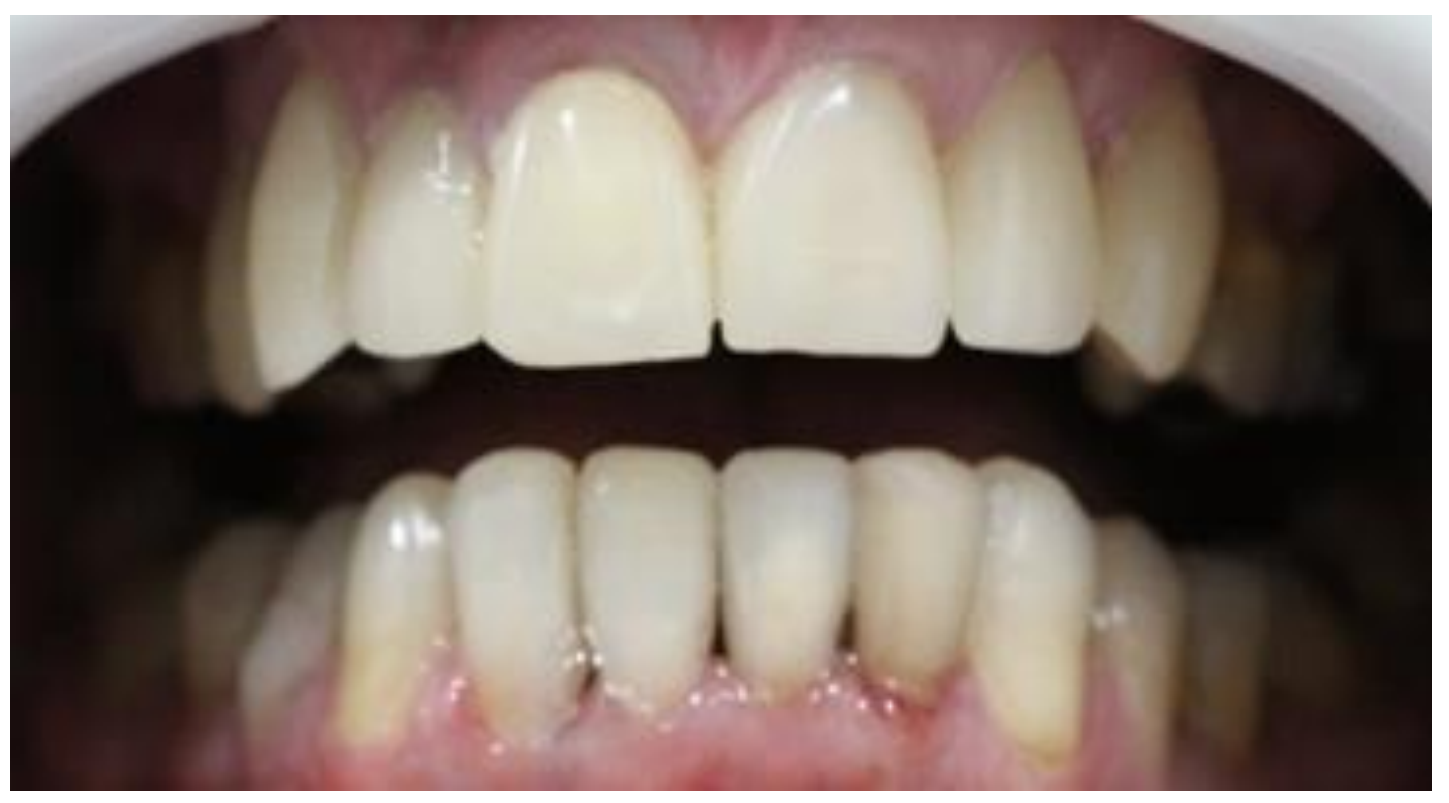

Fonte: Autoria própria.

Em sequência, foram realizados preparos dos dentes posteriores, definidos a partir da extensão em comprometimento, para restaurações do tipo coroas parciais nos elementos dentais 14, 15 e 26, totais nos elementos dentais 16 e 25 . Foram instaladas restaurações provisórias, que passaram por algumas sessões de ajuste oclusal até a 
devida estabilidade de contatos oclusais e, assim, transportado para articulador semi ajustável, como parâmetro aos técnicos em prótese, no processo de transformar o projeto desenvolvido em restaurações transitórias de resina em restaurações efetivas de cerâmica. Para obtenção do modelo de trabalho, foram feitas imagens utilizando escâner intraoral. Um arquivo das restaurações transitórias, previamente a remoção para escaneamento dos preparos, também foi realizado. A posição mandibular habitual justifica-se devido ausência de sintomatologia articular e a estabilidade de contatos em segundos molares, que favorecia a reconstrução dentária extensa, não havendo necessidade de trabalhar para construir uma relação de oclusão cêntrica. O processo de confecção das cerâmicas se deu envolvendo sistema de desenho assistido por computador, seguido de fresagem das peças em cera (computer-aided design - CAD CAM -computer-aided manufacturing), que foram incluídas no anel de silicone em revestimento, para injeção de cerâmica de dissilicato de lítio (figura 5A). As peças foram submetidas a pigmentação e glaze segundo tomada de cor referente ao remanescente dentário do paciente (figura 5B). Devidamente ajustadas e polidas, as restaurações foram levadas a prova em boca que, após aprovação estética pelo paciente, foram cimentadas com cimento resinoso (figuras $6 \mathrm{~A}, 6 \mathrm{~B}, 6 \mathrm{C}, 6 \mathrm{D}, 7 \mathrm{~B}, 8 \mathrm{~A}$ e $8 \mathrm{~B}$ ).

Figura 5- A) Projeto para confecção das restaurações efetivas. B) Restaurações prontas

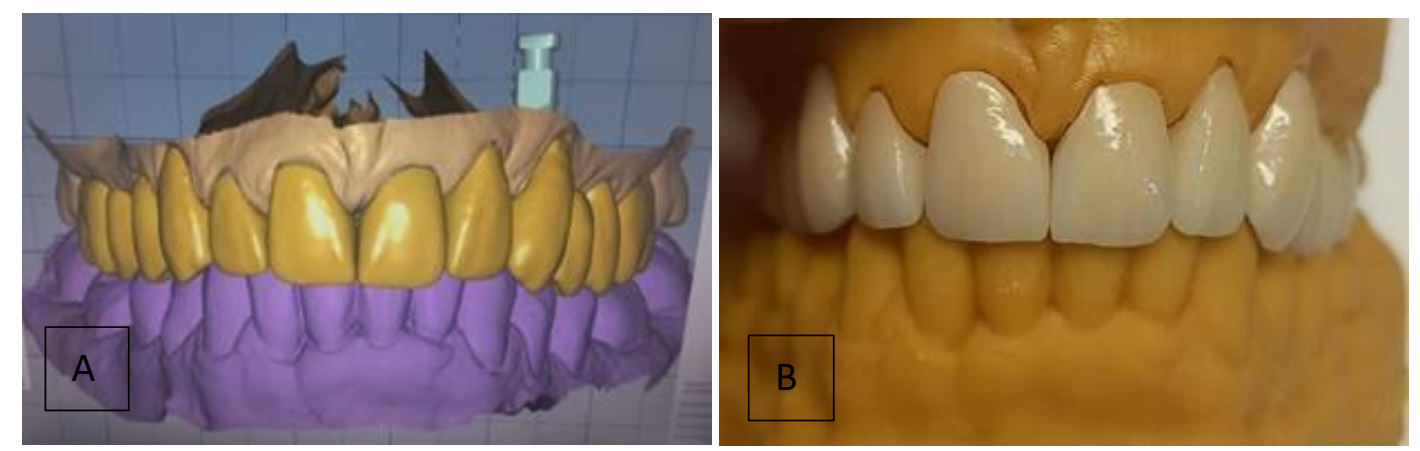

Fonte: Autoria própria. 


\section{CIÊNCIAS DA SAÚDE}

Figura 6- A) Restaurações instaladas. B) Lateralidade direita. C) Máxima Intercuspidação Habitual.

D) Lateralidade esquerda
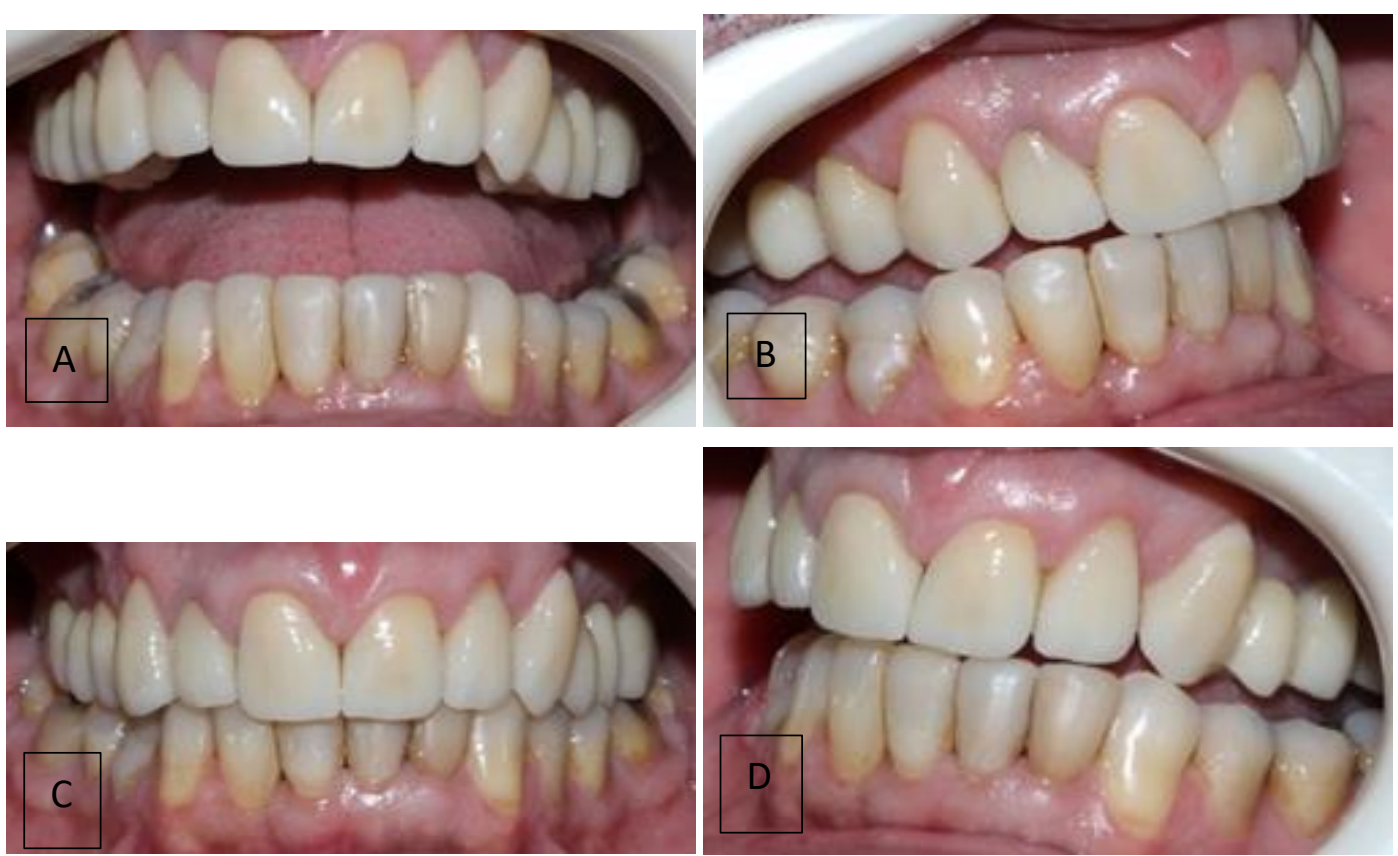

Fonte: Autoria própria.

Figura 7- A) Sorriso Inicial. B) Sorriso Final.
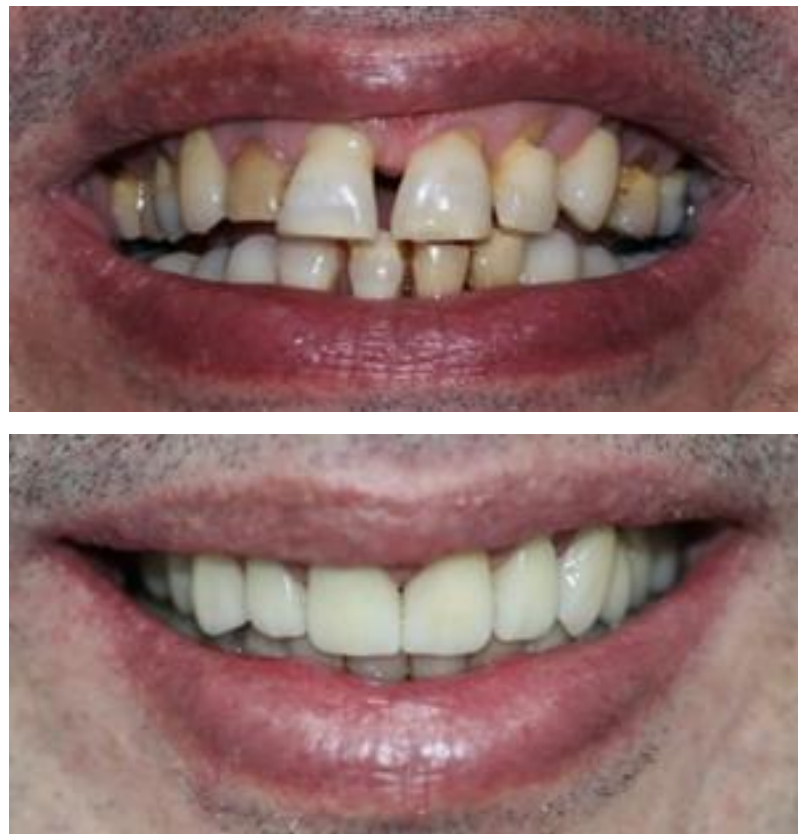

Fonte: Autoria própria.

WWW.AMPLLAEDITORA.COM.BR CONTATO@AMPLLAEDITORA.COM.BR M @AMPLlaEditora O 
Figura 8- A) Acompanhamento em 6 meses pós tratamento. B) Acompanhamento de reabsorção óssea do tipo arceforme e do implante do 24.
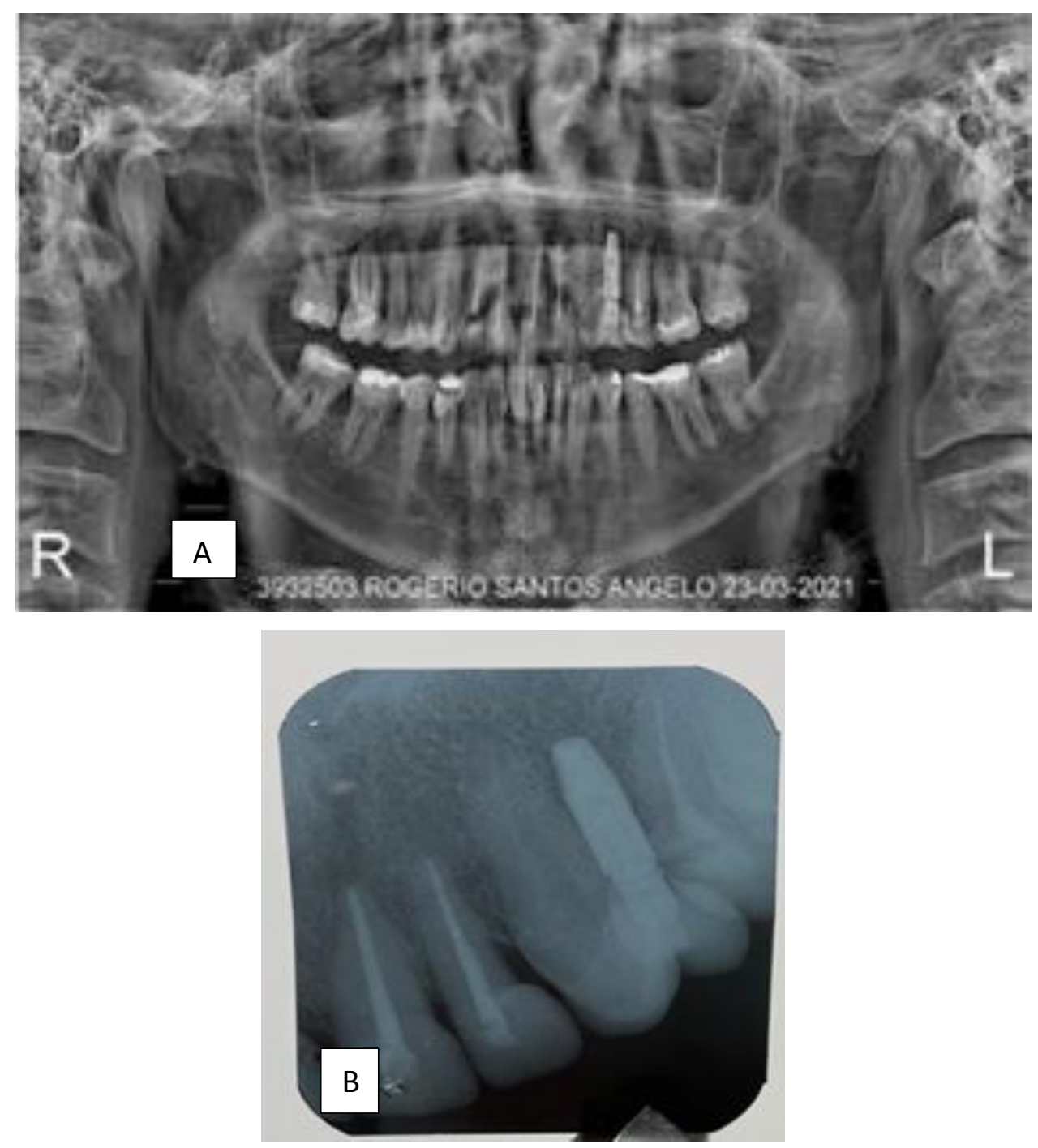

Fonte: Autoria própria.

\section{CONSIDERAÇÕES FINAIS}

Todo tratamento deve ter o objetivo de agir sobre as causas que resultaram a queixa do paciente. Como comprovou a descrição clínica do caso abordado neste trabalho, a efetividade dos resultados é possível quando diagnóstico, planejamento e execução de tratamento possuem assistência interdisciplinar no âmbito odontológico. Os critérios adotados para decisão de execução de cada uma das etapas de tratamento descritas, se deu a partir do momento em que foram descartadas as hipóteses de ortodontia e recobrimento radicular, modalidades de tratamento que podem integrar casos, outros, que envolvam as mesmas características, em situações onde não existam 
limitações biológicas e de aceitação do paciente. Cada indivíduo precisa ser entendido e tratado isoladamente, o que justifica a prática odontológica personalizada e customizada. A necessidade da periodicidade em terapia periodontal deve ser ressaltada, por se tratar da periodontite, uma doença crônica, que possui controle. Terapia periodontal regular, somada a acompanhamento clínico e radiográfico após tratamento, definem estabilidade e longevidade dos resultados.

\section{REFERÊNCIAS}

Abduo, J.; Lyons, K.M. Interdisciplinary interface between fixed prosthodontics and periodontics. Periodontol 2000, Dinamarca, v.74, p. 40-62, 2017.

Erpenstein, $\mathrm{H}$. The role of the prosthodontist in the treatment of periodontal disease. Int Dent J, Londres, v. 36, p. 18-29, 1986.

Gasner, N.S.; Schure, R.S. Periodontal Disease. Statpearls Content is King. disponível em <https://www.statpearls.com/articlelibrary/viewarticle/26983/> acesso em Maio/2021.

Lyons, K.M.; Darby, I. Interdisciplinary periodontics: the multidisciplinary approach to the planning and treatment of complex cases. Periodontol 2000, Dinamarca, v.74, p. 7-10, 2017.

Spear, F.M.; Kokich, V.G.; Mathews, D.P. Interdisciplinary management of anterior dental esthetics. J Am Dent Assoc, Inglaterra, v.137, p.160-169, 2006.

Zahra, J.; Omid, F.; Armin, E. Successful Interdisciplinary Treatment Approach For Dental And Gingival Esthetic Rehabilitation: A Case Report. Journal of Dental and Medical Sciences, v. 15, p. 81-85, 2016.

Zafar, K.; Nazeer, M.R.; Ghafoor R. Interdisciplinary management of gingival recession and pathologic teeth migration-Revisiting dental aesthetics. J Pak Med Assoc, v.69, p. 1385-1389, 2019. 


\title{
CAPITULLO XXXVII
}

\section{AFASTAMENTOS POR LER/DORT NO BRASIL- NECESSIDADE DE ATENGÃO INTEGRAL PARA A SAÚDE DO TRABALHADOR}

\author{
Wilson Carlos Barbosa Almeida ${ }^{1}$ \\ Raissa Beatriz Araújo Prata Galdino ${ }^{2}$ \\ Juliana Cristina Martins de Souza ${ }^{3}$ \\ Fabiola Maria dos Santos ${ }^{4}$ \\ José Gilberto Prates ${ }^{5}$ \\ João Vitor Andrade ${ }^{6}$
}

\footnotetext{
${ }^{1}$ Enfermeiro. Especialista em Enfermagem do Trabalho. Faculdade Venda Nova do Imigrante (FAVENI). Uberaba - MG, Brasil.

2 Enfermeira. Universidade de Uberaba - UNIUBE. Uberaba - MG, Brasil.

${ }^{3}$ Enfermeira. Especialista em Enfermagem em Saúde Mental e Psiquiátrica. Universidade de São Paulo - SP, Brasil.

${ }^{4}$ Graduanda em Farmácia. Faculdade de Ciências Farmacêuticas da Universidade Federal de Alfenas (UNIFAL). Alfenas - MG, Brasil.

${ }^{5}$ Enfermeiro. Doutor em Ciências. Instituo de Psiquiatria da Universidade de São Paulo - SP, Brasil.

${ }^{6}$ Enfermeiro. Especializando em Enfermagem em Saúde Mental e Psiquiátrica no Instituo de Psiquiatria da Universidade de São Paulo - SP, Brasil.
}

\section{RESUMO}

Introdução: as Lesões por Esforço Repetitivo ou Distúrbios Osteomusculares Relacionados aos Trabalho (LER/DOT) são lesões que aparecem após o as estruturas musculoesqueléticas sofrerem esforços. Objetivos: explorar os afastamentos do trabalho como causa de LER/DORT no período de 2014 a 2018 e quantificar os valores dispensados pelo Instituto Nacional do Seguro Social aos acometidos por LER/DORT no período. Método: pesquisa quantitativa-descritiva, transversal, com base em dados secundários referentes aos afastamentos trabalhistas decorrentes das LER/DORT alocados no site do Ministério da Fazenda, especificamente no "Base de dados Estatísticas de Previdência Social". A análise dos dados foi realizada por meio da estatística descritiva. Resultados: foram identificados 2.566 .470 milhões de benefícios concedidos por afastamentos, somando $\mathrm{R} \$ 3.436 .621 .473,00$. A diferença entre os sexos foi de apenas, $4,36 \%$, com maior proporção para o sexo feminino e quanto a natureza da atividade envolvida foi maior a proporção das atividades em área urbana. Conclusão: explicita-se que não se pode subestimar as consequências devastadoras desses distúrbios, sendo fundamental implementar medidas preventivas ao adoecimento relacionado ao trabalho ou que prejudicam seu desenvolvimento.

Palavras-chave: Transtornos Traumáticos Cumulativos. Saúde do Trabalhador. Dor Musculoesquelética. 


\section{INTRODUÇÃO}

As Lesões por Esforço Repetitivo ou Distúrbios Osteomusculares Relacionados aos Trabalho (LER/DOT) possuem causa multifatorial que, não necessariamente são causas diretas, mas contribuem para o aparecimento das lesões de modo que a exposição a esses fatores se dão pela falta de ergonomia no posto de trabalho proporcionando posturas inadequadas, bem como pela exposição do trabalhador ao frio, às vibrações, à pressão mecânica localizada, à carga mecânica musculoesquelética, à invariabilidade da atividade e às exigências cognitivas (CHAVES, 2020). O uso excessivo das estruturas osteomusculares não permite tempo suficiente para sua recuperação com os sintomas aparecendo de forma insidiosa (CHAVES,2020).

Quanto à classificação, as LER/DORT podem ser do Grupo II ou Grupo III, segundo a classificação de Schiling. Esta classificação foi estabelecida em 1984 e é utilizada pelo Ministério do Trabalho, sendo o Grupo II relacionados às doenças nas quais o trabalho é fator de risco, mas não causa direta e o Grupo III é aquele cujas doenças integrantes são agravadas pelo trabalho (SANT et al, 2018).

No Brasil, entre 2007 e 2016, houve um aumento de 170,5\% na taxa de incidência de LER/DORT, sendo a maior taxa em 2015 com 9,8/100 mil trabalhadores (BRASIL, 2019). O documento do Ministério da Saúde aponta ainda que as LER/DORT foram a principal causa pagamento de auxílio doença entre 2011 e 2013, segundo o Ministério do Trabalho (BRASIL, 2019). A região sudeste foi a que apresentou maior coeficiente de incidência, seguida da região nordeste, sul e centro-oeste, respectivamente (BRASIL, 2019).

Em relação à ocupação, a literatura determina que é um fator chave quanto ao risco de desenvolvimento das LER/DORT, sendo mais prevalentes em trabalhadores da construção civil e de indústrias (BRASIL, 2019). Os trabalhadores envolvidos neste ramo estão inseridos, por vezes, em trabalho informal, são do sexo masculino, imigrantes e possuem baixa escolaridade, iniciando o trabalho muito cedo, desenvolvendo doenças pela falta de orientação quanto aos cuidados (JESUS et al, 2017).

Neste sentido, o enfermeiro do trabalho se insere como o profissional que acompanha estes trabalhadores, possibilitando que estes sejam orientados, prevenindo as lesões, adaptando o trabalhador ao ambiente bem como auxiliando em sua 
reabilitação (JESUS et al, 2017). Destaca-se que ao conhecer o perfil das pessoas acometidas e afastadas do trabalho por LER/DORT, pode-se proporcionar a adequação de serviços, em especial do próprio ambiente de trabalho para atender tais necessidades de modo que se possa interferir sobre fatores modificáveis.

Além disso, analisar os números dos afastamentos de trabalho e as principais doenças envolvidas torna-se imperioso para fomentar debates sobre as condições de saúde e doença dos trabalhadores em municípios, estados ou países. Com isso, por meio destes números pode-se elaborar políticas de promoção, prevenção e reabilitação da saúde.

Dessa forma, os objetivos deste trabalho são: explorar os afastamentos do trabalho como causa de LER/DORT no período de 2014 a 2018 e quantificar os valores dispensados pelo Instituto Nacional do Seguro Social aos acometidos por LER/DORT no período.

\section{MÉTODO}

Estudo quantitativo-descritivo, transversal, com base em dados secundários referentes aos afastamentos trabalhistas decorrentes das LER/DORT. Estes dados compreendem o período temporal de 2014 a 2018, e estão alocados no site do Ministério da Fazenda, especificamente no "Base de dados - Estatísticas de Previdência Social" (BRASIL, 2020).

Após, foi realizada a análise das variáveis: LER/DORT, sexo e ano. Para a definição clara do que são as LER/DORT, utilizou-se os diagnósticos definidos pelo Sistema de Informação de Agravos de Notificação (SINAN) (2016), segundo a Classificação Internacional de Doenças 10ª revisão (OMS, 1996), tendo, assim, os códigos explicitados no Quadro 1.

Quadro 1 - Principais códigos CID relacionados a LER/DORT, segundo SINAN

\begin{tabular}{|c|c|}
\hline CID-10 & Definição \\
\hline G50-59 & Transtornos dos nervos, das raízes e dos plexos nervosos \\
\hline G90-G99 & Outros transtornos do sistema nervoso \\
\hline M00-M99 & Doenças do sistema osteomuscular e do tecido conjuntivo \\
\hline
\end{tabular}

Fonte: SINAN, 2016 
A análise dos dados foi realizada por meio da estatística descritiva, a qual possibilita a síntese de valores de uma mesma natureza, proporcionando uma visão global da variação desses valores, organiza e descreve os dados de três maneiras: por meio de tabelas e de medidas descritivas. Utilizou-se o Programa Microsoft Excel, versão 2016 para realização dos cálculos e construção de gráficos e de tabelas.

Em relação aos aspectos éticos em pesquisa, por se tratar de pesquisas baseadas em dados secundários, de domínio público, não necessitam ser submetidas à apreciação do Comitê de Ética em Pesquisa de acordo com a Resolução do Conselho Nacional de Saúde n510, de 7 de abril de 2016 (BRASIL, 2016).

\section{RESULTADOS}

Foram identificados 2.566 .470 milhões de benefícios concedidos por afastamentos no período de 2014 a 2018 no Brasil, para os códigos CID analisados.

A média de benefícios concedidos foi de 513.294 por ano, variando 45663,4 para mais ou para menos entre os anos. O ano com maior número de benefícios concedidos foi 2014 (22,30\%), seguido de 2018 com 21,36\%, a variação percentual entre 2014 e 2018 foi de $1,99 \%$.

Dentre os diagnósticos, aquele com maior proporção foi do grupo de Doenças do Sistema Osteomuscular e do Tecido Conjuntivo, acumulando 93,45\% dos afastamentos, seguido do grupo de Transtornos dos Plexo Nervoso com 6,10\%, conforme observado na Tabela 1.

Tabela 1 - Número de benefícios concedidos em decorrência de LER/DORT no Brasil, 2014-2018

\begin{tabular}{|c|c|c|c|c|}
\hline CID-10 & $\begin{array}{c}\text { G50-59 } \\
\text { N(\%) }\end{array}$ & $\begin{array}{c}\text { G90-99 } \\
\text { N(\%) }\end{array}$ & $\begin{array}{c}\text { M00-M99 } \\
\text { N(\%) }\end{array}$ & Total \\
\hline $\mathbf{2 0 1 4}$ & $34063(1,33)$ & $2451(0,10)$ & $535877(20,88)$ & $572391(22,30)$ \\
\hline $\mathbf{2 0 1 5}$ & $27215(1,06)$ & $1940(0,08)$ & $414333(16,14)$ & $443488(17,28)$ \\
\hline $\mathbf{2 0 1 6}$ & $31089(1,21)$ & $2400(0,09)$ & $484328(18,87)$ & $517817(20,18)$ \\
\hline $\mathbf{2 0 1 7}$ & $29916(1,17)$ & $2251(0,09)$ & $452433(17,63)$ & $484600(18,88)$ \\
\hline $\mathbf{2 0 1 8}$ & $34244(1,33)$ & $2651(0,10)$ & $511279(19,92)$ & $548174(21,36)$ \\
\hline Total & $156527(6,10)$ & $11693(0,46)$ & $2398250(93,45)$ & $2566470(100,00)$ \\
\hline
\end{tabular}

Fonte: Dados do presente estudo.

Em relação às características sociodemográficas, os dados disponíveis no Empresa de Tecnologia e Informações da Previdência (DATAPREV) são apenas relativos 
ao sexo e à natureza da atividade envolvida pelas pessoas que receberam auxílio. A diferença entre os sexos foi de apenas, 4,36\%, conforme Tabela 2 contudo as pessoas do sexo feminino representaram $52,18 \%$ do total de benefícios concedidos. Já em relação à natureza da atividade, a maior parte dos afastamentos foram concedidos para trabalhadores de área urbana, com uma representação de $91,34 \%$ do total de afastamentos.

Tabela 2 - Número de afastamentos segundo sexo e natureza da atividade envolvida. 2014-2018

\begin{tabular}{|c|c|c|c|}
\hline $\begin{array}{c}\text { Sexo/ } \\
\text { CID }\end{array}$ & $\begin{array}{c}\text { Masculino } \\
\mathbf{N}(\%)\end{array}$ & $\begin{array}{c}\text { Feminino } \\
\mathbf{N}(\%)\end{array}$ & $\begin{array}{c}\text { Total } \\
\mathbf{N}(\%)\end{array}$ \\
\hline G50-59 & $6488(0,25)$ & $5205(0,20)$ & $11693(0,46)$ \\
\hline G90-99 & $34590(1,35)$ & $121937(4,75)$ & $156527(6,10)$ \\
\hline MO0-M99 & $1186138(46,22)$ & $1212112(47,23)$ & $2398250(93,45)$ \\
\hline TOTAL & $1227216(47,82)$ & $1339254(52,18)$ & $2566470(100,00)$ \\
\hline Natureza de Atividade Desenvolvida & Urbana & Rural & Total \\
\hline & N(\%) & N(\%) & N(\%) \\
\hline G50-59 & $146752(5,72)$ & $9775(0,38)$ & $156527(6,10)$ \\
\hline G90-99 & $10633(0,41)$ & $1060(0,04)$ & $11693(0,46)$ \\
\hline M00-M99 & $2186912(85,21)$ & $211338(8,23)$ & $2398250(93,45)$ \\
\hline TOTAL & $2344297(91,34)$ & $222173(8,66)$ & $2566470(100,00)$ \\
\hline
\end{tabular}

Fonte: Dados do presente estudo.

No tocante aos valores dos benefícios concedidos, tem-se que, conforme a tabela 3, no período de 2014 a 2018 gastou-se $R \$ 3.436 .621 .473,00$, com uma média de $\mathrm{R} \$ 687.326 .310,64$ ao ano, tendo uma variação de $\mathrm{R} \$ 89.639 .580,90$ para mais ou para menos. Conquanto a variação da proporção não tenha sofrido grandes variações, o maior percentual se deu nos anos de 2018 (23,42\%), 2016 (20,78\%) e 2017. (20,31\%) e o menor percentual no ano de $2015(16,22 \%)$.

Tabela 3 - Valor, em reais, de benefícios concedidos por LER/DORT entre 2014 e 2018 por ano e CID

\begin{tabular}{|c|c|c|c|c|}
\hline CID/ Ano & $\begin{array}{c}\text { G50-59 } \\
\mathbf{n ( \% )}\end{array}$ & $\begin{array}{c}\text { G90-99 } \\
\mathbf{n ( \% )}\end{array}$ & $\begin{array}{c}\text { M00-M99 } \\
\mathbf{n ( \% )}\end{array}$ & TOTAL \\
\hline $\mathbf{2 0 1 4}$ & $36645329,59(1,07)$ & $2833332,52(0,08)$ & $622548612,7(18,12)$ & $662029288,8(19,26)$ \\
\hline $\mathbf{2 0 1 5}$ & $31698367,56(0,92)$ & $2496096,46(0,07)$ & $523367636,3(15,23)$ & $557564115,3(16,22)$ \\
\hline $\mathbf{2 0 1 6}$ & $40621196,98(1,18)$ & $3396061,73(0,10)$ & $669991620,9(19,50)$ & $714010895,6(20,78)$ \\
\hline $\mathbf{2 0 1 7}$ & $41493698,84(1,21)$ & $3299624,02(0,10)$ & $653282526,3(19,01)$ & $698077866,1(20,31)$ \\
\hline $\mathbf{2 0 1 8}$ & $48263395,67(1,40)$ & $4049577,97(0,12)$ & $752634395,8(21,90)$ & $804949387,4(23,42)$ \\
\hline Total & $198721988,6(5,78)$ & $16074692,7(0,47)$ & $3221824792(93,75)$ & $3436621473(100,000$ \\
\hline
\end{tabular}




\section{DISCUSSÃO}

O presente estudo evidenciou que houveram 2.566 .470 afastamentos com benefícios concedidos nos anos de 2014 a 2018. Do grupo de diagnósticos de afastamentos por LER/DORT, a maior parte se deu por doenças musculoesqueléticas. Em estudo semelhante, utilizando-se de dados secundários oriundos do SINAN, foram identificados 17.537 casos de LER/DORT em trabalhadores de indústrias, representando 47,9\% dos trabalhadores com essa condição (VIEGAS; ALMEIDA, 2016).

Do mesmo modo, ao analisar os absenteísmos no Brasil em decorrência de Distúrbios Musculoesqueléticos entre 2007 e 2012, HAEFFNER et al (2018) evidenciaram um número elevado de afastamentos, somando 5 milhões de dias perdidos. Os autores ainda caracterizaram os indivíduos, identificando que a maior parte dessas licenças se deram por pessoas do setor administrativo, com carga horária acima de 6 horas, analfabetos, na faixa etária de 50 a 59 anos, havendo somente na categoria sexo proporção semelhante (HAEFFNER et al, 2018).

Por outro lado, ao investigar os significados do corpo no trabalho em indivíduos com LER/DORT, Dale e Dias (2018), identificaram que os trabalhadores continuam no exercício do trabalho mesmo adoecidos e com dores, por duas necessidades principais: a subsistência e a motivação psicossocial. Os autores justificam que a construção da lógica trabalhista na sociedade capitalista, na qual os indivíduos não são possuidores das matérias primas, do capital e dos meios para a produção de bens são motivadores da venda de suas forças de trabalho a fim de manter seus sustentos. Assim, pode-se inferir o quanto a prevenção, a falta de tratamento precoce e atenção aos primeiros sintomas podem agravar a situação e aumentar os dias de absenteísmo (DALE; DIAS, 2018).

É importante ressaltar que o desconhecimento sobre as possíveis ferramentas de prevenção dos quadros diagnosticados como LER/DORT são fatores etiológicos, mesmo com a diversidade dos distúrbios que se originam por sobrecarga estática e dinâmica (MATIAS et al, 2021). A sobrecarga estática se dá quando há uma elevação no peso e no desempenho de forças acima da capacidade corporal e a dinâmica quando há sobrecarga repetitiva (SANTOS; MELO, 2019).

Alguns trabalhos são mais suscetíveis ao desenvolvimento destas morbidades e, dependendo do tipo dessa, alguns diagnósticos são mais prevalentes. Essa 
identificação foi realizada por Matias et al (2021), os quais discorreram sobre as principais associações entre o tipo de atividade e a lesão causada, sendo as atividades que trabalham com cotovelo apoiado associadas à bursite olecraniana; a movimentação repetitiva do ombro relacionada à bursite subacromial; atividades de costura e dos frentistas de posto associada à Dedo em Gatilho; Aperto de parafusos e de descascar fios relacionadas à epicondilite lateral/medial; atividades manuais repetitivas relacionadas à Síndrome do Túnel do Carpo; Atividades repetitivas somadas à força com o braço associadas à Tendinite bicipital/ do supraespinhoso; A torção de roupas realizadas por lavadeiras associadas à Tenossinovite de De Quervain; A Digitação e operação de mouse relacionada à Tenossinovite dos extensores do carpo e a Flexão repetitiva das mãos associada à Tenossinovite dos flexores do carpo.

Esses achados vão de encontro com os dados deste estudo uma vez que a maior parte dos afastamentos por LER/DORT no Brasil se dá por atividades exercidas em áreas urbanas como atividades administrativas, atividades do setor terciário e atividades industriais, somando um total de $91,34 \%$ de todos os benefícios concedidos.

Outro fator encontrado neste estudo refere-se à pouca discrepância entre os sexos uma vez que foi de apenas $4,36 \%$. Contudo, a maior proporção foi de pessoas do sexo feminino, em concordância com os achados da literatura que justificam estes para além das diferenças biológicas, estão relacionadas à construção social do papel da mulher que tem, por vezes, uma "dupla jornada" entre trabalho, tarefas domésticas e/ou cuidar dos filhos (HAEFFNER et al, 2018).

Além disso, há de se considerar a divisão sexual do trabalho já que esta diferença pode se dar pelas mulheres se ocuparem de trabalhos que exigem maior destreza e habilidade em tarefas repetitivas e simples, considerados também como ocupações que necessitam de docilidade e paciências e, assim, ao associar tais características à mulher, evidenciam a construção social do seu papel (SCHWARZ; THOMÉ, 2017).

Diante do número apontado neste estudo cabe refletir sobre o percurso terapêutico do trabalhador que é identificado e diagnosticado com lesões e distúrbios osteomusculares, pois fica evidente as falhas de prevenção. Seguindo-se o percurso, Zavarizzi e Alencar (2018) identificaram a falta de diretriz no sistema de saúde, sendo essas diretivas dadas pelo próprio usuário que fica mais vulnerável a erros. Cabe salientar o foco em um modelo biomédico, sendo o profissional médico o principal 
agente das ações em saúde nas LER/DORT que estão focadas na medicalização apenas dos sintomas dolorosos, sem qualquer preocupação com as questões biopsicossociais como a reabilitação de casos crônicos, o retorno ao trabalho e o sofrimento psíquico gerado pelos afastamentos (ZAVARIZZI; ALENCAR, 2018; SILVA; ANDRADE, 2021).

Dessa forma, o impacto econômico causado pelas LER/DORT vão além do valor dos benefícios concedidos, que neste estudo foi identificado um total de $\mathrm{R} \$ 3.436 .621 .473$. Somado aos custos, deve-se acrescentar os gastos com exames e medicamentos, nos quais os serviços de saúde públicos e privados centralizam seus atendimentos (ZAVARIZZI; ALENCAR, 2018).

\section{CONSIDERAÇÕES FINAIS}

O presente estudo explicita que as Lesões por Esforço Repetitivo e os Distúrbios Osteomusculares foram responsáveis por 2.566 .470 entre 2014 e 2018, contabilizando R\$3.436.621.473 em auxílios. Em consequência à sociedade, destaca-se os gastos públicos, em virtude não se ter projetos preventivos, bem como redução da mão de obra no mercado de trabalho formal que se tem em virtude dos afastamentos. Ademais, explicita-se que não se pode subestimar as consequências devastadoras desses distúrbios, sendo fundamental implementar medidas preventivas ao adoecimento relacionado ao trabalho ou que prejudicam seu desenvolvimento.

Assim, cabe aos governos, em suas diversas esferas, implementar políticas e programas que forneçam uma linha de cuidado ao trabalhador para que este não tenha, dentre os sofrimentos que as LER/DORT causam, o sofrimento pela falta de resolução de seu problema incluindo a questão psicossocial.

Por fim, vale destacar que somente com o reconhecimento por parte dos trabalhadores e dos empregadores sobre a relação entre trabalho e o adoecimento físico, é que se poderá desenvolver redes de apoio e estruturar ações efetivas de promoção, reabilitação e prevenção de agravos em relação ao adoecimento por LER/DORT. 


\section{REFERÊNCIAS}

BRASIL. Base de dados - Estatísticas de Previdência Social, 2020. Disponível em: http://www3.dataprev.gov.br/infologo/

BRASIL. Conselho Nacional de Saúde. Resolução no 510, de 07 de abril de 2016. Brasília, DF, 2016.

BRASIL. Ministério da Saúde. Saúde Brasil 2018 uma análise de situação de saúde e das doenças e agravos crônicos: desafios e perspectivas. 2019.

https://bvsms.saude.gov.br/bvs/publicacoes/saude_brasil_2018_analise_situacao_sau de_doencas_agravos_cronicos_desafios_perspectivas.pdf

CHAVES, R. Passos gerais para elaboração e implementação de programas de prevenção para lesões por esforço repetitivo e distúrbios osteomusculares relacionados ao trabalho. LOCUS-Revista Interdisciplinar, v. 1, n. 1, 2020.

DALE, A. P.; DIAS, M. D. A. A 'Extravagância' de Trabalhar Doente: O Corpo no Trabalho em Indivíduos com Diagnóstico de LER/DORT. Trabalho, Educação e Saúde, v. 16, n. 1, p. 263-282, 2018.

HAEFFNER, R. et al. Absenteeism due to musculoskeletal disorders in Brazilian workers: thousands days missed at work. Revista Brasileira de Epidemiologia, v. 21, p. e180003, 2018.

JESUS, C. S. et al. Construção civil: o enfermeiro do trabalho na prevenção das lesões por esforços repetitivos. Revista Uniabeu, v. 9, n. 23, p. 50-68, 2017.

MATIAS, A. D. et al. LER/DORT: dominando a abordagem dessa síndrome no Brasil. In: KASHIWABARA et al (Org). Saúde do Trabalhador e da Trabalhadora no Brasil. Diamantina: UFJVM, 2021. p. 54.

OMS - Organização Mundial da Saúde. Classificação Estatística Internacional de Doenças e Problemas Relacionados à Saúde: CID10. São Paulo: EDUSP; 1996.

SANT, P. E. M. S. et al. Occupational headaches: when to suspect? Cefaleias ocupacionais: quando suspeitar? Headache, v. 9, n. 1, p. 29-32, 2018.

SANTOS, G. B. D; MELO, F. X. D. A importância da ginástica laboral no ambiente de trabalho. Diálogos Interdisciplinares, v. 8, n. 4, p. 1-12, 2019.

SCHWARZ, R. G.; THOMÉ, C. F. Divisão sexual do trabalho e impactos na saúde das trabalhadoras: adoecimento por LER/DORT. Revista Direitos, Trabalho e Política Social, v. 3, n. 5, p. 123-149, 2017.

SILVA, L. S.; ANDRADE, J. V. A atenção primária ante a ansiedade: uma inquirição concernente a um mal do século XXI. In. FURTADO, J. H. L.; QUEIROZ, C. R.; 
ANDRES, S. C. Atenção Primária à Saúde no Brasil: desafios e possibilidades no cenário contemporâneo. Campina Grande: Editora Amplla, 2021, p. 127-141.

SINAN. DRT LER/DORT. Portal SINAN, 2016. Disponível em: http://portalsinan.saude.gov.br/drt-ler-dort

VIEGAS, L. R. T.; ALMEIDA, M. M. C. Perfil epidemiológico dos casos de LER/DORT entre trabalhadores da indústria no Brasil no período de 2007 a 2013. Revista Brasileira de Saúde Ocupacional, v. 41, p. e22, 2016.

ZAVARIZZI, C. P.; ALENCAR, M. C.B. Afastamento do trabalho e os percursos terapêuticos de trabalhadores acometidos por LER/Dort. Saúde em Debate, v. 42, p. 113-124, 2018. 


\title{
CAPITULO XXXVIII
}

\section{IMPACTO DO USO DE SMARTPHONE NA QUALDADE DE VIDA E NO RISCO PARA NOMOFOBIA}

\author{
Karen Helena Costa Santos ${ }^{1}$ \\ Bruna da Silva Cruz ${ }^{2}$ \\ Jean Matheus Sena Cardoso ${ }^{3}$ \\ Milena Lara Gomes da Silva ${ }^{4}$ \\ Nahara Benedito Campos ${ }^{5}$ \\ Vitória Monique Costa da Cunha ${ }^{6}$ \\ Marcela dos Santos Ferreira ${ }^{7}$
}

1,2,3,4,5,6 Discente do curso de Enfermagem do Centro Federal de Educação Tecnológica Celso Suckow da Fonseca - CEFET/RJ

${ }^{7}$ Docente do curso de Enfermagem do Centro Federal de Educação Tecnológica Celso Suckow da Fonseca - CEFET/RJ

\section{RESUMO}

OBJETIVO: Analisar a interatividade da população com os smartphones, em relação ao impacto na qualidade de vida e ao risco de desenvolvimento da nomofobia. METODOLOGIA: A amostra foi composta por 96 usuários de smartphones que responderam a um conjunto de perguntas baseadas no formulário: questionário para avaliação de dependência de smartphone (KHOURY, 2017) que abordava afirmações relacionadas à dependência ao celular. As afirmações podiam ser respondidas de forma positiva ou negativa. Os dados foram analisados com o auxílio da estatística descritiva. RESULTADOS: Constatou-se que 90,6\% da amostra é composta por jovens entre 14 e 20 anos e $62,5 \%$ do gênero feminino. Dessas, $53,3 \%$ obtiveram escore positivo para a tendência à nomofobia. Apesar dos sintomas de ansiedade, a dependência ainda não se manifesta na maioria dos participantes, foi observado em $65,6 \%$ da amostra que algumas atitudes já são evidentes, como olhar mensagens ou aplicativos continuamente, esperando alguma interação social recente. CONSIDERAÇÕES FINAIS: Identificou-se que o uso excessivo de aparelhos eletrônicos capazes de acessar a internet é o principal fator para o desenvolvimento da nomofobia, interferindo negativamente na qualidade de vida de indivíduos. Dentre eles, os mais jovens, com mais acesso à internet, revelam-se mais propensos a apresentar manifestações clínicas da nomofobia.

Palavras-chave: Ansiedade. Fobia. Smartphone. 


\section{INTRODUÇÃO}

A população brasileira crescentemente vem adquirindo produtos da área de informática e tecnologia, como computadores, smartphones, televisores, vídeo games, entre outros. Tudo isso facilitou a comunicação interpessoal em conjunto com o desenvolvimento da internet e as redes sociais (FGV, 2020).

Segundo a Pesquisa Nacional por Amostras de Domicílio Contínua 2016 (Pnad Contínua - TIC 2016) divulgados pelo Instituto Brasileiro de Geografia e Estatística (IBGE), milhões de brasileiros se conectaram à internet durante o ano de 2016, sendo o smartphone o dispositivo mais utilizado. Quando consideradas as faixas etárias, indivíduos entre 18 e 24 anos são os que apresentam maior taxa de conexão. A pesquisa apontou que quanto maior a idade, menor era a o uso desses aparelhos, o que pode ser justificado pela dificuldade que essas pessoas possuem em utilizar essas novas tecnologias (IBGE, 2018).

O IBGE também constatou que, quanto maior o grau de escolaridade, maior o uso de smartphones. Em contrapartida, 63,4 milhões de pessoas com 10 anos ou mais de idade não possuem acesso à rede. Desse total, 37,8\% alegaram que não sabem como utilizar a internet, 37,6\% não possuem interesse e 14,3\% não acessaram por considerar um serviço caro (IBGE, 2018).

Toda esta tecnologia usada por boa parcela da sociedade teve início há décadas atrás, sendo seu surgimento relacionado às questões de descobertas e avanços científicos da humanidade. Além destes ganhos, incluem-se alterações positivas na vida das pessoas. Contudo, a tecnologia pode interferir na qualidade de vida das pessoas negativamente (GRISPUN, 2001).

Em se tratando de qualidade de vida, a Organização Mundial da Saúde (OMS) indica que é "a percepção do indivíduo de sua posição na vida, no contexto da cultura e sistemas de valores nos quais ele vive e em relação aos seus objetivos, expectativas, padrões e preocupações" (WHO, 1995). De acordo Giacomini (2005), a qualidade de vida abrange o bem-estar físico, mental, psicológico, emocional e as necessidades humanas básicas, e possui relação com a auto percepção. Definir bem-estar é complexo, pois pode ser influenciado por variáveis como idade, gênero, nível socioeconômico e cultura, direcionando ao bem-estar subjetivo. 
Devido à alta importância da tecnologia no cotidiano da sociedade contemporânea, o contato com a mesma vem se tornando cada vez mais constante. As tecnologias surgem e se transformam numa rapidez e imprevisibilidade incontestáveis, modificando as formas de sermos e estarmos no mundo. No interior destas transformações, uma tendência se configura no mundo tecnológico: reunir todas as mídias em um único artefato - o smartphone. O contato com tal tecnologia pode gerar diversas respostas emocionais e alterar o bem-estar subjetivo (SILVA; TEIXEIRA; MARTINS, 2017). Por conseguinte, a qualidade de vida pode também ser alterada. Essa interferência possibilita até mesmo o surgimento de diversas patologias, sendo uma delas a nomofobia.

O termo Nomofobia se originou na Inglaterra a partir da expressão no-mobile, e significa sem telefone celular. Essa expressão uniu-se à palavra fobos do grego que significa fobia, medo. A associação das palavras resultou no nome Nomofobia - a fobia de ficar sem o telefone celular. O primeiro estudo sobre dependência de internet foi realizado por Kimberly Young, em 1998. A pesquisa realizada examinou mais de 600 casos de pessoas que apresentavam sinais clínicos de dependência, identificados por uma versão adaptada dos critérios do DSM-IV para o jogo de azar patológico (YOUNG, 2011). No Brasil um estudo de 2018 que avaliou jovens acadêmicos de Psicologia concluiu que os participantes apresentaram nível leve e moderado de dependência (TEIXEIRA, et al, 2019). Em 1999, a maior pesquisa sobre o assunto foi realizada e identificou que 6\% das 17.000 pessoas entrevistadas possuíam tal dependência (YOUNG, 2011).

Antes de designar uma pessoa como dependente, é necessário apresentar o termo dependência neste contexto tecnológico. A dependência patológica "acompanha uma inadequação pessoal, social e comportamental, e precisa apresentar sintomas no seu histórico para que seja determinada" (KING; NARDI; CARDOSO, 2014, p.18). Segundo o mesmo autor, a sensação de angústia, desconforto, ansiedade e nervosismo gerado pela ausência da comunicação pelo telefone celular, sinaliza a existência de um possível transtorno, que deve ser investigado e tratado.

Apesar do elevado consumo atual de aparelhos de smartphones, ainda são poucos os conhecimentos sobre os aparelhos e os efeitos de seus usos na saúde da população. (ELHAI; CONTRACTOR, 2018). Esta forma, o presente estudo tem como 
objetivo analisar a interatividade da população com os smartphones, em relação ao impacto ocasionado na qualidade de vida e ao risco de desenvolvimento da nomofobia.

\section{METODOLOGIA}

Para o estudo, de caráter quantitativo e descritivo, foi desenvolvido um questionário denominado: Será que você pode ser nomofóbico? Baseado no formulário validado para o português - Questionário para Avaliação de Dependência de Smartphone - desenvolvido por pesquisadores da Faculdade de Medicina e pelo Centro Regional de Referência em Drogas (KHOURY, et al 2017). O questionário foi aplicado com o auxílio da plataforma do Google e disseminado através de redes sociais - Whatsapp e Instagram - atingindo um grupo de 96 pessoas, entre setembro e outubro de 2018.

O questionário compreende 25 perguntas fechadas relacionadas com possíveis atitudes produzidas pela dependência do celular. As perguntas facultavam a possibilidade de responder sim ou não. Cada resposta positiva acarretava 1 ponto ao indivíduo. As respostas positivas eram consideradas ruins por representar uma atitude de tendência nomofóbica. No questionário uma pontuação final igual ou acima de 8 pontos seria um indicativo para o risco ao desenvolvimento da nomofobia. Foram, também, alocadas 3 perguntas a respeito do perfil do participante, idade, gênero e qualidade do sono. Essas perguntas faziam parte do questionário, mas não foram contabilizadas nas 25 perguntas fechadas.

Os dados obtidos foram analisados por meio da estatística descritiva, que instrumentalizou a analise por meio das frequências absolutas e relativas das respostas positivas ou negativas das perguntas. Os resultados permitiram o estudo das atitudes associadas à utilização das tecnologias referentes ao telefone celular.

O estudo foi aprovado no Comitê de Ética do Hospital Geral de Nova Iguaçu de parecer no 1.615.195/2018, seguindo as normas éticas de pesquisa em saúde.

\section{RESULTADOS}

Para analisar as respostas obtidas no questionário, os resultados foram agrupados em tabelas. Inicialmente, foram identificadas as características sociodemográficas da amostra, isto é, faixa etária e gênero. Na tabela 1, observa-se que 
o público abordado é, redominantemente, de jovens entre 14 e 20 anos $(90,6 \%)$ e do gênero feminino (62,5\%).

Tabela 1 - Frequência relativa (\%) das variáveis sociodemográficas ( $\mathrm{N}=96)$

\begin{tabular}{|c|c|}
\hline \multicolumn{2}{|c|}{ Faixa etária } \\
\hline Entre 14 e 20 anos & $90,6 \%$ \\
\hline Entre 21 e 35 anos & $5,2 \%$ \\
\hline Entre 36 e 50 anos & $4,2 \%$ \\
\hline \multicolumn{2}{|c|}{ Gênero } \\
\hline Feminino & $62,5 \%$ \\
\hline Masculino & $37,5 \%$ \\
\hline
\end{tabular}

Fonte: Autoria própria (2019).

A partir das respostas afirmativas, que valiam 1 ponto cada, foi possível verificar que, aproximadamente, metade dos voluntários apresentaram 8 ou mais atitudes de tendência à nomofobia $(46,9 \%)$, tendo o público feminino $(53,3 \%)$ maior percentual em comparação ao público masculino $(36,1 \%)$, como vista na tabela 2 .

Tabela 2 - Resultado global e por gênero do estudo

\begin{tabular}{|c|c|}
\hline \multicolumn{2}{|c|}{ Pontuação da amostra geral } \\
\hline$<8$ pontos & $53,1 \%$ \\
\hline$\geq 8$ pontos & $46,9 \%$ \\
\hline \multicolumn{2}{|c|}{ Pontuação da amostra feminina } \\
\hline Feminino com $<8$ pontos & $46,7 \%$ \\
\hline Feminino com $\geq 8$ pontos & $53,3 \%$ \\
\hline \multicolumn{2}{|c|}{ Pontuação da amostra masculina } \\
\hline Masculino com $<8$ pontos & $63,9 \%$ \\
\hline Masculino com $\geq 8$ pontos & $36,1 \%$ \\
\hline
\end{tabular}

Fonte: Autoria própria (2019).

As perguntas feitas no questionário foram divididas de modo a facilitar a análise dos dados. Na tabela 3, são apresentados resultados referentes à saúde psicofisiológica relacionada à dependência ao aparelho celular, como relatos de sintomas de ansiedade presentes em 9,4\% dos participantes. 
Tabela 3 - Frequência relativa das respostas referentes a aspectos psicofisiológicos

Não consigo ficar mais de 15 minutos sem utilizar o celular e não sentir sintomas de ansiedade, como por exemplo, coração batendo acelerado, suar, ficar trêmulo.

\begin{tabular}{l|r} 
Sim & $9,4 \%$ \\
Não & $90,6 \%$
\end{tabular}

Já passei mal, como suei excessivamente, tremi, fiquei tonto e/ou irritado, por exemplo, por estar sem o carregador ou sem acesso a internet.

\begin{tabular}{|c|c|}
\hline Sim & $7,3 \%$ \\
\hline Não & $92,7 \%$ \\
\hline
\end{tabular}

Fico inquieto e irritado quando não tenho acesso ao celular.

\begin{tabular}{l|r} 
Sim & $42,7 \%$ \\
Não & $57,3 \%$
\end{tabular}

Sinto-me irritado quando a internet cai e seleciono locais, como por exemplo, shopping e restaurantes, de acordo com a presença ou não de wi-fi.

\begin{tabular}{|c|c|}
\hline Sim & $29,2 \%$ \\
\hline Não & $70,8 \%$ \\
\hline
\end{tabular}

Fonte: Autoria própria (2019).

Na tabela 4 são apresentados dados acerca das características apresentadas sobre a vida social impactada pelo uso do celular, como o fim de relacionamentos ocasionado pelo uso indiscriminado do aparelho $(19,8 \%)$. 
Tabela 4 - Frequência relativa das respostas referentes a aspectos emocionais e de relações

$$
\text { interpessoais }
$$

Quando saio, aciono o celular assim que chego ao lugar pretendido e ligo para casa ou trabalho, por exemplo, apenas para dizer "oi, cheguei" sem que haja real necessidade disso.

\begin{tabular}{|c|c|}
\hline Sim & $16,7 \%$ \\
\hline Não & $83,3 \%$ \\
\hline
\end{tabular}

Fico mais satisfeito utilizando o celular do que passando o tempo com meus amigos e familiares.

\begin{tabular}{l|r} 
Sim & $15,6 \%$ \\
Não & $84,4 \%$
\end{tabular}

Em eventos sociais, como reunião de família, por exemplo, não consigo socializar com as pessoas sem ficar no celular.

\begin{tabular}{l|r} 
Sim & $15,6 \%$ \\
Não & $84,4 \%$
\end{tabular}

Embora o uso do celular tenha trazido efeitos negativos aos meus relacionamentos afetivos, a quantidade de tempo que gasto nele continua a mesma.

\begin{tabular}{|c|c|}
\hline Sim & $19,8 \%$ \\
\hline Não & $80,2 \%$ \\
\hline O uso do celular consegue transformar o meu humor, como por exemplo, me \\
deixando mais feliz, animado, empolgado.
\end{tabular}

Fonte: Autoria própria (2019).

Na tabela 5, foram categorizadas perguntas relacionadas ao impacto do smartphone nas atividades diárias de seus usuários. De modo que $82,3 \%$ dos participantes declararam sentir o desejo ou impulso de colocar para carregar assim que acaba a energia do aparelho. 
Tabela 5 - Frequência relativa das respostas referentes à realização de atividades diárias

Utilizo muito o celular e meu rendimento escolar ou profissional tem caído.

\begin{tabular}{l|r} 
Sim & $18,8 \%$ \\
\hline Não & $81,2 \%$
\end{tabular}

Considero um castigo quando alguém, como por exemplo, professor ou chefe, impõe a proibição do uso de celular.

\begin{tabular}{l|l} 
Sim & $22,9 \%$ \\
\hline Não & $77,1 \%$
\end{tabular}

Utilizar o celular tem causado prejuízo a minha saúde física, por exemplo, uso o celular quando atravesso a rua, enquanto dirijo ou espero algo, e esse uso pode me colocar em perigo.

\begin{tabular}{l|l} 
Sim & $10,4 \%$ \\
\hline Não & $89,6 \%$
\end{tabular}

Já realizei alguma atividade importante às pressas, como prova bimestral, comer, tomar banho para olhar o mais rápido possível ligações, mensagens e afins.

\begin{tabular}{l|l} 
Sim & $20,8 \%$ \\
\hline Não & $79,2 \%$
\end{tabular}

Não consigo realizar atividades diárias sem interrompê-las ao ouvir algum som vindo do celular, como toque de mensagem ou ligação.
Sim
$31,3 \%$
Não
$68,7 \%$

Interrompo em momento inapropriado coisas como atividades sexuais, partida de futebol, aulas e reuniões, por exemplo, para mexer no celular.

\begin{tabular}{l|l} 
Sim & $13,5 \%$ \\
\hline Não & $86,5 \%$
\end{tabular}

Não consigo realizar as refeições em família, nem ir ao banheiro sem mexer ou levar o celular.

\begin{tabular}{l|r} 
Sim & $32,3 \%$ \\
\hline Não & $67,7 \%$
\end{tabular}

Me sinto indisposto para realizar outras atividades, mas arrumo disposição para ficar no celular mesmo estando cansado.

\begin{tabular}{l|r} 
Sim & $63,5 \%$ \\
Não & $36,5 \%$
\end{tabular}

Nunca esqueço o celular em casa ou no trabalho; quando isso acontece, volto de onde estou para ir pegá-lo.

\begin{tabular}{|c|c|}
\hline Sim & $61,5 \%$ \\
\hline Não & $38,5 \%$ \\
\hline
\end{tabular}

Sinto necessidade imediata de colocar o aparelho na tomada quando ele descarrega.

\begin{tabular}{l|r} 
Sim & $82,3 \%$ \\
\hline Não & $17,7 \%$
\end{tabular}

Fonte: Autoria própria (2019). 
A tabela 6 tem como principal objetivo expor como o sono e a rotina matinal podem ser afetados pelo excesso do contato com o aparelho. 0 exemplo disso, o costume de utilizar o celular assim que acordar é apresentado em $79,2 \%$ dos entrevistados.

Tabela 6 - Frequência relativa das respostas referentes aos hábitos de sono

\begin{tabular}{|c|c|}
\hline & Como é a sua qualidade de sono? \\
\hline Péssima & $4,2 \%$ \\
\hline Ruim & $17,7 \%$ \\
\hline Regular & $52,1 \%$ \\
\hline Boa & $17,7 \%$ \\
\hline Excelente & $8,3 \%$ \\
\hline Acordo de madrugada para usar o celular e ver se chegou alguma mensagem. \\
\hline Sim & $19,8 \%$ \\
\hline Não & $80,2 \%$ \\
\hline & \\
\hline Sim & Utilizo celular antes de dormir. \\
\hline Não & $94,8 \%$ \\
\hline Meu primeiro pensamento ou atitude ao acordar é olhar o celular. \\
\hline Sim & $79,2 \%$ \\
\hline Não & $20,8 \%$ \\
\hline
\end{tabular}

Fonte: Autoria própria (2019).

É factível que, em alguns momentos, haja uma substituição de relações interpessoais por virtuais. Na tabela 7, evidencia-se a dependência emocional causada pela utilização de aplicativos de mensagens e afins através da espera de $65,6 \%$ dos voluntários por novas notificações.

Tabela 7 - Frequência relativa das respostas referentes à dependência emocional

Sinto angústia e/ou fico inquieto a não olhar o celular imediatamente ao receber uma mensagem.

\begin{tabular}{l|r} 
Sim & $42,7 \%$ \\
Não & $57,3 \%$
\end{tabular}

Olho as mensagens ou acesso os mesmos aplicativos na esperança de ter algo novo mesmo tendo olhado há pouco tempo.

\begin{tabular}{l|r} 
Sim & $65,6 \%$ \\
Não & $34,4 \%$
\end{tabular}

Fonte: Autoria própria (2019). 


\section{DISCUSSÃO}

Em relação à faixa etária e gênero, identificou-se um público jovem, corroborando com o indicativo de que a população jovem parece ser a mais vulnerável ao uso excessivo das redes sociais. Nesse sentido, ao estarem em um momento de definição da identidade, instabilidade emocional e insegurança própria da juventude podem ser atraídos pelas tecnologias dos smartphones (SOLER; SÁNCHEZ; SOLER, 2017).

Aproximadamente metade dos participantes atingiu pontuação superior ou igual a 8 pontos. Com efeito, foram caracterizados como um grupo que possui risco para o desenvolvimento da nomofobia. Este resultado vai ao encontro a outras pesquisas relacionadas com público jovem, como a de Oliveira (2018) que observou em 55\% dos pesquisados sinais de dependência do aparelho celular. Estes sinais mesmo em um nível considerado leve, já produz problemas ocasionais em algumas situações.

Também foi constatada que a porcentagem de participantes do gênero feminino que obtiveram pontuação maior ou igual a 8 foi superior à do gênero masculino. Observa-se, assim, uma tendência do gênero feminino ao transtorno nomofóbico que também foi verificada nas pesquisas congêneres de Konok et al. (2016) e Oliveira (2018). Para Yildirim e Correia (2015), é importante identificar diferenças quanto ao gênero e determinar quais fatores podem ser preditores da nomofobia, o que possibilitaria identificar os grupos de risco e desenvolver estratégias de prevenção para ajudar tais grupos.

Esta tendência a nomofobia é mais bem visualizada ao analisar de forma isolada algumas perguntas específicas que abordam temas cotidianos. Levando em conta que a nomofobia é um tipo específico de ansiedade, foi observado, que apesar de uma baixa porcentagem dos participantes relatarem sintomas de ansiedade, ao se ausentar do aparelho celular, quase metade $(42,7 \%)$ do total dos entrevistados referiu sentir irritabilidade e inquietação quando não tinham acesso a determinadas funções do dispositivo. Deste modo, é revelada uma tendência para o desenvolvimento do transtorno.

De acordo com Konok et al. (2016), o apego ao celular está relacionado com um maior nível de ansiedade dos sujeitos, posto que o aparelho proporciona uma maior sensação de segurança. Também foi observado que a dependência à internet impõe 
uma limitação a 9,2\% dos indivíduos, que se preocupam com os locais a serem frequentados (os que têm rede $\mathrm{Wi}$-fi).

Em relação às alterações emocionais e relacionais, alguns dos indivíduos que responderam à pesquisa estavam condicionados a terem mais relações sociais através do contato com o smartphone do que pelo contato pessoal. De acordo com Maziero e Oliveira (2017), quando o indivíduo permanece sem contato com os dispositivos eletrônicos, há indicativo de uma dependência patológica que pode ser evidenciada pela rejeição ao contato físico. De maneira que 16,7\% dos indivíduos relataram interagir virtualmente, desnecessariamente, ao chegarem ao destino desejado. Este tipo de relação pode produzir um sentimento de solidão e, consequentemente, outros transtornos mentais. De acordo com Costa (2004, p. 172), na ausência deste acesso, "sentem-se excluídos do convívio de seus amigos, parentes, namorados, etc. e enfrentam uma nova forma de solidão, não menos dolorosa do que as tradicionais: a solidão do sedentário em um mundo de nômades em constante movimento" Desse modo é observada uma deficiência na socialização dos indivíduos.

O relato dos entrevistados de possuir maior satisfação ao utilizarem o aparelho celular em detrimento do contato interpessoal, evidencia uma deficiência em seu bemestar global. Até mesmo relacionamentos afetivos, foram afetados pelo tempo gasto nesses dispositivos e, ainda assim, não houve mudança de hábito por parte desses participantes (19,8\%). É importante destacar que o gregarismo é um dos pilares de um nível satisfatório de qualidade de vida, de acordo com a teoria das necessidades humanas de Maslow (GONÇALVES; NUERNBERG, 2012).

De acordo com Maziero e Oliveira (2017), o termo dependência é considerado patológico quando a vida do ser humano é comprometida pelo uso abusivo dos dispositivos eletrônicos, provocando consequências indesejáveis, como diminuição no rendimento escolar ou profissional (18,8\%). De forma similar, foi possível observar, até mesmo, um risco à integridade física dos voluntários $(10,4 \%)$ que responderam de forma afirmativa a essas ocorrências. Parte dos entrevistados (31,3\%) relatou, também, interromper afazeres cotidianos com algum estímulo sonoro advindo do celular. Além de $13,5 \%$ dos indivíduos que informaram descontinuar atividades importantes em momentos inadequados e $32,3 \%$ o utilizam durante essas ocasiões, sendo esse um comportamento perigoso. 
A necessidade de estar em constante contato com o aparelho celular leva os sujeitos $(63,5 \%)$ a postergar o descanso ou a conclusão de tarefas a fim de manipular o smartphone. Essa carência faz com que, dificilmente, esqueçam o celular no lugar de origem quando se deslocam. Entretanto, quando ocorre, $61,5 \%$ dos entrevistados alegaram retornar para buscá-lo. Esse comportamento demonstra como essa dependência influencia até mesmo no descanso e deslocamento dos indivíduos.

A qualidade de vida abrange também 0 atendimento às necessidades fisiológicas, inclusive o ato de dormir. A dependência de dispositivos como o celular, tem feito com que as pessoas tenham interrupções do sono para a utilização dos mesmos como $19,8 \%$ dos participantes relataram. Analogamente, $21,9 \%$ classificaram a qualidade do sono como ruim ou péssima. Utilizar o celular antes de dormir também interfere na qualidade de vida dos indivíduos, uma vez que desregula o controle hormonal do sono, prejudicando tanto a quantidade, quanto a qualidade e, ainda, a disposição para realizar atividades diurnas (FREITAS et al., 2017). Das pessoas estudadas por Freitas et al. (2017), 79\% revelaram ter este hábito e sentir os seus malefícios, resultados próximos da pesquisa de Amra et al. (2017). O presente estudo reforça os achados destas pesquisas, ao identificar $94,8 \%$ dos participantes com o mesmo costume, bem como 79,2\% costumam utilizar o aparelho ao acordar. Em contraponto, Freitas et al. (2017) constataram que, ao evitar esse hábito, os indivíduos apresentaram melhora na qualidade do sono.

Em contraponto, Freitas et al. (2017) constataram que, ao evitar esse hábito, os indivíduos apresentaram melhora na qualidade do sono.

A carência emocional e social é também gerada a partir da dependência pelas redes sociais e aplicativos de mensagens que podem ser acessados pelos dispositivos eletrônicos. Quando isso ocorre, identificam-se comportamentos de angústia ou inquietação em $42,7 \%$ dos participantes, caso haja a impossibilidade de verificação imediata de mensagens, assim como na ausência de notificações do smartphone (65,6\%) ou então, quando há interação, mas há impossibilidade em utilizá-lo.

A baixa autoestima, ansiedade social e timidez podem ser refletidas na dependência social e emocional pelos recursos disponibilizados através dos dispositivos eletrônicos. As redes sociais vêm obtendo um papel mais enfático na vida da população, a partir do momento em que começa substituir as necessidades de socialização. 


\section{CONSIDERAÇÕES FINAIS}

A partir dos dados coletados evidenciou-se risco para desenvolvimento da nomofobia em aproximadamente metade dos sujeitos pesquisados, em sua maioria jovens, haja vista que esta parcela dos pesquisados apresentou escore indicativo para o transtorno, no questionário aplicado. Também se percebe um impacto na qualidade de vida, com o uso sem controle da telefonia móvel, especialmente as que possuem conexão com internet, como perda da qualidade do sono, mudanças no cotidiano para facilitar o uso do aparelho celular e alterações nas relações interpessoais.

A interação indiscriminada dos indivíduos com o aparelho de telefonia móvel pode ser considerada uma problemática de saúde pública, por tornar a qualidade de vida do portador desse transtorno cada vez menos satisfatória devido às manifestações de ansiedade pelo uso destes dispositivos eletrônicos, que prejudicam aspectos da vida social, educacional e profissional dos indivíduos, assim como o bem-estar físico e mental. A progressão tecnológica e seu uso indevido e abusivo, evidenciado a partir dos resultados obtidos no estudo, indicam um risco para que mais sujeitos desenvolvam a nomofobia, interferindo negativamente na saúde humana através dos sintomas de ansiedade patológica.

\section{REFERÊNCIAS}

AMRA, B. et al. Associação entre o sono e o uso noturno de celular entre adolescentes. Jornal de Pediatria, v. 93, n. 6, p. 560-567, 2017. Disponpivel em: https://www.scielo.br/scielo.php?pid=S0021-

75572017000600560\&script=sci_arttext\&tlng=pt. Acesso em: 10 dez. 2019. https://doi.org/10.1016/j.jped.2016.12.004.

COSTA, A. M. N. Impactos psicológicos do uso de celulares: uma pesquisa exploratória com jovens brasileiros. Psicologia: Teoria e Pesquisa, v. 20, n. 2, p.165-174, ago. 2004. https://www.scielo.br/scielo.php?script=sci_arttext\&pid=S010237722004000200009\&Ing=pt\&tIng=pt. Acesso em: 10 dez. 2019. http://dx.doi.org/10.1590/s0102-37722004000200009.

ELHAI, J. D.; CONTRACTOR, A.A. Examining latent classes of smartphone users: Relations with psychopathology and problematic smartphone use. Computers in Human Behavior, v. 82, p. 159-166, $2018 . \quad$ Disponível em: https://www.sciencedirect.com/science/article/abs/pii/S0747563218300165?vi 
a\%3Dihub. Acesso em: 10 dez. 2019. http://dx.doi.org/10.1016/j.chb.2018.01.010.

FREITAS, C. C. M. et al. Relação entre uso do telefone celular antes de dormir, qualidade do sono e sonolência diurna. Revista de Medicina, v. 96, n. 1, p. 14-20, 2017. Disponível em: https://www.revistas.usp.br/revistadc/article/view/121890. Acesso em: 6 maio. 2021. DOI: 10.11606/issn.1679-9836.v96i1p14-20.

FUNDAÇÃO GETULIO VARGAS (FGV). Brasil tem 424 milhões de dispositivos digitais em uso, revela a 31a Pesquisa Anual do FGVcia. 2020. Disponível em: https://portal.fgv.br/noticias/brasil-tem-424-milhoes-dispositivos-digitais-usorevela-31a-pesquisa-anual-fgvcia/. Acesso em: 10 abril 2021.

GIACOMONI, C.H. Bem-estar subjetivo: em busca da qualidade de vida. Periódicos Eletrônicos em Psicologia, v. 12, p.43-50, mar. 2005. Disponível em: $<$ http://pepsic.bvsalud.org/scielo.php?script=sci_arttext\&pid=S1413389X2004000100005>. Acesso em: 01 dez. 2019.

GONÇALVES, B.G.; NUERNBERG, D. A dependência dos adolescentes ao mundo virtual. Revista de Ciências Humanas, v. 6, n. 1, p. 165-182, 2017. https://periodicos.ufsc.br/index.php/revistacfh/article/view/21784582.2012v46n1p165. Acesso em: 01 dez. 2019.

GRINSPUN, M.P. S. Z. Educação tecnológica: desafios e perspectivas, 2ª ed. São Paulo: Cortez, 2001.

INSTITUTO BRASILEIRO DE GEOGRAFIA E ESTATÍSTICA (IBGE). PNAD Contínua TIC 2017: internet chega a três em cada quatro domicílios do país. 2018. Disponível em: $<$ https://agenciadenoticias.ibge.gov.br/agencia-sala-de-imprensa/2013agencia-de-noticias/releases/23445-pnad-continua-tic-2017-internet-chega-atres-em-cada-quatro-domicilios-do-pais>. Acesso em: 01 dez. 2019.

KHOURY, J.M. et al. Assessment of the accuracy of a new tool forthe screening of smartphone addiction. PLOS ONE, V. 2, N. 5, e0176924, 2017. Disponível em: https://www.ncbi.nlm.nih.gov/pmc/articles/PMC5435144/. Acesso em: 02 dez. 2019. https://doi.org/10.1371/journal.pone.0176924.

KING, A. L. S.; NARDI, A. E.; CARDOSO, A. (Orgs.). NOMOFOBIA: Dependência do computador, internet, redes sociais? Dependência do telefone celular? 0 impacto das novas tecnologias no cotidiano dos indivíduos. 1.ed. São Paulo: Editora Atheneu, 2014.

KONOK, V. et al. Humans attachment to their mobile phones and its relationship with interpersonal attachment style. Computers in Human Behavior, v. 61, p. 537-547, $2016 . \quad$ Disponível em: https://www.researchgate.net/publication/299472808_Humans'_attachment_t 
o_their_mobile_phones_and_its_relationship_with_interpersonal_attachment _style. Acesso em: 10 dez. 2019.

MAZIERO, M. B.; OLIVEIRA, L. A. Nomofobia: uma revisão bibliográfica. Unoesc \& Ciência, v. 8, n. 1, p. 73-80, jun. 2017. Disponível em: https://portalperiodicos.unoesc.edu.br/acbs/article/view/11980. Acesso em: 10 dez. 2019.

OLIVEIRA, T.S. Dependência do smartphone: um estudo da nomofobia na formação de futuros gestores. 2018. 107 f. Dissertação (Mestrado) - Curso de Administração, Universidade Potiguar, Natal, 2018. Disponível em: https://www.unp.br/wpcontent/uploads/2015/08/Disserta\%C3\%A7\%C3\%A3o_ThycianeSantosOliveira.pdf. Acesso em: 10 dez. 2019.

SILVA, V.; TEIXEIRA, I.; MARTINS, J. A convergência midiática e as tecnologias móveis pós-bolonha: novas práticas sociais. Revista Observatório, v. 3, n. 6, p. 229$247,2017$. https://sistemas.uft.edu.br/periodicos/index.php/observatorio/article/view/41 79/11643. Acesso em 10 dez. 2019. DOI: https://doi.org/10.20873/uft.24474266.2017v3n6p229.

SOLER; I. R.; SÁNCHEZ, C. L.; SOLER, C. Q. Adaptación y validación de la escala de nomofobia de yildirim y correia en estudiantes españoles de la educación secundaria obligatoria. Health and Addictions, v. 17, n.2, p. 201-213, 2017. Disponível em: http://rua.ua.es/dspace/handle/10045/68588 . Acesso em: 10 dez. 2019.

TEIXEIRA, I. et al. NOMOFOBIA: os impactos psíquicos do uso abusivo das tecnologias digitais em jovens universitários. Revista Observatório, v. 5, n. 5, p. 209-240, ago. 2019.

Disponível

em: https://sistemas.uft.edu.br/periodicos/index.php/observatorio/article/view/82 20 Acesso em: 30 abril 2021. http://dx.doi.org/10.20873/uft.24474266.2019v5n5p209.

WHOQOL. The World Health Organization quality of life assessment (WHOQOL): position paper from the World Health Organization. Social Science and Medicine, v. $41, \quad$ n. 10, p. 1403-1409, 1995 . Disponível em: https://www.sciencedirect.com/science/article/abs/pii/027795369500112K?vi a\%3Dihub\#!. Acesso em: 01 dez. 2019.

YILDIRIM, C.; CORREIA, A.P. Exploring the dimensions of nomophobia: Development and validation of a self-reported questionnaire. Computers in Human Behavior, v. 49, p. 130- 137, 2015. Disponível em: https://lib.dr.iastate.edu/cgi/viewcontent.cgi?article=5012\&context=etd .Acesso em: 10 dez. 2019 
YOUNG, Kimberly S.; ABREU, Cristiano Nabuco de. Dependência de Internet: Manual e Guia de Avaliação e Tratamento: Compreendendo o comportamento do uso de internet e a dependência. Porto Alegre: Artmed Editora, 2011. 


\section{CAPITULO XXXIX}

\section{A IMPORTÂNCLA DOS ESTUDOS SOBRE BIOSSEGURANGA AOS PROFISSIONAIS DA ÁREA DE SAÚDE} Biologia e em Marketing.

\section{RESUMO}

A Biossegurança se caracteriza por englobar uma série de medidas adotadas em um ambiente de trabalho e/ou pesquisa, a fim de eliminar possíveis riscos aos indivíduos e ao ambiente como um todo, permitindo assim, uma maior segurança das atividades desenvolvidas. Tendo a biossegurança como eixo norteador, o presente estudo teve como objetivo descrever a importância da realização de estudos de Biossegurança no Brasil nos últimos 25 anos para os profissionais da área de saúde. A fim de se alcançar este objetivo, realizou-se um levantamento bibliográfico no site do Catálogo de Teses e Dissertações da CAPES, a fim de encontrar obras que abordassem o tema biossegurança atrelado aos profissionais de saúde. Deste modo, pode-se verificar que as práticas de biossegurança são englobadas em uma série de 4 níveis, as NB-1, NB-2, NB-3 e NB-4, as quais envolvem uma série de medidas a serem adotadas e são apoiadas por uma série de legislações, com destaque a Portaria $n^{\circ}$ 2.594, de 01 de Outubro de 2019 que dispõe sobre a Comissão de Biossegurança em Saúde. Diante do cenário de pandemia, ao qual se vive atualmente em 2021, justamente por questões que norteiam a área de biossegurança, este tema é de extrema importância para discussão e estudos.

Palavras-chave: Normas de biossegurança. Legislação em biossegurança. OMG.

\section{INTRODUÇÃO}

A Biossegurança corresponde ao conjunto de procedimentos realizados a fim de minimizar, prevenir e eliminar riscos que podem agir de forma deletéria a saúde de animais, do meio ambiente ou a qualidade de atividades de ensino, pesquisa ou de prestação de serviços (FANEC, 2005-2019; HIRATA et al, 2012).

Os microrganismos antecedem o surgimento da espécie humana e são capazes de produzirem infecções que comprometem a saúde do indivíduo ao qual parasitam, sendo que a partir desta situação, é essencial a formação de uma equipe 
multiprofissional, constituída por biólogos, enfermeiros, farmacêuticos, agentes de limpeza, biomédicos e médicos a fim de realizar a promoção da saúde (FANEC, 20052019).

É com base em tal problemática, que medidas de biossegurança em âmbito nacional e internacional tem sido realizadas a fim de padronizar o processo de transporte, conservação e manipulação de microorganismos patogênicos, além de um plano de educacional voltado aos trabalhadores da área de saúde (CARVALHO, 1999; BRASIL, 2004).

Estudos da década passada, a exemplo dos estudos de Skinholj (1974) já mostravam a importância da aplicação de medidas de Biossegurança para os profissionais de saúde que atuam em especial em laboratórios. Skinholj mostrou que funcionários de laboratórios clínicos na Dinamarca apresentavam incidência de hepatite sete vezes maior que a população em geral. Resultado similar foi encontrado por Harrington e Shannon (1976) para funcionários de laboratórios médicos na Inglaterra, onde estes tinham cinco vezes mais chances de adquirir tuberculose quando comparado a população total do país (BRASIL, 2004).

A fim de realizar um efetivo controle da propagação de infecções nas práticas de saúde, os profissionais desta área devem ter em mente a realização de quatro princípios, sendo eles: (1) Tornar seguro o uso de artigos, peças anatômicas e superfícies; (2) Limitar a propagação de microorganismos; (3) Evitar o contato com matéria orgânica; e (4) Tomar medidas para proteger a sua saúde e da equipe de saúde (FANEC, 2005-2019).

Deste modo, o presente artigo tem como objetivo geral descrever a importância da realização de estudos de Biossegurança no Brasil nos últimos 25 anos (1995-2020) para os profissionais da área de saúde. Como objetivos específicos, inclui-se: (a) pontuar as aplicações da Biossegurança dentro da área de saúde; (b) relatar estudos ocorridos ao longo dos anos sobre a temática; e (c) enumerar as principais Leis atreladas a Biossegurança.

\section{METODOLOGIA}

O presente artigo foi desenvolvido por meio da realização de uma revisão bibliográfica (revisão de literatura), tratando-se de uma pesquisa descritiva com 
abordagem quali-quantitativa. Nela buscou-se referências bibliográficas no Catálogo de Teses e Dissertações da CAPES que abordassem em seu contexto o tema "Biossegurança + Gestão em saúde", termos estes que deveriam estar descritos no título da obra e/ou em seu resumo (Figura 1).

Por meio da leitura das obras verificou-se se estas eram ou não aplicadas ao contexto da Biossegurança para profissionais da área de saúde, de modo que caso fossem aplicadas (se relacionassem ao tema), as obras seriam utilizadas para a realização do estudo e caso não (critério de exclusão), as obras seriam desprezadas.

Figura 1 - Procedimentos metodológicos aplicados as obras do Catálogo de Teses e Dissertações da CAPES que abordassem em seu contexto os temas "Biossegurança + Gestão em saúde" no período de janeiro a dezembro de 2020

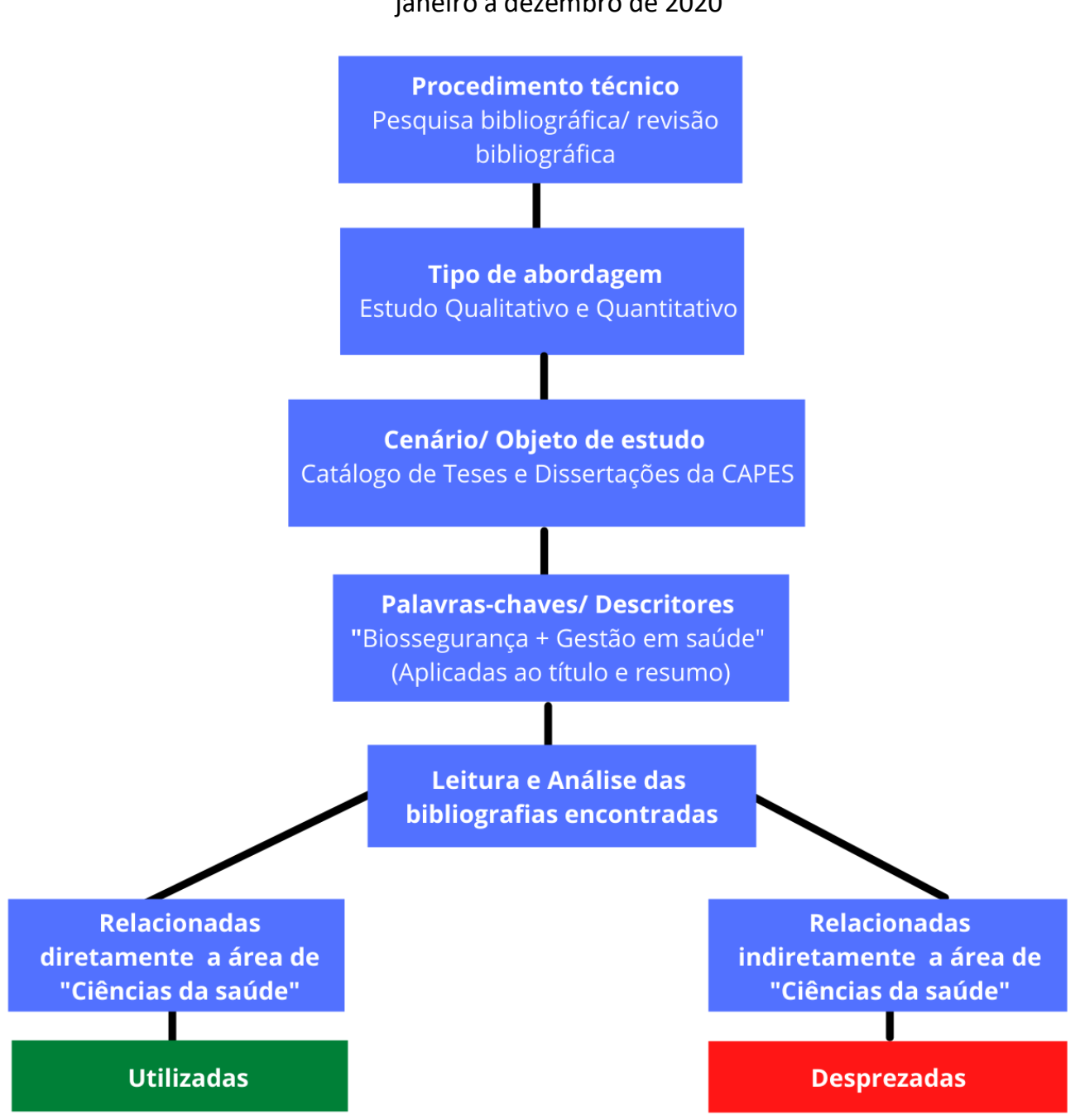

Fonte: Autoria própria. 
A realização das buscas por referências durou um período de 12 meses, compreendendo os meses de janeiro a dezembro de 2020. Como item balizador para a seleção das referências, optou-se por se utilizar todos os trabalhos publicados no Catálogo de Teses e Dissertações da CAPES (http://catalogodeteses.capes.gov.br/catalogo-teses/\#!/) até o ano de 2020.

Os dados tabulados foram convertidos em tabelas e gráficos, os quais foram gerados por meio do programa Microsoft Office Professional Plus Excell 2016.

\section{IMPORTÂNCIA DOS ESTUDOS DE BIOSSEGURANÇA AOS PROFISSIONAIS DE SAÚdE}

A fim de permitir uma melhor compreensão do conteúdo apresentado no presente capítulo, optou-se por subdividi-lo em duas partes, sendo a primeira, o subcapítulo 3.1 destinado a aplicação da Biossegurança em ambientes laboratoriais, e o subcapítulo 3.2 destinado a pontuar os estudos e leis que regem a área da Biossegurança no Brasil.

\subsection{APLICAÇÃo dA BIOSSEGURANÇA NA ÁREA DA SAÚdE}

A aplicação das normas de Biossegurança dentro de ambientes laboratoriais, visa permitir uma maior proteção aos indivíduos ai inseridos, sejam eles pesquisadores ou amostras de estudos, assim minimizando a todos de ações lesivas a sua saúde que sejam desnecessárias.

A fim de padronizar as práticas de biossegurança, uma série de atividades e padrões de instalações e de medidas de segurança são adotadas aos agentes a serem estudados em laboratório, tendo-se medidas especificas para cada nível de biossegurança, conforme exposto a seguir (Quadro 1 - BRASIL, 2004): 
Quadro 1 - Níveis e medidas de biossegurança em ambientes de laboratório

\begin{tabular}{|c|c|}
\hline Nível de biossegurança & Medidas a serem adotadas \\
\hline NB-1 & $\begin{array}{l}\text { - O acesso ao laboratório deve ser limitado ao se realizar experimentos ou } \\
\text { trabalhos com culturas e amostras; } \\
\text { - Deve-se lavar as mãos após o manuseio de materiais viáveis, após a } \\
\text { remoção das luvas e antes de saírem do laboratório; } \\
\text { - Não é permitido comer, beber, fumar, armazenar alimentos ou aplicar } \\
\text { cosméticos nas áreas de trabalho; } \\
\text { - Pessoas que usam lentes devem também usar óculos de proteção ou } \\
\text { protetores faciais; } \\
\text { - É proibida a pipetagem com a boca. Devem ser utilizados dispositivos } \\
\text { mecânicos; } \\
\text { - Devem ser instituídas normas para o manuseio de agulhas; } \\
\text { - Todos os procedimentos devem ser realizados cuidadosamente a fim de } \\
\text { minimizar a criação de borrifos e aerossóis; }\end{array}$ \\
\hline NB-1 & $\begin{array}{l}\text { - As superfícies de trabalho devem ser descontaminadas, ao menos, uma } \\
\text { vez ao dia e sempre depois de qualquer derramamento de material } \\
\text { - Todas as culturas e outros resíduos deverão ser descontaminados antes } \\
\text { de serem descartados através de um método de descontaminação } \\
\text { aprovado; } \\
\text { - Os materiais que forem descontaminados fora do laboratório deverão } \\
\text { ser colocados em recipientes inquebráveis, à prova de vazamentos e } \\
\text { hermeticamente fechados para serem transportados ao local desejado; } \\
\text { - O símbolo de "Risco biológico" deverá ser colocado na entrada do } \\
\text { laboratório em qualquer momento em que o agente infeccioso estiver } \\
\text { presente no local. Este sinal de alerta deverá indicar o (s) agente (s) } \\
\text { manipulado (s) e o nome e número do telefone do pesquisador; } \\
\text { - Deve ser providenciado um programa rotineiro de controle de insetos e } \\
\text { roedores. }\end{array}$ \\
\hline NB-2 & $\begin{array}{l}\text { - O nível de Biossegurança NB-2 é adequado ao trabalho que envolva } \\
\text { agentes de risco moderado para as pessoas e ao meio ambiente, } \\
\text { diferindo-se da NB-1 nos seguintes aspectos: } \\
\text { - O pessoal de laboratório deverá ter um treino específico no manejo de } \\
\text { agentes patogênicos e devem ser supervisionados por cientistas } \\
\text { competentes; } \\
\text { - O acesso ao laboratório deve ser limitado; } \\
\text { - Precauções extremas serão tomadas em relação a objetos cortantes } \\
\text { infectados; e } \\
\text { Procedimentos nos quais exista possibilidade de formação de } \\
\text { aerossóis e borrifos infecciosos devem ser conduzidos em cabines de } \\
\text { segurança biológica. }\end{array}$ \\
\hline
\end{tabular}




\begin{tabular}{|l|l|}
\hline NB-3 & \begin{tabular}{l} 
- Este nível de biossegurança é aplicável a laboratórios clínicos, de \\
diagnóstico, ensino e pesquisa ou de produção onde os trabalhos com \\
agentes exóticos possam causar doenças sérias ou fatais. \\
- Procedimentos com materiais infecciosos deverão ser conduzidos dentro \\
de cabines de segurança biológica ou outro mecanismo de contenção \\
física. \\
- As medidas aplicadas ao NB-1 e NB-2 aqui também são aplicadas. \\
\hline - Recomenda-se que os laboratórios só funcionem sob o controle direto \\
das autoridades sanitárias, além de ser necessário a elaboração de um \\
manual de trabalho pormenorizado; este deve ser testado previamente \\
através de exercícios de treinamento. \\
- Este nível de Biossegurança 4 é indicado para trabalhos/pesquisas que \\
envolvam agentes exóticos e perigosos que exponham o profissional de \\
saúde a um risco alto de contaminação de infecções que podem ser \\
letais. As medidas aplicadas ao NB-1, NB-2 e NB-3 aqui também são \\
aplicadas.
\end{tabular} \\
\hline
\end{tabular}

Fonte: BRASIL, 2004.

\subsection{HISTÓRICO DOS ESTUDOS DE BIOSSEGURANÇA NO BRASIL, APLICAdo A ÁREA da SAÚde E A LEGISLAÇÃo VIGENTE}

Por meio da promulgação das primeiras diretrizes de Biossegurança, em 1976, pela National Institute os Health (NIH) que o tema "Biossegurança" começou a ganhar maior notoriedade nos eventos científicos, sendo que esta primeira diretriz focava estritamente a questão da segurança laboratorial e sobre os agentes patogênicos, aos quais os funcionários de laboratórios estavam susceptíveis, ou seja, restrita aos riscos laboratoriais (FANEC, 2005-2019).

Há 6.000 anos AC, na região da Mesopotâmia, acreditava-se que as doenças eram produto de forças sobrenaturais, que serviam como uma punição divina, e pessoas nomeadas como xamã atuavam como mediadores e as forças sobrenaturais (FANEC, 2005-2019).

Os papiros de Kahum, Edwi e Ebers, datados a 3.000 anos AC já continham descrições de forma simplificada dos professos de inflamação, infecção e das atividades terapêuticas aplicadas para a sua cura (FANEC, 2005-2019).

As técnicas de embalsamento aplicadas no Egito há 2.000 anos AC, por meio da lavagem do corpo com vinho (álcool) e a aplicação de incensos, os quais eram compostos por ácido carbólico (fenol) e a aplicação de sulfaftos e carbamatos mostravam que os 
egípcios já tinham noções sobre desinfetantes aplicados para a futura área da Biossegurança (FANEC, 2005-2019).

Os hindus, a 900 anos AC, criaram o "Código de Ética Médica", nomeado como Susruta, que descrevia, dentre outros procedimentos, a importância dos médicos vestirem sempre roupas limpas, estarem barbeados, com unhas curtas, zelarem pelo sigilo profissional e dedicar-se por inteiro ao paciente (FANEC, 2005-2019).

Com o avançar dos anos, a evolução da sociedade e o aprimoramento dos estudos sobre análises epidemiológicas das doenças, o conceito de Biossegurança, que inicialmente ficava restrito aos riscos microbiológicos, ergonômicos, radioativos, químicos e físicos, passou a integrar também, os chamados riscos ambientais, assim saindo do contexto laboratorial e passando a englobar o contexto planetário (FANEC, 2005-2019).

Em 1847, Ignaz Semmelweis, médico húngaro, demonstrou a importância da realização de profilaxias para a minimização de casos de infecção em ambientes hospitalares, mostrando que o simples hábito de lavar as mãos com uma solução clorada antes de entrar em contato com pacientes enfermados diminuía de forma considerável quadros clínicos de febre puerperal (FANEC, 2005-2019).

No século XX passou-se a se utilizar os famosos níveis de biossegurança (NB), os quais podem ser de quatro tipos (NB-1, NB-2, NB-3 e NB-4) e compreendem um conjunto de práticas e técnicas laboratoriais, instalações e equipamentos de segurança, sendo que combinações específicas são passiveis de realização a depender do tipo e função das atividades laboratoriais (BRASIL, 2004).

Em 1995 foi regulamentada e publicada no Brasil a Legislação de Biossegurança, sendo que esta focava na parte da Engenharia genética, norteando os pesquisadores quanto os procedimentos para o manejo de organismos geneticamente modificados (OMG) (BRASIL, 2004).

Dentre outras leis relacionadas a Biossegurança no Brasil, podemos destacar: 
Quadro 2 - Legislações vigentes no Brasil, no que se refere a Biossegurança, no período de 1997 a 2020

\begin{tabular}{|c|c|c|c|}
\hline $\begin{array}{c}\text { Ano de } \\
\text { Publicação }\end{array}$ & $\begin{array}{l}\text { Tipo de } \\
\text { Legislação }\end{array}$ & Nomenclatura da Lei & O que dispõe \\
\hline 1997 & $\begin{array}{l}\text { Resolução } \\
\text { Normativa }\end{array}$ & $\begin{array}{l}\text { Resolução Normativa № } \\
\text { 7, de } 09 \text { de Junho de } 1997\end{array}$ & $\begin{array}{l}\text { Normas para Trabalho em Contenção } \\
\text { de Animais Geneticamente } \\
\text { Modificados-OGMs }\end{array}$ \\
\hline 1998 & $\begin{array}{l}\text { Resolução } \\
\text { Normativa }\end{array}$ & $\begin{array}{c}\text { Resolução Normativa № } \\
\text { 15, de } 08 \text { de Julho de } \\
1998\end{array}$ & $\begin{array}{l}\text { Normas para Trabalho em Contenção } \\
\text { de Animais não Geneticamente } \\
\text { Modificados onde Organismos } \\
\text { Geneticamente Modificados são } \\
\text { Manipulados. }\end{array}$ \\
\hline 2005 & Lei & $\begin{array}{l}\text { Lei no } 11.105 \text {, de } 24 \text { de } \\
\text { Março de } 2005\end{array}$ & $\begin{array}{l}\text { (...) cria o Conselho Nacional de } \\
\text { Biossegurança - CNBS, reestrutura a } \\
\text { Comissão Técnica Nacional de } \\
\text { Biossegurança - CTNBio, dispõe } \\
\text { sobre a } \\
\text { Política Nacional de Biossegurança - } \\
\text { PNB (...) }\end{array}$ \\
\hline 2006 & $\begin{array}{l}\text { Resolução } \\
\text { Normativa }\end{array}$ & $\begin{array}{l}\text { Resolução Normativa № } \\
\text { 1, de } 20 \text { de Junho de } 2006\end{array}$ & $\begin{array}{l}\text { Dispõe sobre a instalação e } \\
\text { funcionamento das Comissões } \\
\text { Internas de Biossegurança (CIBios) e } \\
\text { sobre os critérios e procedimentos } \\
\text { para requerimento, emissão, revisão, } \\
\text { extensão, suspensão e cancelamento } \\
\text { do Certificado de Qualidade em } \\
\text { Biossegurança (CQB) }\end{array}$ \\
\hline 2006 & $\begin{array}{l}\text { Resolução } \\
\text { Normativa }\end{array}$ & $\begin{array}{l}\text { Resolução Normativa № } \\
\text { 2, de } 27 \text { de Novembro de } \\
2006\end{array}$ & $\begin{array}{l}\text { Dispõe sobre a classificação de riscos } \\
\text { de Organismos Geneticamente } \\
\text { Modificados (OGM) e os níveis de } \\
\text { biossegurança a serem aplicados nas } \\
\text { atividades e projetos com OGM e } \\
\text { seus derivados em contenção. }\end{array}$ \\
\hline 2007 & Lei & $\begin{array}{l}\text { Lei } n^{\circ} 11.460, \text { de } 21 \text { de } \\
\text { março de } 2007\end{array}$ & $\begin{array}{l}\text { Dispõe sobre o plantio de OGM em } \\
\text { unidades de conservação. }\end{array}$ \\
\hline 2007 & Portaria & $\begin{array}{l}\text { Portaria № } 1.608 \text { de } 5 \text { de } \\
\text { Julho de } 2007\end{array}$ & $\begin{array}{l}\text { Aprova a Classificação de Risco dos } \\
\text { Agentes Biológicos elaborada em } \\
\text { 2006, pela Comissão de } \\
\text { Biossegurança em Saúde (CBS). }\end{array}$ \\
\hline 2008 & $\begin{array}{l}\text { Resolução } \\
\text { Normativa }\end{array}$ & $\begin{array}{c}\text { Resolução Normativa № } \\
\text { 5, de } 12 \text { de Março de } \\
2008\end{array}$ & $\begin{array}{l}\text { Dispõe sobre normas para liberação } \\
\text { comercial de Organismos } \\
\text { Geneticamente } \\
\text { derivados }\end{array}$ \\
\hline 2009 & Portaria & $\begin{array}{l}\text { Portaria № } 178 \text {, de } 4 \text { de } \\
\text { Fevereiro de } 2009\end{array}$ & $\begin{array}{l}\text { Institui, no âmbito da Comissão de } \\
\text { Biossegurança em Saúde do } \\
\text { Ministério da Saúde - CBS/MS, o } \\
\text { Grupo de Trabalho para Revisão e } \\
\text { Atualização da Classificação de Risco } \\
\text { dos Agentes Biológicos. }\end{array}$ \\
\hline 2011 & Portaria & $\begin{array}{l}\text { Portaria } N^{\circ} 1.914 \text {, de } 9 \text { de } \\
\quad \text { Agosto de } 2011\end{array}$ & $\begin{array}{l}\text { Aprova a Classificação de Risco dos } \\
\text { Agentes Biológicos elaborada em } \\
\text { 2010, pela Comissão de } \\
\text { Biossegurança em Saúde (CBS), do } \\
\text { Ministério da Saúde. }\end{array}$ \\
\hline
\end{tabular}




\begin{tabular}{|c|c|c|c|}
\hline 2012 & Resolução & $\begin{array}{l}\text { Resolução RDC N¹1, de } \\
16 \text { de Fevereiro de } 2012\end{array}$ & $\begin{array}{l}\text { Dispõe sobre o funcionamento de } \\
\text { laboratórios analíticos que realizam } \\
\text { análises em produtos sujeitos à } \\
\text { Vigilância Sanitária e dá outras } \\
\text { providências. }\end{array}$ \\
\hline 2013 & Portaria & $\begin{array}{l}\text { Portaria Normativa } \mathrm{N}^{\circ} \\
\text { 585/MD, de } 7 \text { de Março } \\
\text { de } 2013\end{array}$ & $\begin{array}{l}\text { Aprova as Diretrizes de } \\
\text { Biossegurança, Bioproteção e Defesa } \\
\text { Biológica do Ministério da Defesa. }\end{array}$ \\
\hline 2014 & Portaria & $\begin{array}{l}\text { Portaria № } 45 \text {, de } 1^{\circ} \text { de } \\
\quad \text { Abril de } 2014\end{array}$ & $\begin{array}{l}\text { Institui a Comissão permanente de } \\
\text { Gestão de Riscos Biológicos e } \\
\text { Biossegurança, em Laboratórios que } \\
\text { manipulam agentes biológicos e suas } \\
\text { partes, vírus e suas partes e príons de } \\
\text { interesse em saúde animal. }\end{array}$ \\
\hline 2014 & Portaria & $\begin{array}{l}\text { Portaria MCTI № 929, de } \\
03 \text { de setembro de } 2014\end{array}$ & $\begin{array}{l}\text { Altera o Regimento Interno da } \\
\text { Comissão Técnica Nacional de } \\
\text { Biossegurança-CTNBio. }\end{array}$ \\
\hline 2014 & Portaria & $\begin{array}{l}\text { Portaria № } 2.349 \text {, de } 14 \\
\text { de setembro de } 2017\end{array}$ & $\begin{array}{l}\text { Aprova a Classificação de Risco dos } \\
\text { Agentes Biológicos elaborada em } \\
2017 \text {, pela Comissão de } \\
\text { Biossegurança em Saúde (CBS). }\end{array}$ \\
\hline 2015 & Portaria & $\begin{array}{l}\text { Portaria } \mathrm{n}^{\circ} 89 \text {, de } 11 \text { de } \\
\quad \text { Novembro de } 2015\end{array}$ & $\begin{array}{l}\text { Instituí no âmbito do Departamento } \\
\text { de Fiscalização de Insumos Pecuários } \\
\text { DFIP/SDAa Comissão Técnica de } \\
\text { Gestão de Riscos Biológicos e } \\
\text { Biossegurança - CTGRB em } \\
\text { estabelecimentos que fabricam ou } \\
\text { realizam controle da qualidade de } \\
\text { vacinas, antígenos e soros } \\
\text { hiperimunes de uso veterinário. }\end{array}$ \\
\hline 2017 & Portaria & $\begin{array}{l}\text { Portaria } N^{\circ} 2.349 \text {, de } 14 \\
\text { de Setembro de } 2017\end{array}$ & $\begin{array}{l}\text { Aprova a Classificação de Risco dos } \\
\text { Agentes Biológicos elaborada em } \\
2017 \text {, pela Comissão de } \\
\text { Biossegurança em Saúde (CBS), do } \\
\text { Ministério da Saúde. }\end{array}$ \\
\hline 2018 & Portaria & $\begin{array}{l}\text { Portaria } N^{\circ} 53 \text {, de } 04 \\
\text { de Julho de } 2018\end{array}$ & $\begin{array}{l}\text { Propõe a Política Nacional de } \\
\text { Biossegurança e Bioproteção. }\end{array}$ \\
\hline 2019 & Portaria & $\begin{array}{l}\text { Portaria } N^{\circ} 2.594 \text {, de } \\
01 \text { de Outubro de } 2019\end{array}$ & $\begin{array}{l}\text { Dispõe sobre a Comissão de } \\
\text { Biossegurança em Saúde. }\end{array}$ \\
\hline 2020 & Portaria & $\begin{array}{l}\text { Portaria MCTIC No } 291 \\
\text { de } 24 \text { de Janeiro de } \\
2020 .\end{array}$ & $\begin{array}{l}\text { Designa representante, } \\
\text { Especialista na Área de Saúde, } \\
\text { para compor a Comissão Técnica } \\
\text { Nacional de Biossegurança - } \\
\text { CTNBio, na qualidade de membro } \\
\text { suplente, para o primeiro mandato } \\
\text { de } 2 \text { (dois) anos. }\end{array}$ \\
\hline
\end{tabular}

Fonte: Autoria própria.

\section{CONSIDERAÇÕES FINAIS}

Medidas de Biossegurança são aplicadas em especial a ambientes laboratoriais, a fim de favorecer e minimizar riscos à saúde aos profissionais de saúde que aí 
trabalham, sendo que para isto uma série de normas de Biossegurança, sendo quatro no total (NB-1 até a NB-4), foram desenvolvidas com o intuito de se alcançar tal objetivo.

Mas para que essas normas de Biossegurança, hoje utilizadas, fossem possíveis de aplicação, uma série de estudos tiveram que ser realizados, a exemplo da aplicação das técnicas de embalsamento aplicadas no Egito há 2.000 anos AC, por meio da lavagem do corpo com vinho (álcool) e a aplicação de incensos, e mais recentemente, os estudos de Semmelweis em 1847 sobre a importância da realização de profilaxias para a minimização de casos de infecção em ambientes hospitalares.

A partir destes e outros estudos, uma série de legislações foram promulgadas a fim de padronizar as medidas de Biossegurança no Brasil, leis estas que incluem desde resoluções normativas, até portarias, sendo estas desenvolvidas desde 1995 com a regulamentação e publicação da Legislação de Biossegurança no Brasil, até o presente ano de 2020, com a designação e representantes para compor a Comissão Técnica Nacional de Biossegurança - CTNBio.

Deste modo, a importância da realização de estudos de Biossegurança no Brasil nos últimos 25 anos (1995-2020) para os profissionais da área de saúde reside no fato desta favorecer a padronização dos procedimentos a serem adotados pelos profissionais, permitindo assim a sua replicação, além de garantir uma redução dos riscos a saúde ao se estabelecer as normas de biossegurança (NB).

\section{REFERÊNCIAS}

BARKER, K. Na bancada: manual de iniciação científica em laboratórios de pesquisas biomédicas. Porto Alegre: Artmed, 2002. 474p.

BRASIL, Ministério da Saúde. Secretaria de Vigilância em Saúde. Departamento de Vigilância Epidemiológica. Biossegurança em laboratórios biomédicos e de microbiologia. Brasília: Ministério da Saúde, 2004. Disponível em: <http://bvsms.saude.gov.br/bvs/publicacoes/funasa/ livro_biosseguranca2.pdf>. Acesso em: 27 jan. 2020.

BRASIL. Ministério da Saúde. Secretaria de Ciência, Tecnologia e Insumos Estratégicos. Departamento do Complexo Industrial e Inovação em Saúde. Classificação de risco dos agentes biológicos. 2 Ed. Brasília: Editora do Ministério da Saúde. 2010.

BRASIL, Ministério da Ciência, Tecnologia, Inovações e Comunicações - MCTIC. Portaria MCTOC, $n^{\circ} 291$, de 24 de janeiro de 2020. Designa representante, Especialista na Área de Saúde, para compor a Comissão Técnica Nacional de Biossegurança - 
CTNBio, na qualidade de membro suplente, para o primeiro mandato de 2 (dois) anos. Diário Oficial da União de 28 de Janeiro de 2020, Seção II, Pág. 6. Disponível em:

http://www.mctic.gov.br/mctic/opencms/legislacao/portarias/Portaria_MCTIC _n_291_de_24012020.html>. Acesso em: 02 fev. 2020.

CARVALHO, P. R. de. Boas práticas químicas em biossegurança. Rio de Janeiro: Interciência, 1999. 132p.

FACULDADE NATALENSE DE ENSINO E CULTURA - FANEC. Manual de Biossegurança. Natal, 2005-2019. Disponível em:

http://www.fanec.edu.br/aluno/arquivos/manual_biosseguranca.pdf. Acesso em: 25 dez. 2019.

HIRATA, M. H.; HIRATA, R. D. C.; MANCINI-FILHO J. Manual de Biossegurança. 2a Ed. Editora Manole Ltda., Barueri, 2012. 


\section{CIÊNCIAS DA SAÚDE}

\section{APRENDIZADOS, ENSINO E PESQUISA NO}

\section{CENÁRIO CONTEMPORÂNEO}




\section{CIÊNCIAS DA SAÚDE}

\section{APRENDIZADOS, ENSINO E PESQUISA NO CENÁRIO CONTEMPORÂNEO}

